\title{
Dionysos in Classical Athens
}




\title{
Religions in the Graeco-Roman World
}

\author{
Series Editors \\ David Frankfurter (Boston University) \\ Johannes Hahn (Universität Münster) \\ Frits G. Naerebout (University of Leiden)
}

VOLUME 181

The titles published in this series are listed at brill.com/rgrw 


\title{
Dionysos in Classical Athens
}

\author{
An Understanding through Images
}

By

Cornelia Isler-Kerényi

Translated by

Anna Beerens

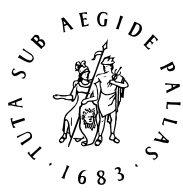

B R I L L

LEIDEN | BOSTON 


\section{B R I L L \\ OPE N}

This is an open access title distributed under the terms of the CC-BY-NC License, which permits any non-commercial use, distribution, and reproduction in any medium, provided the original author(s) and source are credited.

III

An electronic version of this book is freely available, thanks to the support of libraries working with Knowledge Unlatched. More information about the initiative can be found at www.knowledgeunlatched.org.

Typeface for the Latin, Greek, and Cyrillic scripts: "Brill”. See and download: brill.com/brill-typeface.

ISSN 0927-7633

ISBN 978-90-04-27011-4 (hardback)

ISBN 978-90-04-27012-1 (e-book)

Copyright 2015 by Koninklijke Brill Nv, Leiden, The Netherlands.

Koninklijke Brill NV incorporates the imprints Brill, Brill Nijhoff, Global Oriental and Hotei Publishing. All rights reserved. No part of this publication may be reproduced, translated, stored in a retrieval system, or transmitted in any form or by any means, electronic, mechanical, photocopying, recording or otherwise, without prior written permission from the publisher.

Authorization to photocopy items for internal or personal use is granted by Koninklijke Brill NV provided that the appropriate fees are paid directly to The Copyright Clearance Center, 222 Rosewood Drive, Suite 910, Danvers, MA 01923, USA. Fees are subject to change.

This book is printed on acid-free paper. 


\section{Contents}

Foreword vii

List of Figures $\mathrm{x}$

Abbreviations $\quad \mathrm{xix}$

Introduction $\quad 1$

Dionysos in 6th-Century Imagery 2

The Retinue of Dionysos: Who are the Satyrs, Who are the Women? 4

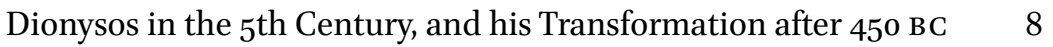

1 Dionysiac Subjects in Red-Figure Pottery 11

2 Dionysos for Athens, Dionysos for All

Dionysiac Pottery around 500 BC $\quad 16$

Late Black-Figure Vases $\quad 16$

Early Red-Figure Vases 19

Red-Figure Cups of the Final Quarter of the 6th Century $\quad 36$

3 All Kinds of Satyrs

The First Decades of the 5 th Century $\quad 40$

The Painters of Large Vases $\quad 40$

Painters of Cups $\quad 5^{2}$

Tentative Conclusions $\quad 65$

4 Dionysos, a God for the Athenians

Developments after 480 вс $\quad 69$

Hermonax and his Contemporaries $\quad 69$

The Imagery of Red-Figure Pointed Amphorae $\quad 76$

The Pelikai of the Painter of the Birth of Athena 83

5 Dionysiac Mythology in Flux

Vase Imagery between 480 and 430 BC $\quad 87$

Traditional Dionysiac Subjects $\quad 87$

The Child Dionysos 100

Dionysos in Love 113

6 Unfamiliar and Unknown Dionysiac Rituals 122

Boys and Girls in the Realm of Dionysos $\quad 122$

A Domestic Dionysiac Ritual 125 
Dionysos' Chair 135

A Satyr Carrying a Chair $\quad 136$

The Unoccupied Chair $\quad 142$

Dionysos Has Arrived 146

Child Satyrs in Dionysos' Retinue $\quad 153$

A Ritually Honored Etruscan Dionysos $\quad 159$

7 A New Dionysos at the Parthenon $\quad 162$

Decoration Program and Message $\quad 162$

Dionysos' Gigantomachy $\quad 164$

Dionysos in the East Pediment $\quad 166$

Dionysos in the Parthenon Frieze $\quad 177$

Reflections of the West Pediment in Vase Painting $\quad 180$

8 The New Dionysos in Vase Painting $\quad 184$

9 Images of Dionysos from 430 BC onwards 211

Dionysos on Stage 211

Kratinos' Dionysalexandros 211

Aristophanes' Frogs $\quad 212$

Euripides' Bakchai 213

Dionysos in 4th-Century Sculpture $\quad 217$

A Look at Vase Painting $\quad 222$

The Derveni Krater $\quad 229$

10 Summing Up 234

Anonymous Prototypes 234

The Changing Image of Dionysos $\quad 236$

Dionysos in Classical Athens 241

Works Cited 243

Index

Museums $\quad 261$

Vases Following Beazley $\quad 266$

Vases Following Beazley Archive Database (BA) $\quad 270$

Vases and Other Works Following LIMC $\quad 274$

General $\quad 276$ 


\section{Foreword}

This book is the, provisional, terminal point of the labor of several decades. As may be gathered from the bibliography, my first studies of single vases, groups of vases, or issues concerning the ceramics of the Classical period, were published as articles at the beginning of the 1970s. In addition, I have made a systematic investigation of representations of Dionysos and his retinue in Beazley's lists. All of this provides the basis for the present survey of the Dionysiac iconography of the $5^{\text {th }}$ and 4 th centuries BC and its historical contextualization, the aim of which is to open up the relevant original material for further reflection on the Dionysos phenomenon.

Concerning the use of this book, let me just quote from the preface of its predecessor, Dionysos in Archaic Greece. An Understanding through Images, which appeared in the RGRW series in 2007: "As there are so many notes, I have tried to make them as concise as possible. For the locations of the pieces quoted, only the place-name is given when the museum is evident: Athens means the National Archaeological Museum and London the British Museum. Here, Copenhagen means the National Museum. Instead of Paris, only the Louvre or the Cabinet des Médailles in the National Library is mentioned. For Rome, the museums are named in abbreviated form, while the Vatican is separate. However, the names of museums appear in full in the list of figures. The same principle applies to the citations from Beazley's lists of Attic vases. By means of the Addenda of 1989, which is the most recent, it is easy to refer back to earlier references, as indicated by the numbers in brackets. Paralipomena, ABV and ARV are mentioned only when the vases have not been repeated in later lists."

I set myself the objective of providing good reproductions of all vases that are relevant to my argument. Although I am convinced of the importance of seeing the relationship between the image and the form and function of the image carrier, I have in many instances fallen back upon old drawings, as they often more clearly reproduce the images than photographs. I have, unfortunately, not been entirely successful in obtaining a representative selection of images. As could be expected, some museums replied kindly and favorably to my request for permission to publish, and even sometimes supplied beautiful new photographs. Some charged me a certain sum, in accordance with their rules and regulations. Some did not react at all; in these cases I have assumed they had no objection to publication, provided the relevant information was added. In some cases, however, I not only had to negotiate considerable bureaucratic obstacles in order to obtain permission to reproduce an image that had already been published, but in addition had to pay a fee 
that is prohibitive for any ordinary scholar. These institutions apparently put their direct commercial interests above long-term scholarly results, in this way endangering iconographical research. To my extreme regret, I had to decide not to use these images, although it meant, in a certain sense, putting my reader at a disadvantage. The reader should, however, with the help of the BA number consistently provided here, be able to consult the literature in the Oxford Beazley Archive: www.beazley.ox.ac.uk/Pottery database/Full database.

I would like to extend my sincerest thanks to the following colleagues for publication permissions and photographs: Gabriella Costantino and Donatella Mangione (Museo Archeologico Regionale, Agrigento), George Kakavas (National Archaeological Museum, Athens), Laurent Gorgerat (Antikenmuseum Basel and Sammlung Ludwig), Ella van der Meijden (Skulpturhalle Basel), Cornelia Weber-Lehmann (Kunstsammlungen der Ruhr-Universität Bochum), Nele Schröder (Akademisches Kunstmuseum Bonn), Jean-David Cahn (Galerie Jean-David Cahn, Basel), Bodil Bundgaard Rasmussen (The National Museum of Denmark, Copenhagen), Mario Iozzo (Museo Archeologico Etrusco, Florence), Samantha Sizemore (Kimbell Art Museum, Fort Worth, Texas USA), Frank Hildebrandt (Museum für Kunst und Gewerbe, Hamburg), Isabella Donadio (Harvard Art Museums/Arthur M. Sackler Museum), Angelika Hildebrand (Badisches Landesmuseum, Karlsruhe), Jérôme Bullinger (Musée Cantonal d'archéologie et d'histoire, Lausanne), Peter Jan Bomhof (Rijksmuseum van Oudheden, Leiden), Javier Rodrigo del Blanco (Museo Arqueológico Nacional, Madrid), Astrid Fendt (Staatliche Antikensammlung und Glyptothek, Munich), Teresa Elena Cinquantaquattro and Valeria Sampaolo (Soprintendenza per i beni Archeologici di Napoli), Marti Anne Funke (University of Mississippi Museum and Historic House, David M. Robinson Memorial Collection, Oxford Mississippi USA), Francesca Spatafora (Museo Archeologico Regionale, Palermo), Ageliki Kottaridi (Archaeological Museum, Pella, 17th Ephorate of Prehistoric and Classical Antiquities, Edessa), Alfonsina Russo and Maria Laura Falsini (Soprintendenza per i beni archeologici dell'Etruria Meridionale, Museo Nazionale Etrusco di Villa Giulia, Rome), Sophie Lambert and Aimee Scillieri (Sotheby's New York), Christos Gatzolis (Archaeological Museum of Thessaloniki), Kathrin B. Zimmer (Antikensammlung des Archäologischen Instituts der Universität, Tübingen), Florian Kugler (Kunsthistorisches Museum, Vienna).

In addition, I am most grateful to Thomas H. Carpenter, François Lissarrague and John H. Oakley for kindly giving me permission to use images from their works.

Special thanks are due to Christoph Reusser, head of the Archaeological Institute of the University of Zurich, for enabling me to work in the library 
under the best possible conditions. Moreover, he has made it possible for me to benefit from the skill and kindness of the institute's photographer, Frank Tomio, whom I would also like to thank most cordially.

The fact that Henk Versnel, who was the first to read my text, was in favor of including it in the prominent Religions of the Graeco-Roman World series was a strong incentive for me to make every effort to complete the manuscript in the shortest possible time. I found a most congenial translator in Anna Beerens. My sincerest thanks to both of them, as well as to Maarten Frieswijk, my contact at Brill Publishers. The steo Foundation (Küsnacht, Switzerland) has generously offered to pay for the not inconsiderable cost of the translation, for which I would like to express my gratitude.

In the spring of 2012 I was invited by director Alain Supiot to spend several weeks at the Institut d'Etudes Avancées in Nantes in order to write a first version of my book. The ambiance was extremely stimulating: I will never forget the many productive hours with a view of the rising and falling Loire.

Finally, I am deeply grateful to my family — my husband, our children and grandchildren - for having put up for such a long time with the demanding presence of Dionysos. Without their support and understanding this book could never have been written.

$$
\text { C. I. }-K \text {. }
$$

Erlenbach (Zürich), June 2014 


\section{List of Figures}

2

3

4

Black-figure lekythos, Athens, National Museum 615 (Haspels 1936, pl. 38.5) $\quad 18$

Black-figure lekythos, Paris, Louvre E LE $15^{2}$ (CVA Louvre 28, pl. 5.4-5) 20 Black-figure lekythos, Athens, National Museum 12273 (Haspels 1936, pl. 30.2 a-b) $\quad 20$ Black-figure lekythos, Athens, National Museum 541 (Haspels 1936, pl. $23.2 \mathrm{a}-\mathrm{b}) \quad 21$ Black-figure kalpis, Hamburg, Museum für Kunst und Gewerbe 1908.253 (CVA Hamburg 1, pl. 27.3) 21

Bilingual belly-amphora, Andokides Painter, Bologna, Museo Civico Archeologico, 151 (Photo H. Bloesch) 24 Bilingual belly-amphora, Andokides Painter, Munich, Staatliche Antikensammlungen und Glyptothek 2301

a. Herakles (F R pl. 4 B)

b. Dionysos (?) (FR pl. 4 A) 25

Bilingual belly-amphora, Psiax, Munich, Staatliche Antikensammlungen und Glyptothek 2302 (Carpenter 1995, 151, fig. 5) $\quad 26$

Bilingual belly-amphora, Munich, Staatliche Antikensammlungen und Glyptothek, 2300 (cVA München 4, pl. 16o.1) 27 Amphora with twisted handles, Euphronios, Paris, Louvre G 30, neck image A (Heilmeyer 1991, 156 A) 30 Psykter, Euphronios, St. Petersburg, State Hermitage Museum B 1650 (FR pl. 63) 31

Stamnos, Smikros, Brussels, Musées Royaux d'Art et d'Histoire A 717, side A (Pfuhl 1923, III, 120, fig. 388) 33

Belly-amphora, Euthymides, Munich, Staatliche Antikensammlungen und Glyptothek 8731 (2307), side A (FR pl. 14.1) 34 Psykter, Dikaios Painter, London, British Museum E 767

a. side B (CVA British Museum 6, pl. 104, 1a)

b. side A (cvA British Museum 6, pl. 104, 1c) 35 Cup, Oltos, Rome, Museo Gregoriano Etrusco Vaticano 498 (Albizzati 1938, pl.69) 37 Cup, Oltos, Rome, Museo Nazionale Etrusco di Villa Giulia 50388 (Gerhard 1840-1858, pl. 85) 37 
17 Calyx krater, Kleophrades Painter, Harvard Art Museum, Arthur M. Sackler Museum, Gift of Frederick M. Watkins, 1960.236

a. side A: Dionysos

b. side view (right)

c. side B: Hephaistos

d. side view (left) 41

18 Panathenaic-type amphora, Kleophrades Painter, Leiden, Rijksmuseum van Oudheden PC 80 (CVA Leiden 3, pl. 120) Amphora with twisted handles, Kleophrades Painter, Harrow, School Museum 55

a. side A (Beazley 1933, pl. 29, 1)

b. side B (Beazley 1933, pl. 29, 2) Antikensammlungen und Glyptothek 2311

a. side A (Beazley 1930, pl. 6)

b. side B (Beazley 1930, pl. 6)

Neck-amphora, Berlin Painter, New York, Metropolitan Museum of Art 07.286.69 (Richter 1936, pl. 18) Stamnos, Berlin Painter, formerly Castle Ashby 72 (cva Castle Ashby, pl. 48.3) $\quad 48$

Dinos, Berlin Painter, Basel, Antikenmuseum Basel und Sammlung Ludwig Lu 39

a. view of the vase with Dionysos (Lullies 1979, 111b)

b. detail: head, probably of Peleus, and head of Dionysos (Lullies 1971, pl. 19.2-3) $\quad 50$ Pelike, Geras Painter, Lausanne, Musée cantonal d'archéologie et d'histoire INV 3250, side A (Bérard 1966, 95, pl. 21) 53 Cup, Onesimos, Boston, Museum of Fine Arts 10.179 (Langlotz 1922, pl. 8) $\quad 54$

27 Cup, Brygos Painter, Munich, Staatliche Antikensammlungen und Glyptothek, 2645, tondo image on a white ground (FR pl. 49.1) Kalpis, Kleophrades Painter, Rouen, Musée Départemental des Antiquités 583.3 (Lissarrague 1987, 88, fig. 22) $\quad 56$ Kalathos, Brygos Painter, Munich, Staatliche Antikensammlungen und Glyptothek, 2416, detail of side B (F R pl. 64 below) $\quad 56$ 
Cup, Douris Paris, Bibliothèque Nationale de France, Cabinet des Médailles 542 (Brommer 1978, 15, fig. 6) $\quad 58$ Cup, Douris Fort Worth (Tx), Kimbell Art Museum (AP2000.02)

a. Pentheus (Buitron-Oliver 1995, pl. 73)

b. Dionysos (Buitron-Oliver 1995, pl. 73) Cup, Makron, Paris, Louvre G 144 (Kunisch 1995, pl. 37)

a. medallion: satyr with female partner

b. side A: Dionysos amidst his thiasos 62 Cup, Makron, Bochum, Ruhr-Universität, Kunstsammlungen S 1062 (Kunisch 1995, pl. 119)

a. Dionysos

b. Ares 64 Amphora with twisted handles, Eucharides Painter, London, British Museum E 279 (BSA 18, 1912, pls. 11 [Dionysos] and 12 [woman]) 67 Pelike, Hermonax, Rome, Museo Nazionale Etrusco di Villa Giulia 50459 (photographs Soprintendenza per i beni archeologici dell'Etruria Meridionale)
a. side A: Dionysos
b. side view (right)
c. side $\mathrm{B}$
d. side view (left)
71

37 Calyx krater, Oreithyia Painter, Agrigento, Museo Archeologico Regionale C 1538, side A (De Miro 1994, pl. 38) 73

38 Column krater, Agrigento Painter, Rome, Museo Nazionale Etrusco di Villa Giulia 846, side A (cVA Villa Giulia 4, pl. 9.1) 75

39 Column krater, Orpheus Painter, Lecce, Museo Provinciale Sigismondo Castromediano 603, side A (CVA Lecce 1, pl. 8.1) $\quad 75$ Pointed amphora, Syriskos, London, British Museum E $35^{\circ}$ a. side A (cVA British Museum 3, III Ic pl. 18.1b)

b. detail of side A: Dionysos is welcomed by a woman (CVA British Museum 3, III Ic pl. 18.1d) 79

41 Calyx krater, Syriskos, formerly Malibu, J. Paul Getty Museum 92.AE.6, side A (Lubsen Admiraal 1999, pl. 22a) 82

42 Pelike, Painter of the Birth of Athena, London, British Museum E 410, side A and B combined (Gerhard 1840-58, pl. 3-4) 85 
43 Calyx krater, Niobid Painter, Ferrara, Museo Archeologico Nazionale di Spina 2891

a. side view (left), detail of the upper frieze: Dionysos' Gigantomachy

b. side B, lower frieze: Dionysos amidst his thiasos (photographs Archäologisches Institut der Universität Zürich, Silvia Hertig) 89

44 Kalpis, Niobid Painter, Ferrara, Museo Archeologico Nazionale di Spina 2683 (photograph Archäologisches Institut der Universität Zürich, Silvia Hertig) $\quad 89$

45 Calyx krater, Altamura Painter, Kunsthistorisches Museum, Vienna 985, detail of side A: Dionysos with Hephaistos (CVA Kunsthistorisches Museum, Vienna 3, pl. 101.1) $\quad 91$

46 Oinochoe, Achilles Painter, Montpellier, Musée de la Société Archéologique 140

a. detail: woman in Dionysos' retinue (Oakley 1997, pl. 67)

b. detail: Dionysos (Oakley 1997, pl. 67) 92

47 Pointed amphora, Achilles Painter, Paris, Bibliothèque Nationale de France, Cabinet des Médailles 357

a. side A: Dionysos (Oakley 1997, pl. 4a)

b. side B: maenad (Oakley 1997, pl. 3a) 94

48 Bell krater, Polygnotos, Agrigento, Museo Archeologico Regionale AG 22797, side A (De Miro 1994, pl. 34) 96

49 Volute krater, Kleophon Painter, Ferrara, Museo Archeologico Nazionale di Spina 44834, detail of side B (photograph Archäologisches Institut der Universität Zürich, Silvia Hertig) 96

$50 \quad$ Pelike, Kleophon Painter, Munich, Staatliche Antikensammlungen und Glyptothek, 2361, side A (FR pl. 29) 97

51 Cup, Makron, Athens, National Museum Acr. 2.325, fragments of outside image, side B (GL II, pl. 20.325) 101

$5^{2} \quad$ Fragment of a krater, artist from the sphere of the Dinos Painter, Bonn, Akademisches Kunstmuseum 1216.19 (CVA Bonn 1, pl. 33.9) $\quad 102$

53 Kalpis, Syleus Painter, Paris, Bibliothèque Nationale de France, Cabinet des Médailles 440 (Arafat 1990, pl. 11a) 104

54 Stamnos, Painter of the Florence Stamnoi, Paris, Louvre M N B 1695 (G 188), side A (LIMC III.2, Dionysos 703) 104 
55 Bell krater, Altamura Painter, Ferrara, Museo Archeologico Nazionale di Spina 2738, side A (photograph Archäologisches Institut der Universität Zürich, Silvia Hertig) $\quad 105$

56 Volute krater, Altamura Painter, Ferrara, Museo Archeologico Nazionale di Spina 2737, side A (photograph Archäologisches Institut der Universität Zürich, Silvia Hertig) 106 Calyx krater, Villa Giulia Painter, Moscow, Pushkin State Museum of Fine Arts II 1b 732, side A (cVA Moscow 4, pl. 22.1) 107 $5^{8} \quad$ Pelike, Chicago Painter, Palermo, Museo Archeologico Regionale 1109, side A (photograph H. Bloesch) 109

59 Calyx krater with a white ground, Phiale Painter, Rome, Museo Gregoriano Etrusco Vaticano 16586 (559), side A (FR pl. 169 below) $\quad 109$ Kalpis, Syleus Painter, Berlin F 2179 (MAL 14, 1904, 55, fig. 18) 114

61 Amphora with twisted handles, Harrow Painter, Oxford (Ms), University of Mississippi Museum and Historic House, David M. Robinson Memorial Collection 1977.3.87 A-B, side A (CVA Robinson [USA 6], pl. 29.2a) 115

62 Cup, possibly Foundry Painter, Tarquinia, Museo Nazionale Tarquinense RC 5291, outside image side A (CVA Tarquinia 2, pl. 18.3) $\quad 116$

63 Lekythos, Pan Painter, Taranto, Museo Archeologico Nazionale 4545 (ÖJh 38, 1950, 5, fig. 3) 117

64 Oinochoe, Niobid Painter, Paris, Bibliothèque Nationale de France, Cabinet des Médailles 46o (Kaempf-Dimitriadou 1979, pl. 22.3-5) $\quad 118$

65 Kalpis, late mannerist, London, British Museum E 184 (cva British Museum 5, III Ic pl. 80.3) 119

66 Calyx krater, Kadmos Painter, Siracusa, Museo Archeologico Nazionale 17427, scroll showing both sides (MAL 14, 1904, pl. I) $\quad 120$

67 Cup, Triptolemos Painter, Paris, Louvre G 138, view of the inside (Knauer 1996, 222, pl. 1) 122

68 Cup, Florence $395^{\circ}$ (photographs Museo Archeologico Etrusco)
a. tondo image
b. outside image A: dancing women
c. outside image B: music lesson and sacrificial scene 
69 Cup, Makron, Berlin F 2290 (Frickenhaus 1912, 6 and 7)

a. outside image A: Dionysos idol

b. outside image B: dancing women $\quad 126$

Stamnoi, Villa Giulia Painter (Frontisi-Ducroux 1991, 73) 128

71

Stamnoi, various painters (Isler-Kerényi 2009b, $88 \mathrm{f.}$,

figs 1-6) 130

72 Stamnos, Phiale Painter, Museo Nazionale Archeologico, Naples 164332, (Oakley 1990, pl. 64). Su concessione del Ministero dei Beni e delle Attività Culturali e del Turismo-Soprintendenza per i Beni Archeologici di Napoli

a. side $\mathrm{A}$

b. side B

132

73 Stamnos, Phiale Painter, art trade, sides A and B (Oakley 1990, pl. 67) $\quad 133$

74 Stamnos, Phiale Painter, Warsaw, National Museum 142465, sides A and B (Frickenhaus 1912, 13) 134

Pelike, art trade, side A (Sotheby's, London 1995, 36 Nr. 72) $\quad{ }_{136}$ Skyphos, Lewis Painter, Moscow, Pushkin State Museum of Fine Arts II lb 6oo, sides A and B (cVA Moscow 4, pl. 39) 137 77 Bell krater, Kleophon Painter (?), Collection S. Rosignoli, London (photograph Nik Bürgin, reproduced with kind permission of Jean-David Cahn)

a. side $\mathrm{A}$

b. side $\mathrm{B}$ 139

78 Bell krater, Phiale Painter, Paris, Louvre G 422 (Simon 1963, pl. 7.5) $\quad 140$

79 Chous, Rome, Museo Nazionale Etrusco di Villa Giulia 50511 (photographs Soprintendenza per i beni archeologici dell'Etruria meridionale) $\quad 142$

80 Chous, Eretria Painter, Athens, National Archaeological Museum BS 319 (photograph National Archaeological Museum, Athens, Spelios Pistas) 143

81 Chous, Meidias Painter, New York, Metropolitan Museum of Art 75.2.11 (Richter 1936, pl. 158 a) $\quad 144$

$82 \quad$ Chous, artist from the sphere of the Dinos Painter, excavation number A 115 (Hatzidimitriou 2012, 121, fig. 4, drawing K. Delí) $\quad 145$ 
83 Calyx krater, Polygnotos group, Copenhagen, The National Museum of Denmark ABC 1021, side A (CVA Copenhagen 4, pl. $146 \mathrm{a}-\mathrm{b}) \quad 147$

84 Fragment of a stamnos, Hektor Painter, Brussels, Musée d'art et d'Histoire R 239 (CVA Brussels 1, III ID, pl. 1.2) 148

85 Calyx krater, Villa Giulia Painter, Karlsruhe, Badisches Landesmuseum 208, side A (cva Karlsruhe 1, pl. 19.1) 154

86 Calyx krater, group of Polygnotos, Tarquinia, Museo Nazionale Tarquinense RC 4197, side A (cvA Tarquinia 2, pl. 18.3) 155

87 Fragment of a calyx krater, group of Polygnotos, Tübingen, Institut für Klassische Archäologie der Universität 5439 (AE 1937, pl. 1) $\quad 156$

88 Cup, Kodros Painter, Würzburg, Martin von Wagner Museum der Universität $\mathrm{H}$ 4616, inside image (Avramidou 2011, pl. 21a) $\quad 157$

$89 \quad$ Volute krater, Curti Painter, Ferrara, Museo Archeologico Nazionale di Spina 2897, scroll showing both sides (Aurigemma 1960, pl. 22a) $\quad 159$

Parthenon, metope east 2: Dionysos' Gigantomachy

a. plaster cast, Basel, Skulpturhalle (Berger 1986, pl. 40e)

b. reconstruction by Praschniker (Praschniker 1928, 192, fig. 119) $\quad 165$

91 Parthenon, east pediment, Dionysos. Plaster cast in the archaeological collection of the University of Zurich, made before 1871

a. frontal view of the head (photograph Archäologisches Institut der Universität Zürich, Frank Tomio)

b. profile view of the head from the left (photograph Archäologisches Institut der Universität Zürich, Frank Tomio)

c. Dionysos (reconstruction by C. Isler-Kerényi) $\quad 169$ Handle of a bronze mirror, Copenhagen, The National Museum of Denmark 4833 (photograph museum) $\quad 170$ Coins from Naxos (Sicily)

a. didrachma: Apollo (Franke/Hirmer 1972, pl. 4 above left)

b. tetradrachm: Dionysos (Franke/Hirmer 1972, pl. 4 above right) $\quad 172$ 1993, 32, fig. 5) 
95 Parthenon, east frieze, detail with Hermes, Dionysos, Demeter, and Ares. Plaster cast in the archaeological collection of the University of Zurich, made before 1871 (photograph Archäologisches Institut der Universität Zürich, Frank Tomio) $\quad 178$

$96 \quad$ Kalpis, workshop of the Pronomos Painter, Pella, Archaeological Museum 80514 (Drougou 2000, pl. 35.1) 181 Kalpis, St. Petersburg, State Hermitage Museum П 1872.130 (Pfuhl 1923, 246. fig. 604) 182

98 Stamnos, Dinos Painter, Naples, Museo Archeologico Nazionale 2419

a. side A (FR pl. 36)

b. side B (FR pl. 37 below) $\quad 185$

99 Dinos, Dinos Painter, Berlin, Staatliche Antikensammlungen, Preussischer Kulturbesitz F 2402 (Furtwängler 1883-87, pl. 56-57)

a. side A: Dionysos

b. side B: thiasos $\quad 186$

100 Volute krater, Dinos Painter, Bologna, Museo Civico Archeologico 283 (AD I, pl. 36)

a. side A: Dionysos and Ariadne watching the thiasos

b. side B: Hephaistos riding towards Hera 188

Calyx krater, Dinos Painter, Kunsthistorisches Museum, Vienna 1024, side A (CVA Kunsthistorisches Museum, Vienna 3, pl. 105.2) $\quad 190$

102 Volute krater, Kadmos Painter, Ruvo, Museo Jatta 1093, scroll showing side A between parts of side B (FR Text II, 329, fig. 107) 191

103 Calyx krater, Kadmos Painter, St. Petersburg, State Hermitage Museum 0.28 (St. 1807), side B (old photograph from the Archäologisches Institut der Universität Zürich) 193

104 Chous, Eretria Painter, Basel, Antikenmuseum Basel und Sammlung Ludwig BS 407 (Lezzi-Hafter 1988, pl. 134) 197

105 Squat lekythos, Eretria Painter, formerly Berlin F 2471 (Furtwängler 1883-87, pl. 55) 200

106 Lid of a lekanis, Paris, Louvre G 445, details with Pentheus and Dionysos (Moraw 1998, pl. 23.57) 202

107 Kalpis, follower of the Meidias Painter, Karlsruhe, Badisches Landesmuseum 259 (B 36), detail of the lower frieze (Burn 1987, pl. 39) 203 
108 Volute krater, Pronomos Painter, Naples, Museo Archeologico Nazionale $\mathrm{H} 3240$

a. side A (FR pl. 143-4)

b. side B (FR pl. 145) 206

109 Calyx krater, circle of the Pronomos Painter, Madrid, Museo Arqueológico Nacional 11011, side A (CVA Madrid 2, pl. 10.2) $\quad 208$

110 Dionysos in Euripides' Bakchai (photomontage C. Isler-Kerényi) 215

111 Theater of Thasos, metope (BC $\mathrm{B} 4,1960,301$, fig. 1) $\quad 216$

112 Dionysos Sardanapalos, Rome, Musei Vaticani, Sala della Biga 2363 (Cain 1997, pl. 16) 219

113 Dionysos Kitharodos, west pediment of the temple of Apollo, Delphi, Museum 2380 (Croissant 2003, pl. 34, drawing K. Iliakis) $\quad 220$

114 Various statues of the youthful Dionysos, Roman Imperial period (Cain 1997, 78 above left) 221

115 Pelike, St. Petersburg, State Hermitage Museum St. 1793 (FR, Text II, 47) 224

116 Calyx krater, Athens, National Museum 1376, two views of side A (Schefold 1934, pl. 46, no. 205) 225

117 Calyx krater, Zürich, Archäologische Sammlung der Universität 3926 (photographs Archäologisches Institut der Universität Zürich, Silvia Hertig)

a. side A: arrival of Dionysos

b. side B: pair of Dionysiac men 227

118 Bronze krater from Derveni, Thessaloniki, Archaeological Museum B 1 (photographs Archaeological Museum of Thessaloniki)

a. side A: Dionysos and Ariadne

b. side view (right): Astion(?)

c. side B: bacchantes

d. side view (left): bacchantes 230 


\section{Abbreviations}

AA Archäologischer Anzeiger

ABV J.D. Beazley, Attic Black-figure Vase-Painters. Oxford 1956

AD Antike Denkmäler. Deutsches Archäologisches Institut. Berlin 1887-1931

Addenda Beazley Addenda ${ }^{2}$. Additional References to $\mathrm{ABV}, \mathrm{ARV}^{2} \&$ Paralipomena, compiled by T.H. Carpenter at the Beazley Archive. Oxford 1989

AE Archaiologiké Ephemerís

AJA American Journal of Archaeology

AM Mitteilungen des Deutschen Archäologischen Instituts, Athenische Abteilung

AntK Antike Kunst

ARV J.D. Beazley, Attic Red-figure Vase-Painters² ${ }^{2}$ Oxford 1963

ASAtene Annuario della Scuola Archeologica di Atene

BA Beazley Archive Pottery Database

BABesch Bulletin Antieke Beschaving

BAR British Archaeological Reports

ВCH Bulletin de correspondence hellénique

BICS Bulletin of the Institute of Classical Studies of the University of London

BSA Annual of the British School at Athens

CVA Corpus Vasorum Antiquorum

DNP Der Neue Pauly. Enzyklopädie der Antike

FR A. Furtwängler/K. Reichhold, Griechische Vasenmalerei. Munich 1904-1932

GL B. Graef/E. Langlotz, Die antiken Vasen von der Akropolis zu Athen. Berlin 1923-1933

JdI Jahrbuch des Deutschen Archäologischen Instituts

JHS Journal of Hellenic Studies

LIMC Lexicon Iconographicum Mythologiae Classicae

MAL Monumenti Antichi pubblicati a cura dell'Accademia Nazionale dei Lincei

MH Museum Helveticum

NAC Quaderni Ticinesi di Numismatica e Antichità classica

ÖJh Jahreshefte des Österreichischen Archäologischen Instituts in Wien 
Para J.D. Beazley, Paralipomena. Oxford 1971

RA Revue archéologique

REA Revue des études anciennes

ZPE Zeitschrift für Papyrologie und Epigraphik 


\section{Introduction}

The period that yields most of our knowledge about Dionysos is the $5^{\text {th cen- }}$ tury в. Scholars can draw on the texts of Herodotus, on the great tragedians, especially Euripides, and on the poets. The information, however, does not come from original sources, but from texts that came into being in later times and for manifold purposes - papyri from the Roman Imperial period or medieval manuscripts. Moreover, their coverage of the age is very irregular and almost all of them concern Athens. What they tell us should be seen against the background of the conventions and agendas of the literary genres of the time; they cannot offer us a complete picture of the significance of Dionysos for the people and the role he played in their everyday lives. The images of Dionysos and his world that Greek art puts at our disposal, however, are original witnesses of their time: the decorative sculpture of the buildings erected by the polis, the votive reliefs which, although privately commissioned, were very much part of public space, and the various decorated utensils. As will be seen, these, too, reveal only part of reality, albeit for different reasons than the written sources mentioned above. Nevertheless, they are indispensable for our understanding of Dionysos.

Clay vessels decorated with figures, many thousands of them, belong to this latter category. Those that concern us here were made in Athens during the $5^{\text {th }}$ and first half of the 4th century. Many of them have come to us via Italy, mainly from the Etruscan necropoleis. Although the wealthy and knowledgeable Italic clientele must have influenced the luxury ceramics produced at the Athenian Kerameikos, we may presume that the creators of the imagery were, first and foremost, guided by the values and interests of their own cultural milieu.

Thus decorated pottery not only provides us with material that is evenly distributed over the period in question and that may be dated relatively precisely, but also presents us with images that must have appealed to the needs and expectations of the anonymous Athenian consumers for whom it was produced. These images were meant for them and not for the modern beholder; because of a gap of two and a half thousand years and profound cultural change, we cannot presume to be able to spontaneously read and interpret them. We must approach them with great care, step by step, without expecting comprehensive and absolute interpretations. Much will remain unexplained or provisional. However, it is better to leave open the way towards future explanations, than to try to find unambiguous answers at all costs. 


\section{Dionysos in 6th-Century Imagery}

As the Dionysiac world of 5 th-century pottery developed from that of the previous age, we should first have a look at the Dionysos iconography from the beginning of the 6th century until about 520 BC. Apart from the usual representations of Dionysos as the god of wine, emotional eruptions and ecstasy, 6th-century pottery also yields a more differentiated image. In both centuries Dionysos was the god who allowed ecstasy - a vigorous extrication from oneself and the boundaries of one's day-to-day life. However, this was only possible because he at first represented these very boundaries; this, at least, is what the decorated pottery of the archaic period allows us to conclude. Compared to the many images of Dionysos surrounded by his (dancing) retinue, mythological scenes are rare. The latter, however, show him in the role of keeper of the order of Zeus and pacifier. ${ }^{1}$

The important stabilizing influence of Dionysos is apparent from three myths depicted in decorated pottery. Here he plays a significant role at a cosmic level. The marriage of Thetis and Peleus, which eventually led to the establishment of the authority of Zeus, became a subject as early as c. 580 вС. In this context, Dionysos is presented as the god who personally appealed to Peleus. ${ }^{2}$ From around 565 BC vase painters also credited the god of wine with bringing back Hephaistos to the Olympus. This frequently depicted episode resulted in the release of the queen of the gods and the restoration of her powers. ${ }^{3}$ And, like the other gods, Dionysos was actively involved in bringing about the victory over the rebellious giants which laid the foundation for the rule of the Olympians over the cosmos. ${ }^{4}$

Although Dionysos plays no active role in episodes such as the birth of Athena and the admission of Herakles to the Olympus, his presence among the gods makes it clear that he is seen as their equal and is not merely placed in a counter world. ${ }^{5}$ The role Dionysos had in the worldview of the original beholders of the images is that of keeper of the order of Zeus. This explains his prominent place in the Athenian calendar mentioned in antique literary sources. Although the festivals dedicated to him—including the accompanying

1 Isler-Kerényi 2007, $215 \mathrm{f}$.

2 Isler-Kerényi $2007,72-75$.

3 Isler-Kerényi 2007, 82-89.

4 Isler-Kerényi 2007, $96 \mathrm{f}$.

5 Isler-Kerényi 2007, 153 (birth of Athena); Mommsen 2002/2003, 25 (apotheosis of Herakles). 
dramatic performances-presented an opportunity for ritually controlled emotional eruptions, their eventual aim was to confirm the order of the polis. ${ }^{6}$

It is not so hard to transfer to a personal level Dionysos' role as protector of the continuity and stability of a system beset by crises. The day-to-day life of the individual within the community as well as the community as a whole is sustained by members who play distinct roles. These roles were determined by the gender, age, and social status of each individual. Gender is an invariable and social status, too, usually remained the same-with the exception of liberated slaves. Age, by contrast, is subject to unavoidable change. Over the generations, a community can, therefore, only function when it has the means to control the transformations and position shifts related to the aging process as well as the attendant personal crises. The Dionysiac imagery of the 6th century allows us to develop the hypothesis that the issue of age-related crises, like the crises acted out on the stage, came under the authority of Dionysos. ${ }^{7}$ Both on stage and in real life Dionysos first evoked a crisis and subsequently produced its solution in order to confirm the value of the established order.

The majority of the vessels decorated with images of Dionysos and his retinue were made to contain wine. They were mostly meant to be used at symposia, festive drinking parties that brought some diversion to the citizens' daily lives. Within normal day-to-day existence, the symposium stood for the nonstandard, the exceptional. It offered the participants the opportunity to step out of their usual role for a certain time and in a clearly defined space. It therefore functioned as a safety valve, and in this way benefitted the established order. The consumption of wine made it easier for the symposiast to cast off the role society had set for him, and to temporarily assume a different character. Thus, on the one hand, wine was the instrument of change. On the other hand, since wine is in itself the product of a process of change - the grape that turns into an intoxicating drink-, it served as a symbol of this particular experience and of the god who was supposed to be responsible for it.

Although in this way wine became the symbol of Dionysos, it would be a simplification to merely see him as the god of wine. ${ }^{8}$ His field of activity was much larger as it embraced both the human world and that of the gods. It also

6 Spineto 2005, 363 f. In addition see Rudhardt 1981, 9o: "Le calendrier religieux de la cité ménage un temps pour la possession bacchique-que d'ailleurs le rituel exalte mais discipline du même coup—de manière à la rendre possible sans dommage pour l'ordre social et bénéfique pour la communauté..."

7 Isler-Kerényi 2007, 60.

8 This is also the conclusion of Gould 2001, 282: "We cannot tidy him [i.e. Dionysos] up ... simply as 'god of wine' for men and 'god of possession' ... for women ..." 
went beyond vegetation, fertility of the soil, and the manufacture and consumption of wine. This extensive terrain explains why Dionysos was also close to those who were, in principle, excluded from the sphere of wine consumption, such as, for instance, women.

\section{The Retinue of Dionysos: Who are the Satyrs, Who are the Women?}

In recent years, we have become ever more aware of the significance of these questions for the understanding of Dionysos. ${ }^{9}$ In the process, it has become evident that our own cultural concepts and biases have strongly, and onesidedly, influenced our interpretation of the Dionysiac imagery.$^{10}$ Because of their hybrid appearance, satyrs - men with the ears, tails, and sometimes also the hooves of horses - were mostly seen as mythological beings who either dwell outside our familiar world or existed in a mythical age. ${ }^{11}$ Systematic study of the history of the satyr imagery from the beginning of the 6th century has, however, yielded a more ambiguous assessment. It is true that satyrs are present in the mythological episode in which Dionysos brings back Hephaistos to the Olympus. However, we also find situations where satyrs blended with the anonymous dancers of the present time, that is to say, where dancers behaved like satyrs, presented themselves as satyrs, and perhaps even felt they were satyrs. ${ }^{12}$ Their half-beast aspect should then be seen as a signal that these satyrs are men in an anomalous Dionysiac state; other scholars have come to comparable conclusions by different ways. ${ }^{13} \mathrm{~A}$ prominent sexuality is very much part

9 For a recent summing up of the issue, see Schöne-Denkinger 2008.

10 Lindblom 2011, 1-3.

11 See, for instance, Hedreen 1992, 180 in his 'Concluding Remarks': “... for one point on which all will agree is that the silens never really existed." In the same vein, surprisingly, Lindblom 2011, 125: “... satyrs, obvious creatures of fantasy ..." of a "mythological nature.”

12 Isler-Kerényi 2004a, 33 and 62.

13 Collinge 1989, 82: "Thus men apparently took delight in leaving behind their own personae and adopting temporarily the fantasy life of the satyr"; Lissarrague 1990, 235: “... the satyrs are antitypes of the Athenian male citizenry and present us with an inverted anthropoloy (or andrology) of the ancient city-state”; Bérard 1992, 16: “... derrière le satyre, sous le satyre, il y a l'homme..." Osborne 1997, 198 note 34 : "Some artists ... seem to have been very interested in the transformation of men into satyrs and women into maenads in the presence of Dionysos." Likewise Catoni 1998 (where the interpretation of Dionysos as "the Other" is, however, too limited) and 2010, 287; Moraw 1998, 105 and 2011, 241; Shapiro 2004; Smith 2007, 168: “... the satyr form safely distances masculine humanity from the negative associations", and 170: "a satyr is a stand-in for a human party mode..." Concerning the satyr play see, in addition, Voelke 2001, 408-412. 
of this exceptional state. In this context 'sexuality' does not mean 'fertility'an equalization typical for our own culture, shaped as it is by Christianity. Here, however, it is an expression of purposeless, playful vitality. ${ }^{14}$ In any case, it cannot be assumed that for the original beholders of the imagery, satyrs only existed in a mythical world that had nothing to do with the 'here and now'. The figure of the satyr seems rather to have served to, in a way, disguise the citizen taking part in the exuberant Dionysiac rituals. ${ }^{15}$

Moreover, from the history of the imagery it is clear that satyrs played a very special role in relation to Dionysos. They were, apparently, seen as the first ones to be aware of the god when he appeared, the ones who disclosed him to the beholders of the images. Despite, or because of, their prominent sexuality, they were considered the ritual intermediaries of the god. Apart from the erotic revelry with their female partners and their role as intermediaries in the encounter with Dionysos, the vase painters attributed an essential cultural contribution to the satyrs: the manufacture of wine. The images, however, do not make it clear whether the satyrs were meant to be seen as the ones who, in mythical times, first managed to make wine following the instructions of Dionysos, or whether ordinary 6th-century men engaged in wine production felt like satyrs or were somehow considered to be like satyrs. ${ }^{16}$ From this discussion of the iconographical situation of the 6th century we must, however, conclude that, contrary to our modern sense of logic, the original viewers of the images saw the satyrs as beings of mythological times as well as of their own time and recognized they were related to Dionysos in an existential way. ${ }^{17}$

Unlike the satyrs, with whom they often interact, the women surrounding Dionysos are (apart from one known exception $)^{18}$ physically no different from

14 Compare Parker 2011, 209: "Sexuality was fundamental to some aspects of Dionysiac cults too, though with the emphasis on potency or virility more than on procreation" and 210: "Fertility' was the catchall explanation of the past... Today we might be more inclined to think of conscious violation of decorous norms..." For the 18th-century origins of the dogma of fertility in the history of religions, see Humphreys 2004, 6. Compare also PaulZinserling 1994, 55: "Die zahlreichen erotischen Themen ... lassen ... den Schluss zu, dass die körperliche Liebe—zumindest für den Mann—als ein positiver Wert empfunden wurde..."

15 Jaccottet 1998 and 2003, 97. Compare Frontisi-Ducroux 1991, 173 and note 13.

16 Isler-Kerényi 2004a, 80 and 94.

17 Isler-Kerényi 2004a, 81: “... neither Dionysos nor the polis could do without the satyrs—or at least without the satyric element in the citizen-..."

18 Lindblom 2011, 146 and 269, fig. F: on a bell krater of around 440-430 with the return of Hephaistos (London GR 2000.11-1.31 [Colossus 15]: BA 213788 [no image]) the woman who follows Dionysos with oinochoe and torch seems to have the ears of a satyr. 
women of the ordinary world. ${ }^{19}$ What distinguishes them is merely their intimate relationship with the god himself, with the satyrs, or with both at the same time. This relationship is made explicit by the vase painters by way of special attributes, such as the thyrsos or the fawn skin, or by the depiction of certain behavior. They serenely stand before Dionysos and devoutly perform the ritual gestures. ${ }^{20}$ They dance together or with the satyrs, either in the god's presence or without him. They accept the sexual advances of the satyrs, or just flirt with them. ${ }^{21}$ However, contrary to a widely held notion, among the women surrounding Dionysos ecstatic dancers are clearly a minority. ${ }^{22}$

For that reason, the term maenad (a woman in a state of frenzy), which since Beazley has become a conventional designation for the women around Dionysos, does not apply to the majority of the cases. ${ }^{23}$ The term bakche (bacchante) would be more neutral and also more correct, all the more so because there already were bacchantes in mythical times, as Euripides impressively shows. ${ }^{24}$ On the other hand, in, for instance, the Homeric Hymn to Aphrodite and the famous volute krater by Kleitias and Ergotimos the female partners of the satyrs are nymphs. ${ }^{25}$ However, this designation is likewise ambiguous because it could refer to both mythical and human beings. ${ }^{26}$

Whatever one might call them, like the satyrs, Dionysiac women belong neither just to the mythical nor exclusively to the human world. In the context of the symposium, they could be identified with the hetaerae. ${ }^{27}$ In other, equally erotic, contexts they could be honorable married women. ${ }^{28}$ And, like

19 See also Lindblom 2011, 157-159, with full references.

20 Compare Vernant 1986, 298 who, apart from thiasos and ecstasy, also refers to other manifestations of the Dionysos cult.

21 For the behavior of the women vis-à-vis the satyrs, compare Lindblom 2011, 69: "In all, the multi-figured scenes make it clear to us that the women's diverse actions were contrasted to each other in different ways, probably as a means of emphasizing the ambiguity in the relation between the women and the satyrs."

22 Fahlbusch 2004, 79.

23 In what follows this term will, therefore, only be used for ecstatic dancers.

24 Bonansea 2008, 121; Lindblom 2011, 135. Compare Paul-Zinserling 1994, 15: "Immer aber kann die Teleté die Frau zur Bakche machen..."

25 h. Ven. $256-263$.

26 Isler-Kerényi 2007, 86 f. Bonansea 2008 discusses the issue of the designation of Dionysiac women on the basis of literary sources and vase inscriptions. Compare Heinemann 2000, 324: “... zwischen dem mythonomastischen Begriff 'Nymphe' und dem Terminus der 'Mänade' bzw. 'Bakche' ... kein inhärenter Widerspruch besteht."

27 Moraw 1998, 118 ff.; Neils 200o, 219-226; Villanueva Puig 2009b, 215.

28 Likewise Bérard 1992, 16-20, and Moraw 1998, 251. Compare Lindblom 2011, 139: “... we should not interpret the women's behaviour according to what we think was considered 
the satyrs, they too should be placed in the mental domain that is so difficult to grasp for the modern viewer-the domain that, on the one hand, belongs to ritual and, on the other, to vase painting. ${ }^{29}$ Characteristically, in this special domain gods and humans can be present together, because human beings who take part in a ritual assume the role of their mythical models and experience the presence of the divine. All the same, they are by no means in a mythical world. From this point of view, the large number of dancing women in the Dionysiac repertoire is symptomatic. ${ }^{30}$ Dance-in which one, needless to say, should include music - is the finest expression of a state beyond normal time, hovering between above and below.

It has now become clear to most scholars that the imagery does not seek to depict the real and tangible world of its creators and users, but their mental world, which only partly corresponded to the real one. The images were, therefore, supposed to evoke experiences brought about by ritual, or at least by extraordinary situations. For the original beholders of the images, this was obvious and natural; for us, however, looking at even the simplest vase painting requires a mental shift. ${ }^{31}$ We would be inclined, for instance, to interpret a thiasos image in a mythological way. We should take into account, however, that the original viewers would have associated it with a timeless state of bliss and, at the same time, with a ritual situation. In the second and third quarter of the 5 th century, ritual objects (altars, torches) are increasingly depicted. This does not mean, however, that the thiasos image has now simply evolved from the mythical world to the ritual present. The image rather enabled the original addressee to re-acknowledge the image and to simultaneously identify with a satyr or with a woman of Dionysos' retinue. ${ }^{32}$ In brief, when reading the

as decent or indecent behaviour for mortal women, especially when we cannot say what behaviour was considered to be decent or indecent for mortal women acting as a maenad" and, summarizing, 158 .

29 Isler-Kerényi 2004a, 79 f.; Sabetai 2011, 153 and 158: "Rituals and painted scenes ... belong to the same imaginary world."

$30 \quad$ Fahlbusch 2004, 76: "Das Thema 7 [i.e. the dancing woman without Dionysos, but with a satyr] gehört zu dem Frauentyp DIE TANZENDE, dem fast 50\% der mir vorliegenden Szenen zuzuordnen sind."

31 Compare Philippe Borgeaud, interpreting Rudhardt: “... il faut renoncer à nos manières de penser, pour raisonner en grec, en cernant les notions grecques dans leurs propres modes d'expression" (Rudhardt 2008, 14). For a meaningful scholarly attitude vis-à-vis the gap between our own way of thinking and that of Antiquity, see Versnel 2011a, 14-16.

32 On the relationship between life and myth and the identification of human beings with mythical figures, see Kerényi 1995, 30-32. 
Dionysiac imagery, the 'as well as' will bring us nearer to the original beholder than the 'either... or. ${ }^{33}$

\section{Dionysos in the $5^{\text {th }}$ Century, and his Transformation after 450 BC}

As we will see, the Dionysiac imagery of the $5^{\text {th }}$ century BC is at first very much marked by the developments of the archaic era. After 450 BC, however, a remarkable change may be discerned: Dionysos sheds his aspect of venerable father or spouse, and transforms into a youthful, often (almost) naked god. Our sources allow us to surmise that this transformation first took place at the Parthenon, this enormous representative building on the Acropolis of Athens, commissioned by the polis, erected by the architect Iktinos, and decorated with countless figures by the sculptor Phidias. After sixteen years of construction, it had been completed in $432 \mathrm{BC}$, and was now there for all to see. The pediment on the eastern side - that is to say: over the main entrance to the temple - contained a representation of the birth of Athena, patron deity of the city, from the head of her father Zeus, king of the gods and ruler of the cosmos. This world-shaking event was witnessed by the other gods, framed by the ascending chariot of the sun god Helios and the descending one of the moon goddess Selene. Of the majority of the figures, especially those of the central part of the pediment, only fragments remain. There is, therefore, much scholarly debate on the exact composition of the most important scene. ${ }^{34}$

33 What Versnel 2011a, 146 assesses for the history of religions, also holds true for iconographic research: “... the modern paradigmatic pressure manifest in the either-or approach has dangerously affected both the presentation and the solution of questions." To what dead ends our modern logic can bring us is illustrated by the conclusion of Schmidhuber 2007, 367: “... eine sichere Deutung muss offenbleiben.” Even more apodictic Carpenter 1997, 69 at the end of his chapter 'Dionysian Women': “... it is perhaps worth reiterating the point that aside from Semele and Ariadne, the female companions of Dionysos in fifth century Attic vases are never mortals." By contrast, we should approve of and keep in mind Paul-Zinserling 1994, 45: "Möglicherweise versagt... nur die Trennschärfe unserer modernen Optik, welche Sachverhalte, die für den antiken Betrachter ganz deutlich waren, im Unscharfen lässt," as well as Heinemann 2000, 340: “... gilt es nicht, eine Interpretation durch eine andere zu ersetzen, sondern lediglich einen von vielerlei möglichen Gedankengängen aufzuzeigen, die von Mythenbildern in der konkreten Situation des Symposions ausgelöst werden können."

Compare Ellinghaus 2011, 140: "Die Rekonstruktion der Gruppe ist jedoch rein spekulativ...." 
Among the attendant gods, only one figure has been almost completely preserved: that of a naked young man, reclining before the horses of Helios, and looking towards the south. Most specialists agree that this figure is Dionysos, because, from 420 BC at the latest, the representation of Dionysos in decorated pottery is very similar. We are, therefore, faced with the problem to establish the meaning of the transformation of a god who held such importance for both the city and the individual.

The written sources do not provide us with a decisive answer; as far as the sculptures of the Parthenon are concerned, we only have a paltry notice by Pausanias, who wrote in the 2 nd century AD. ${ }^{35}$ No reference is made to the sculptures in the records on Phidias, nor in those concerning Perikles, who commissioned them. Literary sources present Dionysos in various forms. He appears as a child in a small episode told by one of the heroes in the sixth book of the Iliad; ${ }^{36}$ he is a youth in the seventh Homeric Hymn (of controversial date), which relates his capture by Tyrrhenian pirates; ${ }^{37}$ he features as a youthful god in the Bakchai, Euripides' famous tragedy, which was first performed after the completion of the Parthenon, in 405 at the earliest. These literary manifestations of an early period are all the more remarkable in view of the fact that art before the transformation mentioned above, consistently depicts him as a mature bearded man. Anyhow, these manifestations demon-

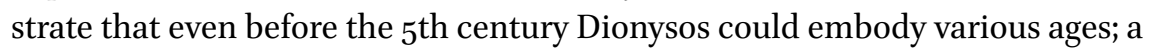
youthful appearance was, therefore, not an invention of Phidias or Perikles, but already part of Dionysos' person. It also helps to explain why this appearance was not only accepted by the vase painters and their customers, but received with enthusiasm.

In order to approach the meaning of the appearance of Dionsyos and the transformation it underwent, we can, it seems, only turn to the sources we do have at our disposal: pottery decorated with figures. We should, however, always be aware of the special nature of such pieces of evidence. The images are secondary to their carriers, the vases. The image can only be considered in relation to its carrier and we should be mindful of how and where the image carrier was used. In any case, the images spoke to the viewers at a more intimate level than the sculptures of a monument such as the Parthenon. ${ }^{38}$ Also, artistic pretentions must have been more modest. Nevertheless, we can clearly discern gradations, from the roughly executed images of cheap, mass-produced

\footnotetext{
35 Paus. I 24.5.

36 Bernabé 2013 .

37 Jaillard 2011, 133 note 2.

38 Also Moraw 2011, $25^{2}$.
} 
pottery, to those that were done with the utmost precision and skill for a particular occasion or on special commission. When interpreting the message of the images, these gradations must, of course, be taken into account.

Let us now have a closer look at the appearance of Dionysos in the decorated pottery of the $5^{\text {th }}$ century in order to determine (without pretense to completeness) the changes in his looks and his surroundings, and to see what the meaning of these changes could be. 


\section{Dionysiac Subjects in Red-Figure Pottery}

What Dionysos meant to the original buyers of vases decorated with figures produced in Athens may be deduced from the importance of Dionysiac subjects within the image repertoire. Such investigations are now facilitated by a most helpful tool: the Beazley Archive in Oxford. The following contentions and considerations are all based on the more than 80.000 Attic vases and vase fragments dating from the 7 th to 4 th centuries registered in that archive. ${ }^{1}$ The relation between this number and the amount of excavated pottery is unknown. In addition, the question of the ratio between the excavated items and the total production of the time is a matter of fierce debate. ${ }^{2}$ In any case, we cannot but assume that the number of vases unknown to us, is much larger than the number we know of, and this fact renders any statistics problematic. Nevertheless, the number of vases available to us through Beazley's inventories and the files of the Beazley Archive is large enough to assess the importance of Dionysiac subjects within the larger repertoire.

Dionysiac subjects, just like any others in the repertoire, were not applied in equal measure to every type of vase. Every scholar who is sufficiently familiar with figural Greek vase painting knows that, even though certain themes are found on all shapes, every shape also has its own preferred imagery, depending on the function of the vessel. Therefore, the frequency of a subject much depends on its appropriateness for the actual use of the carriers of the image. ${ }^{3}$

In the Athenian production of figure pottery, certain vase shapes are more common than others. Cups are by far the most numerous, with almost one third of the total production as known to us. Vessels for mixing wine and water come next; there are about half as many as there are cups. Already in the 6th century, however, a difference was made between the sumptuous, ornate and expensive volute kraters and the more modest column kraters. The calyx krater came into use around $540 \mathrm{BC}$, at a time when the image repertoire, too, saw

1 Personal communication from Thomas Mannack, 18 March 2013, for which I am most grateful. The black- and red-figure vases listed by J.D. Beazley constitute less than half of this number: according to Sparkes 1996, 94 and Mannack 2002, 19 this concerns around 10.000 black- and 20.000 red-figure vases (excluding the 5000 additions in Paralipomena).

2 Kratzmüller 2003; van der Put 2009, 38 (less than 1\%); Sapirstein 2013, online supplement 9 (c. $0,5 \%)$.

3 Schmidt 2005, 25 f.; for Dionysiac subjects in this perspective see Kästner 2008a. 
important innovations. The bell krater was only invented by the end of the 6th century at the earliest, for which reason all bell kraters are red-figure. In the first few decades, bell kraters were quite rare and their decorations often quite original. After about 440-30, however, they were produced in ever greater numbers; in the 4th century bell and calyx kraters were practically the only types of mixing vessels. Parallel to this development, the number of volute and column kraters sharply diminished after the middle of the century; around 400 ВС both types had virtually disappeared. The number of amphorae is less than a third of that of all types of kraters; that of the hydriai about a quarter, around the same amount as that of the oinochoai.

The share of the individual shapes varies over time and so does the total production itself. It steadily increases during the 6 th century as the Athenian market expands into Italy, peaks in the first half of the 5 th, and markedly decreases after about 430 BC. The latter can be easily explained by the economic and political crises Athens went through as a result of the Peloponnesian War. The peak production of the second quarter of the century reflects the political and economic heyday of Athens following the successful outcome of the Persian Wars. Remarkably, vase scholarship has so far given very little attention to the question what the one-year evacuation of $479 \mathrm{BC}$ (which took place as a reaction to the approach of the Persian armies), and the extensive damage to the city meant for pottery production. ${ }^{4}$

Let us now return to the significance of the Dionysiac subject matter. Regarding the vase shapes that will be discussed in this chapter-the cup; the amphora; the column, bell, and calyx krater; the hydria-, it should first be made clear that the human figures the original viewers of the imagery would most readily have identified with were not the Dionysiac figures, nor even the mythological ones, but the anonymous, prototypical ones. ${ }^{5}$ By far the most common among these is the figure of the beardless youth, followed by the anonymous woman and the bearded man. Men and youths are more often found on cups - the symposium vessel par excellence - than women, whereas women are the preferred figures to decorate the hydria, a type of vase that, more than cups and kraters, has female connotations. ${ }^{6}$

That these figures are anonymous does not mean they had no meaning or, as Beazley still contended, were mere space fillers. Closer consideration of, for instance, the youths wrapped in their mantles that are standard figures for the reverse side of column kraters has revealed that this motif most certainly

4 Isler-Kerényi 1977a, 38; Kunisch 1997, 21; Isler-Kerényi 2009a, 14.

5 For this term see Isler-Kerényi 2007, 111.

6 Schmidt 2005, 222. 
referred to a specific state of life and also that there could be concrete and meaningful links with the image on the main side of the vessel. ${ }^{7}$ However, as such figures excited less interest than the mythological ones, they have so far been little studied. ${ }^{8}$

As far as the cups and our three types of kraters are concerned, the prototypical figures are followed, be it at a considerable distance, by more specific Dionysiac subjects: Dionysos, satyrs, Dionysiac women, the komos and the symposium. ${ }^{9}$ Equally numerous, at least on cups, are anonymous athletes and warriors. These, on the other hand, were clearly not very popular for hydriai and amphorae, and even less for kraters. As for the mythological subjects, it is significant to distinguish between scenes with recognizable protagonists and general scenes depicting amazons, centaurs, and giants; the fights that took place in mythical times between heroes or gods and these adversaries are of a very special nature, and it is no coincidence that they were also often the subject of the sculptural decorations of temples. They represent the preconditions required for the current world order and are, therefore, of a more comprehensive character than single mythological events concerning only the individuals in question. Cups and kraters more often feature Dionysiac figures than other identifiable mythological figures-Eros, Herakles, Nike, Athena, and so on. This is the other way around for amphorae and, especially, for hydriai.

After what has been said about the relationship between vase forms and imagery, and taking the use of the vessels into account, it is not surprising that Dionysiac subjects are mostly found on cups. After all, these were, in the first place, meant to be used at the symposium. The fact that they were found in graves and must have been given as burial gifts does not at all imply that the people of the ancient world believed they were actually used by the dead. ${ }^{10}$ A much simpler explanation would be the surviving relatives' wish and hope that the cups would accompany their deceased to an afterlife as full of delight as a symposium. ${ }^{11}$ It should be mentioned that Dionysos himself is not the most-represented figure in Dionysiac imagery: satyrs are more numerous (a ratio of 6:1), as are dancing women (3:1). As groups of figures in motion are more attractive on the surface of a cup than stationary single figures, we

\footnotetext{
$7 \quad$ Isler-Kerényi 1993b and 1996.

$8 \quad$ Ferrari 1990; Langner 2012.

9 Because of their limited number, volute kraters may be left out of consideration. For the history and repertoire of the column krater, see Isler-Kerényi 1993b, 94-96.

10 This typically modern materialistic projection is still widespread.

11 See a comparable interpretation of the images of bliss on Roman sarcophagi by Zanker in Zanker/Ewald 2004, 177.
} 
usually find Dionysos surrounded by several members of his retinue. The fact that we find much more satyrs than dancing women may be explained from the notion that the symposium was primarily a male affair. It also explains why the cups present us with almost as many representations of komos and symposium as of satyrs; these were the two occasions that would have made

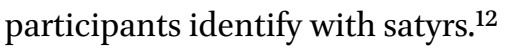

Parallel to the increase in the production of decorated pottery in the first

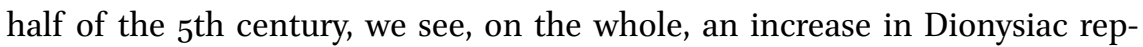
resentations. This again, however, mostly concerns depictions of satyrs and their dancing female companions, and to a much lesser extent the god himself. The increase in representations of komos and symposium should probably be linked to a peak in the demand for column kraters. During the second half of the century, however, the number of Dionysiac figures and subjects suffers a decrease of more than $50 \%$. The total number of vases of all types under discussion also dropped sharply, but this decrease was less than that in the Dionysiac imagery. At that time, especially after 430, mythological representations, too, went into a decline, while, simultaneously, we see a relative increase in the use of anonymous figures. This, like the reduction in the number of vase types already mentioned, is an obvious sign of the decline of red-figure pottery in general.

It would, however, be wrong to conclude that the interest in Dionysiac subjects had diminished, since Dionysos, Ariadne, satyrs and maenads are the most popular figures of the bell and calyx kraters of the 4 th century. ${ }^{13}$ These were now joined by Pan, who had, until then, only made sporadic appearances. During the centuries that followed (the Hellenistic period and the Roman Imperial period), he became an integral part of the Dionysiac thiasos. ${ }^{14}$ However, we definitely find fewer representations of the komos and symposium; kraters were no longer symposium vessels - they had developed into exclusive burial gifts, as had already happened in Greek Southern Italy and in Sicily. ${ }^{15}$ The mythological aura that surrounds Dionysos and his retinue was more suitable for this purpose than either komos or symposium. In this context, a comparison with the, less numerous, hydriai is instructive: here the komos does not appear at all and the symposium only sporadically. On the other hand, Ariadne, Dionysos, satyrs and maenads are only outnumbered by Aphrodite and, especially, Eros. A comparison with cups is equally interesting.

\footnotetext{
12 See above p. 4 f. and notes $13-15$.

13 Similarly Paul-Zinserling 1994, 12 f. and 46.

14 Schöne-Denkinger 2008, 45.

15 Pontrandolfo 1995, 194-195; De Cesare 2007.
} 
Bell kraters are evidently more numerous than cups, but there are twice as many cups as calyx kraters. Cups mostly show representations of anonymous youths, and also many anonymous women and athletes. With Eros and, less frequently, Nike, Dionysos, satyrs, and maenads are practically the only mythological figures. ${ }^{16}$ In the worldview of the original buyers of these types of pottery, who no longer lived in Etruria, but in Greece, Spina, Magna Graecia and on the Black Sea, Dionysos is clearly taking a dominant position.

16 Pellegrini 2009, 201; Lissarrague 2013, 238. 


\section{Dionysos for Athens, Dionysos for All Dionysiac Pottery around 5 oo BC}

\section{Late Black-Figure Vases}

When speaking of Greek decorated vases of the $5^{\text {th }}$ century BC, we usually think of those produced with the new red-figure technique, invented around $5^{20}-515 .{ }^{1}$ At the time of the first two generations of red-figure pottery, however, most vases were still traditional black-figure ones. Furthermore, it is clear that the various vase types were produced in different quantities, different average qualities, and, we may presume, at different prices. Almost half of the late black-figure vases are lekythoi, and about one fifth are cups. We have significantly less large, closed vessels than cups, and among these neck amphorae are most numerous; hydriai constitute about one third of the amphorae. Kraters are least numerous. Lekythoi and cups are mostly of poor quality, the decorations executed quickly and carelessly. The amphorae are of a much better quality although they, in their turn, are inferior to the hydriai, which were, apparently, the most valuable vases produced with this technique. ${ }^{2}$

Dionysos and his world is by far the most common subject for late blackfigure vases. ${ }^{3}$ It even exceeds that of the anonymous women, warriors, youths and men. This may have to do with the fact that kraters, which often feature such anonymous figures on their reverse, are much better represented in redfigure than in black-figure production. No other god, not even Athena, has a comparable presence in the mental world of the users of this pottery, and the same may be said of the most popular among the heroes, Herakles. Naturally, Dionysos' mother Semele and partner Ariadne should be included in his world, although we should discount representations of Ariadne's role in the contest between Theseus and the Minotaur. Mostly, however, the world of Dionysos is evoked by dancing maenads and, especially, satyrs: their number exceeds that of Dionysos himself as well as that of the dancing women. Because of the smaller number of kraters, representations of the komos (i.e. groups of dancing men) are less frequent, as are depictions of the symposium, subjects that refer to situations where Dionysos was felt to be present through the wine.

1 For setting the date of invention somewhat later than usual, see Rotroff 2009, 256.

2 Brunori 2006, 255 .

3 Villanueva Puig 2009b, 175 and 209. 
Most late black-figure Dionysiac representations are found on lekythoi. This was by far the most-produced vase type of the decades just before and after 500 BC, and Dionysiac subjects formed its preferred imagery. ${ }^{4}$ This is also important in view of the fact that these lekythoi were much less frequently exported than, for instance, cups, kraters, amphorae, and especially hydriai; they were, apparently, in principle meant for local customers. This indicates that, at least as far as the occasions associated with the use of lekythoi were concerned, Dionysos and his retinue held an important place in the mental world of the Athenians of the time. As perfume phials, lekythoi were used in the home; they were also used at the symposium and as votive gifts in sanctuaries. Most lekythoi known to us, however, were found in graves. ${ }^{5}$ Plentiful finds from Athenian graves confirm that Dionysiac imagery must have been considered very appropriate for this purpose. ${ }^{6}$ This holds especially true for a group of lekythoi showing women performing a ritual around a kind of Dionysos idol, which will be discussed below in the context of domestic ritual. ${ }^{7}$

The black-figure lekythoi produced between 510 and 480 BC and afterwards were clearly meant for a broad clientele. A recent study concerning the figure of the maenad, which discusses 910 specimens, enables us to have a closer look at their Dionysiac iconography. ${ }^{8}$ Dionysos is depicted standing among his retinue, striding, riding, reclining on the symposium couch, and sittingan attitude he, incidentally, assumes on many late black-figure cups. He may, therefore, have been imagined as a stable presence, but also as a sudden manifestation. Several image types show him with a woman, standing quietly before him, lying with him on the couch, or sitting next to him. As is already the case in earlier stages of Dionysiac iconography, this figure may be clearly distinguished from the women who, with or without satyrs, dance around the couple. She is, therefore, not a maenad, but it is not clear whether she is supposed to represent Ariadne, Semele, or an anonymous woman who approaches the god or shares the delights of the moment with him. After all, in the imaginary world of the vase painters there was nothing unusual in gods and humans appearing together. The same holds true for the image of a woman mounting a chariot in a Dionysiac context, a metaphor for death as a departure on a voyage, possibly with the aim of Bacchic fulfillment.

4 Similarly van de Put 2009, $39 \mathrm{f}$.

5 Schmidt 2005, 31 f.; Lynch 2011, $139 \mathrm{f}$.

6 Villanueva Puig 2009a, 218 f.; van de Put 2009, 41.

7 Frontisi-Ducroux 1991, 101-135. See below chapter 6.

8 Villanueva-Puig 2009b, 189-205. 
A very frequent type (almost $25^{\circ}$ examples) is that of Dionysos among his dancing retinue of satyrs and maenads, or only maenads. The image is brought back to its essence with a single woman dancing before the seated god, who may be flanked by two seated women raising a hand in a gesture of greeting. With almost 400 examples the most frequent motif is the thiasos of dancing satyrs and maenads without Dionysos. It is often enriched by erotic elements, such as an amorous pursuit, a maenad carried off on the shoulders of a satyr, or satyrs approaching a sleeping maenad for evident purposes.

Another group are the representations of Dionysiac women dancing or standing in a space that, through the presence of an altar, a mask, or a louterion on a pedestal, is roughly characterized as 'cultic'. It is impossible to establish if the quite often depicted motif of a figure riding on a mule, surrounded by satyrs or only by vines, refers to Hephaistos or to a corresponding ritual for which no further evidence happens to exist. ${ }^{9}$ In this context it is well
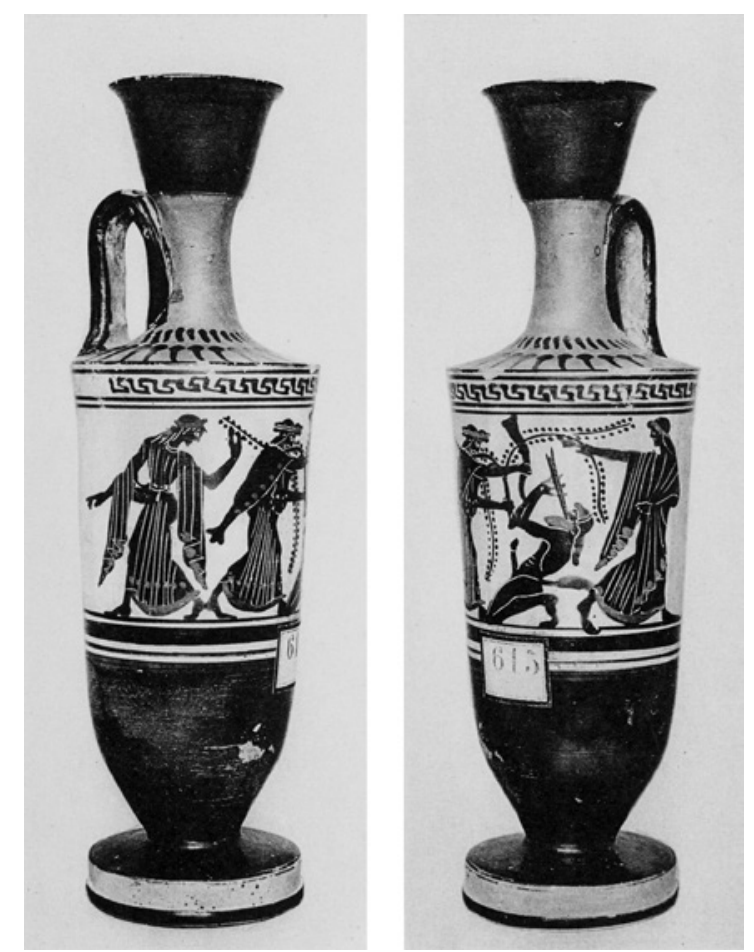

FIGURE 1 Black-figure lekythos, Athens, National Museum 615 (Haspels 1936, pl. 38.5).

9 Isler-Kerényi 2004a, 50. 
to remember that mules, asses and other mounts (belonging to Dionysos himself or to Dionysiac women or satyrs) are often found in this kind of imagery. ${ }^{10}$ The precise meaning of such images, however, remains unclear. In any case, they refer to the accessibility of the Dionysiac world to beings from the infinite wilderness that surrounds the ordered sphere of human culture. Obviously, Dionysiac representations of this kind cannot be related to any specific mythological or cultic event. They rather refer to the limitless life in the sphere of Dionysos' power.

Four situations characteristic of the relationship between Dionysos and the women and satyrs stand out among the Dionysiac imagery of late black-figure lekythoi: the carefree rapture of euphoric dance, the encounter with the god, the departure on a voyage, and the state of bliss evoked by the motif of the symposium (Figures 1-4). As we will see, the repertoire of the late black-figure painters is not substantially different from that of their colleagues who at that time worked in the red-figure technique. It is, however, of a lower artistic level, if only for the outmoded technique. There are few remarkable images; the paintings mostly reproduce the usual motifs in a cursory manner. Nevertheless, they never give the impression of being mere empty formulae. The prospective buyers may have been simple, humble people - when it came to taking leave of their loved-ones, they seem to have made a well-considered choice from what was on offer at the Kerameikos.

Because of their shape and size, the contemporaneous black-figure hydriai are much more distinguished vessels. They were frequently brought to Etruria and were widely found in graves. Compared to other mythological scenes, Dionysiac subjects seem to be much less dominant here. On the other hand, the motif of a fine chariot, with mythological (including Dionysiac) or anonymous figures in attendance, was very popular (Figure 5). ${ }^{11}$ It enabled the painter to employ an appealing form to evoke heroic elevation or death-as-departure, depending on occasion and use. In any case, both in Athens and in Etruria, production was aimed at the higher social strata.

\section{Early Red-Figure Vases}

The so-called Andokides Painter, named after his regular potter who signed with this name, is said to have been the inventor of red-figure technique. He may well have been the first to work in this new technique, not only because

\footnotetext{
10 Villanueva-Puig 200gb, 182 f., and 197.

11 Schmidt 2005, 232 f.; Brunori 2006, 253 f.
} 

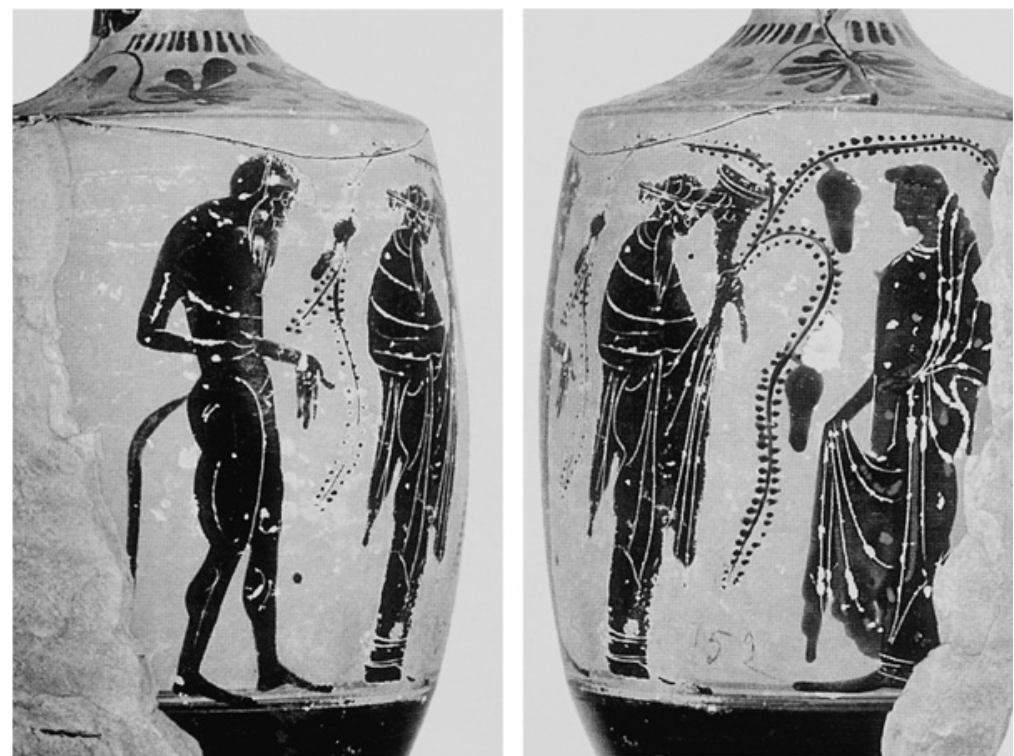

FIgURE 2 Black-figure lekythos, Paris, Louvre ELE 152 (cVA Louvre 28, pl. 5.4-5).

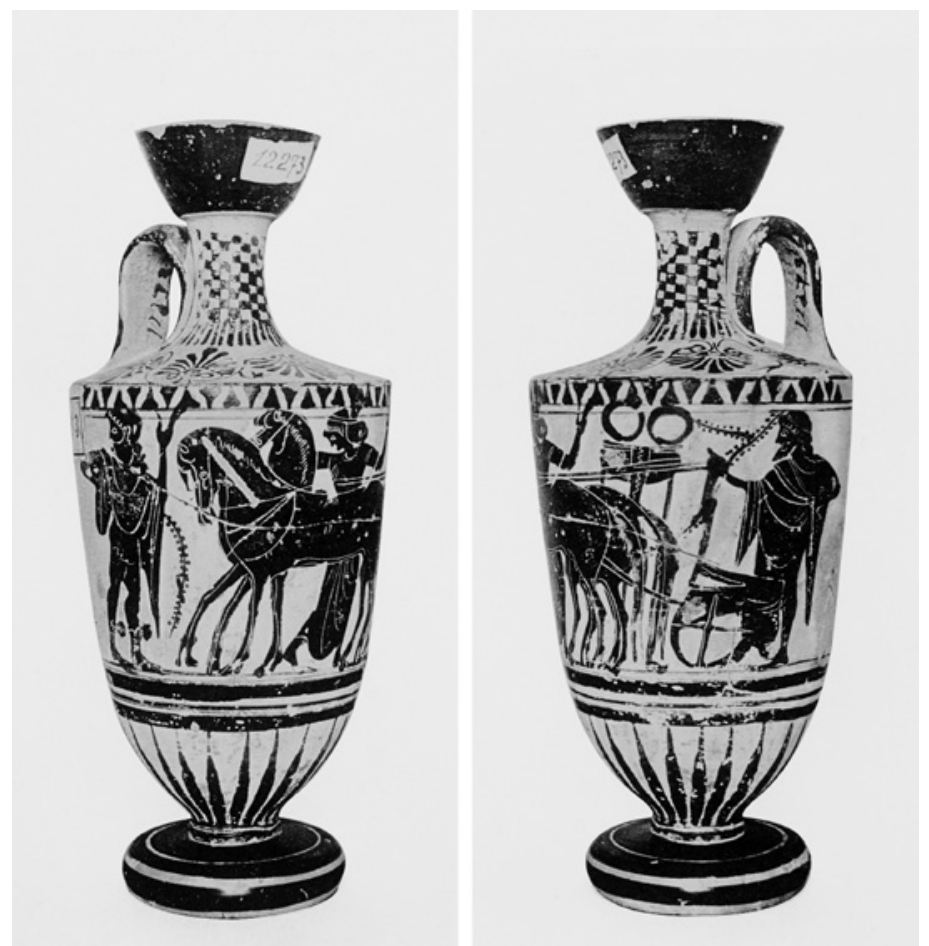

FIgURE 3 Black-figure lekythos, Athens, National Museum 12273 (Haspels 1936, pl. 30.2 a-b). 

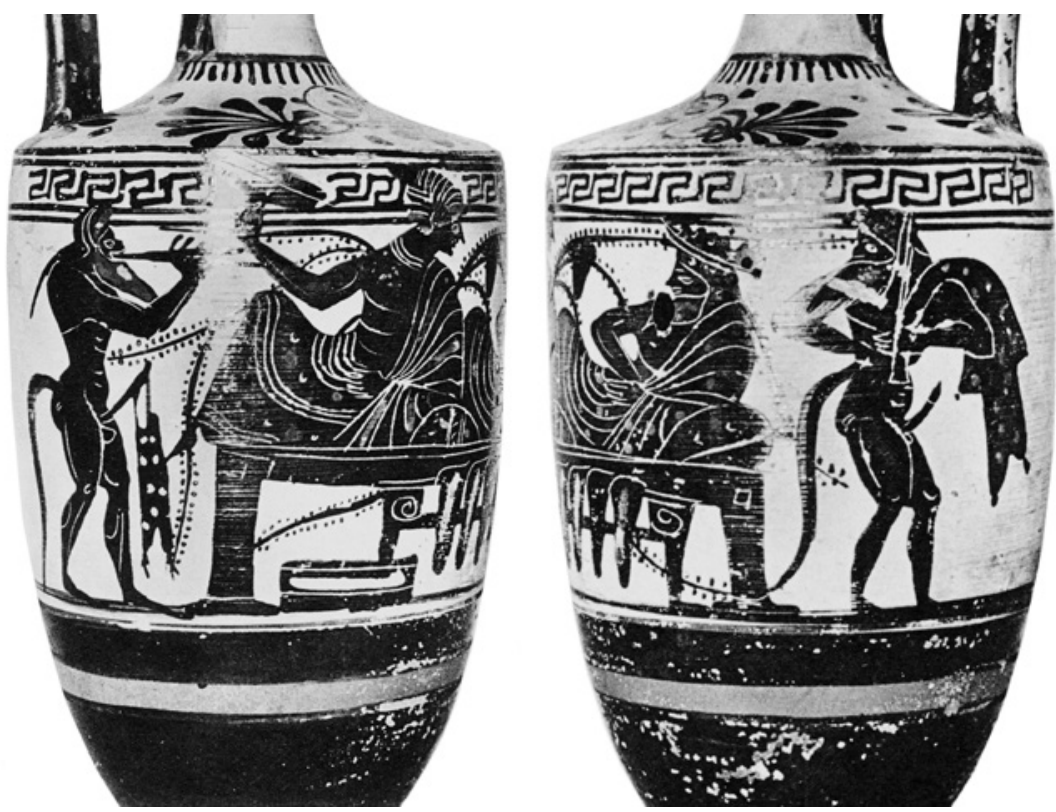

FIgURE 4 Black-figure lekythos, Athens, National Museum 541 (Haspels 1936, pl. 23.2 a-b).

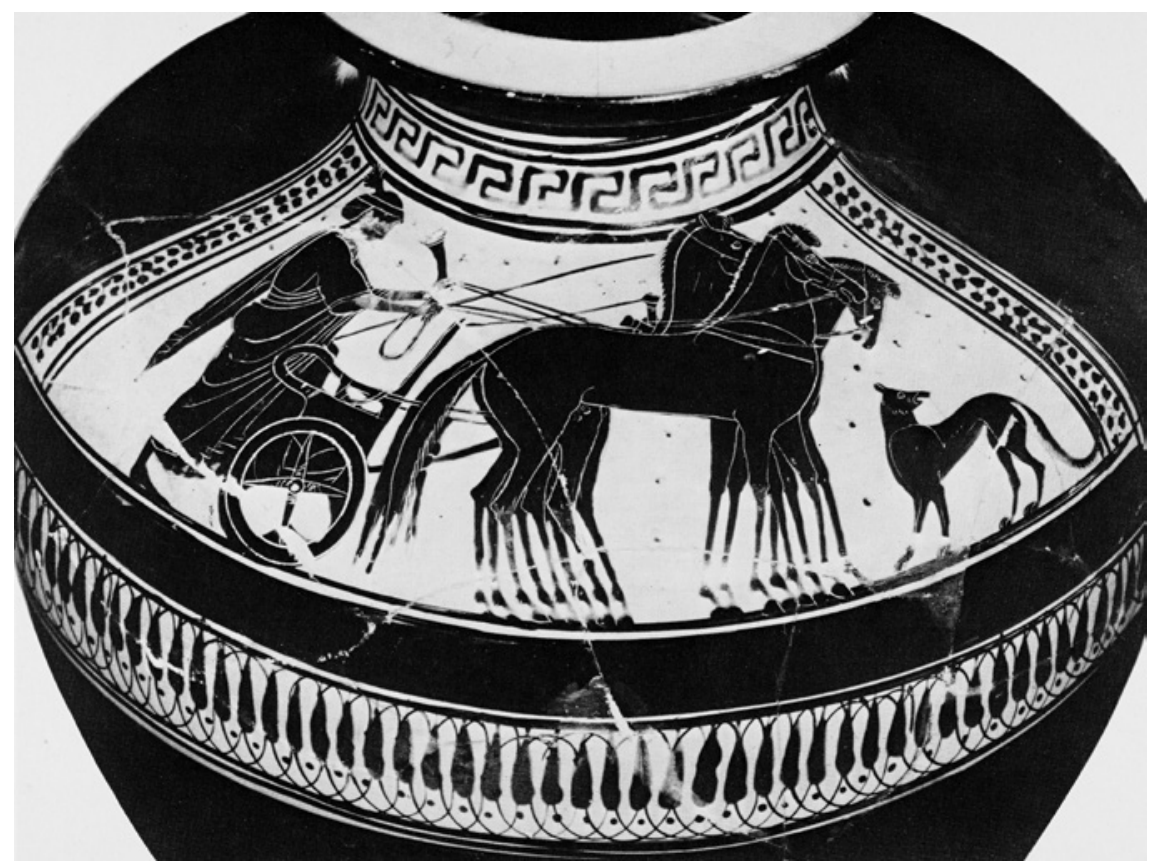

FIGURE 5 Black-figure kalpis, Hamburg, Museum für Kunst und Gewerbe 19o8.253 (cVA Hamburg 1, pl. 27.3). 
stylistically he can be placed in its incipiency, shortly after $520 \mathrm{BC}$, but also because he decorated one side of a series of belly-amphorae in red-figure technique while leaving the other side to his colleague, the Lysippides Painter, who worked in black-figure. ${ }^{2}$ Three of these 'bilingual' amphorae show the same motif on both sides. ${ }^{13}$ They may have been meant to point out the advantages of the new technique to the customers.

Before we turn to the Dionysiac images of this painter and his contemporaries, their preferred medium, the belly-amphora, should be discussed. It may be described as a large, closed vessel with two handles and a continuous curve: there is no indentation between neck and belly. Ever since its beginnings in the late 7 th century it was considered a deluxe vase type and rather costly. This would explain why, from the middle of the 6th century, many belly-amphorae were exported to Etruria. Let me quote Ingeborg Scheibler, who devoted a ground breaking study to this vase type: "Leading potters and vase painters used this form to demonstrate their skill, and it was one of the most important Attic vase types until well into the 5 th century". ${ }^{14}$ It is, therefore, no coincidence that Beazley, whenever possible, began his lists of the works of individual painters with this vase type. On the basis of the shape of the mouth, the handles, and the foot, he distinguished three subtypes-A, B and C. ${ }^{15}$ From depictions of amphorae in vase paintings we may infer that the large and consequently heavy belly-amphora was mainly used as a storage vessel for agricultural produce, such as oil, wine, and seed; it was not very suitable for transport. ${ }^{16}$ From a symbolic point of view the belly-amphora stood for wealth and status, and could therefore, on the one hand, serve as a representative grave gift, and, on the other, be employed in a cultic context. More than any other vase type, the belly-amphora refers to the citizens and the concept of the polis-something that is already evident from its black-figure imagery. ${ }^{17}$

From about $560 \mathrm{BC}$, the belly-amphora was part of the product range of the three leading black-figure painters, Lydos, the Amasis Painter, and Exekias, and, with the invention of red-figure technique, of that of Exekias' pupil, the Andokides Painter. As we will see, the belly-amphora also played an important

\footnotetext{
12 ARV 4. 7-12.

13 Addenda 149 f. $(4 \cdot 7,9,11)$.

14 Scheibler 1987, 59: "Führende Töpfer und Vasenmaler wiesen sich mit dieser Form aus, die bis in das frühe 5. Jahrhundert hinein zu den Leitformen der attischen Vasenkunst gehörte."

15 Beazley 1922, $70 \mathrm{f}$.

16 Scheibler $1987,63-72$.

17 Isler-Kerényi 2007, 108 f. and 121.
} 
role in the work of some of the most prominent members of the next generations of vase painters, such as Euthymides, the Kleophrades Painter, and the Berlin Painter. After $48 \mathrm{o} \mathrm{BC}$ the production of this vase type declined sharply and by 400 BC it had almost completely disappeared..$^{18}$

Her analysis of the image repertoire of the belly-amphora enables Scheibler to identify a common denominator for the anonymous and mythological representations of young men, horses, and chariot rides: that of the celebration of the citizen's entry into adulthood. Her evaluation of the 730 vases of this type in Beazley's inventory shows that, among the mythological figures, Herakles is the most popular role model for young Greek men, but it is rather striking that Dionysos comes in second place and even leaves the polis goddess, Athena, far behind him. ${ }^{19}$ Scheibler explains this in the following way: "When Dionysos is represented on vases of this type, he should be seen as the patron of the young, of the succession of generations, of the development of human society."20 This explanation ties in with the conception of Dionysos proposed in our introductory chapter: the god who, both in the case of the individual and that of the polis community as a whole, controlled the critical transition from one age group to the next as well as the attendant changes of identity. ${ }^{21}$

Three of the Andokides Painter's belly-amphorae have Dionysiac subjects; one of these, rather ill-preserved, has as its central image the bearded god playing the kithara, which is unusual in Dionysiac iconography. ${ }^{22}$ He moves to the right, towards a woman with libation vessels, and turns his head to observe two satyrs playing piggyback — all in all an original, albeit enigmatic, combination. Another amphora has on its black-figure side a depiction of Herakles fighting the Nemean lion in the presence of Athena, attributed to the Lysippides Painter. Its red-figure side, however, shows a solemn encounter: a young woman, richly dressed, with a budding flower in her right hand and a kithara in her left hand, approaches the standing god, who is of a larger stature. He receives her with his usual attributes, the kantharos and the branches of vine shoots and ivy. The scene is framed by two satyrs standing on either side, the one on the left with an aulos (Figure 6). ${ }^{23}$ Is Dionysos welcoming the beautiful musician to his world?

\footnotetext{
18 Scheibler 1987,88 and 116 f. with fig. 39.

19 Scheibler $1987,89$.

20 Scheibler 1987, 118: "Wo Dionysos auf solchen Gefässen dargestellt ist, wäre er als Schutzgott der Jugend, der Geschlechterfolge, des Wachstums der menschlichen Gesellschaft zu verstehen."

21 Isler-Kerényi 2007, 59-62.

22 Orvieto, Faina 64: Addenda 149 (3.5); BA 200005.

23 Bologna 151: Addenda 150 (4.10); BA 200010.
} 


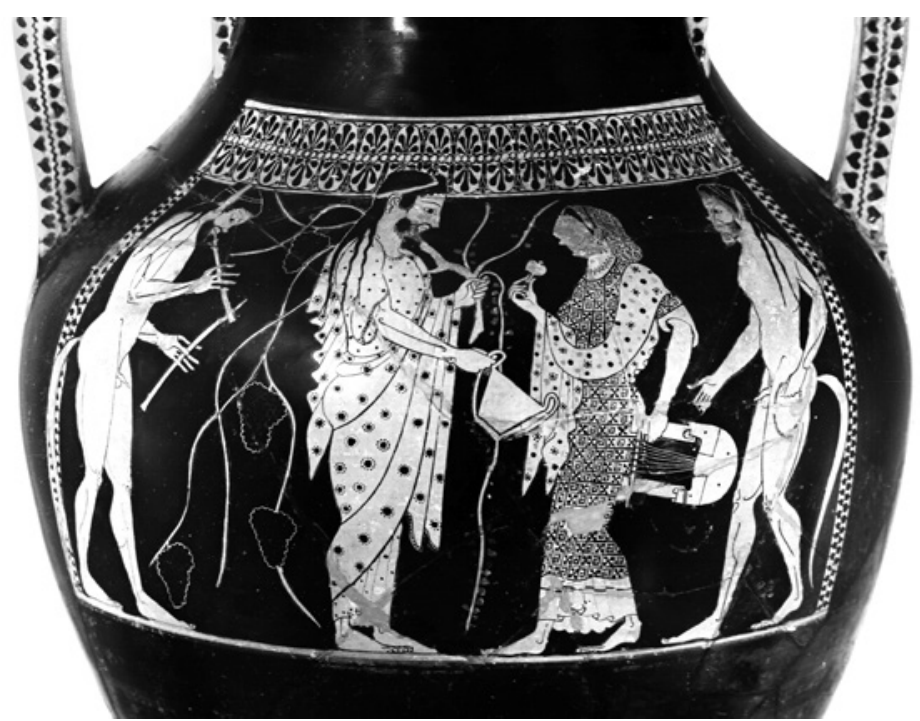

FIg URE 6 Bilingual belly-amphora, Andokides Painter, Bologna, Museo Civico Archeologico, 151. PHOTO: H. BLOESCH.

The third Dionysiac amphora is also bilingual. The side decorated by the Andokides Painter shows Herakles' encounter with Cerberus, with Athena in attendance. The black-figure side, decorated by the Lysippides Painter, has Dionysos as its central figure. He is wearing a wreath and has the kantharos in his right hand, the two branches in his left. A young woman, likewise wearing a wreath, greets him solemnly. She is ready to pour him wine from a raised oinochoe. On the right a satyr is approaching who carries a heavy wine sack; to the left a pair of satyrs adds the music of kithara and krotala. ${ }^{24}$

What may be the best-known of the Andokides Painter's bilingual amphorae on each side presents a symposiast with a kantharos reposing underneath a vine. On the basis of the weapons (sword, quiver, and bow) the one on the black-figure side can be identified as Herakles. That the symposiast on the redfigure side is Dionysos can only be gathered from his impressive size (Figure 7) ${ }^{25}$ This identification is supported by a further bilingual amphora, attributed to Psiax, who also worked in Andokides' workshop. On the red-figure side it

24 Louvre F 204: Addenda 150 (4.11); BA 200011.

25 Munich 2301: Addenda 149 (4.9); BA 200oog; Carpenter 1986, 98 note 2 presents iconographical arguments in favor of Dionysos, but finally reaches the conclusion the figure must be Herakles (p. 112). So does Wolf 1993, 18 f. although apparently unaware of Carpenter's discussion of the style of Dionysos' hair and beard in the work of the Andokides Painter. 


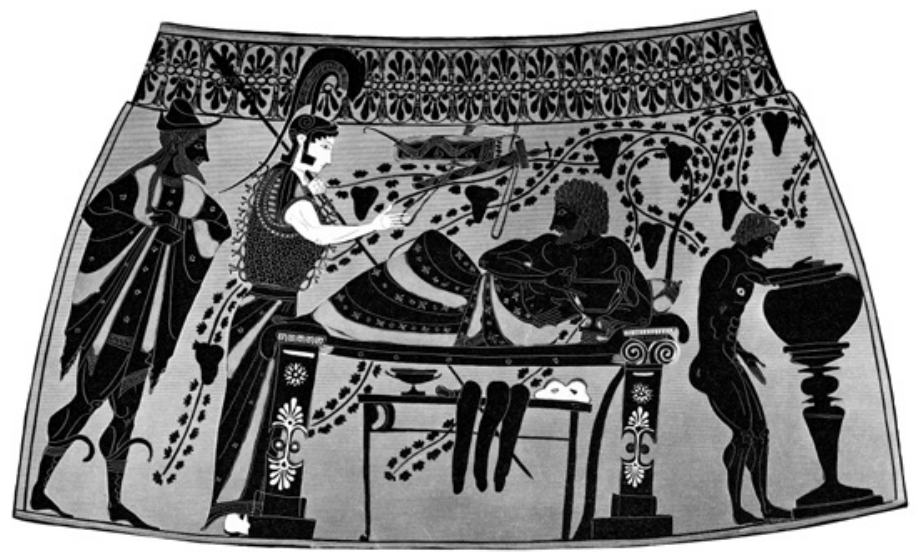

$a$

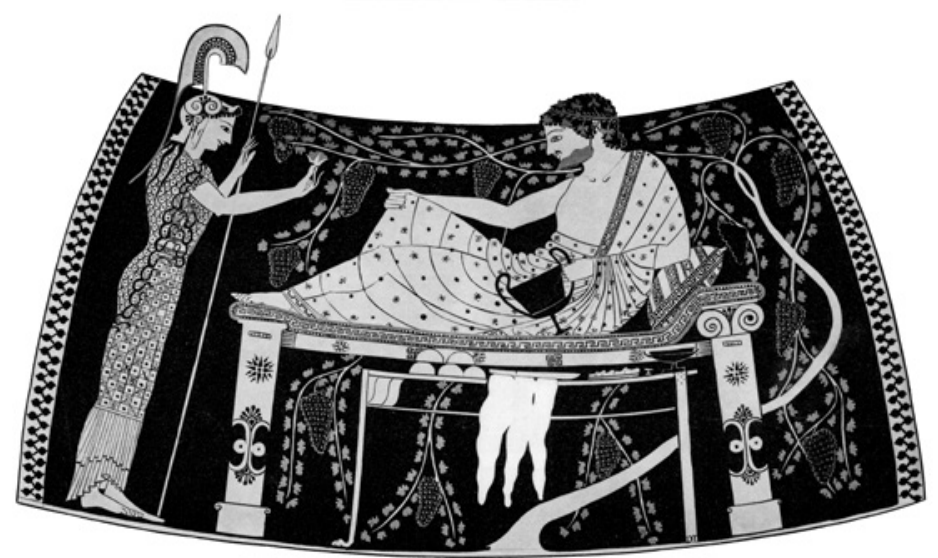

$b$

FIGURE 7 Bilingual belly-amphora, Andokides Painter, Munich, Staatliche Antikensammlungen und Glyptothek 2301.

a. Herakles (FR pl. 4 B).

b. Dionysos (?) (FR pl. 4A).

shows Dionysos reclining on the symposium couch, with a dancing satyr on the right, and a dancing maenad with krotala on the left. ${ }^{26}$ Carpenter's convincing proposition that the enigmatic circles underneath the couch are winding snakes could indicate that Dionysos here represents the hero's blissful state

$26 \quad$ Munich 2302: Addenda 150 (6.1); BA 200021. 


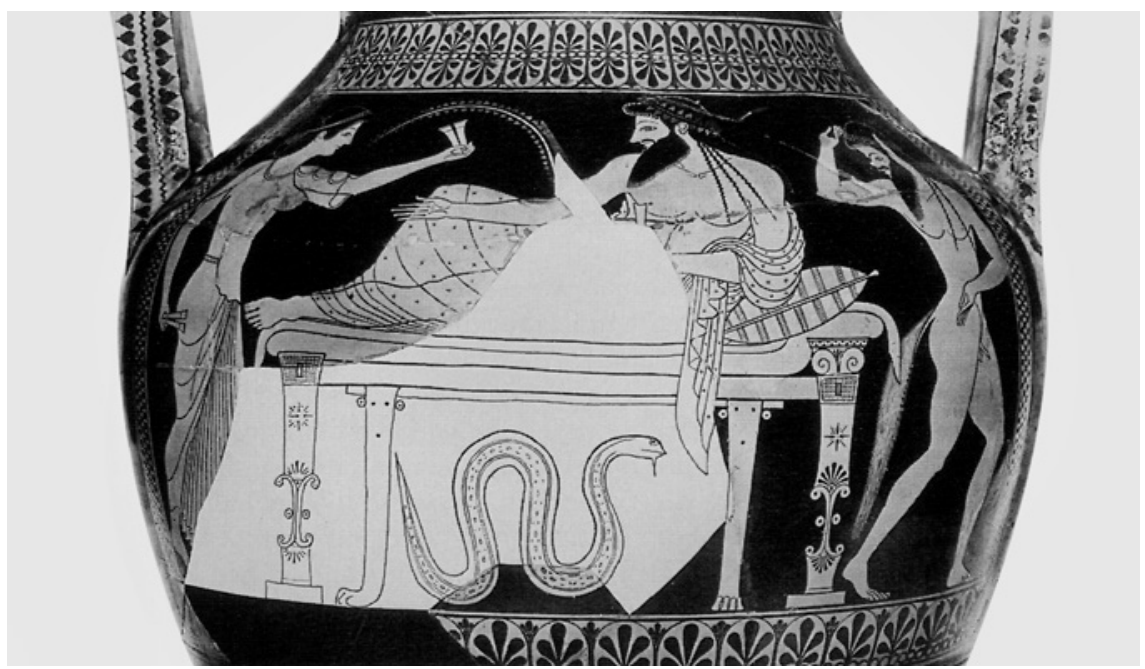

FIGURE 8 Bilingual belly-amphora, Psiax, Munich, Staatliche Antikensammlungen und Glyptothek 2302 (Carpenter 1995, 151, fig. 5).

after death (Figure 8). ${ }^{27}$ This would be in accordance with the black-figure reverse where we see Iolaos steering Herakles's chariot towards Hermes, as well as with the symposiast Herakles on the amphora by the Andokides Painter.

Another of Psiax' belly-amphorae has the Delian Triad and Ares on its redfigure side and an equally quiet scene on the other, black-figure one. ${ }^{28}$ It shows Dionysos, with kantharos and ivy branches, standing between two striding satyrs and two maenads with krotala. The image, although carefully executed, seems somewhat conventional. Remarkable, however, is the satyr standing to the left of Dionysos. The god looks round to him with lips half opened; the satyr, full face, looks out of the image, straight at the viewer. About two decades before, a very similar figure was used to confront the beholder of an amphora from Orvieto; this satyr, in addition, points his index finger at the god, in this way confirming his role as a mediator between Dionysos and humanity. ${ }^{29} \mathrm{~A}$, stylistically much weaker, neck-amphora of the same period testifies to the fact that this motif was taken over by painters working in the red-figure technique. ${ }^{30}$

Yet another bilingual belly-amphora was decorated by an artist, who worked carefully, though somewhat stiffly. It shows two dancing maenads,

\footnotetext{
27 Carpenter 1995, 150 f., fig. 5 .

28 Madrid 11008: Addenda 150 (7.2); BA 200022.

29 Isler-Kerényi 2004a, 43.

$30 \quad$ Boston 03.790: Addenda 151 (11.2); BA 200019.
} 
accompanying Dionysos who, with drinking horn and kantharos, moves solemnly to the right, next to him a vine and a fawn (Figure 9). Its black-figure side has Achilles and Ajax playing at dice. ${ }^{31}$

A young woman approaching Dionysos, framed by dancing satyrs, is very clumsily depicted on a hydria of the same period. ${ }^{32}$ An artistically equally mediocre hydria shows yet another motif; here all three figures-a maenad looking back towards the god, Dionysos with kantharos and ivy branch, and a satyr-move energetically to the right. ${ }^{33}$ The satyr is likewise looking back, which creates the impression of a procession with other participants following the ones depicted. The fact that the leader is a maenad reminds us of the distinct role of Dionysiac women wherever the god appears, which may already be discerned in the work of the Amasis Painter, a generation earlier. ${ }^{34}$

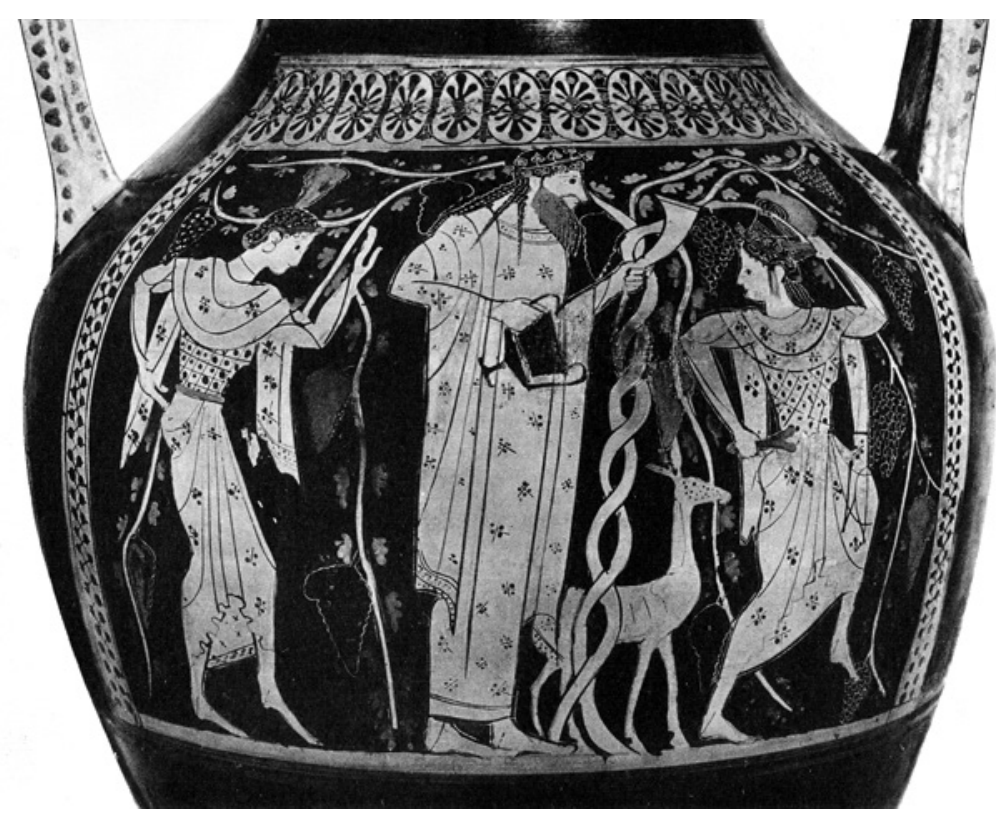

FIGURE 9 Bilingual belly-amphora, Munich, Staatliche Antikensammlungen und Glyptothek, 2300 (cVA München 4, pl. 160.1).

32 Munich 2418: Addenda 151 (12.7); BA 200054.

33 Munich 2419: ARV 12.9; BA 200057.

34 Isler-Kerényi 2007, 136.
} 
Thus, from the earliest stages of red-figure vase painting, the motif of the Dionysiac thiasos presents itself in various forms: a young woman approaching the god in a scene framed by satyrs; Dionysos appearing among satyrs and/or women; the god as a merry symposiast among his retinue; the Dionysiac procession. And, as was already the case with black-figure vases, one of the satyrs may, as it were, draw the viewer into the image and turn him into a participant.

Euphronios is, with Euthymides, the leading vase painter of the next generation, which was active around $510 \mathrm{BC}$ and is best known for its large-size, highquality products. ${ }^{35}$ Among these, the calyx krater is especially characteristic of Euphronios. This wide, goblet-shaped mixing vessel with its slightly thicker rim and solid foot, was probably invented by the potter Exekias only a few decades earlier. ${ }^{36}$ Like the volute krater-equally ambitious in concept, but less suitable for practical use during the symposium - it made great demands on both potters and painters and was, probably also for this reason, much sought after on the Etruscan market. More than any other vase type, the calyx krater offered the artist a surface which lend itself for large compositions and impressive figures. Mythological scenes of combat and death on the battle field on the one hand, and the Dionysiac thiasos and symposium on the other, were recurring subjects for calyx kraters from the beginning. ${ }^{37}$

It seems typical for Euphronios' artistic stature, that of the 54 vases attributed to him, 12 are calyx kraters-a number that is only surpassed by his 19 cups. ${ }^{38}$ We find Dionysiac scenes on three of Euphronios' calyx kraters. A very fragmentary piece with Herakles slaying the Nemean lion on its main side, has komasts in various imaginative attitudes on its reverse. ${ }^{39}$ Another calyx krater shows a splendid symposium on its main side, while on the reverse-in the background, so to speak - the wine is brought in and prepared for serving. ${ }^{40}$ Here we find a more elaborate contrast between main and reverse side than in Euphronios' earliest calyx krater, which opposes preparations for open air discus training and athletes with their small servants in an interior. ${ }^{41} \mathrm{~A}$ boisterous

35 The beginnings of the activities of Euphronios as given in Heilmeyer 1991, 46 and 52, should, on the basis of the findings of Rotroff 2009, be dated about ten years later. The stylistic evolution of his work as presented by Giuliani 1991 still stands, despite the time shift. Concerning Euphronios and his time, see Wehgartner 1992.

36 Boardman 1977, 203; Giuliani 1991, 20; Huber 1992, 58 f.

37 Kästner 2008, $58 \mathrm{f}$.

38 Heilmeyer 1991, 11; Huber 1992, 65-68.

39 Louvre G 110: Addenda 152 (14.3); BA 200065; Heilmeyer 1991, no. 2, 70-76.

40 Munich 8935: Addenda 152 (14.3bis); BA 275007 (no image); Heilmeyer 1991, no. 5, 88-92.

41 Berlin F 2180: Addenda 152 (13.1); BA 200063; Heilmeyer 1991, no. 1, 61-69. 
thiasos in the presence of Dionysos takes up both sides of a third calyx krater. ${ }^{42}$ On its main side the god, carrying vine branch and kantharos, moves towards the right in a lively manner. On both sides of him, maenads with thyrsos and krotala are dancing in opposite directions. Further to the right, a satyr, wine sack on his shoulder, leads the way. He looks back towards the god with the gesture of surprised acknowledgement that was already characteristic of blackfigure satyrs. ${ }^{43}$ Of the satyr in the rear, on the far left, only the lower part of the body remains; his gestures and his relation with the maenad are therefore unclear. On the reverse, two couples of satyr and maenad perform an exuberant dance to the sound of flute and krotala. The erect phallus of the satyr and the bare leg of one of the maenads indicate an erotically-charged situation.

We also find the komos motif in other vase types executed by Euphronios. The two images on the neck of his famous volute krater, for instance, show nineteen energetically moving komasts of various ages, with musical instruments and wine vessels. ${ }^{44}$ Other examples may be found on fragments of the reverse side of a stamnos, ${ }^{45}$ and in the fragmentary tondo of a cup. ${ }^{46}$ Euphronios also left us some highly individualistic interpretations of the symposium motif, such as the two images on the neck of one of his amphorae with twisted handles, a type of amphora introduced by the artistic circle to which he belonged. ${ }^{47}$ They show two merry symposiasts reclining on a couch. ${ }^{48}$ One of them, a cup in his right hand, is preparing for kottabos. His left hand is lifted to draw the attention of an invisible partner (Figure 10). The other one indulges in playing the barbitos. Both are praising the beautiful youth Leagros. One of the most original depictions of a symposium may be found on the best preserved of Euphronios' two psykters, which was, incidentally, signed by him. ${ }^{49}$ It concerns

42 Louvre G 33: ARV 14.4; BA 200o66; Heilmeyer 1991, no. 11, 120-126.

43 Isler-Kerényi 2004a, 41 f., figs 22 and 23.

44 Arezzo 1465: Addenda $15^{2}$ (15.6); BA 200o68; Heilmeyer 1991, no. 13, 128-136; Scheibler 1992, $108 \mathrm{f}$.

45 Louvre Cp 11070: ARV 15.7; BA 200069; Heilmeyer 1991, no. 15, 140-141.

46 New York 1983.524.3a: Heilmeyer 1991, no. 39, 196-197.

47 Giuliani 1991, 22.

48 Louvre G 30: Addenda 152 (15.9); BA 200071. Heilmeyer 1991, no. 20, 154-156. As the inwardly curving arms show, the instrument is the barbitos, see Moore 2006, $22 \mathrm{f}$. The difference between the lyra and the barbitos can be clearly seen on a calyx krater by the Kleophon Painter (Syracuse 23794: Para 457 [1144.18]; BA 215158). I would like to thank Angela Bellia most cordially for this useful information.

49 St. Petersburg B 1650: Addenda 153 (16.15); BA 200078; Heilmeyer 1991, no. 33, 178-181. The other one, of which only fragments remain, showed the death of Dionysos' enemy Pentheus: Boston 10.221: Addenda 153 (16.14); BA 200077; Heilmeyer 1991, no. 32, 174-177. 


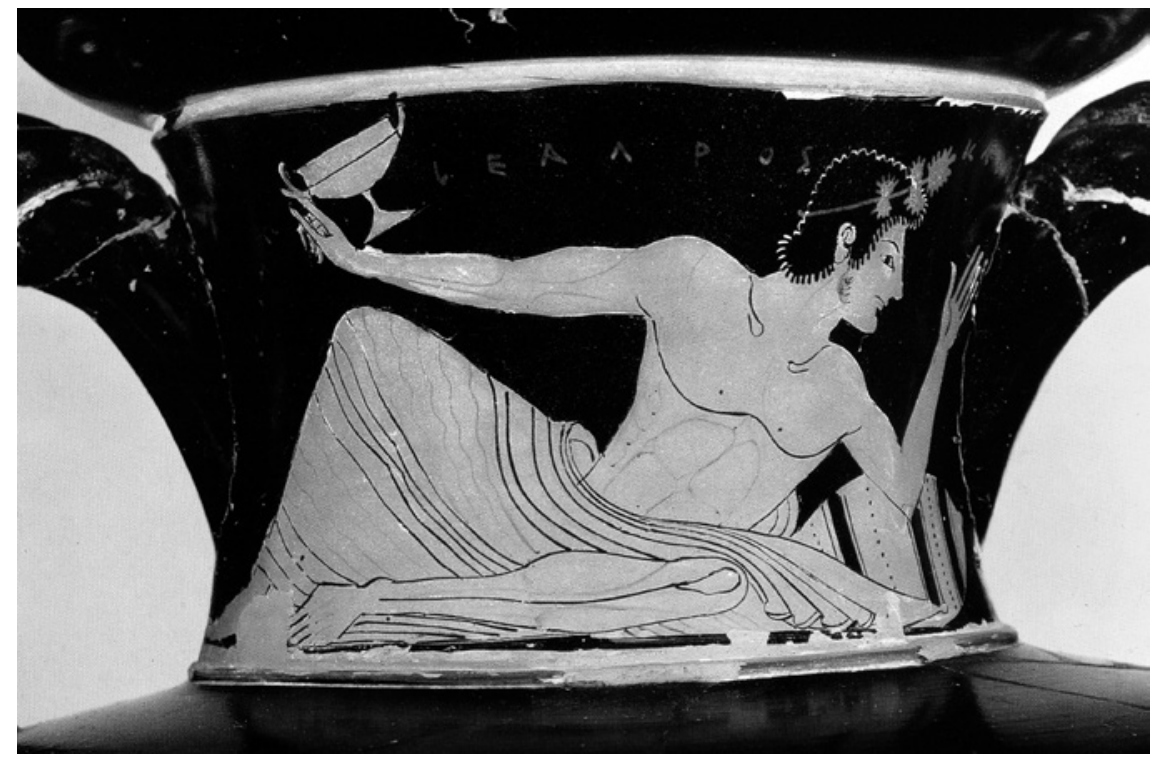

FIGURE 10 Amphora with twisted handles, Euphronios, Paris, Louvre G 30, neck image A (Heilmeyer 1991, 156 A).

a mushroom-shaped type of wine cooler, which was only produced between about 520 and 480 BC at the Kerameikos in Athens. This exclusive symposium vessel would be placed inside a calyx krater. It was especially in demand on the Etruscan market. ${ }^{50}$ This unique image shows four naked hetaerae resting on pillows. All four are named. Each is engaged in a different activity: one of them plays the aulos; the second raises a skyphos (a drinking vessel mostly associated with women); the third, spinning her cup with her right hand, is playing kottabos; the fourth is drinking from her skyphos. She has a cup in her right hand and looks out of the image, straight at the viewer. She is the only one to wear a decorated diadem on her uncovered hair, instead of a cap with a wreath (Figure 11).

The fine figure of a satyr must have adorned both sides of a neck-amphora of which only two fragments remain. ${ }^{51}$ One has a cluster of succulent grapes (executed in relief) in his left hand and puts one of them into his mouth with

50 Scheibler 1983, 18 and 21, fig. 10; for the history of the psykter and its relation to Etruria, see Isler-Kerényi 1987 b, 48-50; Kästner 2008a, 63 f. It is a matter of discussion whether the psykter held the ice or the wine.

51 Princeton University L. 1984.56 and L. 1984.57: BA 9017837 (no image); Heilmeyer 1991, no. $25^{-26,163 .}$ 

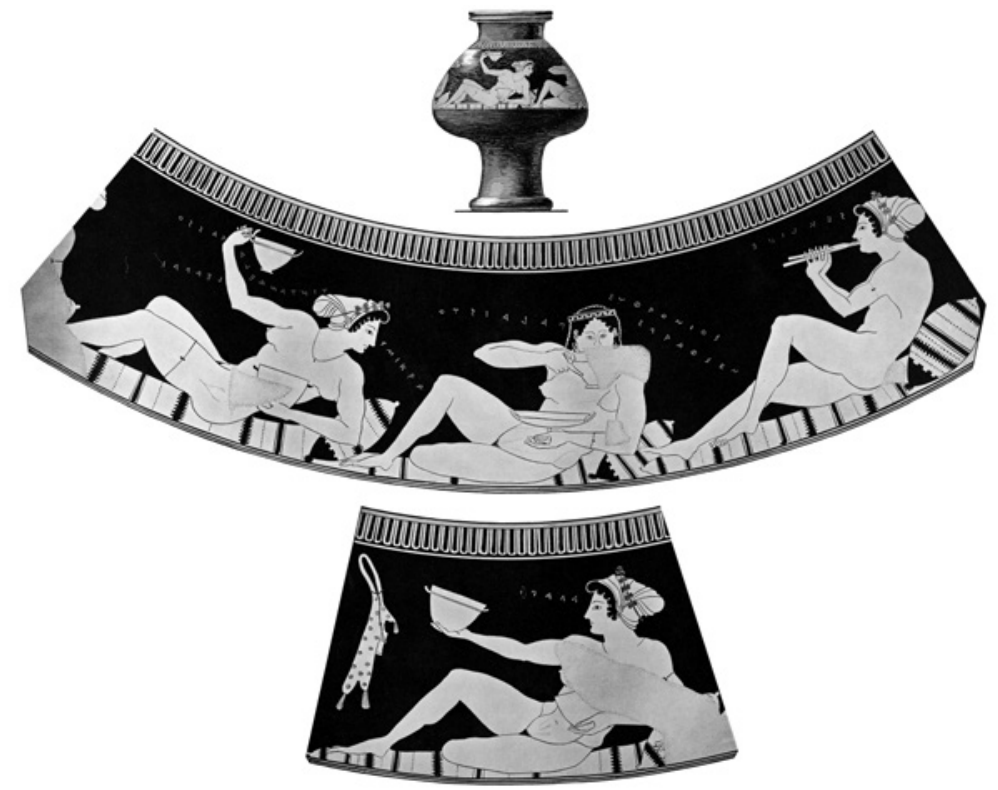

FIGURE 11 Psykter, Euphronios, St. Petersburg, State Hermitage Museum B 1650 (FR pl. 63).

his right; a part of the face is all that is left of the other satyr. Dionysos himself is only found on a cup. ${ }^{52}$ The inside image shows a maenad, energetically resisting the aggressive advances of an ithyphallic satyr; a snake winds itself around her thyrsos. On the outside we find a thiasos, replete with music and eroticism, consisting of four satyrs and two maenads. One of the central satyrs wears a lion's skin on his shoulders and extended left arm, and carries a thyrsos in his right hand. His face is turned to the beholder, whom he seems to address, just as Lydos might have depicted him half a century before. ${ }^{53}$ The other side of the cup shows a highly remarkable procession. Dionysos goes in front, on the far right, carrying kantharos and vine branch, his head inclined as if in a state of intoxication. In the middle a satyr playing the flute accompanies a chariot drawn by four horses. A second satyr, Dionysos' charioteer, holds the reignsone even gets the impression he is pulling them with both hands. His right foot is on the chariot, his left firmly on the ground. A very similar scene may be found on a more or less contemporaneous cup by the Nikosthenes Painter. ${ }^{54}$ Here, too, the procession is headed by Dionysos on the far right; here, too, a

$52 \quad$ Louvre G 34: Addenda 243 (456); BA 212467; Heilmeyer 1991, no. 51, 221-223.

53 Isler-Kerényi 2004a, 53, fig. 27.

54 Rome, Villa Giulia 27250: Addenda 176 (124.8); вA 201036. 
satyr is the charioteer. Instead of the flute-playing satyr, a striding maenad with thyrsos accompanies the chariot. However, here, too, the horses seem desirous to stand still, especially if one compares them with Athena's horses on the other side of the cup. A comparison with a similar image on the outside of a cup by Oltos may be useful. ${ }^{55}$ Here we see Dionysos in the act of getting into his chariot, drawn by four horses and accompanied by maenads and satyrsthe god has already lifted his right heel from the ground. The attitudes of the horses, too, make us aware of the difference between a chariot that has just arrived and one about to leave: on Euphronios' cup it is the arrival of the god that causes the boisterous rapture of his thiasos. ${ }^{56}$

The figure of Dionysos does not seem to have interested Euphronios as much as those of Herakles and other warrior heroes. From the few representations that have been preserved, we may, nevertheless, deduce that he still adheres to the traditions of black-figure vase painting. We find, for instance, both the satyr making the gesture of salute and the satyr looking, full face, out of the image. The same holds good for Phintias, a contemporary of Euphronios, whose bellyamphora shows us Dionysos, with his usual attributes, the kantharos and the vine branch, standing between two couples. The satyr on the left looks out of the image, while the couple on the right, in a manner that reminds us of the Amasis Painter, ${ }^{57}$ draws nearer in an intimate embrace. ${ }^{58} \mathrm{New}$, and characteristic for that point in time, is the interest in ostentatious symposia. At the end of the 6th century these were, apparently, not only open to members of the elite families, but also to the most successful among the vase painters. ${ }^{59}$

One of these was Smikros, a somewhat younger follower of Euphronios. In imitation of his model's calyx krater, he put the participants in a sumptuous symposium on the main side of a stamnos, relegating the activities of the servants in an adjoining room to the reverse (Figure 12). ${ }^{60}$ The stamnos, a new and likewise distinguished vase type, will be discussed in more detail in one of the following chapters. ${ }^{61}$ The main side of another stamnos presents Dionysos amidst dancing maenads. As in the Euphronios cup, his lowered head shows his intoxication. On the reverse, a maenad moves forward between

55 Tarquinia RC 6848: Addenda 165 (6o.66); BA 200502; Moraw 1998, 285, no. 215, pl. 9, figs 26 a-b.

$5^{6} \quad$ Not so Martine Denoyelle in Heilmeyer 1991, 221, who thinks the satyr is leaving.

57 Isler-Kerényi 2007, figs 68 and 69.

58 Tarquinia RC 6843: Addenda 155 (23.2); BA 200117.

59 Giuliani 1991, 16-18.

$60 \quad$ Brussels A 717: Addenda 154 (20.1); BA 200102.

61 See below Chapter 6. 


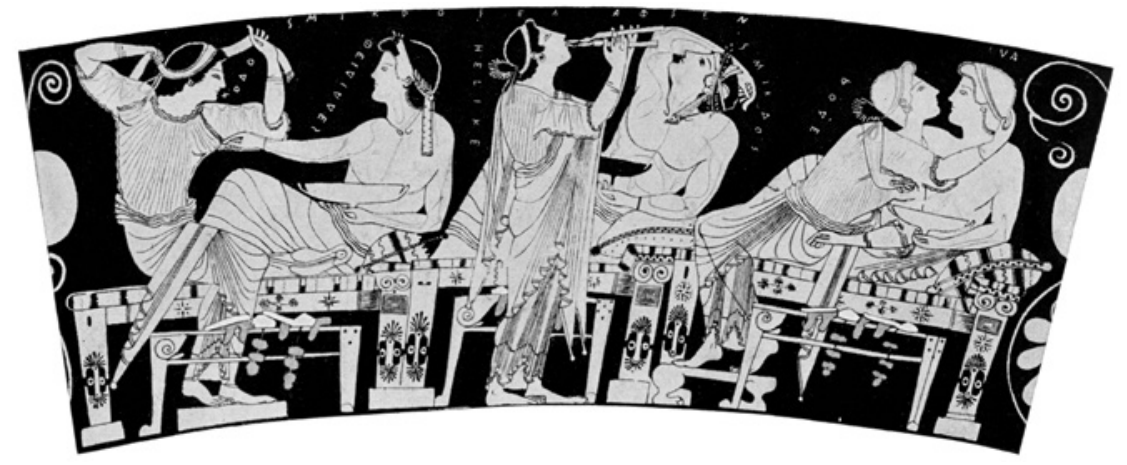

Figure 12 Stamnos, Smikros, Brussels, Musées Royaux d'Art et d'Histoire A 717, side A (Pfuhl 1923, III, 120, fig. 388).

two gesticulating satyrs. ${ }^{62}$ Finally, we find Smikros' signature on an incomplete amphora with twisted handles, which allows us to imagine the decoration of the neck-amphora by Euphronios of which only two fragments remain, mentioned above. ${ }^{63}$ Both sides of the vase contain the imposing figure of a satyr; one performs an ecstatic weapon dance, the other plays the double flute with great abandon. In a succinct but most impressive way the painter here refers to the dual nature of the satyr: the aggressive and the artistic. ${ }^{64}$ This amphora anticipates the very similar satyr figures of the leading vase painters of the next generation, the Kleophrades Painter and the Berlin Painter.

Euthymides was a contemporary and competitor of Euphronios. His bestknown work is a belly-amphora with three dancing komasts-the first threedimensional representation of the male body in movement in Greek vase painting (Figure 13). ${ }^{65}$ One of his amphorae with twisted handles has a single satyr with wine vessels on both sides. ${ }^{66}$ Another shows a satyr playing the flute; a youth holding a pointed amphora is on the other side, a possible reference to the fact that this young komast could turn into a satyr. ${ }^{67}$ The phenomenon of the satyr as the single subject for one side of a vase is a development that may

\footnotetext{
62 Louvre G 43: Addenda 154 (20.2); BA 200103.

63 Berlin 1966.19: Addenda 154 (20.3 bis); BA 352401 (no image); Heilmeyer 1991, no. 61, 254-257.

64 Isler-Kerényi 2004a, 96.

65 Munich 8731 (2307): Addenda 155 (26.1); BA 20016 o.

66 Louvre C 11072: ARV 27.7; BA 200148.

67 Warsaw 142332: Addenda 156 (27.8); BA 200149.
} 


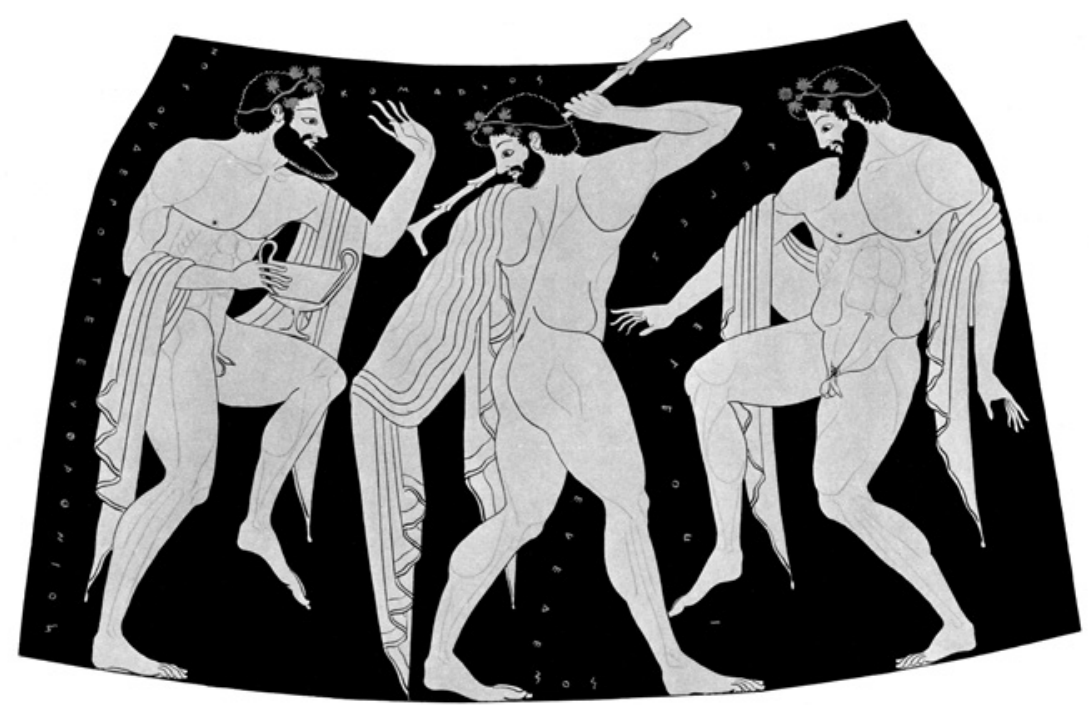

FIGURE 13 Belly-amphora, Euthymides, Munich, Staatliche Antikensammlungen und Glyptothek 8731 (2307), side A (FR pl. 14.1).

also be discerned in the work of Euphronios. ${ }^{68}$ It will be further discussed in the next chapter.

All five hydriai that may with certainty be attributed to Euthymides belong to the new type with rounded shoulders named kalpis, which was invented after the introduction of the red-figure technique. ${ }^{69}$ All of them contain Dionysiac motifs. The imagery of the hydria seems to have been less fixed than that of other vase types, and is, therefore, more varied, more diversified. This is clearly also the case with Euthymides' hydriai. The images are always applied to the shoulders of the vase, and are, therefore, of the same limited height as the decorations on the outside of a cup - a height that favors the representation of reclining and seated figures. One of Euthymides' hydriai shows two reclining young symposiasts making music; the image is reminiscent of the ones on the neck of the neck-amphora by Euphronios mentioned above. ${ }^{70}$ Another has three komasts of various ages; the one on the left, playing the aulos, looks out of the image at the beholder. ${ }^{71}$ Once we see a crouching satyr observing women drawing water from a well. ${ }^{72}$ Dionysos is represented twice, sitting

\footnotetext{
68 See above note 51.

69 Boardman 1974, 186 f.; Scheibler 1983, 15, fig. 2.

70 Bonn 70: Addenda 156 (28.12); BA 200141.

71 Vatican G 71: Addenda 156 (28.14); BA 200137.

72 Frankfurt, without number: ARV 28.13; BA 200136.
} 
among members of his thiasos. ${ }^{73}$ Because of his seated posture, he cannot be the god who makes a sudden appearance- - he must be the person whom one is ready to approach. The small kid on the St. Petersburg hydria makes it clear that nature is, apparently, his locale.

The komos on a psykter by the Dikaios Painter, according to Beazley "companion and imitator of Euthymides", should certainly be mentioned. ${ }^{74}$ Five komasts, moving towards the right with great vivacity, are distributed over both sides of the vase. They seem to pursue a naked prancing boy. A barbitos player with a bald forehead is next, followed in his turn by another elderly man with a cup in his right and a stick in his left hand. The latter looks back towards the bearded, but more youthful komasts on the other side, the first one holding a large skyphos, the second playing the aulos. Except for the boy, all wear boots and have a chlamys over their shoulders. We may, therefore, presume the boisterous procession takes place in the street (Figure 14).

Dionysos is not only depicted with his thiasos, he is also presented in a mythological setting. We find him, for instance, on a hydria, in a procession moving towards the right, between Hermes and a woman who may be Ariadne. They are preceded by Poseidon and Amphitrite. ${ }^{75}$ On another, incomplete, hydria we see a seated Dionysos, looking on as Athena leads Herakles towards the Olympus. ${ }^{76}$ This, incidentally, is a subject that, around $540 \mathrm{BC}$, may have been

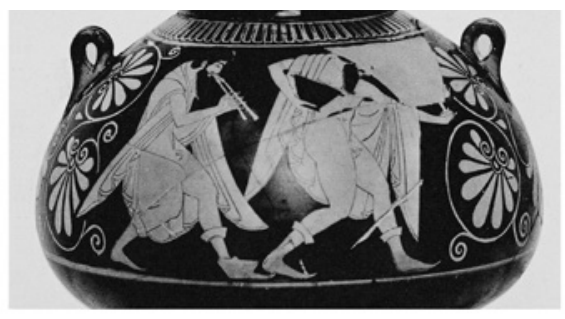

$a$

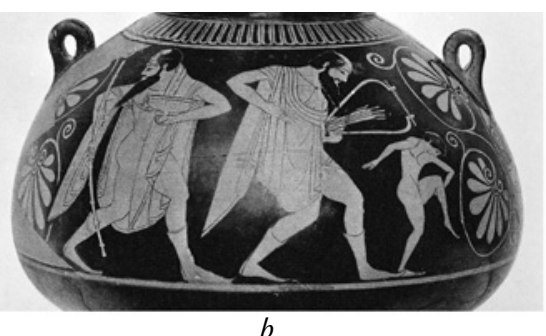

$b$

FIgURE 14 Psykter, Dikaios Painter, London, British Museum E 767.

a. side B (cva British Museum 6, pl. 104, 1a).

b. side A (cva British Museum 6, pl. 104, 1c).

73 St. Petersburg St. 1624: Addenda 156 (28.15); BA 200132; Lissarrague 2013, 138 f., fig. 111; Orvieto, Faina 68: ARV 28.16; BA 200133.

74 London E 767: Addenda 157 (31.6); BA 200191. The instrument is a barbitos. For the difference between lyra and barbitos, see above note 48 .

75 Louvre G 41: Addenda 157 (33.8); BA 200182; Diez del Corral Correidora 2011.

76 Florence 1 B 16: ARV 34.9; BA 200183. 
introduced as an allusion to the career of Peisistratos: Exekias had already included Dionysos in the scene, highlighting in this way his high rank among the gods. ${ }^{77}$

\section{Red-Figure Cups of the Final Quarter of the 6th Century}

Oltos was the most prominent cup painter of Euphronios' generation. Occasionally, he also decorated other vase types, but the majority of his work consists of cups: first of all, bilingual eye-cups (which do not offer much space for multi-figure compositions), where we sometimes find a running Dionysos in the black-figure medallion (Figure 15 ). ${ }^{78}$ Apart from numerous satyrs and maenads, he also depicted the Dionysiac thiasos, contrasting it with the departure of a young warrior on the other side. ${ }^{79}$ Most remarkable, however, is the large cup already mentioned, which has on its one side an assembly of the gods, with Ganymede in their midst, and on its other Dionysos in the act of getting into his chariot, to the accompaniment of the music of a satyr's kithara, with two maenads in attendance. ${ }^{80}$ The one in the front has a snake on her left arm. She carries a thyrsos and a live fawn. Like Herakles, Ganymede was a mortal admitted to the Olympus, a change of status that belonged to the type of events controlled by Dionysos. It is no coincidence that Dionysos is present among the gods welcoming Herakles to the Olympus in a superb, but unfortunately very incomplete, depiction of the scene on a more or less contemporaneous cup by Sosias. ${ }^{81}$ We see him here with a partner, Ariadne or Semele, as the fourth divine couple, next to Zeus and Hera, Poseidon and Amphitrite, and Aphrodite and Ares. Significantly, this sequence corresponds to that of the gods present at the marriage of Peleus and Thetis on a dinos by Sophilos, three generations earlier. ${ }^{82}$ Cups by Oltos also provide us with the first redfigure versions of Dionysos fighting the giants, paired in both cases with one of Herakles' famous combats (Figure 16). ${ }^{83}$

\footnotetext{
77 Mommsen 2002/03, $25 \mathrm{f}$.

78 For instance Munich 2581: Addenda 163 (55.11); BA 200239 and Vatican 498: Addenda 163 (55.15); BA 200281. In addition see ARV 67.3 and 5 ("near Oltos").

79 London E 16: Addenda 165 (61.75); BA 200511.

8o Tarquinia RC 6848: see above note 55 .

81 Berlin F 2278: Addenda 154 (21.1); BA 200108.

82 Isler-Kerényi 2008a, $76 \mathrm{f}$.

83 London E 8: Addenda 165 (63.88); BA 200524 and Rome, Villa Giulia 50388: Addenda 166 (65.114); BA 200550.
} 


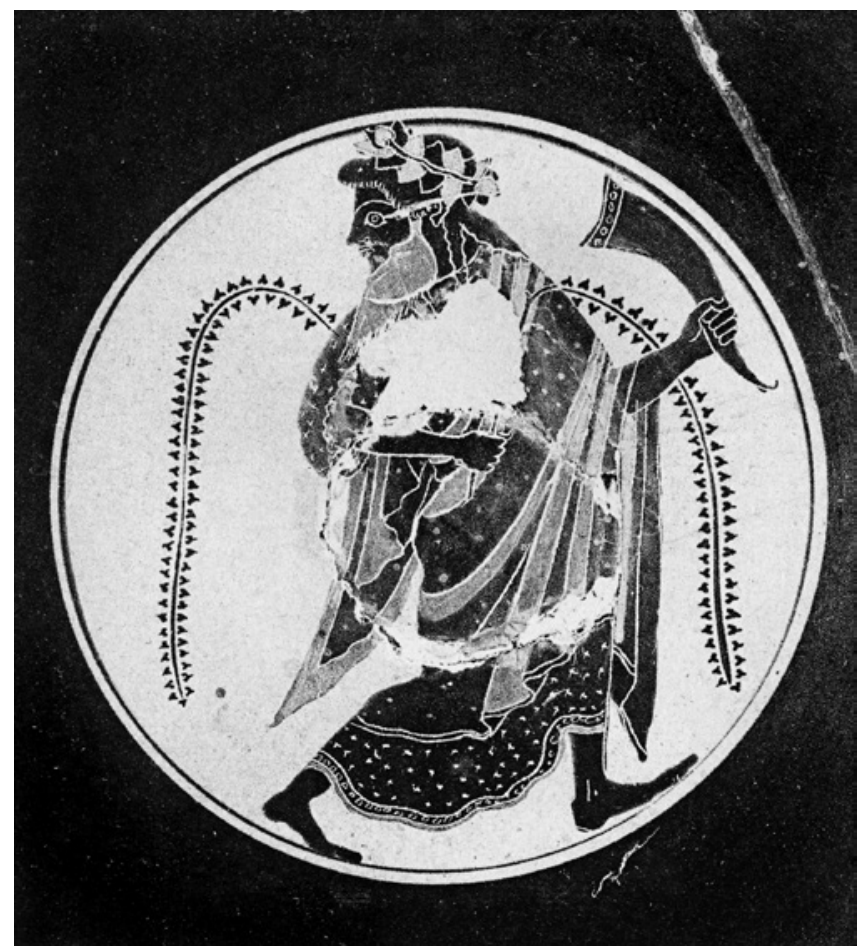

Figure 15 Cup, Oltos, Rome, Museo Gregoriano Etrusco Vaticano 498 (Albizzati 1938, pl. 69).

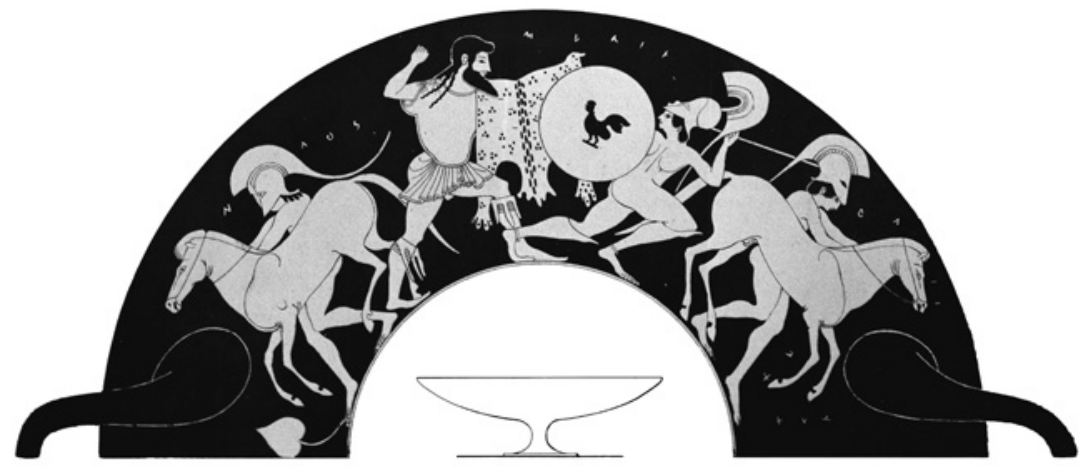

FIGURE 16 Cup, Oltos, Rome, Museo Nazionale Etrusco di Villa Giulia 50388 (Gerhard 1840-1858, pl. 85). 
Oltos' work frequently features mules, but without any link to the return of Hephaistos to the Olympus. ${ }^{84}$ With satyrs and maenads they, apparently, belong to the Dionysiac world in their own right. Sure enough, the motif of Dionysos riding a mule is found throughout the $5^{\text {th }}$ century, be it not very often. ${ }^{85}$ In one case the thiasos celebrates his arrival as a symposiast lying on a mule. ${ }^{86}$ On the other side, the god is seated among his euphoric retinue, while the tondo shows a warrior, in a very frequent combination of the themes of Dionysiac bliss and the fate of the warrior. Another cup by Oltos shows the god seated between two mules, one of them mounted by a satyr, while on the other side two youths are riding towards an older man wearing a himation. In the tondo a naked hetaera is busy with her sandals. ${ }^{87}$ Here horses and mules evoke opposing but complementary worlds: the official one of the polis and the counter world of the symposium.

Dionysos and his satyrs and maenads are less often found in the work of Oltos' contemporary, the cup painter Epiktetos, and his circle. Epiktetos' oeuvre is dominated by anonymous komasts and symposiasts, and especially by warriors and athletes. ${ }^{88}$ The god may even be completely absent, as is the case with the work of the, even less distinguished, Epeleios Painter. He and his circle mostly depicted komasts. ${ }^{89}$ A very richly decorated cup by Epiktetos contrasts, analogous to many of Oltos' cups, wildly dancing maenads and the tumult of combat. $^{90}$

The satyr is, at this time, the most popular among the Dionysiac figures, especially because of the many creative ways in which he can be presented in the circular field of the medallions of cups and dishes. ${ }^{91}$ In the tondo of

84 The combination satyr-donkey frequently occurs, see Lissarrague 2013, 130.

85 Taranto without number: Addenda 252 (512.8); BA 205744 (Painter of Bologna 228); Cape Town 15: ARV 543.45; BA 206176 (Florence Painter); Berlin F 2334: ARV 646.5; BA 207517 (Oionokles Painter); Reading, Univ. 85.3.1: Addenda 330 (1112.1); BA 214706 (Painter of Tarquinia 707), the other side of the krater shows Hephaistos on a mule, both are preceded by small torch-bearing satyrs; London E 102: ARV 1253.70; BA 217008 (Eretria Painter).

86 Orvieto, Museo Civico 1049: ARV 64.103; BA 200539. Compare Dionysos lying on a goat by the Berlin Painter, Louvre CA 944: Addenda 194 (207.142); BA 201961.

87 Munich 26o6: Addenda 166 (64.102); BA 200535.

88 ARV 70-81.

89 ARV 146-153.

9o Louvre G 6: ARV 72.21; BA 200465 .

91 Some examples: stand by Sosias, Berlin F 2315: Addenda 154 (21); BA 200110; dish in the manner of Euthymides, Boston 13.193: ARV 29.3; BA 200162; eye-cup, Louvre G 88: ARV 48.162; BA 200372; dish by Epiktetos, Cab. Méd. 509: Addenda 169 (77.91); BA 200618. 
a cup by Epiktetos the satyr is combined with Dionysos. ${ }^{92}$ The Nikosthenes Painter and Euphronios ${ }^{93}$ often combine him with a maenad, who fends off his embrace with snake and vine branch ${ }^{94}$ — the satyr looking provocatively at the viewer.

On a contemporaneous white ground alabastron a maenad is contrasted with an amazon. ${ }^{95}$ We may see this as an indication that maenads were by no means considered harmless. A kantharos attributed to the Nikosthenes Painter shows Dionysos on both sides. ${ }^{96}$ On the one he appears as a symposiast in a state of bliss between two satyrs with wine containers; on the other we see him pouring wine from his kantharos on a burning altar, in the presence of a, seemingly, praying woman between two dancing maenads. This is an important vase, because it is only in red-figure vase painting (and, mind, this is a kantharos, a vase with religious connotations) that it becomes clear that the thiasos not just refers to the symposium, but also has a ritual dimension. ${ }^{97}$ In the following we will see that, at least as far as maenads are concerned, the latter is the more prominent aspect.

\footnotetext{
92 Whereabouts unknown: ARV 78.98; BA 200626.

93 Compare Louvre $\mathrm{G}_{34}$, see above note $5^{2}$.

94 Tarquinia RC 2066: Addenda 176 (126.23); BA 201051.

95 Athens NM 15002: Addenda 172 (98.2); BA 200860.

96 Boston 00.334: Addenda 176 (126.27); BA 201055 (no image).

97 Hoffmann 2007, 165 .
} 


\section{All Kinds of Satyrs}

\section{The First Decades of the 5 th Century}

\section{The Painters of Large Vases}

The great significance of Dionysiac imagery becomes strikingly evident when we consider the work of the Kleophrades Painter and the Berlin Painter, two leading painters of large vases such as the amphora, the more distinguished krater types, and the stamnos. Both artists also painted Panathenaic prize amhorae, commissioned by the polis, which is an indication of the eminent position they held at the Kerameikos of Athens already in their own time. It is, therefore, no coincidence that the earliest known pointed amphora is the work of the Kleophrades Painter. ${ }^{1}$ The pointed amphora, one of the rarest and most valuable types of vases, was inspired by the prize amphora. We will discuss this vase type below. ${ }^{2}$

The Kleophrades Painter was probably a pupil of Euthymides and active between 505 and 475 BC. ${ }^{3}$ He painted a multi-figure version of the return of Hephaistos to the Olympus on two of his many calyx kraters, which, unfortunately, have mainly been preserved in a fragmentary state. ${ }^{4}$ Calyx kraters belonged to the most sumptuous vase types of the time. On the one Beazley considers a very early work ${ }^{5}$ the Kleophrades Painter depicted both Hephaistos and Dionysos, each on one side of the vase, as Lydos did on his large column krater, now in New York. ${ }^{6}$ They are accompanied by eight satyrs, whose attributes - musical instruments, symposium vessels, and the tools of the smith - subtly refer to the analogy between wine and fire and in this way to the close relationship between Hephaistos, the divine smith, and Dionysos, the god of the symposium. ${ }^{7}$ Interestingly, Dionysos here wears a short chiton underneath the panther skin, which is the way he is depicted in the

1 Munich 8732 (2344): Addenda 186 (182.6); BA 201659.

2 See below Chapter 4.

3 Boardman 1981, 93.

4 ARV 185 f., 31-49.

5 Harvard 1960.236: Addenda 187 (185.31); вA 201683; Huber 1992, 63.

6 New York 31.11.11: Addenda 29 (108.5); BA 310151; Isler-Kerényi 2004a, 51-56.

7 Lissarrague 1990, 203, pl. 23 . 


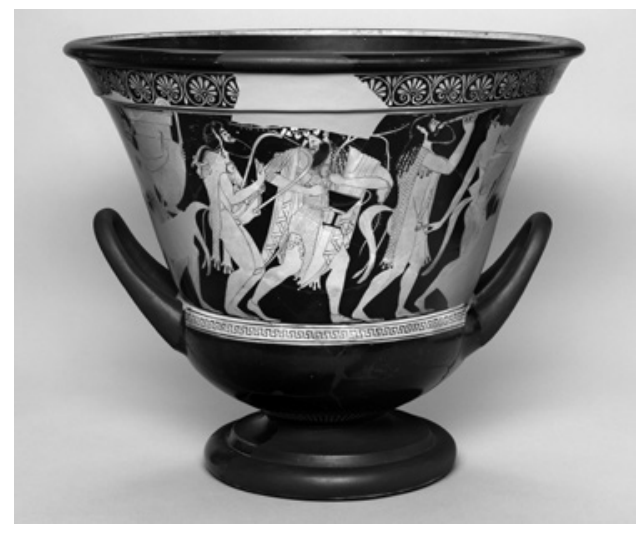

$a$

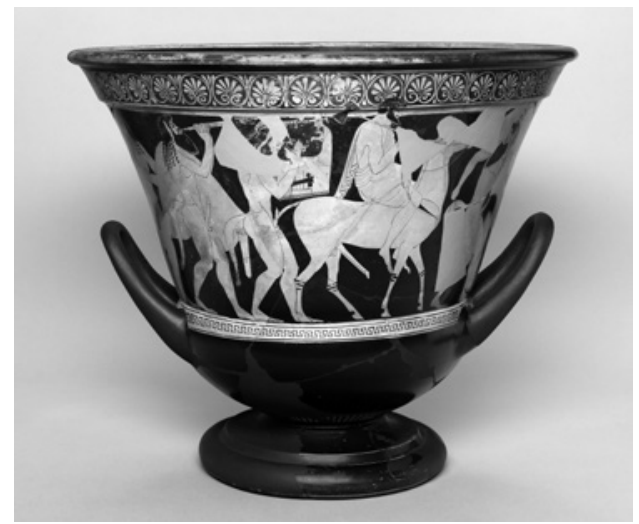

$c$

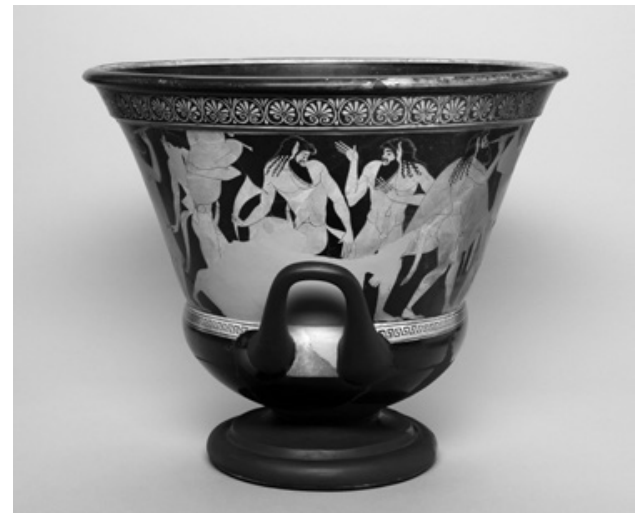

$b$

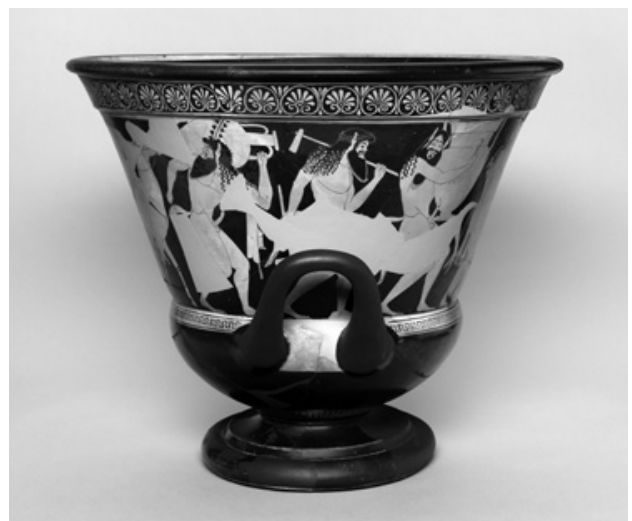

$d$

FIGURE 17 Calyx krater, Kleophrades Painter, Harvard Art Museum, Arthur M. Sackler Museum, Gift of Frederick M. Watkins, 1960.236 (photographs Imaging Department (C) President and Fellows of Harvard College).

a. side A: Dionysos.

b. side view (right).

c. side B: Hephaistos.

d. side view (left).

Gigantomachy. ${ }^{8}$ One of the satyrs, carrying a heavy volute krater, looks out of the image and in doing so directly addresses the viewer (Figure 17).

8 Compare Carpenter 1997, pl. 1B, 2A, 7A-B, and, more than a generation earlier, the frieze of the Siphnian Treasury, LIMC III, Dionysos 651. Compare also a running bearded Dionysos in a short chiton, probably hastening to the scene of combat, on a somewhat younger calyx krater by the Oreithyia Painter in Agrigento C 1538: Para 380 (497.7); BA 205992. 
This same event is presented in an even more elaborate manner on a later calyx krater. ${ }^{9}$ On the one side we see Hephaistos, preceded by Hermes. Rather clumsily in sidesaddle, he rides towards Hera stuck to her throne. Dionysos, visibly intoxicated, is the central figure on the other side. He leans on a satyr, who carries smiths' tools. The satyrs have been joined by two ecstatically dancing maenads. In these two very original versions of the myth, Hephaistos' tools indicate that the images depict the mythical event and not, for instance, a ritual re-enactment. ${ }^{10}$ As in the François krater, Dionysos' course of action not only brings about the reconciliation of the Olympian family, but also the introduction to the Olympus of the satyrs and their female partners. ${ }^{11}$

Further examples of the early work of the Kleophrades Painter are two psykters, one of them depicting a multi-figure thiasos. ${ }^{12}$ The other shows Herakles approaching Dionysos at a symposium with satyrs in attendance. The latter are moving towards the right in a rather peculiar manner: they seem to glide on their knees while making the familiar gesture of surprised recognition or salute known since the 6th century, as if this were the chorus of a satyr play. ${ }^{13}$

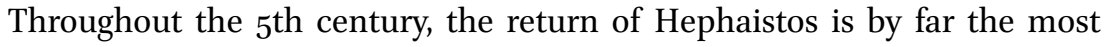
popular among the scarce depictions of episodes from Dionysiac mythology. ${ }^{14}$ Another of these is the Gigantomachy, ${ }^{15}$ which may be seen on the fragments of a stamnos. ${ }^{16}$ This subject was particularly topical at the time of the Persian Wars, when the Greeks had to defend themselves against a superior foreign power, just like the gods had once fought their subversive antagonists. Vases of the 6th century ${ }^{17}$ (as well as the Oltos cups mentioned in Chapter 2$)^{18}$ already show Dionysos taking part in the battle. In the case of this stamnos his companions are Apollo and Ares. In this way, Dionysos helps to confirm the order of Zeus - the prevalent order for the original beholders of the vases. ${ }^{19} \mathrm{~A}$ snake

\footnotetext{
Louvre G 162: Addenda 187 (186.47); BA 201699; Huber 1992, 64.

Isler-Kerényi 2004a, 48-50.

Isler-Kerényi 2004a, 19-21.

Louvre G 57: Addenda 188 (188.65); BA 201715.

Hedreen 1992, 112, pl. 35 .

Natale 2008, 73-106.

Lissarrague 2013, 175-189.

Louvre C 10748: Addenda 188 (187.55); BA 201707.

LIMC IV, Gigantes 171, and 175 as well as 289 .

See above Chapter 2 , note 83 .

19 Compare the Gigantomachy on the cup of the Painter of the Paris Gigantomachy, Cab. Méd. 573 (Addenda 234 [417.1]; BA 204546). Here we have on the outer side the Gigantomachy of Poseidon and Hephaistos. A striding, bearded Dionysos between Apollo
} 
serves as his weapon. ${ }^{20}$ In view of his later iconography, it is significant that he is naked except for the chlamys he wears on his shoulders.

In short, as far as the subject matter and the role of the participants in the thiasos are concerned, the Dionysiac imagery of the leading vase painters of the early $5^{\text {th }}$ century does not differ fundamentally from that of the blackfigure phase. From the fact that we find so many inventive, high-quality representations, we may conclude that the interest in this kind of imagery was undiminished. The figure of the satyr, however, is clearly more popular than before; on several amphorae a single satyr dominates the whole of one side. We came across the earliest examples of this in the work of Euphronios, Smikros, and Euthymides. ${ }^{21} \mathrm{~A}$ Panathenaic-type amphora by the Kleophrades Painter is very comparable. ${ }^{22}$ On the one side we see a satyr in counterpose with a barbitos; on the other a young man with a sprouting beard seems to be waiting, leaning on a stick. He carries a hare, which may be a reference to a budding love affair. Does the lover identify himself with the musical satyr (Figure 18)? Perhaps the same idea of a change of role from citizen to satyr is hinted at with a neck-amphora by the Kleophrades Painter. ${ }^{23}$ On the one side we see two athletes with sporting implements standing side by side, on the other two satyrs with wine containers are hurrying towards a symposium. And, as is evident from an amphora with twisted handles, both satyrs and citizens could go to war. The amphora shows on the one side a satyr with shield and spear walking towards the right, on the other a satyr holding shin guards and a helmet (Figure 19). ${ }^{24}$

A satyr with a noble appearance who takes up the whole side of a vase also features in the work of the Berlin Painter, the Kleophrades Painter's best-know contemporary, who was active until well after $470 \mathrm{BC}$. The most famous version, and rightly so, may be found on the splendid amphora, which gave the

and Ares dominates the other side. He wears a long robe. He entangles his adversary (whose shield, significantly, carries a kantharos as its emblem) in branches of ivy.

20 Like, for instance, on a kantharos by the Amphitrite Painter of the next generation, Boston 98.932: BA 205038.

21 See above Chapter 2, notes 51,63 , and 66.

22 Leiden PC 80: Addenda 186 (183.7); BA 20166o. For the correct designation of the instrument, see above Chapter 2, note 48 .

23 St. Petersburg B 1550 (6o9): Para 510 (184.19); вA 201672.

24 Harrow 55: Addenda 187 (183.11); BA 201664; Lissarrague 2013, 180 ff., fig. 153. A satyr wearing a helmet, who puts on his shin guards in the presence of a woman carrying a thyrsos, may be found on a somewhat younger pelike by the Deepdene Painter, London E 377: Para 381 (501.35); вА 205622. 


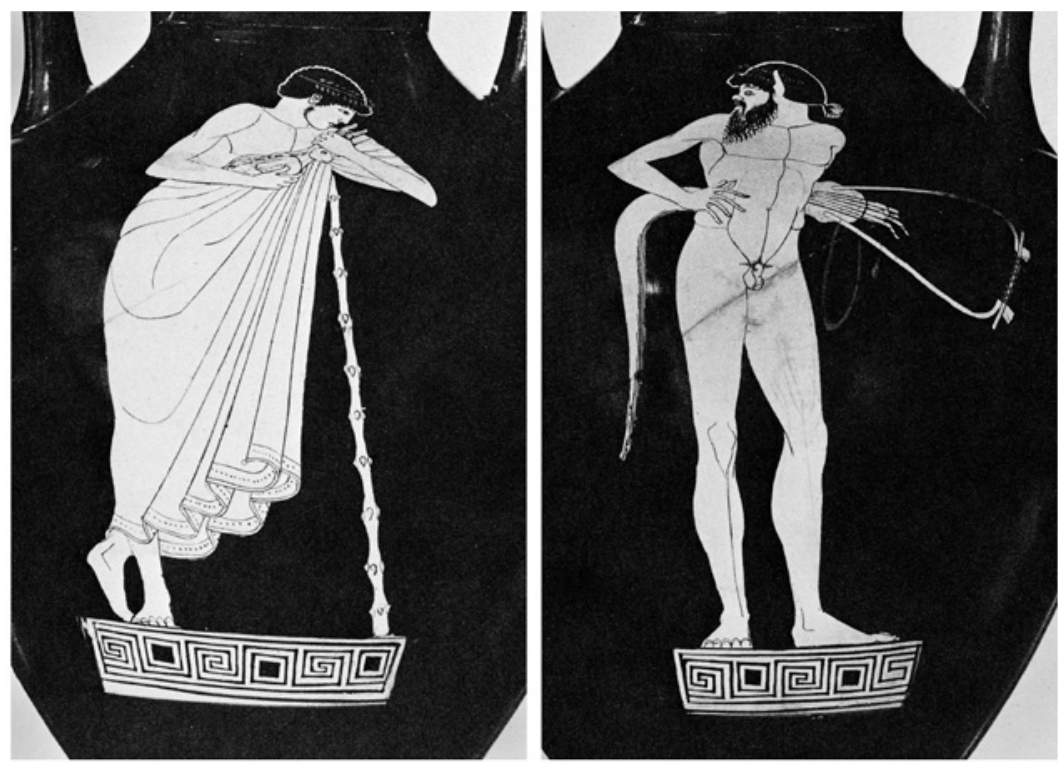

FIGURE 18 Panathenaic-type amphora, Kleophrades Painter, Leiden, Rijksmuseum van Oudheden PC 8o. Photograph (C) RMO.NL (CVA Leiden 3, pl. 120).

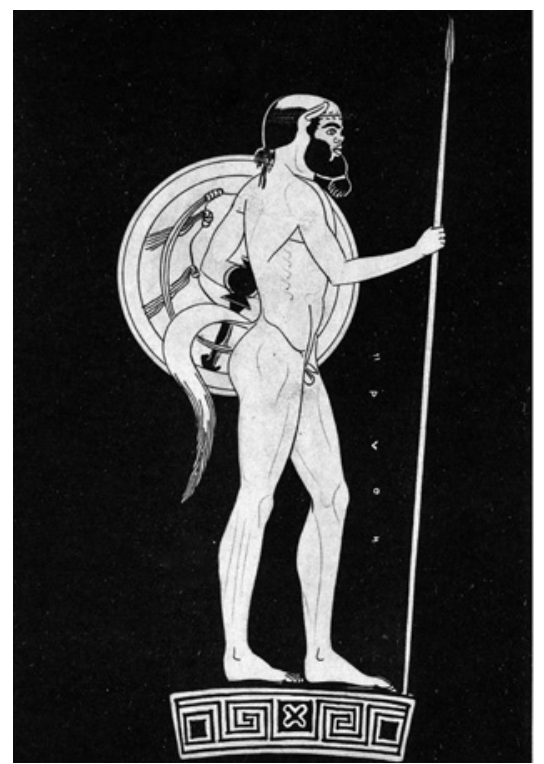

$a$

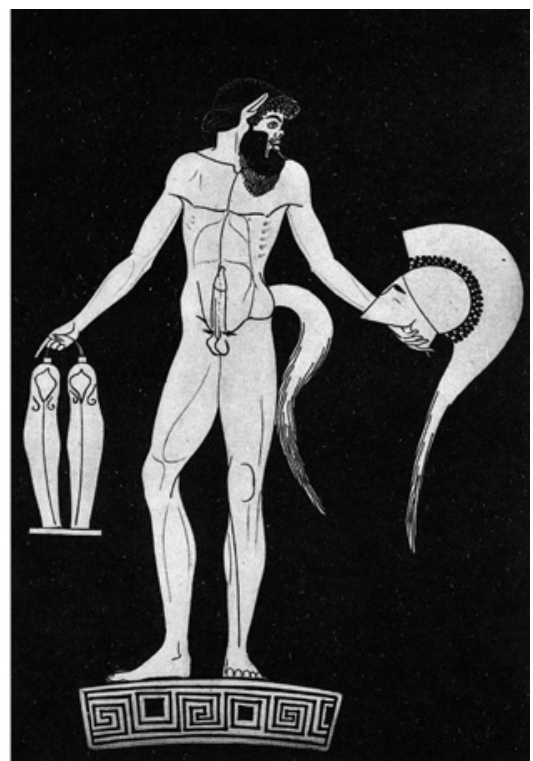

$b$

FIGURE 19 Amphora with twisted handles, Kleophrades Painter, Harrow, School Museum 55.

a. side A (Beazley 1933, pl. 29, 1).

b. side B (Beazley 1933, pl. 29, 2). 
painter his name. ${ }^{25}$ On the one side we find a pensive satyr moving to the right with a barbitos in his left hand and a kantharos in his right. His name is Orochares ('he who rejoices on the mountain'). The reverse shows a satyr by the name of Oreimachos ('he who fights on the mountain') who seems about to play the barbitos. Next to the satyr, and partly obscured by him, Hermes with his kerykeion and a kantharos in his left hand and a libation oinochoe in the other, moves energetically to the right as if to overtake the satyr, who seems to tarry. Between the two, we see a fawn gracefully lifting its head (Figure 20). Without any doubt, the artist also had aesthetic reasons for placing the two figures so very closely together; one look at the amphora as a whole makes this abundantly clear. The precision and elegance of the image are unsurpassed.

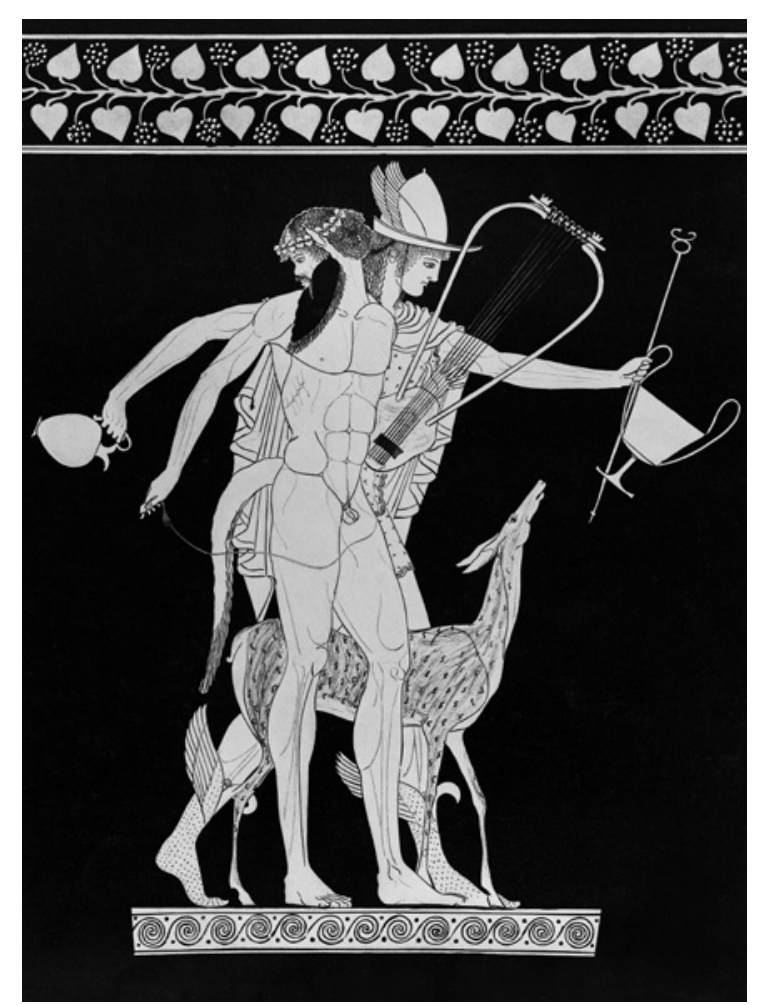

FIGURE 20 Belly-amphora, Berlin Painter, Berlin, Staatliche Museen, Preussischer Kulturbesitz F 216o, side A (FR pl. 159.2).

25 Berlin F 2160: Addenda 190 (196.1); BA 201809; Moore 2006, 17 f.; Lissarrague 2013, 233 f., fig. 203. For the instrument, see above Chapter 2, note 48 . 
Yet, to us it seems enigmatic. What is Hermes doing here? Does he mean to take the satyr to Dionysos, who is evoked by the two kantharoi and the delicate ivy branches on the neck of the vase? The satyr may, however, be more than a being from mythical times; perhaps he also represents a state that may be realized by every citizen entering the sphere of Dionysos. ${ }^{26}$ In that case, the presence of Hermes, the conductor of souls, is perfectly understandable.

The Berlin Painter presented the satyr with the barbitos again and again. We also find him, for instance, on one of his Panathenaic-type amphorae (Figure 21). ${ }^{27} \mathrm{~A}$ rather badly preserved calyx krater shows that in this role he is close to Dionysos himself. ${ }^{28}$ On a bell krater he is awaiting Herakles as a merry symposiast, with his barbitos and an oinochoe. ${ }^{29}$ But the Berlin Painter not only gave the satyr noble features, he also presented him as a comical character. On a small amphora, for instance, we see him flaunting his belly in the manner of the padded dancers of the archaic era (Figure 22). ${ }^{30}$ The latter are, incidentally, closely related to the satyrs. ${ }^{31}$ But why are these two satyrs holding a drinking horn? Is this a reference to primeval times, when drinking utensils were not manufactured but provided by nature?32 From the satyr play we know that satyrs already existed in heroic times, in the era that preceded, indeed prepared, the present. ${ }^{33}$

Among the Berlin Painters finest works are several stamnoi featuring Dionysos. The most original version shows him as a symposiast lying on a goat; Oltos had already similarly depicted him lying on a mule. ${ }^{34}$ On the other side, as a parallel, we see Hermes lying on a ram. He holds the kantharos and the kerykeion in his left hand, and with the right he seems to be beating time for the music-making satyr who is next in the procession. ${ }^{35}$ Another stamnos

26 See the Introduction, page 5, note 15. The hypothesis in Moore 2006, 25 f. that the Berlin Painter alludes to the fact that (on the basis of much later sources) Hermes is often said to be the father of the satyrs, does not accord with the bearded satyr and the youthful Hermes. Nevertheless, playful, exuberant satyrs do sometimes resemble Hermes.

27 Munich 2311: Addenda 190 (197.9); BA 201817.

28 Syracuse 15205: ARV 205.121; BA 201930.

29 Louvre G 174 and Florence 12 B 105: ARV 205.123; BA 201932.

$30 \quad$ New York 07.286.69: Addenda 192 (201.70); BA 201878.

31 Isler-Kerényi 2004a, 33.

32 Isler-Kerényi 2004a, $55 \mathrm{f}$.

33 Brelich 1985, 70: "I miti ... narrano di un passato tutto diverso dal presente, di un tempo in cui accadevano cose che ora non accadono più ..., ma in cui sono state gettate le fondamenta dell'esistenza reale della società che li ricorda".

34 Orvieto, Museo Civico 1049: ARv 64.103; BA 200539. Compare above Chapter 2, note 85.

35 Louvre CA 944: ARV 207.142; BA 201961. 


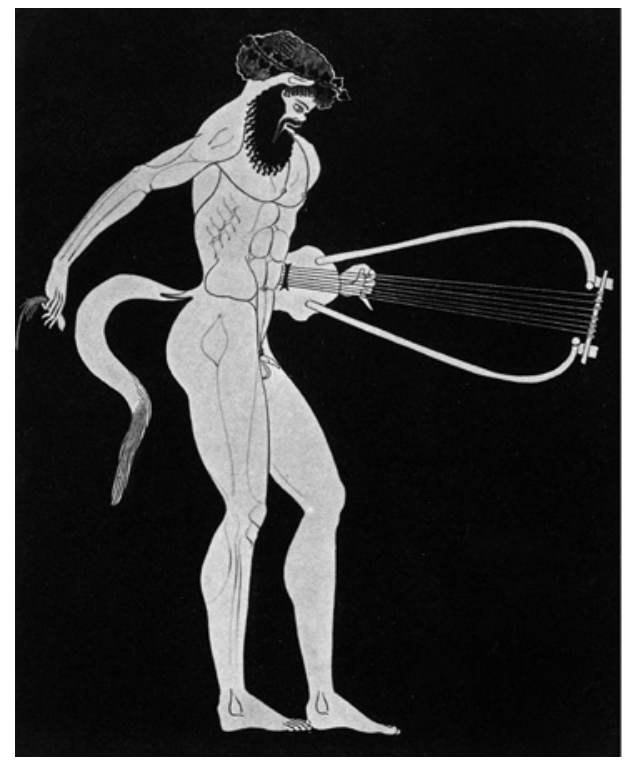

$a$

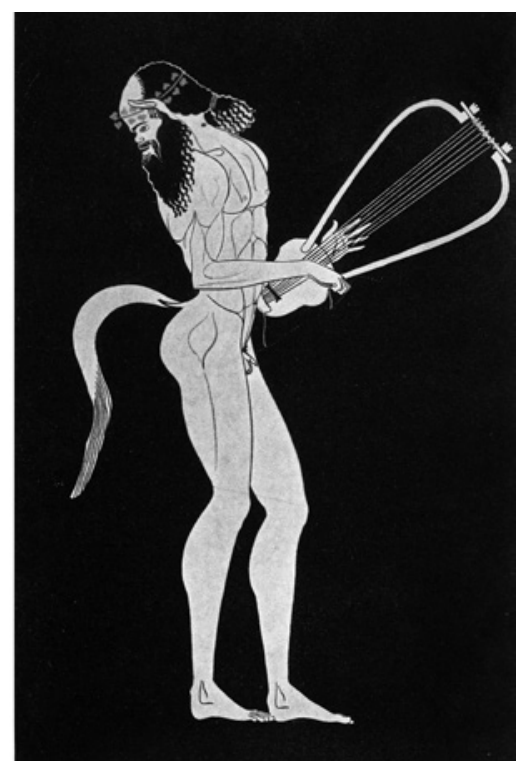

$b$

FIGURE 21 Panathenaic-type amphora, Berlin Painter, Munich, Staatliche Antikensammlungen und Glyptothek 2311.

a. side A (Beazley 1930, pl. 6).

b. side B (Beazley 1930, pl. 6).
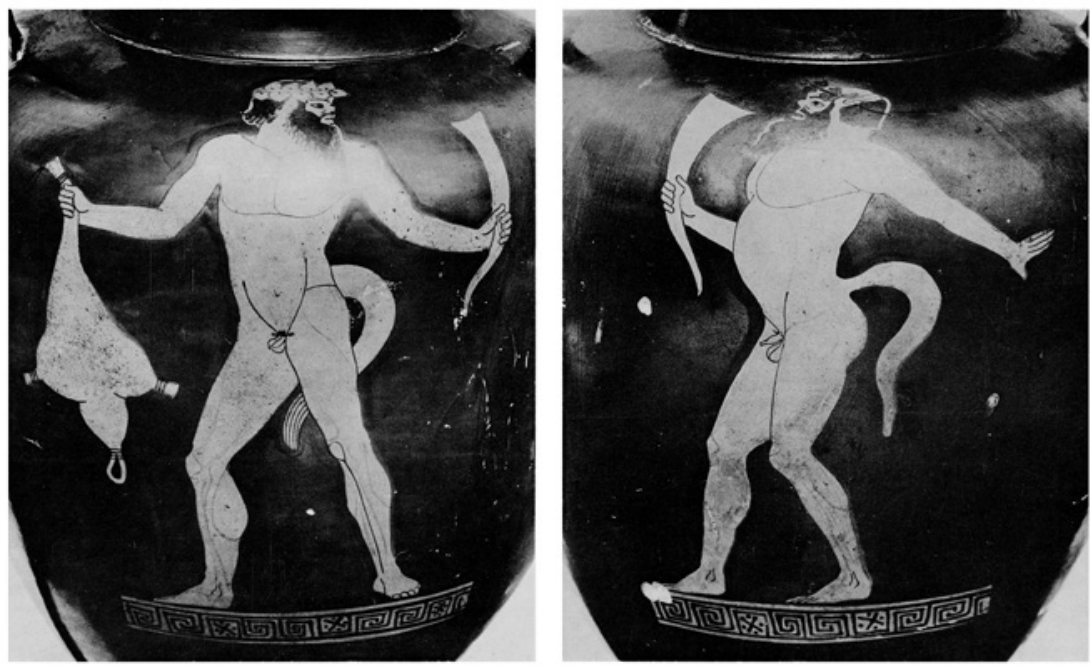

FIGURE 22 Neck-amphora, Berlin Painter, New York, Metropolitan Museum of Art 07.286.69 (Richter 1936, pl. 18). 
shows a version that is more like the familiar thiasos. It has, however, two peculiarities: one of the maenads has a small panther on her arm, and Dionysos carries a gnarled stick instead of a thyrsos (Figure 23). ${ }^{36}$

A fragment of a volute krater by the Berlin Painter shows a bearded figure in a short chiton and a panther skin, whose hand reaches out to Dionysos hastening towards the right. He may be Hephaistos, but this is unclear. ${ }^{37}$ In addition to the motif of Hephaistos riding a mule, which goes back to the 6th century, the early 5 th century sees the emergence of a new motif, that of the two gods walking together, supporting each other, which, in any case, shows them in a much more intimate relationship than the one we find here. ${ }^{38}$ This motif

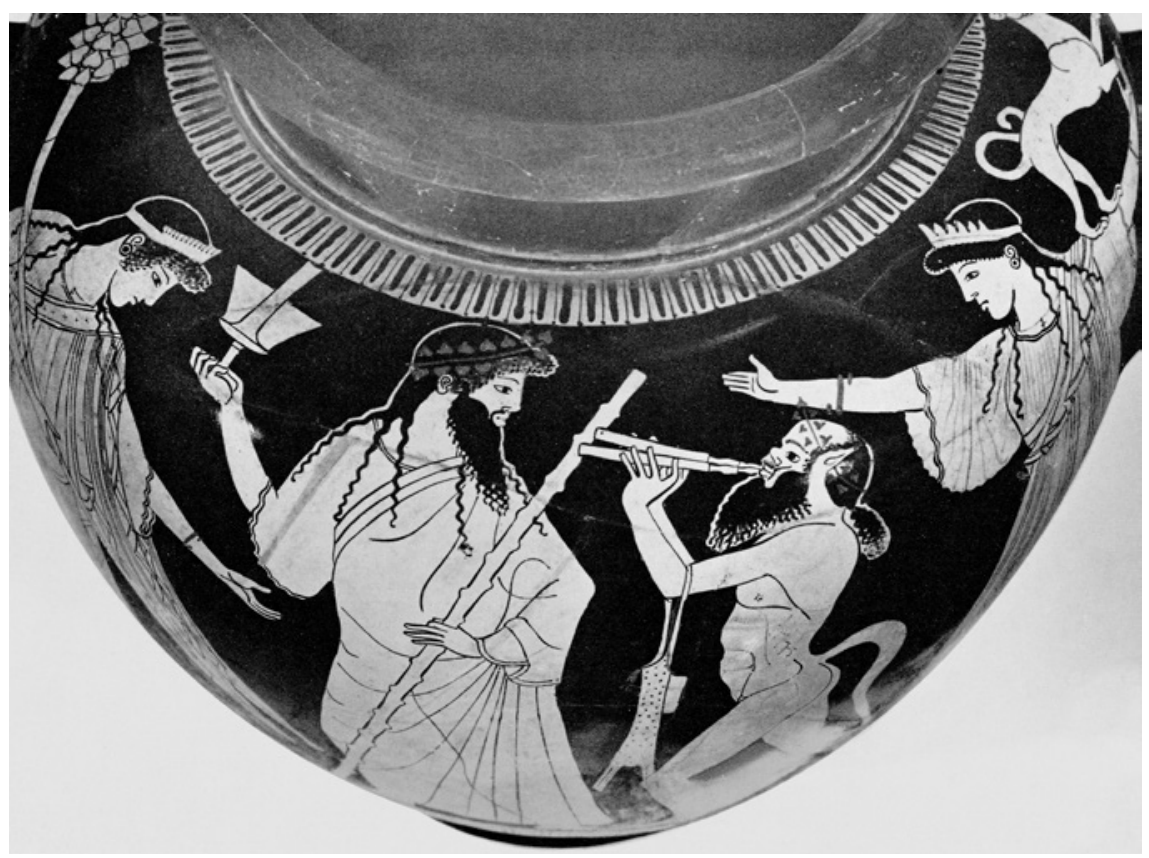

FIgure 23 Stamnos, Berlin Painter, formerly Castle Ashby 72 (cva Castle Ashby pl. 48.3).

36 Formerly Castle Ashby: Addenda 194 (208.145); BA 201964.

37 Vatican AST 703: Addenda 194 (1634.132 bis); BA 275092.

38 Fragments of a krater, Adria B 515 and B 1412: ARV 242.81; BA 202432 (Myson); probably also on an amphora, whereabouts unknown: Addenda 202 (246 below); вA 202463 (perhaps by the Painter of the Munich Amphora, no image); column krater, Tarquinia 683: Addenda 210 (290.7); BA 202639 (Tyszkiewicz Painter). For this new motif: Halm-Tisserant 1986, 8 f.; Schöne 1987, 44; Natale 2008, 102 f. 
underlines the sense of solidarity between these two little-loved scions of the Olympic family. It is conceivable, that the novelty was inspired by a satyr play, ${ }^{39}$ and that a discussion about the status of the nothoi (the unlegitimized sons of Athenian citizens) formed the background to the use of this motif in both the performing and the visual arts. ${ }^{40}$

The solidarity with Hephaistos brings us to the question of how the Berlin Painter treats the relationship between Dionysos and the other gods. The assembly of the gods on one of his stamnoi is hard to interpret. ${ }^{41}$ We see Apollo with his kithara who is hailed by Zeus in the presence of two female figures. On the left, he is followed by Nike or Iris. The scene is continued on the other side of the vase where we see Dionysos and Hermes walking towards the right, i.e. likewise towards the Olympus. Between them is a woman holding aloft two torches. The young Apollo with his kithara is also the protagonist of one of the sides of a sumptuous, but fragmentary calyx krater by the Berlin Painter. ${ }^{42}$ He stands between two youthful women, probably Muses rather than Artemis and Leto. ${ }^{43}$ To the left of this group, a bearded Dionysos moves in the opposite direction. On the other side of the vase we see Athena and her quadriga, hailed by Zeus and Hermes.

These are two artistically outstanding but rather enigmatic works. The only thing that may be deduced from them with any certainty is Dionysos' connection with the family of Olympian gods and his special relationship with the two other sons of Zeus, Apollo and Hermes. A magnificent dinos by the Berlin Painter offers further information about his role in this context (Figure 24). ${ }^{44}$ This exclusive vessel for mixing wine, a rarity in Greek ceramic art, presents him and other gods taking leave of Zeus who is about to depart from the Olympus. ${ }^{45}$ Zeus is shown with Athena, Hermes, Apollo with his kithara, Poseidon with fish and trident, and Amphitrite. To the left of Zeus, Dionysos follows Nike. With lips parted, which indicates he is speaking, he turns towards a goddess carrying a scepter, and an anonymous male figure, possibly a mortal. Dionysos is the only one among the gods to directly address this man. We do not know

39 Buitron-Oliver 1995, $39 \mathrm{f}$. In support of this see the calyx krater, Vienna 985 by the Altamura Painter (Addenda 264 [591.20]; BA 206838), where the two brothers are preceded by a satyr in a phallus costume: Natale 2008,103 , fig. 31 and here 91 fig. 45 .

Compare Isler-Kerényi 2007, $90 \mathrm{f}$.

41 London E 444: ARV 208.149; BA 201968.

42 Athens, Acr. 2.742 and London E 459: Addenda 193 (205.117); BA 201926 (no image).

43 See Lullies 1971, 53.

44 Basel Lu 39: BA 308 (no image); Lullies 1971, 44-55; Isler-Kerényi 2008a, 78 and fig. 8.

45 Kästner 2008a, $62 \mathrm{f}$. 


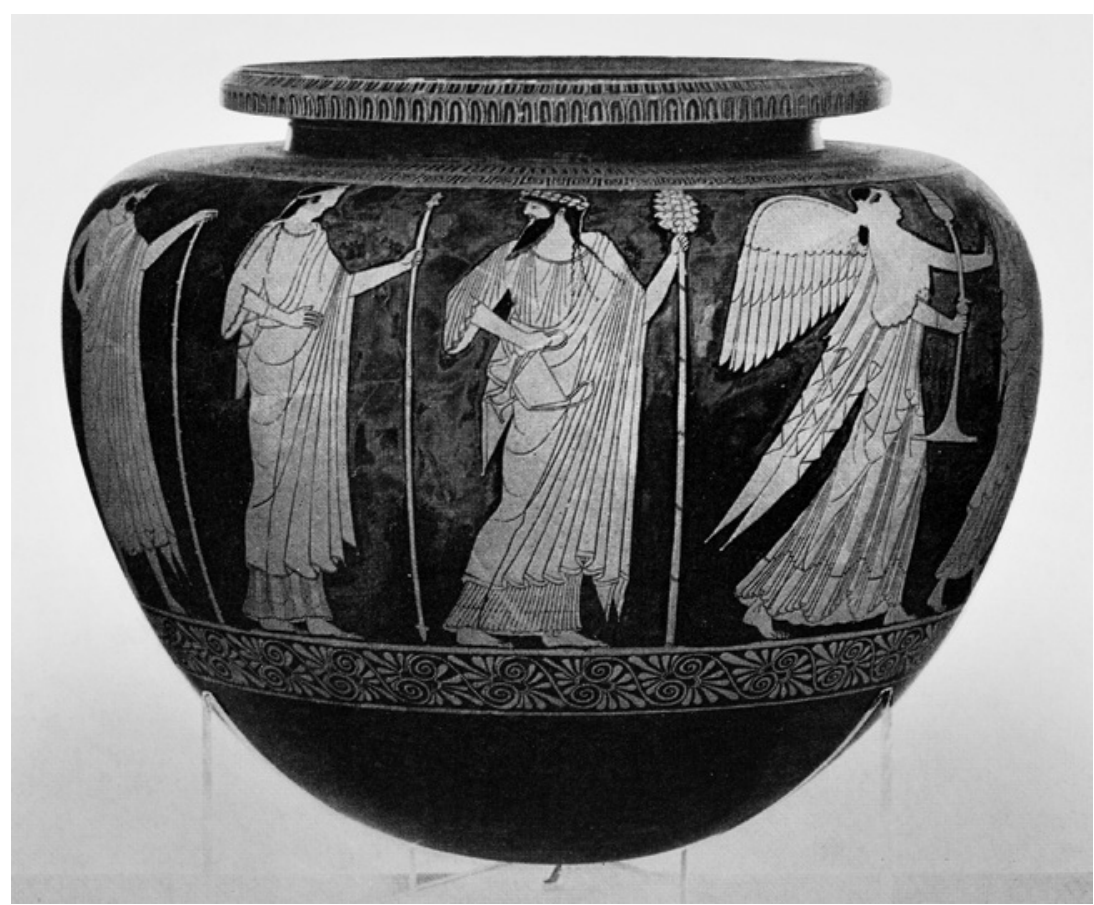

$a$
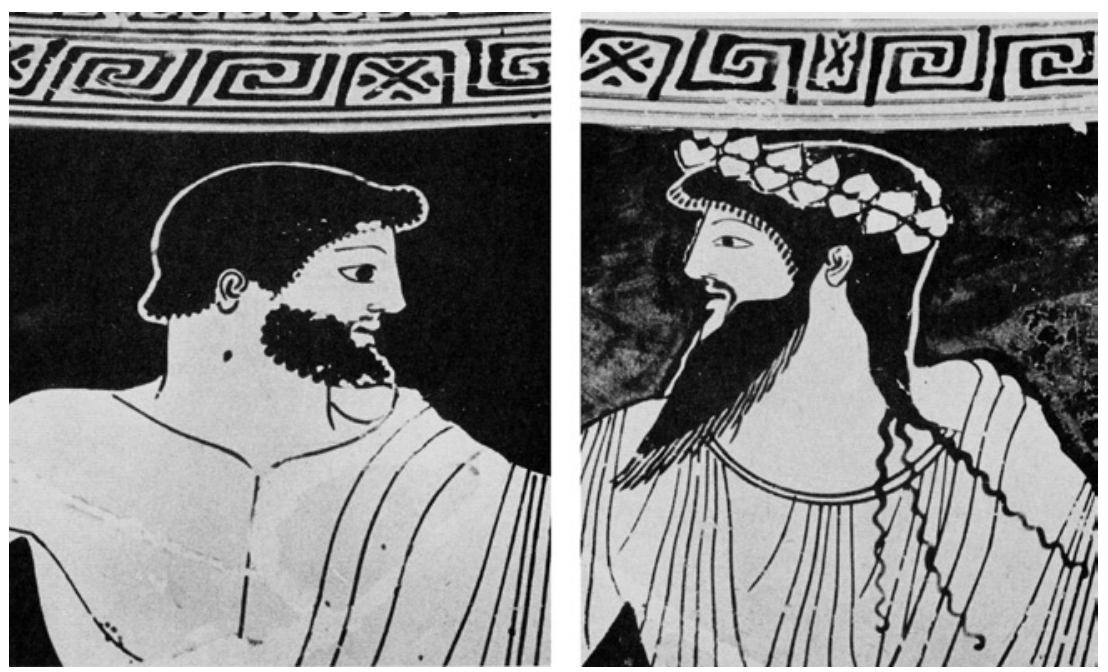

$b$

FIGU Re 24 Dinos, Berlin Painter, Basel, Antikenmuseum Basel und Sammlung Ludwig Lu 39. a. view of the vase with Dionysos (Lullies 1979, 1116 ).

b. detail: head, probably of Peleus, and head of Dionysos (Lullies 1971, pl. 19.2-3). 
the mythological context of this particular leave-taking scene, but because it is Dionysos who speaks to the man and his divine companion, we may presume the anonymous mortal is Peleus and the occasion, therefore, is the marriage of Peleus and Thetis. This would correspond with the role given to Dionysos on a dinos by Sophilos a hundred years earlier. ${ }^{46}$ It was Dionysos who, as the only one among the gods, directly addressed Peleus at his marriage to a goddess. The mortal hero Achilles, one of the protagonists of the Trojan War, was born from this marriage, all of which in the end served to confirm the order of Zeus. A somewhat younger pointed amphora by Syriskos, discussed below, proves that in the $5^{\text {th }}$ century one was still aware of Dionysos' role as a mediator in situations which threatened the legitimate world order. ${ }^{47}$

On two of his kalpides, the Syleus Painter, another of this generation of painters of large-size vases, has depicted elements from Dionysiac mythology that are not often seen in vase painting: we see Ariadne who is led away by the god while Theseus is sent away by Athena, ${ }^{48}$ and Zeus leaving the child Dionysos in the care of the nymphs. ${ }^{49}$ We will come back to these motifs in the context of comparable younger representations. ${ }^{50}$

Among the lesser painters of this time, we find Myson, the Harrow Painter, and the Flying-Angel Painter, who all seem to have favored column katers, as well as the Geras Painter, who preferred pelikai. It is remarkable that, apart from Dionysos, mythological figures hardly feature in their work. In addition, their repertoire is dominated by anonymous youths and men, and by athletes and warriors. The main protagonist in the work of these less eminent, but nevertheless often original artists, is the satyr. We have earlier seen him as the alter ego of the symposiast, in the role of the musician and the carrier of wine sacks, mixing vessels and pitchers. Now he is also depicted as an athlete, almost indistinguishable from a normal human one. ${ }^{51}$ We also see him as Hermes' assistant in a ludicrous scene, making a goat dance to the music of his flute. ${ }^{52} \mathrm{He}$ can play with other satyrs in a childlike manner, or lug about an enormous

\footnotetext{
46 Isler-Kerényi 2007, 75 .

47 See below Chapter 4, note 47.

48 Berlin F 2179: Addenda 203 (252.52); BA 202898.

49 Cab. Méd. 440: Addenda 203 (252.51); BA 202896.

50 See below Chapter 5 .

51 Munich 2381: Addenda 198 (221.14); BA 202099 (Nikoxenos Painter), and New York 12.229.13: ARV 276.80; BA 202679 (Harrow Painter).

$5^{2}$ Samothrake 57.565: ARV 232.1; Para 174.23bis; BA 202274 (Eucharides Painter, black-figure).
} 
artificial phallus. ${ }^{53} \mathrm{He}$ can play pranks in front of a statue of Dionysos. ${ }^{54} \mathrm{He}$ can approach the god in a comical costume. ${ }^{55} \mathrm{He}$ can be scolded by Dionysos. ${ }^{56}$ Just like normal people, he can get water from a spring, ${ }^{57}$ cook a meal, ${ }^{58}$ draw water from the public well. ${ }^{59} \mathrm{He}$ makes us laugh when he mimes a respectable citizen ${ }^{60}$ or eats stolen grapes. ${ }^{61}$ It is hardly a coincidence that the majority of these images were created by the Geras Painter. He favored the pelike, a vase type that must have been predestined to carry unconventional representations. ${ }^{62}$ But how should we explain the fact that, apparently, satyrs could damage gravestones or herms (Figure 25), ${ }^{63}$ or molest or even threaten women carrying out rituals? ${ }^{64}$ Would this not also be sacrilege for satyrs?

\section{Painters of Cups}

The ascendancy of anonymous figures over mythological ones is even more evident in the work of the cup painters of the period between 500 and about 470 вс. ${ }^{65}$ Their output was often very large: Beazley attributed more than 170 items to Onesimos and his circle, over 220 to the Brygos Painter, over 310 to Douris, and more than 350 to Makron. Almost all of these are cups. However,

53 Boston 98.882: Addenda 208 (279.7); BA 202711 (Flying-Angel Painter) and Copenhagen, Thorvaldsen Museum 99: Addenda 209 (287.24); BA 202595 (Geras Painter).

54 Louvre G 227: Addenda 208 (283.2); BA 202563 (Painter of Louvre G 238).

55 Boston 64.2032: Addenda 209 (285.2); BA 202577 (Geras Painter).

56 Leipzig T 643: Addenda 209 (286.9); BA 202584 (Geras Painter).

57 Harvard 1925.30.34: ARV 285.7; BA 202582 (Geras Painter).

58 Berkeley 8.4583: Addenda 209 (286.10); BA 202585 (Geras Painter).

59 Berlin F 2173: Addenda 209 (286.18); BA 202589 (Geras Painter).

6o Oxford 283: ARV 286.21; BA 202592 (Geras Painter); Lissarrague 2013, 200, fig. 170 (Geras Painter). Satyr-citizens occur in red-figure vases from about 480 вС onwards: Lissarrague 2013, 204. Concerning the black-figure version, see Lissarrague 2013, 291, Annexe 26.

61 Oxford 1922.67: ARV 312.1; BA 203213 (Class of Vienna 3717).

62 Shapiro 1997; Schöne-Denkinger 2014, $13 \mathrm{f}$.

63 Louvre CA 1947: Addenda 201 (240.44); BA 202393 (Myson) and Florence v 5: Addenda 208 (281.34); BA 202540 (Flying-Angel Painter), likewise Lausanne 3250: Para 355 center; BA 352524 (no image) (Geras Painter); Bérard 1966. In Bérard/Bron 1986 he himself refuted his earlier interpretation, current at the time, of satyrs as a kind of fertility demon; Lissarrague 2013, $201 \mathrm{ff}$., figs 173-174.

64 For instance Oxford 307: ARV 393.37; BA 204235 (Painter of Munich 2676). For a similar situation, a satyr pursuing a woman who holds a torch, see Louvre G 202: ARV 226.4; BA 202223 (Eucharides Painter).

65 Compare Kästner 2008a, 64 f. and 69 . 


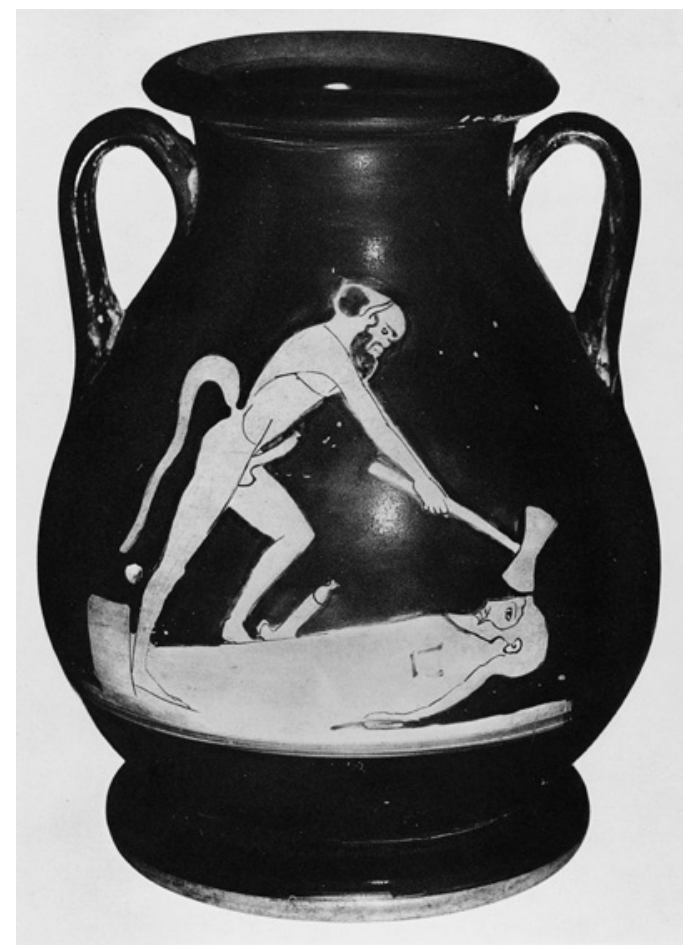

FIgURE 25 Pelike, Geras Painter, Lausanne, (C) Musée cantonal d'archéologie et d'histoire INV 325o, side A (Bérard 1966, 95, pl. 21).

Dionysos and his thiasos are depicted rather infrequently; komos and symposium are better represented.

Let us first look at Onesimos, who was active between c. 510 and c. 480 BC and whose signed cup was produced by the potter Euphronios. ${ }^{66} \mathrm{He}$ was mainly interested in athletes and horses; his favorite mythological figures were, appropriately, Athena and Herakles. Among Dionysiac subjects, he favored komos and symposium, followed by satyrs. His best known satyr is found on a cup of which only the medallion is decorated. This aged, ithyphallic satyr is sitting rather unstably on a transport-type amphora in a typical attitude of 'indecent exposure' (Figure 26). ${ }^{67}$

The Brygos Painter, a skillful and original artist, seems to have had more affinity with Dionysiac subject matter. Apart from a few small vases, he mostly

\footnotetext{
66 Boardman 1975, 133.

67 Boston 10.179: ARV 327.110; BA 203364.
} 


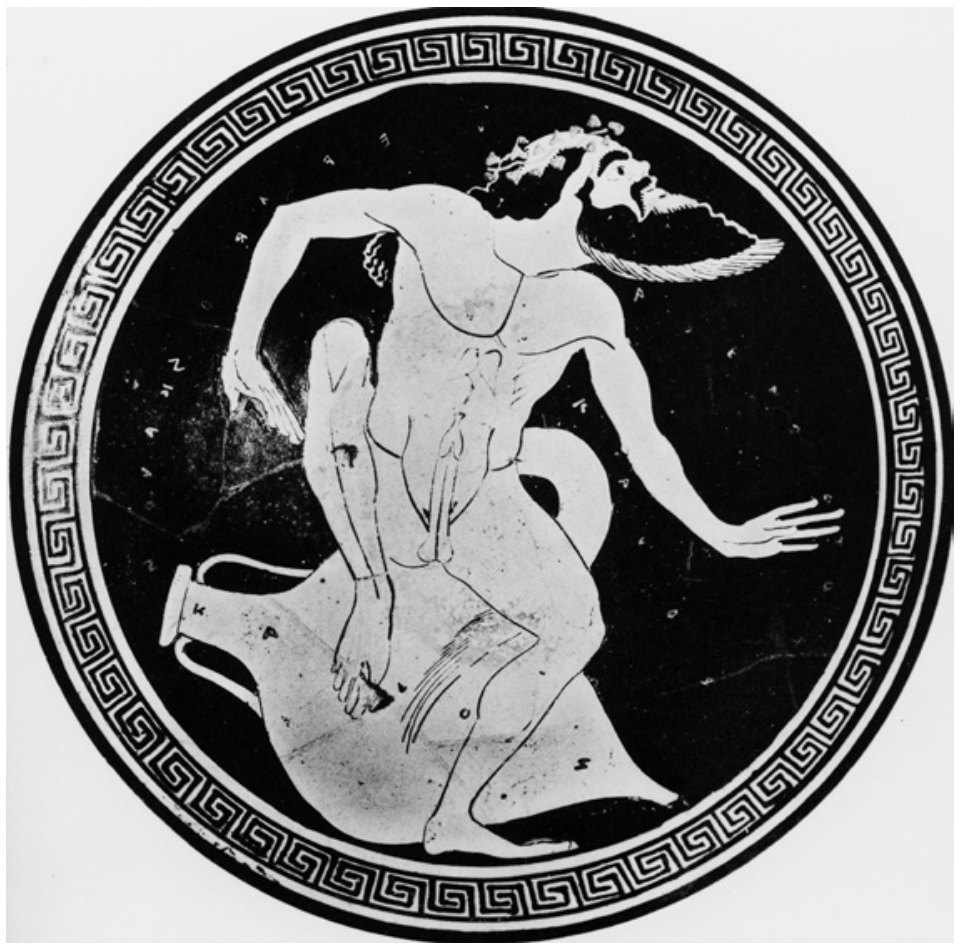

FIGURE 26 Cup, Onesimos, Boston, Museum of Fine Arts 10.179 (Langlotz 1922, pl. 8).

painted cups. His activities began after 490 BC and continued beyond $470 .^{68}$ Here, too, anonymous figures dominate. Besides athletes and warriors, however, we also quite often find komos and symposium as well as satyrs and maenads. His thiasoi are rather poetic and music is given an important role: even Dionysos himself may appear on the scene as an ecstatic barbitos player. ${ }^{69}$ One thiasos cup deserves special mention because of its high quality: its tondo shows, on a white ground, a maenad wearing a snake diadem, who brandishes a small panther (Figure 27). The effect is both graceful and uncanny. ${ }^{70}$ Even though figures are rarely seen on this vase in the shape of a drinking horn, the Brygos Painter also decorated several rhyta. ${ }^{71}$ The one that is best known shows, on both sides of the body, a satyr welcoming Dionysos with the music

68 Boardman 1975, 135.

69 For instance Cab. Méd. 576: Addenda 225 (371.14); BA 203913.

$70 \quad$ Munich 2645: Addenda 225 (371.15); BA 203914.

71 ARV 382 f., 185-195. For this type of vase: Hoffmann 2007, 161-205, especially 165. 


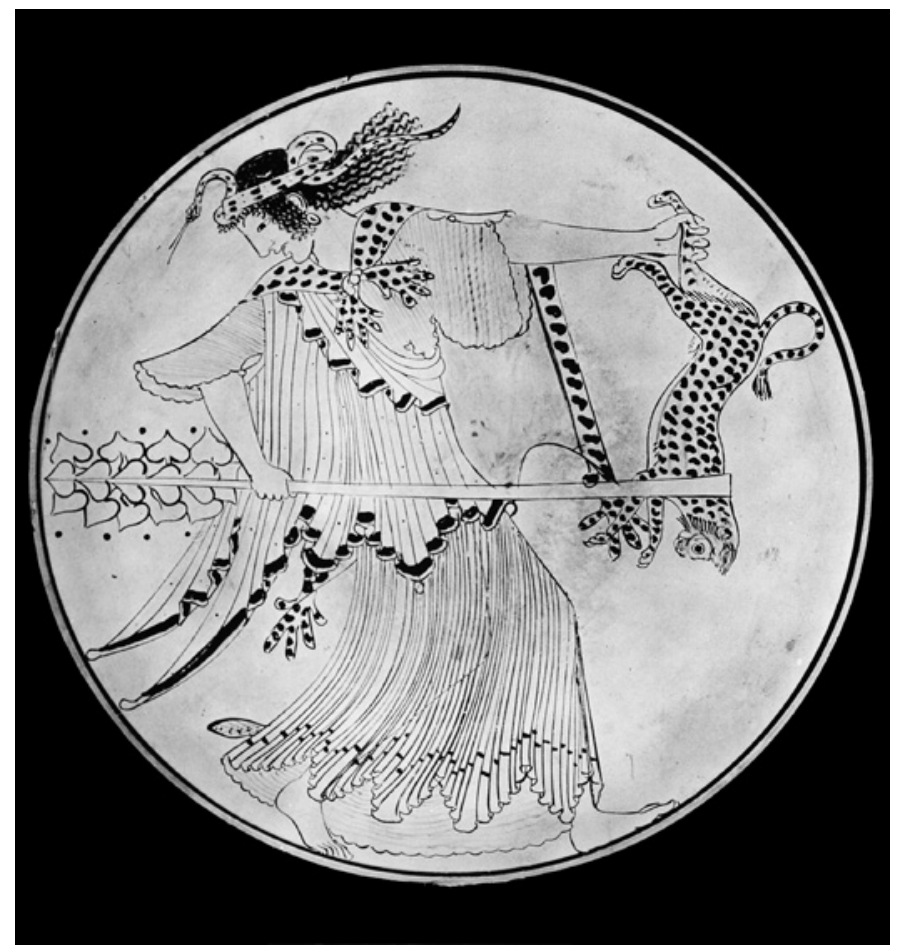

FIGURE 27 Cup, Brygos Painter, Munich, Staatliche Antikensammlungen und Glyptothek, 2645, tondo image on a white ground (FR pl. 49.1).

of the aulos at an altar decorated with ivy. ${ }^{72}$ On both sides of the opening a satyr is stealing on a sleeping maenad. The motif of lecherous satyrs surprising maenads in their sleep can already be found on a kalpis by the Kleophrades Painter (Figure 28). ${ }^{73}$ However, it appears more often on cups than on other vase types. ${ }^{74}$ The motif refers to the subversive nature of satyrs. Its mythological counterpart is the assault made by satyrs on Hera and Iris depicted on another of the Brygos Painter's cups. This motif may have been inspired by

72 Warsaw, ex Goluchow 119: Addenda 228 (382.185); вА 204084.

73 Rouen 583.3: Addenda 188 (188.68); BA 201716.

74 For instance: Baltimore without number: Addenda 215 (320.10); вА 203260 (Onesimos); Louvre S 1339, S 1328: ARV 320.11; BA 203261 (Onesimos); Boston (Onesimos); Boston 01.8072: Addenda 244 (461.36); BA 204718 (Makron) and, of a later date, Louvre G 206: ARV 530.22; BA 205998 (neck-amphora by the Alkimachos Painter). For this motif, see McNally 1985, 157 f.; Paul-Zinserling 1994, 53 f.; Lindblom 2011, 38-45; Lissarrague 2013, 89 f. 


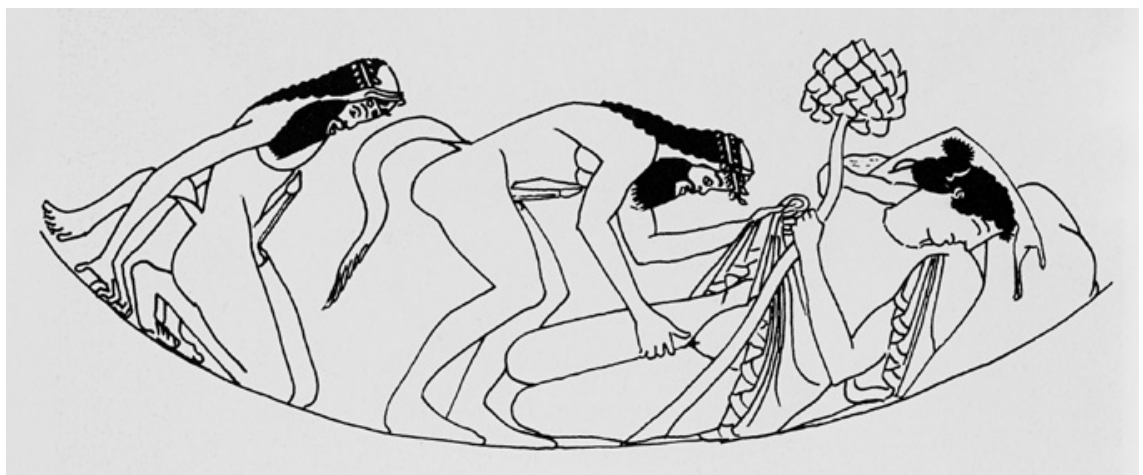

FI U RE 28 Kalpis, Kleophrades Painter, Rouen, Musée Départemental des Antiquités 583.3 (Lissarrague 1987, 88, fig. 22).

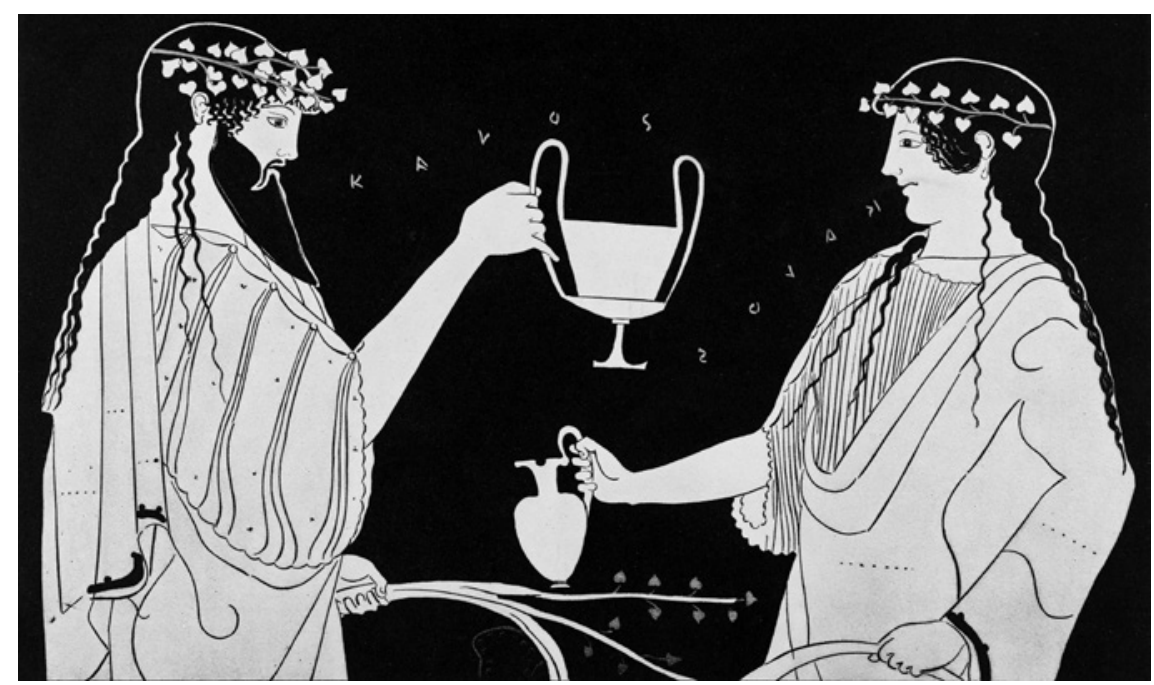

FI U URE 29 Kalathos, Brygos Painter, Munich, Staatliche Antikensammlungen und Glyptothek, 2416, detail of side B (FR pl. 64 below).

a satyr play. ${ }^{75} \mathrm{~A}$ unique, and rightly famous, cooling vessel in the shape of a basket, designated as a kalathos, shows a dignified young woman solemnly approaching Dionysos (Figure 29). On the other side we see the meeting of the poets Alkaios and Sappho. ${ }^{76}$

75 London E 65: Addenda 224 (370.13); BA 203912. In addition Schoenmann/Krumeich in: Krumeich/Pechstein/Seidensticker 1999, $5^{26}$ f., fig. 29; Lissarrague 2013, 47 ff., fig. 22.

76 Munich 2416: Addenda 228 (385.228); вA 204129. 
The Briseis Painter, a minor cup painter from the circle of the Brygos Painter, was mainly interested in the everyday life of women. ${ }^{77}$ Two of his works, however, are exceptional for various reasons. One of his cups not only stands out because its outside shows Dionysos dancing like a maenad, but also because its tondo has an enigmatic encounter between an ephebe and an elderly man in front of the door to a house. ${ }^{78}$ The outside of a cup from Ruvo in Apulia-a site that gains in importance in the late 5 th century-shows quiet scenes with anonymous figures. Its white background tondo is remarkable for its depiction of a satyr with a noble appearance in the manner of the Kleophrades Painter and the Berlin Painter. ${ }^{79}$

One of the most productive painters of this time is Douris. About three hundred vases are attributed to him. Most of them are cups, but he also decorated a number of other small vase types. His activities begin shortly before 500 and continue well beyond $470 \mathrm{BC} .{ }^{80}$ His main theme is the world of men: war, sport, love, komos and symposium. Douris is no different from other painters of cups in that in his work, too, Dionysos and his thiasos occur more frequently than mythological scenes. His version of the return of Hephaistos is, however, remarkable. ${ }^{81}$ Dionysos lovingly leads his half-brother by the hand in a procession headed by a satyr making music and one carrying a heavy bell krater. A dancing nymph accompanies them. Hephaistos has his hammer over his shoulder; a third satyr, carrying the goat skin bellows, brings up the rear (Figure 30). On the other side, youthful and mature komasts dance in pairs to the music of a barbitos player. In the tondo Hera sits on her throne in a dignified manner. She holds a conversation with Zeus who stands before her. Douris in this way underlines the mythologlical context of the episode, while at the same time highlighting the analogy between the human komos and the Dionysiac thiasos. This analogy may also be hinted at in the tondo of another cup where a komast is apparently leading his friend to the symposium. The outside has, on both sides, five bearded komasts dancing solemnly towards the right. $^{82}$

77 Boardman 1975, 137 .

78 London 1843.11-3.54: Addenda 232 (406.2); BA 204401. Compare a stamnos with Dionysos dancing, London E 439: Addenda 211 (298 center); BA 203092 (Hephaisteion Painter).

79 Ruvo 1529A: Addenda 232 (408.33); BA 204431.

80 Buitron-Oliver 1995, 3 .

81 Cab. Méd. 542: Addenda 239 (438.133); вA 205179; Buitron-Oliver 1995, 39 no. 178, pl. 100.

82 London 1843.11-3.4 (E 54): Addenda 238 (436.96); BA 205142; Buitron-Oliver 1995, no. 144, pl. 85 . 


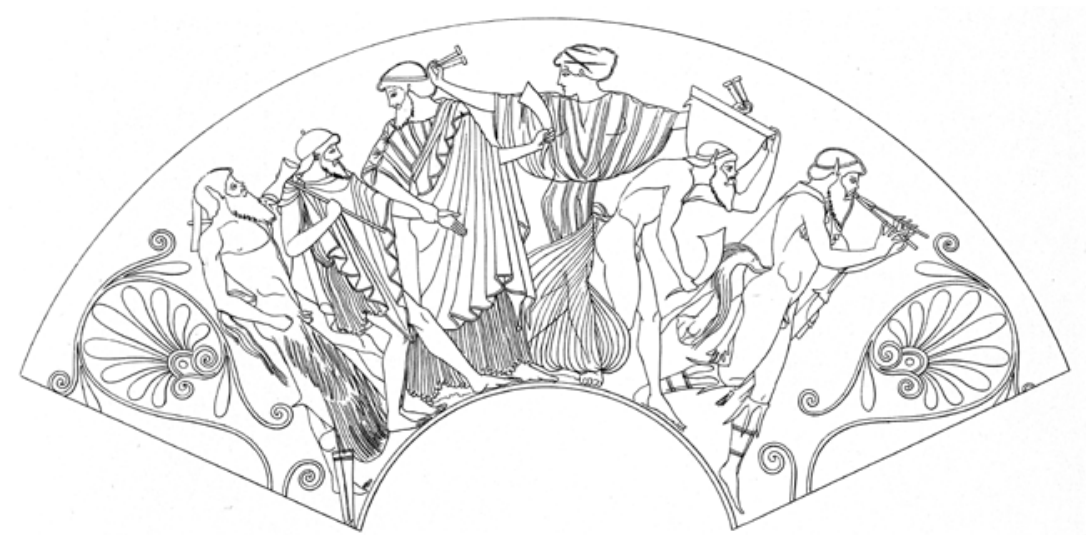

FI GURE 30 Cup, Douris Paris, Bibliothèque Nationale de France, Cabinet des Médailles 542 (Brommer 1978, 15, fig. 6).

The punishment of Pentheus, best-known from Euripides' Bakchai, belongs to the mythology of Dionysos, but is not often depicted. The tondo of one of Douris' cups shows a bacchante with a thyrsos in her left hand, while her right hand holds a leopard by the tail. ${ }^{83}$ On the outside we see two women grabbing hold of Pentheus' arms and head; only his upper body is still intact. Two other women and a satyr are present at the scene. The latter, appalled, looks out of the image at the viewer. The other side shows a Dionysos of gigantic stature sitting on a folding chair with the kantharos and ivy branch in his hands. To the left a satyr is approaching, playing the double flute. A woman on the left side and two on the right are moving energetically, each with a part of Pentheus' body in her hands; the two women near the handles are shown en face, a device for which Douris had, as other images show, a predilection (Figure 31). ${ }^{84}$

The medallion of another of Douris' cups shows Dionysos as a symposiast on one couch with Herakles. ${ }^{85}$ The outside has, on both sides, three youthful pairs of friends in conversation; it is clear that Dionysos and Herakles are their mythical models.

83 Fort Worth AP2000.02: BA 11686 (no image); Buitron-Oliver 1995, no. 121, pl. 73. Lissarrague 2013, 168 f., fig. 144. In the case of the psykter by Euphronios (see above Chapter 2, note 49) it is unclear if and how Dionysos was represented.

84 Buitron-Oliver 1995, 35.

85 Private collection: Buitron-Oliver 1995, no. 185, pl. 103. 


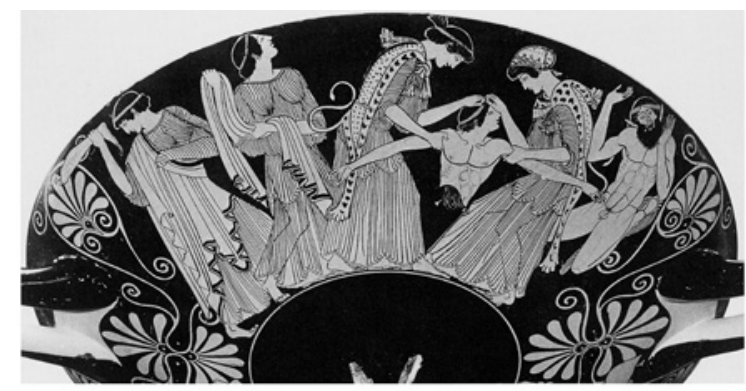

$a$

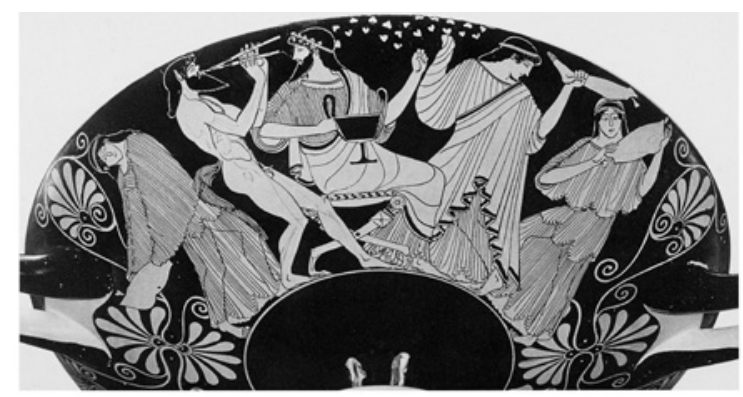

$b$

FIgURE 31 Cup, Douris Fort Worth (Tx), Kimbell Art Museum (AP20oo.o2).

a. Pentheus (Buitron-Oliver 1995, pl. 73).

b. Dionysos (Buitron-Oliver 1995, pl. 73).

We find one of Douris' best-known Dionysiac scenes on a psykter. ${ }^{86}$ Ten satyrs, probably his earliest, are performing various acrobatic tricks with symposium vessels. Another, exotically attired, satyr is apparently delivering a message to them; with his kerykeion he seems to be miming Hermes (Figure 32). A painter from Douris' entourage decorated the outside of a cup with satyrs enjoying themselves in a similarly imaginative manner. ${ }^{87} \mathrm{~A}$ comparable scene on a cup by a painter from the circle of the Nikosthenes Painter is grossly homoerotic. ${ }^{88}$

The Triptolemos Painter was an artist who belonged to Douris' circle. He was active from the 8 os until around 470 BC. He only decorated cups in the early

86 London E 768: Addenda 241 (446.262); BA 205309; Buitron-Oliver 1995, 34, no. 84, pl. 54 f.; Lissarrague 2013, 146 f., figs 122-123.

87 Vatican 16541: Addenda 242 (451.1); BA 205372 (Oedipus Painter).

88 Berlin 1964.4: Addenda 177 (Para 334); вA 275638 (no image); Schlesier/Schwarzmaier 2008, 21, fig. 3 . 


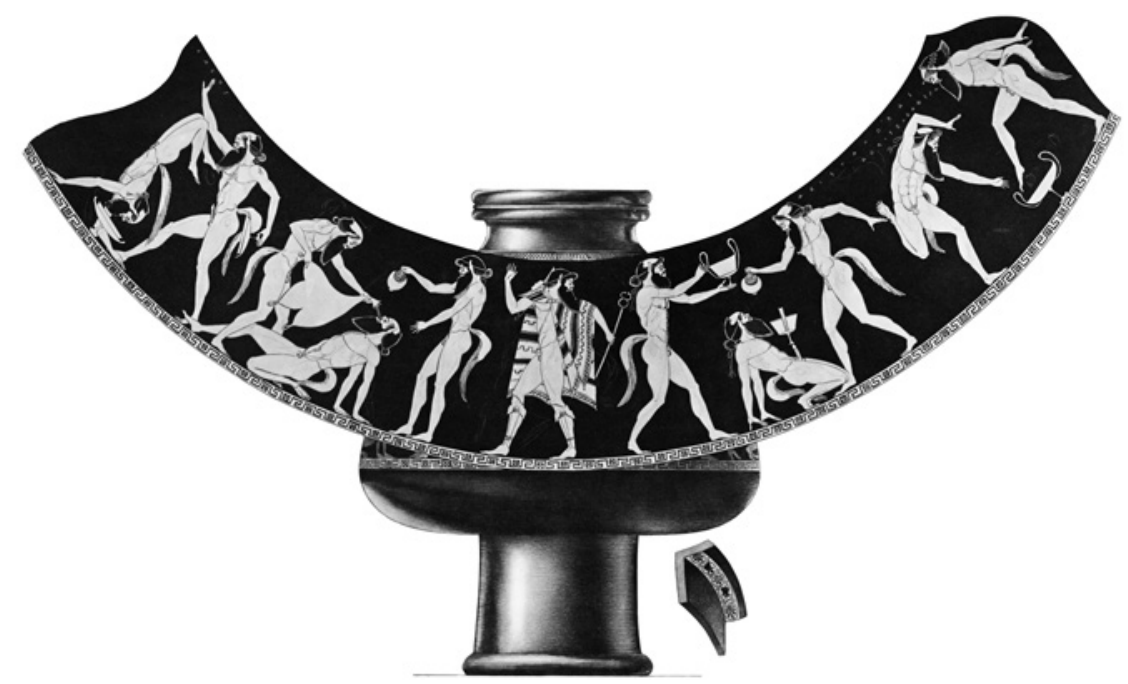

FIGURE 32 Psykter, Douris London, British Museum E 768 (FR pl. 48).

stages of his career, later he also decorated larger vase types, such as stamnoi, column kraters and pelikai. ${ }^{89}$ One of his cups is a good example of a conventional theme depicted in an original manner. ${ }^{90}$ In the tondo a satyr, full of lust, is assaulting a nymph, who seems more surprised than frightened. On the outside in the center Dionysos is walking to the right, but turns towards the maenad nearest to him; the maenad to his right is approaching with an oinochoe. In contrast to the other side, where women are dancing gracefully, the four women on this side are behaving unusually quietly. In this way the painter has managed to merge the thiasos theme and the motif of the encounter-salute, which normally features no more than two figures. Another cup, with a unique depiction of a ritual, will be discussed in one of the following chapters. ${ }^{91}$

In the context of the study of Dionysiac imagery, Makron, whose work may be dated between 490 and $470 \mathrm{BC}$, is the most rewarding among the cup painters of his generation. ${ }^{92}$ Most cups, about 350, are attributed to him. Although anonymous men and youths are also Makron's main subject, he seems to have been more interested in the Dionysiac thiasos than his colleagues. Numerous fragments found on the Acropolis testify to his popularity, not only in Etruria

\footnotetext{
89 Boardman 1975, $139 \mathrm{f}$.

9o Louvre G 250: Addenda 223 (365.58); BA 203850.

91 See below Chapter 6, note 2.

92 Boardman 1975, 140. For the dating see also Isler-Kerényi 1984, 154-156 and Kunisch 1997, $18-21$.
} 
but also in Athens. ${ }^{93}$ Many of his tondi are Dionysiac: we find various scenes depicting the advent of the god or with Dionysos dancing on his own, ${ }^{94} \mathrm{a}$ single satyr ${ }^{95}$ or a satyr with a nymph, mostly in non-aggressive relationships (Figure 33). ${ }^{96}$ We also find maenads, alone ${ }^{97}$ or in pairs. ${ }^{98}$ Single satyrs seem to be rather the exception. ${ }^{99}$ The designs of the innumerable, more or less energetic, thiasoi on the outsides are as varied and inventive as those of the tondi. We find thiasoi with and without Dionysos, sometimes (even though there are maenads in the tondo) with only maenads, ${ }^{100}$ once with only satyrs. ${ }^{101}$ One never has the impression that the artist is unthinkingly using familiar themes, on the contrary: he seems to have done his best to constantly come up with new compositions and gestures. As a rule, the thiasos is supposed to be a circle dance. Occasionally, however, it appears to be a procession moving to the right, in the direction of an unknown destination. ${ }^{102}$ This is a novelty that after 480 B can also be found on other image carriers.

\section{Pala 2012, $217 \mathrm{ff}$. with table fig. 122.}

94 Rome, Villa Giulia 50396: Addenda 245 (465.82); BA 50396; Kunisch 1997, no. 63, pl. 25; Athens, Acr. 2.307: ARV 478.38; BA 204990 (no image); Kunisch 1997, no. 168, pl. 62.

95 Brussels R 247: Para 377 (462.41); BA 204723; Kunisch 1997, no. 103, pl. 38; Boston 13.67: Para 378 (478.309); BA 204991 (no image); Kunisch 1997, no. 197, pl. 68; private collection: Para 377 (462.44); BA 204726 (no image); Kunisch 1997, no. 314, pl. 105; Berlin F 2290: Addenda 244 (462.48); BA 204730; Kunisch 1997, no. 345, pl. 116.

96 Louvre G 144: Addenda 244 (462.43); BA 204725 (no image); Kunisch 1997, no. 98, pl. 37; New York 06.1152: Addenda 245 (463.52); вA 204734 (no image); Kunisch 1997, no. 151, pl. 54; Florence 3943: ARV 478.311; BA 204993; Kunisch 1997, no. 188, pl. 65; Harvard 1972.41: ARV 462.45; BA 204727 (no image); Kunisch 1997, no. 305, pl. 101; Munich 2654: ARV 462.47; BA 204729 (no image); Kunisch 1997, no. 340, pl. 114; New York 20.246: ARV 467.118; BA 204800 (no image); Kunisch 1997, no. 377, pl. 130.

97 Basel Kä 410: Addenda 245 (463.53); BA 204735; Kunisch 1997, no. 128, pl. 44; Louvre G 160: Addenda 247 (478.312); BA 204994 (no image); Kunisch 1997, no. 16o, pl. 57.

98 Baltimore B 10: Addenda 245 (463.51); BA 204733; Kunisch 1997, no. 307, pl. 102; Louvre G 145: ARV 463.50; BA 204732 (no image); Kunisch 1997, no. 313, pl. 104.

99 Munich 2657: Addenda 246 (475.267); вA 204946 (no image); Kunisch 1997, no. 507, pl. 163 (stage satyr in phallus costume, dancing next to a large column krater decorated with a wreath); Louvre MNE 961: ARV 475.261; BA 204940 (no image); Kunisch 1997, no. 509, pl. 164 (satyr performing an elegant dance next to a symposium table with a kantharos).

100 Basel Kä 410: Addenda 245 (463.53); BA 204735; Kunisch 1997, no. 128, pl. 44; Louvre G 145: ARV 463.50; Kunisch 1997, no. 313, pl. 104.

101 Fragments in several places: Para 377 (462.49); BA 204731; Kunisch 1997, 107 note 449, no. 109, pl. 39 .

102 Tarquinia RC 1118: Addenda 244 (Para 378.46bis); BA 275978 (no image); Kunisch 1997, no. 133, pl. 46; Baltimore B 10: Addenda 245 (463.51); BA 204733; Kunisch 1997, no. 307, pl. 102; Private collection: Para 377 (462.44); BA 204726 (no image); Kunisch 1997, no. 314, pl. 105 . 


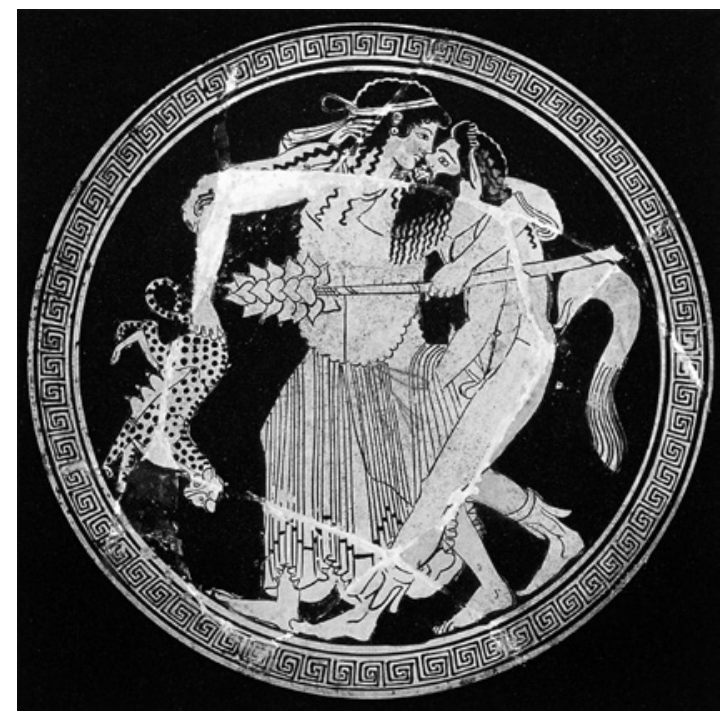

$a$

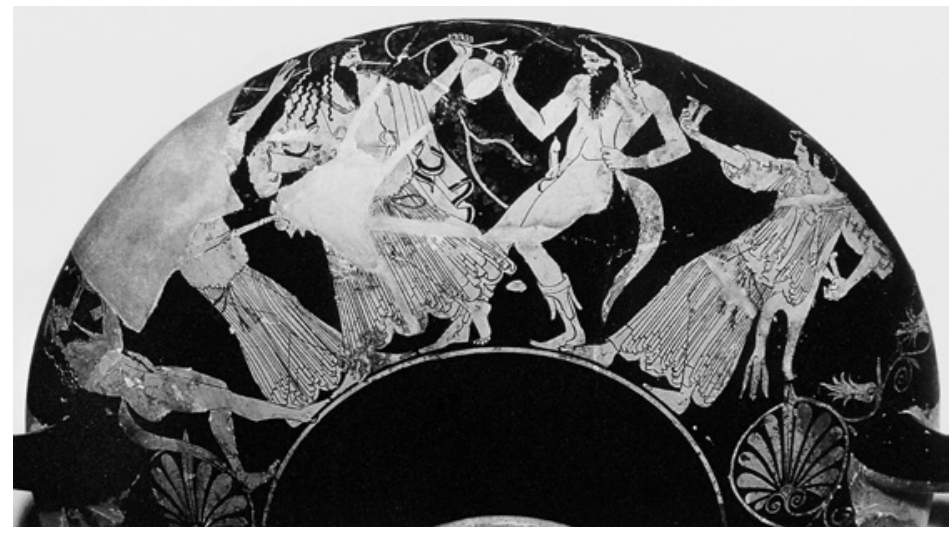

$b$

FIGURE 33 Cup, Makron, Paris, Louvre G 144 (Kunisch 1995, pl. 37).

a. medallion: satyr with female partner.

b. side A: Dionysos amidst his thiasos.

On the outsides of cups by Makron, we usually find Dionysos amidst the members of his thiasos. In one case he appears as a symposiast, but because of the fragmentary state of the cup it is impossible to determine who his comrade could be. The only remaining symposiast on the other side is definitely human. ${ }^{103}$ On a mental level, the presence of Dionysos at a human symposium

103 Oxford 1911.631: ARV 467.129; BA 204811; Kunisch 1997, no. 198, pl. 68. 
would in any case be considered entirely natural. Makron's famous skyphos shows how the artist saw Dionysos' position vis-à-vis the other gods. Here we see him, on the one side, with his ivy branch, as the central figure between Zeus and Amphitrite, set against Triptolemos, who is on the other side, seated in his winged chariot amidst the Eleusinian goddesses. ${ }^{104}$ The juxtaposition of these two culture heroes is probably also represented on a, unfortunately fragmentary, pelike by the Pan Painter - a more or less contemporaneous work of great artistic quality. ${ }^{105}$ The theme is likewise found in the work of the Niobid Painter. ${ }^{106}$ No less informative is an exquisite cup in Bochum (Figure 34). ${ }^{107}$ Its very damaged inside showed Athena welcoming Herakles, its outside has gods sitting enthroned. On one side we see Dionysos in the middle between Zeus and Poseidon, with Ganymede, a young woman-perhaps Ariadne-and Amphitrite standing next to them. The other side shows Ares in the middle between Apollo and Aphrodite. Artemis and Nike stand between them; Eros, coming from the right, is flying towards Aphrodite. Under the handles we can discern small panthers, ready to jump. Ever since Exekias, the assembly of the gods on the occasion of the apotheosis of Herakles is part of tradition. ${ }^{108}$ One of the most prominent examples, the Sosias cup in Berlin, has already been mentioned. ${ }^{109}$ What is unusual here is the conspicuous position of Ares and his opposition to Dionysos. Kunisch proposes a relationship with the Persian Wars: the work may be dated in the middle period of Makron's artistic career, around $48 \mathrm{o} \mathrm{BC} .{ }^{110}$ Kunisch' proposition is plausible and is, moreover, supported by the panthers under the handles; the panther symbolizes Asia. ${ }^{111}$ Dionysos is presented here as the counterpart of Ares, the god of war and victory. We may therefore presume Dionysos embodies cosmic peace, which would suit his role as the peace maker of the Olympic family (we could think of the return of Hephaistos) to perfection. As we will see, this characteristic of Dionysos will appear again and again, also in the later iconography.

Makron's oeuvre for the first time shows a subject that would be much in demand from 480 BC until well after the middle of the century: the handing

\footnotetext{
104 London E 140 (1873.8-20.375): Addenda 243 (459.3); BA 204701 (no image); Raubitschek/ Raubitschek 1982, 113; Kunisch 1997, no. 319, pl. 107; Clinton 1992, 124.

105 Malibu 81.AE.62: Robertson 1986, 72-88.

106 See below Chapter 5, note 3. We already find the juxtaposition of Dionysos and Triptolemos on black-figure vases of the early $5^{\text {th }}$ century, see Raubitschek/Raubitschek $1982,110$.

107 Bochum, Univ. S 1062: BA 13378 (no image); Kunisch 1997, 198, no. 352, pl. 118-119.

108 Mommsen 2002/03; Knell 1965, 47-54.

109 See above Chapter 2, note 81.

110 Kunisch 1997, 151.

111 Isler-Kerényi 2011a, $85 \mathrm{f}$.
} 


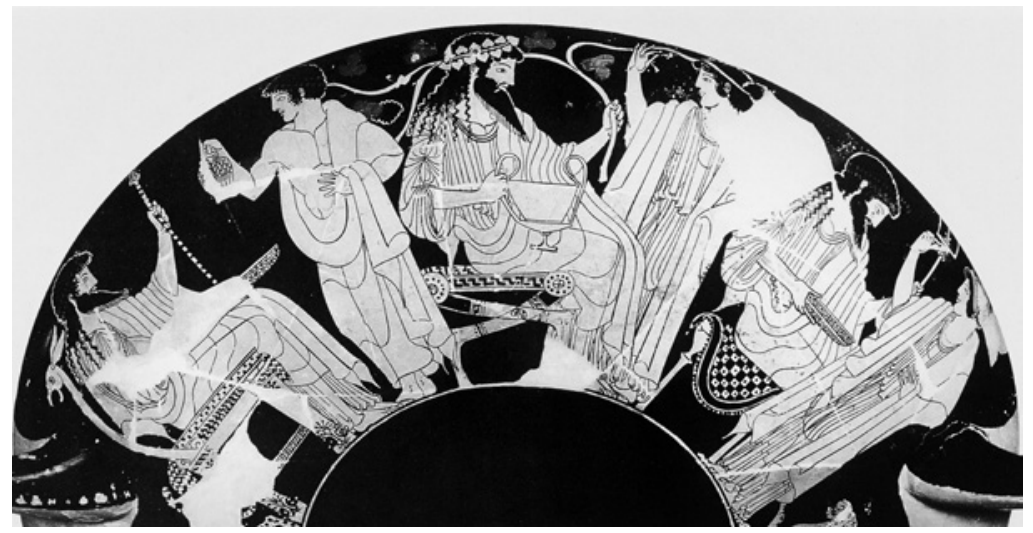

$a$

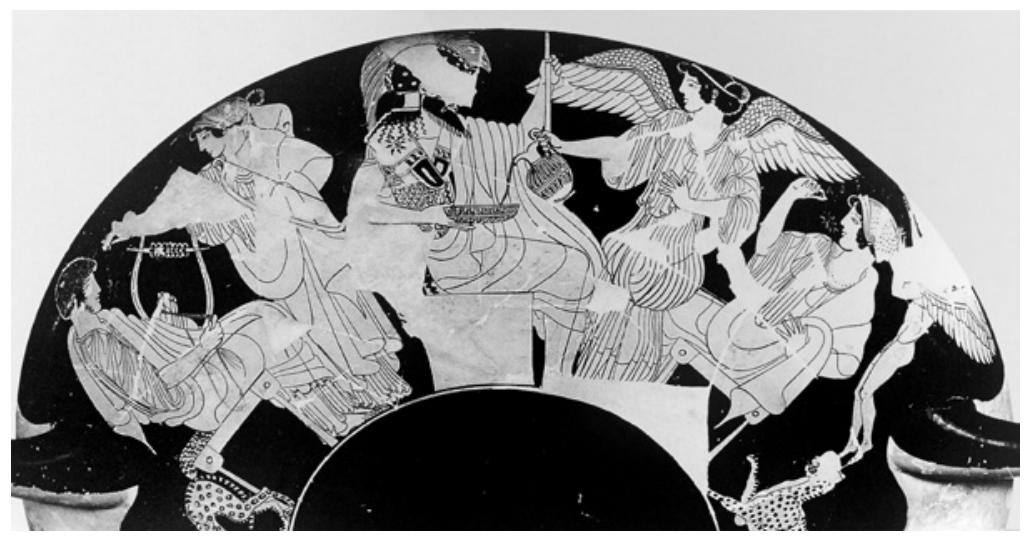

$b$

FIGURE 34 Cup, Makron, Bochum, Ruhr-Universität, Kunstsammlungen S 1062 (Kunisch 1995, pl. 119).

a. Dionysos.

b. Ares.

over of the child Dionysos to the nymphs. ${ }^{112}$ This motif will be discussed in more detail in one of the following chapters. ${ }^{113}$ Makron's famous Berlin cup presents an evident allusion to a Dionysiac ritual performed by women. We see Dionysos with a satyr playing the flute in the medaillon, as well as maenads

112 Athens, Acr. 2.325: Addenda 244 (460.20); BA 204701 (no image); Kunisch 1997, no. 437 , pl. 149 .

113 See below Chapter 5 , note 51 . 
dancing around an altar and a pillar-mask of the god on the outsides. ${ }^{114}$ This motif will also receive special attention below. ${ }^{115}$

In comparison with other vase types, the Dionysiac imagery of the cups from the first decade of the $5^{\text {th }}$ century seems rather uniform, despite some highly original examples. Like the prevalence of prototypical male figures, this may be explained from the relationship between this vase type and the symposium.

\section{Tentative Conclusions}

What conclusions may be drawn for the images of the vases of the late 6th and early $5^{\text {th }}$ century? Although very similar representations of encounter, thiasos, sexual confrontation, and symposiasts' bliss may be found throughout the period, no two versions are identical. The vase painters never contented themselves with the mindless repetition of familiar formulae, but were ambitious to give their personal interpretation: Dionysos and his world were apparently always considered topical and challenging. The thiasos and its mythological variant, the return of Hephaistos, were as important as ever, and have been innovatively depicted by the most prominent painters.

Compared to earlier stages, the many original representations of satyrs are a novelty. Lofty or base, solemn or grotesque, there seems hardly anything a satyr-alone or with companions - cannot do. ${ }^{116}$ The fact that the emergence of this new satyr imagery is contemporaneous with the introduction of the satyr play by Pratinas just before 500 вС cannot be without significance. ${ }^{117}$ Nevertheless, the hypothesis that there is a connection between vase paintings and certain satyr plays seems, apart for a few exceptions, less probable than the idea that both the introduction of the satyr play and the new importance of the satyr imagery reflect a general interest among the Athenians. ${ }^{118}$ One should keep in mind that the satyrs in the chorus of the satyr play were performed by citizens: in this perspective, identification with satyrs was not merely natural,

\footnotetext{
114 Berlin F 229o: Addenda 244 (462.48); BA 204730; Kunisch 1997, no. 345, pl. 116 f.

115 See below Chapter 6, note 10.

116 Compare Lissarrague 2013, 215: "La logique de ces images est plutôt de rendre étonnantes les pratiques les plus banales, et par là les remettre en question." Also Steinhart 2004, 127 (after his discussion of all satyr types and satyr scenes which occur in "Bildern mit Rollenspielen", p. 3): "Der Satyr kann ... als ein Spiegelbild unterschiedlichster Aspekte des Menschen verstanden werden."

117 Voelke 2001, 18.

118 See Krumeich 1999, especially 47-51; Steinhart 2004, 101-104, 131.
} 
it was required. ${ }^{119}$ Satyr plays were part of the official performance repertoire of the City Dionysia, which makes us wonder whether this official exhibition of the identification of citizens with satyrs may have something to do with the recent reform of the polis by Kleisthenes. ${ }^{120}$ It is well known that one of the main points of this reform was a greater involvement of rural Attica in the polis. ${ }^{121}$ On the other hand, the Dionysiac iconography of the archaic period makes it clear that satyrs lived and acted in all three spheres of the mental world: in the city, in the wilderness, and also-especially as manufacturers of wine-in the rural countryside, the sphere that connects the two other antithetic zones. ${ }^{122}$ Seen against this background, the introduction of the satyr play, and the simultaneous rise of the figure of the satyr in the pictorial world of the vase painters is consistent and understandable. ${ }^{123}$

What about the representation of Dionysiac women during this period? Most frequently they are found in the context of the thiasos, as maenads dancing ecstatically or being pursued by satyrs. Sometimes the roles are reversed and the maenad is pursuing the satyr. ${ }^{124}$ It is far from clear whether the maenads view the often aggressive sexual advances of the satyrs with genuine distaste; their reaction could also be one of suggestive playfulness. ${ }^{125}$ Relatively often, especially on small neck-amphorae and pitchers, we find Dionysos approached by a woman who is not in the grip of madness; she is not a maenad, but a dignified figure carrying a libation vessel. ${ }^{126}$ In most cases it is impossible to decide whether this woman is meant to be Ariadne. ${ }^{127}$ On one of his pointed amphorae the painter and potter Syriskos ${ }^{128}$ gives her a name, Nymphaia,

119 Voelke 2001, 411: "Ainsi le public, tout en riant du spectacle du satyre, riait sans doute toute autant du spectacle de concitoyens jouant le satyre et de sa propre expérience, indirecte, d'une telle identité."

120 Voelke 2001, 18.

121 Voelke 2001, 31.

122 Isler-Kerényi 2007, $232 \mathrm{f}$.

123 Compare Spineto 2005, 353: "È comunque ai Dionysia megala ... che il meccanismo di definizione dell'identità di Atene attraverso le componenti della società che partecipano alla festa si manifesta nella maniera più chiara."

124 Basel Lu 45: Para 352 above; BA 352509 (Syriskos Painter, no image) and Naples, without number: ARV 287.25; BA 202596 (no image) (Geras Painter).

125 Lindblom 2011, 69 .

126 This formula may also be used for a single satyr, see for instance Munich 2343: ARV 531.27; BA 206003 (neck-amphora by the Alkimachos Painter): Dionysos with a woman carrying a thyrsos on the one side, and with a satyr carrying an askos on the other.

127 For this problem, see Sabetai 2011, $137 \mathrm{f}$.

128 Formerly known as the Copenhagen Painter: Weiss 1997, 104. 


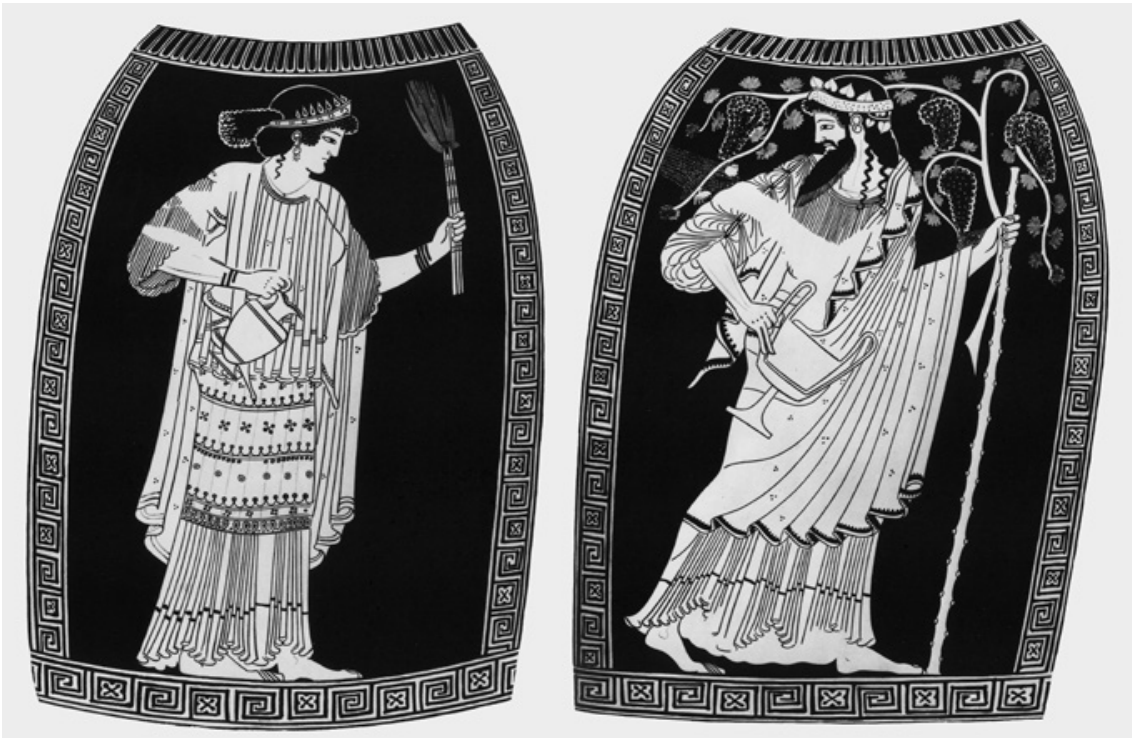

FIGURE 35 Amphora with twisted handles, Eucharides Painter, London, British Museum E 279 (BSA 18, 1912, pls. 11 [Dionysos] and 12 [woman]).

which is, however, a name that could refer to any nubile young woman. ${ }^{129}$ In any case, every woman approaching Dionysos in a ritual context could identify with Ariadne. ${ }^{130}$ This also holds true for the, less frequently depicted, woman who mounts a chariot in the company of Dionysos. ${ }^{131}$ The motif of the encounter is executed with great precision on both sides of an amphora with twisted handles by the Eucharides Painter, a contemporary of the Kleophrades Painter and the Berlin Painter. ${ }^{132}$ The large torch in the woman's hand explicitly refers to a ritual context (Figure 35).

As we have seen, satyrs may appear wherever humans are present, but their aspect is surprising and unsettling. Moreover, they can misbehave to the point of sacrilege. In contrast, the outward appearance of their female counterpartsthe women who interact with Dionysos and the satyrs, or dance as maenads

\footnotetext{
129 London E 350: Addenda 204 (256.2); BA 202921; Bonansea 2008, 116. For highly comparable images see a neck-amphora by the Syriskos Painter, Orvieto, Museo Civico 1040: ARV 261.20; BA 202974 and a pelike by the Deepdene Painter, Brussels R 250: ARV 501.34; BA 205621.

130 Isler-Kerényi 2007, 123.

131 For instance Naples 2410: Addenda 201 (239.18); BA 202367 (Myson). For a black-figure version: Villanueva Puig 2009b, $192 \mathrm{f}$.

132 London E 279: Addenda 199 (226.1); BA 202054.
} 
with Dionysiac attributes - is the same as that of women active in a different manner or a different place. ${ }^{133}$ Neither is it possible to ascribe a definite status to such Dionysiac women. ${ }^{134}$ As we will see, the Dionysiac ritual brings together women of various ages and positions. ${ }^{135}$ It is the male figure of the satyr that enables vase painters to put the societal role of men into perspective, to give it a comical or dubious twist. ${ }^{136}$ It must have pleased the Athenian as well as the Etruscan customers that the most bizarre fantasies could be depicted on vases. The phenomenon of the satyr provided them with a figure on which they could project everything that went against the norms and rules of civilized society, ${ }^{137}$ especially because satyrs could, as we will see, represent every age group from children to old men. ${ }^{138}$ Most of the time he is youthful; sometimes, however, his bald head and hairy body suggest a more mature age. Evidently, both young and elderly men could become satyrs, feel like satyrs or appear as satyrs.

It is illuminating that this figure belongs to the sphere of Dionysos. On the one hand Dionysos is responsible for all metamorphoses, those of the theater as well as those that inevitably belong to human life. On the other hand he is responsible for the order of the polis and for the regulated outbursts of disorder at the symposium and during festivals. Nevertheless, questions arise that should be kept in mind. Why does the satyr, ubiquitous on symposium vessels, not appear in sympotic poetry? ${ }^{139}$ On the other hand, why does he so often appear on pelikai? These were not characteristic symposium vessels, but were often used by women in their day-to-day chores. ${ }^{140}$ And if the satyr stands for immoderate and therefore reprehensible behavior (that must be accepted because it exists), ${ }^{141}$ how can we explain his important role as mediator between Dionysos and human beings? ${ }^{142}$

\footnotetext{
133 Lindblom 2011, $158 \mathrm{f}$.

134 Lindblom 2011, 145.

135 See below Chapter 6.

${ }_{13}$ As we have seen in the Introduction, Jaccottet 2003 draws similar conclusions on the basis of later Bacchic inscriptions.

137 The various details of this subject are extensively discussed in Lissarrague 2013.

138 See below Chapter 6 .

139 Catoni 2010, 258.

140 For the imagery of the pelike, see below Chapter 4 with note 63 .

141 Shapiro 2004; Catoni 2010, 262 and 287.

142 Isler-Kerényi 2004a, 96.
} 


\section{Dionysos, a God for the Athenians Developments after $480 \mathrm{BC}$}

\section{Hermonax and his Contemporaries}

We have seen that in the decades before 480 Dionysos was most frequently depicted among his thiasos of satyrs and maenads, as was already the case with black-figure vases. Another important motif of that time was his encounter with a standing woman or, less frequently, with a satyr. We also see him, surrounded by his retinue, as a symposiast or at the arrival or departure of his quadriga. Depictions of Dionysos participating in mythological events, such as the return of Hephaistos and the Gigantomachy, are much rarer; the admission of Herakles to the Olympus is found only sporadically. In general, there does not seem to have been much interest in Dionysos' relations with the other gods. New elements in the iconography of Dionysos are, however, emerging in the second quarter of the century and becoming ever more visible towards 450 B . These developments will be the subject of the next three chapters.

As far as Dionysiac imagery is concerned, Hermonax stands out among the painters of larger vessels of the generation following that of the Kleophrades and Berlin Painter; Beazley assumes he was a pupil of the latter. Over 160 vases are attributed to him, an extensive oeuvre even though much of it remains only in a fragmentary state. His work includes large, high-quality vases (more than twenty stamnoi, almost thirty pelikai, and one bell krater) as well as many large and small amphorae, several loutrophoros fragments found in Athens, hydriai, oinochoai, lekythoi, and even cups. ${ }^{1}$ Most of his vases with non-anonymous subjects are Dionysiac in character.

A stamnos that still clearly shows a stylistic indebtedness to the Berlin Painter has a thiasos divided over both sides. ${ }^{2}$ It consists of four couples of a satyr and a maenad in various, more or less peaceful, relationships. On one side we see a satyr in the center, next to a thyrsos set aside. Playing the aulos, he is moving towards the right. A maenad greets him cordially. On the left follows a woman, carrying a torch in each hand. A satyr, partly hidden by the handle of the vessel, tries to seize her. The next maenad is captured by a satyr coming from the left, while a fourth, seen from the back, is fending off a satyr with her

1 Isler-Kerényi 1987a, 170; concerning cups by Hermonax, see Isler-Kerényi 1984b.

2 St. Petersburg 4121: ARV 484.11; BA 205394 (no image); Peredolskaja 1967, pl. 77, 3-4. 
thyrsos. Hermonax not only works with great accuracy, but also nuances the various relationships in such a way that the viewer gets the impression of a narrative. There seems to be a purposeful contrast between the satyr with the aulos and the other ones who behave aggressively.

Of even greater interest is a large, signed pelike showing a thiasos in the presence of Dionysos (Figure 36). ${ }^{3}$ It is represented here for the first time in a clear and readable manner. The god stands in the center on one side of the vase, with a kantharos in his right hand and the thyrsos in his left. He turns his head to the left towards a young woman who greets him, an oinochoe in her lowered right hand. Next to her, below the handle, is an altar with an ivy branch on it. On the reverse we see a girl, executed at a somewhat smaller size. She looks back towards the couple following on the left: a satyr clasping the shoulder of a woman with a thyrsos in her right hand and a torch in her left. Both are looking towards the left. Next comes a dancing satyr and behind him a dancing woman. She carries the thyrsos in her right hand, her left arm is wrapped in the fabric of her robe. Another satyr is below the other handle, almost on his knees, dancing to the music of a satyr playing the aulos while he walks towards the right, ahead of the god. All figures on the reverse are looking towards the left, in the direction of Dionysos. All women are wearing a fawn skin over their chiton or peplos. All are wearing their hair loose, in a girlish fashion, except one: the woman who is dancing. She has gathered her hair in the neck, as is usual for mature women. The altar and the torches indicate a ritual context. The main event seems to be the meeting between Dionysos and the young woman, the other figures participating joyfully. One has the impression that Hermonax is referring to a very specific ritual that was of importance for women and young girls and in which satyrs personified the erotic element.

The scene is very similar to one on a pelike by the Painter of the Birth of Athena, a follower of Hermonax. ${ }^{4}$ We see Dionysos moving towards the right, with his thiasos consisting of maenads with torches and obtrusive satyrs. One of these is clasping the god's shoulder, as if he were Hephaistos. Likewise quite similar is the scene on a more or less contemporaneous column krater of lesser quality. ${ }^{5}$ Here, too, the thiasos is unambiguously moving in a specific direction, even more than was the case with some of Makron's cups. ${ }^{6}$ It has become a

3 Rome, Villa Giulia 50459: Addenda 248 (485.27); вA 205410 (no image); Mingazzini 1971, pl. 146-148 (675).

4 Private collection: ARV 495.4; BA 205563 (no image); Ars Antiqua AG Luzern, auction II 14.05.196o, pl. 62/63 No. 16o. On the painter see below p. 83 .

5 Caltanissetta 69: Para 385; BA 275997 (probably by the Florence Painter).

6 See above Chapter 3, note 102. 

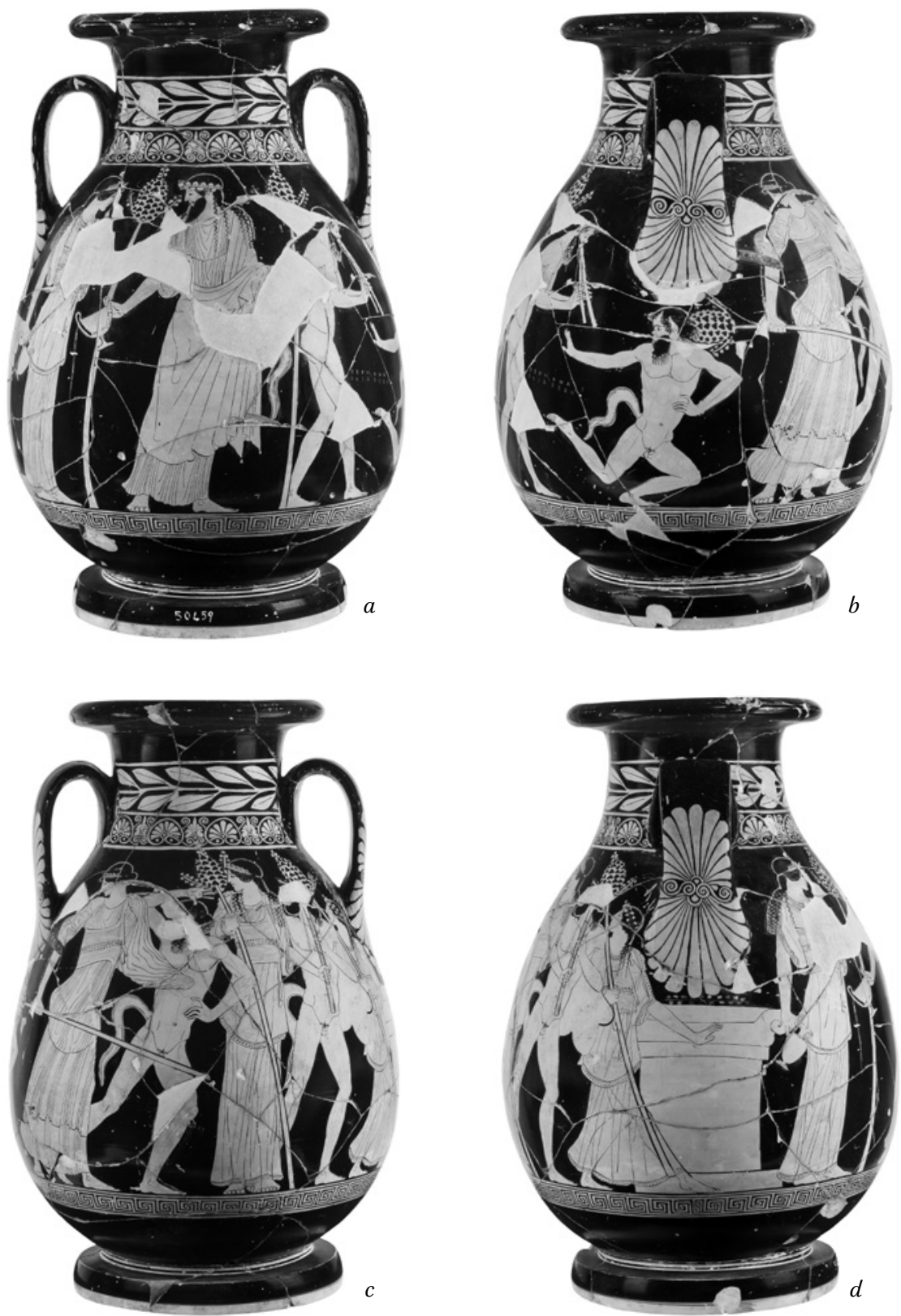

FIGURE 36 Pelike, Hermonax, Rome, Museo Nazionale Etrusco di Villa Giulia 50459 (photographs Soprintendenza per i beni archeologici dell'Etruria Meridionale).

a. side A: Dionysos.

b. side view (right).

c. side $B$.

d. side view (left). 
kind of procession and in this way has moved from the mythical to the ritual (i.e. human) level.

An analogous shift may be discerned in a smaller, less elaborate pelike by Hermonax. ${ }^{7}$ A woman, looking over her shoulder, is walking towards the right. Her hair is gathered at the nape of the neck. She has a thyrsos in her left hand and her right is covered by the himation she wears over her chiton. One feels this is a woman moving and acting in a Dionysiac sphere, and not a mythical maenad. Two women on a more or less contemporaneous column krater give the same impression. Wrapped in their himatia, they look completely human as they move towards the right with measured pace amid gesticulating satyrs. ${ }^{8}$

Probably unique representations may also be found in the work of the lesser masters of this period. Let me mention Dionysos running in a short chiton on a calyx krater by the Oreithyia Painter ${ }^{9}$ (Figure 37 ) and a neck-amphora by the Alkimachos Painter. ${ }^{10}$ Or Dionysos in a stage costume, dancing between two satyrs on a column krater by the Leningrad Painter. ${ }^{11}$ We also find scenes that cannot be interpreted. They may have been inspired by the theater or belong to lost myths. ${ }^{12} \mathrm{~A}$ familiar, though rarely depicted, myth, however, is shown on a lekythos by the Alkimachos Painter, who is known for his predilection for Dionysiac subjects: the birth of the god from the thigh of his father in the presence of Hermes. ${ }^{13}$ The same painter also depicted satyrs, dressed like citizens, in conversation with a herm ${ }^{14}$ or offering a hare to a seated youth. ${ }^{15}$ But what is the meaning of a satyr wearing a helmet, who puts on leg guards in the presence of a woman with thyrsos and leopard skin, the maenad's attributes? ${ }^{16}$

\footnotetext{
$7 \quad$ St. Petersburg 727: Para 512 (486.45); BA 205428.

8 Ferrara 1685: Addenda 252 (511.5); BA 205738 (Painter of Bologna 228).

9 Agrigento $\mathrm{C}_{1538} 8$ : See above Chapter 3, note 8.

$10 \quad$ Naples 81783: Addenda 254 (529.13); BA 205985.

11 Madrid 11040: ARV 568.36; BA 206525 (Leningrad Painter). In the work of the Berlin Painter compare Dionysos in a stiff and ornate robe with a lion on his arm, Munich 8766: Addenda 191 (198.21bis); BA 275643.

12 For instance St. Petersburg B 201: Addenda 258 (555.95); BA 206338 (hydria by the Pan Painter).

13 Boston 95.39: Addenda 255 (533.58); BA 206036. This motif will be discussed in the next chapter.

14 Dresden ZV 2635; Addenda 254 (531.29); BA 206005.

15 St. Petersburg 734: ARV 531.33; BA 206oog. Compare a satyr in a himation who looks on as a frightened bride is running away from Dionysos on the column krater Ferrara 2818: Addenda 254 (524.23); BA 205905.

16 London E 377: Para 381 (501.35); BA 205622 (Deepdene Painter).
} 


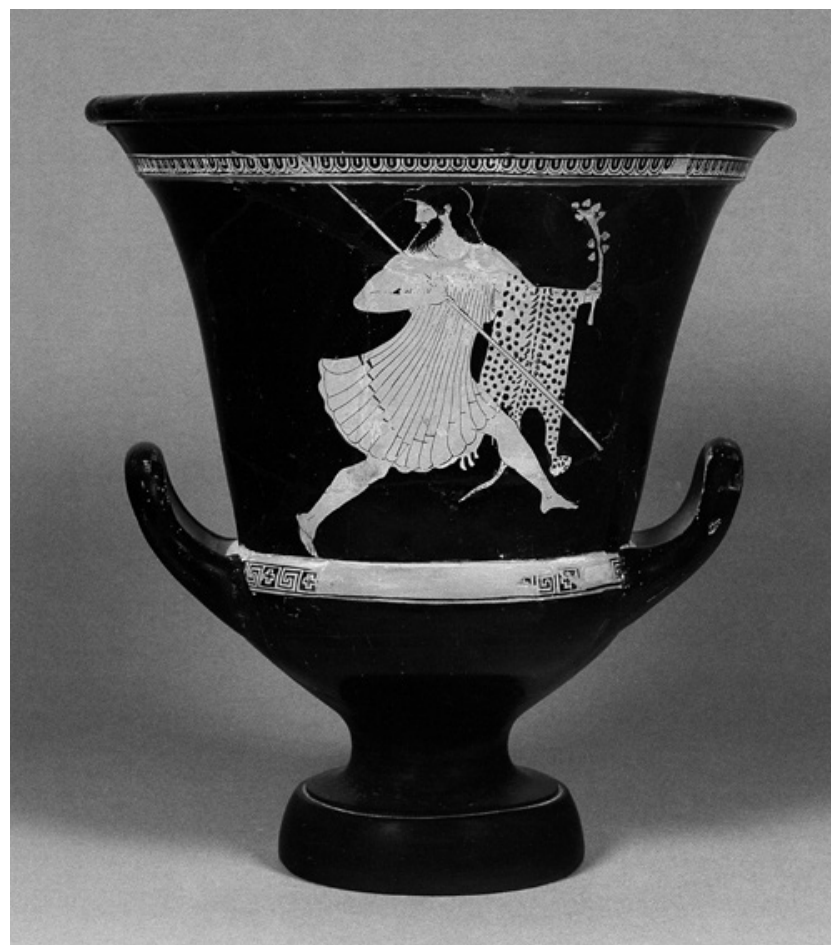

FI GURE 37 Calyx krater, Oreithyia Painter, Agrigento, Museo Archeologico Regionale C 1538, side A (De Miro 1994, pl. 38) ( Regione Siciliana-Assessorato Reg.le dei Bв.cc. e dell'I.S.

In any case, at this stage, too, vase painters treated Dionysos and the satyrs in a more imaginative way than Dionysiac women. In addition, we find that, apparently, some subjects were at the time considered particularly topical: apart from the handing over of a child in a Dionysiac setting (which will be discussed in the next chapter), there is the making of wine, usually by satyrs, but in one instance by men of various ages. ${ }^{17}$ The harvest, the transport of the baskets, and the treading of the grapes in pithoi or large bell kraters were widely depicted since the middle of the 6th century; the splendid Basel amphora by the Amasis Painter comes to mind. ${ }^{18}$ The motif is reproduced in an abbreviated formone person treading grapes - in the medallion of some early red-figure cups. Now, however, the subject is taken up by several painters of column kraters and

\footnotetext{
17 Ferrara 42684: Addenda 254 (524.26); BA 205908 (Orchard Painter); Bérard/Bron 1984, 131, fig. 185 .

18 Basel Kä 420: Addenda 43 (151); BA 350468. See also Isler-Kerényi 2007, 132, fig. 68.
} 
executed in various manners. ${ }^{19}$ Apart from the exception mentioned above, we see satyrs at work, sometimes in the presence of women with thyrsoi or the wine god himself. ${ }^{20}$ Another theme that emerges at this time and establishes itself after the middle of the century is a Dionysiac ritual in which a chair seems to play a certain role. We will return to this motif below. ${ }^{21}$

The most remarkable phenomenon in Dionysos-inspired vase painting of the second quarter of the century is the transformation of the circle dance of satyrs and maenads into a procession-like train accompanied by torches. This is illustrated by two column kraters by the same mediocre painter, where the maenads carry torches instead of thyrsoi. It should also be noted that on the second (see the note) Dionysos, obviously intoxicated and leaning on a young satyr making music, is now for the first time practically naked (Figure 38 ). ${ }^{22}$ The development mentioned above even extends to the motif of the return of Hephaistos, as is clear from a column krater decorated around $440 \mathrm{BC}$, where a woman with burning torches in her hands shows the smith-god on his mule the way (Figure 39). ${ }^{23}$ It would, however, show little understanding of the fundamentally unrealistic manner of expression of the vase painters, to assume that Dionysiac processions had only now arrived in Athens. We should rather consider this a manifestation of a new need to stress the human side of the thiasos. For the same reason it is not surprising that, at this point, we sometimes see satyrs who act like caricatures of citizens, and women who almost imperceptibly turn into maenads. ${ }^{24}$

As the motif of the altar demonstrates, the ritualization of the imagery is at this time a general phenomenon. We are not speaking here, of course, about altars that fulfill a narrative role, as is the case, for instance, in the Ilioupersis or the story of Busiris, nor about scenes showing the abduction of women. On red-figure vases before $500 \mathrm{BC}$ altars, as a kind of optional element in traditional depictions of gods, are rare. It is only in the first half of the $5^{\text {th century }}$

19 Sparkes $1976,54 \mathrm{f}$.

$20 \quad$ For instance Louvre C 10774: Addenda 253 (518.4); BA 205809 (Syracuse Painter); Naples, Capodimonte 96o: Addenda 26o (563.4); BA 206429 (Pig Painter); Vatican 16505: ARV 1170.7; BA 215533 (Painter of Bologna 322).

21 See below Chapter 6.

22 Agrigento Painter: Vienna 341: ARV 575.17; BA 206617, and Rome, Villa Giulia 846: ARV 575.20; BA 206620.

23 Lecce 6o3: Addenda 329 (1104.7); вA 216174 (Orpheus Painter). For the torch-bearing woman in the context of the return of Hephaistos, see Schöne 1987, 45.

24 The fact that, as far as Dionysiac images are concerned, the number of dancing women on red-figure lekythoi increases significantly after $460 \mathrm{BC}$, also belongs to this context, see Paleothodoros 2011, 137 . 


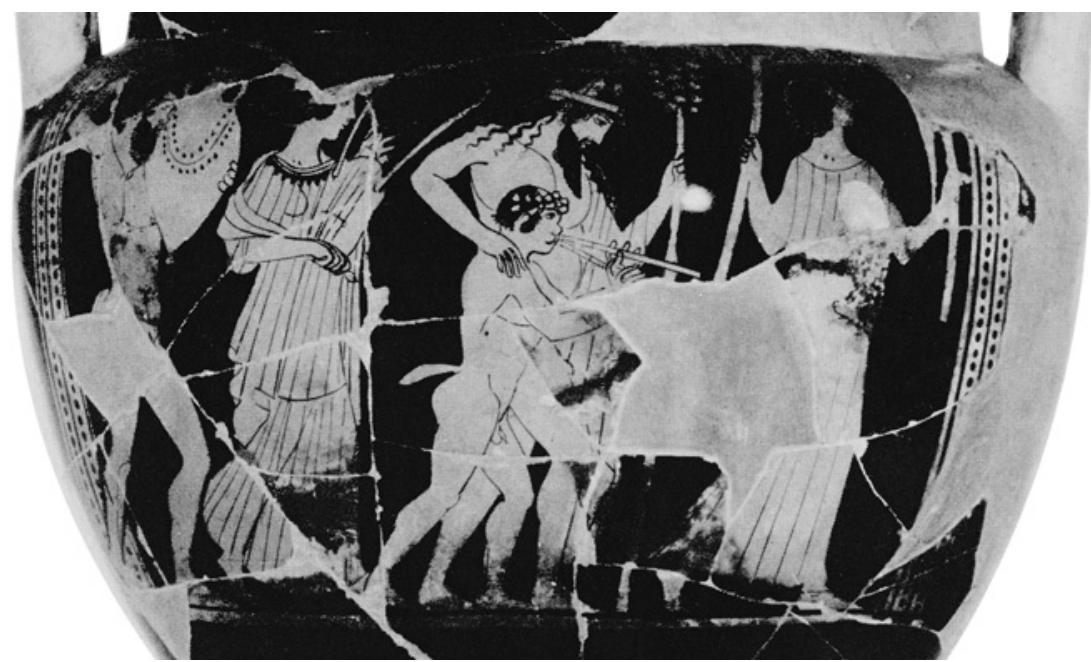

FI GURE 38 Column krater, Agrigento Painter, Rome, Museo Nazionale Etrusco di Villa Giulia 846, side A (cva Villa Giulia 4, pl. 9.1).

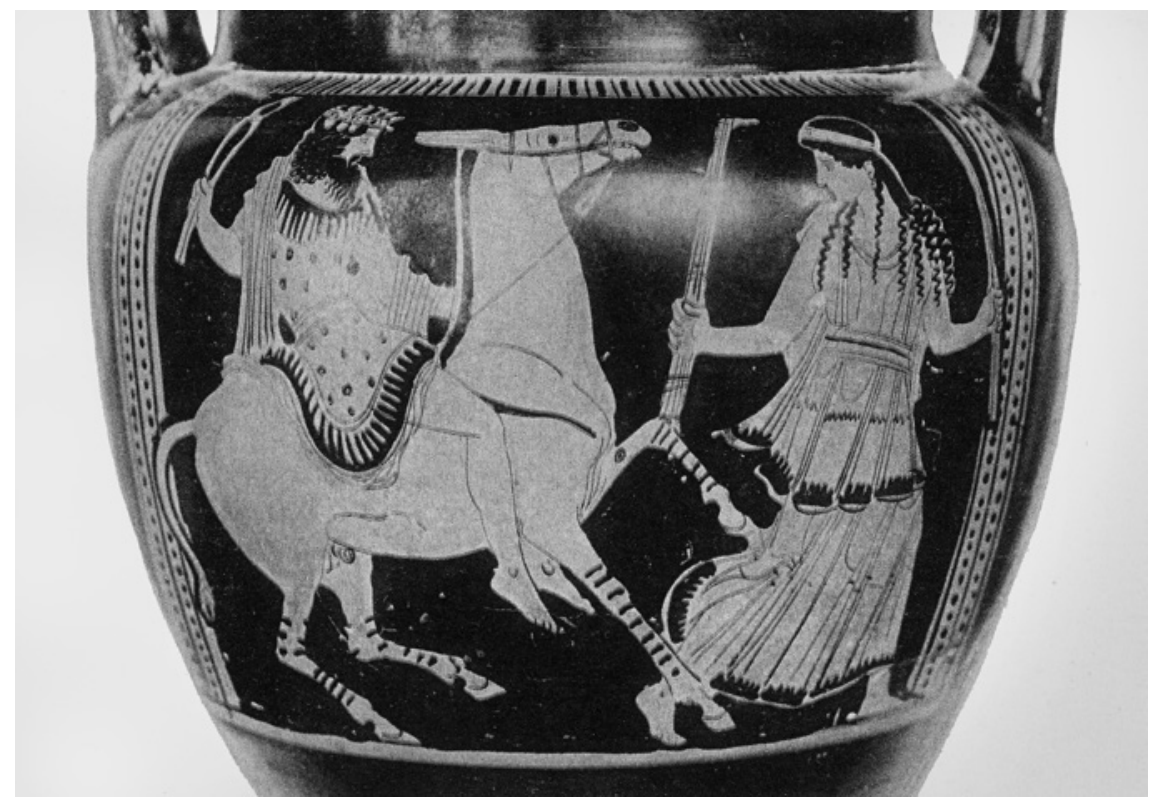

FI G U 39 Column krater, Orpheus Painter, Lecce, Museo Provinciale Sigismondo Castromediano 6o3, side A (cVA Lecce 1, pl. 8.1). 
that we find a substantial number of altars, mostly on cups. The motif culminates in the decades around $45^{\circ}$ (especially in the work of the Niobid Painter), after that the number of altars decreases markedly. The motif of the altar is usually combined with anonymous figures, mostly women. Not surprisingly, Nike is the one among the gods who is most often shown with an altar, which, apparently, is there to hallow the moment of her appearance. ${ }^{25}$ Dionysos is next and after him comes Apollo; in the case of the other gods, altars are added only sporadically. ${ }^{26}$

It seems, therefore, that by $450 \mathrm{BC}$ both the vase painters and their clientele find themselves involved in a growing religiosity, which also embraces Dionysos and his retinue. The decision to erect a large new temple on the Acropolis fits this atmosphere very well, as do the activities of the great tragedians Aischylos and Sophokles. ${ }^{27}$

\section{The Imagery of Red-Figure Pointed Amphorae}

The second quarter of the 5 th century presents us with even more surprising representations of Dionysos. In these cases, the unusual image carriers as well as the images themselves allow us to speculate about Dionysos' significance for the people for whom these images were intended. One of the rarest image carriers was the pointed amphora, a neck-amphora which tapers to a point at the bottom, for which reason it had to be placed in a ring stand. The pointed amphora originated shortly after 500 вС and was inspired by the official Panathenaic prize amphora. From an artistic point of view it was a particularly demanding vase type. ${ }^{28}$ So far only five black-figure and ten red-figure specimens are known. ${ }^{29}$ The latter can all be dated between 500 and about 450 BC. Two were decorated by the Kleophrades Painter, one by the Syleus Painter, two by the Oreithyia Painter, four by Syriskos, and one by the Achilles Painter. ${ }^{30}$ Five of them are known to have been excavated at the same site, Vulci in Etruria:

\footnotetext{
25 Isler-Kerényi 1971, 30; Thomsen 2011, $171 \mathrm{f}$.

26 Of particular interest is a representation of Hades between two altars, Louvre G 187: Addenda 222 (361.2); BA 203793 (stamnos by the Triptolemos Painter, with Triptolemos on the reverse).

27 Schneider/Höcker 2001, 113. See also below Chapter 7.

28 Isler-Kerényi 1977b, 10 and 14.

29 Oakley 1997, 85, note 103. Massa-Pairault, 50. In addition, the unpublished amphora Basel 2405, black-figure, with scenes of symposium and winepress: CVA Basel 5 (V. Slehoferova), forthcoming.

30 Syriskos is the name of the Copenhagen Painter: Weiss 1997, 104.
} 
the Kleophrades Painter's only complete one, the one by the Syleus Painter, the two by the Oreithyia Painter, and Syriskos' London amphora. We may presume that the three other pointed amphorae decorated by Syriskos were likewise found here. At any rate, the two which have been adequately published, carry Etruscan graffiti, which suggest buyers from the institutional elite. ${ }^{31}$

The oldest known red-figure pointed amphorae are attributed to the Kleophrades Painter. ${ }^{32}$ The idea of the official prize amphora being a probable source of inspiration for this new vase form is supported by the subject of the neck image of the Munich amphora: young athletes with sports utensils. ${ }^{33}$ As is well known, athletes of various disciplines are depicted on the reverse of every Panathenaic prize amphora-Athena Promachos is on the main side. Side A of the Berlin amphora shows young warriors arming themselves. This refers to the background of sports activities: the acquisition of military skills in order to defend the polis. ${ }^{34}$ The main image of the Munich amphora is one of the most famous and beautiful representations of Dionysos surrounded by his thiasos, here consisting of four ecstatically dancing maenads and three satyrs. The satyr playing the double flute in the center of the reverse image is shown en face. The two others are placed beneath the handles; each harasses one of the maenads. The satyrs have been given the role we already know from 6thcentury imagery: their primary interests are sex and music. ${ }^{35}$ When shown full face they are supposed to directly address the beholder. Both the image carrier and the combination of subjects eloquently illustrate that the Dionysiac thiasos was an essential part of polis life.

Six of these exceptionally high-quality red-figure vases explicitly refer to the polis's most important festival, not only through their form, but especially through their subject matter which emphatically focuses on Athenian mythology. The main image of the second amphora by the Kleophrades Painter shows Theseus slaying the Minotaur in the presence of Ariadne and her wet nurse. On the reverse we see the afflicted Athenian youths. The shoulder images of the amphora by the Syleus Painter present the Gigantomachy of Athena and Poseidon, and Theseus fighting the Marathonian bull in the presence of Athena. A line of images on the amphora's belly shows heroes and centaurs in combat. ${ }^{36}$ Here, too, one of the warriors must be Theseus, the founder

\footnotetext{
$31 \quad$ Martelli 1991, 282 f.; Maggiani 1996, 107 f. and note 53.

32 Greifenhagen 1972 dates both of them to just after 500 BC.

33 Munich 8732 (2344): Addenda 186 (182.6); BA 201659; Lissarrague 2013, 151 f., fig. 125.

34 Berlin 1970.5 ( fragmentary): BA 5766 (no image); Greifenhagen 1972, 13-21.

35 Isler-Kerényi 2004a, 96.

36 Brussels R 303: Addenda 203 (249.6); BA 202485.
} 
of Athens. Both the second Munich vase and its lost counterpart, formerly in Berlin, have a multi-figure representation of the abduction of the Attic princess Oreithyia by the wind god Boreas. ${ }^{37}$ Boreas was credited with the victory over the Persian fleet at Cape Artemision, for which reason he had his own cult in Athens since 479 BC. ${ }^{38}$ The Zurich pointed amphora by Syriskos contrasts Achilles mourning Patroklos and a victorious Theseus. ${ }^{39}$ The neck images depict Centauromachies, also the one involving Theseus. ${ }^{40}$ The main image of a Syriskos amphora in a private German collection shows Athena protecting Herakles in the Garden of the Hesperides. ${ }^{41}$ In addition, it has several river gods and fresh water nymphs, whose individual names are given. The three pointed amphorae by Syriskos that have figures on the shoulders present heroes and centaurs in combat. Again it is clear that not only the image carriers, but also the images themselves (especially those of Athena and Theseus), were supposed to convey the glory of their place of production to the distinguished foreign clientele. ${ }^{42}$

Apart from Athena, pointed amphorae regularly celebrate Dionysos. As we have seen, the Kleophrades Painter presents him in the main image, surrounded by his thiasos. The neck image of the B side of the Berlin fragment showed a maenad between two satyrs. On Syriskos's London vase - a scene comparable to the one on the Munich kalathos by the Brygos Painter ${ }^{43}$ —Dionysos accepts the welcoming gift a young woman named Nymphaia offers him at an altar (Figure 40).44 On the reverse, two women with different hairstyles are engaged in conversation. In the center of the main image of the pointed amphora by the Achilles Painter, which we will discuss in more detail below, ${ }^{45}$ an energetically moving Dionysos is surrounded by a boisterous thiasos consisting of eight maenads and two satyrs. ${ }^{46}$

37 Formerly Berlin F 2165: Para 380 (496.1); BA 206421 (no image); Miller/Kästner 2005, 124; Munich 2345: Addenda 250 (496.2); BA 206422.

38 LIMC VII.1, 64 (E. Simon).

39 Zurich, Archäologische Sammlung der Universität L 5: BA 275252 (the attribution is out of date); Isler-Kerényi 1977b. Compare the inscription on its counterpart in a private collection in Germany: Weiss 1997, 108.

41 Private collection Germany: Tiverios 1991; Weiss 1997, 104-111; BA 30676 (no image).

42 Compare Massa-Pairault 2007, $47 \mathrm{f}$. where the choice of subjects for pointed amphorae is considered from an Etruscan perspective.

43 See above Chapter 3, note 76.

44 London E 350: Addenda 204 (256.2); BA 202921.

45 See below Chapter 5 , note 20.

46 Cab. Méd. 357: Addenda 311 (987.2); BA 213822. 


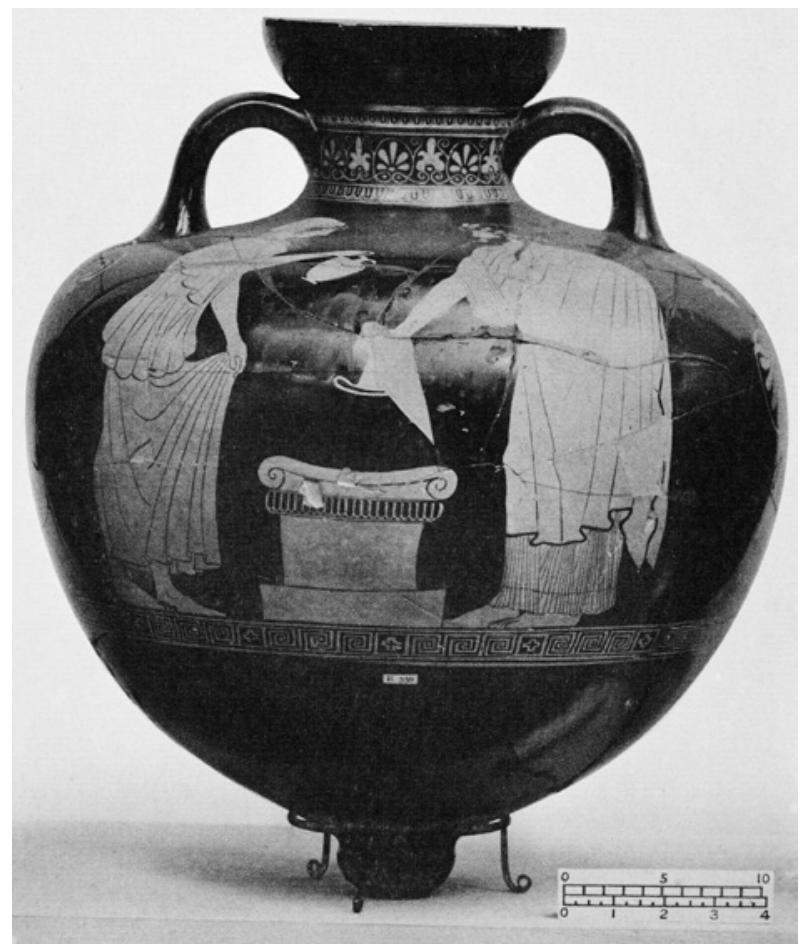

$a$

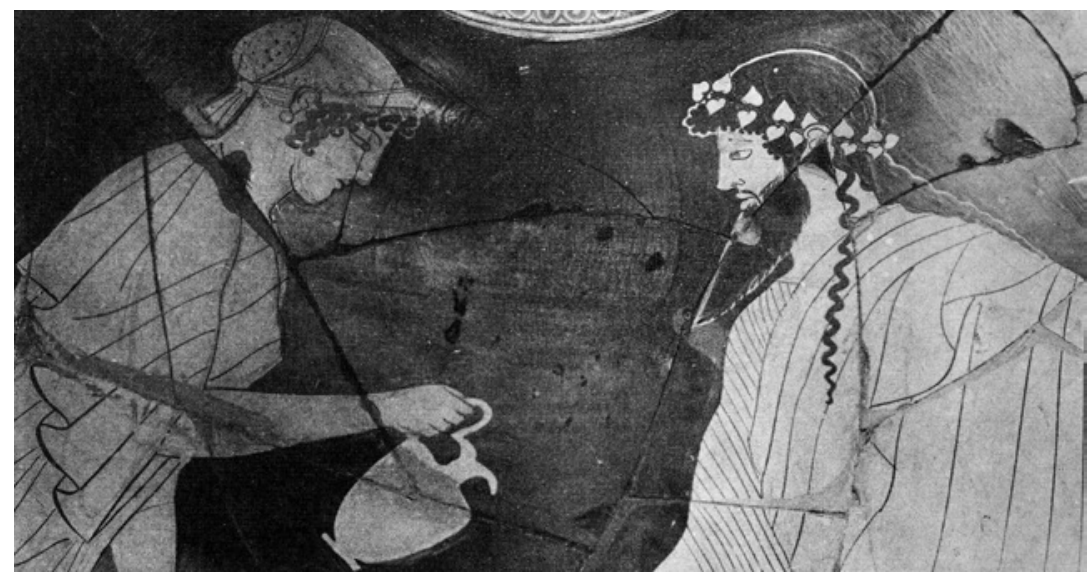

$b$

FIgURE 40 Pointed amphora, Syriskos, London, British Museum E 350.

a. side A (cva British Museum 3, III Ic pl. 18.1b).

b. detail of side A: Dionysos is welcomed by a woman (cva British Museum 3, III Ic pl. $18.1 d)$. 
This brings us to Syriskos' New York amphora, which, like the one in Paris, still has its original, richly decorated stand. ${ }^{47}$ On the main side we find a depiction of Peleus leading Thetis to his home. All figures are given familiar names, except one. In the center of the main image the groom is leading the bride towards the centaur Chiron on her right, who receives the couple with two torches. Thetis performs the typical gesture of anakalypsis for the groom. Behind Chiron is his mother, Philyra, likewise carrying two torches. In the background beneath the handle, two columns with an architrave indicate the house; inside we can see the bed that has been prepared. Artemis, again with two torches, follows on Thetis's left, beneath the other handle Apollo, with kithara, turns towards his mother Leto, who carries a wreath. The scene seems to continue on the reverse side: in the center we see a dignified standing Dionysos with his thyrsos, facing him on the right his mother Semele with a torch, and on the left a young woman with a wreath-like branch. She is referred to as Hopla, a name otherwise unknown.

So far this version of the famous wedding is unique. From the middle of the 6th century, the scene was usually represented with the couple mounting a chariot. ${ }^{48}$ It is important to note who are present: Chiron will raise Achilles, the son who is born from this union; Artemis is the patron goddess of childbirth, not because she is a fertility deity (this would be incompatible with her chastity), but because she is responsible for untamed human beings-infants and children. ${ }^{49}$ The image implicitly refers to a future birth. The presence of three mother figures-Philyra, Leto, and Semele-is likewise remarkable. Their appearance seems to highlight the idea of the house, which in turn reminds us of the concept of the oikos, the family as an integral part of the polis. This concept could already be discerned in Sophilos's marriage of Peleus and Thetis of a century before, and in Kleitias' version on the famous François krater-here, too, through the inclusion of a house and prominently placed mother figures. ${ }^{50}$ And Sophilos also depicted Apollo, whose song would immortalize this event that was of decisive importance for cosmic order.

In the archaic versions Dionysos was the key figure. He was the representative of the gods, the only one of them to speak to Peleus. In the case of Syriskos' New York amphora, he dominates the reverse side of the vase. He is standing between a mother and a young woman, conceivably because he is responsible for the transition from one life phase to another and, thus, for all weddings. The

\footnotetext{
47 New York SL 1990.1.21: BA 43937 (no image); LIMC VII, Peleus 210.

48 Vollkommer 1994, 266 f. (Peleus 205-208 including the note to no. 209).

49 Montepaone 2002, 70-72; Isler-Kerényi 2002b, 480 f.

5o Isler-Kerényi 2007, $75^{-79}$.
} 
reference to Athens is implicit here in the shape of the vase and in the shoulder image, which shows Theseus' Centauromachy. This battle-the result of a mistaken indulgence in wine at a wedding feast-is here contrasted with the most exemplary of weddings. Moreover, the subversive, wild centaurs are opposed to the one that would be entrusted with the education of the couple's offspring. The shoulder image shows the founding hero of Athens fighting for the order that is celebrated in the main image-Sophilos had already presented Dionysos as its most important guarantor.

The glorification of Athens is particularly appropriate in the years $480-470$ BC, the decade that follows the victory over the Persians. It is the decade to which this pointed amphora and the majority of the other ones are dated. It also fits into the oeuvre of the vase painter Syriskos, whose preference for such motifs is also evident from other original works. We could think of the stamnos with the tyrannicides, ${ }^{51}$ or the one showing Theseus slaying the Minotaur with the Athenian children anxiously awaiting the outcome of the fight on its reverse (compare the Berlin pointed amphora by the Kleophrades Painter), ${ }^{52}$ or the Acropolis fragment with the dead Minotaur. ${ }^{53}$

How much importance Dionysos held for Syriskos is also evident from a signed calyx krater of about 470 ВС on which all figures are mentioned by name (Figure 41) $\cdot{ }^{54}$ On the main side Dionysos, accompanied by a panther, solemnly offers Ge Panteleia ('the all-embracing earth') a plant, which has been identified as the branch of a fig tree..$^{55} \mathrm{In}$ his left hand he holds an ivy branch. Because the kantharos is absent, the scene is evidently not about wine. This also accounts for the presence of Okeanos, who, with a scepter in his hand, stands behind the goddess on the left. On the reverse we see Themis (which is, according to Aischylos, an alternative name for $\mathrm{Ge}),{ }^{56}$ standing between

\footnotetext{
51 Würzburg 515: Addenda 204 (256.5); вA 202924.

52 Private collection: BA 202929; Isler-Kerényi 1977a, 66-69.

53 Athens, Acr. 2.780: ARV 258.28; BA 202946 (no image).

54 Formerly Malibu (Ca) 92.AE.6: BA 28083 (no image); Shapiro 1993, 219-221; Lubsen Admiraal 1999; Smith 2011, 27 f. and 150 VP 3, fig. 3.1.

55 According to Lubsen Admiraal 1999, 239, who studied the vase in great detail. This attribute is extremely unusual. I am therefore most grateful to her for the following personal communication of August 11, 2013: "Dionysos is here a Meilichios/Dionysos Sykeatis (or Sikitis)... For his association with figs, cf. Ath. III 78c citing Sosibios telling us that the introduction of the fig tree took place by Dionysos; Hesychius s. v. sykatis; Usener 1896, 146." Incidentally, the branch of a fig tree may also be discerned on the very fragmentary outside image A of Makron's Acropolis cup depicting the handing over of the infant Dionysos, see Chapter 3 note 112, Kunisch 1995, no. 437, pl. 149b.

$5^{6}$ Shapiro 1993, 221.
} 


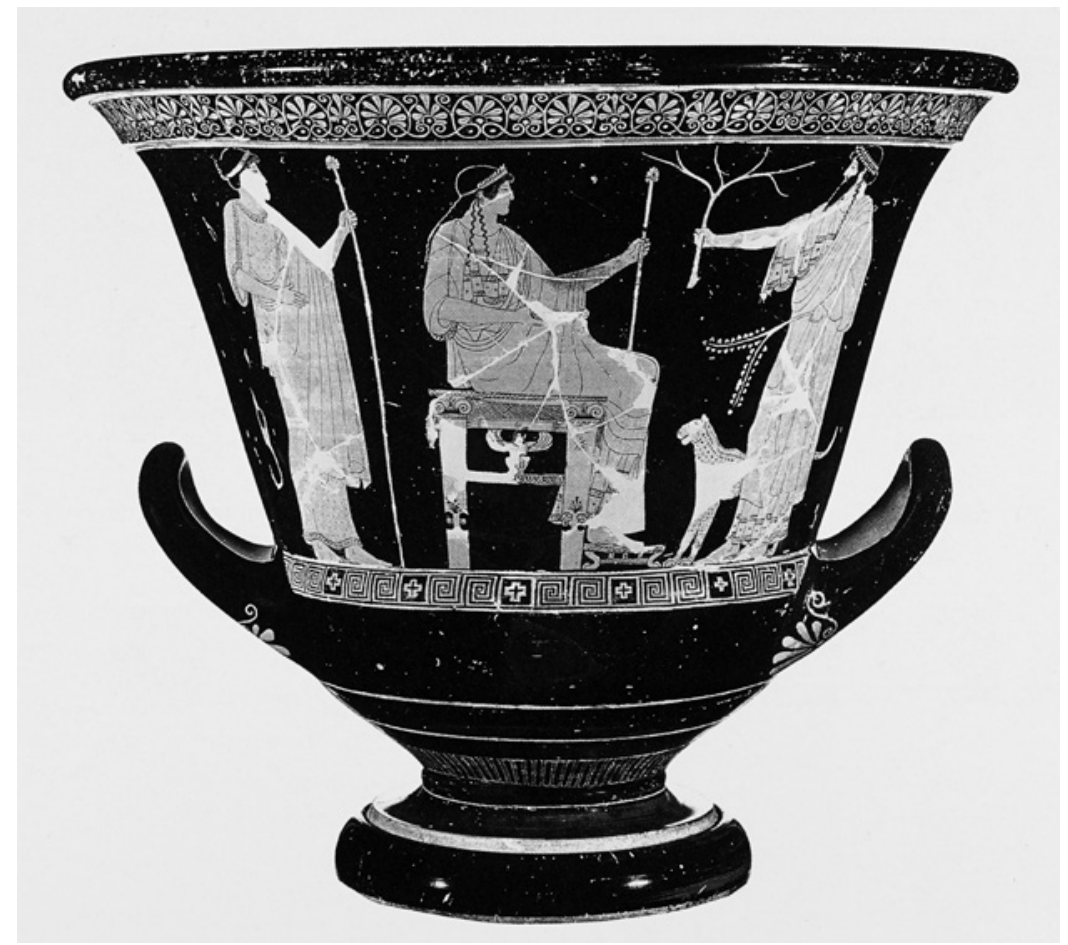

FIGURE 41 Calyx krater, Syriskos, formerly Malibu, J. Paul Getty Museum 92.AE.6, side A (Lubsen Admiraal 1999, pl. 22a).

two mythical kings: Balos, who sits on the left, and Epaphos. These two names would probably have reminded the original beholders of Egypt and Argos. ${ }^{57}$ The image on the A side, however, refers to the whole earth, surrounded by Okeanos and endowed with figs by Dionysos. The tame panther could refer to Asia, or, like the more or less contemporaneous Gigantomachies, ${ }^{58}$ designate Dionysos as the lord of the wilderness. ${ }^{59}$ What is clear, however, is that, as far as Syriskos is concerned, Dionysos' stature has cosmic dimensions and reaches far beyond Athens.

57 LIMC ViII.1, 540 Belos II 1 (M. True) and 574 Epaphos 1 (M. True).

$5^{8}$ See for example Carpenter 1997, pls. 2A and 6A.

59 Because of the great skill and originality of the vase painter, one should actually consider these two images against the background of Syriskos' known oeuvre. Unfortunately this is impossible here. 


\section{The Pelikai of the Painter of the Birth of Athena}

A representation of Dionysos in a specifically Athenian context may again be found on a large vase that was made ten to fifteen years later. It concerns a pelike by the Painter of the Birth of Athena, who was close to Hermonax. ${ }^{60}$ The pelike belongs to a group of seven vases of this type by the same painter.

Let us first have a closer look at the vase type. 'Pelike' is currently the conventional term; its antique designation is unknown. ${ }^{61}$ The pelike is different from the amphora in that it has a lower belly. It therefore seems to be sagging and makes a less elegant impression. It has a flanged mouth. Depictions of pelikai are, almost without exception, also found on pelikai. ${ }^{62}$ From these depictions we may conclude that it was mainly used as a container for oil, often perfumed oil for the women's quarters. Like the bell krater and the stamnos, which will be discussed in Chapter 6, this vase type was only invented around $520 \mathrm{BC}$ and was, from its earliest times, produced with both red-figure and black-figure decoration. As Scheibler did for the belly amphorae, Shapiro studied the about one hundred known black-figure pelikai, in order to determine their characteristic image repertoire. ${ }^{63}$ It mainly consists of three themes: firstly, trade and the work of the artisan, in other words, the world of the banausoi, the less-distinguished Athenians who had to make a living as laborers and craftsmen; secondly, musicians, especially musical contests in the context of the Panathenaic festival; thirdly, Dionysiac subjects. The latter far outnumber any other mythological representations. In addition, it is remarkable that, as far as the subject of the Gigantomachy is concerned, black-figure pelikai nearly always feature Athena. It seems evident that the idea of the Panathenaea dominated the pelikai repertoire, and that this included the lower segments of Athenian society, which may have been less respected, but nevertheless gave the city much of its wealth and prestige. This conclusion, moreover, ties in with the use of the pelike as a container for oil, which was the most important product of the Attic region.

\footnotetext{
6o London E 410: Addenda 250 (494.1); BA 205560 (no image).

61 Shapiro 1997, $63 \mathrm{f}$.

62 Agrigento 34: ARV 185.30; BA 201682 (Kleophrades Painter); Adolphseck 42 and Vienna 895: ARV 285.1 and 2; BA 202574 and 202575 (both Group of Vienna 895); Berlin F 2173: Addenda 209 (286.18); вA 202589 (Geras Painter); Bern 12227: Addenda 265 (596.1); вА 206905 (in the manner of the Altamura Painter); Karlsruhe 206 (B10): ARV 735.111; BA 209103 (Karlsruhe Painter). Also Shapiro 1997, 64. In addition, rather exceptionally, the depiction of a pelike in the tondo of a cup at present in the art trade (?): Addenda 242 (451.3); BA 205374 (Oedipus Painter).

63 Shapiro 1997, 64-68. See above Chapter 3, p. $5^{2}$.
} 
In the course of the $5^{\text {th }}$ century the red-figure pelike apparently came into use in Athens as a funerary urn for warriors who died at an early age. ${ }^{64}$ It can be assumed that the pelikai found in Etruscan necropoleis were at least eventually meant as grave gifts. This, in any case, holds true for those by the Painter of the Birth of Athena, which were found partly in Cerveteri and partly in Vulci. We shall now look at them in more detail.

Their subject matter, with its focus on Athena and Dionysos, very well fits the black-figure repertoire established by Shapiro. Significantly, they also feature episodes from Athenian mythology, which are only rarely depicted. Two of his pelikai, probably made as counterparts, show Zeus pursuing Aegina on one side, and on the other Poseidon's pursuit of Amymone. ${ }^{65}$ The Aegina motif must have been especially topical at the time: 460 BC was the year the Athenians conquered the island. ${ }^{66}$ Poseidon was, of course, Lord of the Aegean and therefore had a special relationship with Attica, whereas Amymone personified the Peloponnesos. The motif of the amorous pursuit was furthermore a common metaphor for an early death and therefore appropriate for funerary vases.

A third pelike by the Painter of the Birth of Athena has on the one side Athena and Zeus with Iris, the messenger of the gods, as well as the Peloponnesian twins Castor and Pollux, and on the other various warrior heroes among whom Theseus's rarely-depicted sons Akamas and Demophon. ${ }^{67}$ Another of his pelikai shows Theseus taking leave of his human father Aegeus on the one side, with on the other Boreas and Oreithyia in the presence of this archaic Athenian king. ${ }^{68}$ As far as the two remaining pelikai are concerned, the one showing a Dionysiac thiasos with ritual connotations has already been discussed. ${ }^{69}$ The pelike fragment in the Louvre is likewise of a Dionysiac nature. ${ }^{70}$

This brings us back to the eponymous piece showing an episode rarely depicted in red-figure vase painting: the birth of Athena from the head of her father (Figure 42). ${ }^{71}$ The main side shows Zeus seated on his throne. He turns

\footnotetext{
64 Shapiro 1997,63 and 68 , with note 7.

65 Rome, Villa Giulia 20846 and 20847: Addenda 250 (494.2 and 3); BA 205561 and 205562.

66 Isler-Kerényi 1979, 34 f. (here still 456 вС); Gehrke 2013, 147-149.

67 Kurashiki, Ninagawa 40: Addenda 250 (495.5 bis); BA 275985 (no image). The figures on the reverse are mentioned by name.

68 Hamburg 1980.174: BA 5647 (no image).

69 See above note 4.

70 Louvre CP 11115: Addenda 250 (495.5); BA 205564 (no image).

71 Two further examples: fragments of a volute krater, Reggio Calabria 4379: Addenda 203 (251.27); BA 202504 (Syleus Painter); hydria Cab. Méd. 444: Addenda 330 (1112.3); BA 214704 (Painter of Tarquinia 707).
} 


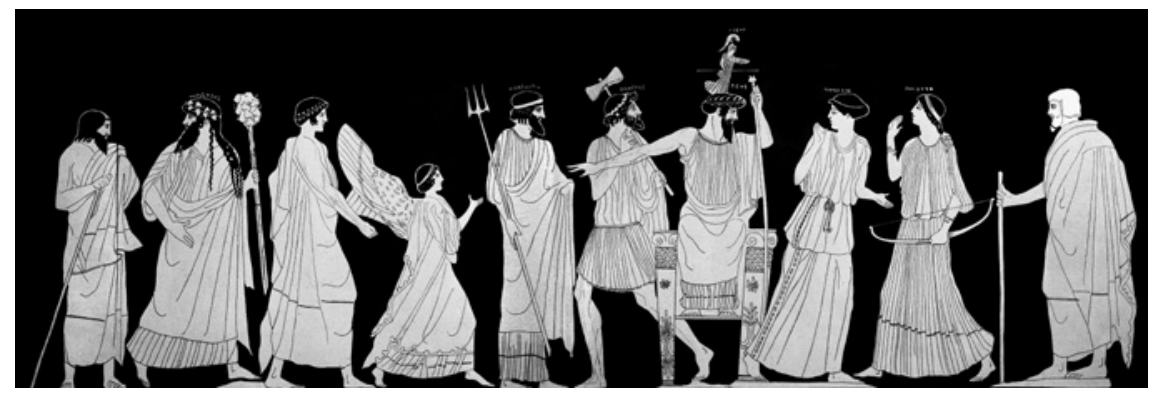

FIGURE 42 Pelike, Painter of the Birth of Athena, London, British Museum E 410, side A and B combined (Gerhard $1840-58, \mathrm{pl}$. 3-4).

to the right, towards a woman who hastens away in dismay, possibly the midwife Eileithyia, while his daughter, depicted at a smaller size, rises from his head in full armor. To the left we see Hephaistos running away with the axe he used to split the head of the father of the gods and effectuate the birth. To the right of Eileithyia, Artemis greats her new-born sister, on the left Poseidon with his trident is following Hephaistos. Artemis here stands for the region of Attica; her most famous sanctuary is situated in Brauron at its northeastern border; Poseidon stands for the Aegean, which surrounds Attica. Next to Poseidon, below the left handle, we see the slightly smaller figure of Nike. The other side of the vase is rather similar to Syriskos's pointed amphora discussed above. Here, too, Dionysos (who is named on the vase) dominates the main image. He moves energetically to the right, but turns his head towards an anonymous bearded man. To the right of the god an anonymous youth is hastening ahead of him. Analogous to the Syriskos amphora showing Dionysos between a young woman and a mother figure, the god here seems to mediate between two male representatives of different age groups. As in the dinos by the Berlin Painter discussed in the previous chapter, he is again the only one to be in direct contact with human beings. ${ }^{72}$ It may be for this reason that, in contrast to the other figures, he is shown with his feet on the ground.

Both the exclusive group of the pointed amphorae and the pelikai of the Painter of the Birth of Athena clearly illustrate not only the human dimension of the god Dionysos, but particularly his special alliance with the Athenian polis during the Classical period. This may, incidentally, have made him 
even more attractive for the Etruscan buyers. ${ }^{73}$ It seems significant, however, that although he features prominently on the two vases that were discussed in detail, Dionysos is not shown in the main mythological scene, but on the reverse, in direct contact with prototypical anonymous figures-for the original beholders of the images he, more than other gods, was actively involved in the lives of human beings.

73 Compare for the case of the Kodros Painter, Avramidou 2011, 84 . 


\section{Dionysiac Mythology in Flux Vase Imagery between 480 and $430 \mathrm{BC}$}

\section{Traditional Dionysiac Subjects}

It is well known that for Athens the decades between the victory over the Persians and the beginning of the Peloponnesian war were a period of selfconfidence and secured prestige in the Greek world. In Greek art the punctilious late archaic style is followed by the so-called severe style which is most markedly expressed by the figures of the metopes and pediments of the temple of Zeus at Olympia, completed in 456. The invention of counterpose for freestanding figures added spatiality and movement to the bodies; the faces were allowed to express feelings. These changes probably next made themselves felt in monumental painting, of which no examples remain, and only somewhat later-and less noticeably — in vase painting. In the more modest production of column kraters, pelikai and hydriai that Beazley attributes to the so-called early mannerists, archaic formulae continued in use, albeit in a more fluent manner. ${ }^{1}$ Nevertheless, the severe style may already be discerned in Hermonax' oeuvre and also turns up in the work of other painters, in the softer and richer folds of the robes and in the perspectival traits of the lively bodies.

It is only from 460 BC onwards that the direct influence of monumental painting becomes manifest in vase painting: figures become bigger, their movements more spatial, the background becomes deeper creating the impression of a genuine landscape-even though this could, at the same time, spoil the aesthetic effect of the curved surface of the vase. As for the Italian exports of the Kerameikos, it may not be entirely contingent that in these years the Etruscan cities on the Tyrrhenian coast are superseded by a new market north of the Apennines: Bologna, Spina and Adria. New consumers meant changes in the demand. The leading figures in these new developments are, for the large, closed vases and the kraters, the Niobid Painter, and for the cups, the Penthesilea Painter.

Next to this new direction, more conservative and academic painters, such as the Altamura Painter and the Villa Giulia Painter and his circle, hold their ground. For them, the total effect of the image carrier remains more important than bold perspectival and monumental experiments. As we will see, from

1 ARV Chapter 34. 
around 430 вС the sculptures of the Parthenon will have a profound influence, both stylistically and iconographically.

In what follows we will first look at the most important vase painters of these decades against the background of Dionysiac imagery, and subsequently discuss Dionysiac mythology as it is presented in different variants by these as well as other artists. In the next chapter we will examine groups of vases by several painters referring to Dionysiac rituals which have so far been somewhat overlooked.

Dionysos was not a prominent theme for the Niobid Painter; he hardly features in that painter's sculpturesque imagery. To be sure, however, the thiasos is depicted once on a volute krater and once on a calyx krater, but in both cases in one of the narrow friezes and therefore at a small size. ${ }^{2}$ The larger surfaces present other subjects: the main image of the volute krater, for instance, is an Amazonomachy. In the upper frieze of the calyx krater we see Dionysos among other gods, engaged in the Gigantomachy (Figure 43). The Greeks saw both battles as decisive events in the history of the world. It is therefore remarkable that in the lower frieze of this same calyx krater the Dionysiac thiasos is set against the sending out of Triptolemos on the reverse of the vase, as in the skyphos by Makron discussed earlier. ${ }^{3}$ Not much later it will be said in Euripides' Bakchai that grain and grapes, from which bread and wine are made, enabled humanity to make the step from nature to culture. ${ }^{4}$ It seems clear that in these two Dionysiac images the Niobid Painter transcends the individual perspective and seeks to express the wider one of the polis. As in the work of Hermonax, here too, the ritual elements - altar, torch, and in the case of the volute krater sacrificial baskets - are striking. Moreover, the altar has a prominent place on one of the painter's belly amphorae, one of his neck amphorae and three of his late hydriai. ${ }^{5}$ Instead of the thiasos, these vases present the motif of the encounter between Dionysos and a dignified standing woman (Figure 44). Apparently, the current trend towards ritualization also affected the Niobid Painter's Dionysiac images. In addition, the use of a static, symmetrical motif

2 Volute krater Ferrara 9355: Addenda 266 (60o.14); BA 206942 (no image); calyx krater Ferrara 2891: Addenda 266 (602.24); BA 206956; Raubitschek/Raubitschek 1982, 114.

3 See above Chapter 3, note 106. This juxtaposition may also be found on the volute krater in the manner of the Kleophon Painter, Stanford University 70.2: BA 8110 (no image); Clinton 1992, 124 and 166 f. fig. 11-14; Smith 2011, 154 VP 15.

4 E. $B a .278-285$.

5 Belly amphora London E 257: Addenda 267 (604.50); BA 206989; neck amphora New York 99.13.2: ARV 605.61; BA 207000 (no image); hydriai Ancona 4862: ARV 606.76; BA 207017 (no image); Ferrara 2683: Addenda 267 (606.77); вA 207018 (no image); Naples Stg 199: ARV 6o6.78; вA 207019 (no image). 


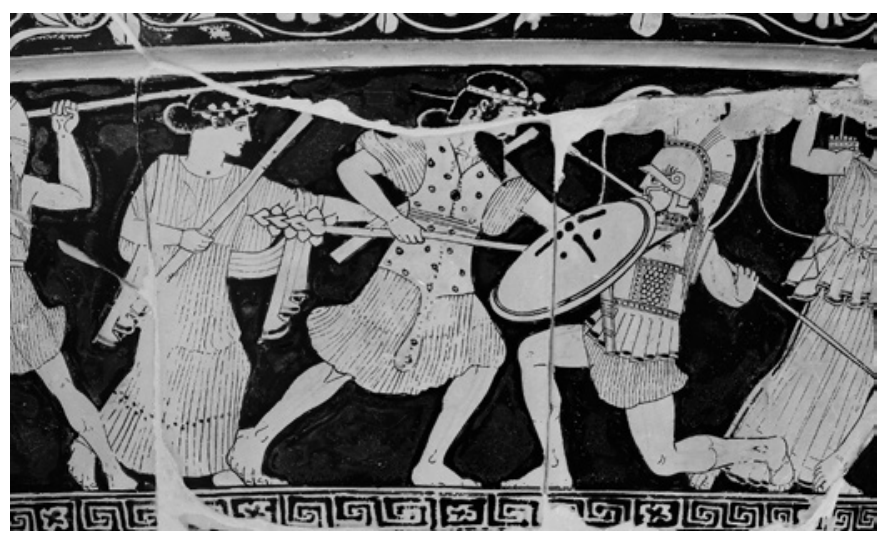

a

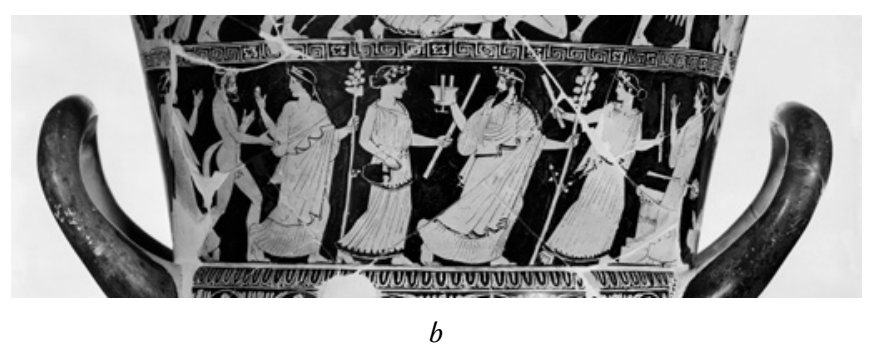

FIg URE 43 Calyx krater, Niobid Painter, Ferrara, Museo Archeologico Nazionale di Spina 2891. a. side view (left), detail of the upper frieze: Dionysos' Gigantomachy.

b. side B, lower frieze: Dionysos amidst his thiasos (photographs Archäologisches Institut der Universität Zürich, Silvia Hertig).

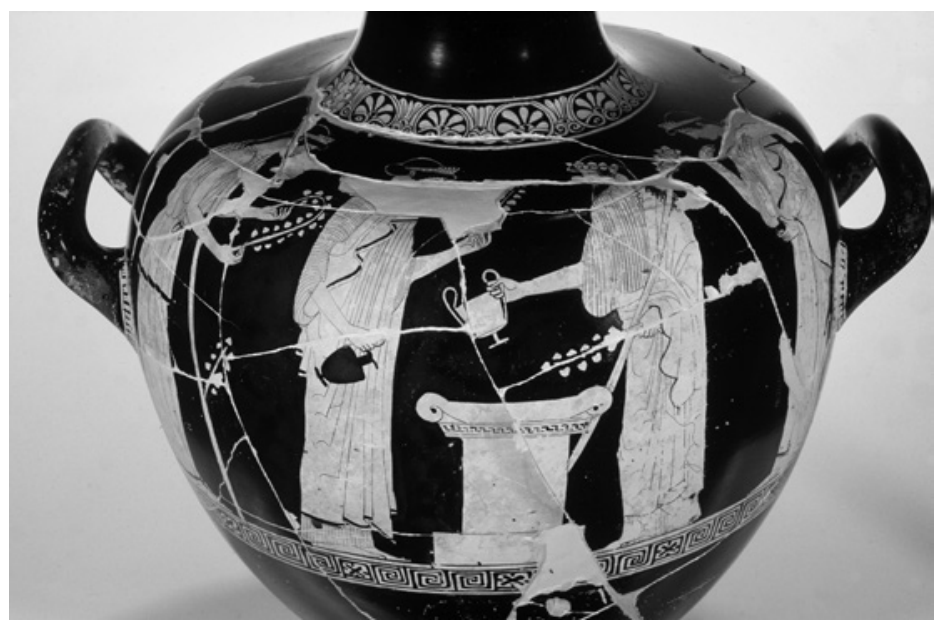

FIGURE 44 Kalpis, Niobid Painter, Ferrara, Museo Archeologico Nazionale di Spina 2683 (photograph Archäologisches Institut der Universität Zürich, Silvia Hertig). 
enabled him to underline the almost architectural character of the image carriers of the time. We will come back to the, rather rare, depiction of Dionysos' amorous pursuit of Ariadne on one of his oinochoai. ${ }^{6}$

The Altamura Painter is seen as the Niobid Painter's stylistic 'elder brother'. He produced several unremarkable but nevertheless original Dionysos images. On one of his calyx kraters Dionysos is leading a staggering Hephaistos towards the right; a satyr playing the kithara goes in front (Figure 45). On the reverse a maenad is using a torch to keep off a satyr who has fallen to his knees. ${ }^{7} \mathrm{~A}$ pitcher shows two women handing the god, who is accompanied by his panther, the pieces of armor he will need in the battle against the giants. ${ }^{8}$ Two vases by the same painter showing a Dionysiac child have become famous. These, a sumptuous bell krater and a volute krater, were likewise found in the Spina necropolis. They will be discussed in more detail below.

The Villa Giulia Painter is the most prominent representative of the socalled academic direction in early classical vase painting. His oeuvre mostly consists of the more distinguished vase types - calyx and bell kraters, stamnoi, and kalpides. Among the mythical figures Dionysos, with his retinue of women and satyrs, dominates. Only anonymous women, men and youths are more numerous. A number of original representations concerning both Dionysiac mythology and Dionysiac ritual will be discussed below. ${ }^{9}$

As far as Dionysiac subjects are concerned, the komos is the most important motif for the kraters by the early mannerists, followed by the thiasos, with or without Dionysos, and the symposium; other mythological scenes are much rarer. ${ }^{10}$ At any rate, it is notable that the thiasos is no longer a circle dance, but clearly turning into a procession with ritual implements, as was the case in the work of Hermonax and the Niobid Painter.

A prominent Kerameikos personality of the third quarter of the $5^{\text {th }}$ century was the Achilles Painter. He and Hermonax were the Berlin Painter's most

6 Cab. Méd. 46o: Addenda 267 (6o6.83); BA 207024.

7 Vienna 985: Addenda 264 (591.20); BA 206838; Natale 2008, 103, fig. 31. An almost identical version of the same scene may be found on the calyx krater Naples Stg. 701: Addenda 264 (591.21); вА 206839 (no image). In this case, however, the satyr playing the kithara who walks in front is not wearing a phallus costume so that there is no explicit reference to the theater, see Carpenter 1997, 47. Compare in addition a stylistically similar calyx krater with Hephaistos riding a mule in side saddle, Oxford (Ms) 1977.3.89: ARV 597; BA 206922.

8 Bologna 338: Addenda 265 (595.65); вA 206890.

9 See below and Chapter 6 .

10 ARv Chapter 34. For the history and repertoire of the column krater, see Isler-Kerényi 1993 b, 96 . 


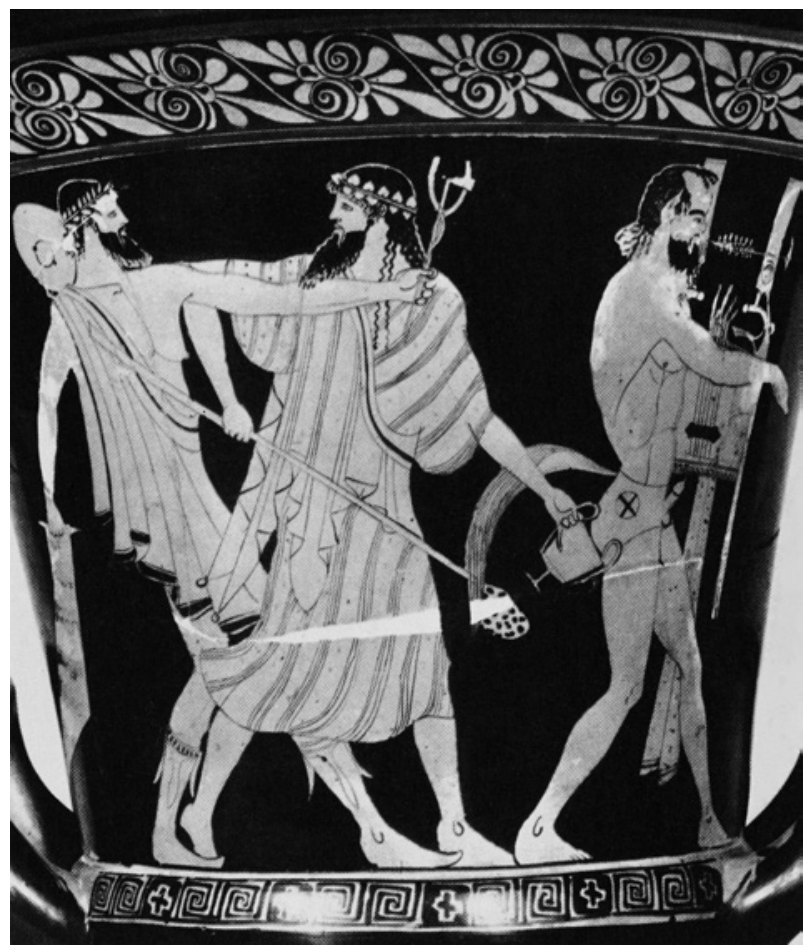

FIgURE 45 Calyx krater, Altamura Painter, Kunsthistorisches Museum, Vienna 985, detail of side A: Dionysos with Hephaistos (cva Kunsthistorisches Museum, Vienna 3 , pl. 101.1).

influential pupils. ${ }^{11}$ His oeuvre mainly consists of neck-amphorae and lekythoi and of the latter he made much more white- ground than red-figure ones; whiteground lekythoi were produced as funerary offerings and not meant to be used at the symposium. The Achilles Painter's red-figure activities begin between 470 and 460 and end around 430 BC. ${ }^{12}$ Dionysos is not among his preferred subjects: apart from the pointed amphora already mentioned, two early oinochoai (still very much showing the influence of the Berlin Painter) and a later chous show Dionysiac motifs in a ritual atmosphere. ${ }^{13}$ The first oinochoe shows a woman who, with thyrsos and torch, follows Dionysos (Figure 46). He is carrying a kantharos and a thyrsos, and is walking towards the right while looking

\footnotetext{
11 Oakley $1997,111$.

12 Oakley 1997, 5 .

13 For the pointed amphora see above Chapter 4, note 46; oinochoai and chous see Oakley $1997,43 \mathrm{f}$.
} 
back at her. ${ }^{14}$ He leads, and she follows him, more enchanted than euphoric. A woman with the same attributes is the only figure on the other oinochoe. ${ }^{15}$ The chous, unfortunately, is only fragmentarily preserved: a figure with thyrsos and kantharos-possibly Dionysos - is standing in the foreground to the right. On the left a small satyr is approaching with a casket in his hand. On the floor between the two is a chous, perhaps a reference to the Anthesteria. ${ }^{16} \mathrm{~A}$ stamnos, likewise in a fragmentary state, has on the one side Dionysos between a satyr playing the barbitos and a woman who salutes the god, and on the other a satyr between two women; the torches give the latter image a ritual aura. ${ }^{17}$ The Achilles Painter's middle period is represented by his only preserved komos on a bell krater. ${ }^{18}$ It is a rather quiet scene showing a young komast playing the lyra and an elderly one with cup and stick. A glossy black stamnos with a

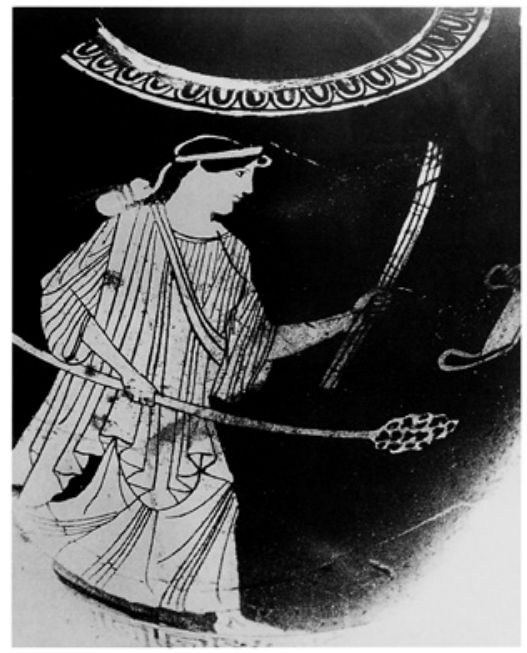

$a$

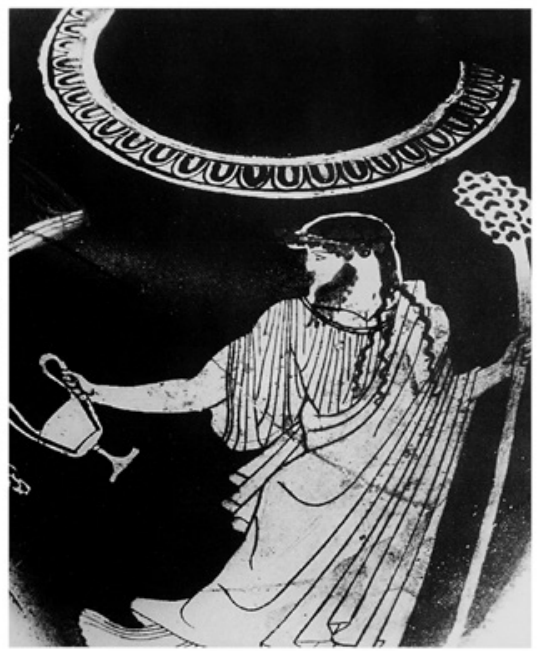

$b$

FIgURE 46 Oinochoe, Achilles Painter, Montpellier, Musée de la Société Archéologique 140.

a. detail: woman in Dionysos' retinue (Oakley 1997, pl. 67).

b. detail: Dionysos (Oakley 1997, pl. 67).

\footnotetext{
14 Montpellier 140: Addenda 312 (992.74); BA 213895; Oakley 1997, no. 102, pls. 67 and 68 A.

15 Vienna 350: ARV 992.75; BA 213896; Oakley 1997, no. 103, pl. 68 B.

16 Athens, Agora P 5729: ARV 993.78; BA 213899; Oakley 1997, 43, no. 107, pl. 69 C.

17 Florence 3988: Para 437 (992.66); BA 213887; Oakley 1997, no. 91, pls. 57 and 59 C. For the barbitos, see above Chapter 2, note 48 .

18 Metaponto 202446: BA 19768; Oakley 1997, 44 and 82 (for the somewhat unusual form of the krater with a sharp lined lip, concave exterior profile and lug handles), no. 84, pl. 53 .
} 
comical, prying little satyr walking to the right as a shoulder image is attributed to his later work. ${ }^{19}$

As for the pointed amphora, its well-considered composition and careful execution are in perfect accordance with its exclusive shape (Figure 47). ${ }^{20}$ In the center of the main side, unequivocally determined by the position of the handles, we see Dionysos, striding briskly towards the right. He wears a panther skin over his chiton and carries thyrsos and kantharos in his hands. He turns towards a dancing maenad on his left, likewise with animal skin and thyrsos. A maenad with thyrsos and torch walks in front of him; a maenad with a tympanon and a woman playing the flute follow below the left handle. All women mentioned so far wear their hair loose and uncovered except for an ivy wreath. On the left an energetically moving satyr with thyrsos and torch makes up the rear. A maenad with short waving hair, shown from the back, takes the center on the reverse. In her lifted hands she holds one half of the fawn she has apparently torn apart. To her left are two women, one of them holding a snake, the other a thyrsos. Both have their hair neatly gathered up, one even wears a cap. They are walking in a close embrace, as did, a century earlier, the two maenads on the neck-amphora of the Amasis Painter in Paris. Like them, they may be interpreted as a Sapphic pair and as a reference to that part of the life of adolescent girls they spend away from the city in the sole company of women. ${ }^{21}$ Behind them, below the other handle, follow a second dancing satyr, holding his thyrsos upside down, and a woman who may be playing cymbals. On the Dionysos side the image can be read as a ritual thiasos. The reverse is more dramatic: we may presume that the Achilles Painter wanted to depict the, in the eyes of the citizens, more unpleasant side of maenadism - things that took place outside the city in unspoiled nature. This would very well fit the close relationship between image carrier and polis discussed earlier. ${ }^{22}$

The vase painter Polygnotos, active from around 450 until c. 420 BC, was presumably a pupil of the Niobid Painter. ${ }^{23} \mathrm{He}$ was the leading decorator of stamnoi, kraters and large neck-amphorae of the Kerameikos. His sixteen remaining stamnoi present original mythological subjects; six of them are of a Dionysiac

19 Munich 2403: Addenda 312 (992.67); BA 213888; Oakley 1997, 43, no. 94, pl. 61 A-B.

20 Cab. Méd. 357: Addenda 311 (987.2); BA 213822; Oakley 1997, 52 f., no. 2, pl. 2 B-4. It is, however, sometimes hard to determine how much of the image is original and how much is due to the restorers.

21 See Isler-Kerényi 2007, 134 f. Compare Robertson 1992, 195 about the two women: “. . one, her arm over the other's shoulder, looks back and down to her with great tenderness..."

22 See above Chapter 4.

23 Matheson 1995, 3. 


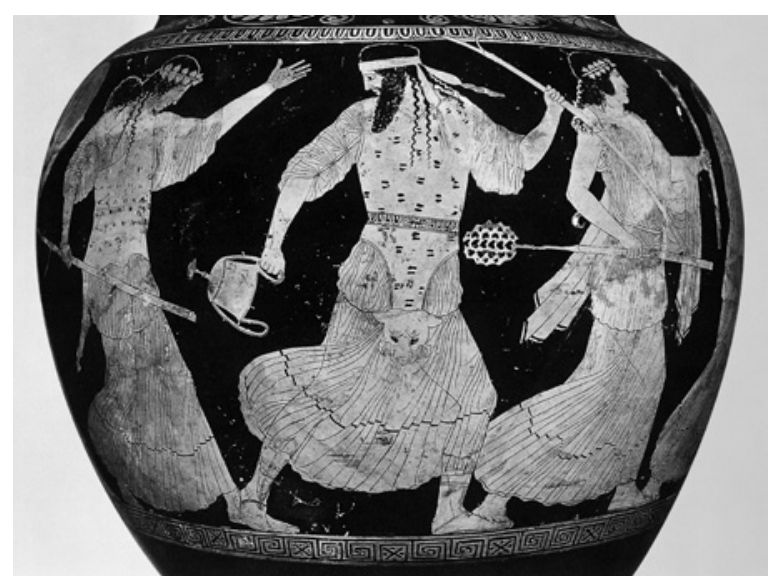

$a$

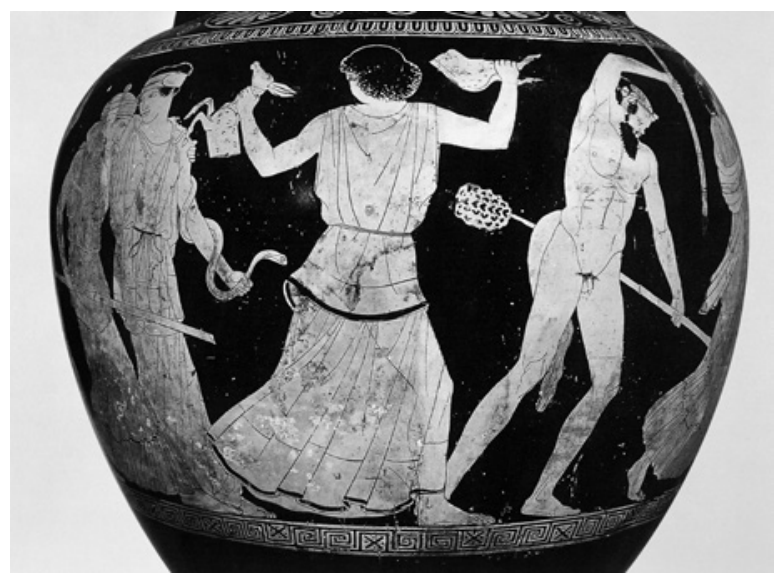

$b$

FIGURE 47 Pointed amphora, Achilles Painter, Paris, Bibliothèque Nationale de France, Cabinet des Médailles 357.

a. side A: Dionysos (Oakley 1997, pl. 4a).

b. side B: maenad (Oakley 1997, pl. za).

nature. ${ }^{24}$ Komos and symposium inspired him to conduct interesting artistic experiments, such as the daring three-quarter view of the face of one of the symposiasts on the Rome stamnos and the expansive dance movements

24 Florence 4227: ARV 1028.11; BA 213392; Louvre 406: Addenda 317 (1028.12); BA 213393; Athens, Acr. 18063: Addenda 317 (1028.13); BA 213394 (no image); London E 454: ARV 1028.14; BA 213395; Oxford (Ms) 1977.3.96: ARV 1028.15bis; BA 213397 (no image). 
of the komasts on a well-preserved bell krater from the Pezzino necropolis at Agrigento, which, finally, served as a burial urn (Figure 48). ${ }^{25}$

Belonging to the circle of Polygnotos, the somewhat younger Kleophon Painter is stylistically equally innovative and of the same artistic level. He was active from around 440 until c. $410 \mathrm{BC}$; his style shows the strongest influence of the Parthenon sculptures. ${ }^{26}$ Apart from his numerous stamnoi, with ever varying komos scenes, and his dinos with symposiasts, three of his vases merit special mention. ${ }^{27}$ The most impressive one is the Ferrara volute krater, with a depiction of a sacrificial procession for the Delphic Apollo on the one side, and, supposedly, on the other the return of Hephaistos by Dionysos with his thiasos retinue (Figure 49 ). ${ }^{28}$ The two scenes, however, are not strictly separated: the thiasos directly follows the sacrificial procession. Moreover, the youthfulness of the figure on the mule rather suggests a ritual train evoking the mythical return, as it was presumably already depicted in black-figure imagery. ${ }^{29}$ Apparently, the juxtaposition of Apollo and Dionysos was especially topical in these years. As we will see, Phidias made the young Dionysos he created for the east-pediment of the Parthenon resemble Apollo-made them brothers in outward appearance as well. ${ }^{30}$ We will again find Apollo and Dionysos in Delphi on an important later calyx krater by the Kadmos Painter. ${ }^{31}$

The large pelike showing the return of Hephaistos-on foot-in a mythological ambiance, presents Dionysos as a remarkably majestic presence, his thyrsos vertically fixing the image (Figure 50$) \cdot{ }^{32}$ Over his chiton he wears the multicolored ependytes and the fawn skin. He walks to the right, followed by his intoxicated brother, who leans on a helpful satyr. Another satyr walks ahead, making expressive gestures at a maenad who leads the train with her tympanon.

25 Stamnos Rome, Villa Giulia 3584: ARV 1028.15; вA 213396; bell krater Agrigento AG 22797: BA 31415 (no image); De Miro 1994, Color plate 34; Torelli 2012, 422 f. The other side has two standing youths wrapped in their mantles.

26 Isler-Kerényi 1973, 29 f.; Matheson 1995, 135-145.

27 Stamnoi: Munich 2414: Addenda 334 (1143.6); BA 215146; St. Petersburg 2353 (810): Addenda 334 (1144.7); вА 215147; Copenhagen NCG 293: Addenda 334 (1144.8); BA 215148; Brussels A 3091: Addenda 334 (1144.9); BA 215149; Minneapolis (Mn) 09.6: Addenda 334 (1144.10): BA 215150; for the dinos see Ferrara 9379: Addenda 334 (1144.11); BA 215151.

Ferrara 44834: Addenda 334 (1143.1); BA 215141 (no image). See also Isler-Kerényi 2002a, 74 f.; Halm-Tisserant 1986, 8-13 (return of Hephaistos).

29 Isler-Kerényi 2004a, 49.

$30 \quad$ See below Chapter 7 .

31 See below Chapter 8, note 25.

32 Munich 2361: Addenda 335 (1145.36); BA 215176. 


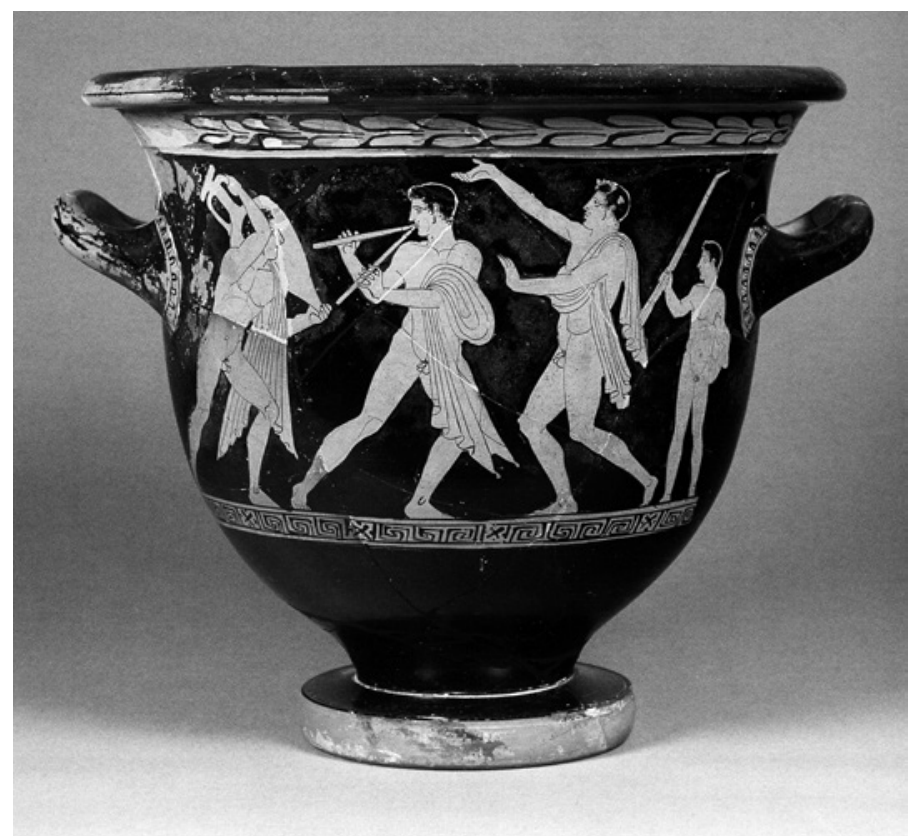

Figure 48 Bell krater, Polygnotos, Agrigento, Museo Archeologico Regionale AG 22797, side A (De Miro 1994, pl. 34). (C) Regione Siciliana-Assessorato Reg.le dei BB.cc. e dell'I.S.

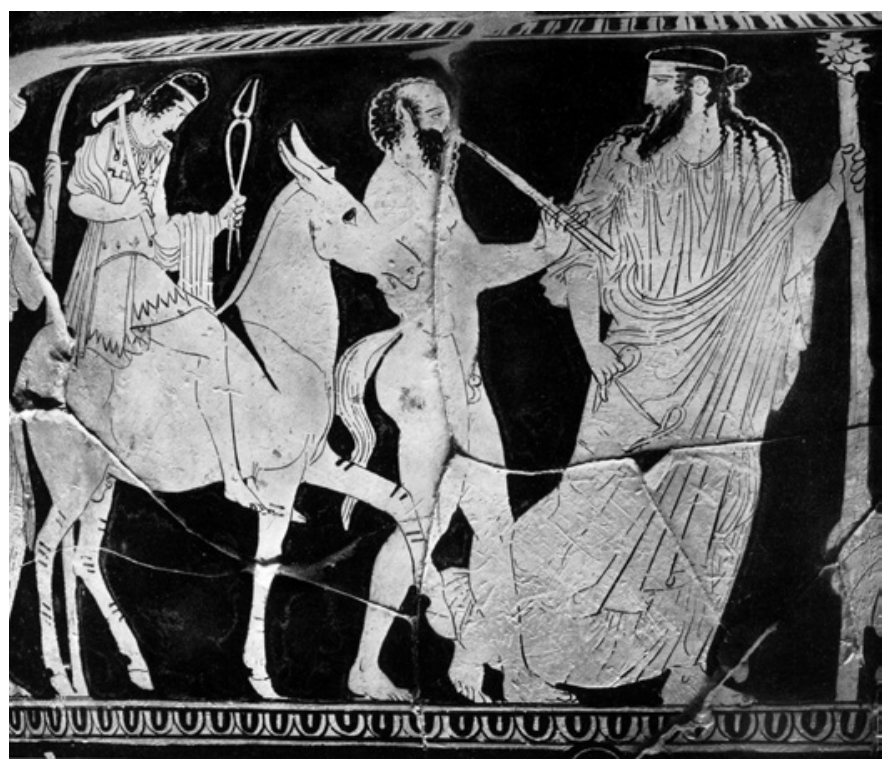

FIGU RE 49 Volute krater, Kleophon Painter, Ferrara, Museo Archeologico Nazionale di Spina 44834, detail of side B (photograph Archäologisches Institut der Universität Zürich, Silvia Hertig). 


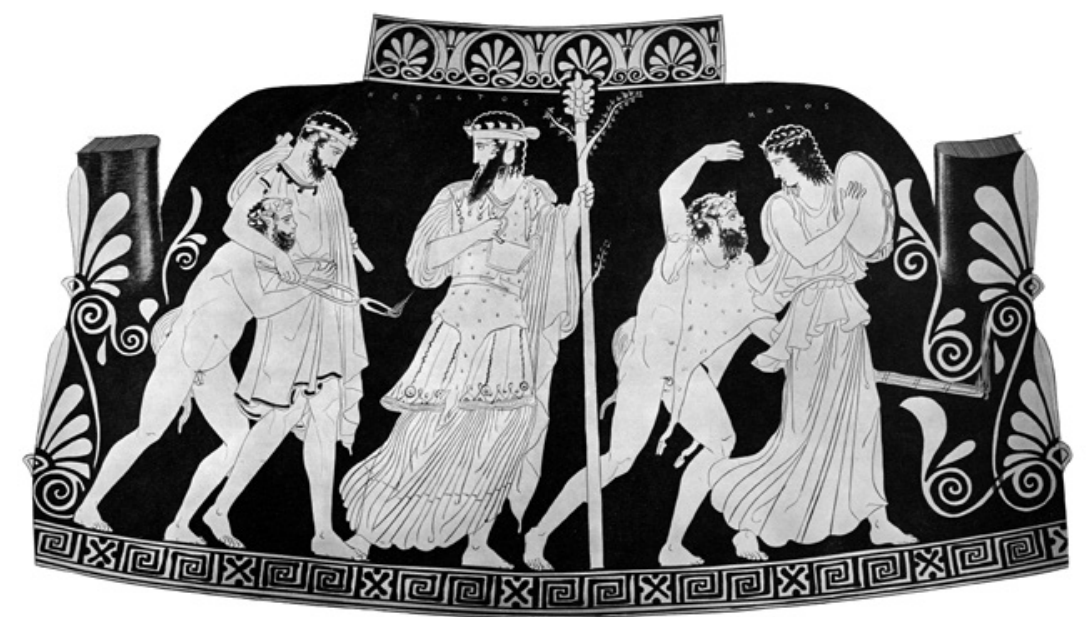

FIGURE 50 Pelike, Kleophon Painter, Munich, Staatliche Antikensammlungen und Glyptothek, 2361, side A (FR pl. 29).

One of the Kleophon Painter's bell kraters was noticed by scholars at an early stage because of its unique depiction of a dithyrambos chorus. ${ }^{33}$ Five singing bearded men in embroidered hymatia, and a youthful aulos player are standing on both sides of a peculiar, seemingly temporary, cultic object, the lower part of which is swathed in ivy. Interestingly, the precentor is shown full face. On the reverse we see a satyr in a himation with a torch in his hand walking between two women with thyrsoi. Is this likewise an otherwise unknown Dionysiac ritual? The outside images of the only remaining cup of the Kleophon Painter both have two lively pairs of obtrusive satyrs and vehemently resisting maenads. In the medallion a satyr parades before Dionysos with his aulos. ${ }^{34}$ The bell krater in St. Petersburg, with komasts on the one side and youths wrapped in mantles on the other, is remarkable because of the site where it was found: Nymphaion on the northern coast of the Black Sea. ${ }^{35}$ In this area Attic pottery (and its Dionysiac imagery) dating before the middle of the century is rarely found. It usually dates after $440 \mathrm{BC}$, especially the 4 th century.

Compared to the great cup painters of the second quarter of the centurythe Brygos Painter, Douris, Makron - the next generation shows much less distinction, and only the work of the Euaion Painter has a sizeable number of Dionysiac motifs: thiasos, komos and symposium can be found on many of his

33 Copenhagen 13817: Addenda 335 (1145.35); BA 215175.

34 Oxford 1925.621: Addenda 335 (1147.68); BA 215208.

35 St. Petersburg St. 2077: Addenda 335 (1145·30); BA 215170. 
cups, otherwise populated by anonymous athletes and warriors. ${ }^{36}$ The work of the considerably less productive Amymone Painter is quite comparable. ${ }^{37}$ The oeuvre of the Euaion Painter makes us aware how quiet the thiasos consisting of satyrs and maenads has become, compared to the images of, for instance, Douris and, especially, Makron. The situation is no different for the Pistoxenos Painter and his circle. ${ }^{38}$ And neither can the satyrs and maenads on the cups of the Penthesilea Painter be called innovative. ${ }^{39}$

Among the cup painters who were active between 440 and 410 BC the Kodros Painter and the Eretria Painter, who will be discussed later, are the most important. ${ }^{40}$ The former is remarkable for some rather original representations of Athenian mythology. As we have seen, Dionysos held a special place in the hearts of the Athenians, and it is therefore not surprising that, apart from unremarkable thiasos images, two unique depictions of Dionysos by the Kodros Painter have survived. We will come back to the inside image of the superb cup in Würzburg, showing Dionysos, Ariadne, and other figures. ${ }^{41}$ Instead of the traditional lively thiasos, the two outside images each have clusters of quietly standing figures: three satyrs and two maenads. Here too, the trend towards restraining the thiasos, already discerned in the work of the Euaion Painter, cannot be overlooked.

The Kodros Painter also presents Dionysos on another cup, which is dated to an earlier stage in his career, between 440 and 430 BC. ${ }^{42}$ The outside images each have two divine couples, the inside image has one. All are presented in a symposium situation. Side A shows Zeus with Hera, and Poseidon with Amphitrite. Side B has Dionysos with Ariadne, and Ares with Aphrodite. The medallion shows Hades and Persephone. In all five instances the god is reclining on a couch that seems rather too small for him. The goddess is sitting at his feet so that the heads are all on the same level. This gives the images a strikingly uniform rhythm, broken by the head of Aphrodite, the only one to be standing. Because of this uniformity it is all the more striking that only on the A side a pillar marks the center of the image. Perhaps it indicates the oikos, a suitable framework for the two regularly married divine couples, a

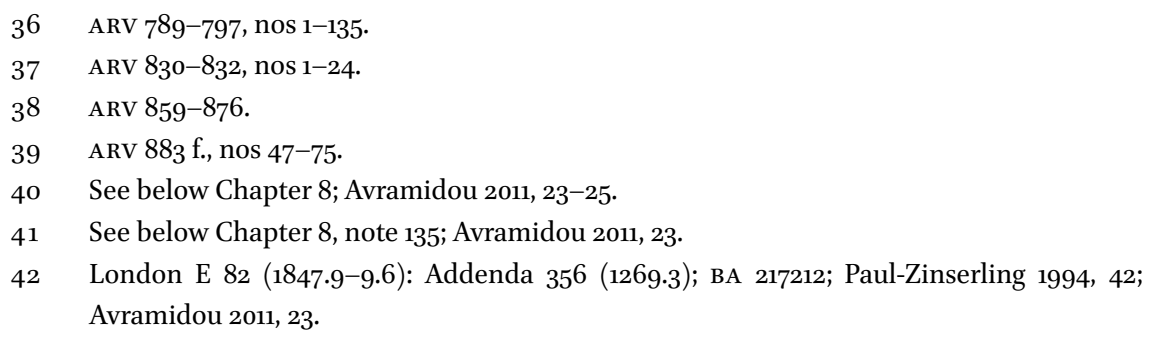


status neither Ares and Aphrodite, nor Dionysos and Ariadne can claim. Zeus is flanked by the Olympian cup-bearer Ganymede; a satyr is next to Dionysos. All figures have their names: the satyr is called Komos. ${ }^{43}$ Like the other male gods (with the exception of Ares), Dionysos holds a phiale here instead of his kantharos, and, like Hades, very noticeably so. ${ }^{44}$ Each god wears a different headdress; Dionysos has his ivy wreath. As is becoming for mature men and worthy spouses, all gods are bearded.

Although the decoration seems at first sight quite accessible, due to the uniqueness of the images there is, in fact, much that remains enigmatic. Let us only say that the symposium setting in which the divine couples are placed, expresses at least two things: a salutary state of bliss, which implicitly includes matrimony and its promise of stability and continuity for the polis, and the equality of the gods in power and rank. ${ }^{45}$ Only Hades, placed in the medallion of the cup, has more prominence. ${ }^{46}$ It is no coincidence that this reminds us of black-figure cups whose inside images evoke at the same time Dionysiac bliss and death. ${ }^{47}$ The fact that, as far as the goddesses are concerned, only Persephone's feet are not touching the ground must, in the case of a highminded artist like the Kodros Painter, be intentional; it is probably a reference to her youth. ${ }^{48}$ The selection of divine spouses for the outside of the cup is likewise significant: they are the same as those in the first three chariots of Thetis' wedding procession on the dinos by Sophilos and later on the François krater. The Kodros Painter adds Dionysos, who played a key role on these earlier vases. A splendid cup signed by the potter Sosias with the same selection of gods may be dated around 500 BC, exactly between the earlier depictions and the Kodros Painter's cup. ${ }^{49}$ As already became clear from our discussion of one of Syriskos' pointed amphorae: the recollection of the fact that the stability of the

43 The same name is given to a satyr boy on the roughly contemporaneous bell krater Compiègne 1025, which will be discussed below, see Chapter 6, note 99. See also Smith $2007,156-158$.

44 I am not certain if he, as Avramidou 2011, 43 says, offers it to Ariadne, like Hades offers his to Persephone. There can be no doubt, however, about the significance of the analogous gestures of the two gods.

45 Compare Avramidou 2011, 44: "... the cup presents us with a banquet of democratic parity," and 46: "The Divine Banquet cup offers a good opportunity for a multiple approach to its interpretation." Similarly Schmitt Pantel 2011, 134-136.

46 For this and for a possible relationship with the Etruscan site where the cup was found, see Avramidou 2011, $44 \mathrm{f}$.

47 Isler-Kerényi 2007, $186 \mathrm{f}$.

48 Compare Avramidou 2011, 43.

49 Berlin F 2278: See above Chapter 2, note 81; Isler-Kerényi 2008a, 76 f., figs 7 a-b. 
order of Zeus - the existing order for the original beholders of the cup-was guaranteed by the marriage of the goddess Thetis with the mortal Peleus was apparently still present, and with it the awareness of Dionysos' important position on the Olympus..$^{50}$

\section{The Child Dionysos}

We first encountered this motif - in a fragmentary but very lavish version - on a cup by Makron which may be dated shortly after $480 \mathrm{BC} .{ }^{51}$ The cup was found on the Acropolis and was therefore a valuable votive gift. Followed by Athena and Poseidon, Zeus walks towards an altar with the child in his arms, behind Hermes who is on his right. The child, at the center of the scene, is holding a vine branch with big grapes. Two women are busy at the altar, which is decorated with a small image of a kid. One is handling a jug, the other scattering something on the altar from a sacrificial basket. To the right of the women, in the handle zone of the cup, a hill behind some trees indicates Mount Nysaunspoiled nature, dwelling place of the nymphs (Figure 51).

The motif of the infant Dionysos handed over by his father may also be found on a neck-amphora attributed to the Eucharides Painter, as well as on a fine kalpis by the Syleus Painter, whose work should be dated in about $480-470$ вС. Both are more or less contemporaneous with Makron's cup. It is furthermore reproduced on a stamnos by the Painter of the Florence Stamnoi, and finally, between 460 and $450 \mathrm{BC}$, on two magnificent kraters by the Altamura Painter and a more modest pelike by the Nausikaa Painter. ${ }^{52}$ We should, however, also take into consideration a number of images designated as the handing over of the infant Dionysos, where the figure who brings the child is not his father. ${ }^{53}$ The theme was topical from around 480 until c. $420 \mathrm{BC}$ - the evidence peaks around $450-$, its aftermath reaching beyond $400 \mathrm{BC}$.

50 See above Chapter 4, note 47.

51 Athens, Acr. 2.325: see above Chapter 3, note 112. Also Kunisch 1997, 137; Schöne 1987, 85; Carpenter 1997, fig. 20 A; Moraw 1998, fig. 32; Stark 2012, 94-103, 238, Cat. D rV 2.

Charles Ede, sales catalogue Pottery from Athens v, 1979, no. 22. On a rather badly preserved belly amphora in Bologna, which may be dated around 460 вС (Museo Civico Archeologico 17100: Pellegrini 1912, 48, no. 153), we see a woman with a child on the left, and on the right a woman with a kantharos; it is not clear whether the cloaked figure, with thyrsos and ivy wreath, in the center of the image is Zeus or another nymph.

53 Compare Gasparri 1986, $479 \mathrm{f}$. In addition the kalpis by Hermonax, see below note 61 . 


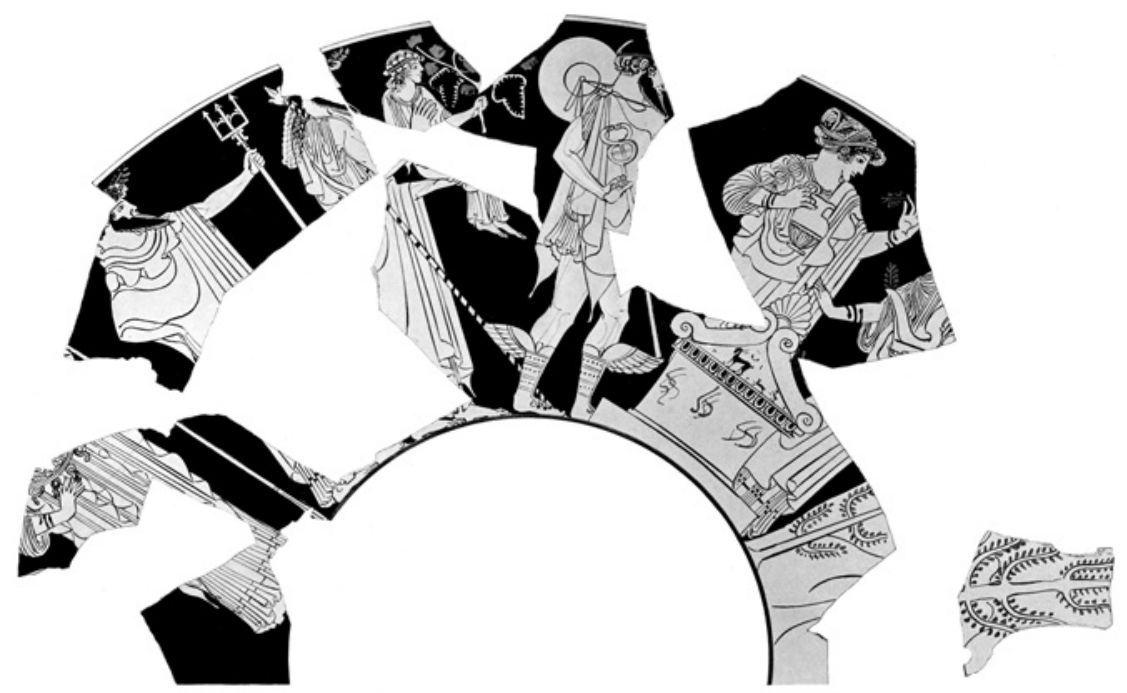

FIGURE 51 Cup, Makron, Athens, National Museum Acr. 2.325, fragments of outside image,side B (GL II, pl. 20.325).

Three thematically related representations, specifying the mythological situation, can also be added to the group with the handing over of the Dionysos child. The lekythos by the Alkimachos Painter showing Dionysos' birth from the thigh of his father was made around 450 вС. ${ }^{54}$ The presence of Hermes, ready to take his leave, here refers to the handing over of the child which followed his birth. A fragment of a calyx krater in the manner of the Dinos Painter, produced about thirty years later, indicates the same event. ${ }^{55}$ It shows the infant Dionysos rising from the thigh of a seated Zeus. He extends his little arms towards a figure about to receive him (Figure 52). The famous hydria by the Semele Painter of about 400 BC has the dead Semele on her couch as the central figure of an image with an almost theatrical atmosphere. In the foreground to the left Hermes is carrying away the infant Dionysos, who holds a large ivy branch. ${ }^{56}$ Zeus, Aphrodite, Hera, Iris, nymphs, satyrs, and several anonymous figures are present at the scene.

In any case, the depictions of the handing over of the infant just mentioned do not present an iconographic whole. Makron's cup best corresponds to

54 Boston 95.39: Addenda 255 (533.58); вA 206036; Zanker 1965, 80.

55 Bonn 1216.19: BA 12464; Stark 2012, 247, Cat. D rV 25.

56 Berkeley 8.3316: Addenda 367 (1343.1); BA 217563; Zanker 1965, 8 o. 


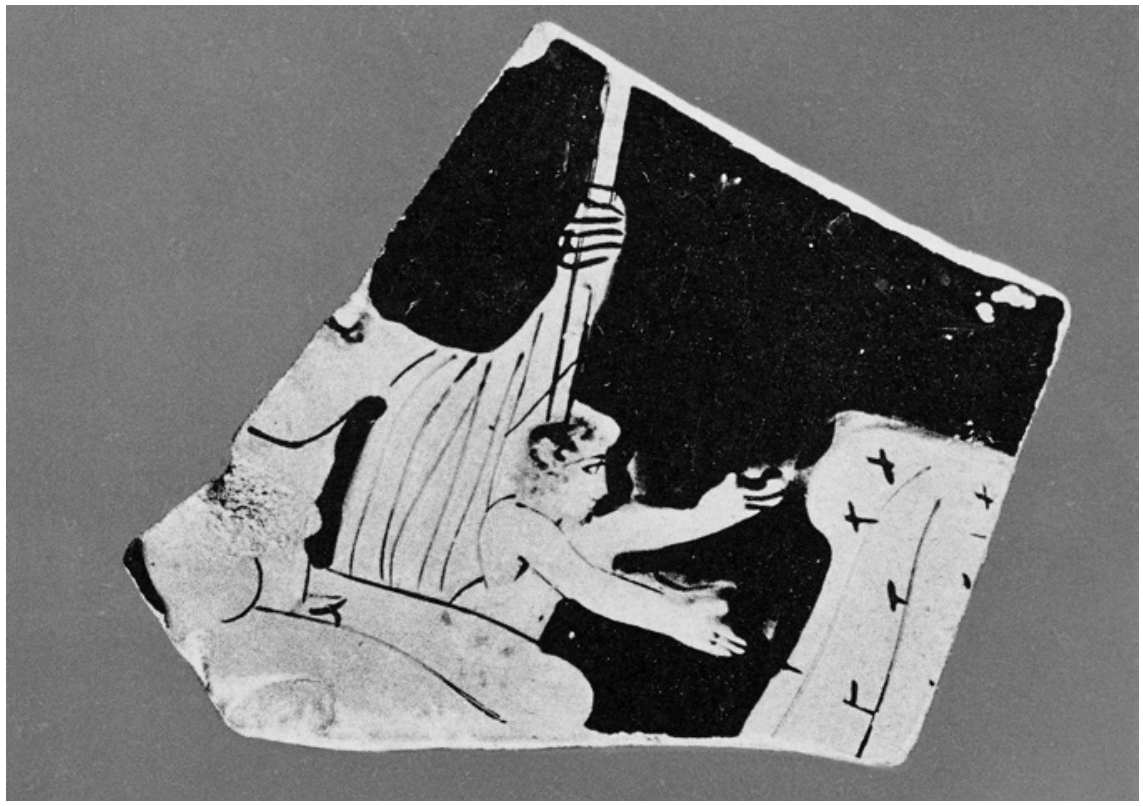

FIGURE 52 Fragment of a krater, artist from the sphere of the Dinos Painter, Bonn, Akademisches Kunstmuseum 1216.19 (cVA Bonn 1, pl. 33.9).

the familiar myth. ${ }^{57}$ The Eucharides Painter's amphora depicts Zeus striding towards the right with the swaddled infant. ${ }^{58}$ On the reverse we see a standing woman who, Muse-like, carries a lyra. It is very well possible that she is one of the nymphs of Nysa, whose lyra characterizes her as an educator. ${ }^{59}$ The luxuriant palmette volute extending from the handles to the images, evokes unspoiled nature.

As far as the composition is concerned, on the version of the Syleus Painter and, somewhat later, those of Hermonax and the Painter of the Florence Stamnoi, the event takes place in a space situated between exterior and interior, as the pillar near the center of the images indicates. In this respect these images differ from the Makron cup as well as from the amphora discussed above, and seem more closely related. The Syleus Painter presents Zeus, with his characteristic scepter, handing the child to a young woman wearing a

$57 \quad$ See above note 51 .

58 New York L 1982.27.8: BA 9025040 (no image) (on loan from G. Callimanopoulos); Van Keuren 1998; Stark 2012, 68, 237, Cat. D rV 1.

59 The literary tradition also refers to Muses as the educators of Dionysos: Privitera 1970, 98. See below Chapter 6, note $5^{2}$. 
diadem. She is sitting on a folding chair in front of the pillar. On the left another young woman looks on. She is wearing an ivy wreath and, likewise, holding a scepter. ${ }^{60}$ The child and the seated woman both hold an ivy branch (Figure 53).

In the incomplete image of the Hermonax kalpis, Hermes is calmly approaching an edifice indicated by two pillars. ${ }^{61}$ The gesture he makes with his left arm probably signifies hushing or whispering; on his right he carries the naked infant. Inside the building a figure holding a phiale is seated on the left-possibly the enthroned woman discussed in the next example. The woman standing before her looks towards Hermes. Instead of ivy branch and thyrsos, two kantharoi on a table in the center of the image indicate the Dionysiac ambiance. ${ }^{62}$ Most likely, the infant is Dionysos who should be concealed from Hera.

At the center of the image on the stamnos by the Painter of the Florence Stamnoi stands a young woman holding a child (Figure 54). ${ }^{63}$ To the right, turning towards her, is a dignified, bearded man carrying an otherwise undetermined stick in his right hand; the left is hidden in the folds of his himation. The child is extending its arms towards him. Has he just handed it over or is he about to receive it? On the left, in a temple-like structure, a mature woman sits enthroned like a goddess on a taboret without armrests. In her left hand she holds a magnificent thyrsos, in her right a phiale. On the reverse three women, wrapped in their himatia, are excitedly deliberating. One of them is holding a thyrsos. We do not know if the pillar these three versions (datable to c. 470 or shortly afterwards) have in common stands for the oikos or for a sanctuary. On the basis of the attributes, the images definitely belong to Dionysiac mythology. However, they sit uneasily with the myth of the handing over of the child Dionysos to the nymphs of Nysa as represented by, for instance, Makron.

On one side of the Altamura Painter's superb bell krater we find an athlete between a musician and a victory goddess. ${ }^{64}$ On the other, a seated bearded man with a thyrsos in his left hand dominates the center of the image. He has on his thigh a slender boy with a kantharos in his right hand and an ivy branch in his left. Left of the scene is a woman with flowers in her hands, and on the right another woman who lifts her right hand in a gesture of wonder, in her left she holds a piece of cloth. Blossoms and leaves protrude from the handle ornament, underlining the joyful atmosphere of the scene while simultaneously

\footnotetext{
6o Cab. Méd. 440: Addenda 203 (252.51); BA 202896; Stark 2012, 86, 238 DrV 3.

61 Private collection, Greece: BA 5703 (no image); Carpenter 1997, pl. 22 B; Stark 2012, 70 f., 86, 241 DrV 8.

62 Bérard/Bron 1986, $20 \mathrm{f}$. and note 46.

63 Louvre MNB 1695 (G 188): Addenda 252 (508.1); BA 205715; Stark 2012, 86, 240 DrV 6.

64 Ferrara 2738: Addenda 264 (593.41); вA 206865.
} 


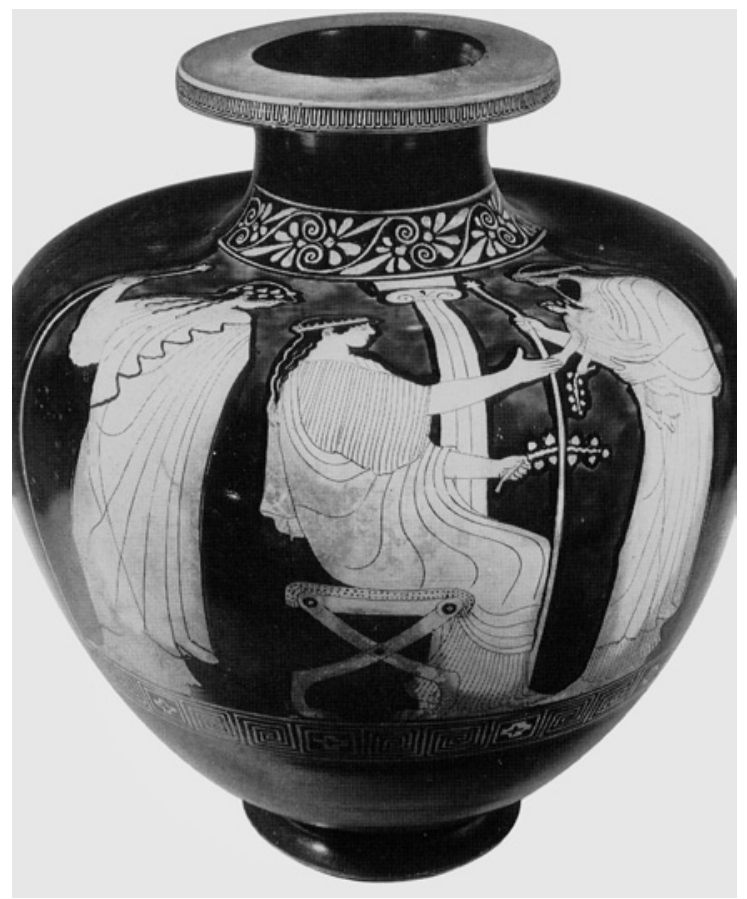

FIgu re 53 Kalpis, Syleus Painter, Paris, Bibliothèque Nationale de France, Cabinet des Médailles 440 (Arafat 199o, pl. na).

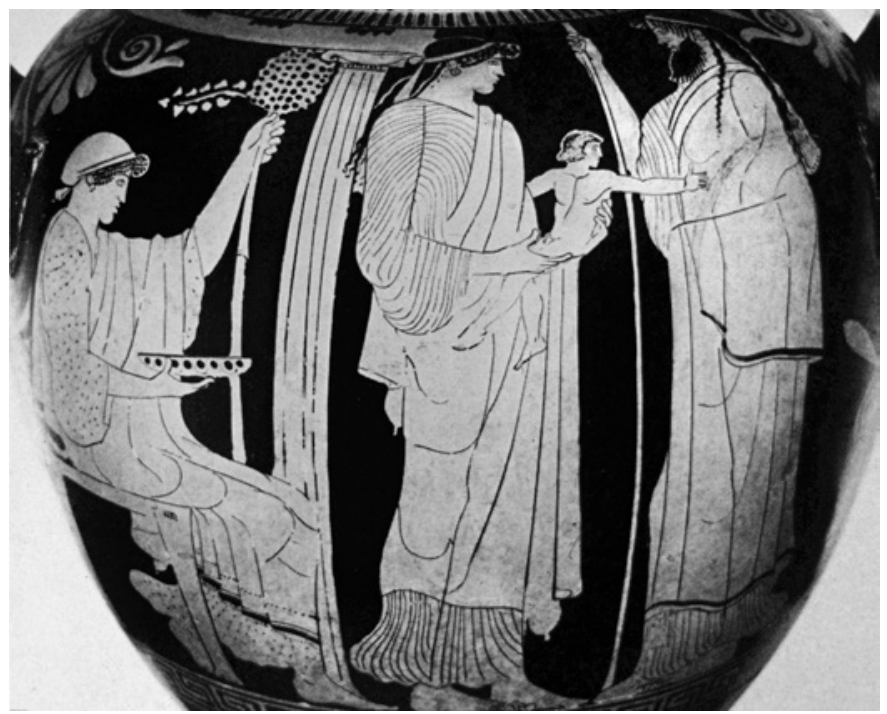

FIgURE 54 Stamnos, Painter of the Florence Stamnoi, Paris, Louvre MNB 1695 (G 188), side A (LIMC III.2, Dionysos 703). 


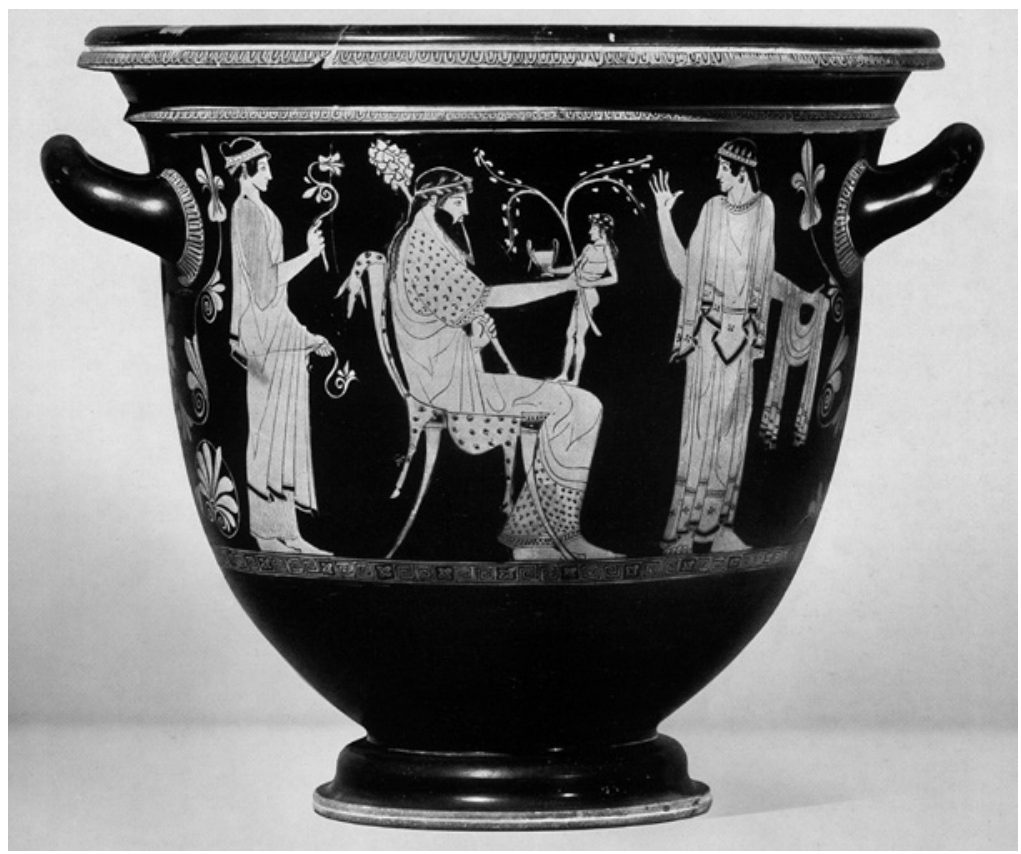

Figure 55 Bell krater, Altamura Painter, Ferrara, Museo Archeologico Nazionale di Spina 2738, side A (photograph Archäologisches Institut der Universität Zürich, Silvia Hertig).

evoking nature (Figure 55). The fawn skin on the chair has given rise to scholarly debate about whether the father figure is Zeus or Dionysos. ${ }^{65}$ The artistically more modest, but iconographically similar image on a more or less contemporaneous pelike by the Nausikaa Painter makes it clear that a father figure with a scepter should be identified as Zeus. ${ }^{66}$

The handing over of the infant Dionysos may also be seen on the main side of the volute krater by the Altamura Painter (Figure 56). ${ }^{67}$ There can be no discussion about the identity of the figure here: Zeus is holding his scepter and the child kantharos and ivy branch. As for the young women on both sides of the central group: the one on the left has a small wild cat on her shoulder, the one on the right a flower in each hand. Because of their obvious relationship with nature they must be nymphs. It is, however, not really clear whether Dionysos is about to be received by his father or by the nymphs: his position

\footnotetext{
65 Simon 1976, 132 f.; LIMC III, Dionysos 705.

66 Possibly in the art trade: BA 6306 (no image); Stark 2012, 67 f., 240, Cat. D rV 7; Carpenter 1997, 54 f. and note 20.

67 Ferrara 2737: Addenda 264 (589.3); BA 207139; Stark 2012, 74 f., 239 DrV 4.
} 


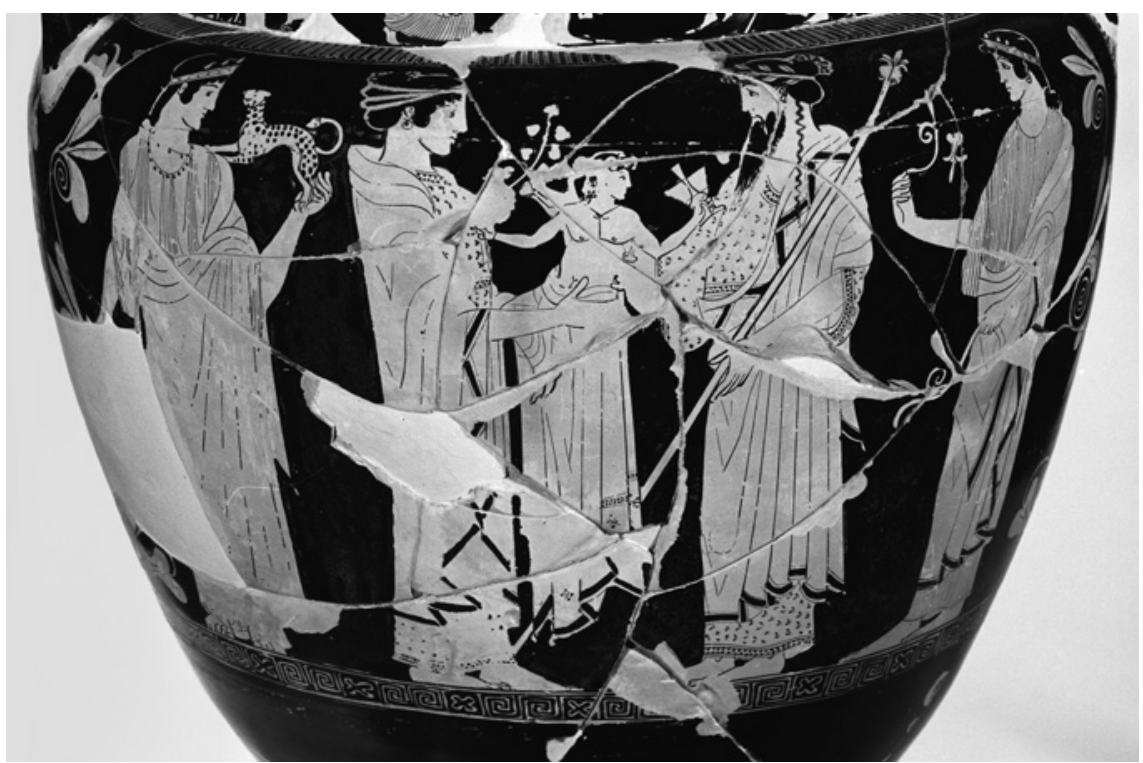

FIGURE 56 Volute krater, Altamura Painter, Ferrara, Museo Archeologico Nazionale di Spina 2737, side A (photograph Archäologisches Institut der Universität Zürich, Silvia Hertig).

between the two is ambivalent. Scenes from the lives of successful young men provide a counterbalance. The reverse side takes us to the palaestra: it shows two athletes, a trainer or referee, and an aulos player. On the main side the smaller neck image shows Nike crowning a kithara player; on the reverse we find erotic overtures between men and boys.

The images by the Altamura Painter, probably created around $45^{\circ} \mathrm{BC}$, are remarkable for their variety. However, in both cases the child Dionysos holds center stage and the women involved are nymphs who belong to unspoiled nature. Comparable discrepancies between images depicting the same event - which highlights the topicality of the theme - may be discerned in the work of the Villa Giulia Painter, who was active around the same time. He will be discussed in greater detail in the next chapter. Both his bell krater and his calyx krater have Hermes, with wide-brimmed hat and kerykeion, at the center of the image, seated on a rock (Figure 57). ${ }^{68}$ The child he is holding extends his little arms towards a Dionysiac woman standing before him. On the left

68 Bell krater London E 492: Addenda 270 (619.16); BA 207166; calyx krater Moscow, Pushkin Museum II 1 b 732: Addenda 270 (618.4); BA 207152; Zanker 1965, 78; Stark 2012, 79, 242 Cat $\operatorname{DrV} 12$. 


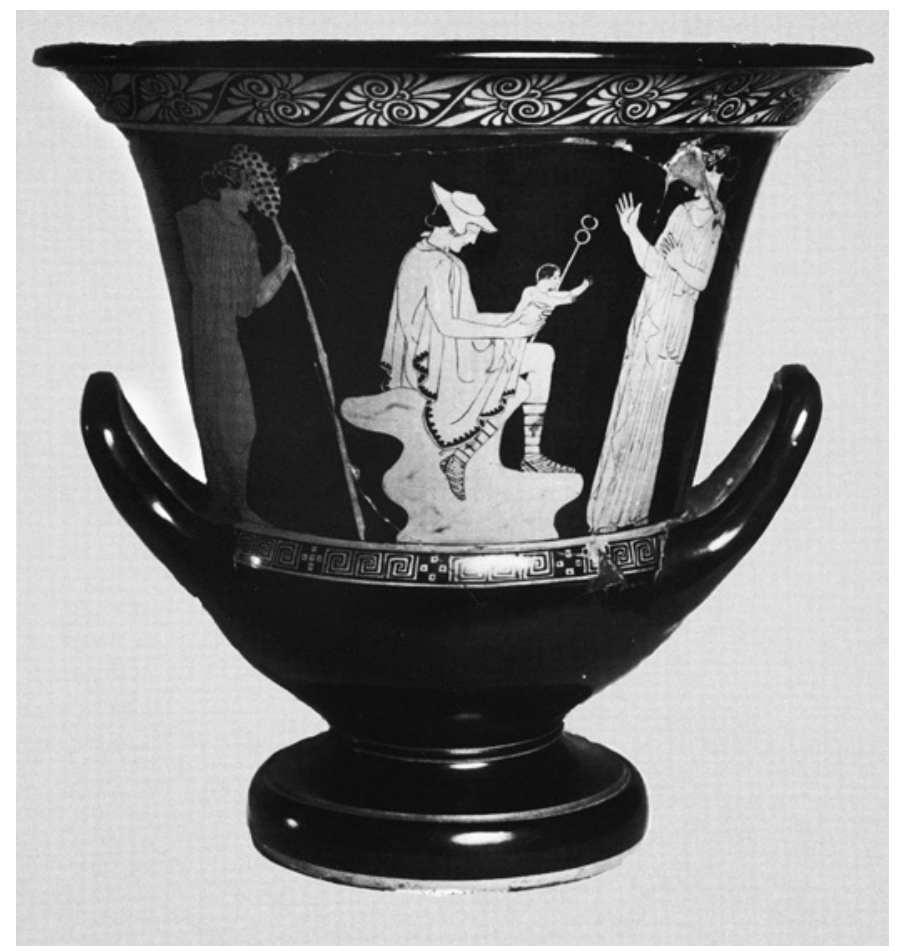

FIgURE 57 Calyx krater, Villa Giulia Painter, Moscow, Pushkin State Museum of Fine Arts II 16 732, side A (cVA Moscow 4, pl. 22.1).

another woman is watching intently. On the reverse of the bell krater we see figures from the palaestra; the reverse of the calyx krater shows an aged king between two women who hasten away in fear. ${ }^{69}$ On his hydria an elderly satyr carries the little boy towards a woman seated on a rock. She wears the nebris and holds a thyrsos. The child gently strokes the satyr's beard. On the left, a woman in a coif is holding an object that is hard to define; it may be a wreath. ${ }^{70}$

The unattributed pelike, which possibly dates from around $45^{\circ} \mathrm{BC}$, shows Hermes, who, coming from the right, walks towards the aged Silenus sitting on a rock in the center of the image. He carries the child, wrapped in a cloth. On the left a woman carrying kantharos and oinochoe is approaching in a

\footnotetext{
69 If the main image had been an amorous abduction, this image would have been more suitable.

$70 \quad$ New York X.313.1: Addenda 271 (623.69); BA 207223; Stark 2012, 83, 245 DrV 21.
} 
respectful manner. ${ }^{71}$ The pelike is iconographically very similar to another one that was probably considerably repainted. ${ }^{72}$

A pelike of about 440 BC decorated by the Chicago Painter, who belonged to the Villa Giulia Painter's circle, shows Hermes handing over the little lad to a young woman left of him (Figure 58). ${ }^{73}$ The direction of the gesture is clear from the way they and the child hold their arms. All figures have their names mentioned; the young woman is designated Ariagne, probably an allusion to Ariadne, most famous among Dionysiac women. ${ }^{74}$ The reverse has two anonymous young women engaged in conversation. On an, iconographically strongly related, pelike by the Barclay Painter the scene has been reduced to only two figures. ${ }^{75}$ Hermes approaches from the right with the child wrapped in a cloth. He walks towards a woman, whose lifted left hand expresses her willingness to receive the infant. There is nothing that characterizes this female figure. On the reverse two anonymous youths, wrapped in their cloaks, are engaged in conversation.

We will discuss the Phiale Painter in more detail in the next chapter. The best-known version of the scene on a white ground, however, belongs to his oeuvre (Figure 59) $\cdot{ }^{76}$ It shows the aged Silenus, wearing an ivy wreath and with a thyrsos in his left hand. He is sitting on a rock overgrown with ivy, his right hand ready to take the child, wrapped in a cloth, which Hermes carries towards him from the left. Behind Silenus a woman, leaning on him, looks on; on the left, behind Hermes, another woman does the same. She is sitting pensively on a rock with an ivy branch in her hand. The reverse side of the krater shows a seated female musician - possibly a Muse - between two standing women. The bell krater by the Clio Painter, probably likewise created around 430 BC, shows a woman handing over the child to a seated satyr, who presents his right hand. He has a thyrsos in his left. On the right and left two standing women, each holding a thyrsos, frame the scene. ${ }^{77}$ According to Beazley, a satyr and a maenad are represented on the reverse side. On a somewhat later calyx krater

71 Formerly Liverpool: Krumeich/Pechstein/Seidensticker 1999, 254 and note 18; Buschor 1904-1932, 305, fig. 146; Stark 2012, 245, Cat. D rV 19.

72 Rome, Villa Giulia 1296: Zanker 1965, pl. 6a; Stark 2012, 244, Cat. D rV 17. ARV does not confirm the attribution to the Villa Giulia Painter.

73 Palermo 1109: ARV 630.24; BA 207307; Zanker 1965, 78; Stark 2012, 78 f., 241, Cat. D rV 9.

74 According to Carpenter 1997,58 , the vase painter made a mistake here.

75 Rome, Villa Giulia 49002: Addenda 325 (1067.8); BA 214379; Stark 2012, 81, 242, Cat. D rV 10.

76 Vatican 16586 (559): Addenda 315 (1017.54); BA 214232; Oakley 1990, 19, no. 54, pl. 38; Stark 2012, 237 DWgr 1.

77 Naples, Stg 283: ARV 1080.3; BA 214510. See in addition the old drawing in Moraw 1998, fig. 48; Stark 2012, 245 f., Cat. D rV 22. 


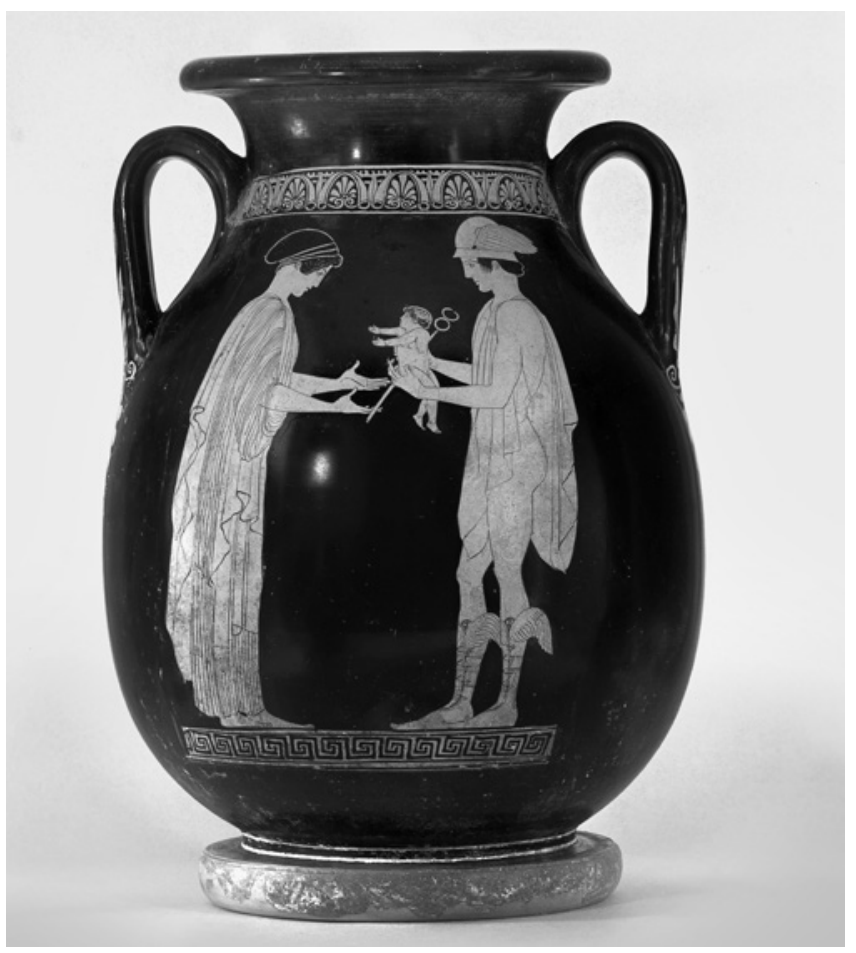

Figure 58 Pelike, Chicago Painter, Palermo, Museo Archeologico Regionale nog, side A (photograph H. Bloesch).

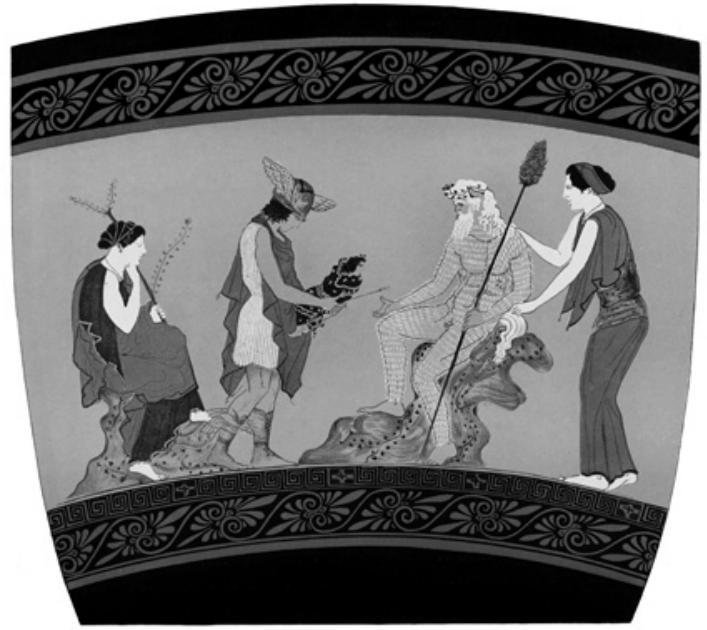

FIGURE 59 Calyx krater with a white ground, Phiale Painter, Rome, Museo Gregoriano Etrusco Vaticano 16586 (559), side A (FR pl. 169 below). 
in the manner of the Dinos Painter Hermes hands over the infant. ${ }^{78} \mathrm{He}$ dominates the center of the image as he moves rather boisterously towards the left with the swaddled child. Here a woman is waiting. She carries a long stick, possibly a thyrsos. On the right, a white-haired satyr looks on, leaning on one foot.

After 400 ВС the handing over of the infant Dionysos also occasionally occurs in Attic vase painting. ${ }^{79}$ We find it, for instance, on the lid of a lekanis, which may be dated around 360 вС. Here the person who brings the child is a satyr and, for the first time, the event is depicted as a turbulent, eroticallycharged dance scene.$^{80}$ The multi-colored garb of the aulos player, and the fact that one of the satyrs wears animal skin trunks can, however, be interpreted as a reference to the theater. Finally, the image on an important Eleusinian pelike may be attributed to the heyday of the Kerch style, the decade between 340 and $330 .{ }^{81}$ On one side it shows Demeter with other gods and heroes, among whom a youthful Dionysos who resembles the one on the east pediment of the Parthenon. On the reverse we see a female figure rising from the earth, who hands Hermes a Dionysiac child-possibly Dionysos-Zagreus, the son of Persephone. Other gods are looking on, with Athena dominating the scene. The image is of importance for the present discussion, not only because of the interpretation of the individual figures, but also because it demonstrates that the handing over of a Dionysiac child played a part in the Eleusinian Mysteries. ${ }^{82}$

What conclusions can we draw from the set of images that belongs to the $5^{\text {th }}$ century? The thyrsoi and ivy branches, and also the names given to the figures all refer to the child Dionysos. From literary sources we know that there were several versions of the myth; this is normal in a polytheistic thought system. ${ }^{83}$ The person handing over the child may therefore be Zeus, but also Hermes, and the place where the infant finds refuge from Hera's wrath may be a temple instead of Mount Nysa. The main question remains, however, why vase painters only took up the subject around 480 and applied it over the next fifty years.

78 Louvre G 478: Addenda 337 (1156.17); BA 215317; Stark 2012, 81 f., 85, 243, Cat. D rV 13. On the reverse, a young man playing the aulos (left) faces a dancing youth in a himation.

It remains uncertain whether the little naked boy handed over to Athena on the bell krater fragment from Paros, dated shortly after 400 BC, is indeed Dionysos. It is equally unclear if the wreath he is wearing is made from ivy leaves. See Avramidou 2009, 2.

$80 \quad$ St. Petersburg 2007: Stark 2012, 246, Cat. D rV 23; Walter 1959, 21, fig. 14.

81 St. Petersburg St. 1792: Addenda 381 (1471.1); BA 230431.

82 The interpretation of the figures on both sides of the vase remains open, because Clinton 1992, 172 does not support Simon's interpretation first published in 1966 (1998b, 182-19o, fig. 15, 3-4).

83 Compare Carpenter 1997, 55 f. 
In order to answer this question it is advisable to look at both the common and the distinguishing characteristics of this set of images.

From Makron until about 450 BC there is the marked importance of the regal father figure: Zeus. With Hermonax and the Villa Giulia Painter we enter a new phase and Hermes and Silenus make their appearance. As we have seen, vase paintings may show ritual manifestations of myths in which the role of the mythical original is taken over by a human agent. ${ }^{84}$ This insight allows us to construct a hypothetical relationship between the images featuring Zeus and Athenian reality. Like many Athenian children, Dionysos had been fathered out of wedlock. However, because it was his father who, miraculously, completed the pregnancy, he became the most legitimate of the sons of Zeus, and every Athenian father who acknowledged his son through a legitimization ritual could identify with Zeus. ${ }^{85}$ It is possible that the ambivalence of the representation on the bell krater by the Altamura Painter is intentional. ${ }^{86}$ Its aim may have been to point at a matter of vital importance to both divine and human fathers: the legitimacy of their children. In the years just before $45^{\circ}$ BC, when Perikles issued his famous law, the subject must have been discussed openly. ${ }^{87}$ The athlete who is greeted by the victory goddess on the reverse side of the vase perhaps evoked the successful future envisaged for the acknowledged son. ${ }^{88}$

After 450, the father figure and the emphasis on the legitimacy of the child disappear and the attention shifts to the moment of the handing over of the infant by the divine messenger and conductor of souls. Why this development takes place remains a problem for which not even Sophocles' satyr play Dionysiskos offers a solution. ${ }^{89}$ In any case, the important role Hermes now fulfills, refers to the existential significance the handing over has for the child. What can be the reason the Villa Giulia Painter chose to depict a seated Hermes? Did he mean to indicate that, before it was brought to the nymphs, the child was in the care of the conductor of souls?

\footnotetext{
84 Isler-Kerényi 2004a, 49.

85 See Isler-Kerényi 1993a, 9.

86 For the intentional ambivalence of vase paintings, see Sparkes 1996, 135.

87 Welwei 1999, 111; Will 2000, 568.

88 The reverse of the pelike by the Nausikaa Painter shows two youths wrapped in their mantles, see Beaumont 1993, 465, no. 4.

89 Carpenter 1997, 156; Moraw 1998, 153; Stark 2012, 88; Oakley 1990, 19; compare S. Scheurer/ R. Bielfeldt in: Krumeich/Pechstein/Seidensticker $1999, \quad 253^{-258}$ and especially 255 : "... die Vasenbilder und das Satyrspiel des Sophokles sind ein Reflex davon" (i.e. reflect

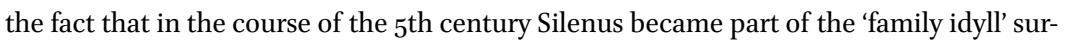
rounding the handing over of the infant).
} 
In the images with the father figure, as well as in those featuring Hermes, the action takes place in the presence of Dionysiac women. These represent the wilderness as opposed to the polis. The same holds true for the aged Silenus. This particular Dionysiac world is clearly distinguishable from that of the ecstatic, erotically-charged dance of the satyrs and their female partners. The role of the old satyr here seems comparable to that of the good and wise centaur Chiron in the life of Achilles. This suggests that, between 480 and $420 \mathrm{BC}$, a third type of Dionysiac women joined the dancer and the woman who, amidst the noisy members of the thiasos, quietly approaches the god: the nymph who takes care of children..$^{90}$ Nevertheless, the event not only concerns the world of women. To be sure, in three instances the image decorates a kalpis, a vessel with female connotations. Moreover, judging from the image on the reverse, the stamnos, the calyx krater, and one of the pelikai likewise mainly seem to address women. This cannot be said, however, about the two vases by the Altamura Painter, the Villa Giulia Painter's bell krater, and the pelike by the Barclay Painter. The theme of a little boy fated to be brought up, not by his own mother, but in the wilderness, apparently carries significance for the entire polis. The handing over of the child Dionysos to the nymphs of the wilderness or to the aged Silenus - tutor and father of the satyrs, known from the satyr play-indicates that the god himself, although a legitimate son of Zeus and guarantor of his order, went through a phase of taming and cultivation outside the civilized world. Would there have been real Athenian women who could take on the role of the nymphs and bring up these little untamed creatures for the polis?

Within this set of images, the frequent occurrence of the ivy (both the ivy branch and the ivy wreath) is also rather striking. This ties in with my earlier thoughts on the ivy in relation to archaic Dionysiac iconography. ${ }^{91}$ Depending on whether the branches are old or new, the leaves of the ivy are different: those of the previous year are dark green and have pointed tips-the new ones, however, are a clear green and heart-shaped, as they appear on the vases. ${ }^{92}$ This eminently suits the idea of Dionysos as the god of all metamorphoses and is especially appropriate for the Dionysiac child.

9o Compare Carpenter 1997, 69, who presumes all these women are mythical nymphs. About the women who interact with satyrs, Lindblom 2011, 158, on the other hand, states: “... it is on iconographical grounds impossible to identify the women as hetairai, maenads or nymphs."

91 Isler-Kerényi 2007, 141.

92 Kaeser 1990, 331, fig. 56. 9a-b. 
Every god has a history that starts with his or her birth, but Dionysos is the only one of the children of Zeus whose birth and childhood developed into a theme for the decoration of vases, specifically red-figure vase painting. ${ }^{93}$ There was no other god with whom young children could be identified. ${ }^{94} \mathrm{He}$ was present in every individual's life from its very beginning. Moreover, the images served as a reminder of the fact that, next to Zeus and his powerful brothers Poseidon and Hades, there was a younger generation of gods, of which Dionysos was a representative. As we will see, around 450 BC this may have inspired the new Dionysos concept visible in the Parthenon. ${ }^{95}$

\section{Dionysos in Love}

When a vase painting shows a meeting between Dionysos and a woman, scholarship usually designates her as Ariadne, even when she is no different from any other female approaching the god in a ritual context. ${ }^{96}$ So much is certain: within mythology as we know it, Ariadne was the only woman to become Dionsyos' regular spouse. In the decades between 480 and 440 вС the subject of gods in amorous pursuit was popular in red-figure vase painting. ${ }^{97}$ From these years, we have several representations of Dionysos approaching a woman - who can be no other than Ariadne - with obvious purposes. In contrast to other famous amorous pursuits, such as those of Zeus, Poseidon or Apollo, the mythological circumstances of this particular love story, as well as its fulfilment in marriage, were, from the very beginning, part of this impressive imagery.

At the beginning of the series stands a splendid kalpis by the Syleus Painter of around 475 BC, with a grand composition of carefully executed figures (Figure 6o).98 Two pairs of figures each take up one half of the image: the left half shows Athena, who, with an imperative gesture sends Theseus away

93 Stark 2012, 91. For similar literary developments, Henrichs 2008, 19.

94 For this reason Dionysos is also sometimes represented as a young boy, for instance LIMC III, Dionysos 692, 699 and Carpenter 1993. Compare the calyx krater in Caltanissetta S 46 (вA 28005) dated around 400 BC: Froning 1996, 107 f. fig. 1.

95 See below Chapter 7.

96 For this problem in black-figure vase painting see Isler-Kerényi 2007, 121-123; PaulZinserling 1994, 41-44; Diez del Corral Correidora 2007.

97 See the catalogue in Kaempf-Dimitriadou 1979, 76-109. This popularity culminated between 460 and $45^{\circ}$.

98 Berlin F 2179: Addenda 203 (252.52); BA 202898; Schlesier/Schwarzmaier 2008, 26 fig. 8, and 166 f., cat. 17 . 


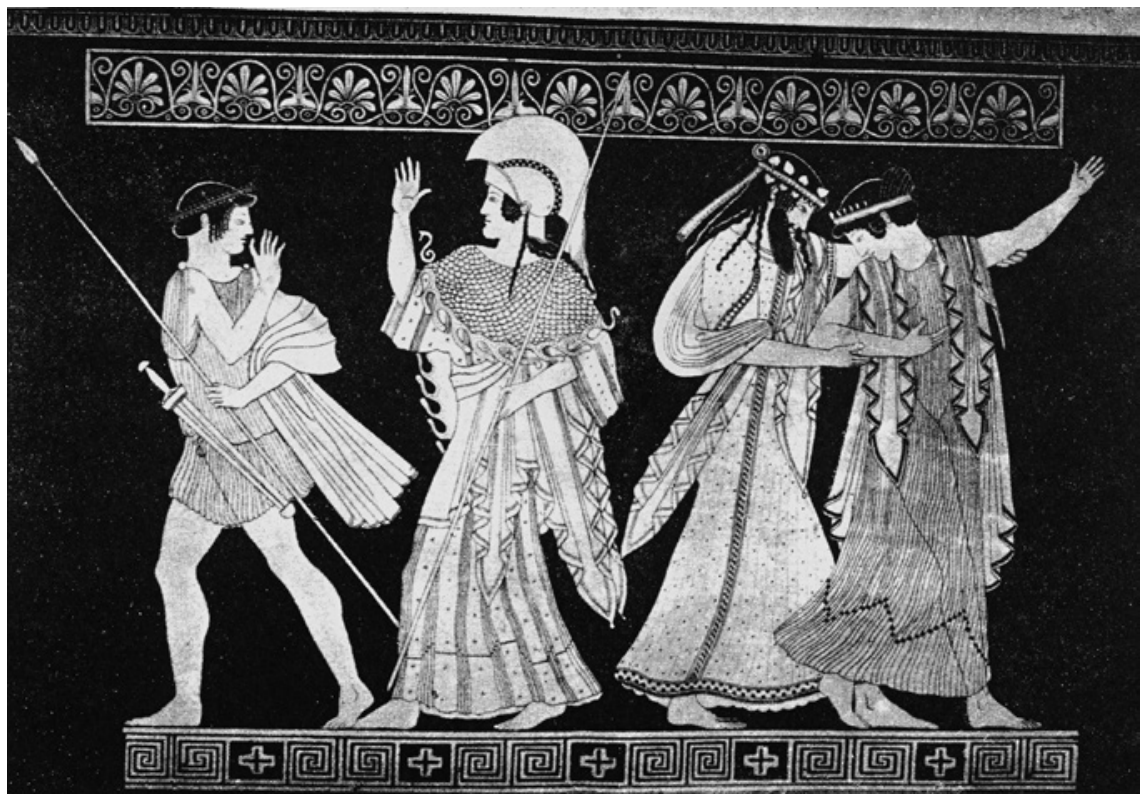

FIGURE 60 Kalpis, Syleus Painter, Berlin F 2179 (MAL 14, 1904, 55, fig. 18).

towards the left, on the right a bearded Dionysos with both hands grasps Ariadne, who is trying to flee towards the right. The composition of the image suggests that the subject here is the separation of Ariadne from Theseus, rather than her union with Dionysos. ${ }^{99}$ It is striking that explicit reference is made to the sexual prelude that preceded this scene: the painter shows the naked bodies of both Theseus and Ariadne underneath their sheer chitons. The forceful presence of Athena, who acts in solidarity with Dionysos, reminds us of the fact that the Syleus Painter also decorated one of the earliest pointed amphorae, a vase type that celebrates the fame of Athens with an image repertoire in which the city goddess and Dionysos are the most prominent figures. ${ }^{100}$

The images of two, more or less contemporaneous, amphorae with twisted handles by the Harrow Painter are very similar, though not completely identical (Figure 61). ${ }^{101}$ On the main side Dionysos' right hand lightly grasps Ariadne, who is fleeing towards the right; the whole of the reverse is taken up by the figure of a woman hurrying towards the left, possibly one of Ariadne's

\footnotetext{
99 Compare U. Kästner in Schlesier/Schwarzmaier 2008, 166 f.

100 See above Chapter 4.

101 Rome, Villa Giulia 50471: Addenda 206 (272.1); BA 202837, and Oxford (Ms) 1977.3.87A-B: ARV 272.2; BA 202838.
} 
companions. Such a figure does not occur in the myth; the painter may have borrowed her from other representations of amorous pursuits, such as those of Peleus, Zeus or Boreas, in order to highlight the dismay of the moment. Judging from the way the robes are depicted, the Mississippi version is the younger of the two. The difference in size between the overpowering god and the much smaller pursued girl is striking here; it suits the funerary function of the vessel.

Dionysos himself is absent from a cup from about 480 BC, which may be attributed to the Foundry Painter, a collaborator of the Brygos Painter.102 In the tondo a man with a spear, perhaps Agamemnon, leads a veiled woman,

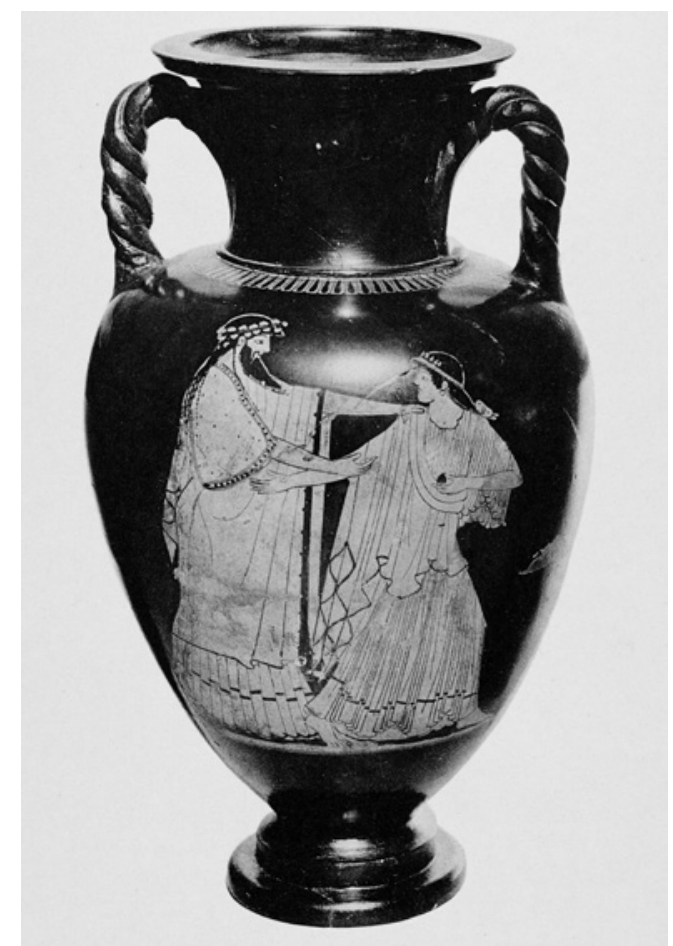

FIGURE 61 Amphora with twisted handles, Harrow Painter, Oxford (Ms), University of Mississippi Museum and Historic House, David M. Robinson Memorial Collection 1977.3.87 A-B, side A (cvA Robinson [USA 6], pl. 29.2a).

102 Tarquinia RC 5291: Addenda 231 (405.1); BA 204395. By analogy with the lekythos in Taranto (see next note) Shapiro 1993, 156 and Borg 2002, $157 \mathrm{f}$. interpret the small winged figure as Hypnos. The fact that Hypnos looks like Eros here means that love as well as sleep prevent Ariadne from noticing Theseus' departure. In any case, the message is more important than the name. 
possibly Briseis, by the hand towards the right. In one of the outside images a warrior pursues a woman towards the left, where we see an altar and an inner room with a seated woman. The naked right breast of the beleaguered woman allows us to assume that the scene represents Menelaos harassing Helena in Troy. The other side is dedicated to a third dramatic love story with an unexpected ending. Ariadne is soundly asleep on a rock, in the shadow of a vine heavy with grapes. From the right Eros is flying towards her with a string of beads. In the foreground Theseus stoops to fasten his sandals; Hermes, on the far left, urges him to make haste. The painter presumes that the viewer will imagine the subsequent scene: the arrival of Dionysos (Figure 62).

The same event is the subject of a large lekythos by the Pan Painter, which can likewise be dated between 480 and 470 вС (Figure 63). ${ }^{103}$ Ariadne lies on pillows, her face towards the viewer, little Hypnos squatting on her head. Beside her Theseus, woken by Athena, rises. At the foot of the bed lies a boy, possible the pais amphithales, who in Athens played a role in the official marriage ritual. ${ }^{104}$ Top left a small, delicate female figure flies away: she may be Partheneia, the personification of virginity, or Nyx. ${ }^{105}$ As in the case of the Syleus Painter, the fact that Athena intercedes in favor of Dionysos and against her protégé Theseus is crucial.

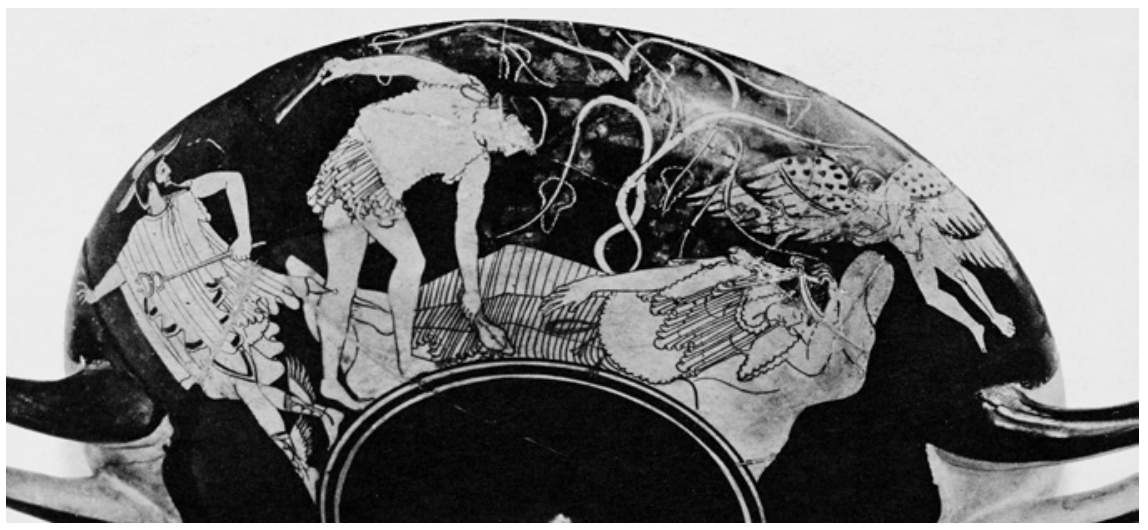

FIGURE 62 Cup, possibly Foundry Painter, Tarquinia, Museo Nazionale Tarquinense RC 5291, outside image side A (cva Tarquinia 2, pl. 18.3).

103 Taranto 4545: Addenda 259 (560.5); BA 206410.

104 Oakley/Sinos 1993, 37.

105 Shapiro 1993, $157 \mathrm{f}$. 


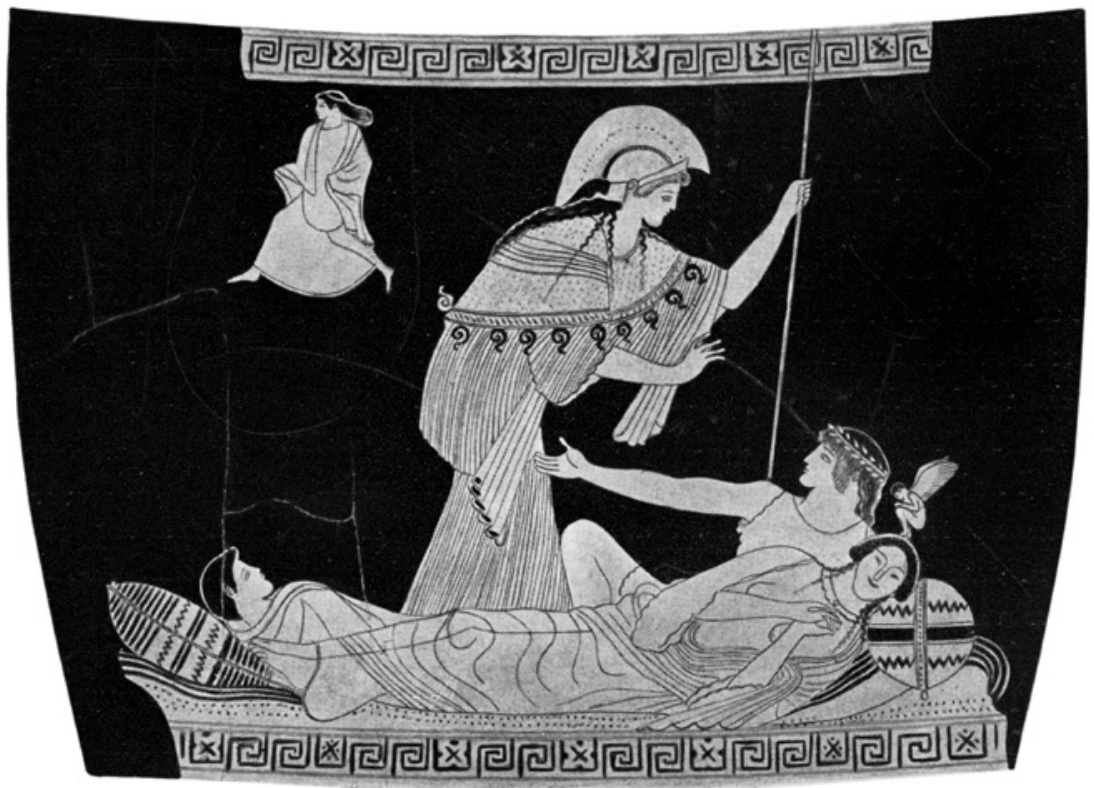

FIGURe 63 Lekythos, Pan Painter, Taranto, Museo Archeologico Nazionale 4545 (ÖJh 38, 1950, 5, fig. 3).

A neck amphora by the Alkimachos Painter, who was influenced by the Pan Painter, presents Dionysos as the pursuer of a young boy, instead of Ariadne. ${ }^{106}$ He strides towards the right, with the thyrsos in his right hand and the kantharos and an ivy branch in his left. Although he is bearded, he wears a short chiton, whereas the boy is dressed in a wide himation, his right shoulder bare. That the pursuit by Dionysos here apparently stands for a sudden and early death is supported by the provenance of the vessel: the necropolis of Nola.

A volute krater by the Altamura Painter is of a later date, between 460 and 450 BC. ${ }^{107}$ Here we see Dionysos, thyrsos and ivy branch in his left hand, calmly leading Ariadne towards the right, holding her hand like a bridegroom. She wears a veil and a diadem and has a flower in her right hand. ${ }^{108}$ On the reverse side a satyr is pursuing a woman wrapped in her himation. ${ }^{109}$

106 Naples 81483: Addenda 254 (529.13); вA 205985.

107 Vatican 17886: ARV 590.5; BA 207147 (no image); Simon 1963, pl. 6.1.

108 Compare Peleus and Thetis on the pointed amphora by Syriskos discussed in Chapter 4.

109 Prange 1989, 159 A 11, pl. 23. 
Somewhat later, the Niobid Painter, too, represented the same episode on a large oinochoe (Figure 64). ${ }^{110}$ Ariadne, a diadem in her hair, flees to the right. She looks back towards a bearded Dionyos, who wears a short chiton and an animal skin and carries thyrsos and kantharos in his left hand. She seems bewildered, but the presence of Eros, who comes flying from the left, and Aphrodite, who watches on the right, indicates the auspicious outcome of the event.

A fragmentary vase in the shape of a mule's head, attributed to a very productive minor cup painter from the Penthesilea workshop, shows a rather curious version of the story, almost a caricature. ${ }^{111}$ A humpbacked old man, wearing an ivy wreath, with both hands grasps a girl who is rushing towards the right. The two protagonists of a skyphos by the Lewis Painter behave rather more elegantly. ${ }^{12}$ Dionysos, in a long robe and with the thyrsos in his left hand, strides towards the right, while on the reverse Ariadne tries to escape. She wears a heavy diadem and a ritual gown over her chiton, and holds a shawl which flares out. A late mannerist painter, active around 450 and during the third quarter of the century, probably decorated the hydria on which Dionysos pursues Ariadne towards the right, holding his thyrsos. An anonymous woman, possibly Aphrodite, looks on. Eros is sitting on the far right, and on the left a seated satyr is playing the aulos. ${ }^{113}$ In front of Ariadne, at ground level, a pillow is hovering, possibly an allusion to the imminent celebration of the marriage (Figure 65). ${ }^{114}$
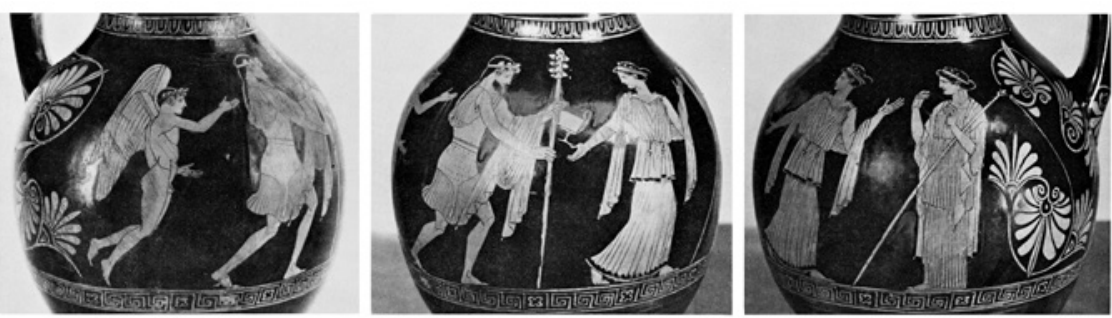

Figure 64 Oinochoe, Niobid Painter, Paris, Bibliothèque Nationale de France, Cabinet des Médailles 460 (Kaempf-Dimitriadou 1979, pl. 22.3-5).

110 Cab. Méd. 46o: Addenda 267 (6o6.83); BA 207024 (no image); Kaempf-Dimitriadou 1979, pl. 22. 3-5.

111 Adria B 482: ARV 917.197; BA 211134 (Painter of Bologna 417).

112 New York 56.171.59: Para 435 (973.13); BA 213247.

113 London E 184: Addenda 330 (1113.4); BA 214724.

114 A badly preserved hydria, which may be dated around $470-460$, in a private collection in Basel, also has a large pillow on the floor in the center of the image. The hydria, shows the abduction of Ariadne by Dionysos, with Athena sending Theseus away, see Tiverios 2011, 167, fig. 9 . 


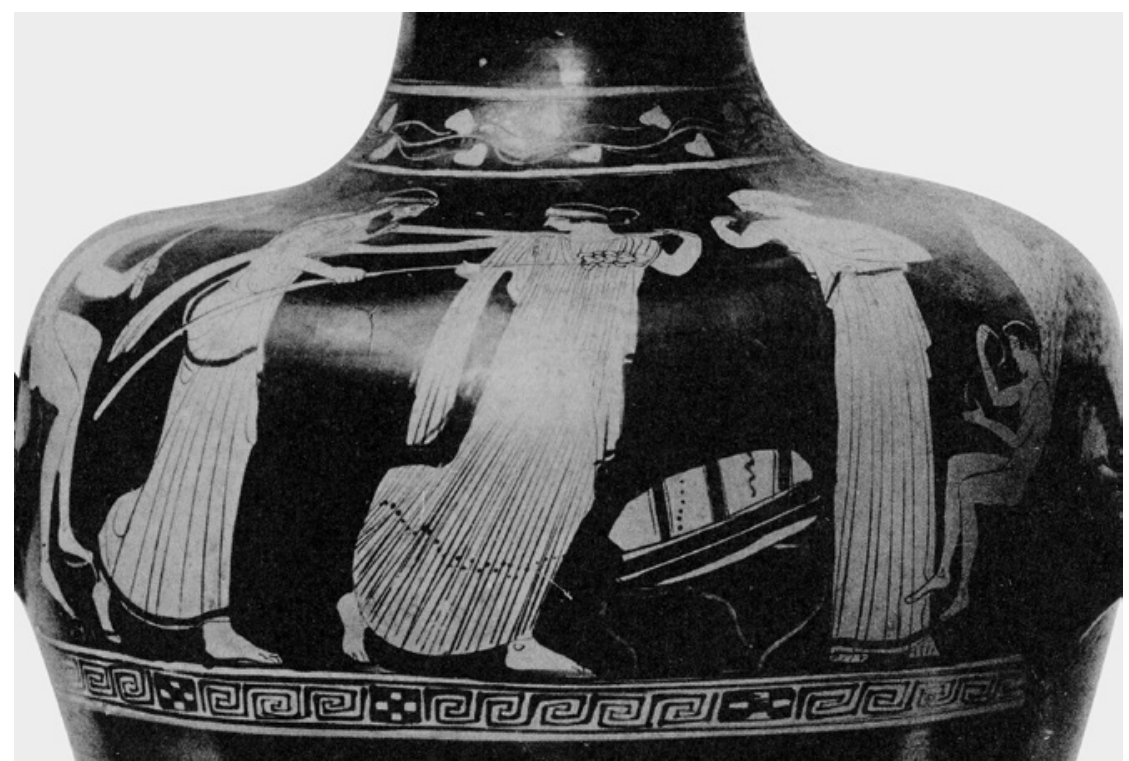

FIGURE 65 Kalpis, late mannerist, London, British Museum E 184 (cva British Museum 5, III Ic pl. 8o.3).

Two images from the circle of Polygnotos will be discussed below in the context of the satyr boy. ${ }^{115}$ Let me mention, however, that in both cases it is uncertain whether the bride is Ariadne, her ritual counterpart the Basilinna, or an anonymous Athenian woman. Both images highlight the imminent wedding. The same holds true for the youngest piece of our series, a calyx krater by the Kadmos Painter, which may be dated around 420 at the earliest, but in this case the image doubtlessly refers to the mythological event (Figure 66). ${ }^{116}$ In gist and composition it is similar to the kalpis by the Syleus Painter. In the presence of his father Poseidon, Athena urges Theseus to embark, while the left half of the image shows a bearded Dionysos with a thyrsos in his left hand, festively dressed and with flowing locks. He approaches a heavily veiled Ariadne, who, resigned to her fate, is already sitting on the bed. Eros comes flying with a wreath, whereas Theseus is crowned with a wreath by his patron goddess.

115 See below Chapter 6, notes 129 and 131.

116 Syracuse 17427: Addenda 341 (1184.4); BA 215692; Kaempf-Dimitriadou 1979, pl. 23.3-4. See also Chapter 8 , note 24. Tiverios 2011, 172 proposes a relationship between this image and the painting with the same motif which, according to Pausanias (I 20.3), could be seen in the temple of Dionysos Eleuthereus in Athens. There, however, Ariadne was depicted sleeping. 


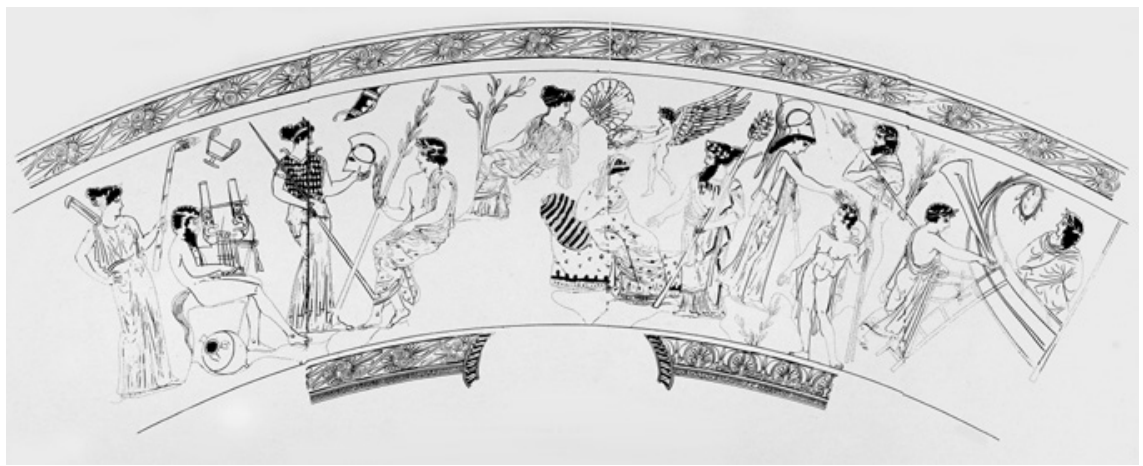

FIgU RE 66 Calyx krater, Kadmos Painter, Siracusa, Museo Archeologico Nazionale 17427, scroll showing both sides (MAL 14, 1904, pl. I).

When one looks at the whole of the series, it is evident that the vase painters counted Dionysos among the amorous pursuers, such as Zeus, Poseidon and other gods and heroes, whose affection could be a terrifying intervention in its object's life. In contrast to the other pursuers, however, in Dionysos' case the outcome of the pursuit - the union of the lovers in marriage-is always manifest. Two elements of the myth are particularly emphasized. Firstly, the fact that Ariadne, before her meeting with Dionysos, had given herself to Theseus-compare the two artistically superior examples from about $480 \mathrm{BC}$. And what is equally striking, and should also be elucidated, is the intervention of Athena in favor of Dionysos and to the detriment of her protégé. This version of the myth is largely in accordance with the one given by Pherekydes of Athens in the early 5th century, and the presence of Aphrodite on the Niobid Painter's oinochoe, dated shortly after $45^{\circ}$, and on the more or less contemporaneous mannerist hydria seems appropriate in this context. ${ }^{117}$

Nevertheless, even if we take Calame's careful analysis of mythological and cultic tradition into account, it remains enigmatic how the union between Ariadne and Dionysos could have become a model for the legitimate bond of matrimony — had the god's bride not belonged to another?118 Moreover, what is Athena's role in this paradox and what the concomitant interest for the polis? Let me make an attempt at explanation. It seems evident that Theseus' actions against the king of Crete in liberating the Athenian children should be seen as a mythological justification of the ambitions of the city within the Aegean region. The fact that the Cretan princess fell in love with him and

117 Calame 1990, 107.

118 Calame 1990, 108 and 250. Compare Isler-Kerényi 2007, 122. 
followed him on his homeward journey can only be appreciated as a sign of success. ${ }^{119}$ At Naxos, the Isle of Dionysos, however, Theseus was confronted with someone whose superior power was even recognized by the city goddess, which prompted her to intervene. In this way Dionysos was won over to the side of the city and integrated into the cult system of the polis. ${ }^{120}$ This also supports Dionysos' dominant place next to Athena as illustrated by the repertoire of the pointed amphorae and pelikai of the Painter of the Birth of Athena. ${ }^{121}$ Nonetheless, the history of his birth and that of his union with Ariadne show elements, which sit uneasily with the ideal solutions proposed by the laws and precepts of the polis. However, they show the many facets of the reality of life, legitimized by the language of mythology. This more befits Dionysos, than any other god.

119 Calame 1990, 198-203.

120 Calame 1990, $336 \mathrm{f}$.

121 See above Chapter 4. 


\title{
Unfamiliar and Unknown Dionysiac Rituals
}

\author{
Boys and Girls in the Realm of Dionysos
}

Amongst the cups of around 490 BC one by the Triptolemos Painter stands out. It refers explicitly to some Dionysiac ritual. ${ }^{1}$ In the unusual tondo image Dionysos is greeted with a libation, but not by a woman or a satyr, but by a boy: either Dionysos' son Oinopion or a boy who, in some ritual context, doubles as Oinopion (Figure 67). ${ }^{2}$ This motif is already attested in the 6th century in the work of Exekias and the Amasis Painter and may, even at this early stage, refer to a festival during which Athenian ephebes had a ritual encounter with Dionysos. ${ }^{3}$ The opinion, still current, that in vase imagery the mythical world and that of ordinary human life can be distinguished from each other, should

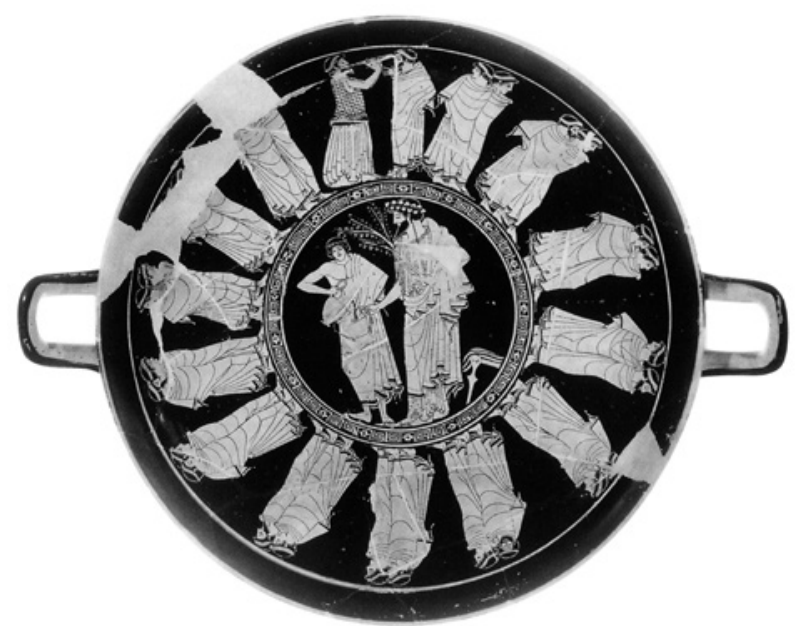

FIGURE 67 Cup, Triptolemos Painter, Paris, Louvre G 138, view of the inside (Knauer 1996, 222, pl. 1).

1 For the Triptolemos Painter, see above Chapter 3 , note 89.

2 Louvre G 138: Addenda 223 (365.61); вA 203853; Knauer 1996, 221-239. The image of another cup by the Triptolemos Painter has been said to refer to the Dionysiac festival known as the Oschophoria (Knauer 1996, 239-246). This interpretation, however, remains uncertain because of the extremely fragmentary condition of the cup.

3 Isler-Kerényi 2007, 140-142, figs 74 and 75. 
really be considered obsolete. On the Triptolemos Painter's cup, thirty-four men and boys solemnly move in pairs towards the right around the medallion and in one of the outside images. They are wrapped in their himatia and led by an aulos player. ${ }^{4}$ Nineteen boys have their name indicated; some of them are known from kalós inscriptions on other vases of the same period. The other outside image shows a bearded man and four youths, who seem to be looking at the procession. It is obvious that here-if ever there was an example in vase painting - we have the depiction of a particular procession. Elfriede Knauer has convincingly argued that this procession took place on the third day of the Dionsysiac festival of the Apatouria. On this day, called Koureotis, the sixteenyear olds came out, accompanied by their fathers, to celebrate that they had reached the status of ephebe, after the ritual cutting of their long hair. ${ }^{5}$

A cup that can be dated around the middle of the century from the circle of the Penthesilea Painter deserves to be discussed in some detail, even though it is artistically much more modest (Figure 68). ${ }^{6}$ The interior shows an anonymous woman performing a libation in front of a seated Dionysos who holds a kantharos in his right hand. On one of the outside images we see a line of eight girls and women, who stride solemnly towards the right holding hands. Is this a procession, a quiet dance, or both? ${ }^{7}$ On the other side two scenes are juxtaposed. The right hand scene shows a girl, characterized as such by her uncovered long hair, with a torch in each hand in front of an altar. ${ }^{8}$ To her left an older woman holds a skyphos over the altar, possibly for a libation. Next there are two women interacting by way of a gesture that is, so far, unclear. The left hand scene also has four figures. On the right stands a young man, dressed in a himation, who seems to be holding an aulos in each of his lifted hands. In front of him, also looking towards the left, stands a little girl, wrapped in a himation. She watches a young man, who plays the aulos in a most lively manner. He is naked apart from a narrow chlamys over his left shoulder. The last figure in this scene is a bearded komast, seen en face, who swings his gnarled stick and chlamys as he dances along.

4 Pairs of men (in this case in a pedagogic-erotic sphere) also occur in the tondo image of a cup by Douris, Louvre G 121: Addenda 238 (434.78); BA 205123; Buitron-Oliver 1995, 26 and 8o, no. 125 , pls. $76-77$.

Knauer 1996, $233 \mathrm{f}$.

6 Florence 3950: ARV 914.142; BA 211080; Paleothodoros 2010, 247-249, fig. 17.8.

7 Compare the dance of young girls on the eponymous calyx krater by the Villa Giulia Painter, Rome, Villa Giulia 909: Addenda 270 (618.1); BA 207149. In this case, however, only the aulos could be an indication that this is a Dionysiac ritual.

8 It is, therefore, improbable that this is one of the gerairai at the Anthesteria as Paleothodoros 2010, 248 supposes. 


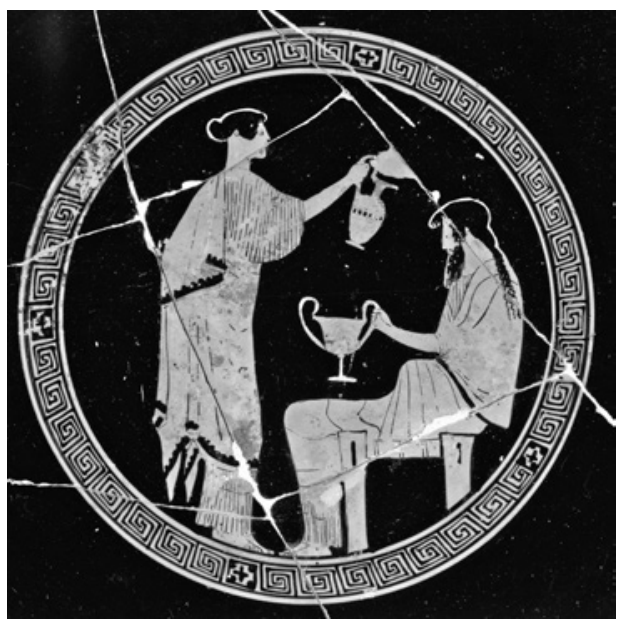

$a$

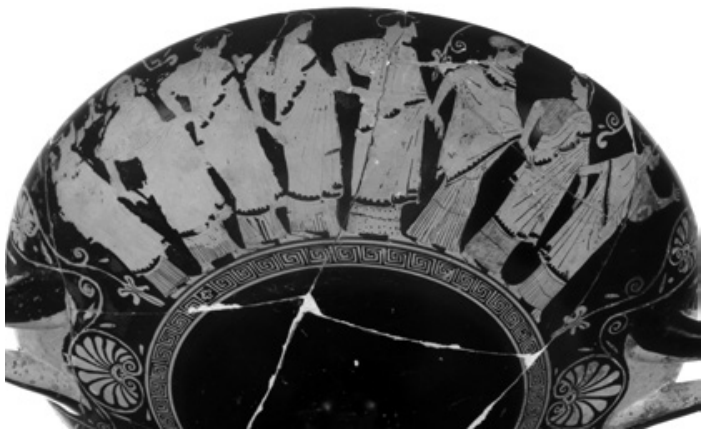

$b$

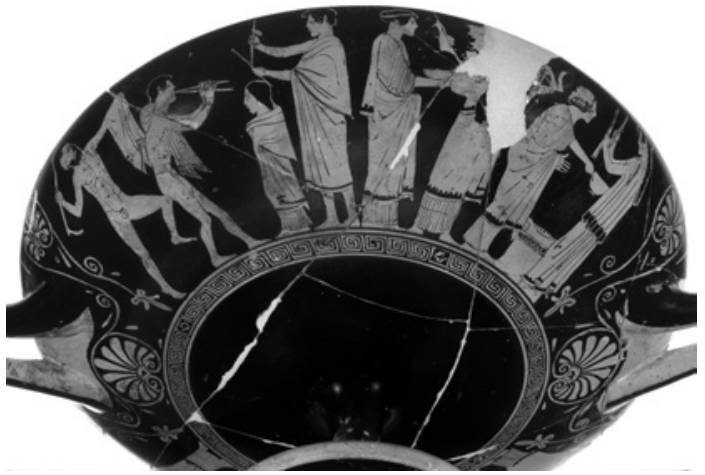

$c$

FIGURE 68 Cup, Florence 3950 (photographs Museo Archeologico Etrusco).

a. tondo image.

b. outside image A: dancing women.

c. outside image B: music lesson and sacrificial scene. 
How should all this be interpreted? Surely these scenes must show some ritual occasion of a Dionysiac nature and in the female sphere, as the interior image of the cup indicates - a ritual in which women of various ages participate. It is rather surprising to find this little girl among the komasts. Is she training for a career as a symposium musician? ${ }^{9}$ The only parallel piece, though of far better workmanship, is the cup by the Triptolemos Painter discussed above, with Dionysos and perhaps Oinopion on the inside, and the processions of men and boys. One could imagine that the cup with the little girl presents the female counterpart of the ritual depicted by the Triptolemos Painter.

\section{A Domestic Dionysiac Ritual}

In the decades after $470 \mathrm{BC}$ a rather striking Dionysiac motif became popular at the Kerameikos. It shows a ritual performed by women around a remarkable idol of the god. The motif is already used between 490 and 480 on a series of late black figure lekythoi and on the Berlin cup by Makron discussed earlier (Figure 69). ${ }^{10}$ From about 470 the motif is found exclusively on the vase type we now call stamnos. Let us, before investigating the imagery, have a closer look at the carrier.11

The vases we designate as stamnoi belong to the new shapes introduced by potters at the Kerameikos around 530 BC. As was the case with several other shapes, this novelty was intended for the Etruscan market and inspired by Etruscan examples. In Etruscan territory, its antecedents were used as burial urns as early as the 7 th century. ${ }^{12}$ Stamnoi were made in Athens for only slightly more than a century. Their disappearance from the repertoire coincides-but not coincidentally - with a decrease in demand on the Etruscan export market. These were always exclusive and probably expensive items. This is not only clear from their sophisticated and variegated forms, but also from the fact that their decoration shows greater refinement compared to that of the more common vase types, such as column kraters and small neck-amphorae. ${ }^{13}$ Apart from the ubiquitous anonymous women, men and youths, stamnoi frequently

Compare, for instance, the fine interior image of a cup in Paris, Louvre G 135: Addenda 221 (355.45); BA 203728 (Colmar Painter) and the komos accompanied by a young female flute player on the column krater Cefalù 1 (Painter of the Florence Centauromachy): Tullio 1996, 142 f., fig. $1-2$.

10 Berlin F 229o: Addenda 244 (462.48); BA 204730. See above Chapter 3, note 114.

11 What follows is discussed in greater detail in Isler-Kerényi 2009b.

12 Isler-Kerényi 1976, 41-45; Sisto 2006, 154.

13 Philippaki 1967 passim, especially $150-152$. 


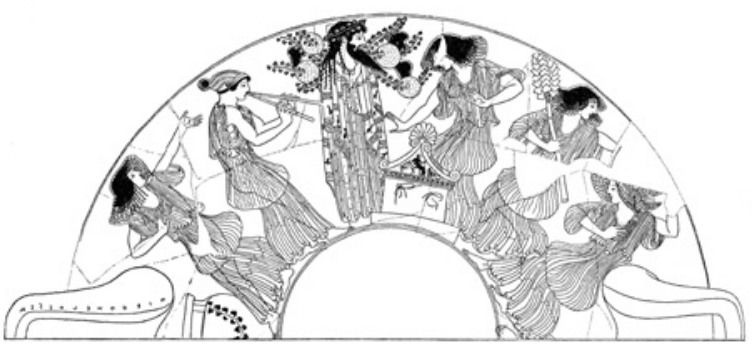

$a$

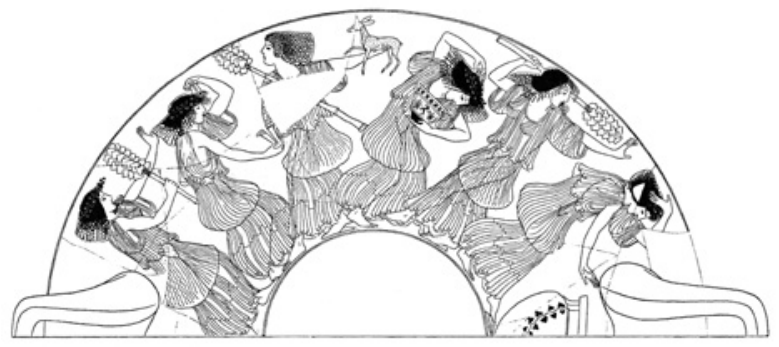

$b$

FIGURE 69 Cup, Makron, Berlin F 2290 (Frickenhaus 1912, 6 and 7).

a. outside image A: Dionysos idol.

b. outside image B: dancing women.

show figures from the Dionysiac realm: Dionysos himself, women dancing and performing rituals, satyrs. These figures (and depictions of komos and symposium) are even more numerous than mythological characters, which are also frequently depicted. Relatively common is the motif of the amorous pursuit or abduction by a god, which, as is well known, served as a metaphor for a sudden death. I should add, though, that the pursuit of a woman by a male figure (Thetis by Peleus, Oreithyia by Boreas, Helena by Theseus, Aithra or Amymone by Poseidon, Aegina by Zeus) is much more frequent than its opposite (for instance Kephalos or Tithonos by Eos). Also quite common is that other metaphor of death: the arming and farewell of a warrior. It befits the exclusivity of the stamnos shape that, more than other shapes, it carries unique designs: Herakles wrestling with Acheloos (by Oltos); Orestes killing Aigisthos (by the Berlin Painter); Danae and her little son Perseus (by the Eucharides Painter); the assassination of the tyrants (by Syriskos), and so on. ${ }^{14}$

14 London E 437: Addenda 163 (54.5); BA 200437; Boston 91.227a and 91.226b: Addenda 195 (208.151); BA 201970; St. Petersburg 1549 (B 642): Addenda 199 (228.30); BA 202231; Würzburg 515: Addenda 204 (256.5); BA 202924. 
What purpose did the stamnos serve? With its small horizontal handles it asks for circumspection when lifting it—as is, incidentally, confirmed by some images..$^{15}$ For this reason, and because of its comparatively narrow opening, the stamnos seems less useful for mixing wine at the symposium than the krater, even though it may occasionally have been used for just this purpose. The narrow neck was originally closed by a lid: this has been preserved with some of the surviving stamnoi. ${ }^{16}$ The provenance of most stamnoi is unfortunately unknown and thus we have but little clues as to their use. There are, however, some indications. A grave in Eleusis contained one of the very few stamnoi with an indisputable Greek provenance. ${ }^{17}$ That an Attic stamnos could be used as an urn is proven by an example (preserved with its lid) from a grave in Capua, legitimately excavated, and still containing the cremation. ${ }^{18}$

The other usage is ritual. This is not only clear from the stamnos from Eleusis just mentioned, which featured an Eleusinian procession; it can also be concluded from the special motif that is our main interest here. The motif occurs on 29 stamnoi and fragments of stamnoi, eight of them with only minor variations on a single design. In the center of the symmetrical composition we see a construction that obviously represents the god Dionysos: it consists of a pillar on which are fastened a mask, several branches, two round objects at shoulder height, and a garment that almost reaches to the ground. The interpretation of the round objects has been discussed at length: cakes and libation dishes have, for instance, been proposed. ${ }^{19}$ Cultic bronze cymbals are, however, more likely — these have been excavated at several sanctuaries across the Greek world. ${ }^{20}$ The identification as cymbals is also supported by the fact that they are fastened at shoulder height. ${ }^{21}$ In front of the idol there is a low table, like the table in symposium scenes, on which are placed two stamnoi. To either side a woman is, quietly and intently, ladling wine from the stamnoi with ladles and drinking vessels. The reverse sides of these stamnoi are also quite uniform:

\footnotetext{
15 See for instance Frontisi-Ducroux 1991, 98, fig. 38, and 157, fig. 94.

16 Isler-Kerényi $2009 \mathrm{~b}, 76$, note 10.

17 Eleusis 636: Addenda 321 (1052.23); вA 213653 (no image).

18 Johannowsky 1983, 201 f., pls. 39-40; Hamilton 1992, 136 with note 50. This probably also holds true for an example from Gela: Isler-Kerényi 2009b, 76, note 7. See in addition De Cesare 2007, 12.

19 Frontisi-Ducroux 1991, 72; Halm-Tisserant 1991, $81 \mathrm{f}$.

20 Bellia 2012, 3-14, especially 6 , fig. 7.

21 Personal communication from Angela Bellia, August 7th 2012: "L'uso di appendere al collo doveva essere funzionale nel corso dei riti e delle processioni: non si correva il rischio di perderli ed erano sempre 'pronti' per essere suonati."
} 

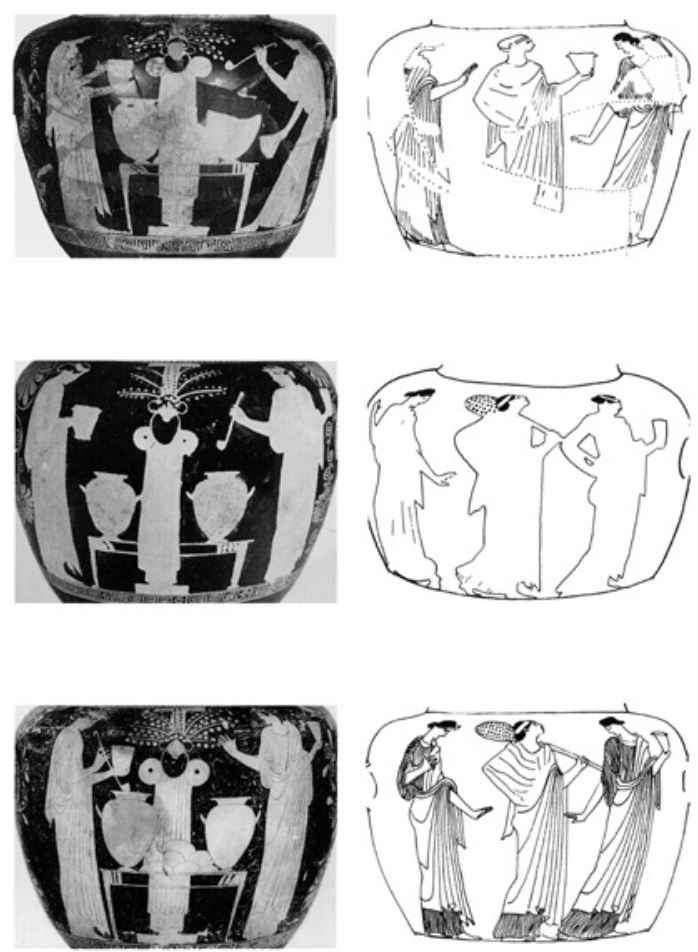

FIGURE 70 Stamnoi, Villa Giulia Painter (Frontisi-Ducroux 1991, 73).

they show three of four women who, in a measured dance, move towards the right, carrying thyrsoi, drinking vessels and sometimes an aulos or a parasol.

Because of their uniformity these images have aroused great interest among students of ancient religion ever since their first publication in 1912 (Figure 70). ${ }^{22}$ This turned into a long-running debate on the question which of the known Dionysiac festivals these images referred to. Since the fundamental re-appraisal of the evidence by Frontisi-Ducroux, however, the problem has been solved. ${ }^{23}$ These images should not be seen as depicting a certain moment in an actual ritual, but rather as an evocation. They do not refer to one of the official festivals of Athens, but, as we will see, to domestic rituals in honor of the god, for which we have independent evidence. ${ }^{24}$ Beazley has shown that of the 29 stamnoi with this motif, thirteen have been decorated by the Villa

\footnotetext{
22 Frickenhaus 1912.

23 Frontisi-Ducroux 1991, 41-63.

24 Compare Paul-Zinserling 1994, 19 f.; Schlesier 1997, 656 (with some question marks). Compare also Seaford 2006, 46 and 71, although it remains an open question where the
} 
Giulia Painter, including the eight nearly identical ones. ${ }^{25}$ This painter must have been the inventor of this symmetrical design that was aesthetically pleasing and became popular.

As stated above, however, the motif itself was already present in the repertoire of Athenian vase painters for over a generation. It was also adopted by other painters, more or less related to the Villa Giulia Painter, and they came up with their own versions: the little table may be absent, one of the women may be seated, a sacrificial basket may be added to the composition (Figure 71). ${ }^{26}$ These variations show that the execution of the ritual was not bound to rigid rules, as one might expect of a ritual in a private, domestic setting. In every instance, however, the ceremony is performed by women around a temporary idol of Dionysos (although men were definitely not completely excluded). ${ }^{27}$ The mask, or rather the portrait of the god in frontal view, evokes, together with the empty garment, the absent god-his gaze, however, is all the more effective as it is not directed towards the women in the image, but towards the female viewer who identifies with them. ${ }^{28}$ Obviously, one of the ritual acts was the ladling of small amounts of some liquid from the stamnoi. The kantharos, that is often present in addition to the skyphos, the drinking vessel usually associated with women, implies that the liquid is unmixed wine. ${ }^{29}$ With the wine the women ingest the god: their, literally, enthusiast state is reflected in the Bacchic dance on the reverse side of the vase. ${ }^{30}$

Individual ritual acts always refer to the deeper meaning of the ritual itself. In order to identify that meaning we should depart from what we can conclude from provenance and function. On the one hand, stamnoi could contain the pure wine that was equated with Dionysos. On the other, they could function as urns to receive the ashes of the dead. What could be the common denominator of pure wine and ashes? Both are the result of a metamorphosis, a Dionysiac event: the grapes change into wine, the dead into ashes. This leads almost automatically to the understanding that, just as the crushed, 'killed', grape turns into wine, a new and wonderfully effective substance, the enthusiast human will after death enter a new, as yet unimagined, existence.

\footnotetext{
"secret cult" (as opposed to the official and public one) took place; Schöne-Denkinger 2008, 51; Schwarzmaier 2008, 86-89. 

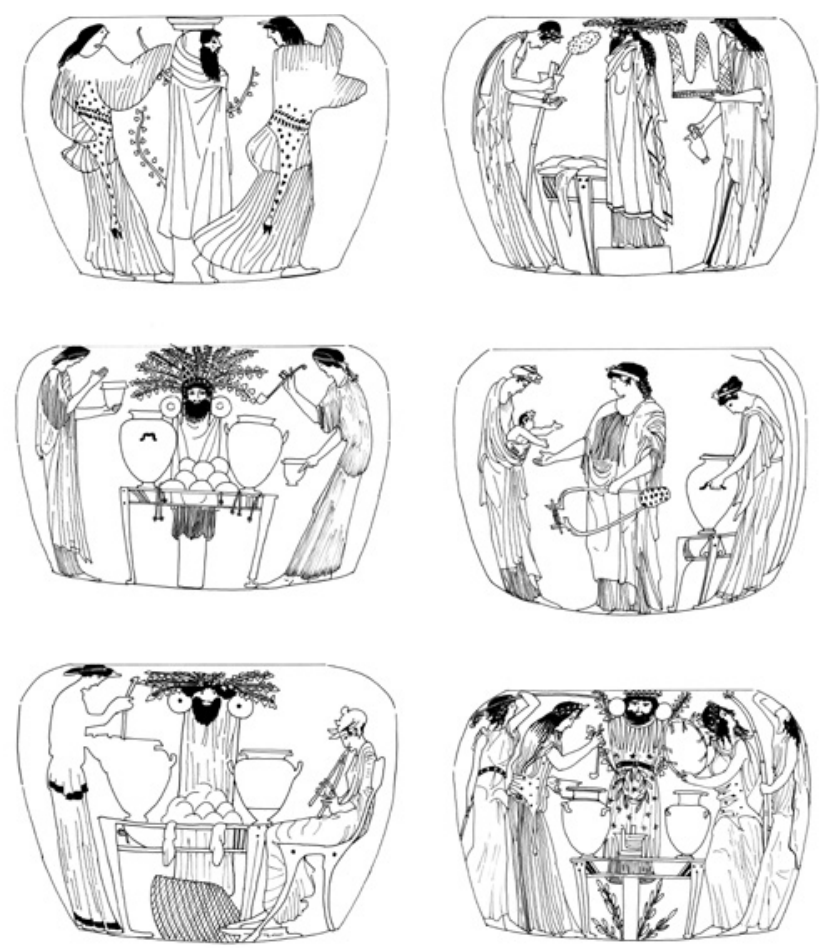

FIGURE 71 Stamnoi, various painters (Isler-Kerényi 20ogb, 88f., figs 1-6).

Our perusal of the Dionysiac repertoire on vases of the second quarter of the century has shown a ritualizing of the imagery, which points to a growing sacralization of the public mood around $45^{\circ}$ вС. It is within that context that we should situate the stamnoi evocating Bacchic ongoings in the private sphere. It is certain that such ongoings took place in Athens. ${ }^{31}$ Nevertheless, considering the provenance of the Athenian stamnoi, especially the group discussed above, we should ask ourselves for what kind of buyers these images were intended. It can be calculated that of every twenty stamnoi produced at the Kerameikos, at most just a single one remained in Greece: the others were exported to Italy. ${ }^{32}$ All vases decorated with the ritual around the Dionysos idol of which the provenance is known, have either been found in Etruria, especially Vulci, or in the north of Campania, culturally much influenced by Etruria. That the stamnoi by the Villa Giulia Painter and his colleagues were so

\footnotetext{
$31 \quad$ See above note 27.

32 Isler-Kerényi 1994, 48.
} 
much in demand in Etruria cannot only be explained from the huge popularity of Dionysos since archaic times and the adoption of the symposium. Ancient cultural boundaries were much more permeable than we can imagine in our own times, so much characterized by national feeling. ${ }^{33}$ And there are more direct indications: we have several Etruscan graffiti on vases imported from Athens around 470 BC that point to the existence, also in Vulci, of a cult of Fufluns Pachies, i.e. Dionysos Bakchos. ${ }^{34}$ Thus, our stamnoi may have been used outside Athens in a way that matches their decoration. ${ }^{35}$

A series of stamnoi decorated by younger associates of the Villa Giulia Painter cannot be seen apart from the stamnoi with the Dionyos idol. These show a female thiasos, without any characteristic accoutrements, but in an obviously ritual setting. ${ }^{36}$ Particularly remarkable are the stamnoi by the Phiale Painter, who was active between $45^{\circ}$ and $425 \mathrm{BC}$. He was a pupil of the Achilles Painter and one of the leading artists of his time. ${ }^{37}$ Like his teacher, he mostly decorated small red-figure neck-amphorae and lekythoi, and a series of whiteground vases. In his work, too, Dionysiac imagery is not pre-eminent, but it has some interesting individual representations. His white-ground krater with the handing over of the infant Dionysos has already been discussed. ${ }^{38}$ Dionysos rarely appears on the small neck-amphorae. More common are various scenes with satyrs and maenads who look strikingly human. ${ }^{39}$ Komasts probably only appear on some of his rare cups. ${ }^{40}$ We repeatedly encounter satyrs wearing himatia, as we did in the oeuvre of the Geras Painter-satyrs presented as citizens. ${ }^{41}$ They walk together, stand opposite two Dionysiac women, or are

33 Isler-Kerényi 1999a.

34 Isler-Kerényi 2003, 45 with notes 35 and 36.

35 Similarly La Genière 2013, $33 \mathrm{f}$.

36 ARV 628 f. 7-12 (Chicago Painter); Addenda 272 (633.8); BA 207343 and ARV 633.9; BA 207344 (no image, Methyse Painter). Frontisi-Ducroux 1991, 100, note 72; Osborne 1997, 206. Compare in addition a stamnos by Syriskos, datable between 480 and $470 \mathrm{BC}$, in a private collection in Germany: Wehgartner 1997, 116-119 (the reference to the Lenaia is no longer tenable).

37 Oakley 1990, 6.

38 Vatican 16586 (559): see above Chapter 5 , note 76.

39 Oakley $1990,36$.

40 Leipzig T 3376: ARV 1023.149; BA 214332; Adria B 604: ARV 1024.152; BA 214335; Adria B 626: ARV 1024. 153; BA 214336.

See above Chapter 3 , note 60 . 


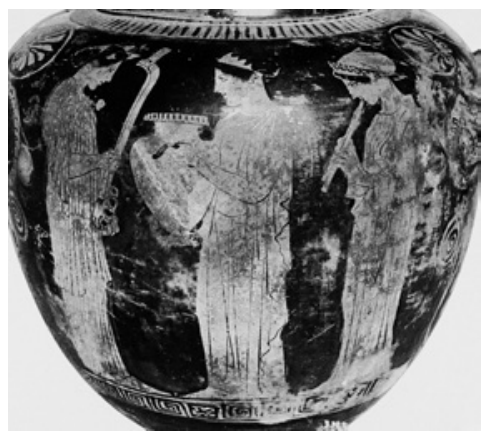

$a$

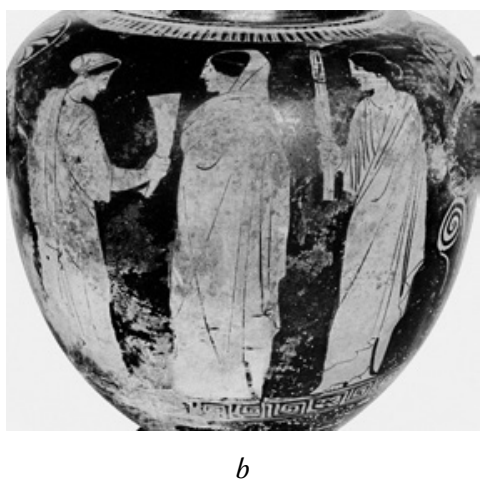

FIgure 72 Stamnos, Phiale Painter, Museo Nazionale Archeologico, Naples 164332, (Oakley 199o, pl. 64). Su concessione del Ministero dei Beni e delle Attività Culturali e del Turismo-Soprintendenza per i Beni Archeologici di Napoli.

a. side $A$.

b. side $B$.

engaged in conversation with one of these. ${ }^{42}$ Are these satyrs dressed up as citizens, or citizens identifying with satyrs? ${ }^{43}$

On the first stamnos, to be dated at the beginning of his career, around $45^{0-}$ $445 \mathrm{BC}$, each side is decorated with women engaged in ritual acts (Figure 72) ${ }^{44}$ In the center of the main side a woman wearing a diadem appears to carry

42 Naples Stg 240: ARV 1015.22; BA 214199 (Nolan amphora); London E 384: ARV 1017.48; BA 214226 (pelike); Louvre G 422: Addenda 315 (1019.77); BA 214255 (bell krater).

43 See above Introduction note 13 and 15. In addition Paul-Zinserling 1994, $46 \mathrm{f}$. As for the so-called "satyre bourgeois": Lissarrague 2013, 204-206.

44 Naples 164332: ARV 1019.83; BA 214263 (no image); Oakley 1990, no. 83, pl. 64. The stringed instrument is a barbitos. 

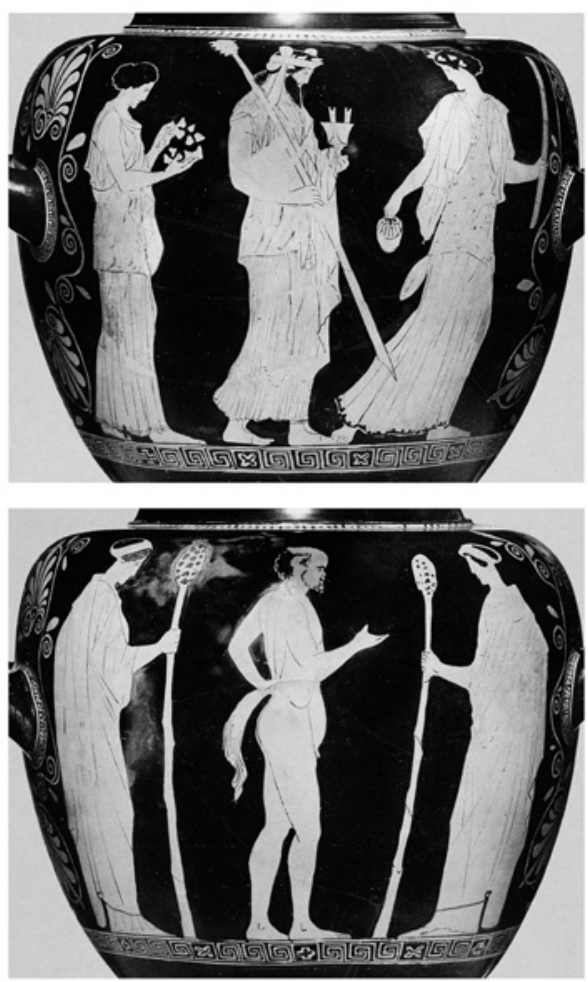

FIgURE 73 Stamnos, Phiale Painter, art trade, sides A and B (Oakley 1990, pl. 67).

a large stamnos to a woman holding a barbitos on the left, assisted by the music of a female aulos player on her right. On the reverse, a woman completely wrapped in a himation stands between a female torch bearer (right) and a woman presenting a drinking horn (left). The presence of the stamnos makes it probable that this, too, is a representation of the ritual at the temporary Dionysos idol. The imagery decorating a stamnos of about the same period is comparable. ${ }^{45}$ The stamnos is absent, but the attributes of the three women on either side include three thyrsoi, a kantharos and a drinking horn, a barbitos, and two torches. A procession with Dionysos himself between two women is depicted on the third of these stamnoi (Figure 73). ${ }^{46}$ The god is bearded, wears soft shoes with his chiton, and has thyrsos and kantharos in his hands. The woman who walks on his right appears to be showing the way with her torch. In her left hand she has an oinochoe to welcome the god and over her

45 Palermo 2183: ARV 1019.84; BA 214264; Oakley 1990, 36 and 80, no. 84, pls. 65 A-B and 66.

46 Art trade: BA 31374 (no image); Oakley 1990, 36 and 8o, no. 8bis, pl. 67. 
chiton she wears an animal skin. The woman to the left of the god holds an ivy wreath and also has an animal skin over her garment. On the reverse a satyr is seen conversing with two women carrying thyrsoi. Such images are in essence no different from the Dionysos imagery on other vase types, where we also encounter Dionysos himself in the thiasos in the company of a young satyr, as on the bell kraters by the Methyse Painter and Christie Painter to be discussed below. ${ }^{47}$

Amongst the stamnoi decorated with the ritual around the idol, the one by the Phiale Painter is particularly original and informative (Figure 74$).^{48}$ It can be seen as a link between the stamnoi with women engaged in ritual, the images of child satyrs to be discussed in a moment, and the representations of the handing over of the child Dionysos explored already. ${ }^{49}$ The main side shows three women with ivy wreaths. The one on the right is in the act of carefully placing a stamnos, which she holds by its handles, on a small table. A pillar indicates that this scene takes place indoors. The statuesque woman in the center, the only one to wear her hair loose, turns to the left, towards the child that her companion on the left extricates from the folds of the chiton gathered around her waist and hands to her. In her left hand, and therefore prominently in the center of the image she holds a barbitos. As one of the stamnoi of the series discussed above confirms, a stringed instrument belonged to the requi-

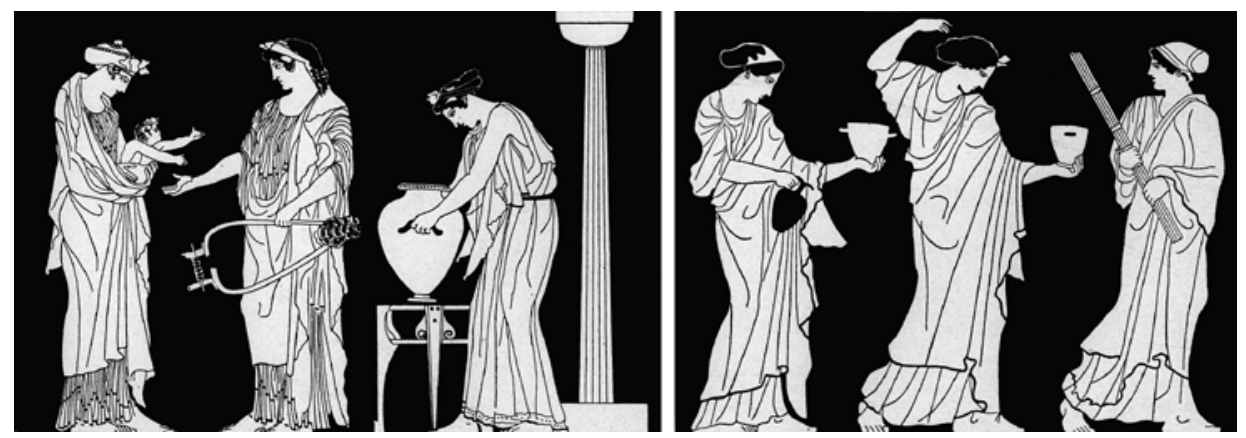

FIGURE 74 Stamnos, Phiale Painter, Warsaw, National Museum 142465, sides A and B (Frickenhaus 1912, 13).

48 Warsaw 142465: Addenda 315 (1019.82); BA 214262; Oakley 1991, 36 and 8o, no. 82, pls. 62A, 63A-B; Frontisi-Ducroux 1991, 156-158, figs 94 and 95. Concerning his calyx krater with the handing over of the child Dionysos, see above Chapter 5 , note 76 . 
sites of the ceremony, together with the aulos. ${ }^{50}$ Also it symbolizes music and, in this way, enculturation. The truly remarkable thing is that the child is not the infant Dionysos, nor a human baby, but a newborn satyr. ${ }^{51}$ On the other side three women move towards the right. On the left an apparently somewhat younger woman with a skyphos and an oinochoe, in the center a woman with her hair done up dances with a skyphos in her left hand, and on the right a woman with her hair in a coif indicates the way with her torch. It seems as if the stamnos not only refers to a ritual, but also to three successive stages in a woman's life.

A comparison with the handing over of the child Dionysos is illuminating. Dionysos is usually entrusted to the nymphs of the uncultivated wild or to the old satyr, the father and educator known from satyr plays. As stated above, the god, though a son of Zeus and guarantor of Zeus' order, had to go through a phase of taming and education in nature. The mother of the newborn satyr, however, apparently hands him to a Muse, in some interior where a stamnos with the 'newborn' wine has just been brought in..$^{52}$ A satyr baby will have a satyr father, and will have been conceived in a state of Dionysiac suspension, possibly out of wedlock. ${ }^{53}$ The image therefore suggests that the purpose of domestic Dionysiac rituals of this kind may have been to integrate even these children into the family and, in this way, into the polis. ${ }^{54}$

\section{Dionysos' Chair}

In the second quarter of the $5^{\text {th }}$ century chairs that may have played some ritual role appear in a Dionysiac context, even though they figure less prominently than torches and altars. It seems therefore worthwhile to study the meaning of this requisite, which figures in three different scene types. ${ }^{55}$

$5^{0} \quad$ For the stringed instrument see Frontisi-Ducroux 1991, 87, fig. 21; Osborne 1997, 205.

$5^{1}$ A detail not noticed by Osborne 1997, 205, although this does not weaken his generally sound argument.

$5^{2} \quad$ For a Muse at the handing over of the child Dionysos, see above Chapter 5 , note 59 .

53 Compare Lindblom 2011, 68: "No doubt, the child satyrs have to be the ultimate consequence of a sexual relation between satyrs and women". Also "... the satyrs ... should be counted as presumptive and capable lovers of the women that they are shown interacting with on Attic red-figure vases." Some tragedies also make reference to children sired out of wedlock in a Dionysiac context: Schlesier 2010, 215-217.

54 For comparable conclusions concerning the case of twins, see Isler-Kerényi 2007, $120 \mathrm{f}$.

55 The first version of what follows will be published in the forthcoming Festschrift for Michalis Tiverios. For that version as for the present one, I do not claim the documentation to be exhaustive. 


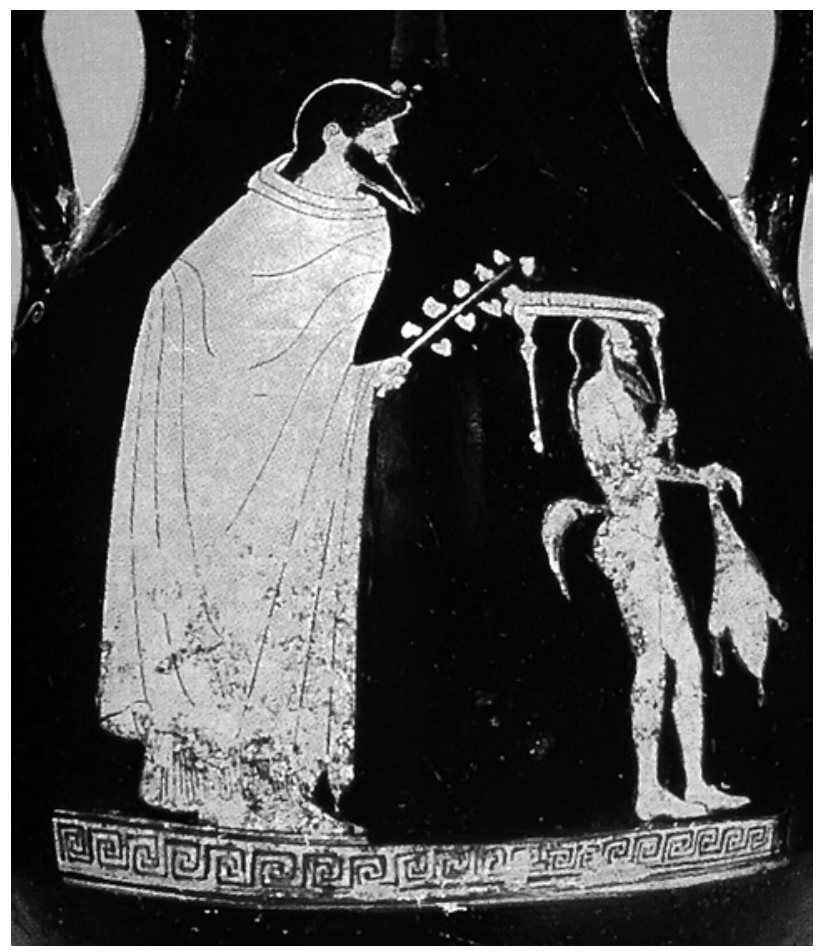

FIGURE 75 Pelike, art trade, side A (Sotheby's, London 1995, 36 Nr. 72). Photograph Courtesy of Sotheby's, Inc. (C) 1995.

\section{A Satyr Carrying a Chair}

Our first example is a sumptuous column krater by the Pan Painter, dated 480 BC or shortly afterwards. ${ }^{6}$ On the main side Dionysos, dressed in a white himation and crowned with an ivy wreath, strides solemnly towards the left. He is followed by a satyr who has a kantharos and an ivy branch in his left hand, and with his right balances an upholstered chair, a diphros, over his head. On the other side of the vase an ithyphallic satyr comes towards them carrying a large, apparently full skyphos. The image carrier calls to mind the symposium: one could almost think Dionysos was expected there. However, when participating in a symposium the god would recline on a couch and would not need a chair.

$56 \quad$ New York 16.72: Addenda 257 (551.6); BA 206281; see also a pelike, dated around 470, in the art trade, where a small bearded satyr precedes Dionysos holding the diphros over his head (Sotheby, Sale LN 5398, 06.07.1995, 36 Nr. 72), (Figure 75) as well as a small column krater in the art trade on which the satyr carrying the diphros is half dressed: Lissarrague 212 , fig. 185 . 

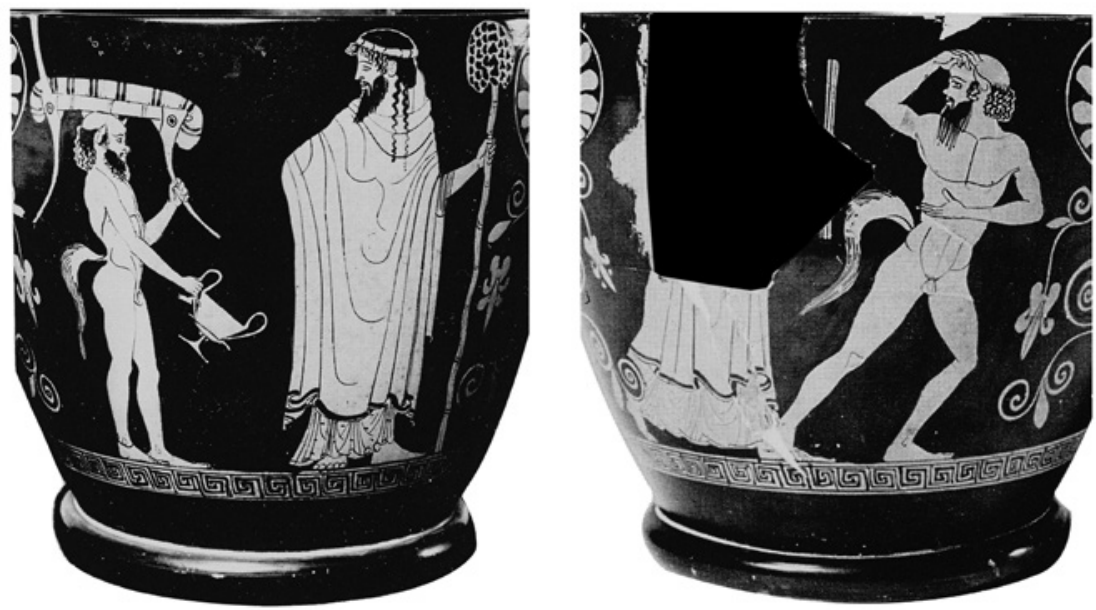

FI GURe 76 Skyphos, Lewis Painter, Moscow, Pushkin State Museum of Fine Arts II 1 b 6oo, sides A and B (cva Moscow 4, pl. 39).

The chair is not a realistic element, but a metaphoric one. When one satyr, like a faithful servant, follows Dionysos with his chair (or precedes him as on the pelike), and another one receives him with wine, this expresses the expectation that the god will join the fold of satyrs.

Quite comparable is the image on a skyphos typical for the Lewis Painter, which may be dated around 450 вс (Figure 76 ). ${ }^{57}$ Here, too, Dionysos walks in front, again in a white himation and with a thyrsos in his left hand. Turning his head, he looks at a small bearded satyr, who carries a kantharos in his right hand and with the left supports the curved leg of an upholstered easy chair, a klismos, which he balances on his head. The reverse side, disfigured by a stray fragment inserted by a restorer, a satyr moves to the right, but looks back towards a woman with a torch who is following him. His skopeuma gesture, typical for archaic-period satyrs, can, however, hardly be meant for her, but must be for the god. ${ }^{58}$ Accordingly, both sides should be read as a single procession, with Dionysos and his small satyr servant following the bigger satyr and the torch-bearing woman. ${ }^{59}$

57 Moscow II 1b 6oo: BA 19347; cVA Moscow, Pushkin State Museum IV, 45, pl. 39, 1-4 (Russia 190).

58 See Isler-Kerényi 2004a, 36 .

59 A similar female torch bearer leading a procession can, for instance, also be found on the column krater by the Agrigento Painter in Rome, Villa Giulia 846 (ARV 575.20; BA 206620), 
On a small calyx krater of about 430 BC attributed to the circle of Polygnotos a bearded satyr of small stature follows the god, who is wrapped in his himation and carries a thyrsos in his left hand. ${ }^{60}$ The satyr has a torch in his right hand and with his left supports the klismos he carries on his shoulder. On the reverse we see a youth with a stick likewise wrapped in a mantle. Is he waiting or looking on?

The motif of the chair is also used on a bell krater of about the same time which may be attributed to the Kleophon Painter, the most important of the followers of Polygnotos (Figure 77). ${ }^{61}$ It can be dated to $440-430$ BC. ${ }^{62}$ The procession shown on this vase is composed of three participants. A woman with a torch and a thyrsos goes in front, towards the right. She looks back at the god, who is wrapped in his himation and wears a strange diadem that seems more suitable for a goddess. ${ }^{63}$ In his left hand he holds a kantharos and an ivy branch. As in all examples described here the god hides his right hand in his himation. Apparently, he does not intend to take any action. He is followed by a boy satyr who carries a klismos on his right shoulder and holds aloft an ivy branch. As is the case with many kraters of this period, the reverse side has three anonymous youths wrapped in their mantles. This very frequent motif was not some meaningless space filler, but meant to evoke an atmosphere of reverent expectancy. ${ }^{64}$

All examples discussed so far of Dionysos accompanied by a satyr carrying a chair have in common that the god is depicted as striding, but wrapped to his neck in his himation and with his right hand hidden in the garment. That hand is therefore idle, while the left hand holds the thyrsos, and in one instance also the kantharos. A mantle covering the whole of the body generally expresses a demeanor known as aidos, which may be, according to the context, piousness, dread and awe in the face of some superior power, or respectful reticence. ${ }^{65}$

and the calyx krater by the Niobid Painter in Ferrara 2891 (Addenda 266 [602.24]; BA 206956).

$60 \quad$ London E 465: Para 445 (1057.102); BA 213732 (no image); Simon 1963, 21, pl. 7.4; Oakley 1997, pl. 184 A.

61 See above Chapter 5, p. 95 .

62 Cahn International AG, Sales London 24-29 June 2010.

63 Compare for instance the headdress worn by Ariadne on the skyphos by the Lewis Painter in New York, discussed in Chapter 5 , note 112. It could be a dilettantish modern replacement, but the krater is said to be intact.

64 Isler-Kerényi 1993b, 96-99, and 1996.

65 Ferrari 1990, especially 193: “... properly speaking, aidos is neither shame, nor honor, nor fear, nor disgrace, but stands in some relationship to each.” 


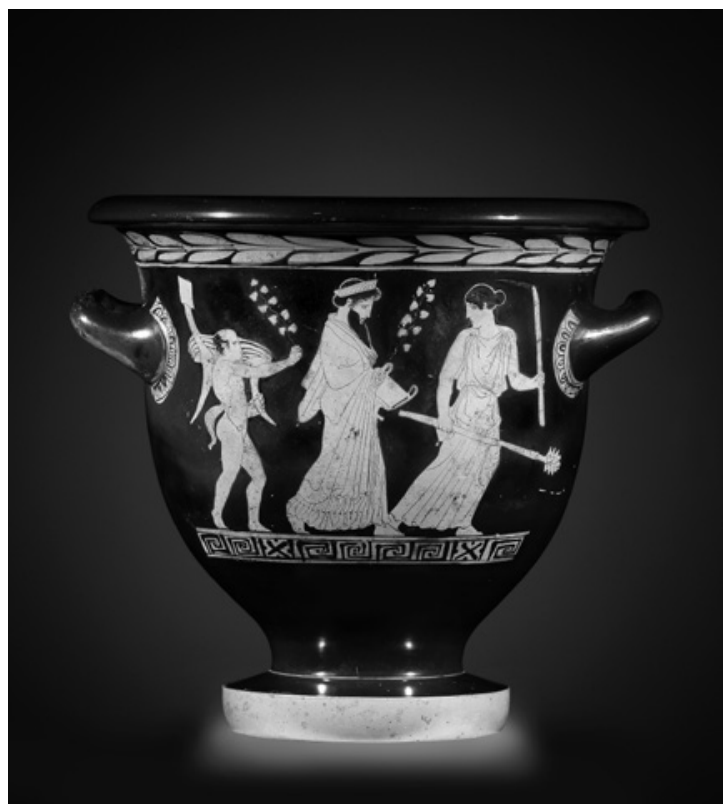

$a$

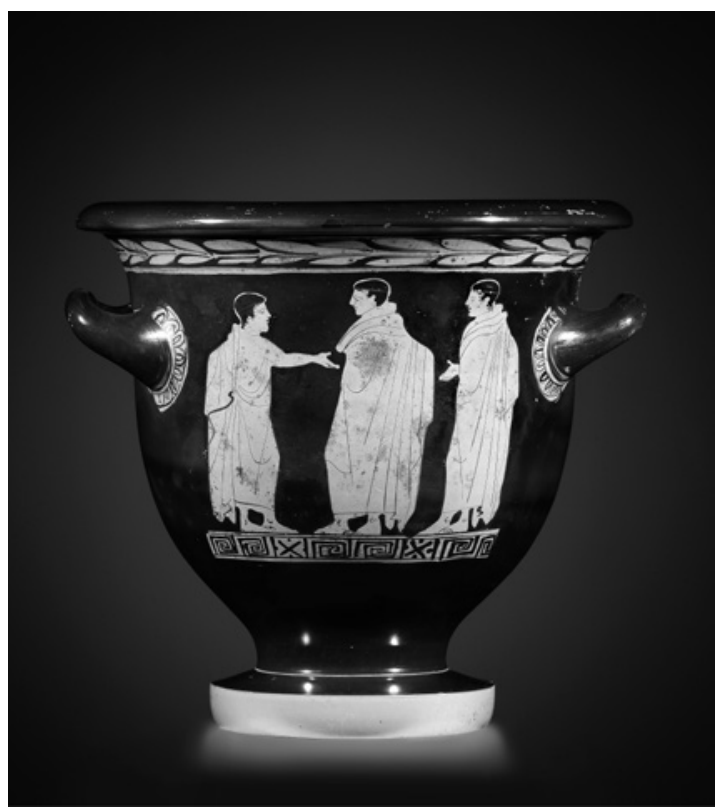

$b$

FIGURE 77 Bell krater, Kleophon Painter (?), Collection S. Rosignoli, London (photograph Nik Bürgin, reproduced with kind permission of Jean-David Cahn).

a. side $A$.

b. side $B$. 


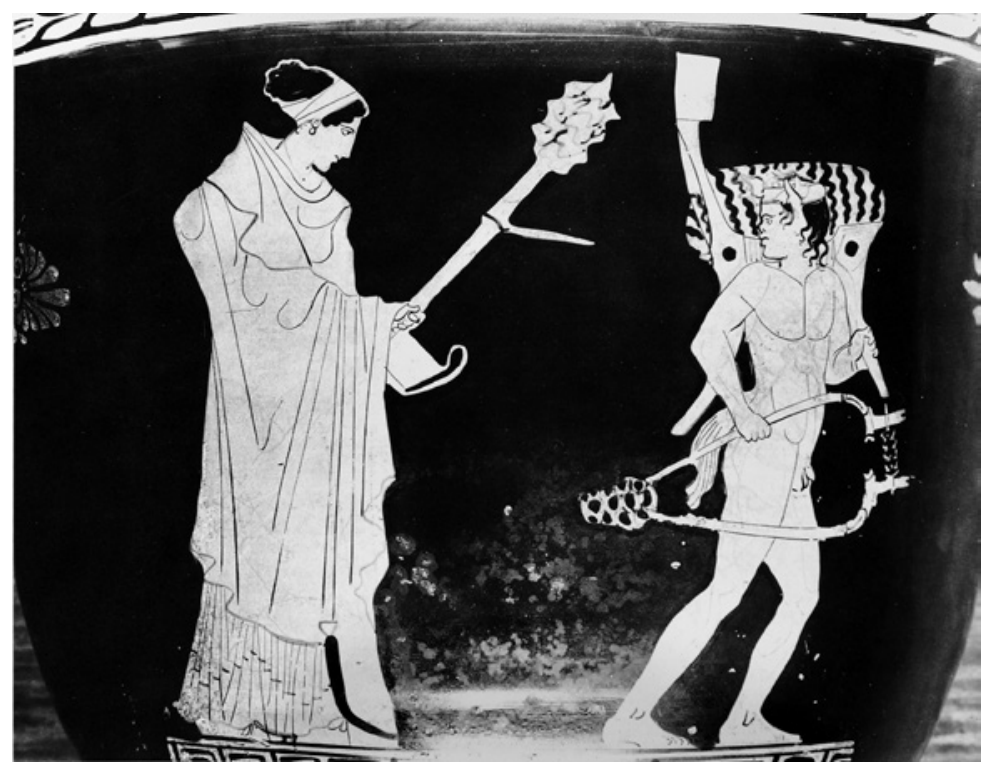

FIgURe 78 Bell krater, Phiale Painter, Paris, Louvre G 422 (Simon 1963, pl. 7.5).

Aidos is therefore a suitable attitude for those taking part in a ritual event. ${ }^{66}$ Even gods can be dressed in this manner, when they themselves are ritually engaged - as is evident from a comic depiction of Hermes at an altar. ${ }^{67}$ Thus, when Dionysos appears wrapped in his himation, he is on his way to and likely to participate in a ritual event.

In the instances discussed above, a satyr with a chair follows Dionysos as a servant, but on a bell krater by the Phiale Painter of about 440-435 BC, the satyr, moving towards the right and looking over his shoulder, precedes a woman wrapped in a himation, who holds a thyrsos and a kantharos in her left hand (Figure 78). ${ }^{68}$ This is remarkable, because usually it is the god himself who carries the kantharos, while a woman pours wine from an oinochoe to welcome him. As we will see, this unusual formula is also found in an image belonging to the third iconographic type to be discussed below. ${ }^{69}$ Here, too, the satyr is

66 For instance LIMC V.2, Hermes 101; Hermes 147; Hippothoon 10; LIMC VIII.2, Silenoi 43 a. Compare Knauer 1996, 227, note 12: "Mature muffled adults occur almost exclusively in ceremonial contexts, either as worshippers or mourners."

67 LIMC V.2, Hermes 820.

68 Louvre G 422: Addenda 315 (1019.77); BA 214255; Simon 1963, 21 f., pls. 7.5-6; Oakley 199o, 6 (for the date), 36 and 79, no. 77, pl. 59 .

69 See below note 110. 
depicted as a boy. In his right hand he holds a barbitos. He turns his head to look at the woman behind him. It may very well be assumed that the woman is on her way to meet Dionysos. Whether a wedding banquet is intended, is impossible to establish. ${ }^{70}$ Klismos and diphros are not symposium requisites, because the married women who were present used to sit at the foot of the couch. ${ }^{71}$ On the reverse a woman with a thyrsos confronts a mature satyr, who wears a himation and leans on a stick, as a citizen would do.

The motif of the citizen-satyr, which even before 450 BC already occurs several times in the work of the Geras Painter and subsequently in that of the Phiale Painter, seems to assimilate satyrs and anonymous citizens. C. Bérard and C. Bron go further and conclude that the motif in fact refers to the metamorphosis of the citizen into a satyr, a transformation that would be brought about by Dionysiac ritual. ${ }^{72}$ As was already shown in the introductory chapter above, the original viewers of Dionysiac imagery had no objections to 'normal', decent women being depicted in the role of ecstatic bacchantes or maenads, whereas male citizens who in a Bacchic context acted ecstatically or sexually uninhibited, could, because of some taboo, only be shown dressed up as satyrs-creatures of the imagination. ${ }^{73}$

That the klismos carried by the satyr is intended for Dionysos, is confirmed by the imagery of a chous from the workshop of the Shuvalov Painter, dated between 435 and 420 (Figure 79). ${ }^{74}$ The god stands on the right with his kantharos and thyrsos; his body is shown in frontal view, but his head is turned towards the left. He looks at the satyr boy approaching from the left who carries a klismos with both hands. Between the two on the floor stands a chous, which shows that the encounter takes place at the occasion of the festival of the Choes.

As to the klismos, let me quote an authoritative study of Greek furniture: "... it is the comfortable chair par excellence, less formal than the throne, more luxurious than the diphros. It is prevalent especially in scenes of women's apartments, but by no means confined to them ..." ${ }^{75}$ We could adduce many examples of the period under discussion here to support the statement that

\footnotetext{
$70 \quad$ Simon 1963, 21.

71 As they do, for instance, on the London cup by the Kodros Painter discussed earlier: see above Chapter 5 , note 42 .

72 Bérard/Bron 1986, 24-26.

73 See above Introduction, note 15 .

74 Rome, Villa Giulia 50511: BA 526 (no image); Simon 1963, 21, pl. 7.3; Lezzi-Hafter 1976, $111 \mathrm{~S}$ 96, pls. 137 C-D.

75 Richter 1966, 33.
} 


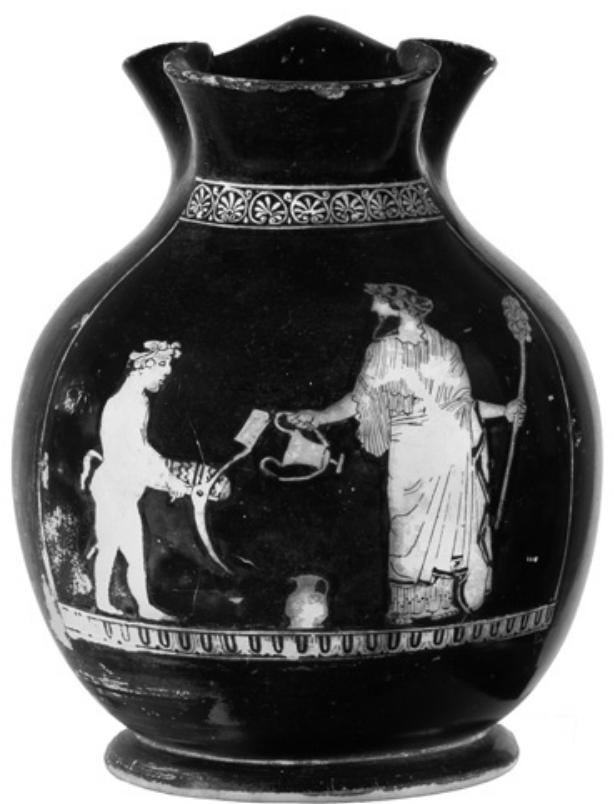

FIGURE 79 Chous, Rome, Museo Nazionale Etrusco di Villa Giulia 50511 (photographs Soprintendenza per i beni archeologici dell'Etruria meridionale).

this piece of furniture above all evokes the female quarters. ${ }^{76}$ But as the klismos was also used in other settings, it would be wrong to associate some kind of chair ritual with women only. However, we can conclude that, whenever a chair is brought in for Dionysos, this implies that the god came from elsewhere, which in turn suggests that his presence is not permanent and a matter of course. Another implication is that Dionysos, as the only one among the gods, was expected to visit people and be with them in their everyday lives.

\section{The Unoccupied Chair}

No other kind of vase is so strongly associated with one of the well-known Athenian Dionysos festival as the chous with the festival of Choes. ${ }^{77}$ Many of these small jugs show some combination of characteristic motifs: the small

76 Lissarrague 1998, 182: “Ce meuble à lui seul ... suffit presque à désigner le gynécée.” A very striking example may be found on another skyphos by the Lewis Painter: Addenda 310 (975.38); вА 276060.

77 Schmidt 2005, 152-221 also provides the earlier literature. The relationship between the chous and the Anthesteria develops gradually and is particularly evident after $430 \mathrm{BC}$, see especially pp. 174-186. 


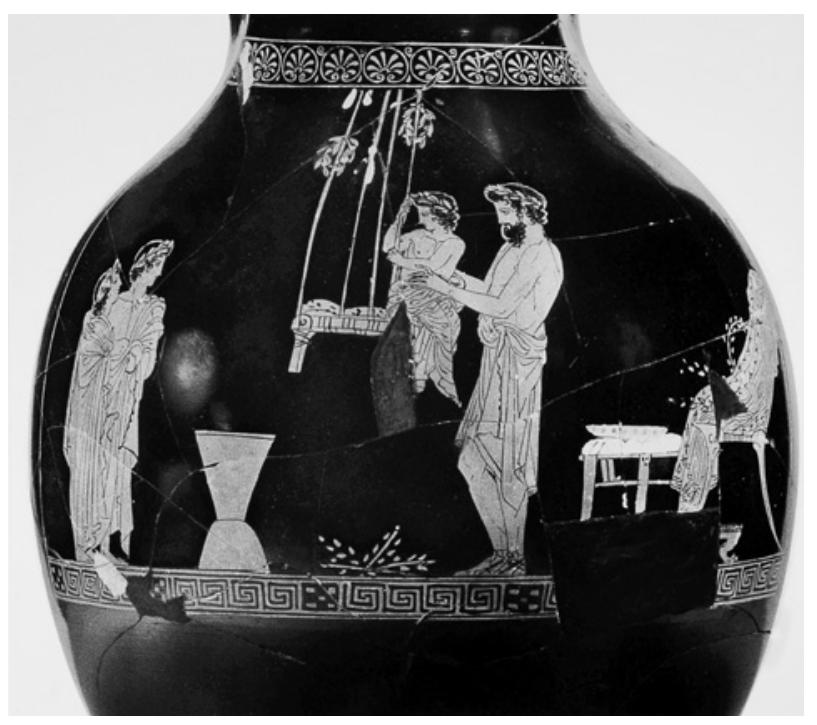

FIgU RE 80 Chous, Eretria Painter, Athens, National Archaeological Museum Bs 319 (photograph National Archaeological Museum, Athens, Spelios Pistas) (C) Hellenic Ministry of Culture and Sports/Archaeological Receipts Fund.

child, the jug, the table with gifts, etc. ${ }^{78}$ However, four of the much less numerous larger choes, between 21 and 23 centimeters in height, carry unique images depicting ritual ongoings. ${ }^{79}$ As both the actors and the accoutrements differ, it seems clear that this is not one and the same ritual. On two of the large-size choes the klismos makes an appearance.

A very fine large chous by the Eretria Painter, dated to $430-425$, is decorated with a swing ritual in which a father figure and boys of various ages take part (Figure 80). ${ }^{80}$ Near the right hand edge of the image we see an outsize easy chair with colorful cloths and laurel wreaths on it. Under the chair stands a footstool and next to it a three-legged table with three cakes and a gilded bowl. Apparently the ritual — a mature man in an artisan's outfit puts a small boy on an improvised swing with two somewhat older boys looking on-is performed

78 Hamilton 1992, 83 .

79 Athens вs 319 (ex Vlastos): Schmidt 2005, 178, fig. 91 (Eretria Painter); Athens BS 318 (ex Vlastos): Schmidt 2005, 183, fig. 93 (Eretria Painter); Athens, 3rd ephory, inv. 3500: Schmidt 2005, 184, fig. 94 (Eretria Painter); New York 75.2.11: Schmidt 2005, 177, fig. 90 (Meidias Painter).

8o Athens вs 319: вA 216950; Lezzi-Hafter 1988, 198-201 and 339, no. 214, fig. 66, pl. 136. Schmidt 2005, 178 dates it around 430-420. 


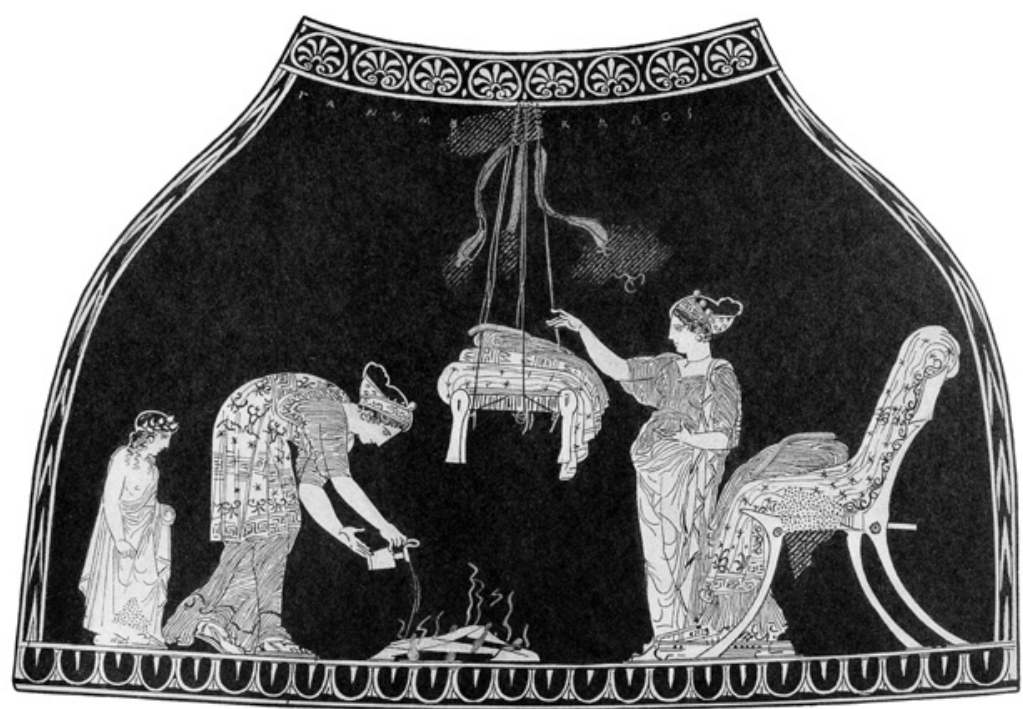

FIGURE 81 Chous, Meidias Painter, New York, Metropolitan Museum of Art 75.2.11 (Richter 1936, pl. $158 a)$.

in the expectancy of a visitor, someone for whom the chair with the festive cloths and the gifts on the little table are meant. ${ }^{81}$

The swing, in the center of the image, and an even larger klismos can also be found on a slightly younger chous by the Meidias Painter. ${ }^{82}$ Costly fabrics lie folded on the swing. These are impregnated with perfumes poured onto burning twigs. On the left a boy approaches, wreathed and dressed in a festive himation (Figure 81).

Although both images with swings appear to refer to an actual ritual, it has proved impossible to identify them with any ritual known from our written sources. ${ }^{83}$ In any case, the unoccupied chair indicates that during the Anthesteria women, men, and boys were preparing for the arrival of the god in a festive mood. Whether the swinging was performed in memory of the tragic death of Erigone should for now remain an open question. ${ }^{84}$ Still, it certainly transports us to a Dionysiac sphere. In swinging, as in dance, one is lifted up, raised above the ground, and finds oneself between up and down, back and

\footnotetext{
81 See Schmidt 2005, 179 and $185 \mathrm{f}$.

82 New York 75.2.11: Addenda 362 (1313.11); BA 220503; Lezzi-Hafter 1988, 201 f. and 341, no. 225, pl. 195 d; Schmidt 2005, 177, fig. 90, dated 420-410 BC.

83 Schmidt 2005, 178-180.

84 For critical comments see Humphreys 2004, 242 f.; Schmidt 2005, 179.
} 


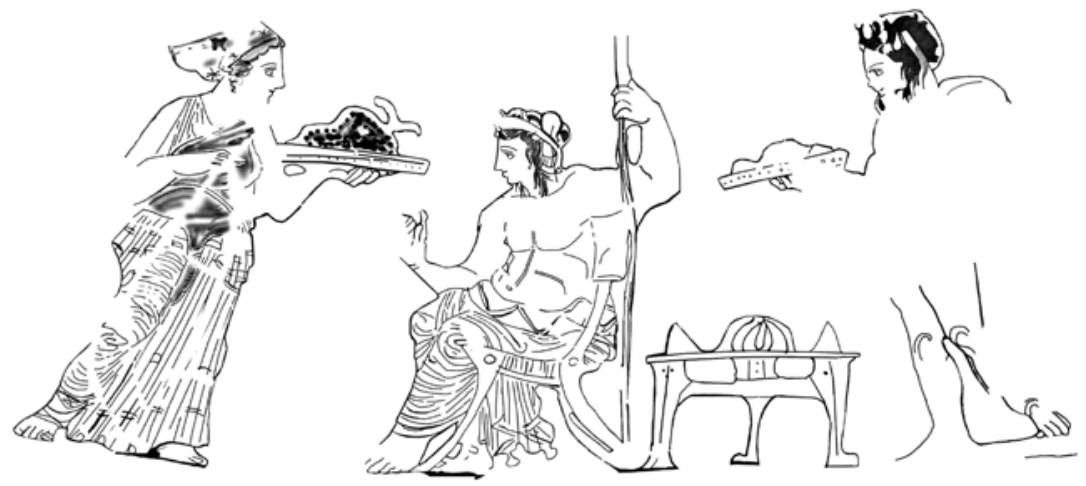

FIGURE 82 Chous, artist from the sphere of the Dinos Painter, excavation number A 115 (Hatzidimitriou 2012, 121, fig. 4, drawing K. Deli).

forth - symbolically in a state of transition, a state brought about by Dionysiac metamorphoses, for instance from one age group into another. ${ }^{85}$

The chous by the Marsyas Painter, some two generations younger, is not the only source to show that the empty chair is meant for Dionysos and not for the Basilinna. ${ }^{86}$ The chous shows a youthful Dionysos seated on a klismos standing on top of a low platform. He turns towards an alluring female figure on his left, who is identified by an inscription as Pompe ('procession'). On the far left, Eros is putting on his sandals next to a large sacrificial basket. Apparently, the woman here personifies a complete procession, on its way to ritually unite with Dionysos. This particular image can only be read symbolically, but there is another one, only recently published, that is closer to real life.

This concerns the decoration of a large chous of which only the lower half has been preserved. It was found in 2010 in Trachones near Athens, and is likely to have been a grave gift. It has been attributed to the circle of the Dinos Painter and dated to $420-410$ (Figure 82). ${ }^{87}$ A youthful Dionysos dominates the center of the image. He wears a fillet tied over a wreath of leaves. He sits on a klismos, turned towards the left and with a thyrsos in his left hand. Whether he also held something in his right hand is now impossible to tell. ${ }^{88} \mathrm{~A}$ woman approaches from the left. She wears an animal skin over her chiton, and has her hair in a decorated coif. With her outstretched left hand she offers the god

85 Isler-Kerényi 2007, 59 and $214 \mathrm{f}$.

86 Similarly Schmidt 2005, 176-180; New York 25.190: BA 503 (no image); Schmidt 2005, 191 f., fig. 98; Smith 2011, 86 and 171 VP 58.

87 Hatzidimitriou 2012.

88 Hatzidimitriou 2012, 118. 
a plate with a giant bunch of grapes. A satyr carrying a plate of sweetmeats approaches from the other side. In front of him, near the god's klismos, we see a low three-legged table with more pastries. It is very similar to the table on the chous with the boys' swing ritual just discussed. ${ }^{89}$ The situation is unambiguous: the god has arrived, sits on the chair that had been prepared for him, and accepts the gifts of his believers. The prominent bunch of grapes, also a recurrent motif on small choes, should, of course, not be taken in a literal, but in a symbolic sense: even in Greece there were no ripe grapes in spring, at the time of the Anthesteria. ${ }^{90}$ The grapes would rather refer to the young wine in the choes - wine made from the grapes of Dionysos.

Within the series of images presented here, the one just discussed is of particular importance because it is close to that on a more or less contemporaneous bell krater by the Pothos Painter belonging to another iconographic tradition to which we will turn now. ${ }^{91}$ From the imagery explored above we can conclude that the chair is associated with Dionysos and that it was somehow part of the Anthesteria — symbolically, but possibly in actual ritual practice. ${ }^{92}$

\section{Dionysos Has Arrived}

Thus, Dionysos was expected during the Anthesteria and when he came, he was received with gifts. The easy chair prepared for him indicates he came in order to stay. Of the arrival, or epiphany, of the god and his being greeted with a libation by a woman or a satyr, there are countless examples in Dionysiac iconography, ever since vase painting began. ${ }^{93}$ Usually, however, the protagonists are shown standing - although for black- and red-figure cups Dionysos sitting amidst his thiasos was a popular motif. ${ }^{94}$ After 450 BC, in work by or inspired by Polygnotos, we encounter a new version of the god's arrival that explicitly refers to a reception ritual.

As a first example let us consider an early stamnos by Polygnotos. ${ }^{95}$ The center of the image shows Dionysos, his name inscribed, sitting on a folding chair, and a veiled woman who fills the god's kantharos from her oinochoe.

89 See above note 80.

$90 \quad$ Similarly Hamilton 1992, 116.

91 Madrid 11052: Addenda 341 (1188.4); BA 215738 (no image); Queyrel 1984, 134 f., no. 20, fig. 19.

92 Compare also, for instance, the small neck-amphora in Brussels R 249: ARV 668.38; BA 207833 .

93 The earliest known example is an impressive Cycladic vase from the late 7 th century, see Isler-Kerényi 2007, figs 1-2.

94 Compare in addition the medallion image of the Florence cup, see above 124 fig. 68a.

95 Louvre G 406: Addenda 317 (1028.12); BA 213393; Matheson 1995, 34, fig. 22 (dated 450-440). 

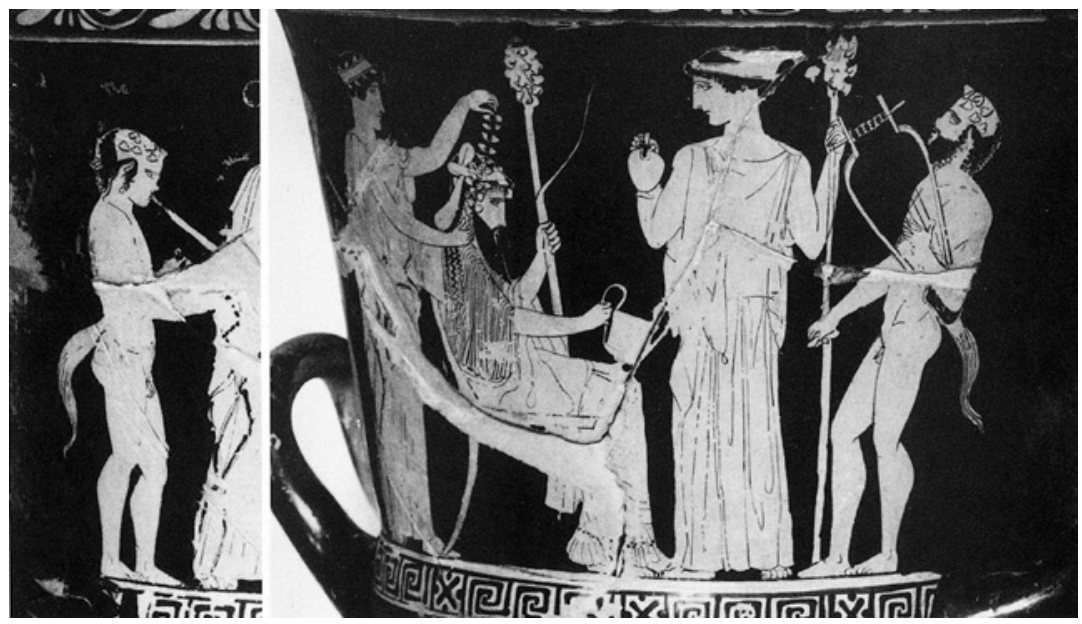

FIGURE 83 Calyx krater, Polygnotos group, Copenhagen, The National Museum of Denmark ABC 1021, side A (cVA Copenhagen 4, pl. $146 a-b)$.

The inscription "Arsin ..." possibly refers to Ariadne. The god wears a voluminous headband over his wreath of leaves and holds the thyrsos in his left hand. Instead of a chiton, the woman wears a peplos with a decorated border. On the right a satyr energetically strides towards them, carrying a torch in his left hand. He lifts his right arm in surprise — or is he supposed to be dancing? On the left another satyr approaches, strumming the barbitos. On the reverse, three women are quietly standing about: one with an oinochoe, the middle one with a thyrsos, and the one on the right with a torch. Both images have an air of reverence.

A calyx krater of about the same date is quite comparable (Figure 83). $\cdot{ }^{96} \mathrm{In}$ the center of this symmetrically composed image we find Dionysos on his klismos, again with a large headband tied over an ivy wreath, with a kantharos in his right and a thyrsos in his left hand. Before him, shown en face, is another peplos-clad woman with a thyrsos in her left hand, her hair beautifully done up. She pours wine for the god from her oinochoe. A second woman in a peplos, wearing a costly diadem, lifts both hands in order to crown Dionysos from behind with another ivy wreath. From the right a singing satyr is approaching with a barbitos, from the left comes a younger, beardless satyr playing the aulos. Both satyrs are smaller than the women, and therefore cannot be adult satyrs. On the other side of the vase, the center of the image is occupied by a

96 Copenhagen ABC 1021: Addenda 318 (1035.2 and 1037.1); BA 213467; Bérard/Bron 1984, 140, fig. 201; Matheson 1995, 164. 
woman dressed in chiton and himation. Her hair is in a coif and she holds a thryrsos. On her right a satyr with a kantharos, and on her left one with a torch. Both satyrs wear the himation of the citizen. In these images, too, there is pious calm.

Another stamnos, from the circle of Polygnotos and likewise dated between 440 and 430 , carries a comparable scene. ${ }^{97}$ On the far left, Dionysos is sitting on a klismos covered with an animal skin. He wears an ivy wreath and again holds the kantharos in his right hand and the thyrsos in his left. Before him, in frontal view, stands a young beardless satyr, who pours the god a drink from an oinochoe, while holding a wine skin in his left hand. To his right follows a maenad wearing and ivy wreath, a fawn skin over her chiton and a richly embroidered robe. She has lighted torches in both hands. She looks back towards another satyr, this one bearded, who approaches from the right, singing and playing the barbitos. The maenad's name is inscribed as Helike, both satyrs are called Marsyas. On the reverse, we again find the woman in the coif, holding a long branch. To her left and right are two naked satyrs. The one on her right seems to be gesticulating. She may be having a conversation with him.

A fragmentary stamnos by the Hector Painter also belongs to this series. Of Dionysos, who sits on the left wearing an ivy wreath, only the head and

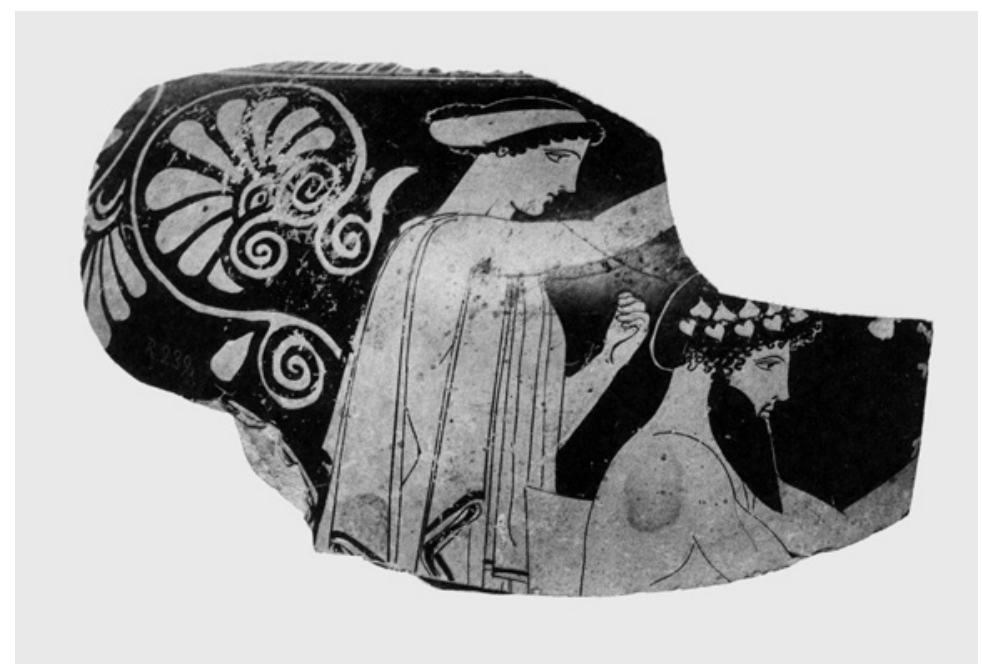

FIgURE 84 Fragment of a stamnos, Hektor Painter, Brussels, Musée d'Art et d'Histoire R 239 (cva Brussels 1, III ID, pl. 1.2).

97 New Haven (Ct), Yale University 1913.132: Addenda 318 (1035.4); BA 213471; Matheson 1995, 116, fig. 98 (Midas Painter). 
shoulders are preserved. He is crowned by a woman in a peplos standing behind him (Figure 84).98

An original variation on the scheme discussed above may be found on an exquisite bell krater from the same circle, likewise dated between 440 and 430 BC. ${ }^{99}$ This image, too, shows Dionysos being greeted by two women. Seated on his klismos, he has drawn towards himself a child satyr whom, like a father, he gives a taste of wine from his kantharos. Satyrs of various ages figure regularly in the images discussed here, and continue to appear during the second and third quarter of the century. ${ }^{100}$ This is hardly surprising. As stated above, in vase painting satyrs are substitutes for citizens taking part in Dionysiac rituals-bacchants. ${ }^{101}$ Childlike and young satyrs fit into this world of vase imagery just as readily as boys and young men. The name Komos is used repeatedly for satyrs in vase painting after $450 \mathrm{BC} .{ }^{102}$ It refers to the wild, euphoric parading before and after the symposium, something the little drinker can look forward to as he grows up.

When the woman pouring wine to the right of the central group is referred to as Ariadne, this implies a close relationship with the god. However, it does not necessarily mean that the scene has shifted from a human to a separate, mythological plane. In the transition from one age group to the next or one status role to another, any woman could identify with Dionysos' bride Ariadne. ${ }^{103}$ For the modern viewer, the name Tragoidia for the woman who is playing with a hare on the left remains enigmatic. ${ }^{104}$ The depiction of Dionysos as a father in the context of a wine ritual is unique and very striking.

\footnotetext{
98 Brussels R 239: ARV 1036.9; BA 213480; Matheson 1995, 102 and 105, fig. 83.

99 Compiègne 1025: Addenda 322 (1055.76); BA 213708; Moraw 1998, 90 and 296, no. 398, pl. 18, figs 47a-b; Matheson 1995, 165; Lissarrague 2013, 35 f., fig. 15.

100 Lissarrague 1998, 186-196.

101 Isler-Kerényi 2004a, $61 \mathrm{f}$., and in addition the Introduction above, note 15.

102 LIMC VI.1, 96 f., Komos 6-20.

103 Isler-Kerényi 2007, 123.

104 For other Dionysiac women with this name, see Schmidt 2005, 189-191; LIMC VIII.1, 49, Tragoidia $7-10$. It is well known that the hare, as pet, love gift, or catch was a common reference to the erotic. It was already used as an attribute for Dionysiac nymphs in the Archaic period, see Isler-Kerényi 2007, 134 and figs 7, 63, 69, and 70. But even if one keeps in mind that Attic tragedies not always have a tragic ending, one may wonder what a figure that evokes a genre that is anything but lighthearted is doing with a hare. However, in view of the fact that the performance of tragedies was part of the ritual of the Athenian Dionysiac festivals, the presence of Tragoidia in a Dionysiac context is not remarkable: Lissarrague 2013, $35 \mathrm{f}$.
} 
A comparable composition as well as a Dionysiac father may be found on the equally magnificent, but fifteen or twenty years older, bell krater attributed to the Altamura Painter. ${ }^{105}$ The comparison with this krater confirms that the Dionysos on the klismos of the Compiègne bell krater should indeed be seen as a father figure. It seems, therefore, plausible that the seated Dionysos in the scenes we have just discussed was seen above all as someone fatherly — this in contrast to his role in the Bacchic thiasos.

To these four more or less contemporaneous representations of the seated Dionysos celebrated by women and satyrs, we can add a bell krater of about 420 BC attributed to a later Polygnotos circle. ${ }^{106}$ Again Dionysos (his name is inscribed) seated on a klismos is the main protagonist. Again he wears the ivy wreath and holds the thyrsos-but here he is portrayed as a bare-chested young man with cropped hair. His rejuvenation, often remarked upon before, has apparently taken place sometime between 440 and $420 .{ }^{107}$ It can be convincingly connected to the new Dionsyos as represented on the east pediment of the Parthenon; an image with which Phidias surprised the Athenians in or shortly before $43^{2}{ }^{108}$ The fatherly role attributed to the god on somewhat earlier vases is no longer compatible with this youthful Dionysos. From now on he is rather the longed-for lover. ${ }^{109}$

In this same image there is a woman whose name is inscribed as Bakche. She wears a simple headband over her short hair. With her right hand she offers the god a kantharos, in her lowered left hand she holds an oinochoe: a surprising change of attributes, difficult to account for, but not unique as can be seen from a bell krater by the Phiale Painter, already mentioned above. ${ }^{110} \mathrm{~A}$ second woman, named Orania, seems to touch the back of the god's head. Her long loose hair appears from under her fillet and she lifts a large tympanon in her left hand. A satyr, designated as kalós, comes from the right while playing the aulos. The reverse image shows three young men in their himatia. An aryballos and a strigil over their heads evoke the world of the gymnasium. All three are characterized as adolescents: beardless and with uncut hair. The middle one, wrapped in his himation to his neck, seems to listen to his gesticulating companion on the right, while the third one, likewise fully covered, approaches from the left. The mood of pious expectation, common to numerous scenes

\footnotetext{
105 Ferrara 2738: see above Chapter 5 , note 64 and p. 105 fig. 55 .

106 London E 503: Addenda 337 (1159); BA 215344; LIMC III.1, 8o Bakche 2.

107 Queyrel 1984, 157; Matheson 1995, 187.

108 Carpenter 1997, 92; see below Chapter 7.

109 Isler-Kerényi 2011a, 81-84.

110 See above note 69 .
} 
such as this one, is quite palpable here. It befits the celebration of Dionysos depicted on the main side of the krater.

All images explored in these paragraphs have in common that they present Dionysos in an ordinary human environment where he is honored with ritual acts; the reverse sides of these vases show pious quiet instead of the boisterous thiasos. Taking part in these acts are satyrs of various ages and women in a range of different garments. These, too, are probably representative of various age groups and/or social positions. It is unlikely that we will ever know if these images refer to a specific reception rite. We can merely point at the fact that, of all the gods, the vase painters only depicted Dionysos in this way, thus highlighting his closeness to ordinary mortals.

The motif of the seated Dionysos who is ritually greeted, is continued in the work of the Kadmos Painter and the Pothos Painter. A somewhat mediocre bell krater by the Kadmos Painter, dated after $430 \mathrm{BC}$, is decorated with a bearded Dionysos sitting hieratically on a klismos with a kantharos in his right hand and a thyrsos in his left."11 The libating Nike comes flying from the right, in front of him a tame feline crouches on the floor. The scene is framed on either side by satyrs. The bearded one on the left plays the aulos, a lyra at his feet. The one on the right is younger. On the reverse we again see three youths wrapped in their himatia.

Quite comparable are three, likewise rather mediocre, bell kraters by the Pothos Painter, from the early fourth quarter of the century. On two of these the god is shown bearded, with kantharos and thyrsos; a maenad pours him wine from an oinochoe. ${ }^{112}$ A satyr and other women frame the scene. It is hardly surprising that this obviously conservative vase painter preferred to stick to the traditional formula of the bearded god as long as was viable. All the more remarkable is the third vase on which Dionysos appears beardless, almost naked, and facing left instead of right as in all other images discussed here, with the exception of the chous from Trachones. ${ }^{113}$ Moreover, the god is not received with a libation from an oinochoe, but with a gift of grapes. ${ }^{114} \mathrm{In}$ this way the vase clearly appears to be iconographically related to the chous

\footnotetext{
111 Madrid 11074: ARV 1185.17; BA 215705.

112 Vienna 1065: ARV 1188.3; BA 215737 (the main image incorrectly shows Madrid 11052); Queyrel 1984, no. 16, 133, fig. 15; Tapley Park (Devon): ARV 1188.2; BA 215736; Queyrel 1984, no. 21, 135, fig. 20.

113 Madrid 11052: Addenda 341 (1188.4); BA 215738 (no image); Queyrel 1984, no. 20, 135, fig. 19.

114 Queyrel 1984, 154. Compare the dinos by the Dinos Painter, Berlin 2402, and the volute krater by the Kadmos Painter, Ruvo 1093: Queyrel 1984, 152, figs 28 and 29.
} 
mentioned above, so that the whole set of images may be linked to the Anthesteria imagery featuring a chair.

However, the three examples by the Pothos Painter show a further innovation: the god is no longer seated on a klismos, but on a little knoll. The scene has, consequently, lost relationship with the human household. It has shifted to a mythological level — and there it will remain in both Attic and Apulian imagery. To evoke reverent expectation, in a general way, three youths in their himatia always decorate the reverse side. The formula will subsequently be taken into the early 4 th century by the Meleager Painter. ${ }^{115}$

To sum up: there are three series of images sharing the element of the chair of Dionysos. The first and earliest shows the chair being carried by a satyr in the god's retinue; the second exclusively attested by the choes of the period between 430 and 410 , shows the klismos-empty at first, later occupied-in the context of the Anthesteria; the third shows the seated god ritually greeted by his venerators. The chous from the workshop of the Shuvalov Painter links the first and the second series, and the recently discovered chous from Trachones the second and third. In Athens during the second half of the $5^{\text {th }}$ century, three different formulae were, therefore, used to evoke the arrival of the god at the Anthesteria. Apparently, this was not part of public polis religion, but a ritual in the domestic sphere, in which several family members were engaged: children, young girls and married women, and, in the guise of satyrs, young and adult men. ${ }^{116}$ Possibly, the chair was not merely an element of the imagery, and thus a mental category, but also part of the actual ritual.

We have to keep in mind that, of all the gods who are represented in vase painting as seated on an elegant klismos, only Dionysos has it carried before him; and only Dionysos has a chair prepared for him with cloths and gifts: no other god's arrival is expected. Only Dionysos' arrival is ritualized in this way: he is the only god who always returns to visit people's homes. The first Dionysos chair that is not domestic but plays a part in polis life is depicted on a bell krater by the Kadmos Painter from just before 400 в . ${ }^{117}$

\footnotetext{
115 See, for instance, Kathariou 2002, 391-440, figs 14, 17, 18, and 40.

116 It seems advisable, therefore, to take into account that rituals, including those of the Anthesteria, changed over time: Humphreys 2004, 223-225.

117 See below Chapter 8, note 25 .
} 


\section{Child Satyrs in Dionysos' Retinue}

Although satyrs of various ages are not a particularly popular motif, satyrs as child, boy or youth appear regularly in vase painting between 480 and $430 .{ }^{118}$ If one understands satyrs to be men in a Dionysiac context or a Dionysiac mood, it need not surprise that the newborn male, naturally an untamed being, can also appear as a small satyr. ${ }^{119}$ We saw this on a stamnos by the Phiale Painter. ${ }^{120}$ We could see all this as an illustration of the human trait of going through changes during one's life cycle, i.e. of one's Dionysiac nature.

Some images from around $450 \mathrm{BC}$ allow us to observe changes in the lives of satyrs. This is not about those images that refer to satyr plays, but about images that refer to Dionysiac ritual. ${ }^{121}$ On a calyx krater by the Villa Giulia Painter we see a Dionysiac procession (Figure 85$).{ }^{122}$ In front, on the left hand side of the image, goes a white-haired satyr by the name of Marsyas, playing the aulos. Next comes a boy satyr, named Posthon, with a lighted torch. ${ }^{123}$ Behind him comes a pensive woman, named Mainas (i.e. Maenad) with a thyrsos in her right hand and a kantharos in the left, and finally an adult satyr, Soteles, also with thyrsos and kantharos, who is singing with his head thrown back. The involvement of satyrs of three age groups in a ritual event, the festive nature of which is palpable, cannot be made more explicit. ${ }^{124}$

Boy satyrs also often appear in a Dionysiac context with one single maenadlike woman. On a small neck-amphora by the Phiale Painter, a woman with a thyrsos hastens towards the left behind a young satyr with a heavy wine sack. ${ }^{125}$ On another of his neck-amphorae, a young satyr wearing a wreath plays the aulos with total abandon. A maenad, also wearing a wreath, dances wildly to its music, her thyrsos planted in the ground in front of her. ${ }^{126}$

Youthful as well as adult satyrs may also accompany the god himself. One of the painters of column kraters active during the second quarter of the century presents Dionysos as a participant in a ritual procession on the main side of

\footnotetext{
118 Lissarrague 1998, 186-196 and 2013, 63-66. Lindblom 2011, 68 points at 125 vase images in an unpublished study by J. Michael Padgett.

119 Isler-Kerényi 2004a, $94 \mathrm{f}$. Also above Introduction note 13.

120 See above note 48 and 134 fig. 74.

121 Satyrs in satyr plays: Krumeich 1999.

122 Karlsruhe 208: Addenda 270 (618.3); BA 207151.

123 According to Lissarrague 1998, 191 this is a term for the penis.

124 Lissarrague 1998, 188-191, fig. 36.

125 Madrid L 188: ARV 1015.18; BA 214195.

126 Bedford, Woburn Abbey: ARV 1015.19; BA 214196.
} 


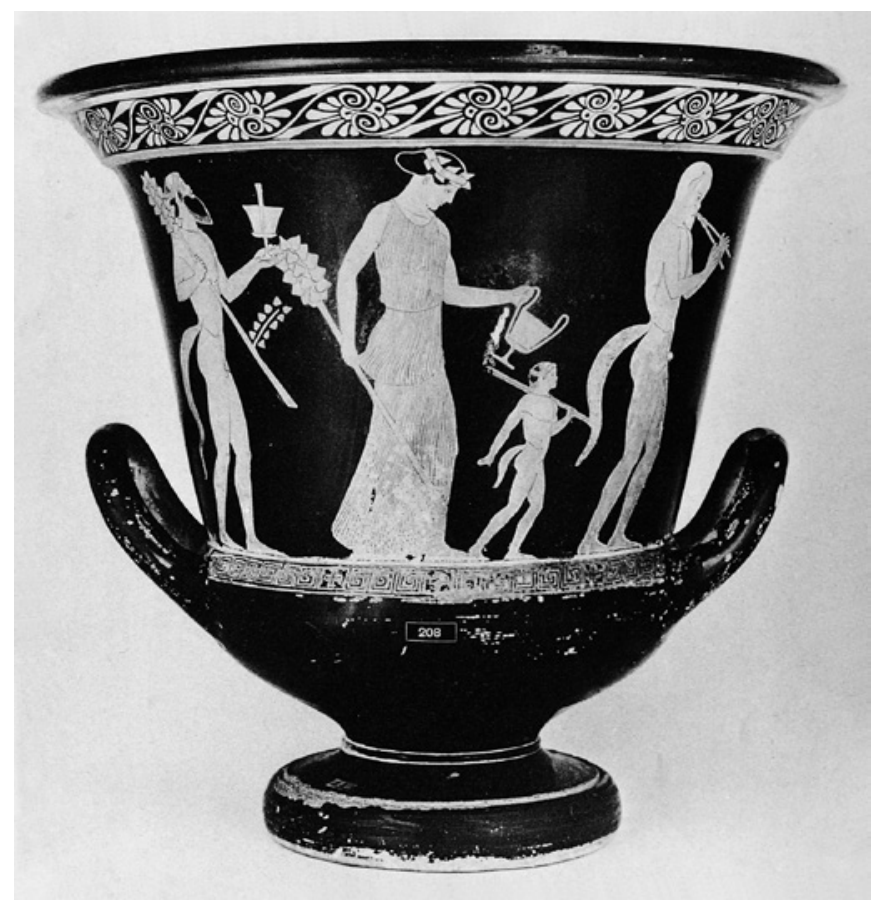

FIgURE 85 Calyx krater, Villa Giulia Painter, Karlsruhe, Badisches Landesmuseum 208, side A (cVA Karlsruhe 1, pl. 19.1).

a vase. ${ }^{127} \mathrm{~A}$ woman with a large torch in each hand moves in front towards the right. She is followed by the god, who leans on a young satyr playing the aulos. Dionysos is bearded, wears nothing but a chlamys over his left arm, and carries a thyrsos. A woman playing the lyra comes next, and she is followed in her turn by an adult satyr dancing along with a pointed amphora decorated with a wreath, and probably filled with wine. Related are a bell krater by the Methyse Painter and four somewhat later ones by the Christie Painter, who belongs to the circle of Polygnotos. They show Dionysos moving towards the right between a young satyr playing the aulos and a torch-bearing woman. ${ }^{128}$

127 Rome, Villa Giulia 846: ARV 575.20; BA 206620 (Agrigento Painter): here 75 fig. 38 . The instrument is the barbitos, see above Chapter 2, note 48 .

128 Methyse Painter: New York 07.286.85: Addenda 272 (632.3); BA 207338; Christie Painter: Vienna 782: Addenda 320 (1047.10); BA 213579; Baltimore 48.74: ARV 1047.11; BA 213580; fragments in Syracuse and Athens, private collection: ARV 1047.12 and 13. 


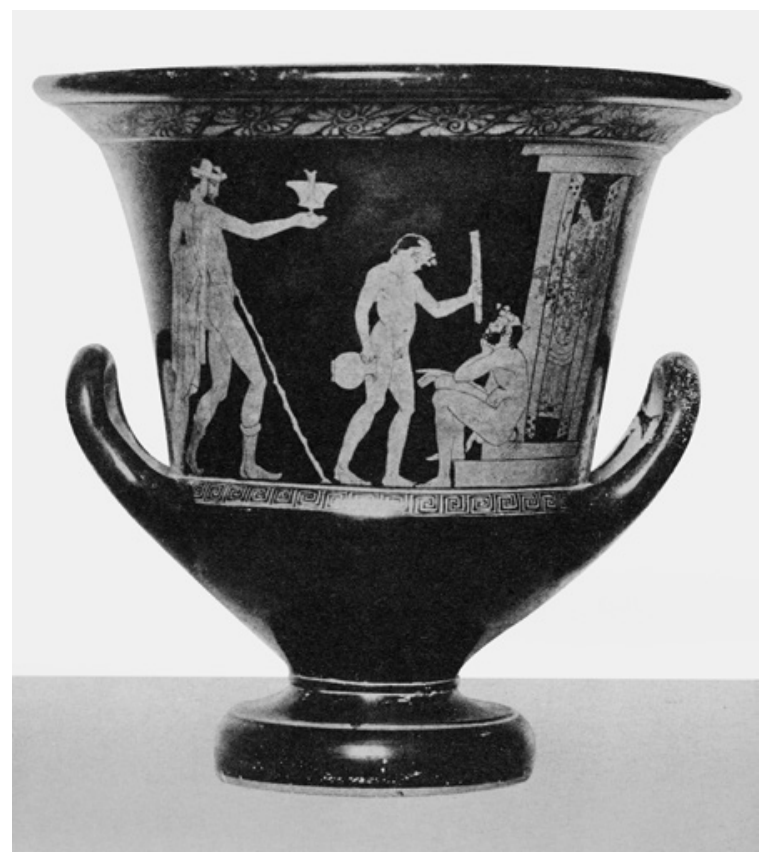

FIGURE 86 Calyx krater, group of Polygnotos, Tarquinia, Museo Nazionale Tarquinense RC 4197, side A (cva Tarquinia 2, pl. 18.3).

A unique image decorates a calyx krater of the Classical period from the circle of Polygnotos (Figure 86). ${ }^{129}$ Dionysos enters on the left. He is shown as a naked, staggering komast, with the kantharos lifted in his right hand and a gnarled stick in his left. A satyr boy with a torch in his left hand and an oinochoe in his right shows him the way to a house. It looks as if he asks the adult satyr who sits on the threshold like a guard for permission to enter. Through the halfopen door we see a seated woman, who seems to gesture with her right hand to be quiet. Her body is shown in frontal view, but her face is turned to the left. On the reverse a mature satyr, dressed as a citizen in a himation, moves in the same direction as the couple on the main side between a gesticulating woman and a woman holding a torch. It is difficult to decide whether both scenes are related. It also remains an open question whether the scene on the main side should be interpreted as the marriage of Dionysos and the Basilinna, a ritual that belongs to the Dionysiac spring festival of the Anthesteria. This interpretation could find support in the oinochoe carried by the boy satyr. ${ }^{130}$ For our

129 Tarquinia RC 4197: Addenda 322 (1057.96); BA 213726; Paul-Zinserling 1994, 44.

130 Simon 1963, 21, pl. 5.3. 


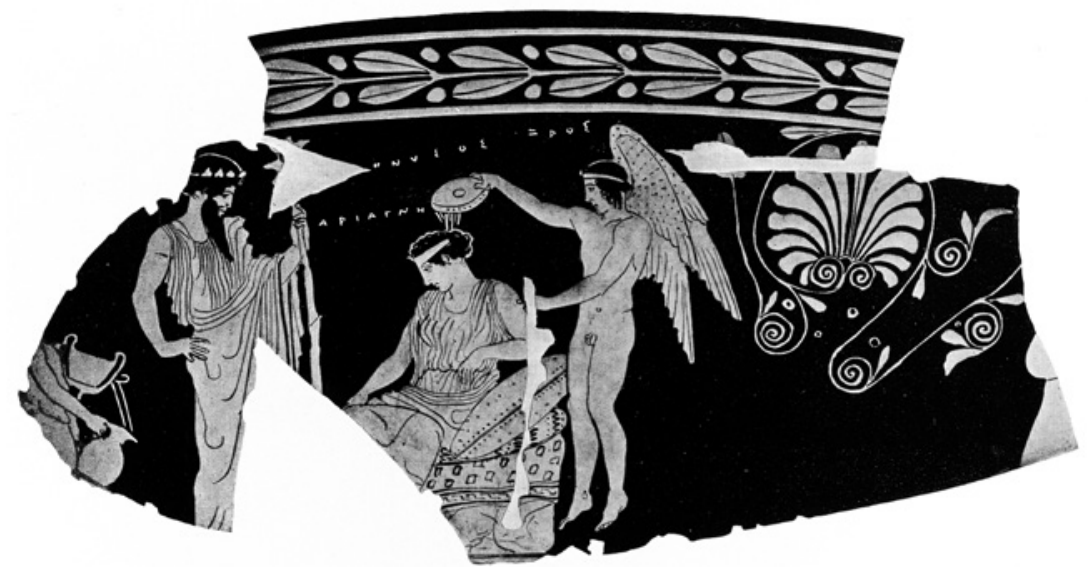

FIGURE 87 Fragment of a calyx krater, group of Polygnotos, Tübingen, Institut für Klassische Archäologie der Universität 5439 (AE 1937, pl. 1).

present purpose, however, it is not as important as the presence of a boy satyr and an adult one within the same scene. The image on a calyx krater from the same workshop, now in a fragmentary state, was probably comparable (Figure 87 ). ${ }^{131}$ It shows a young woman sitting on a bed with a pillow and a mattress. Before her stands Dionysos, crowned with ivy, leaning on the thyrsos in his left hand. Eros comes flying from the right behind the woman. He holds a phiale over her head and touches her upper arm. To the left of Dionysos we find what seems to be a small satyr, unfortunately badly preserved, with an oinochoe in his right hand and a kantharos in his left.

We already discussed Dionysos personally taking care of a boy satyr, as portrayed on a bell krater from the circle of Polygnotos. ${ }^{132}$ The name Komos seems rather suitable for the little satyr who, as an adult, will certainly take part in komoi. Once again the identity of the individual figures remains ambivalent, which seems to hold good for all denizens of the Dionysiac sphere. Instead of clarifying, the inscribed names rather serve to confirm this ambivalence.

A large chous by the Eretria Painter shows Dionysos and Hephaistos riding a mule. ${ }^{133}$ It enters on the right, led by a boy satyr, who looks back and

131 Tübingen 5439: Addenda 322 (1057.97); BA 213727. With respect to content, this image is very similar to the one by the Kadmos Painter showing Dionyos as the bridegroom, see above Chapter 5 , note 116 .

132 See above note 99.

133 See below Chapter 8, note 48 . 


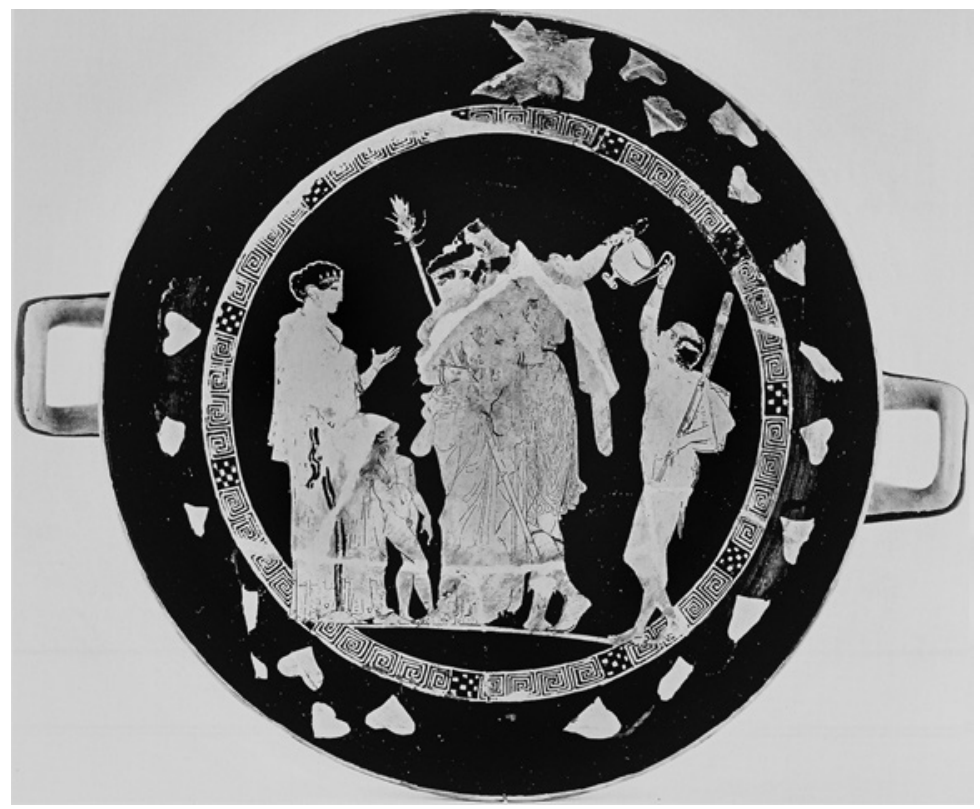

FIgURE 88 Cup, Kodros Painter, Würzburg, Martin von Wagner Museum der Universität H 4616, inside image (Avramidou 2011, pl. 21a).

raises his thyrsos as if it is a banner. An adult satyr playing the aulos leads the procession. ${ }^{134}$

The inside image of an extremely fine cup by the Kodros Painter from around 420 BC forms a worthy conclusion to this series (Figure 88). ${ }^{135}$ The Kodros Painter was the leading cup painter of the Parthenon period; he also created the beautiful scene with the divine symposium discussed earlier. ${ }^{136}$ In the center of this tondo a euphoric Dionysos leans heavily on his companion, who can be no other than Ariadne. He lifts a kantharos by its handle and seems on the verge of handing it to a boy-like satyr named Komos, who stands on the right with a torch in his left arm. Ariadne, however, looks towards the left. She is apparently engaged in conversation with a quietly standing woman wearing a sumptuous diadem and a heavy peplos. She is named as Pethon (possibly for Peitho). A young boy is leaning against her. He is called Pophs

\footnotetext{
134 New York 08.258.22: Addenda 354 (1249.12); BA 216948.

135 Würzburg H 4616 (491): Addenda 356 (1270.17); BA 217226; Shapiro 1993, 257, no. 118; PaulZinserling 1994, $41 \mathrm{f}$.

136 See above Chapter 5 , note 42 .
} 
(possibly Pothos), and looks up at Ariadne. ${ }^{137}$ The boy has neither the ear nor the tail of a satyr. Peitho und Pothos ('persuasion' and 'desire') are figures who belong to the circle of Aphrodite. The relationship between her circle and that of Dionysos, especially in the context of his love for Ariadne, is well known and supports the proposed interpretation of the inscriptions. However, as we have seen, in vase paintings gods and humans are sometimes brought together: Pethon could just as well be a prototypical Athenian woman, who presents her son (whose name could also be Posthon as on the calyx krater by the Villa Giulia Painter mentioned above) to the divine couple at some festive occasion.

In the eyes of François Lissarrague, who focused on the playful irony of satyr imagery, vase painters used the figure of the satyr child as a device to breach the boundaries of the polis and put into question the conventions of age and gender. His conclusion is plausible: “... le monde des satyres est un monde enfantin, un monde du jeu qui brouille sous forme plaisante l'image de l'identité masculine, virile et adulte du citoyen." ${ }^{138}$ This ties in with the fact that-as we have established for the first half of the century -in the minds of the vase painters and their original clients, satyrs perform the same acts, whether meritorious or dubious, as human men. ${ }^{139}$ The series presented here, which clearly stands out when one systematically investigates the whole iconography, has two other salient aspects. First, satyrs can be old, young or childlike, and therefore, like humans, move through various stages of the life cycle and experience the necessary Dionysiac changes. Secondly, satyrs make their appearance in contexts with obvious ritual connotations, and within those contexts their behavior is quite different from that shown in most thiasos images found on cups. Thus, they are not, with the father figure Silenus, the ageless beings of the mythical world of the past evoked in satyr plays, and neither can they only be found on the stage, separated from the audience. ${ }^{140}$ They also belong in the here and now of the original viewers of the vase imagery. They live in this world - as we had already established for the dancers and satyrs of the early 6th century-, a world permeated by the power of Dionsyos, where identities are in flux, where men appear as satyrs and satyrs as citizens. ${ }^{141}$ And satyrs can even be seen to play a ritually important role in all this.

\footnotetext{
137 Lezzi-Hafter 1985.

138 Lissarrague 1998, 193-196; for satyrs of various ages see also Lissarrague 2013, 63-66.

139 See above Chapter 3, p. $5^{1}$ f. and p. 67 f.

140 Which is the gist of the argumentation of Hedreen 1992, $155 \mathrm{f}$.

141 Isler-Kerényi 2004a, 33.
} 


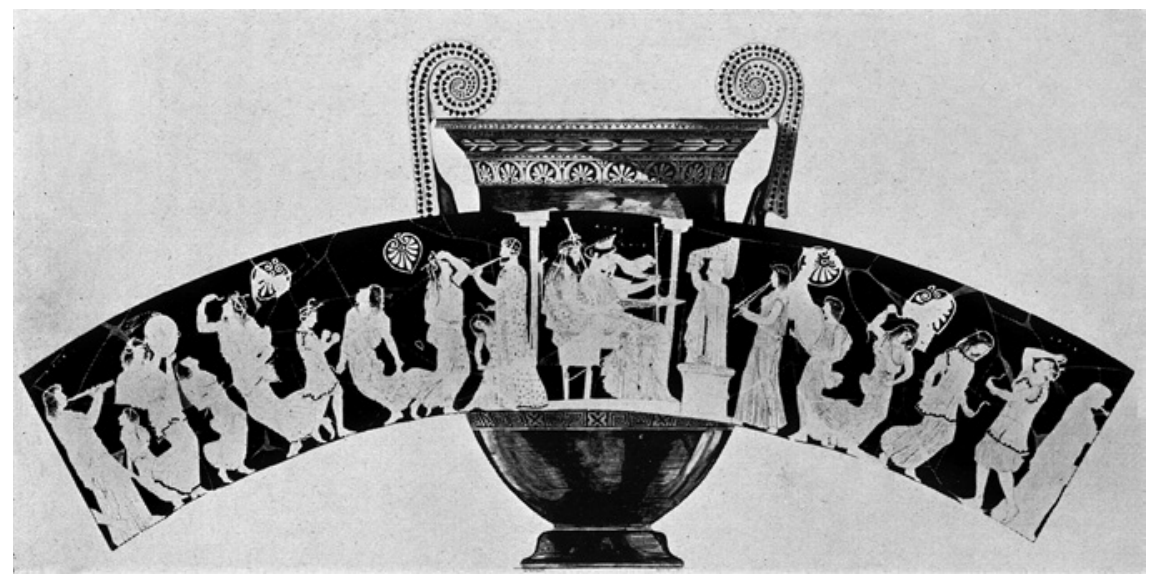

FIgURE 89 Volute krater, Curti Painter, Ferrara, Museo Archeologico Nazionale di Spina 2897, scroll showing both sides (Aurigemma 196o, pl. 22a).

\section{A Ritually Honored Etruscan Dionysos}

We repeatedly touched upon the issue of the reception of Greek vases and their imagery by an Eruscan clientele, for instance when we discussed the stamnoi with women ritually engaged before a temporary Dionysos idol or the Kodros cup with divine couples as symposiasts. ${ }^{142}$ The problem of the relationship between the Athenian vase painters and their Italian customers can be illuminated with the help of one of the most famous vases of the Classical period (Figure 89). ${ }^{143}$

The vase in question is a splendid volute krater, now attributed to the Curti Painter from the circle of Polygnotos and dated to shortly after 430 BC. ${ }^{144}$ It was found with other Attic red-figure vases, including a unique phallus vase as well as older Etruscan symposium utensils, in an extremely rich grave in the necropolis of Spina. ${ }^{145}$ Scholarship has so far neglected this important fact about the context of our vase. The questions of authorship, date, and especially the identification of the main figures have been approached as if this vase came from an Attic necropolis. The central element of the vase's iconography, a god enthroned, is quite problematic when considered in relation to the rest of the decoration. This may be divided into three parts. In the center of the

\footnotetext{
142 See above p. $130 \mathrm{f}$. and Chapter 5 , note 46.

143 Ferrara 2897: Addenda 322 (1052.25); BA 213655; LIMC III, Dionysos 869.

144 Halm-Tisserant 1984, 137 and $153 \mathrm{f}$.

145 A detailed interpretation, based on extensive iconographic research may be found in Isler-Kerényi 2002a and 2003.
} 
image a divine couple sits on a base between two pillars indicating a building. From the right approach, with measured pace, three female figures of various ages. The oldest woman, who leads the procession, carries on her head a liknon covered with a cloth; the second, younger one plays the aulos; the third one, a young girl, carries a tympanon. This obviously refers to some mystery cult. On the reverse a thiasos of twelve individuals, women and men, children and adults, dances ecstatically to the music of the aulos played by a musician who stands behind the seated gods, and by another, female, musician in the center of the image. The sound of the aulos is accompanied by the tympanon and cymbals held high by a boy under the left handle of the vase. ${ }^{146}$ Obviously, a very noisy affair. Some of the participants wear the ependytes, a colorfully embroidered short garment which makes an exotic impression. Most of them hold live snakes in their hands or have diadems with snakes on their heads. Such a diadem is also worn by the enthroned god. The Greeks associated this type of headdress with the Erinyes, the emissaries of the underworld.

On the one hand the god looks like Zeus, on the other like Hades. He cannot be Dionysos, because he holds a phiale instead of a kantharos, and a scepter instead of a thyrsos. Moreover, he does not wear an ivy wreath or a headband, but this remarkable snake diadem. His partner is represented supporting a lion on her lower arm. Because of this she has been identified as Kybele, a goddess from Asia Minor, and consequently her male partner as Sabazios-a god whose ecstatic cult had newly arrived in Athens towards the end of the $5^{\text {th }}$ century. ${ }^{147}$ However, women joining Dionysos in the battle against the giants or Dionysiac nymphs also carry lions in this manner. ${ }^{148}$ Seen from the perspective of Greek iconography, this god looks most like Hades, also because he sits inside a house. His partner would then be identified as Persephone.

But when considering the non-Greek clients, we come up against the problem that there is no iconography of the Etruscan Fufluns, that is, independent of that of the Greek Dionysos. From the Etruscan dedications on imported Greek ceramics already mentioned above one can conclude with certainty that at the time our krater was made, there was a mystery cult at Vulci for Dionysos assimilated with Fufluns. ${ }^{149}$ What we know of Etruscan religion in general allows us to state that this god had the same characteristics as the Greek Dionysos: the symbolism of grapes and wine, the symposium, ecstatic ritual,

146 Concerning the cymbals see above note 20.

147 In this way Halm-Tisserant 1984, 153.

148 Rausa 1991, 57; Carpenter 1997, 72.

149 See above note 34. The graffiti on a column krater found in Pyrgi are also very instructive, see Isler-Kerényi 2003, 45 . 
and, mediated by the figure of the satyr, male sexuality mostly as an expression of playful vitality. The latter aspect is represented amongst the Spina grave goods by a vase with a unique shape: a kind of tea mug with a sieve, decorated with erotic symposium scenes and with three large, plastically formed erect phalloi attached to its shoulder: a clear allusion to the hoped-for vitality. ${ }^{150}$ In addition, there is the relationship between Fufluns and the world of death, which was much stronger in the case of the Etruscans. Our krater makes this clear in the prominent place of the snakes in the ecstatic ritual. An Etruscan red-figure cup from Montepulciano, some three generations younger, shows Fufluns, slightly tipsy, in a symposium context. He is supported by a satyr, who wears the same snake diadem as the god on the Attic volute krater. ${ }^{151}$

If the enthroned god is supposed to be the Etruscan Fufluns instead of the Greek Dionysos, we must conclude that the volute krater-and, incidentally, the phallus pot-was made and decorated at the Kerameikos after the precise instructions of an Etruscan customer. Because the Curti Painter probably only had a very general knowledge of his client's cultural background, he combined disparate iconographical elements into this figure of a Hades-like Dionysos, venerated by exotic people of various ages, who was expected to bring succor to a wealthy citizen of Spina in his grave. Thus, the image of Dionysos was not set in stone, but could be adapted to the historical circumstances and culture of its beholders. This explains why this god of Athens and of Greece was enthusiastically adopted and venerated for centuries on the other side of the Adriatic. ${ }^{152}$ And it is not surprising that even in Athens itself, on the Parthenon, the god could be presented in an unfamiliar guise-which was immediately taken up by the vase painters, as we will see in the next chapter.

\footnotetext{
$150 \quad$ Isler-Kerényi 2002a, 79 f., 87 , fig. 7.

$15^{1}$ Isler-Kerényi 2002a, 81 and 87 , fig. 8. A similar snake diadem is worn by a female figure in a context that is unfortunately unknown on a fragment of an Attic column krater from Lokri, dated around 450-440 (Reggio Calabria, without inventory number): Giudice 2007, 114, no. 190.

$15^{2}$ Compare Bonfante 1993, whose ideas of Fufluns as a vegetation deity probably simplify matters too much. For the adoption of the iconography and cult of Dionysos in the Etruscan cities to the north of the Apennines, see Pizzirani 2009.
} 


\section{A New Dionysos at the Parthenon}

\section{Decoration Program and Message}

Around $450 \mathrm{BC}$ it was decided to erect a large new temple for the city goddess Athena and to provide it with sumptuous sculptural decorations. ${ }^{1}$ Dionysos appears thrice, like the other important deities of the Greek pantheon in each instance on the east, i.e. front, side of the building where the entrance was situated: in one of the metopes of the peripheral colonnade, in the pediment, and in the frieze around the upper edge of the outer wall of the cella. ${ }^{2}$ There can, therefore, be no doubt as to the significance of Dionysos at the time. As the polytheistic systems of Antiquity and the societies that supported them were subject to the constant shifts and changes resulting from historical developments, what image of the god the polis sought to present in a prominent representative building of this kind is a question of considerable importance. Even more so because it was at the Parthenon that Dionysos was first represented as a young god, a new form which, as we will see, would be of permanent influence for other artistic media, especially vase painting. ${ }^{3}$

In order to properly understand this alteration of the Dionysiac image, we should try to grasp the meaning of the sculptural decoration of the Parthenon as a whole. Before we embark on the analysis of each of the Dionysos images, we will therefore briefly explore the decoration program and its possible relationship with the political context of the time. ${ }^{4}$

The 92 metopes were the oldest of the building's decorations and the ones that were closest to the viewer. They showed the great battles of primeval times: on the east side the gods versus the giants, in the south the heroes versus the centaurs, in the west the Attic hero, Theseus, versus the amazons, and in the north the Greeks versus the Trojans. These battles mark subsequent stages in the development of the world order as seen by the Greeks at the time: the

1 Grütter 1958, 121; Welwei 1999, 120 f.; Schneider/Höcker 2001, 113; Hurwit 2004, 94 (towards the end of the year 449); Jenkins 2006, 76. Compare Isler-Kerényi 2010a, largely unmodified.

2 That Dionysos (and the other gods) appeared in all three of the sculpted fields of the east side, was probably meant as a stimulus for the viewer to make comparisons, see Osborne 1994, $148 \mathrm{f}$.

3 Carpenter 1997, 85; See below Chapters 8 and 9.

4 Rolley 1999, 69-86; Schneider/Höcker 2001, 142-152 (and the relevant literature pp. 229-231). 
order of Zeus. The rebellion of the giants against the Olympian gods had been the biggest threat to that order; the Trojan War was nearest in time to the present. The battles with the centaurs and the amazons had presented opportunities for the heroes to distinguish themselves - the heroes, who, as children of gods and founders of prominent families of humans, were the protagonists of the transition from the age of the gods to present time. ${ }^{5}$ The two pediments reminded the viewers of two mythical events, which formed the basis of Athens' pre-eminent position in the world: in the east the birth of the city's patron goddess Athena from the head of her father Zeus, in the west Zeus' final decision in the dispute between Athena and Poseidon about the domination of Attica. ${ }^{6}$ The frieze shows an idealized representation of the procession which was the culmination of the Panathenaic festival, the main festival dedicated to Athena; the imagery of the frieze was very likely inspired by it. This festival, commemorating the birth of the goddess, was celebrated every year and every fourth year with special pomp and circumstance. ${ }^{7}$ Recurrent themes of the sculptural decoration of the Parthenon are, therefore: battle, the pre-eminence of Athens, the end of the struggle, the celebration of harmony.

A look at the position of Athens at the time of the conception and planning of the decoration is instructive. As we know, work on the Parthenon started in the year 447; it must have been preceded by a period of design and organization. We should therefore ask ourselves what motivated Phidias and his patrons to come up with the image program described above and simultaneously revolutionize the traditional image of Dionysos. The building of the Parthenon followed the transfer of the treasury of the Delian League from Delos to Athens in $454 \mathrm{BC}$. Athens was its most important member and the new building on the Acropolis was meant for the treasury's safekeeping; the transfer allegedly protected the funds from the Persian arch-enemy. Shortly afterwards Athens organized military campaigns against the Persians in Egypt and Cyprus. ${ }^{8}$ The Egyptian fiasco seems to have brought about a change of mind within Athenian politics, because, in whatever way one dates the individual events,

5 Brelich 1958, 386-389 (= 2010, 306-309). Compare Rudhardt 1978, 1: “Cet 'illud tempus' (= le temps mythique) comprend plusieurs moments successifs, parfaitement distincts, et les événements mythiques ne se situent pas tous au même moment dans cette série."

6 Knell 1990, 119; Grütter 1997, 122 f.; Rolley 1999, 78; Palagia 2005, 252. That the west pediment does not show the rivalry between Athena and Poseidon, but the end of the conflict, is evident from a superb Attic hydria found in Pella, see below note 88.

7 Hurwit 2004, 236: “... a distillation of the many processions [...] that characterized Athenian life in the age of Pericles..." For Wesenberg's new interpretation of the scene in the center of the east pediment, see below note 79 .

8 Welwei 1999, 101-107. 
it is clear that around $450 \mathrm{BC}$. Athens launched a series of initiatives the aim of which was to obtain a permanent peace. ${ }^{9}$ A truce with Sparta was arranged in $45^{2} / 1$, followed by the Thirty Years' Peace in $446 / 5{ }^{10}$ The so-called Peace of Kallias between the Delian League and Persia is generally dated in 450/449. This was followed by an invitation to "the Greeks of Europe and Asia" to attend a peace conference in Athens. ${ }^{11}$ The decision to build the Parthenon belongs to this political context. ${ }^{12}$ It is plausible that the idea of a pax atheniensis as the outcome of the many battles of gods and heroes was the common denominator of the decoration program of the Parthenon.

\section{Dionysos' Gigantomachy}

When the Parthenon was converted into a Christian church, the metopes on the east side were (deliberately) so heavily damaged as to be unrecognizable. As they remained in situ, however, we can be certain of the situation of the Dionysos metope: the second on the left, near the south edge of the row, in one field of vision with the Dionysos in the east pediment. ${ }^{13}$ Praschniker's suggestions for the metope's reconstruction (including the elucidative drawing) of 1928 largely retain their value, all the more so because they are in accordance with the corresponding, somewhat older, vase paintings. ${ }^{14}$ Dionysos, wearing a short chiton and coming from the left, menaces his adversary. He is assisted by a panther and a snake and probably uses his thyrsos as a weapon (Figure 90). ${ }^{15}$ A bearded Dionysos in a short chiton already appeared a hundred years earlier in the Gigantomachy of the Siphnian treasury in Delphi. ${ }^{16}$ In addition, he is represented in this way in most of the vase paintings of the $5^{\text {th century. }}{ }^{17}$ It is uncertain whether the Dionysos of the Parthenon metope is already a beardless

\footnotetext{
$9 \quad$ Raubitschek 1979.

$10 \quad$ Welwei 1999, 105 and 125; Will 1995, 59.

11 Plutarch, Perikles 17: Welwei 1999, 120; Musti 2008, $354 \mathrm{f.}$

12 Welwei 1999, 120-121; Will 1995, 58; Castriota 1992, 137.

13 Berger 1986, 55 f.; Schwab 2005, 165.

14 Praschniker 1928, 192, fig. 119. See for Dionysos' Gigantomachy in vase painting: LIMC III, Dionysos 6o9-650, 655, 656; Carpenter 1997, 15-34.

15 Carpenter 1997, 87. For more information on Dionysos' Gigantomachy, see Paul-Zinserling 1994, 35-37.

16 LIMC III, Dionysos 651.

17 Very exceptionally, Dionysos Gigantomachos is completely naked on the kyathos, Berlin F 2321: ARV 333.3: Schlesier/Schwarzmaier 2008, 75 fig. 5; 187 Cat. 37. He wears a long chiton in the Paris cup Cab. Méd. 573: Addenda 234 (417.1); BA 204546; LIMC III, Dionysos 648.
} 


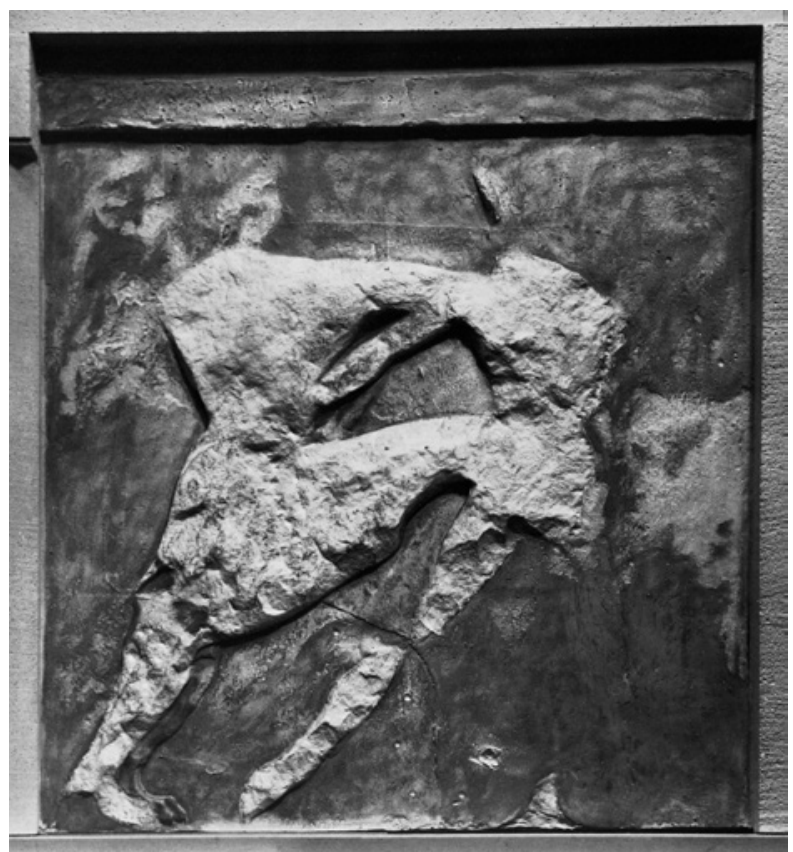

$a$

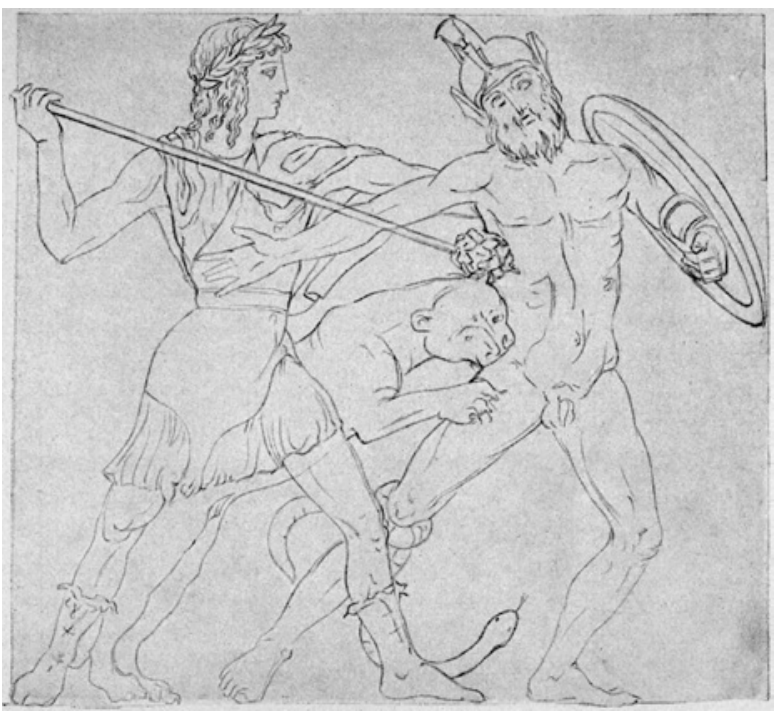

$b$

FIGURE 90 Parthenon, metope east 2: Dionysos' Gigantomachy.

a. plaster cast, Basel, Skulpturhalle (Berger 1986, pl. 4oe).

b. reconstruction by Praschniker (Praschniker 1928, 192, fig. 119). 
youth, as in the east pediment, or still bearded, as in the vase paintings. It would not be surprising if the latter were the case: the metopes, as I have already mentioned, stylistically belong to the older parts of the Parthenon decoration. ${ }^{18}$ What distinguishes Dionysos from the other gods in the Gigantomachy is the fact that the enemy seems overcome by the animals that accompany him, rather than by the strength of the god himself.

\section{Dionysos in the East Pediment}

Apart from a few fragments, the figures from the center of the pediment have been lost. In what way the great event of the birth of Athena was represented at the Parthenon is, therefore, likely to remain an open question. ${ }^{19}$ From what is left we can only conclude that a dramatic sweeping movement emanated from the central event to both sides, which slows to a halt in the three reclining figures nearest the ends of the pediment and is finally 'absorbed' in the corners by the teams of the ascending Helios en the descending Selene. That the young man reclining just in front of the heads of the horses of Helios' team must be Dionysos can be maintained on the basis of the history of the imagery of the birth of Athena as well as his hairstyle, as we will see. There can, therefore, be no doubt as to his position within the whole. ${ }^{20}$ A Dionysos reposing after a successful hunt eminently suits the political climate of the time and the pax atheniensis initiated by Perikles. At the same time, his line of vision includes the theater of Dionysos on the south side of the Acropolis and in this way the relationship between the god and 'his' theater is confirmed and secured. ${ }^{21}$ The theater was only erected in stone more than a hundred years after the completion of the Parthenon, more or less as it remains now. ${ }^{22}$ We may, however, presume that, during the $5^{\text {th }}$ century, the performances which were part of the Dionysian festival took place at the same site, near the venerable temenos of Dionysos. ${ }^{23}$

18 Rolley 1999, 68; Schwab 2005, 160.

19 Rolley 1999, 74-76; Schneider/Höcker 2001, 142; Palagia 2005, 242 and note 78; Jenkins 2006, 87-91 See above 8 note 34 .

20 Arguments for and against identification as Dionysos or Herakles are summarized in Traficante 2007, 77-89.

21 Most recently Queyrel 2006, $221 \mathrm{f}$.

22 Isler 2002, 535.

23 Kolb 1981, 92. 
In what way is Dionysos represented? He presents himself here as a young athletic adult, in a relaxed half-reclining position: the image type of the symposiast. The object that supports his back is covered by an animal skin, probably that of a panther, which strengthens the idea that he is conceived as a successful hunter. He is the only figure in the east pediment whose head remains, even though it is now so worn away as to seem too small. It has been assumed he wore his hair cropped as was usual for athletes, and is appropriate for his body type. ${ }^{24}$ His exact hairstyle has been lost, however, and so have the attributes he probably carried. The body in itself, however, also presents iconographical problems, because in vase painting the symposiast Dionysos was, neither before nor after, represented fully naked. ${ }^{25}$ One gets the impression the sculptor wanted to draw the attention to the manly beauty of his body. However, Dionysos' fine body can only have been seen and admired during the time preceding the placement of the figure in the pediment. After that, his most striking feature must have been his legs which rather protruded from the pediment. ${ }^{26}$ We will come back to the beauty of Dionysos below.

Moreover, at the time of the planning and execution of the east pediment, Dionysos as a young man was even rarer than Dionysos as a nude symposiast. As the work of, for instance, the Kleophon Painter demonstrated, even around $440 \mathrm{BC}$, the god was usually represented as a dignified bearded father and/ or spouse. ${ }^{27}$ Every scholar involved in the history of Dionysiac imagery has been struck by the abrupt change in his appearance after 430 вс. Naturally, the change was attributed to the influence of the Parthenon sculptures, which, as we all know, were completed in $432 \mathrm{BC}$ and were since there for all to admire. ${ }^{28}$ What did the Dionysos of the east pediment of the Parthenon look like at that time? The photographs of the badly eroded throat and neck areas published by E. Pochmarski in 1984 have already shown that Dionysos' hairstyle was not the cropped head of the athlete. ${ }^{29}$ In addition, more recent photographs of the old cast in the archeological collection of the University of Zurich clearly show the original center parting over the forehead and, when the head is seen in

\footnotetext{
24 According to Brommer 1963, 9, Furtwängler already did so.

25 LIMC III, Dionysos No. 362-381. This also holds true for other symposiasts, see Dentzer 1982, pl. 19-22; 25-29; 44-117. For an example of a naked symposiast (Herakles): pl. 118, fig. 729 .

26 Brommer $1963,8$.

27 Compare for instance the Dionysos figures by the Kodros and the Kleophon Painter: cup London E 82 (Addenda 356 [1269.3]; BA 217212); pelike Munich 2361 (Addenda 335 [1145.36]; BA 215176).

28 For instance Carpenter 1997, 85; Traficante 2007, 77.

29 Pochmarski 1984, 278-280, pl. 26, 2 and 3.
} 
profile, the contour of the plaits horizontally attached to the back of the head (Figure 91). ${ }^{30}$ It is probably for this reason that J. Neils assumes Dionysos also wore the old-fashioned plaits fastened around the head that can be seen in the figures of the handsome elderly men in the north frieze of the Parthenon. ${ }^{31}$ It seems to me, however, that Pochmarski's documentation rather suggests a hairstyle comparable to that of the Acropolis Apollo Parnopios, attributed to Phidias. ${ }^{32}$ This hairstyle would not only reconcile the proportions of the head with to those of the body; it would also be in accordance with the usual representation of Dionysos in vase painting after 430 BC: the oeuvre of the Dinos Painter presents some good examples, which belong to the earliest representatives of the new iconography. ${ }^{33} \mathrm{~A}$ miniature version of the Dionysos of the east pediment may be found on a bronze mirror from Southern Italy datable to the 4th century, now in Copenhagen. He wears the 'Apollo hairstyle' and has boots on his legs (Figure 92). ${ }^{34}$ This figure of a young Dionysos, nude and with 'Apollo hairstyle', but standing, was then taken over by late Classical and Imperial-period sculptors. ${ }^{35}$

The fact that the young man wears his hair long rules out the identification with Herakles, which on the basis of the iconographical tradition of the birth of Athena was improbable anyway. ${ }^{36}$ In addition there are the suggestions made as to the way the attributes - cup or kantharos, and thyrsos - may have been held: from the position of the lower right arm we can conclude that the vessel belonged on this side and that the left arm therefore held the staff. This is supported by examples from vase painting. ${ }^{37}$

This reconstruction of the Dionysos in the east pediment of the Parthenon marks him out as a son figure instead of the traditional father or spouse and, first of all, defines Dionysos as the son of Zeus. For the Greeks Zeus was representative of the current cosmic order. Mythology abounds in love affairs

$30 \quad$ See also Jenkins 2007,49 and 51 .

31 Neils 2005, 238.

32 Hurwit 2005, 140 also describes figure D as a "longhaired nude youth". For the hairstyle of Phidias' Apollo see Pfeiff 1943, pls. 31-33; Rolley 1994, 13, fig. 9.

33 See the calyx krater Vienna 1024: ARV 1152.8; BA 215261. Also the dinos Berlin F 2402: Addenda 336 (1152.3); BA 215255. About the Dinos Painter, see below chapter 8.

34 Copenhagen 4833: LIMC III, Dionysos 137. These boots would explain the holes in the lower legs of the Parthenon Dionysos observed by D. Williams (probably the ones described by Brommer 1963, 3). Compare in addition the statue (unfortunately without head and attributes) from the 3 rd century BC in Olympia: LIMC III, Dionysos 142. LIMC III, Dionysos 119-125 and 128.

36 See above note 20.

37 For the cup by the Kodros Painter, see above Chapter 5 , note 42; for the bell krater in Budapest 50.568: ARV 1439.1; BA 218088; Kathariou 2002, 413 fig. 54. 


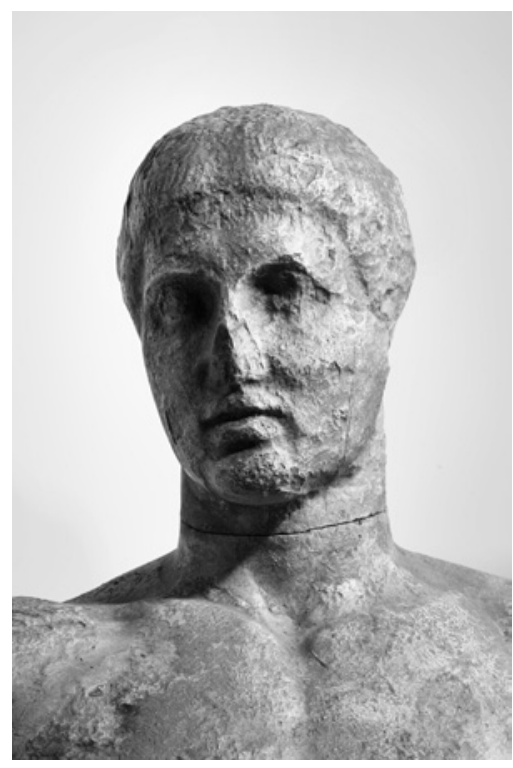

a

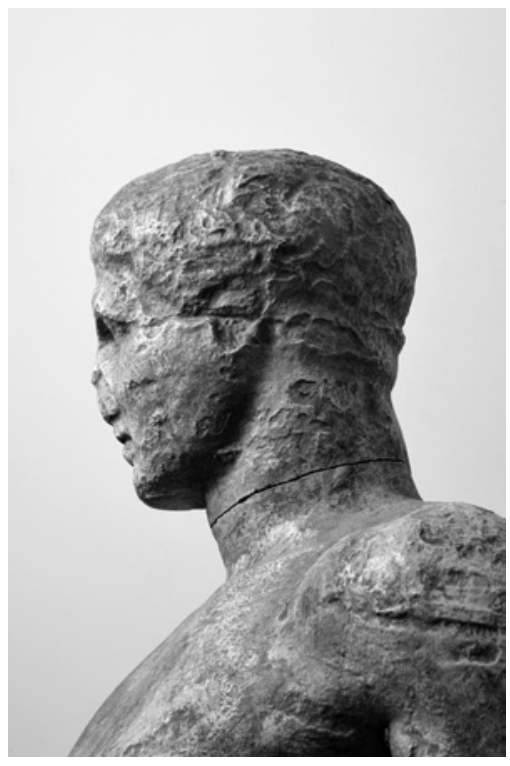

$b$

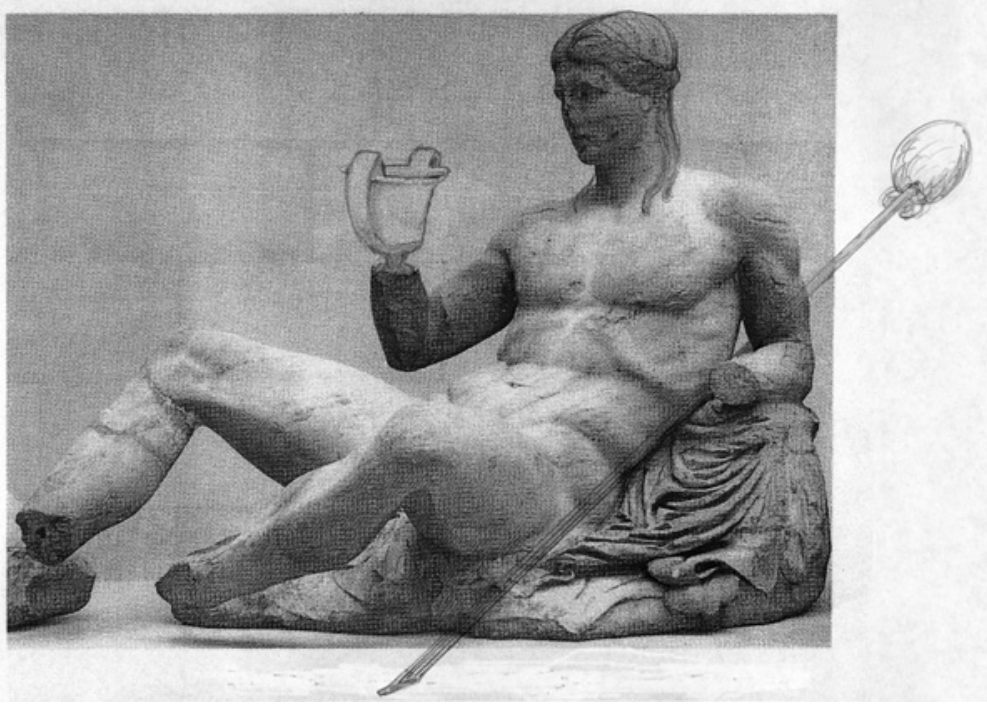

c

FIGURE 91 Parthenon, east pediment, Dionysos. Plaster cast in the archaeological collection of the University of Zurich, made before 1871.

a. frontal view of the head (photograph Archäologisches Institut der Universität Zürich, Frank Tomio).

b. profile view of the head from the left (photograph Archäologisches Institut der Universität Zürich, Frank Tomio).

c. Dionysos (reconstruction by C. Isler-Kerényi). 


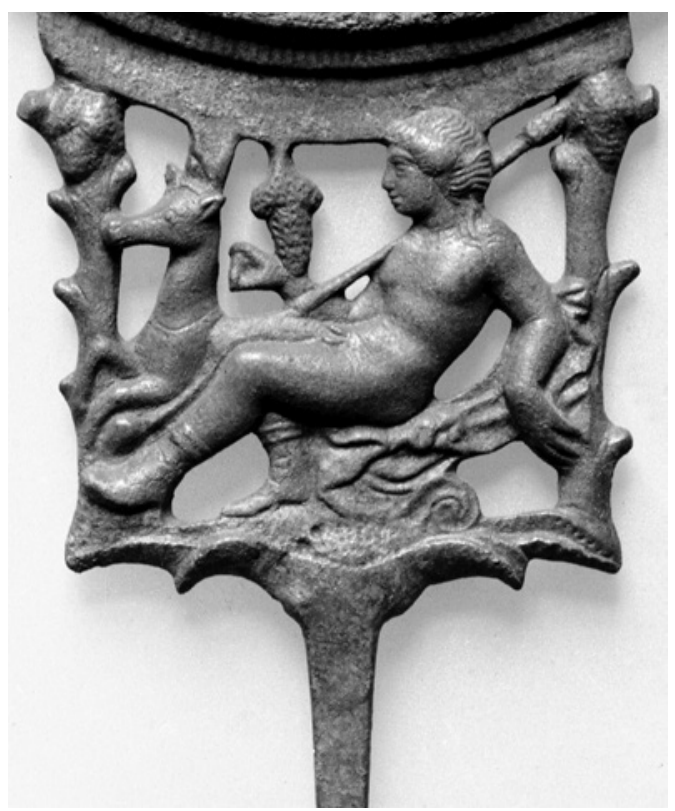

FIGURE 92 Handle of a bronze mirror, Copenhagen, The National Museum of Denmark 4833 (photograph museum).

and the children that resulted. However, none of Zeus' children had divine offspring: at best they produced heroes, of immortal fame perhaps, but nevertheless mortals who, in their turn, sired mortals. Zeus' sovereignty could therefore not be contested and he could not be dethroned, like he had dethroned his own father Kronos, who had dethroned his father Uranos. ${ }^{38}$ The sons of Zeus, who as father figures could never be on a par with him, were in this way guarantors of the future of the order of Zeus. Naturally, Zeus' daughter Athena also belonged to this order. The east pediment of the Parthenon was meant to show the Athenians, their allies and their subjects, as well as every visitor that, within the order of Zeus, the birth of Athena inaugurated a new era under the direction of the city whose patroness she was.

The transformation of Dionysos into a son figure must, at the time, have made a considerable impression on the beholders: vase painting after 430 abundantly testifies to this, as we will see. The change cannot, however, have been completely unanticipated. We have already discussed some representations of Dionysos as a naked komast: on the column krater by the Agrigento Painter, on the bell krater by the Methyse Painter in a ritual procession with 
satyrs and Dionysiac women, on the calyx krater from Tarquinia with the midnight visit. ${ }^{39}$ As we have seen, the motif of the infant Dionysos-especially Dionysos as the child of Zeus-was topical in the years around 450 вС. ${ }^{40}$

In the east pediment of the Parthenon Dionysos presents himself as the son of Zeus and therefore as the brother of Apollo. Evidence from various art forms makes it clear that this is not a modern projection influenced by Nietzsche's ideas, but a reality of that time. ${ }^{41}$ In vase painting, just after $440 \mathrm{BC}$, we find a Dionysos who, in the role of punisher of Pentheus, shows a startling resemblance to Apollo in the role of punisher of Marsyas. ${ }^{42}$ As far as coin engraving is concerned: Walter Burkert already pointed out that coins from Naxos from around $460 \mathrm{BC}$ still had the traditional bearded head of Dionysos, but that after $420 \mathrm{BC}$ the god was deliberately made to look like Apollo (Figure 93). ${ }^{43}$

The increased similarity to his brother Apollo first of all has a mythological explanation. In the decades after the Persian Wars, Apollo was generally seen as the one who, among the sons of Zeus, enforced his father's order in times of crisis: he took center stage in the west pediment of the temple of Zeus at Olympia (where, significantly, another protagonist is Theseus, the founder of Athens), completed some years before the Parthenon. Phidias was commissioned to make the cult statue of Zeus - the same Phidias created the statue of Athena at the Parthenon. ${ }^{44}$ In Athens Dionysos had held a comparable role as guarantor of the order of Zeus since the time of Solon. ${ }^{45}$ If Phidias and/or Perikles had the intention to proclaim a new permanent world order under the

39 Rome, Villa Giulia 846: ARV 575.20; BA 206620 (Agrigento Painter); New York 07.286.85: ARV 632.3; BA 207338 (Methyse Painter); Tarquinia RC 4197: see above Chapter 6, note 129, and in addition the representations of Dionysos as a boy mentioned in Chapter 5 , note 94.

$40 \quad$ See above Chapter 5, p. 111.

41 For the theme of Dionysos versus Apollo in the history of the Altertumswissenschaft, see Isler-Kerényi 2007, 235-254.

42 Lekanis Louvre G 445: BA 45070 (no image); Moraw 1998, pl. 2o, fig. 50c (Dionysos: here p. 202 fig. 106); volute krater by the Kadmos Painter in Ruvo 1093: Addenda 340 (1184.1); BA 215689; Sichtermann 1966, pl. 16 (Apollo). Compare Queyrel 1984, 157 concerning the work of the Pothos Painter who was active around the same time: "N'étaient ses attributs, Dionysos risquerait d'être pris pour Apollon."

43 Burkert 1977, 341; Franke/Hirmer 1972, pl. 4.11 (Dionysos), pl. 4.12 (Apollo), both dated 420-403 вс. Compare in addition the tetradrachms from Maroneia, idem pl. 139.431 V, dated 430-400, as well as the later ones from the same town (LIMC III, Dionysos 194, 195): head of Dionysos with Apollo hairstyle.

44 Hurwit 2005, 140-142.

45 Isler-Kerényi 2007, 75 and 104. 


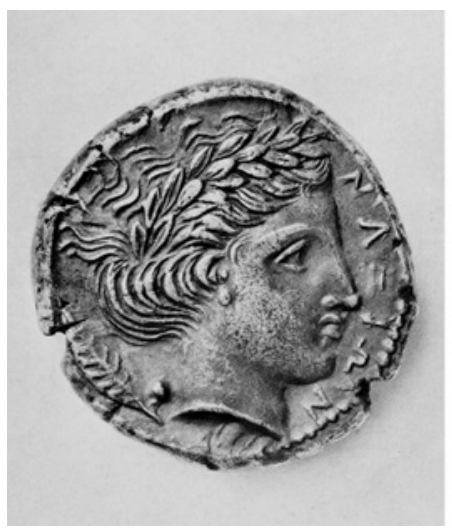

$a$

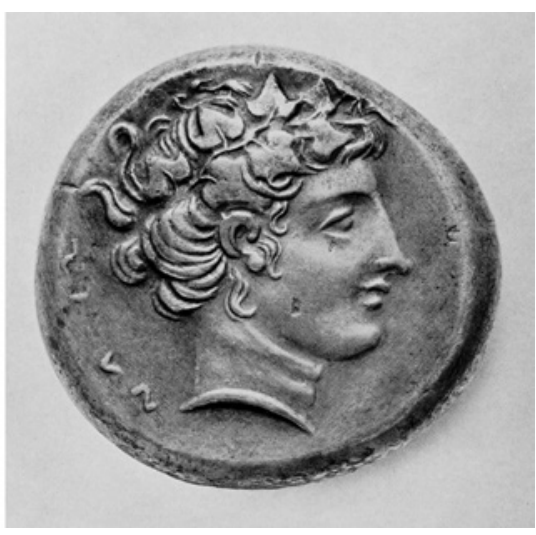

$b$

FIGURE 93 Coins from Naxos (Sicily).

a. didrachma: Apollo (Franke/Hirmer 1972, pl. 4 above left).

b. tetradrachm: Dionysos (Franke/Hirmer 1972, pl. 4 above right).

leadership of Athens, it would be natural to assign a complementary stabilizing task to both Apollo and Dionysos.

On the other hand, Apollo held a very special position in Athens. ${ }^{46} \mathrm{He}$ had four sanctuaries here and was therefore very much present in the city's cultic life. His pre-eminence is also evident in vase painting. Reference to Delos seems logical in this context: this is where the treasury of the Delian League had been kept before it was transferred to Athens and it was the traditional religious center for all Ionians. ${ }^{47}$ Moreover, the transfer of the treasury to Athens-a significant decision in view of the Athenian ambitions-had been the occasion for the building of the Parthenon. It explains why the statue of Athena in the cella of the Parthenon was influenced by the cult statue of Apollo at Delos. ${ }^{48} \mathrm{In}$ addition there is the relationship with Delphi; according to Aischylos, Apollo had traveled from Delos to Delphi via Athens. ${ }^{49}$ As the center of the earth, it was in the 450 s of strategic importance for Athens in its rivalry with Sparta. ${ }^{50}$

46 Shapiro $1989,5^{0-52 .}$

47 For the relationship Athens-Delos before Perikles: Tausend 1992, 52; Ulf 1997, 51 f. After Perikles: Etienne/Braun 2007, $26 \mathrm{f}$.

48 Fehr 1979, 71-80, especially 77: “... die Parthenos nimmt als die jüngere Statue auf das archaische Apollonbild bezug und legt dem Betrachter einen Vergleich nahe."

49 A. $E$ u. $8-11$.

50 Welwei 1999, 122 f. Correspondingly Suàrez de la Torre 2002, 160: "Pendant le Ve siècle, on observe un effort redoublé d'assimilation et de rapprochement des traditions mythiques 
If indeed Perikles intended the conformity of Apollo and Dionysos, it can hardly be a coincidence that the Athenian tragedians of the time made mention of the presence of Dionysos in Delphi. In this context, it is worthwhile to quote a recently published study: "It can be demonstrated that Apollo and Dionysos shared the same sacred spaces, cultic practices and mythical tales, and that their relationship is revealed in their encounter, and their dividing and even exchanging roles."51 The antithesis is not so much between Apollo and Dionysos, as has been maintained ever since Nietzsche, as between these two complementary guarantors of the order of Zeus, and Ares, the god of war. ${ }^{52}$

Incidentally, from the hypothesis proposed above it follows that the reflection and discussion concerning the relationship between Apollo and Dionysos (which lies at the basis of the one-sided interpretation of Dionysos in the study

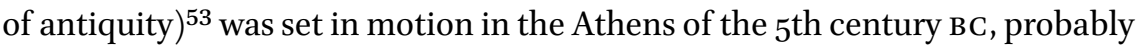
in the circle of Perikles. For this reason it is extremely regrettable that all that remains of the Apollo on the north side of the east pediment of the Parthenon are his tortoise-shell armor, the sounding board of his lyra, and part of the arm that held it. ${ }^{54}$ We do not know in what way he wore his hair and if he resembled Dionysos. ${ }^{55}$ Still, the assembly of gods in the frieze, dilapidated though it may be, still shows very well that their beardlessness distinguishes the sons of Zeus from the father figures Zeus and Poseidon - with the exception of Hephaistos, however, who, as the ancestor of the mythical kings of Athens, was represented as a father figure. ${ }^{56}$

d'Athènes et de Delphes." The oracle played an important part in the development of Athenian power, see Knell 1990, 125. For Delphi as the center of the earth: Parker 1985, 303. Massa 2006-2007, 77: "Da questa analisi è possibile mostrare che Apollo e Dioniso condividevano spazi sacri, pratiche cultuali e racconti mitici e che il loro rapporto si rivelava giocato sull'incontro, sulla condivisione e talvolta persino sullo scambio delle parti." The same holds true for Alkaios and his world: Privitera 1970, 106. The Kadmos Painter may be referring to the reception of Dionysos in Delphi on the calyx krater we will discuss in detail in the next chapter, note 25 fig. 103, and Gasparri 1986, $509 \mathrm{f}$. For instance in Sophokles: Massa 2006-2007, 87 . See above note 41.

54 Despinis 1982, 37-44: the author is of the opinion that a standing Apollo is more probable than a seated one. In earlier representations of the birth of Athena Apollo likewise usually takes part as a musician: LIMC II.1, 315 (W. Lambrinoudakis and others).

On the basis of their attitudes and the attributes in their left hands as attested by the sources it may, incidentally, be assumed that the Delian Apollo and Phidias' Parnopios statue were quite similar: LIMC II.1, 234, Apollo 390, cf. LIMC II, Apollo 295. There was no canonical image for the Delphic Apollo: Pfeiff 1943, 16.

LIMC IV.1, 629 f. (A. Hermary); Kerényi 1997a, 94-96 and 1997b, 172; Shapiro 1995, 1-3. 


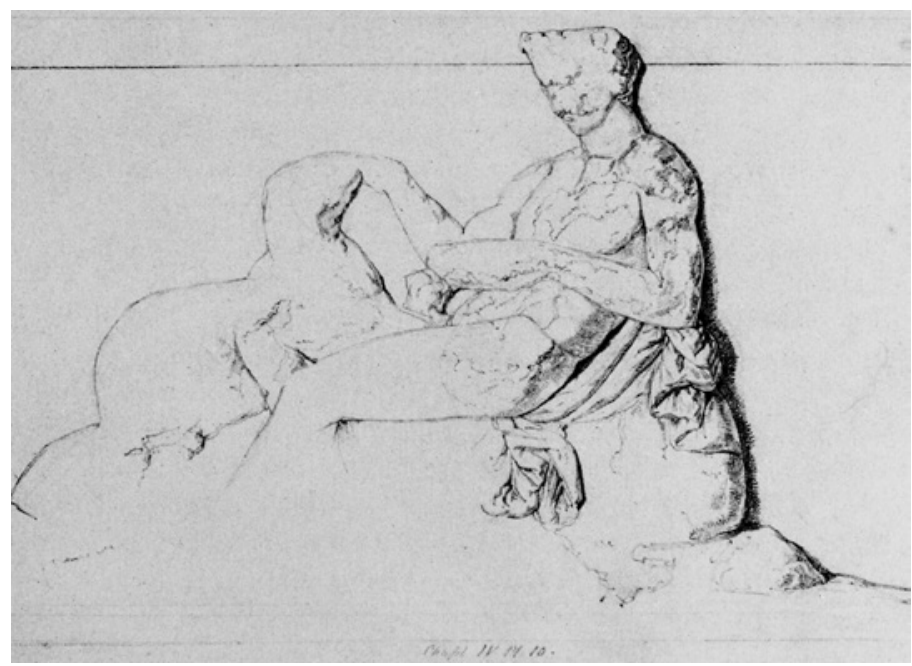

FIGURE 94 Monument of Lysikrates, Athens, detail of the frieze (Ehrhardt 1993, 32, fig. 5).

In this regard, the fact that Dionsyos turns away from Athena emerging from her father's head in full armor and looks towards his theater instead, acquires a deeper meaning. Although every genre had its own mode, the antique drama presented severe conflicts and their solutions in a manner that demanded strong emotional participation from the audience. In this way, it served as a beneficial safety valve for the citizens amidst the stresses and strains of society; the same may be said for the symposium. This is typical for the effectiveness of Dionysos and forms the basis of his prestige among the deities of the state. ${ }^{57}$ That the optical relationship between the reclining figure in the pediment and the theater is not a modern over-interpretation, is supported by the Monument of Lysikrates, erected near the Acropolis in 335/4 BC. It shows a reclining youthful naked Dionysos watching a satyr play (Figure 94)..$^{58}$ Thus, the idea of a Periclean vision of peace offers an explanation for the fact that in the Parthenon pediment Dionsyos looks away from the great central event. We should therefore have a closer look at his appearance in the context of this event and the tradition of its imagery.

57 Pellizer 1990, 182.

$5^{8}$ LIMC III, Dionysos 792; Ehrhardt 1993, 12: locks of hair reach to the neck. The iconographic connection has already been determined by Palagia 1993, 20 and Carpenter 1997, 87 . 
In vase painting the presence of Dionysos at the birth of Athena goes back to the beginnings of the motif in the first half of the 6th century. ${ }^{59}$ People apparently believed that Dionysos was already there when the miraculous birth of Athena inaugurated a new world era. But even though he is present, we rarely see him near the main protagonists Zeus, Athena and Hephaistos; he is usually placed in a marginal position, which indicates a certain distance. ${ }^{60}$ At the Parthenon - in the east pediment and, as we shall see, also in the frieze-his proximity to the Eleusinian goddesses is of special significance. In the Carrey drawings he seems even nearer to them than in the British Museum display or in the drawing by Ernst Berger. ${ }^{61}$ This could be an allusion to their cultic propinquity in Eleusis and in Athens. ${ }^{62}$ After all, the Panathenaic procession came past the city's Eleusinion. ${ }^{63}$

As mentioned above, however, it is also significant that he turns away from the central event: this expresses an inner distance. Whether one assumes a seated or a standing Zeus, the center of the image was dominated by Athena emerging in full armor. Aphrodite, who figures near the north side of the pediment, matches Dionysos perfectly. She looks towards her sanctuary on the north slope of the Acropolis and expresses the same outward and inner distance. ${ }^{64}$ And the same relaxedness: no other deity embodies the idea of peace as does the goddess of love. ${ }^{65}$ Perhaps both Aphrodite and Dionysos are so little impressed by the birth of Athena because the scope of their power is larger and their influence on the world and on human beings is older and reaches beyond Athens. The denomination lysios ('he who unfastens') presents itself as a suitable designation for the Dionysos in the east pediment of the Parthenon. On the basis of an Eretrian inscription from the end of the 4th century в С, Anne-Françoise Jaccottet has demonstrated that Dionysos Lysios'

59 LIMC III, Dionysos 490-492. Concerning the Tyrrhenian amphora Berlin F 1704, see IslerKerényi 2008a, $75 \mathrm{f}$.

6o To conclude that Dionysos is not an Olympian, as does Neils 2005, 238, is, however, unwarranted in view of his marked presence in the decoration of the east side. Contentions of this kind are, finally, expressions of long-standing prejudices within the history of the study of antiquity: Isler-Kerényi 2007, 235-254.

61 Knell 1990, 122.

62 Clinton 1992, 123-125.

63 Kavoulaki 1999, 300.

64 Queyrel 2006, 222. The relationship between the pediment figures and the topographical situation around the Parthenon has been noted before. It is plausible in the cases of Dionysos and Aphrodite, but less convincing for other gods.

65 Pironti 2007, 284: “... cette déesse est capable à la fois d'assurer la cohésion de la communauté et de maîtriser les forces diverses qui traversent tout l'ensemble civique." 
preeminence lies in the fact that he liberated the city in a peaceful way, without combat. ${ }^{66}$ On the east pediment of the Parthenon, Dionysos embodies the idea of peace-as does Aphrodite, to whom this role was more familiar. ${ }^{67}$ As we all know, Perikles' vision of peace would soon be shattered by political reality. This would explain why, outside vase painting, Phidias' Dionysos did not have a lasting effect. The cult statue for the temple in the temenos of Dionysos next to the theater, created somewhat later by Alkamenes, was again in line with traditional iconography. ${ }^{68}$

As far as the attributes of the Dionysos of the east pediment are concerned: already at this time the kantharos (or phiale) and the thyrsos were closely associated with him. These two do not refer to the theater, but, as many vase paintings have shown us, to the ritual aspect. ${ }^{69}$ The thyrsos was introduced into the iconography around $530-520 \mathrm{BC}$, at first as an attribute of Dionysiac women. Dionysos himself uses it in the Gigantomachy and it increasingly takes the place of his traditional attributes, the branches of ivy and vine. As we have seen, it is a fixed element of the ritual thiasos, which, from the second quarter of the $5^{\text {th }}$ century, gradually supersedes the mythical thiasos. The thyrsos, the ferula communis, is light as a feather, but very tough and therefore eminently suitable as a weapon for women. That it can be used for the transport and keeping of fire is not so well known..$^{70}$ Prometheus already did so when he brought fire to the humans. ${ }^{71}$ It therefore also symbolizes civilized life. This is remarkable in view of Plato's oft-quoted passus about the many bearers of thyrsoi and the few real bacchantes. ${ }^{72}$ Apparently, Bacchic rites and a real Greek way of life were inseparable, as was also Herodotus' opinion. ${ }^{73}$ As an attribute of the Dionysos of the east pediment of the Parthenon, the thyrsos defines him as the god of Bacchic celebrations. In the next chapter, we will see that, as the result of radical changes in the political climate, vase painters after $420 \mathrm{BC}$ address

66 Jaccottet 1990. It is significant that the temple in Thebes was dedicated to this Dionysos. Like in Athens and Eretria, it was situated next to the theater, see Jaccottet 1990, 152-153.

67 It may not be a coincidence that on two vases and an altar from the late 5 th century one of the women in Dionysos' retinue is called Eirene: Shapiro 1993, 45-48; Smith 2011, 78.

68 LIMC III.1, 446 Dionysos 214; Rolley 1999, 144.

69 For the kantharos as a mark of heroes or the transition to the state of heros, see IslerKerényi 1990, 45. For the cultic connotations of the thyrsos, which appears in the Dionysiac thiasos around 520 вС, see Schöne 1987, 192; Krauskopf 2001, 47; similarly Kaeser 1990, 333.

70 Baumann 1982, 61. This confirms the close relationship between Hephaistos and Dionysos.

71 Vernant 1988, 265.

72 Phaidon 69c, compare Krauskopf 2001, 50.

73 Isler-Kerényi 1999, 45 . 
themselves to the individual rather than to the collective of the polis and come to emphasize the Bacchic aspect of Dionysos. ${ }^{74}$

The third attribute, the animal skin, characterizes Dionysos as the master of a predator, probably the panther. More than the lion, the panther evokes colorfulness, the untamed, the exotic, in other words: the Asiatic. ${ }^{75}$ Dionysos, who in the Gigantomachy was supported by a panther, here presents himself as the vanquisher of the panther. This is remarkable in the context of Perikles' peace policy of around $450 \mathrm{BC}$ and the allegations made by his political adversaries that he was too little anti-Persian. ${ }^{76}$ After 420 BC the Dionysiac world repeatedly presents a third panther type: the tamed, playful one.

Finally we must discuss the unusual nudity of Dionysos. Robin Osborne, who made an extensive study of this motive in Greek art, ascertains that "... the beardless body is very often a sculptural construct, an idealization, distanced from the male body of life by its combination of beardless immaturity with distinctly mature musculature," and concludes: "To show a male figure without clothes was certainly to invoke the beautiful body of the young athlete..."77 The beauty of Dionysos brings us to the consideration of the frieze.

\section{Dionysos in the Parthenon Frieze}

For constructional reasons this part of the external sculptural decoration of the Parthenon must have been completed before the pediment. In its present form, however, it seems to have been planned after the pediment had been devised. ${ }^{78}$ But its place in the total effect justifies taking it into consideration after the metopes and the pediment: the viewer would, after all, only perceive it on his way towards the interior of the temple, after he had seen the metopes and the pediment. The frieze shows a festive procession, in which representatives of the Athenian population, male and female, and of various ages, participate. The procession leads to the assembly of Olympian gods who, divided

74 Paul-Zinserling 1994, 10. Concerning Dionysos in vase painting after 420 вС see below Chapters 8 and 9 .

75 Wiesner 1965, 2213; Isler-Kerényi 2011a, 85 f. For more details on the panther in ancient thought see also Detienne 2007, 66-69.

76 Klein 1979, 501. It is significant that the panther supports Dionysos in the Gigantomachy, while after 420 BC so many representations show it peacefully at his side.

77 Osborne 1998, 100. Similarly Himmelmann 1990, 47: “... Nacktheit... ist vielmehr die natürliche Begleiterscheinung von Jugend und Schönheit."

78 Wesenberg 1983, 83-86; Neils 2001, 39. 


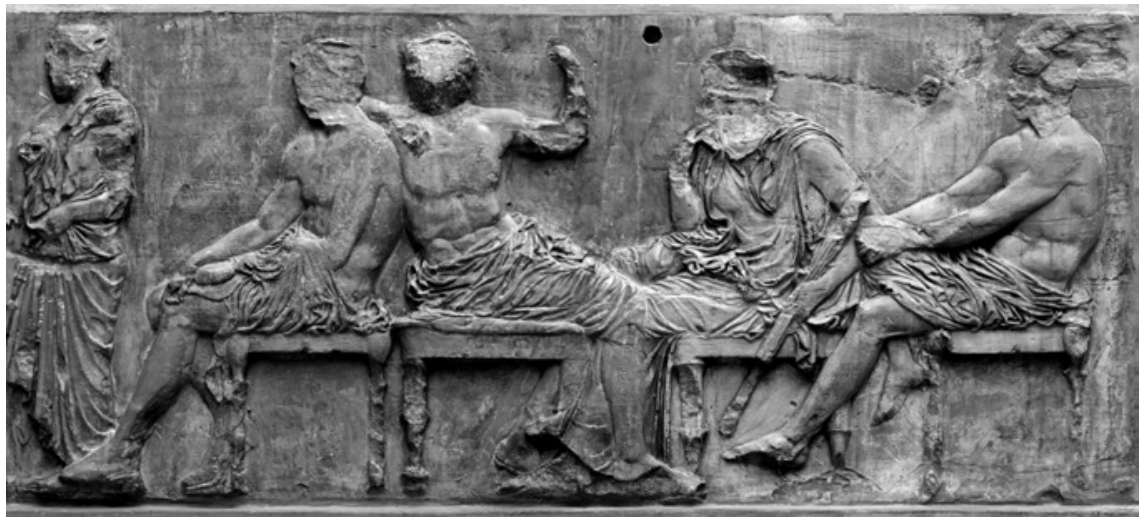

FIGURE 95 Parthenon, east frieze, detail with Hermes, Dionysos, Demeter, and Ares. Plaster cast in the archaeological collection of the University of Zurich, made before 1871 (photograph Archäologisches Institut der Universität Zürich, Frank Tomio).

into two groups of six persons, are seated to the left and right of a central scene, the interpretation of which is the subject of controversy. ${ }^{79}$ As in the metopes and the pediment, Dionysos is the last figure but one in the left group; only his brother, the divine messenger Hermes, separates him from the humans in the procession.

As in the pediment, he presents himself as a young adult, with the thyrsos in his left hand (Figure 95). Because of the condition of the frieze, his hairstyle cannot be determined, but it was probably smarter than that of Hermes; he may even have worn a diadem. The face was shown in three-quarter view; the contours of the right jaw still remain and perhaps some traces of the right eye. ${ }^{80}$ The composition suggests a close relationship between Dionysos and Hermes. This is in line with the iconographic history of the divine assembly, but it is particularly emphasized here. ${ }^{81}$ The emphasis on this relationship is the reason why Dionysos' seated body is turned towards the other gods, which

79 Against the traditional reading of the scene as the presentation of the peplos to the priests of Athena, Wesenberg 2014, with arguments worthy of consideration, proposes that the scene juxtaposes a ritual belonging to the Arrhephoria and one which took place during the Plynteria.

8o This is evident from a cast, made before 1871 , in the hall of the University of Zurich. I am grateful to Simone Voegtle and Rolf Fritschi for assisting me in my research. Compare Brommer 1977, pl. 172. This aspect should be corrected in reconstruction drawings that still show Dionysos in profile.

81 Isler-Kerényi 2008a, 75-77. Compare the “... très grande familiarité qui existe entre Hermès et Dionysos ..., LIMC v.1, 373 (G. Siebert). 
necessitates the turn of his head to face the incoming procession. Without this turn of the head, Dionysos would have his back towards the humans and remain invisible. On the other hand, his contrary position brings him closer to the grieving Demeter. This underlines their common quality as mystery gods, already indicated in the east pediment, and explains the proximity of Hermes, who is not only the messenger of the gods, but also the conductor of souls, psychopompos.

This position enables Dionysos to present his fine torso in all its beauty. The frieze shows Hera in a similar manner, although she is fully dressed. She is more than just beautiful here: her gesture of unveiling clearly has an erotic meaning. It is of interest, that the beauty of the Athenian men was very much a theme of the Panathenaic festival. Beauty contests for men of various age groups were part of the competitions at many festivals, but the Euandria of the Panathenaea were the most famous. ${ }^{82}$ The most beautiful among the mature men took part in the procession as bearers of olive branches, thallophoroi. These are perhaps also shown in the Parthenon frieze. ${ }^{83}$

Taking part in a procession meant making a spectacle of oneself. More than any other form of ritual behavior the procession is therefore related to the theater: "... processional ritual shares with theatrical performances... an explicitly declared emphasis on viewing: processions as well as theatre ... are 'viewing occasions', 'spectacles', theoríai, théai." ${ }^{\prime 4}$ What did processions represent? First of all: the community itself in its most glorious, timeless form, and secondly the community's relation to divine power. "The procession is articulated as a response to the authority of the divine but it articulates at the same time a call for the response of the divine." 85 Processions can also fulfil these roles in the context of a theatrical performance, such as Aischylos' Eumenides, which had its premiere 458 вс. ${ }^{86}$ Needless to say, the same holds true for the procession on the Parthenon frieze. The visitor would only behold the frieze after he had seen the warlike metopes and had experienced the tension and release of the event depicted on the pediment. All of this supports the idea that the actual theme of the frieze was the celebration of the alliance between gods and humans. ${ }^{87}$

To sum up, at the Parthenon Dionysos successfully embodies various aspects of peace, its conditions and its consequences: in the metopes he is a

\footnotetext{
82 Crowther 1985,285 f. In addition, Goldhill 1994, 355 .

83 Berger/Gisler-Huwiler 1996, text volume p. 68.

84 Kavoulaki 1999, 294.

85 Kavoulaki 1999, 303.

86 Kavoulaki 1999, 306-307.

87 Similarly Osborne 1994, 148-149.
} 
champion of the legitimate order; in the east pediment he represents male beauty and divine ease following victory; in the frieze he expresses the joyful alliance between gods and humans. It would have been hard to believe that this Dionysos had no influence on the vase painters and their clients, and as we will see in the next chapter his appearance, indeed, underwent a permanent change. Before moving on, however, we should have a look at two special vases which help to explain the meaning of the representation in the west pediment of the Parthenon, and in one case document an unusual manifestation of Dionysos.

\section{Reflections of the West Pediment in Vase Painting}

Some years ago a lavishly decorated hydria turned up, which is attributed to the workshop of the Pronomos Painter and may, on stylistic grounds, be dated around 400 BC. ${ }^{88}$ It was found in a necropolis of the Macedonian capital Pella. The unique and very rich decoration takes up the theme of the west pediment of the Parthenon: it shows the bolt of lightning sent by Zeus to end the dispute between Athena and Poseidon about Attica in the presence of several godsAmphitrite, Triton, Apollo, Artemis, Hermes-, the heroes Erechtheus und Eumolpos, as well as Kekrops, Nike, and, above each handle, a figure which has been variously identified. ${ }^{89}$ From the top of the image, on the left, a youthful Dionysos rides towards Athena on a peculiar horned panther (Figure 96). He is greeted by a nymph with an ivy wreath, who seems to be rising from the earth.

Dionysos was not represented in the west pediment of the Parthenon and there are no literary sources mentioning his presence at the event. ${ }^{90}$ On the other hand, it is not really surprising to find him on Athena's side in view of the group of pointed amphorae or the pelikai of the Painter of the Birth of Athena, which all show his special close relationship with the polis. ${ }^{91}$ Incidentally, the scene on the hydria from Pella possibly has a parallel in that on the very fragmentary lid of a lekanis of about the same date, found on the Acropolis of

88 Pella 80514: BA 17333; Drougou 2000; Tiverios 2005; Neils 2013. This painter will be further discussed in the next chapter.

89 Tiverios 2005, 306 f.: Kydoimon and a maenad; Neils 2013: Kychreus and the personification of Marathon.

9o Tiverios 2005, 301.

91 See above Chapter 4. Tiverios 2005, 314 also concludes that in the dispute with Poseidon, the god of the aristocracy, Dionysos, supports Athena, because "dieser Gott der politische Gott der 'Volksherrschaft' (dem Gegenteil der Aristokratenherrschaft) und der Demokratie ist." 


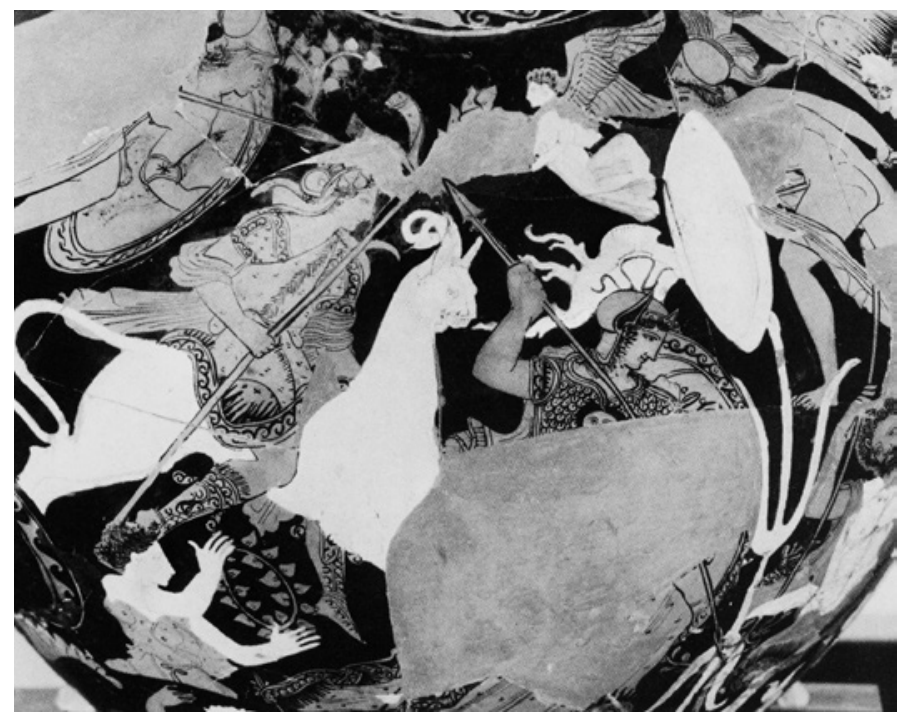

FIgURE 96 Kalpis, workshop of the Pronomos Painter, Pella, Archaeological Museum 80514 (Drougou 200o, pl. 35.1) @ Hellenic Ministry of Culture and Sports, 17th Ephorate of Prehistoric and Classical Antiquities.

Athens. Apart from Athena with her olive tree, it showed Kekrops and probably Poseidon - and also a lively Dionysos, who comes running in a short chiton and boots. ${ }^{92}$ Michalis Tiverios convincingly links this images with the peace treaty of 403 between Athens and Sparta, and the reconciliation of the democrats and the oligarchy within the polis. The mythical model for these reconciliations is the end of the dispute depicted on the west pediment of the Parthenon. Still, the hydria painter has pushed Poseidon into the center of the image, and has highlighted his armor in white: the capital of Macedonia, with its aristocratic governance, is likely to have been sympathetic to the Poseidon Hippios of the Athenian elite. ${ }^{93}$

Dionysos' mount on the hydria from Pella is very peculiar indeed. As has been mentioned above, the panther stands for Asia, for the exotic. The horns, however, turn it into a creature of the imagination. The god then comes from a world that is unknown to us. Perhaps it is the world of timeless bliss in which, as we will see, he is placed by the vase painters active after 430 - the world he hurries towards with Ariadne. But how can it be explained that of all the gods, the one who spoke to humans and walked with them in torch-lit processions now comes riding from unknown territories? The place where the vase

92 Tiverios 2008b, 13o, fig. 4.

93 Tiverios $2005,312 \mathrm{f}$. 


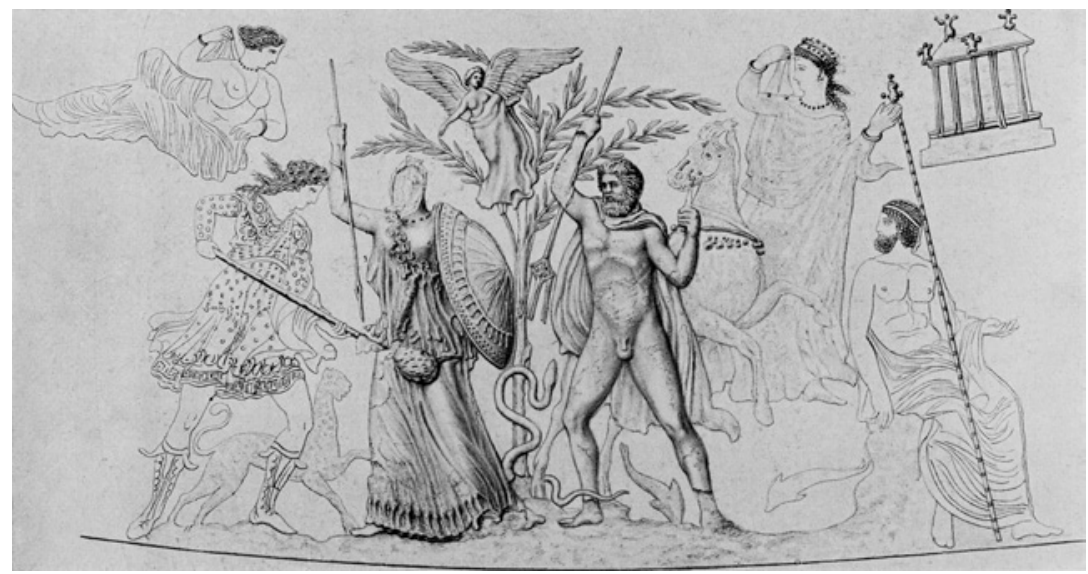

FIGURE 97 Kalpis, St. Petersburg, State Hermitage Museum П 1872.130 (Pfuhl 1923, 246. fig. 604).

was found, the necropolis of Pella, perhaps offers a clue for this expansion of Dionysos' domain beyond Asia into the supernatural: ultimately, the image was meant for a dead person.

Another reflection of the west pediment of the Parthenon, and one of long standing, is provided by a hydria from the ancient city of Pantikapaion on the Black Sea, created about half a century later. ${ }^{94}$ The vase has red-figure paintings, but the bodies of the two protagonists were individually sculpted in relief and subsequently painted, whereas molds were used for the heads. Several parts of the image and the decoration were painted over in white or gilded. From the end of the $5^{\text {th }}$ century, such techniques were applied for sumptuous, high-quality ceramics not meant for practical use. ${ }^{95}$ Consequently, our hydria, too, served as a cinerary urn for a man's grave. ${ }^{96}$

The center of the image is taken up by an olive tree; above it Nike flies towards Athena on the left, while on the ground a large snake is moving towards the trunk of the tree. Athena strides towards the left, carrying her shield and a raised spear. Poseidon, trident also raised, comes from the right. His left hand holds the reins of his rearing horse. Dolphins are jumping in the water depicted next to him, which must have sprung at the touch of his trident. Behind the horse, a woman wearing a diadem, possibly Amphitrite, is running

94 St. Petersburg П 1872.130 (кав 6 а): ва 6988 (no image); Tiverios 2005, 310, fig. 11; Cohen 2006, no. 105, 339-341; Brinkmann 2013, 246 and 334 no. 47.

96 Cohen 2006, 339. 
away while performing the familiar gesture of the bride. ${ }^{97}$ Below, on the right, a seated male figure with a scepter, possibly Kekrops, is looking on. A schematic representation of a temple, perhaps the Acropolis, may be seen at the top on the right. In the foreground, Dionysos, with youthful curls and wearing a short chiton, a panther skin, and boots with tongues, storms into the image from the left. He points his thrysos at a slant towards the right, as if it were a weapon. As in the Gigantomachy metope at the Parthenon, and later in the Gigantomachy frieze of the Pergamon Altar, he is accompanied by a panther. ${ }^{98}$ On the left, above Dionysos, a reclining female figure is looking on. She may be a personification of Attica (Figure 97) $\cdot{ }^{99}$

In comparison to the hydria from Pella, the bolt of lightning is conspicuous by its absence, which creates the impression of a confrontation in progress, with only the figure of Nike indicating the victory of Athena. Dionysos has been given a more active role here: even more than Athena he seems to be Poseidon's adversary. ${ }^{100}$ The clear reference to the Athenian myth and the west pediment of the Parthenon must have been of importance to the original buyer of the vase, a high-ranking citizen of a town on the border with the barbaric regions; it showed his cultural affiliations. For our discussion the participation of Dionysos on the side of Athena is significant. His appearance as Gigantomachos and his role as fellow combatant of the polis goddess are unusual in 4th-century vase painting, and seem more appropriate for monumental art forms than for the more private ceramic art. Here again, as in earlier instances, he is close to the goddess of the most Greek of all poleis. The presence of the panther, however, seems to indicate that his influence now reaches beyond Athens, even beyond Greece, and has come to include Asia.

97 The various possible interpretations are listed in LIMC III.1, 19 f., s. v. Attike 2 (G. Berger-Doer).

98 Isler-Kerényi 2010b, $66 \mathrm{f}$.

99 The various possible interpretations are listed in LIMC I.1, 291, s. v. Aglauros 38 (U. Kron).

100 Tiverios 2005, 310, fig. 11. 


\section{The New Dionysos in Vase Painting}

Shortly after the completion of the Parthenon, striking innovations could be discerned in the way Dionysos appeared in vase painting: the dignified mature bearded man was increasingly replaced by a youthful figure, sitting or reclining in a relaxed manner. It is evident that the Dionysos 'who unfastens' in the east pediment of the Parthenon is behind the changes. It is instructive to have a look at some examples.

In the work of the Washing Painter, active from just after 440 until around $410 \mathrm{BC}$, Dionysos is completely absent and only six of his more than fifty pelikai have satyrs and maenads. ${ }^{1}$ This may be partly explained from the fact that he mainly produced vases-loutrophoroi, lebetes, pelikai-that were meant to be used by women at special occasions, such as weddings; their imagery was therefore rather uniform and dictated by tradition.

From the perspective of Dionysiac iconography, the Dinos Painter is the most important painter at this stage. He is said to have been a pupil of the Kleophon Painter, whose style he continues "in a less solemn and a sweeter form", as Beazley puts it. ${ }^{2}$ His work may be dated between 430 and 400 BC; it has its acme around $410 .^{3} \mathrm{He}$ seems to have been particularly interested in Dionysiac subjects.

His famous stamnos in Naples still shows the strong stylistic influence of the Parthenon, even though it is by far the youngest of the series depicting a domestic ritual with a pillar idol of Dionsyos, and may therefore be a nostalgic revival of the motif (Figure 98). ${ }^{4}$ The scene with the woman ladling the wine from the stamnos is here explicitly linked to the procession of women on the other side of the vase: the woman beating the tympanon to the right of the idol is looking back towards the approaching dancer carrying torches, who in turn is followed by the four women on the reverse. All women are wearing the sleeveless chiton, some with an animal skin over it. Only the last woman in the procession is wrapped in her himation, which creates the impression that she is the one to be led to the ritual. The veiled women on the reverse sides of the two

1 ARV 1130. 144-149. For the dating see Isler-Kerényi 1973, $28 \mathrm{f}$.

2 ARV 1151.

3 McPhee 1973, 1; Halm-Tisserant 1988, 8 and 12.

4 Naples 2419: Addenda 336 (1151.2); BA 215254; Frontisi-Ducroux 1991, 84 f., figs 19 and 20; HalmTisserant 1988, 7. See also above Chapter 6. 


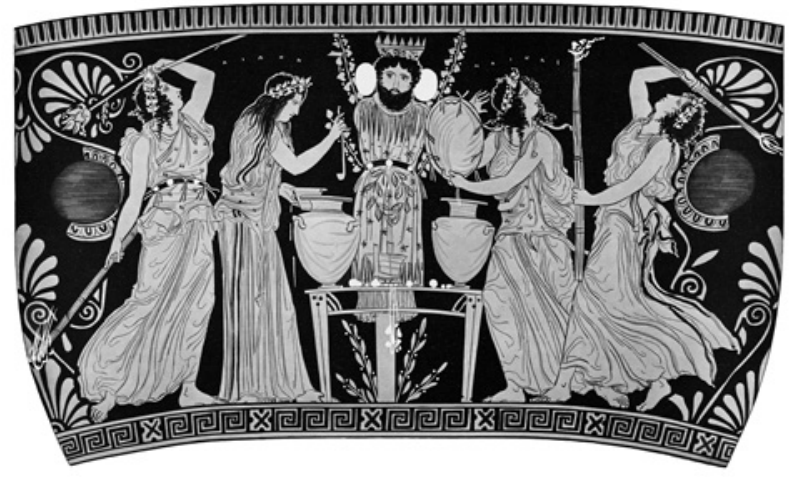

$a$

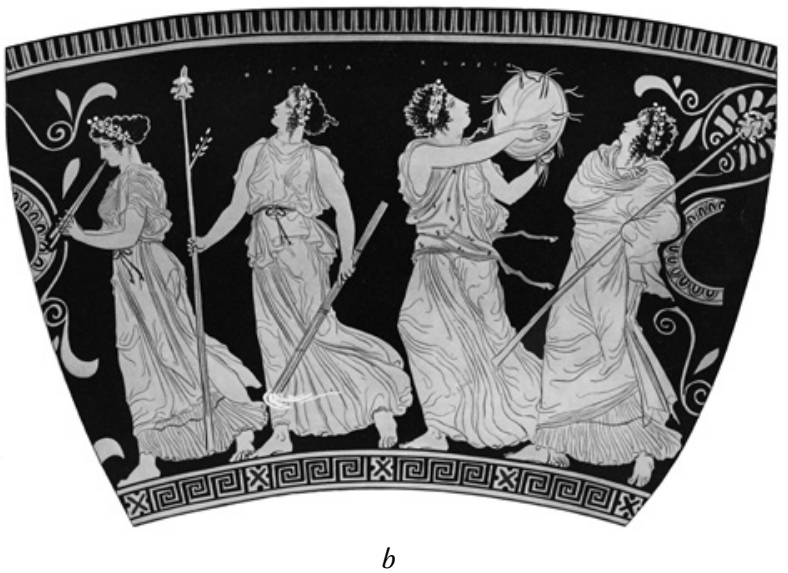

FIgure 98 Stamnos, Dinos Painter, Naples, Museo Archeologico Nazionale 2419.

a. side A (FR pl. 36$)$.

b. side $B$ (FR pl. 37 below).

stamnoi by the Eupolis Painter which also belong to the series are very similar. ${ }^{5}$ Are they also waiting to be introduced? Is the anonymous bearded man in a himation, who may be seen in one of the images, a member of the family? The four names added on the Naples stamnos-Aione, Mainas, Thaleia, Choreiasound mythological, but in view of the iconography the ritual depicted most likely reflects human circumstances. ${ }^{6}$

5 Frontisi-Ducroux 1991, 157, figs 92 and 93.

6 See above Chapter 6 . We will return to the issue of inscribed names at the end of this chapter. 

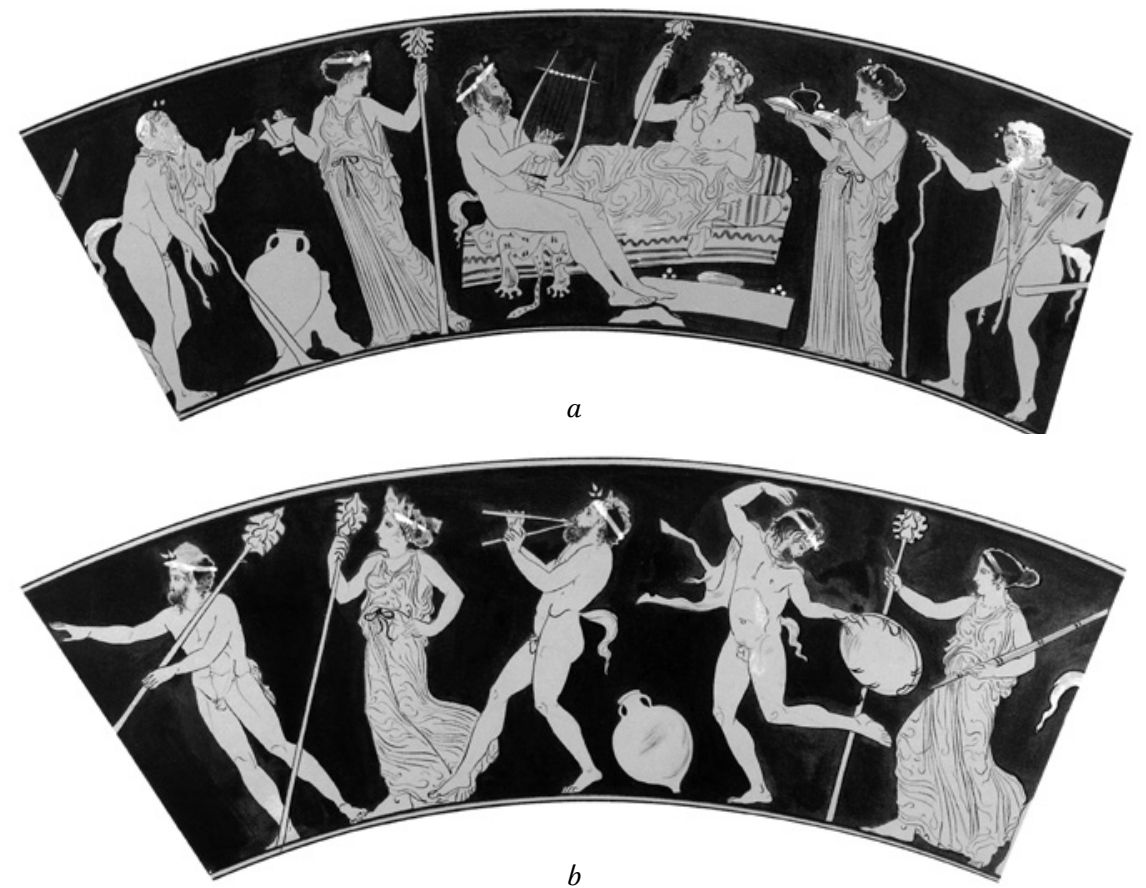

FIGU Re 99 Dinos, Dinos Painter, Berlin, Staatliche Antikensammlungen, Preussischer Kulturbesitz F 2402 (Furtwängler 1883-87, pl. 56-57).

a. side A: Dionysos.

b. side B: thiasos.

Another work by this painter that is of importance for our discussion is the eponymous dinos, dated around 420 ; the best-known of the four dinoi attributed to him. ${ }^{7}$ No less than three of these were found in Athens and several other vases by the Dinos Painter were also found here. We may therefore presume these works present the Athenian perspective on Dionysos and his rituals. The dinos in Berlin shows one of the earliest examples of the young Dionysos as a symposiast - a motif that would be among the most common ones also in Apulian vase painting. ${ }^{8}$ The amphora placed against a rock to the left of the main scene must be a reference to unspoiled nature; the ambivalent characterization of the locale seems intentional. In addition, it is remarkable that the satyrs who are present, are of different ages. The one playing the lyra who sits on Dionysos' bed, and the dancing ones on the reverse, are clearly

7 ARV $115^{2.3}-6$.

8 Berlin F 2402: Addenda 336 (1152.3); BA 215255. Similarly Sabetai 2011, 139. 
younger than the white-haired one who, leaning on his stick, approaches on the right. A woman stands in front of him, turned towards the left. She solemnly carries a basket with, probably, loaves of bread, and — as on the chous from Trachones, discussed above-a large cluster of grapes. ${ }^{9}$ She will probably put these on the podium-like structure in front of Dionysos' couch. On the other side of the god another woman is ready with the kantharos she perhaps just filled from the amphora: Dionysos is comfortably settled and given a warm reception (Figure 99).

A recently published small calyx krater in Athens, attributed to the Dinos Painter, shows the Parthenon type, albeit with a himation draped over the lower body. He is, however, holding kantharos and thyrsos in the appropriate hands. ${ }^{10}$ As in the Berlin dinos, Dionysos reclines on a couch. Instead of a satyr, Ariadne sits at its foot, a wreath in her hands as in the Kodros Painter's cup, discussed above." Between the two, Eros can be seen, flying towards Ariadne. Dionysos brings the kantharos to his lips, his thyrsos is decorated with a ribbon. In the foreground stand a gilded volute krater as well as a podium, highlighted in white, with offerings. Above right a bacchante beats the tympanon, and another, wearing a colorful ritual robe, is bringing further offerings. A boylike satyr is approaching from the left with drinking horn and oinochoe. On the reverse, two women are walking towards the right - the one in front carries a thyrsos, the other one a tympanon. They seem to be moving towards the scene on the main side of the krater and the altar visible above the handle between the two images. In addition there is an elderly satyr in a himation. He is dancing along while looking back with a greeting gesture. Behind him, above the other handle, we can see an open door. Does this refer to the thalamos, where the wedding of Dionysos and Ariadne takes place, or to a sanctuary of the god? Perhaps the door is supposed to represent an ideal transition from inside to outside world and vice versa, or even what we might call the Final Transition. ${ }^{12}$ The two satyrs of different ages, and especially the one in the himation, indicate an event which, like the processions discussed earlier, takes us from the human here and now to an imagined world populated by immortal beings-a higher world for humans to look forward to. ${ }^{13}$

\footnotetext{
$9 \quad$ See above Chapter 6, note 87 .

$10 \quad$ Sabetai 2011.

11 London E 82 (1847.9-9.6): see above Chapter 5, note 42.

12 Sabetai 2011, $152 \mathrm{f}$. The motif of the (sometimes half-open) door on sarcophagi from the Imperial period very likely refers to this idea of Final Transition. See for instance: Koch/ Sichtermann 1982, figs 258, 290, 291, 523, 529, and 535 .

13 See above Chapter 6.
} 

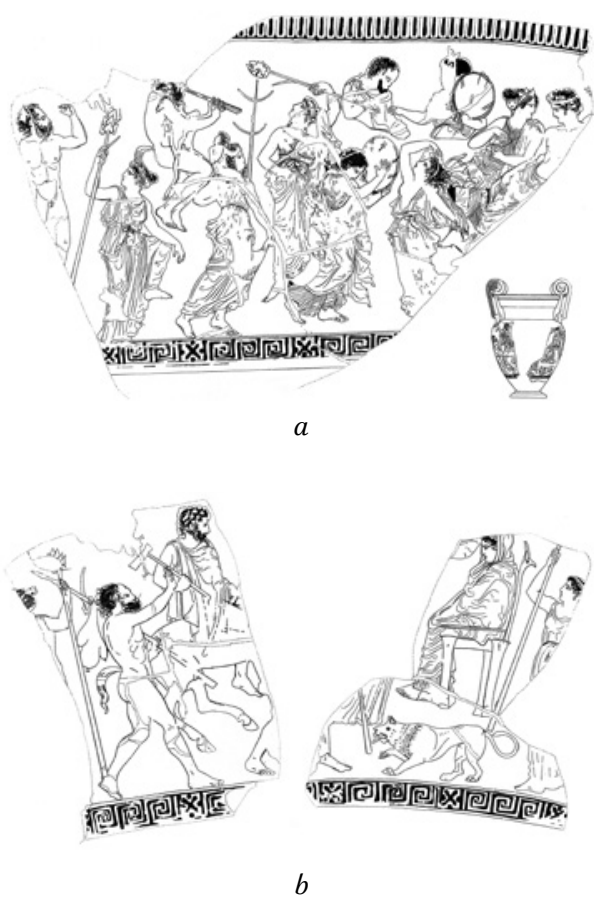

Figure 100 Volute krater, Dinos Painter, Bologna, Museo Civico Archeologico 283 (AD I, pl. 36$)$.

a. side A: Dionysos and Ariadne watching the thiasos.

b. side B: Hephaistos riding towards Hera.

Of prime importance among the works of the Dinos Painter known to us is a somewhat younger volute krater from North-Etruscan Bologna, which is, unfortunately, badly preserved (Figure 100). ${ }^{14}$ It showed an exceptionally lively thiasos of women and satyrs accompanying Hephaistos riding his mule. He is on his way to Hera, who is stuck on the right. She sits like a mourner wrapped in her himation and is guarded by an aggressively roaring lioness. On the other side of the vase, a youthful seated Dionysos, half naked and relaxed, is watching the thiasos in the loving company of Ariadne. ${ }^{15}$ The whole scene, especially the women dancing ecstatically to the music of flute and tympanon, strongly reminds us of a vase which was discussed in the previous chapter: the more or

\footnotetext{
14 Bologna 283: Addenda 336 (1151.1); BA 215253. For the motif of the return and Hera stuck in her seat, see Halm-Tisserant 1986, 18-21.

15 The same motif can be found on a fragment of a bell krater from Phanagoria in the Crimea, attributed to the Dinos Painter: BA 1012120.
} 
less contemporaneous volute krater from Spina decorated by the Curti Painter, possibly for an Etruscan client. ${ }^{16}$ Here, however, the male participants are satyrs (one of them seems to be wearing a himation) and there are no snakes. One of the dancing women is carrying her small child on the shoulder: this representation of what must be a woman with mother status, a gynè, is unique. On the extreme left a satyr looking towards the right is closing off the scene; he lifts his left hand in what is probably the skopeuma gesture. ${ }^{17}$ This could indicate that we are witnessing an epiphany of the divine couple. In this juxtaposition of a mythological scene and a thiasos resounding with music, it remains unclear whether the latter takes place among human beings or in a blissful other world. What is most striking when one compares this version of the return of Hephaistos with the earlier depictions of the theme is the difference in mood between the anxiety of the Hera side - with the intimidating lioness providing an ominous touch - and the euphoric happiness of the Dionysos side. There even seems to be an intentional pictorial contrast: on the one side Hera is waiting to be set free by the son she rejected, while on the other a bacchante and her little son are joyfully taking part in a euphoric thiasos. In any case, here too, Dionysos is the god of peace, who unfastens, unfetters.

A Dionysos figure that is evidently inspired by the rendering of the god in the east pediment of the Parthenon is the one on the calyx krater in Vienna (Figure 101). ${ }^{18} \mathrm{He}$ dominates the main side of the vase, and is surrounded by women in colorful ritual robes (Dione and Opora) who bring gifts-among which two large clusters of grapes-, and by satyrs (of whom the one on the right is named Komos). As on the dinos, a seated satyr plays the lyra. To the right of Dionysos' head we see Eros who crowns the god with a wreath. The figure of Eros is highlighted in white, as is the podium-like structure in the foreground, which gives both elements additional significance. A panther's cub near the podium seems eager to play with the satyr-musician. From now on, we increasingly see the relaxing Dionysos in the company of a tame panther. Perhaps it stands for a subdued Asia; in this way the presence of the animal would be enough to evoke the idea of a utopian peace. On the reverse a satyr is moving towards a fleeing maenad with alacrity. To the left, a dancing maenad is turning away. Her gesture is apparently meant to express her disapproval of the satyr above the right handle who, with obvious intentions, is approaching an unsuspecting woman (Oinanthe) watching Dionysos. Above the left handle, a woman (Eirene) is sitting on the left; a satyr (Hedyoinos) who is lying in the

\footnotetext{
16 Ferrara 2897: see above Chapter 6, note 143.

17 CVA Bologna 4, pl. 69.6 with text p. 11 (G. Bermond Montanari).

18 Vienna 1024: Addenda 336 (1152.8); BA 215261.
} 


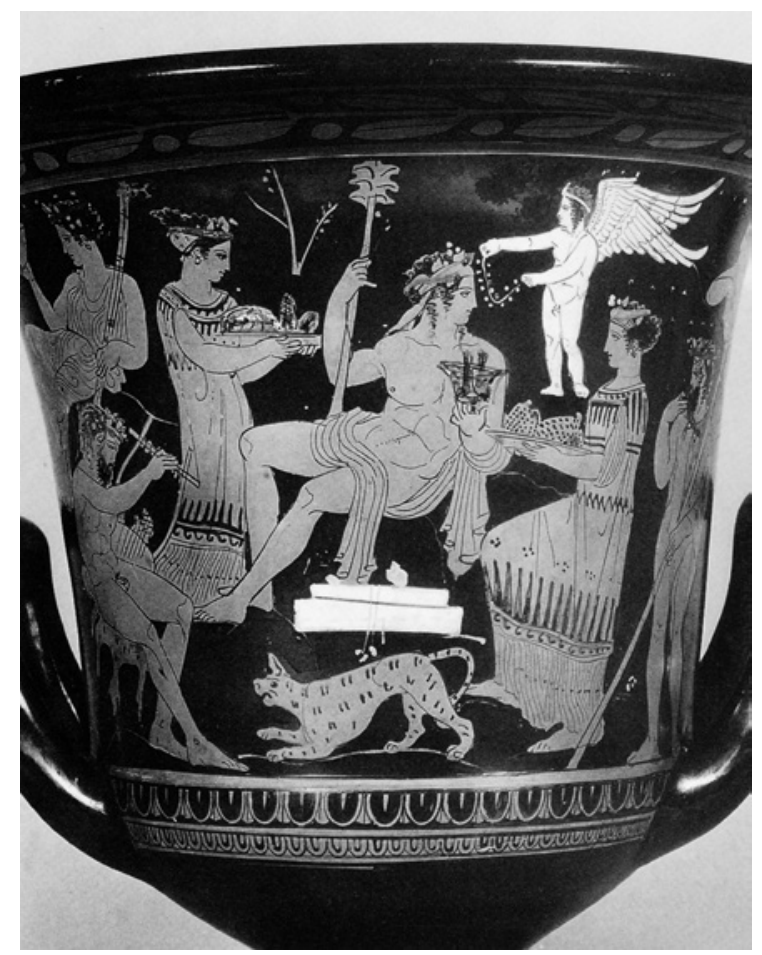

FIGU RE 101 Calyx krater, Dinos Painter, Kunsthistorisches Museum, Vienna 1024, side A (cVA Kunsthistorisches Museum, Vienna 3, pl. 105.2).

field in a half-reclining attitude turns towards the god, a kantharos in his right hand. 19

Images such as this, often with Ariadne next to Dionysos, were the Athenian painters' preferred imagery from this time onward until far into the 4 th century. A comparison between the Dinos Painter's return of Hephaistos and the not much earlier version by the Kleophon Painter convincingly shows the profound changes in the Dionysiac climate in Athens around 420. One only has to remember the rather solemn procession-like trains with torches and thyrsoi presented by the Phiale Painter or on the stamnos by the Dinos Painter and it becomes evident that the ritual event has shifted from the immediate surroundings of the viewer to a seemingly timeless, blissful, distant world, standing out as if on a stage.

A contemporary of the Dinos Painter whose oeuvre contains several interesting Dionysiac images, is the Kadmos Painter. He was active during the same

19 Smith, 2007, 169. 


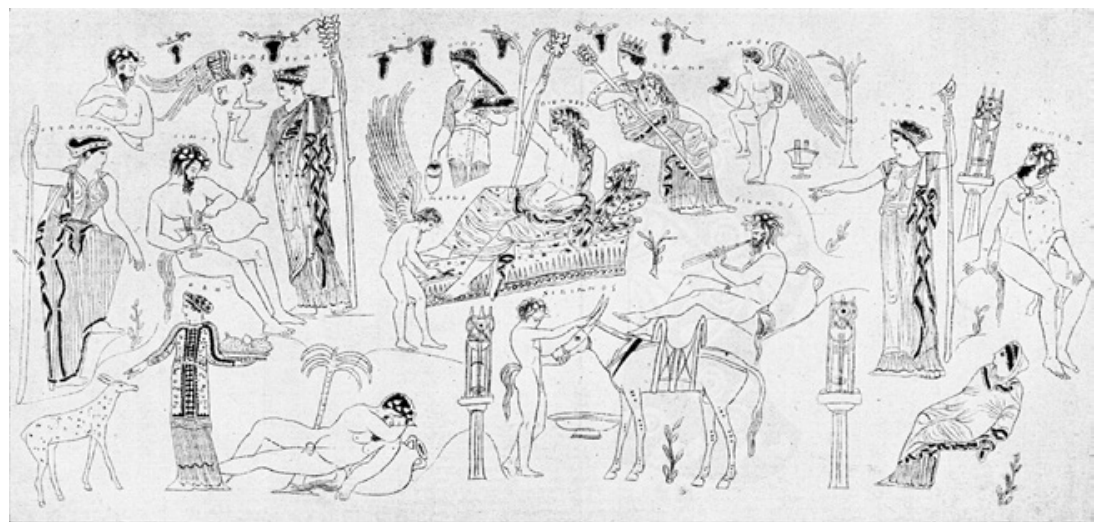

FIGURE 102

Volute krater, Kadmos Painter, Ruvo, Museo Jatta 1093, scroll showing side A between parts of side B (FR Text II, 329, fig. 107).

decades, but, at least as far as his numerous bell kraters are concerned, not at the same artistic level. His volute and calyx kraters as well as his amphorae with twisted handles, however, distinguish themselves by their original subject matter and their careful execution. ${ }^{20}$ Among these we find several remarkable representations of Dionysos.

Most richly decorated is the volute krater found in Ruvo, in the Apulian inland. ${ }^{21}$ This location provides an indication of one of the possible routes via which Dionysiac iconography from Athens found its way to the workshops of Southern Italy.22 The krater has four images: two small ones on the neck and two larger fields on the belly. One side is completely dedicated to the story of Marsyas, the musician-satyr. On the neck Marsyas plays the aulos for Apollo in the presence of a dancing satyr, a woman with two torches, and Hermes. The center of the image on the belly is dominated by Marsyas (the name is given), who is represented as an elderly satyr playing the kithara, and Athena, who is listening. Apollo is sitting in a relaxed attitude to the right of Athena; Artemis is leaning on his shoulder. Several other figures surround the main protagonists. Below on the left a bacchante holding a thyrsos is conversing with a young satyr; above them we see a partly veiled goddess (Hera perhaps) with

20 See above Chapter 5, note 116. For the dating of the Kadmos Painter, see McPhee 173, 51. For the Kadmos Painter see in addition Tiverios 2011.

21 Ruvo 1093: Addenda 340 (1184.1); BA 215689; Sichtermann 1966, K 10, 20 f., pls. 12-17; Shapiro 1993, 235, no. 22; Borg 2002, 220; Lissarrague 2013, 161 f., figs 134-135 (the dating seems too early).

Similarly Paleothodoros 2011, 140 and Tiverios 2011, 176. 
a young woman whose name, Hebe, is given; above right are Nike or Iris with Hermes. A tripod is standing on a pedestal in the foreground, a little higher a palm tree may be seen, in front of Artemis a grazing fawn. Evidently, we find ourselves in a sanctuary of Apollo, where there is no indication whatsoever of the further tragic developments. Rather, the atmosphere is one of peace and relaxation.

The neck image on the other side shows pieces of meat roasting on a spit over the altar with anonymous boys, mature men, and women in attendance. The main image is dominated by a youthful Dionysos, whose name is inscribed. He is reclining on a richly decorated couch and wears an ivy wreath on his head. In his left hand he holds the thyrsos (Figure 102). The winged boy Himeros is putting sandals on Dionysos feet. The god is surrounded by women carrying various objects: Eudia is on his left; Opora above has a basket with large bunches of grapes. ${ }^{23}$ A matron in festive dress sits on the right in a somewhat elevated place. She is the only one to wear a halo-like diadem; this is in accordance with her name, Thyone, the name given to Semele after her death. In addition we see Pothos (who looks like Eros) with a bunch of grapes, as well as satyrs engaged in various activities ( from left to right Simos, Sikinnos, Seilenos and Oinopion). One of them seems to be trying to lead a mule. Next to Dionysos a large vine carrying ripe grapes has sprouted, and here, too, there are tripods and palm trees. How do these two scenes relate? Is this the same locale, as the presence of bacchante and satyrs on the Apollo side suggests? In any case, both sides show the relaxed, idyllic atmosphere we also found on the dinos and the calyx krater by the Dinos Painter.

On one of the Kadmos Painter's calyx kraters we again see Apollo and Marsyas in the company of other gods; the other side has the encounter of Dionysos with Ariadne discussed above. ${ }^{24}$ In contrast to earlier versions, in which the encounter was more like a pursuit, the mood here is one of respectful solemnity.

The other calyx krater was found in Kerch on the Black Sea. ${ }^{25}$ One side has a detailed depiction of the Judgment of Paris. In the center we see Paris seated in the foreground. He is wearing the multi-colored oriental trousers in which he is first portrayed around $430 \mathrm{BC}$ - this will be further discussed in the next chapter. He is surrounded by Hermes, Athena, Hera, and Aphrodite. In the

23 Other women are named Eudaimonia, Hebe and Oreias, see fig. 102.

24 Syracuse 17427: see above Chapter 5, note 116.

25 St. Petersburg 0.28 (St. 1807): Addenda 341 (1185.7); BA 215695; LIMC III, Eris 7, and VII, Paridis Iudicum 48 (side A) and LIMC II, Apollo 768a (side B); McPhee 1973, 95-99; Shapiro 1993, 233, no. 15 . 


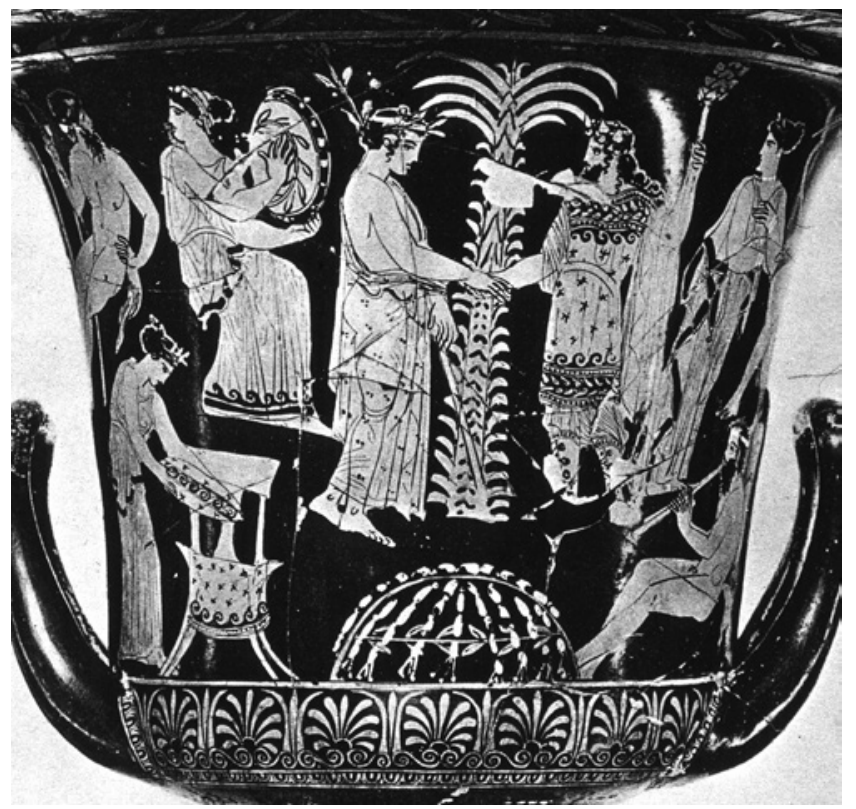

FI GURE 103 Calyx krater, Kadmos Painter, St. Petersburg, State Hermitage Museum 0.28 (St. 1807), side B (old photograph from the Archäologisches Institut der Universität Zürich).

upper field, framed on the left and right by the chariots of Eos and Selene, we see two women directly above Paris. Their names are given: Themis is leaning against Eris, who is wearing multi-colored robes. This prominently-placed pair, until that time not found in representations of the Judgment of Paris, and the presence of the celestial bodies of Day and Night, underline the significance of the event for the history of the world. As we all know, the Judgment of Paris had been the cause of the Trojan War, Greece's ill-fated confrontation with the power of Asia, as Herodotus had argued some time before the creation of this image. ${ }^{26}$ Themis, the goddess of lawful order, leaning against Eris, the goddess of strife, means that the war was justified and, in this way, was a condition for the current order.

The image on the reverse side is unique. In the center we see the omphalos, which symbolizes Delphi, with immediately above it a large palm tree. The latter stands for Delos, the other major sanctuary of Apollo. ${ }^{27}$ The main event takes place in front of the palm tree: Apollo, dressed like a young citizen, with a

26 Hdt I, 1. 4.

27 Simon 1998a, 457. The palm tree, however, also belongs to Artemis, see Torelli 2002. 
laurel branch in his left hand and a laurel wreath in his hair, shakes the hand of Dionysos who comes from the right. He wears an ivy wreath in his long hair and is bearded and therefore clearly older than Apollo. Over his chiton he wears the multi-colored ependytis and he has boots on his feet. We must therefore conclude that he has traveled far, from the east perhaps. Dionysiac women and satyrs liven up the scene with the music of tympanon and aulos. In the foreground on the left, a woman is putting a colorful cushion in an armchair. This is probably where the newly-arrived god will take his seat. The whole scene radiates quiet solemnity (Figure 103).

We do not know what myth or real event the scene refers to. Nevertheless, it acquires meaning when we relate it to the image on the reverse which refers to a war that was inevitable - the war that, for the original viewers, ended the era of the heroes and inaugurated that of human beings. For did one not calculate the time according to the generations that had passed since the ancestors of the great families, the heroes of the Trojan War? The goddess of strife and the handshake, a symbol of peace, are juxtaposed. The peace in question may be the one between Dionysos, who comes from afar, and Apollo, god of all the Greeks and also of the Athenians, who is shown in his sanctuary, the place that, with the prominently presented omphalos, was seen by the Greeks as the center of the earth. ${ }^{28}$ This Dionysos, however, is no more an Asian deity than the Dionysos in Euripides' Bakchai, who around the same time speaks of himself as returning to Thebes from Asia: the difference between his costume and that of Paris already make this clear. ${ }^{29}$ Nevertheless, Dionysos represents the world beyond Greece. In the words of Henk Versnel: "Dionysos is a cosmopolitan god who demands reverence by all people all over the world."30 It may be for this reason that he is depicted as being older than Apollo, albeit clearly not like a father figure. A chair is prepared for him, like in Athens during the Anthesteria, indicating that he should stay. ${ }^{31}$ An evocation of peace such as this one eminently suits the later stages of the Peloponnesian War. And it is particularly apt for the place where the vase was found: Kerch on the northern shore of the Black Sea, that is, the northern frontier of what was then for the Greeks the known world. It cannot be a coincidence that this location (with its new concept of a far-reaching Dionysos) is also the one where the hydria of two generations earlier was found which presented the dispute between Athena

\footnotetext{
28 Versnel 2011a, 506: quotation from Dem. 18.141 concerning Apollo: patroos esti te polei.

29 E. $B a .1-19$.

30 Versnel 1990, 164.

31 See above Chapter 6, p. 152.
} 
and Poseidon inspired by the west pediment of the Parthenon, discussed in the previous chapter. ${ }^{32}$

Thus we owe the Kadmos Painter three of the most original and therefore least accessible images of Dionysos. As far as Dionysos' outward appearance is concerned, it is striking that next to the youthful Dionysos inspired by the east pediment of the Parthenon on the volute krater, the mature spouse-type could also still be found in his sanctuaries. ${ }^{33}$ Finally, in the sanctuary of Apollo in Delphi we meet a very special exotic Dionysos who is neither young nor elderly. Evidently, the new Dionysos of the east pediment of the Parthenon had not come to replace the traditional Dionysos; it inaugurated his polymorphism, the variety of forms that would be the hallmark of Dionysiac imagery (including sculpture) from the 4 th century вС onward. ${ }^{34}$

In all three instances, Dionysos is either placed next to to Apollo or combined with him on the same vessel. As is demonstrated by, for instance, the work of the Shuvalov Painter (with more than twenty representations of Apollo) as well as that of the Pothos Painter and the Meidias Painter, in the years following the Plague of Athens Apollo was more in evidence than earlier or later: would he have been seen as the cause of the epidemic or as a healer? In any case, he was the embodiment of a longing for a moral code, justice, recognition of the divine order, which always seems more pregnant in times of crisis. ${ }^{35}$ Moreover, the juxtaposition of the two gods is in accordance with the fact that at the Parthenon Dionysos is presented as the brother of Apollo, i.e. as someone who complements Apollo. As far as monumental art is concerned, this perspective is continued in the decoration of the west pediment of the temple of Apollo in Delphi, created around 350 BC by an artist from Athens, where Dionysos appears as Kitharodos, a role associated with Apollo. ${ }^{36}$

The Kadmos Painter, the circle of Polygnotos, and the cups of the Kodros Painter present the relationship with Ariadne in a manner that is quite different from that of the somewhat earlier work of the Syleus, Harrow, Niobid and Lewis Painters. ${ }^{37}$ This is no longer a dramatic —and for Ariadne perhaps

\footnotetext{
32 St. Petersburg $\Pi_{1872.130}$ (КАв 6 a), see above Chapter 7 , note 94.

33 He is also depicted in this way, reclining with Herakles on the symposium couch, on the more modest pelike London 1956.2-17.1: ARV 1186.31; BA 215720.

34 Compare Plutarch, quoted by Massa $2006-2007,82 \mathrm{f}$.

35 Moret 1982, 134.

36 Croissant 2003, 85-87, pl. 34 .

37 Circle of Polygnotos: Tarquinia RC 4197 (see above Chapter 6, note 129) and Tübingen 5439 (see above Chapter 6, note 131); Kodros Painter: London E 82 (see above Chapter 5, note 42) and Würzburg H 4616 (491) (see above Chapter 6, note 135); earlier works: see above Chapter 5 , notes 104, 107, 114, and 119 .
} 
even traumatic — confrontation, but a marriage based on mutual agreement, a situation of joyful companionship. ${ }^{38}$ It is not a coincidence that Eros now seems part of the Dionysiac world, even in images where Ariadne is lacking. The winged child not only embodies Dionysos' erotic aura, but also, as Greifenhagen already pointed out, everything that comes into being and is, therefore, unknown. ${ }^{39}$ The presence of Eros speaks of a new era beginning with Dionysos, and now not just for the polis, but first and foremost for the individual beholder of the image. ${ }^{40}$

The Kodros Painter, one of the cup painters who were active just after the completion of the Parthenon, has already been discussed. ${ }^{41}$ Another prominent artistic personality of the time is the Eretria Painter, whose work may be dated between 440 and 415 BC. ${ }^{42}$ Apart from cups, he decorated a number of the smaller-size vase types. ${ }^{43}$ As far as cups are concerned, his Dionsyiac scenes, which, with images of athletes, belong to his most frequently represented subjects, consist of rather conventional depictions of the thiasos with satyrs and dancing women. In one instance, dated around 430-425, one of the outside images shows Dionysos riding a mule or a donkey amidst ecstatically moving satyrs. He is bearded, wears a short chiton and boots with tongues, and has a thyrsos in his right hand. ${ }^{44}$ There are, so far, no parallels for this image. On the reverse, we find a satyr, who sits somewhat precariously on his mount, accompanied by two comrades with torches. The inside image shows a satyr riding in side saddle. It is evident from black-figure iconography that a man riding a mule in a Dionysiac ambiance is not necessarily the mythological Hephaistos returning to the Olympus. ${ }^{45}$ It is quite possible that a carnivalesque ritual of this kind actually took place in 5 th-century Athens. In addition, I would like to mention another cup which has recently been attributed to the Calliope Painter, a somewhat older collaborator of the Eretria Painter. ${ }^{46}$ It shows satyrs in the citizen's himation: on both outside images they are engaged in quiet conversation with women carrying thyrsoi, in the inside image they are standing

38 Sabetai 2011, 146: "In general, the imagery of Dionysos' union with Ariadne after the mid5 th century вс conveys the idea of conjugal union." Greifenhagen 1957, 24; Isler-Kerényi 1984a, 385; Isler-Kerényi 2004b, 247.

40 As is the case with the east pediment of the Parthenon, see above Chapter 7 .

41 See above Chapter 5, p. 98.

42 Lezzi-Hafter 1988, 23.

43 Boardman 1989, 98.

44 London E 102: ARV 1253.70; вA 217008; Lezzi-Hafter 1988, 159 and 312, no. 15, pls. 10 and $53 \mathrm{c}$.

45 Isler-Kerényi 2004a, 48-51.

46 Ruvo 1442: ARV 1261.54; BA 217123; Lezzi-Hafter 1988, 323, no. 90, pl. 69. 


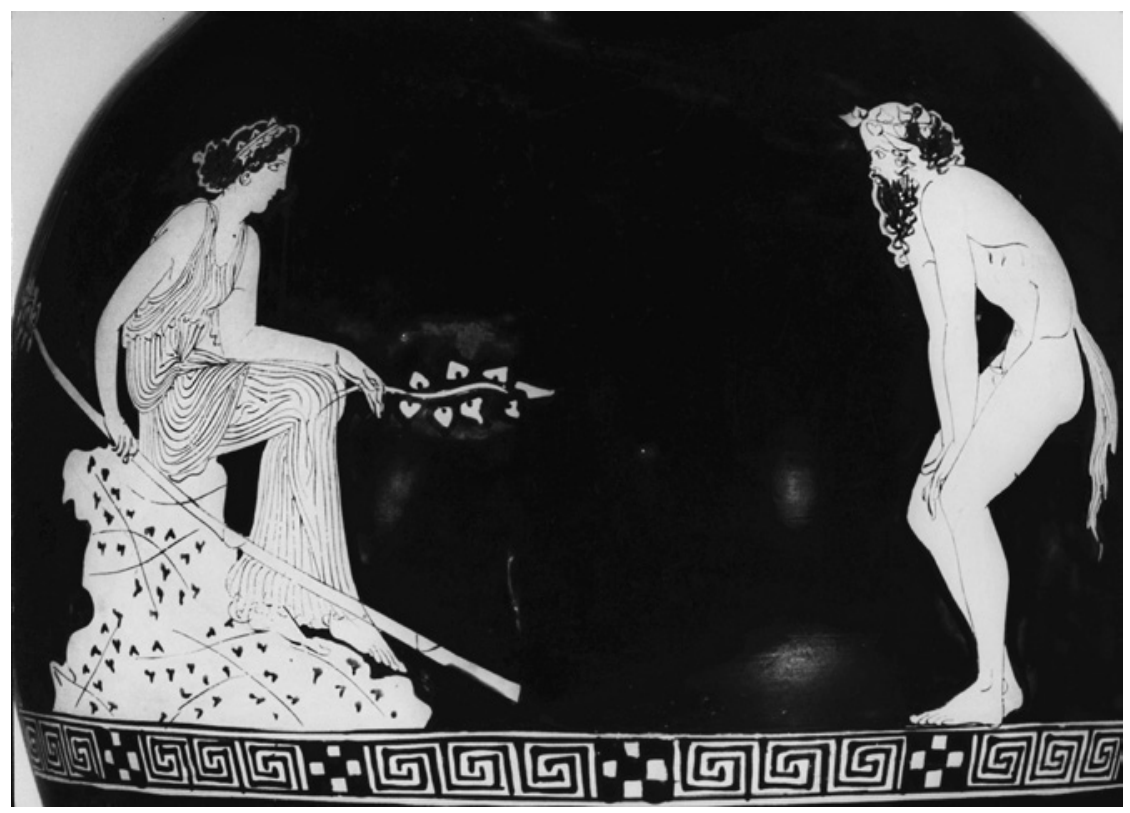

FIGURE 104

Chous, Eretria Painter, Basel, Antikenmuseum Basel und Sammlung Ludwig BS 407 (Lezzi-Hafter 1988, pl. 134).

next to an altar. This is not a thiasos situation, but just men and women meeting in a Dionysiac context.

The Eretria Painter's best work is perhaps his large chous. Especially attractive is the calm but suspenseful confrontation of a woman who, armed with a thyrsos, is sitting on a ivy-covered rock, with a satyr ready to jump (Figure 104). ${ }^{47}$ The chous showing a rather original version of the return of Hephaistos briefly discussed earlier, dates to the same period: the years between 430 and $425 .{ }^{48}$ The two gods, bearded and with ivy wreaths, together ride the same mule: Dionysos is in front with his kantharos, Hephaistos behind him with a smith's cap on his head and a pair of tongs in his left hand. With his right he salutes the satyr who walks in front of them. The spaciousness of the composition has turned the familiar boisterous train of earlier versions into a solemn event.

Scholarship has given special attention to three choes by the Eretria Painter excavated in Attica and in Athens, and another one of a slightly younger date

47 Basel bs 407: Addenda 354 (1249.12 bis); BA 275512; Lezzi-Hafter 1988, 338, no. 212, pl. 134; Schmidt 2005, 188, fig. 95 .

48 New York 08.258.22: see above Chapter 6, note 141; Lezzi-Hafter 1988, 339, no. 213, pl. 135; Schmidt 2005, 174, fig. 88; Smith 2007, 157 f.; Lissarrague 2013, 156, fig. 129. 
by the Meidias Painter who originally was one of his collaborators. ${ }^{49}$ The reason for this is that the ritual acts depicted on them can, on the basis of the image carrier, be associated with the Anthesteria. We already discussed the two choes with the swing in the center of the image and on the left the outsize klismos apparently meant for Dionysos. ${ }^{50}$ The other two choes have a threelegged table at the center of the image, with on it a liknon, a wide basket. On the oldest known of the two, a large Dionysos mask has been placed inside the liknon. ${ }^{51} \mathrm{~A}$ woman is solemnly approaching from the left with a kantharos in her hands, on the right a young woman with an ivy wreath is bringing a dish with grapes. She is followed on the far right by a little girl, who carries an object that is no longer recognizable. On the left a decorated calyx krater has been put on another small table.

On the chous that was discovered later, in Athens, the liknon on the little table is partly covered with a cloth. ${ }^{52}$ It may have contained the mask that is hanging on the structure on the far left of the image, but this is by no means certain. In addition, the mask, shown in profile, is too much damaged to allow us to identify it as a Dionysos mask. To the right of the table stands a bearded man, who, apart from the laurel wreath on his head, wears nothing but a loosely held piece of cloth. With his right hand he seems to offer a youth standing on the left some laurel branches. This young man wears an ivy wreath and is only dressed in a piece of cloth wrapped around his hips, like an artisan. He is shown en face, drinking from a skyphos. His left hand probably takes the proffered branches. On the floor to his left stands a column krater swathed with ivy; more ivy branches can be seen in front of and above the mask. On the far right, a naked boy in a wreath approaches with a large chous. Inscriptions make it clear that the elderly man is called Prometheus, and the youth Epimetheusfigures from mythology with whom the Athenian artisans, who were also allowed to take part in the Anthesteria, would be able to identify. ${ }^{53}$

49 Lezzi-Hafter 1988, 208; Schmidt 2005, 177 ff., who largely agrees with Lezzi-Hafter 1988, dates the ones by the Eretria Painter between 430 and 420, and the one by the Meidias Painter in the following decade. Tzachou-Alexandrí 1997, 480 is of the opinion that the more recently discovered chous is slightly older: $435^{-430 .}$

$5^{\circ} \quad$ See above Chapter 6 , notes 80 and 82 .

$51 \quad$ Athens BS 318 (ex Vlasto), from Anavyssos: Addenda 354 (1249.13); BA 216949; FrontisiDucroux 1991, 16o, fig. 97; Lezzi-Hafter 1988, 200 f. and 339, no. 215, pl. 137; Schmidt 2005, 183, fig. 93; Schwarzmaier 2008, 88, fig. 9.

Athens, 1st ephory 3500 , from a grave discovered underneath the present Pireus Street in Athens: BA 28128 (no image); Tzachou-Alexandrí 1997.

53 Schmidt 2005, 185 f. 
In contrast to the series with the women's ritual around the Dionysos idol, these four images are remarkable for their diversity. This may perhaps be explained from the locations where they were excavated: they were apparently not part of a series for export, but manufactured for the local market. They strike us as snapshots of certain rituals, but are actually aesthetic compositions consisting of combinations of carefully selected motifs: "It was by no means the intention of the vase painters to provide illustrations of the proceedings at the Anthesteria or to document them. Instead, they chose representations that would just remind Athenians of what took place during these large collective festivals in a very general way." ${ }^{\prime 5}$ Nevertheless, they give us a lot of information on these proceedings: that there were events for women and for men; that children of various ages and citizens who made a living as craftsmen and laborers also actively participated in them. This latter category not only identified with Prometheus, but especially with Hephaistos, whom we found on another of the Eretria Painter's choes, riding a mule with his brother Dionysos. ${ }^{55}$ On two of our four choes, as on the stamnoi, Dionysos is present through his mask. ${ }^{56}$ Just his face, even just his eyes can be effective. As Euripides explicitly states in his Bakchai, being in contact with the god Dionysos is to see him and to be seen by him. ${ }^{57}$ On the one hand the empty chair emphasizes his absence, on the other it tells us that his arrival is imminent and anticipated with joy. None of these images depicts some kind of official ceremony: the improvised swing, the baby's chair standing upside down, the little three-legged tables- they all strengthen our impression that this is about activities taking place in a family environment in the context of the Anthesteria. These images clearly illustrate how hard it is to combine our rare literary sources concerning a certain subject—in this case a concrete ritual—with the relevant vase imagery. ${ }^{58}$ In our perspective these choes are evidence of the strong presence of Dionysos in the mental world of the original buyers during the period immediately following the erection of the Parthenon - and not only in the life of the polis, but in the life of every citizen from the days of his childhood. Nevertheless, it is

54 Schmidt 2005, 193: "Die Vasenmaler wollten mit ihren Bildern keineswegs die Vorgänge an den Anthesterien im einzelnen illustrieren oder gar dokumentieren. Sie wählten statt dessen oft Darstellungen, die jeden Athener an die Ereignisse bei den grossen kollektiven Festen im allgemeinen erinnerten."

56 Frontisi-Ducroux 1991, 161.

57 E. Ba. 470.

58 Similarly Schmidt 2005, 180: "Wir müssen vielmehr damit rechnen, dass ein Grossteil der dargestellten Praktiken nie eine schriftliche Erwähnung gefunden hat. Wozu auch? Schliesslich waren die Vorgänge jedermann bekannt, da sie jedes Jahr stattfanden." 


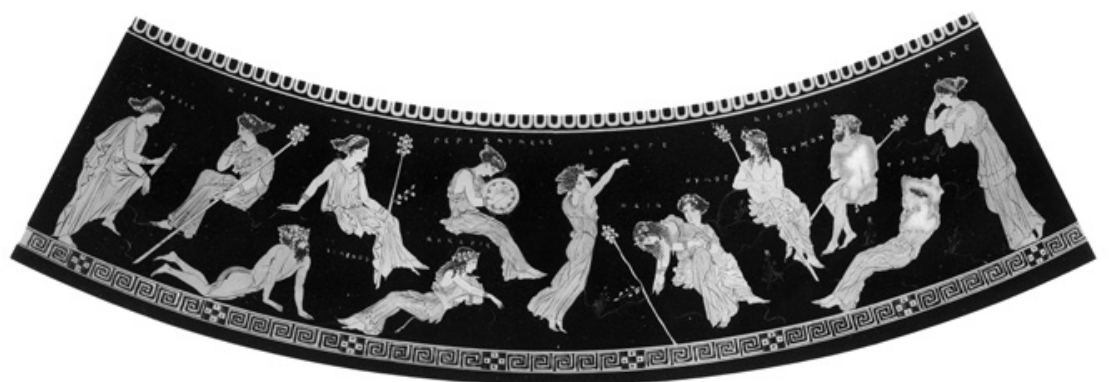

FIGU RE 105 Squat lekythos, Eretria Painter, formerly Berlin F 2471 (Furtwängler 1883-87, pl. 55).

striking that in none of the rituals represented the god himself is present-at best there is a mask. This provides a stark contrast with the images of around $440 \mathrm{BC}$ presenting the train with torchlight and music in which the god himself participates, and whose other participants can either be identified as mythical beings or as ordinary humans taking on the roles of nymphs and satyrs in a ritual situation. ${ }^{59}$

Although, as we have seen, the Eretria Painter rarely depicted Dionysos, he was deeply involved in the representation of the god's festivals. This makes his squat lekythos of around 425, which disappeared during the Second World War, all the more important (Figure 105) ${ }^{60}$ Not only was the vase type new at the time-it was also quite innovative as far as composition and choice of subject were concerned. ${ }^{61}$ The god is not represented at floor level, but (like in the work of the Dinos Painter or the Kadmos Painter) has been placed in a hilly landscape. In the company of the women of his thiasos, he watches the whirling dance of one of the younger women. A satyr is sitting next to him, another one is lying in the lower left corner and looks at the scene with great curiosity. One of the maenads, completely exhausted, is hanging in the arms of a companion. Dionysos looks boyish. He wears his long hair loose, his

59 For instance: a pointed amphora by the Achilles Painter, Cab. Méd. 357 (see above Chapter 5, note 20); a stamnos by the Curti Painter, Cambridge (Ma) 1925.30.40: Addenda 320 (1042.1); BA 213538; a bell krater by the Christie Painter, Baltimore 48.74: ARV 1047.11; BA 213580; a bell krater by the Painter of Munich 2335, Louvre G 486: ARV 1163.34; BA 215383.

6o Formerly Berlin F 2471: Addenda 353 (1247.1); BA 216937; Lezzi-Hafter 1988, 226 f. and 342, no. 234, pls. 143d-145; Shapiro 1993, 256, no. 112; Miller/Kästner 2005, 129; SchöneDenkinger 2008, 49 .

61 Lezzi-Hafter 1988, 234-237. 
himation leaves his upper body bare. All figures, including the god, have their names inscribed. ${ }^{62}$ Could this be because the god is represented in an unfamiliar way? The Eretria Painter may have been inspired by the Parthenon's new youthful Dionysos, but presents a version of his own: it is not the athletic body, but the grace of the adolescent that he seeks to emphasize.

Like the Kadmos Painter, the Eretria Painter adapts the outward appearance of Dionysos to the situation, which is rather apt for the god of metamorphoses. This innovative spirit in the handling of Dionysiac imagery is also evident in the work of the Dinos Painter. It is all the more remarkable in view of the fact that the Athenian production of figured pottery diminished sharply after 430 and the whole genre was in a decline. Symptomatic for the situation is the excessive number of anonymous figures in comparison to identifiable ones. This phenomenon is perceptible in the work of all painters. Apart from Eros, Dionysos and his retinue remain well represented, but komos and symposium all but disappear. In the mental world of the beholders of the images Dionysos apparently stills plays an important role, but not in the same way as before $430 \mathrm{BC}$.

Before the 4th century there were still workshops, which produced pieces of a more than average quality that enriched Dionysiac imagery, for instance the workshops of the Meidias Painter and the Pronomos Painter. Compared to the decorators of larger vessels (Beazley speaks of Pot-Painters as opposed to CupPainters) we just discussed, the Meidias Painter and his circle are remarkable for their rather individual selection of vase types: hydriai, some pelikai, loutrophoroi, lebetes, oinochoai. ${ }^{63}$ Especially characteristic is the preference for lekythoi, both normal and squat, and pyxides - kraters only appear incidentally. It is evident, that their clientele is very different form that of, for instance, the Kadmos Painter, which is supported by the provenances of the finds: here, as in the case of the Eretria Painter, Athens and Attica are relatively better represented. These vase types more belong to the household than to the symposium and are used by women rather than citizens.

There is only one representation of Dionysos that can be attributed to the Meidias Painter: a very badly preserved kalpis of about $410 \mathrm{BC}$, which was found at the Kerameikos. ${ }^{64}$ The main image shows a scene in the women's quarters; the frieze of the base has the punishment of Pentheus. Pentheus and a maenad who holds him by the head form the focal point of the main side of the vessel. The standing nude Dionysos, only partly preserved, was placed on the reverse

\footnotetext{
62 From left to right: Silenos, Makaria, Periklymene, Nymphe, and Maia.

63 Boardman 1989, 146; Langner 2013, 152.

64 Athens, Kerameikos 2712: Addenda 362 (1313.6); BA 220498; Schöne 1990.
} 

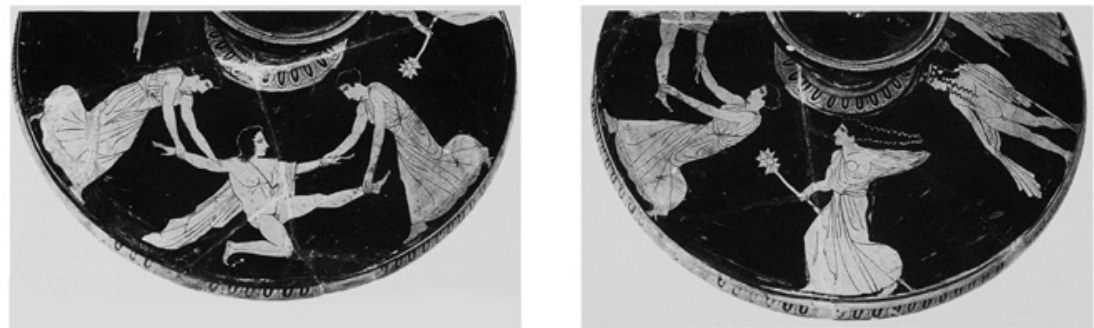

FIGURE 106

Lid of a lekanis, Paris, Louvre G 445, details with Pentheus and Dionysos (Moraw 1998, pl. 23.57).

side in such a way that his thyrsos stands almost precisely underneath the handle. When the reconstitution of the fragments is correct, Dionysos could have watched the punishment of Pentheus for where he stood: a position we also find on a somewhat younger Apulian version of the same event. ${ }^{65}$ In addition, we have a very comparable Dionysos of about one generation earlier who watches the maenads tearing Pentheus apart on an unattributed lekanis from around 440 (Figure 106). ${ }^{66}$

To the right of Dionysos we can see some remains of a small laurel: does this mean Apollo was also depicted? In any case, this Dionysos who invisibly takes his retribution must have looked like a twin brother of the Apollo who, on a volute krater by the Kadmos Painter mentioned earlier, watches Marsyas the musician going towards his gruesome death. ${ }^{67}$ As we have seen in the previous chapter, this resemblance of the two sons of Zeus is far from coincidental: in punishing Pentheus, Dionysos acts in the way Apollo normally acts, as the executor of the order of Zeus. This aspect of Dionysos was not new, but had already been presented in the early 6th century: Dionysos who, on the order of Zeus, addresses Peleus at the occasion of his marriage to Thetis; Dionysos who persuades Hephaistos to liberate the queen of the gods; Dionysos who, with the other Olympians, fights against the giants.

The famous kalpis with the Judgment of Paris of around 400 BC may be attributed to the inner circle of the Meidias Painter. ${ }^{68}$ As in the version by the Kadmos Painter, Paris is represented as an oriental. In the field above him an awe-inspiring Eris seems to rise from a hillock. Themis is absent, however,

65 LIMC VII, Pentheus 16. See in addition Chapter 9, note 16.

66 Louvre G 445. See above Chapter 7, note 42 and below Chapter 9, note 16.

67 See above note 21 .

68 Karlsruhe 259 (B 36): Addenda 362 (1315.1); BA 220515. 


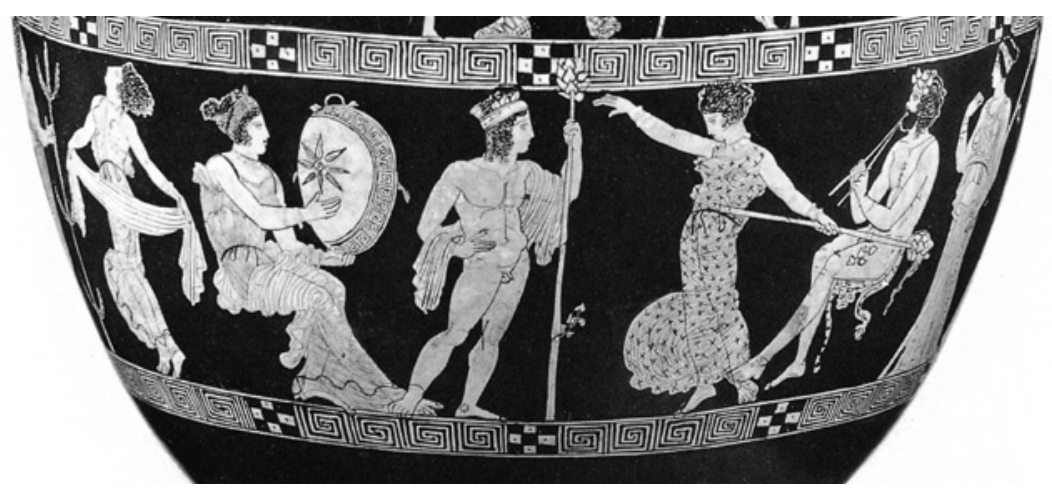

FIGURE 107 Kalpis, follower of the Meidias Painter, Karlsruhe, Badisches Landesmuseum 259 (B 36), detail of the lower frieze (Burn 1987, pl. 39).

which may imply that Eris' actions should not be interpreted as being of significance for the correct progress of world history.

The narrower frieze image of the base shows Dionysos amidst his gracefully dancing bacchantes. He looks very much like the punisher of the lekanis, mentioned earlier, and the kalpis by the Meidias Painter, but the situation seems completely different. Around the god no less than seventeen persons are gathered in a peaceful atmosphere full of music. In the center, to the left of Dionysos, sits a beautiful woman. She beats a richly decorated tympanon placed exactly in line with the head of Eris in the image above. Her rhythms and the tones of the aulos played by a satyr sitting on the far right, accompany a girl in a light, colorfully embroidered chiton, who gracefully spins around her own axis (Figure 107). Two other women dance to the left of the tympanon player: the one on the right is ecstatic, the one on the left appears to be jumping up and down. Between the two we see a small tree: the scene takes place in the open air, as in the lost squat lekythos by the Eretria Painter, the dinos by the Dinos Painter, the cup by Makron, and the Judgment of Paris in the image just above. ${ }^{69}$ On the far left, below the handle, the only woman wearing an animal skin is looking on. Like the woman watching the dance to the right of the satyr, she holds a thyrsos.

The lower border image on the reverse of the kalpis has a composition with four pairs of women of various ages and status groups. They wear their hair uncovered, in a chignon or pinned up with the help of a decorated headband. They are engaged in friendly conversation, standing or sitting, or with one foot supported by an object—a familiar formula for the representation of a Muse.

$69 \quad$ See above Chapter 5 , note 51. 
Although here, too, the scene takes place in the open air, the difference between the main side and the reverse is striking: on the one side Dionysiac ecstasy, on the other peaceful companionship. Under the sign of Dionysos, the absence of conflict and tranquil peace are not the same thing. Nevertheless, the whole frieze is permeated with a feeling of harmonious contentment, which stands in stark contrast with the ominous quiet of the Judgment of Paris.

The inner circle of the Meidias Painter also produced a sumptuously decorated pyxis found in Eretria. ${ }^{70}$ The cylindrical part shows women in a feminine interior, and Aphrodite on the verge of mounting her chariot drawn by erotes. At first sight, the image on the lid reminds us of the Eretria Painter's Dionysiac idyll. It shows Dionysos with his thyrsos, his face presented in three-quarter view. Two seated women with lyra and tympanon provide the accompaniment for the whirling dance of five of their companions. Two women each hold the leg of a fawn; they are ready to tear it apart, like Pentheus. The woman to Dionysos' left seems to be addressing him. One of the next two dancers holds a thyrsos, while the other carries a frightened child over her shoulder, just holding it by one of its little legs. Will the child be torn apart, like the fawn?

Although no actual horrors are depicted, a gruesome event of this kind seems rather unsuitable for a pyxis; the image is unique. In the second half of the $5^{\text {th }}$ century, the pyxides repertoire is dominated by Eros and images of a peaceful female world with appropriate requisites such as boxes, baskets and mirror. Heroes such as Herakles hardly ever occur, and Hermes and Aphrodite are the most frequently depicted gods. Once in a while one finds satyrs and their dancing female partners. ${ }^{71}$ In any case, the contrast between the lid and the 'box' is striking: does this perhaps refer to the two extremes of female life? As we will see, a similar contrast may be found in the decoration of the bronze Derveni krater. ${ }^{72}$

The 'box' of another, similar pyxis has a decoration of laurel branches; its lid presents an idyllic image. ${ }^{73}$ Two erotes are kneeling on either side of the image. They each have a fillet in their hands. Between them we see Ariadne with a mirror and a youthful naked Dionysos with his thyrsos. They sit closely together, but are facing away from each other. This is a simplified version of

$70 \quad$ London E 775 (1893.11-3.2): Addenda 364 (1328.92); BA 220648; Burn 1987, 34 and 79 f., pl. 18 a-c, pl. 19 a; Grassigli 1999, 112, fig. 16.

71 Collection unknown: BA 8904 (no image: satyr pursuing a maenad); in the art trade: BA 9021718 (no image: maenad and anonymous figures); Sarajevo 34: BA 9495 (seated satyr). Concerning pyxides imagery see in addition Schmidt 2005, 119-151.

72 See below Chapter 9 .

73 Karlsruhe 296 (B 1873): Addenda 364 (1328.95); вA 220651. 
the so-called pyramid composition that was popular during the 4th century and continued in use until Imperial times. ${ }^{74}$ The remaining space is taken up by a seated naked youth who is approached by a young woman carrying a large plemochoe, a vessel used for ointments. Divine and human wedding are juxtaposed: a highly appropriate motif for a vase that was frequently given as a token of love or a wedding present. ${ }^{75}$

An artistically modest, but stylistically similar kalpis seems to introduce the Dionysiac imagery of the 4 th century. ${ }^{76}$ In the center of the image we see a seated Dionysos, youthful and with long flowing locks. He sits in a relaxed attitude as in the east pediment of the Parthenon, and has the thyrsos on his left arm. He looks back towards an unidentified young woman approaching from the right. Between the two a small panther is reaching for her hand. A satyr with a thyrsos appears to have been waiting for her. Aphrodite is seated above on the left, Hermes above right. An eros is hovering above Dionysos, another one is approaching Hermes. Below on the right a seated nymph is looking at the scene. Some flowers and an ivy branch in the field between the figures indicate an open-air situation. Is the nameless woman Ariadne, or is this a mortal woman play-acting? Did she come for Dionysos or for the satyr?

An exquisite cup fragment from Kerch on the Black See is another forerunner of the 4th century. It shows an, unfortunately incomplete, Dionysos riding a large panther, which is cheerfully stepping along. ${ }^{77}$ Instead of his kantharos, he holds the horn of plenty; his thyrsos is decorated with an embroidered bow. We already encountered Dionysos riding a panther on the kalpis from Pella, in a very special mythological context inspired by the west pediment of the Parthenon. ${ }^{78}$ Like several other Dionysos figures just discussed, the god wearing elegant lace-up boots on a fine squat lekythos from Corinth seems to have been inspired by the east pediment of the Parthenon. ${ }^{79}$

This brings us to the Pronomos Painter, a brilliant vase painter of around $400 \mathrm{BC}$; only a few of his works are known. His name is derived from the famous and often-discussed volute krater from Ruvo (Figure 108). ${ }^{80}$ Its best-known

\footnotetext{
74 Gasparri 1986, 509.

75 Schmidt 2005, 150.

76 Cambridge (Ma) 1960.347: Addenda 367 (1341.2); BA 217539 (apparently identical with BA 1012159, Braunschweig, A. Loebbecke).

77 St. Petersburg 1867.68.953: ARV 1329.117; BA 220672; Burn 1987, 8 o.

78 See above Chapter 7 , note 88.

79 London E 703: Addenda 365 (1330.9); BA 220684.

$80 \quad$ Naples H 3240: Addenda 365 (1336.1); BA 217500; Paul-Zinserling 1994, 44; Lissarrague 2010, and $2013,30-32$, fig. 7 .
} 

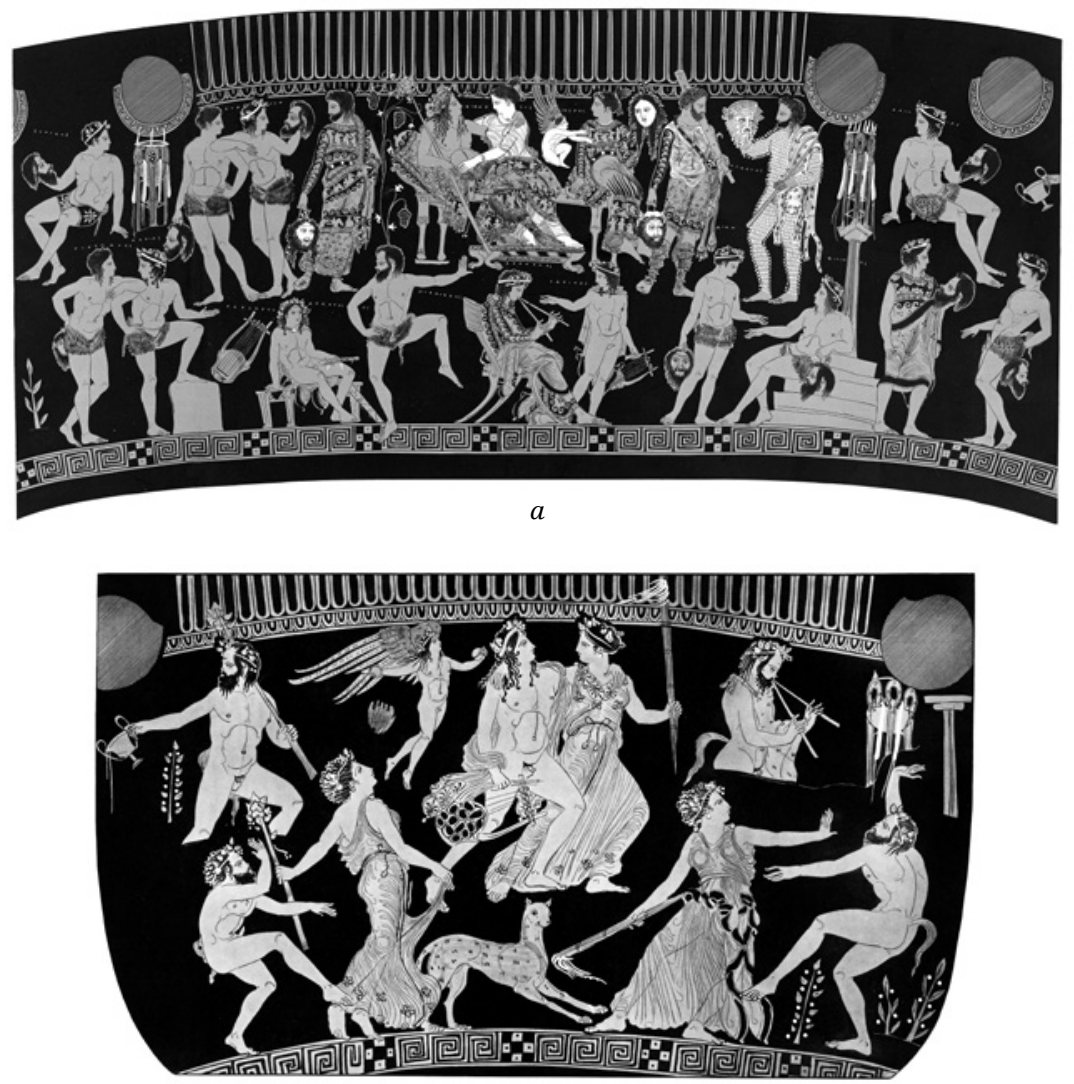

$b$

FIgU Re 108 Volute krater, Pronomos Painter, Naples, Museo Archeologico Nazionale H 3240.

a. side A (FR pl. 143-4).

b. side $B$ (FR pl. 145).

side shows the young Dionysos, his lower body covered by a rich himation, watching from his bed a performance by a large group of actors, in the company of Ariadne who holds him tenderly. As Claude Calame convincingly demonstrates, the image is an idealized representation of a celebratory ritual in honor of the liberator Dionysos Eleuthereus. ${ }^{81}$ This celebration of the victory in the dramatic contest was the high point of the series of theatrical performances which took place on the occasion of Anthesteria; the closing performance was

81 Calame 2010, 70: “... Dionysos Eleuthereus, Liberator of men who are free, coming from Eleutherai (Sophokles TrGFr. 172 Radt).” 
a satyr play. ${ }^{82}$ The image on the reverse side is closely linked to that on the main side, but, on the other hand, takes us from the ritual to the mythical level. It shows a naked Dionysos, with a lyra in his hand, and Ariadne, carrying a torch, moving euphorically towards the right in close embrace. To the left of Dionysos, Eros, cymbals in his hands, comes flying to escort them. On each side of the pair a satyr is moving in the same direction, in both cases partly hidden by an elevation in the landscape. The one in front plays the aulos, the one in the rear, carrying thyrsos and kantharos, looks back towards the scene on the other side of the vase. Below, on the left as well as on the right, we see a female dancer and a satyr, who appear to act out the titillation of their relationship in a mimic dance. One of the women is holding a thyrsos, the other a lighted torch. The latter seems to keep in check the panther which appears between the two pairs, its head shown in three-quarter view. Where is the divine couple going?

A more or less contemporaneous lekanis from Spina, stylistically more similar to the Meidias Painter, likewise seems to leave this question deliberately unanswered. ${ }^{83}$ It roughly shows the same motif, but here it is Ariadne who carries the lyra and leads the way. The aim is, apparently, the blissful unknownthe future promised to the Bacchic initiates in the famous gold tablets that accompanied them in death. ${ }^{84}$

A sumptuous calyx krater showing the stylistic influence of the Pronomos Painter presents Dionysos surrounded by women and satyrs in a paradisiacal ambiance very similar to that of the Dinos Painter's calyx krater of a few years earlier; the god's pose is almost identical (Figure 109). ${ }^{85}$ Here the god is flanked by two erotes; the women do not seem to be engaged in the ritual presentation of gifts, the accompanying podium is also lacking. One of the women lifts a bunch of grapes; bunches of grapes can also be seen in the surrounding landscape. There is no panther, however; in the foreground a woman is playing with a hare. The god looks into the distance, and sees neither the women, nor the beholder of the vase. The image gives the impression of an apotheosis of Dionysos in a permanent state of bliss. The contrast with the scene depicted on the reverse is therefore rather forceful. Two dancing satyrs are blocking the way of a woman swinging a thyrsos, who is briskly moving towards the

\footnotetext{
82 Calame 2010, 71-78. The vase itself may have been an agalma for Dionysos and Ariadne on the occasion of a victory in a dramatic contest and, in fact, have been part of a ritual.

83 Ferrara 5388: BA 19154.

84 Calame 2008, 161.

85 Madrid 11011: Addenda 366 (1336.1 below); BA 217505; Paul-Zinserling 1994, 44 f.; Moraw 1998, 300, no. 469, pl. 24 fig. 59 a-b.
} 


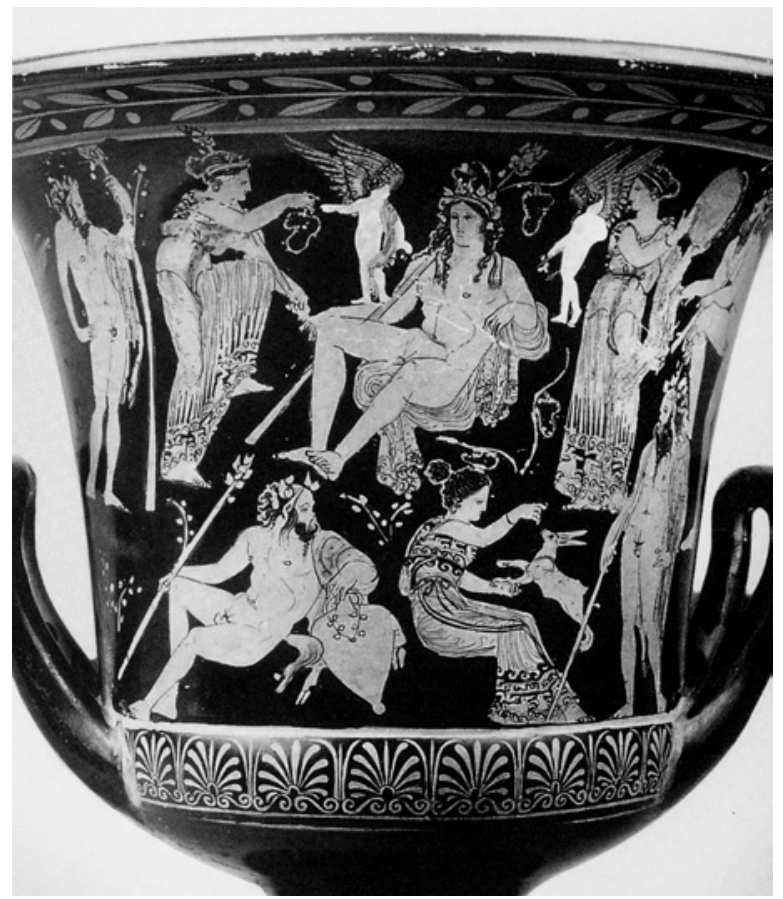

FIGURE 109

Calyx krater, circle of the Pronomos Painter, Madrid, Museo Arqueológico Nacional non, side A (cva Madrid 2, pl. 10.2).

right. Above left and right another satyr and a Dionsyiac woman are watching the scene.

As far as the Dionysiac repertoire of the vase painters active just after 430 is concerned, we find that the work of the Pronomos Painter and his milieu confirms the striking changes: the triumph of the new, youthful Dionysos, his idyllic existence-blissful, erotically tinted-in a distant world. ${ }^{86}$ The bearded Dionysos and his accompanying thiasos only appear in representations of the return of Hephaistos - a myth that apparently remained topical. ${ }^{87}$ A unique depiction of Silenos being captured by a group of Orientals looks like a scene

86 In this context it is significant that Eros is increasingly part of the Dionysiac retinue, compare Paul-Zinserling 1994, $5^{2}$ f.

87 Pelike Munich S 68: Para 482 (1347.1); BA 217593; calyx krater Agrigento C 1581: Para 482 (1347); вА 217595 . 
from a play. ${ }^{88}$ The disappearance of the bearded god also meant the ritual procession disappeared from the repertoire; the figures who participated in it now engage in various activities - music or the preparation of sacrificial gifts, for instance - in the idyllic surrounding landscape. Their identities are no longer ambivalent: the satyrs cannot be taken for citizens or for the actors from the satyr play, the women do not belong to the human world.

All of this is borne out by the names that are now increasingly given. This brings us to the issue of 'personification'. Scholars still use this term to refer to abstract concepts turned into mythological personages by poets and artists. These are said to have particularly occurred during the late $5^{\text {th }}$ century $\mathrm{BC}$, and mostly in images with an Aphrodisiac or Dionysiac theme- to remain with Dionysos, for instance Eirene, Makaria, Eudaimonia, etc. The origins and derivations of these 'personifications', however, are often far from clear. ${ }^{89}$ In addition, inadequate modern projections concerning the very different way of thinking of the ancient world are, as B. Borg has shown, not very helpful. ${ }^{90}$ It seems more useful to investigate in what way the inscription of names changed the Dionysiac thiasos-what it was that the vase painters wanted to refer to. What immediately strikes us is that Dionysos' retinue is less and less presented as a group of anonymous figures engaged in the same actions. Whether they carry a mythological name or a name that to the modern beholder seems rather like an abstract concept: every woman and every satyr around Dionysos becomes an individual. Moreover, the names of these individuals characterize the god's world: it is a world of peace (Eirene), a world of good fortune and material wellbeing (Eudaimonia), a world where life ends with a happy death (Makaria). ${ }^{91}$

88 Munich 67: Addenda 368 (1347.2); BA 217594. Dionysos on the stage will be discussed in the next chapter.

89 Gemelli Marciano 2013, 56; compare earlier Isler-Kerényi 1969, $7 \mathrm{f}$.

90 Borg 2002, 80: "So ist uns in vielen Fällen jede Möglichkeit genommen, sicher zu entscheiden, ob ein Wesen als göttliche Macht oder als auf Abstraktion beruhende Fiktion geschaffen oder generell rezipiert wurde" and in conclusion p. 233: "Dies bedeutet..., dass es letztlich nicht nur unmöglich ist, (bestimmte) Personifikationen von göttlichen Wesen grundsätzlich zu unterscheiden, auch nicht nur unnötig, sondern nicht einmal wünschenswert, denn gerade diese 'Schnittstelle' zum Göttlichen, die grundsätzlich alle Personifikationen besitzen, ist ebenso Ausdruck wie Ursache der Lebhaftigkeit des Eindrucks, den die Darstellungen vermitteln."

91 Compare Smith 2011, 78 f. (Eirene); Shapiro 1993, 62 (Eudaimonia). The figure named Hebe on the volute krater by the Kadmos Painter in Ruvo (see above p. 191 fig. 102), for instance, evokes the daughter of Hera and Herakles' bride on the Olympus-post-mortal conjugal bliss as a reward for a life of suffering; Shapiro 1993, 171. 
Vase painting after 430 вс does not only show a significant change in the outward appearance of the god; his relationship with the figures that surround him and the environment in which he is shown, have also changed completely. No longer do we find individual participants addressing the beholders and engaging them. These, in their turn, can no longer identify with the figures, but look at the scene as if it takes place on a stage. In addition, this 'stage' and the polis are not interchangeable; the scene rather refers to a blissful counter world. Both the deified Semele of the Kadmos Painter's volute krater in Ruvo and Makaria on the lost squat lekythos by the Eretria Painter make it clear that the scene is set in the future-the future that is in store for the Bacchic initiates. ${ }^{92}$ As is evident from Euripides Bakchai, which had its premiere in the final years of the $5^{\text {th }}$ century, Dionysos is still very well able to interfere in the life of the community. The vase painters, however, are no longer concerned with a god who acts for the rightful order, but with one who embodies the hope of admission to a joyful counter world.

92 For Semele as a prototype of a female initiate, see Isler-Kerényi 2007, 168-170. 


\section{Images of Dionysos from 430 BC onwards}

\section{Dionysos on Stage}

The visual arts did not provide the only means through which in Classical Athens images of Dionysos were communicated to the public: the appearance of the god on the stage must have been equally effective-perhaps even more so. In order to produce the desired effect, Dionysos must have appeared in a way that was instantly recognizable and at least partly appealed to the audience's familiar mental picture. In short, his appearance must have been in accordance with the iconography we know. On the other hand we may presume that the most impressive stage appearances in their turn influenced the imagery; as will be shown in what follows, this was especially the case with the Dionysos of the Bakchai. Most of the plays that have come down to us are incomplete and for this reason it is often impossible to tell if and how Dionysos was presented. Only three examples from the 5 th century allow us to draw some conclusions concerning the outward appearance of the god. All three may be dated in the decades between 430 and 400 BC: Kratinos' Dionysalexandros, Frogs by Aristophanes, and Euripides' Bakchai. The enormous impact of the latter was still discernable in Hellenistic times. ${ }^{1}$

\section{Kratinos' Dionysalexandros}

Dionysalexandros, a comedy by Kratinos, was first performed in 430 or 429 BC. Apart from a few fragments of the original text, only a summary (hypothesis), composed around $200 \mathrm{AD}$, remains. ${ }^{2}$ It tells us of Dionysos impersonating Alexandros, otherwise known as the shepherd and Trojan prince Paris, the protagonist of the Judgment of Paris, which is actually acted out on the stage. Dionysos-Alexandros subsequently goes to Sparta to abduct the beautiful Helena. Back on the Ida, the two hide for fear of the invading Greeks. The real Paris appears and decides to turn the couple over to the Greeks. He takes pity on Helena, however, and makes her his wife; Dionysos is handed over, accompanied by wailing satyrs. The hypothesis explicitly mentions that the

1 The subject was first discussed in Isler-Kerényi 2011b. For a more complete overview of the imagery, see Isler-Kerényi 2012a.

2 Bakola 2010, especially 180-272; Imperio 2011, 303-310. Concerning Dionysos in Attic comedy, see Casolari 2003, especially 98-112 devoted to Dionysalexandros. 
play's intention was to draw a bead on Perikles, who had brought war to the Athenians.

What Dionysos looked like when in Kratinos' play he appeared as Paris may be deduced from the history of the imagery of the Judgment. In the 6th century the Trojan prince is presented as bearded; from the $5^{\text {th }}$ century onwards he is youthful. ${ }^{3}$ It is precisely around $430 \mathrm{BC}$ that vase imagery shows the turnabout from Greek shepherd to Oriental with multi-colored leggings. ${ }^{4}$ It is possible that this change of costume can be attributed to a flash of wit of Kratinos'. Just the idea to cast the god in the role of the young lover could have been an ironic comment on the new Dionysos of the Parthenon, whose youthful beauty was, as we have seen, particularly highlighted both in the east pediment and in the east frieze. If, as Kratinos suggests, it was Dionysos who had caused the Trojan War, the contrast with the relaxed reclining god must have been all the more striking. In vase painting the oriental garb of Paris stresses the fact that the war had turned into a confrontation between Greece and Asia; a Dionysos (who in reality was strongly associated with the polis of Athens, as we have seen) decked out in oriental leggings must have produced a paradoxical and shocking effect comparable to the ridiculous Dionysos presented by Aristophanes. This probably made the criticism directed at Perikles even more acrimonious.

\section{Aristophanes' Frogs}

Aristophanes' comedy is named after its chorus of frogs. It was probably written after Euripides' Bakchai and had its premiere in Athens in January of the year 405 BC. $^{5}$ Its comic mood is established right at the beginning when Dionysos enters with his servant Xanthias, who is riding a donkey. This would have immediately reminded the audience of the motif of the return of Hephaistos, so often depicted at the time on vases and in monumental art. ${ }^{6}$ The announcement that the two were not on their way to the Olympus but to Hades, must have led to peals of laughter. ${ }^{7}$ Dionysos was on his way there to bring back Euripides who had just died. From the words of Herakles and Charon, with whom he meets, we can conclude that Dionysos is presented as young and rather chubby. ${ }^{8}$ During the first half of the play the audience was regaled with the pair's adventures in the underworld. Dionysos' frequent

3 LIMC VII.1, 186-188 (A. Kossatz-Deissmann concerning Paridis iudicium).

4 Lid of a pyxis, Copenhagen 731: BA 7928; LIMC viI Paridis Iudicum 40.

5 Lada-Richards 1999, 17.

6 Lada-Richards 1999, 156; for the painting in the temple of Dionysos see Natale 2008, $107 \mathrm{f}$.

7 Ar. Ra. 69 .

8 Ar. Ra. 60 (adelphidion), and 200 (gastron). 
disguises as Herakles or Xanthias (and the fact that he was just as frequently unmasked) must have been genuinely funny; we can see him continually putting on the lion skin over his saffron yellow chiton - and taking it off again. Incidentally, it is probable that the traveler as well as the slave wore a short chiton instead of a long one. ${ }^{9}$ The many disguises and changes of costume were very likely meant as a parody of the theater itself. ${ }^{10}$ In the second part, in which Dionysos features as adjudicator between Euripides and Aischylos, he may have appeared as a dignified figure in a long robe-as referees are usually depicted in vase painting. ${ }^{11}$ At the end of the comedy it is not Euripides who, for the greater good of the polis, is led out of Hades by Dionysos, but Aischylos who represents the polis' good old days. Here Dionysos assumed his familiar role of mediator and liberator-as he did when he brought back Hephaistos. Everyone in the audience knew that he had not only accompanied his unfortunate brother back to the Olympus, but also brought his own mother from Hades to heaven and, in so doing, had granted eternal life to her who had died so young. Thus, from the moment he came onto the stage and even before he had uttered a single word, Dionysos delivered a message of hope and reconciliation to the Athenians just before the disastrous end of the Peloponnesian War. ${ }^{12}$

\section{Euripides' Bakchai}

The subject of Euripides' Bakchai is the horrible punishment of Pentheus, king of Thebes. The sudden entry of Dionysos at the beginning of the play can only have provided the desired theatrical effect when the god was immediately recognized by the audience. Even when Euripides would have added new elements to Dionysos' outward appearance, it must have answered to the visual expectations of the audience and fitted into the iconographical landscape of his time. On the other hand, because of the tremendous success of the play in the centuries that followed, it is more than likely that this particular Dionysos had a Nachleben in the imagery. ${ }^{13}$ What does the text tell us about the way he looked? From the words of Pentheus we can deduce that the god had long blonde locks and was young and effeminate. ${ }^{14}$ An additional element is the fact that he is said to have just arrived from Asia, that is: from afar.

\footnotetext{
9 Compare the slightly older representations of Herakles: LIMC IV, Herakles 1477 and 1562.

10 Tasinato $2003,13-15$.

11 Compare for instance Berti-Restani 1988, 72, fig. 17, and 74, fig. 19.

12 Similarly Lada-Richards 1999, 326-329.

13 For the successes of the play, see Seaford 1996, $5^{2} \mathrm{f}$.

14 E. $B a .235^{-236}$ und $455^{-459 .}$
} 
The iconography of Pentheus' death in vase painting is not very helpful. ${ }^{15}$ It starts at the end of the 6th century, with very gruesome images, and continues until about 480 BC. Dionysos only appears on the cup by Douris in Fort Worth (Tx); bearded and wearing a long robe, he sits dignifiedly as the hectic, bloodthirsty events take place around him. Only forty years later the subject comes up again on the lekanis lid discussed earlier, and subsequently on the badly preserved hydria by the Meidias Painter. ${ }^{16}$ Dionysos appears on both, although it is possible that he is supposed to be invisible; he is young, naked, and very much like the punishing Apollo. Nevertheless, we can hardly presume he appeared naked on the stage. We do not know if he already appeared as a young man in the Pentheus tragedies by Thespis, Aischylos and Xenokles, which preceded Euripides' play. ${ }^{17}$ In view of what we know of his iconography, this does not seem very probable.

This is everything vase painting has to offer. Of the sculptural types that may have existed at the time of Euripides, neither the bearded nor the naked god seems eligible. Likewise improbable, because he wears a long garment unsuitable for a traveler, is the type of the young, long-haired kithadoros in the west pediment of the temple of Apollo in Delphi. ${ }^{18}$ On the other hand, the Bakchai may have inspired a Dionysos type that, for stylistic reasons, is dated in the early 4th century and is known from several copies and versions in relief. ${ }^{19} \mathrm{He}$ has long, flowing locks, and wears a short robe and boots, which would be suitable for both the traveler and the actor. As has been mentioned above, the panther skin refers to Asia, from where the god just came. The femininity of his appearance is not confined to the face framed by the long locks. None of the other male children of Zeus would wear a short chiton with an animal skin over it; only Artemis does. In fact, a votive relief was found not far from the so-called Chapel of Dionysos on Delos which shows a Dionysos who could have been Artemis, but for the cluster of grapes and the panther. ${ }^{20} \mathrm{~A}$ mold for a goblet from Hellenistic times makes it clear that this type was known as

15 March 1989; LIMC VII.1, 315-317 (J. Bažant/G. Berger-Doer); Weaver 2009.

16 For the cup: see above Chapter 3 , note 83 fig. 31. For the lekanis lid: see above Chapter 7 , note 42 , and 8 , note 66 . For the hydria: Chapter 8 , note 64 .

17 Aélion 1983, 251-254.

18 Croissant 2003, 85-87, pls. 34-41.

19 LIMC III, Dionysos 128; Cain 1997, 30-34.

20 Isler-Kerényi 2012a, fig. 7. In addition Marcadé 1996, 182 f.: "Et pourtant, de manière extrèmement singulière, c'est à Artémis que font penser le vêtement, la coiffure et même les bottines." (Ph. Jockey). 


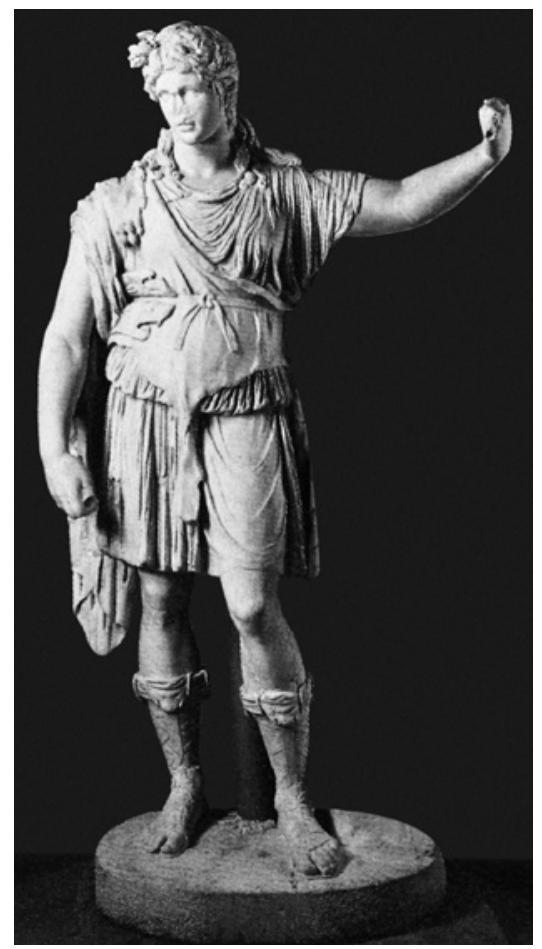

FIGURE 110 Dionysos in Euripides' Bakchai (photomontage C. Isler-Kerényi).

Thriambos. ${ }^{21}$ And, after all, this suits the memory of the triumphant Dionysos of the Bakchai (Figure 110).

This Dionysos type is not only preserved in an impressive Hellenistic bronze statuette and copies from the Imperial period, but also in some 4 th-century votive reliefs from Greek sanctuaries, as well as sporadic vase images. ${ }^{22}$ The neck of an Apulian volute krater provides an explicit reference to Euripides' tragedy, although, unfortunately, the only available photograph presents the image in a much disfigured form. ${ }^{23}$ We see Dionysos, who, on the extreme left, watches the furious maenads killing Pentheus, while Nike flies towards

\footnotetext{
21 Cain 1997, 34.

22 For the bronze statuette, see Karusu 1975. For the copies: LIMC III, Dionysos 128 a-c. For the votive reliefs: Cain 1997, 30 and pl. 3. For an example of a vase image, see the lid of an Attic lekanis found at the south foot of the Acropolis, Athens Acropolis Museum 1956 NAK 232, with Dionysos amidst women and maenads (I am indebted to Victoria Sabetai for this personal communication).

23 LIMC VII, Pentheus 16.
} 


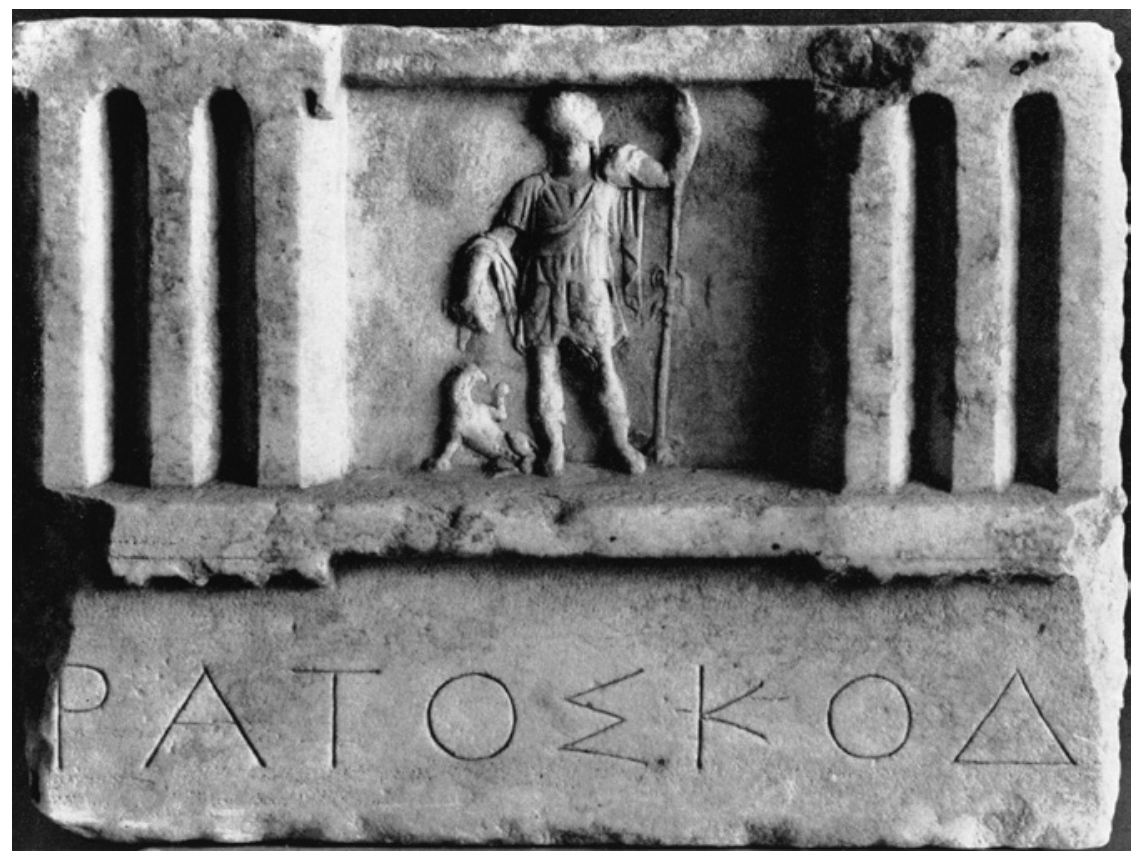

FIGURE 111 Theater of Thasos, metope (всн 84, 1960, 301, fig. 1).

him with a wreath; apparently here, too, he is seen as triumphant. The god is young and wears a short chiton and boots; whether he also wore an animal skin is now impossible to make out. A relationship between this Dionysos type and the world of the theater may also be discerned in an, unfortunately badly preserved, votive relief found near the theater of Dionysos in Athens. ${ }^{24}$ Other examples are a relief (refurbished in the 2nd century AD) from the metopes of the scene house of the theater of Thasos, (Figure 111) and one of the Imperial-period reliefs. ${ }^{25}$ These latter decorate the stage front of the socalled Phaidrosbema of the theater of Dionysos in Athens and show various scenes from Dionysiac mythology. Our type is shown in the scene depicting the presentation of the vine to the Attic heros Ikarios-likewise a tragic tale. ${ }^{26}$

If indeed the triumphant Dionysos of the Bakchai lives on in this type, it is not hard to imagine what the audience's visual associations must have been. First of all, there is the association with Artemis, the ruler of the wilderness and of untamed women - the world into which Dionysos the punisher leads

\footnotetext{
24 LIMC III, Dionysos 853.

25 Salviat 196o, 314 f.; Daux 1968, 54.

26 LIMC III, Erigone I 1.
} 
the maenads, cut loose from the well-ordered community. In addition, the short chiton with the animal skin over it would have reminded the Athenians of Dionysos Gigantomachos, known from the second metope on the east side of the Parthenon and from somewhat older vase imagery. Incidentally, this way of depicting Dionysos as a combatant remains canonical after Euripides, as is borne out by mirror reliefs and vase paintings of the 4 th century, ${ }^{27}$ and, eventually, by the Gigantomachy and Telephos friezes of the Pergamon altar. ${ }^{28}$

If we assume that Euripides really gave his Dionysos the appearance of the triumphant Gigantomachos, what sense would this have made?29 While Pentheus was under the impression that he was dealing with an Asiatic member of Dionysos' retinue, the audience immediately realized that this was the god himself: Dionysos who, with the other gods, had fought for the order of Zeus and had been victorious. The terrible punishment of the blinded Pentheus cannot have been a total surprise: ultimately, it was all for the good of the polis. ${ }^{30}$

\section{Dionysos in 4th-Century Sculpture}

We can be sure that at the end of the $5^{\text {th }}$ century at least three very distinct sculptural Dionysos types could be discerned: the relaxed, naked young god of the east pediment of the Parthenon; the young triumphant god of the Bakchai; and the gold and ivory cult statue of the temple at the sanctuary near the theater, created by Alkamenes, a close collaborator of Phidias. ${ }^{31}$ The latter, as is evident from coins from Imperial times, reverted to a traditional type: that of the dignified, bearded enthroned Dionysos, the one who resembled the Zeus of Olympia. ${ }^{32}$ Although the Parthenon type was extremely popular in vase painting and small statuary, it had, as far as we know, no follow-up in monumental sculpture. It has been argued above that this may be related to the fact that the vision of peace that was at the basis of the sculptural program of the Parthenon had been rendered obsolete by the outbreak of the Peloponnesian war. On the other hand, the idea of Dionysos and his promise of Bacchic bliss

\footnotetext{
27 For instance LIMC III, Dionysos 633 and 641.

28 Isler-Kerényi 2010b.

29 It may not be a coincidence that in E. Ba. 537-544 the chorus associates Pentheus with the giants (I am indebted to Richard Seaford for pointing this out to me).

3o March 1989, 65; Seaford 2006, 49.

31 What follows largely corresponds with Isler-Kerényi 2011 .

$32 \quad$ LIMC III.1, 446 Dionysos 214.
} 
gained pregnancy in the current dangerous situation and it was given a significant place in vase imagery, which also suited the function of funerary gift. ${ }^{33}$

There must have been other sculptural representations of Dionysos-as Pausanias tells us: the god had many sanctuaries in Greece. ${ }^{34}$ Some cult statues were old, or archaistic, xoana and sphyrelata. ${ }^{35}$ This is illustrated by two Apulian vase images, where statues of this kind are shown next to the real, young god. ${ }^{36}$ Others, of which we know nothing, were newly created in the 4 th century by artists active at the time.

In any case, as we have seen, multiformity seems to have been a characteristic of Dionysos ever since the final years of the 5 th century. ${ }^{37}$ This multiformity even found ritual expression: a procession with two Dionysos statues (one the Bakcheios, the other the Lysios) regularly took place in Sikyon. ${ }^{38}$ Greek coins, too, show Dionysos in a multitude of guises, although in many cases it is uncertain when they were formed. The standing, bearded god in the long chiton or the himation that leaves the chest bare was probably a type of the Classical period. ${ }^{39}$ The same holds true for the youthful, standing nude figure. ${ }^{40} \mathrm{On}$ coins from Thessaly, Crete and Athens, Dionysos appears bearded and seated like Alkamenes' cult statue; the earliest of these coins may be dated to around 470 BC. ${ }^{41} \mathrm{He}$ is depicted youthful and seated on Greek coins from the 4th century onwards, as well as on wall paintings from the Imperial period. ${ }^{42}$ Finally, the infant Dionysos may be found on coins from Thrace and Asia Minor of the $5^{\text {th }}$ and 4 th centuries. ${ }^{43}$ It is, however, impossible to know whether these figures reflect cult statues or local Dionysiac myths.

The so-called Dionysos Sardanapalos probably appeared in the 4th century (Figure 112). This Dionsyos, in a long, rich robe, bearded and with an elaborate long hairstyle, may have been created for the theater of Dionysos in the circle of Praxiteles. ${ }^{44}$ A choragic monument of about 340 BC presents a very similar

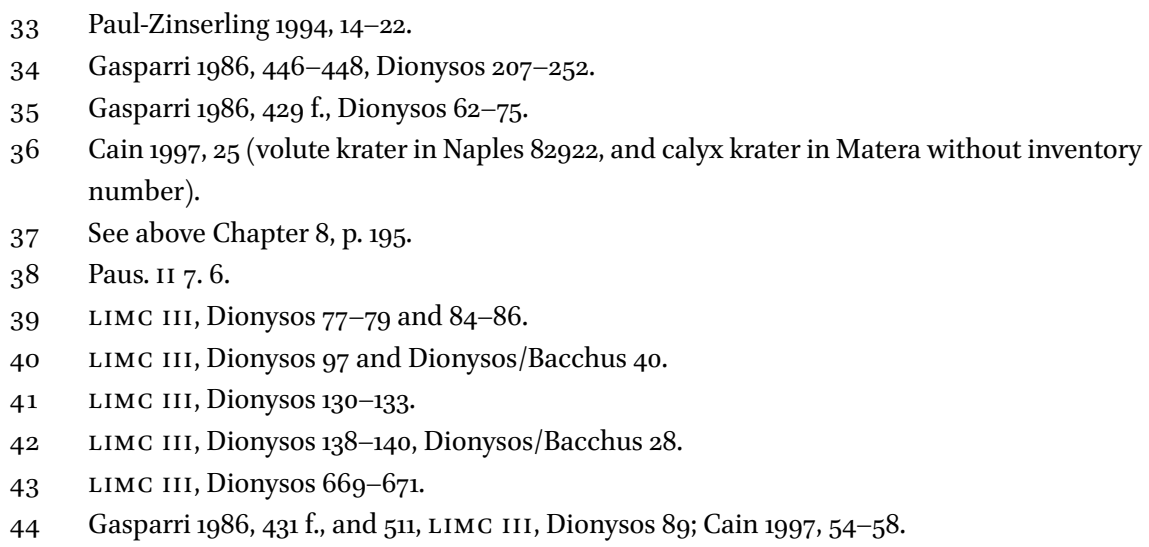




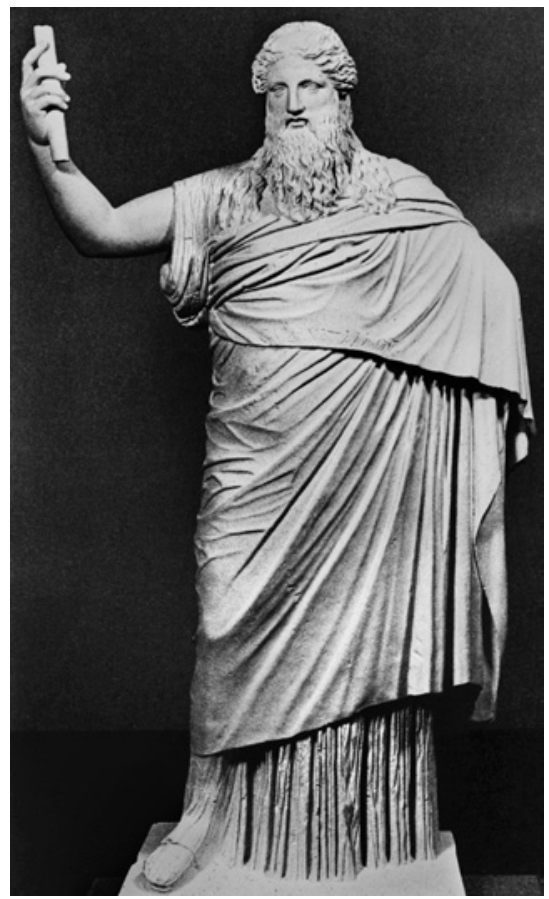

FIgURE 112 Dionysos Sardanapalos, Rome, Musei Vaticani, Sala della Biga 2363 (Cain 1997, pl. 16).

figure..$^{45}$ Dionysos Kitharodos of the west pediment of the temple of Apollo in Delphi, mentioned above, is likewise wearing a long robe, but he is a youthful standing figure surrounded by the members of his thiasos (Figure 113). ${ }^{46}$ The pediment was made by artists from Athens between 360 and $330 .{ }^{47}$ As we have seen, after 430 this kind of typological similarity to Apollo can also be found in vase painting. ${ }^{48}$ It may be explained from the fact that the two divine brothers

\footnotetext{
45 LIMC III, Dionysos 88.

46 See above note 18.

47 LIMC III, Dionysos 489 (body) and 205 (head): Croissant 2003, $30 \mathrm{f}$. and 85 has convincingly shown that the two belong together. The identification of this figure as Apollo in LIMC II, 201 concerning Apollo 101 (Lambrinudakis) has been refuted by the archeological circumstances and is out of date. A colossal head of Dionysos, datable to around 340 BC or somewhat later, from the sanctuary of Dionysos on Thasos, is very comparable because of its effeminate appearance and its erotic aura, see LIMC III, Dionysos 206; Holtzmann 2010, 268 f., no. 77 .

$48 \quad$ See above Chapter 7, p. 171 , note 42.
} 


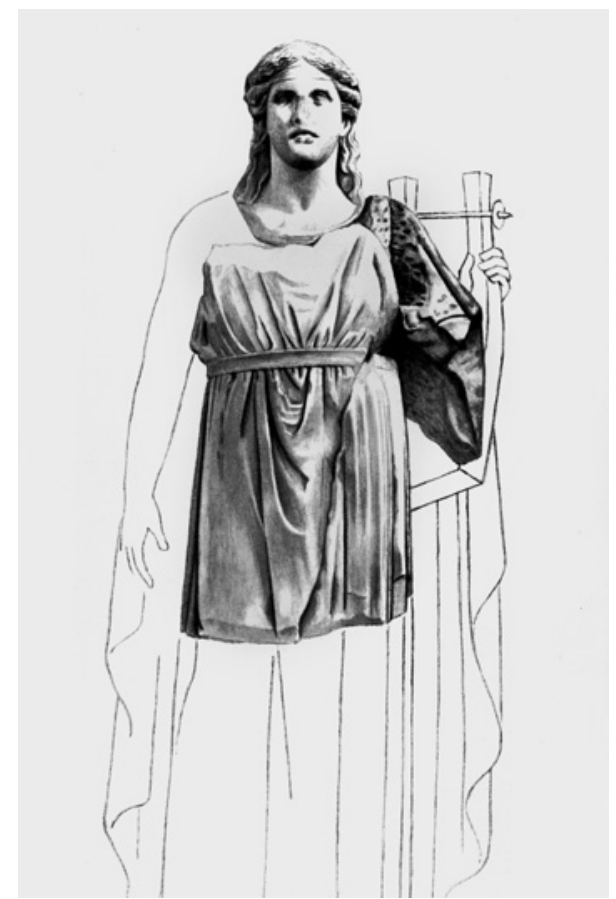

FIGURE 113 Dionysos Kitharodos, west pediment of the temple of Apollo, Delphi, Museum 2380 (Croissant 2003, pl. 34, drawing K. Iliakis).

had complementary functions in the Olympic family ruled by Zeus and, consequently, in the human world.

The various shapes and forms of Dionysos we have looked at so far, bear out his multiformity in monumental art and in public space. They completely answer to modern expectations about divine grandeur and credibility in cult statuary. The figure of the young, almost or completely naked god in a relaxed attitude, mainly preserved in copies from the Roman Imperial Period, is, however, different and more problematic. ${ }^{49}$ The origin of this frequently modified type lies in the 4th century and is stylistically close to Praxiteles who, according to the sources, created more than one statue of Dionyos. ${ }^{50}$ In the years that followed the prototype underwent several, be it superficial, changes (Figure 114). ${ }^{51}$ The young and erotic Dionysos whose himation has slipped to his thighs so that his

49 Concerning this issue, see Cain 1997, 12-14 and 77-79.

50 LIMC III, Dionysos 120. For statues by Praxiteles mentioned in literary sources: LIMC III, Dionysos 215-217.

$5^{1} \quad$ LIMC III, Dionysos 121-124; Cain 1997, 78. 


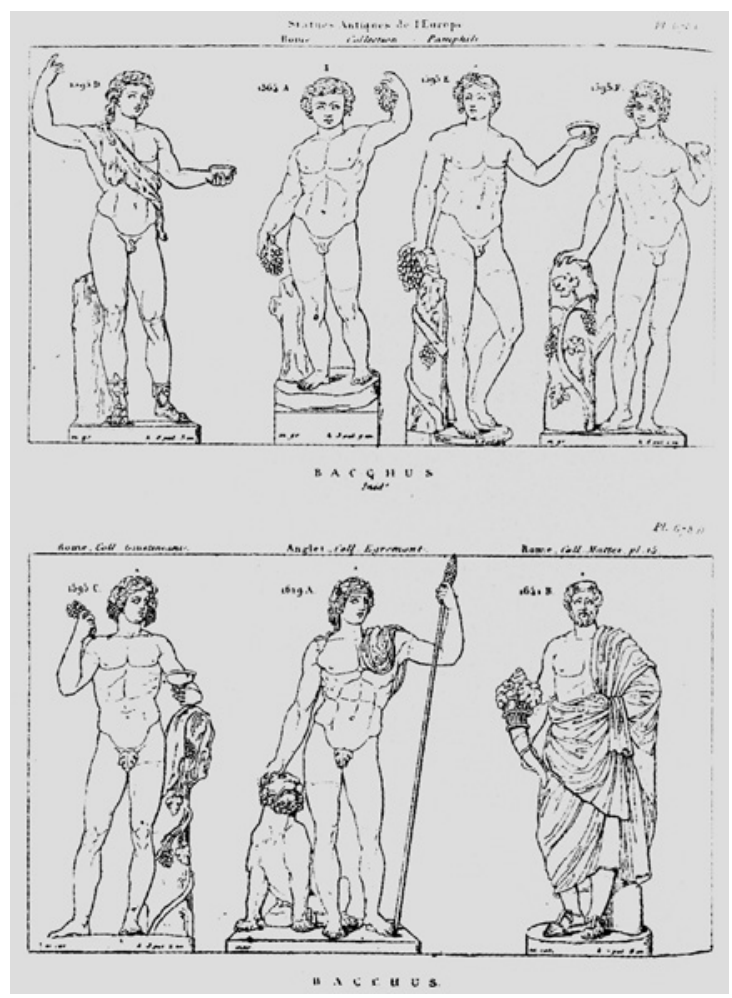

FIGURE 114 Various statues of the youthful Dionysos, Roman Imperial period (Cain 1997, 78 above left).

genitals are revealed, must be of comparable origin. ${ }^{52}$ The motif of the effeminate youth expresses itself even more clearly in small statuary and is subsequently applied to larger sizes; here we see a Dionysos who is no longer able to stand on his own two feet, but is has to be supported by a companion. ${ }^{53}$

As we have seen, the youthful Dionysos was officially introduced with the Parthenon sculptures. Phidias gave him the body of an athletic adult. The Praxiteles type, however, is an ephebe who increasingly resembles Eros and, like Eros, takes on an effeminate form. A possible explanation for this androgynous Eros may be that Eros, as the god of all commencements, unites several potential forms of existence: male and female; human, animal and vegetal. ${ }^{54}$ As Bakchos, Dionysos, too, is a god of initiation, and as such of new beginnings.

$5^{2} \quad$ LIMC III, Dionysos 126 and 127, also Dionysos/Bacchus 181 and 186.

53 Pochmarski 1990.

54 Isler-Kerényi 2004b, 247. 
Dionysos' feminine aspect increasingly goes hand in hand with a passive, relaxed attitude; all of this was the complete opposite of what was expected from a citizen. Nevertheless, the god seems to have remained a significant figure. By revealing his genitals he presents himself as the seducer, not only of Ariadne, but also of the human beings who met him in the sanctuaries of Greece and the gardens of Rome. ${ }^{55}$ The meaning of this aspect of Dionyos will become clearer when we compare the sculptural type with its counterpart in vase painting, in other words: when matters are viewed in context.

\section{A Look at Vase Painting}

For the vase painters active in the decades between the Dinos and Pronomos Painters and the so-called Kerch style, Dionysos was clearly the most important god. ${ }^{56}$ This is not only evident from the output of the Meleager Painter and his workshop, which mainly produced kraters, but also from the workshop of the Jena Painter, the leading producer of cups. ${ }^{57}$ According to Verena PaulZinserling the great importance of Dionysos and his retinue in vase imagery reflects the significance of Bacchic ceremonies in the lives of the buyers of the ceramics. ${ }^{58}$ Because vase painting is allusive instead of descriptive, this is hard to prove. Nevertheless, as will be clear from what we have seen and from what follows, the development of Dionysiac iconography certainly supports this proposition.

As far as choice of subject is concerned, we first of all notice that in the first decades of the 4th century traditional mythological themes (including the return of Hephaistos with its special significance for the polis, which regularly occurred until around $400 \mathrm{BC}$ ) are as good as absent-with the exception of the Gigantomachy. ${ }^{59}$ Future scholarship should make a special study of the marked differences between the image repertoire of the first quarter of the century and that of the second quarter, and look at the various phenom-

55 Fragmentary Apulian calyx krater, Taranto 52.230: Isler-Kerényi 2011a, 81, fig. 10; Tiverios 2011, 163 and 169, fig. 11.

$5^{6}$ Boardman 1989, 10 (dating of the Kerch style in the second and third quarter of the century) and 190-193 (Kerch style ceramics); for an extensive study of the dating of 4 thcentury Athenian ceramics, see Langner 2013.

57 Meleager Painter: Kathariou 2002, 27-37; Jena Painter: Paul-Zinserling 1994.

58 Paul-Zinserling 1994 passim, especially 32 and 70 . Kathariou 2002, 35 remains sceptical about this.

59 Natale 2008, 99-106. 
ena against the background of the political and cultural situation in Athens at the time. Of the types we found in sculpture, the bearded Dionysos does not appear in vase painting and neither do the fully dressed types such as the so-called Dionysos Sardanapalos and the Kitharodos type from Delphi. After the Kadmos Painter, the regal seated Dionysos like the one by Alkamenes no longer occurs. ${ }^{60}$ The victorious Dionysos of the very few Gigantomachy scenes wears only a himation that leaves his chest bare or a long himation, and in this way differs from Dionysos Gigantomachos in sculpture. ${ }^{61}$ In any case, a dressed Dionysos is much rarer than a completely or almost naked one. Images of a standing Dionysos are not very numerous and rarely correspond to those in large-size sculpture. ${ }^{62}$ The walking god may be supported by Ariadne, Herakles, a satyr or even Eros. ${ }^{63}$ When, under the influence of music, wine, or love (or all of these together), he appears in a euphoric mood, this does not seem to refer to a specific myth, but to a state that is considered characteristic of him. Most often we find Dionysos as he was depicted by the Dinos or the Kadmos Painter: naked, in a relaxed seated pose, receiving gifts from the members of his retinue, or being tenderly caressed by Ariadne (Figure 115). ${ }^{64}$

A standing naked Dionysos similar to the Praxiteles type from sculpture may be found, for instance, on a calyx krater of the so-called LC Group from the middle of the century. ${ }^{65}$ This group of vases of mediocre quality was probably not manufactured in Athens itself, but in a Boeotian workshop. ${ }^{66}$ The group, however, shows an image repertoire and iconography that is almost indistinguishable from those used in Attica as a result of the fact that in the course of the 4th century manufacture and form throughout Greece, and even in Greek Southern Italy, had become increasingly similar under the influence of the magnificent Athenian creations of the Parthenon epoch. ${ }^{67}$

\footnotetext{
6o LIMC III, Dionysos 598 .

61 Paul-Zinserling 1994, 35-37; LIMC, Dionysos 660 and possibly also 630; LIMC, III Dionysos 631 (= LIMC IV, Gigantes 389), which seems Attic rather than Apulian, see Kästner 2008b, 188 , cat. 38 .

62 For instance LIMC III, Dionysos 315 and 316.

63 Some examples: LIMC III, Dionysos 720 (= Kathariou 2002, 404, fig. 39 B), 583 (bearded here), 584, 834; Kathariou 2002, 391, fig. 14 Г.

64 Two examples: bell krater Budapest 50.568: ARV 1439.1; BA 218088, and pelike St. Petersburg St. 1793: Furtwängler/Reichhold 1904-32 text volume II, 47. Concerning the motif: Kathariou 2002, 197, and pl. 414, fig. 57 A; LIMC III, Dionysos 731.

65 Athens 1376: ARV 1458.34; BA 218307 (no image); Schefold 1934, 25, no. 205 pl. 46. From Boeotia.

66 Schöne-Denkinger 2009, 89 f.; Sabetai 2011, 157, note 83.

67 Borbein 1995, $436 \mathrm{f}$.
} 


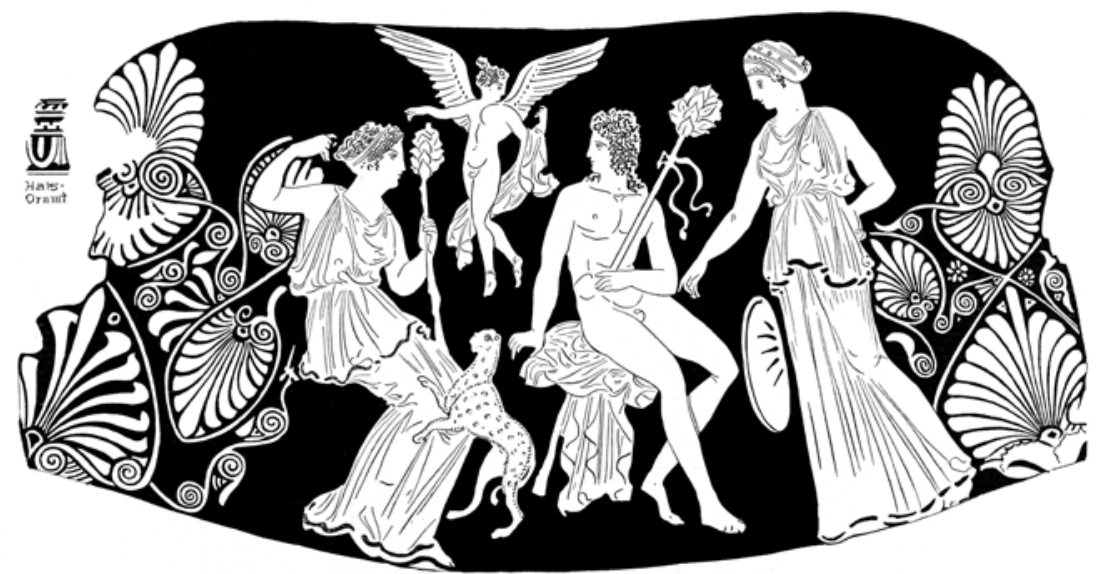

FIgure 115 Pelike, St. Petersburg, State Hermitage Museum St. 1793 (FR, Text II, 47).

The composition of the image on one side of the vase is very clear (Figure 116). In the middle on the left we see a standing young Dionysos wearing a wreath. His himation, held by his right elbow, leaves his whole body bare. Behind his left shoulder we can discern a thyrsos. The god is gazing at a woman who sits on his right; the uncovered parts of her body are highlighted in white. On the floor between the two is an altar. Above it, on an elevation in the landscape that is not indicated, stands Eros. He turns towards the woman, his wings spread. He has taken a necklace or another piece of jewelry, no longer visible, from a flat box in his left hand. He wears his hair in a chignon on the top of his head-a feminine style. His body also has the conspicuous white color. To the left of Dionysos, a satyr wearing a panther skin over his left arm, looks back towards the main scene. Another woman stands to the right of the seated one. Her raised hairstyle perhaps indicates she is elderly. Between her and Eros we see Pan approaching with a ribbon in his right hand. It is only in the 4 th century that the figure of Pan appears in the Dionysiac repertoire of the vase painters. ${ }^{68}$ As on the Roman sarcophagi of a much later period, he may represent the wild, unpredictable world beyond what can be experienced by mortals - a world only known in death. ${ }^{69}$ The image apparently means to show an epiphany of Dionysos which precedes the erotic encounter. Beazley is wondering whether the seated woman could indeed be identified as Ariadne; Metzger interprets

68 Paul-Zinserling 1994, 43.

69 Isler-Kerényi 2012b, 73 and 75. 

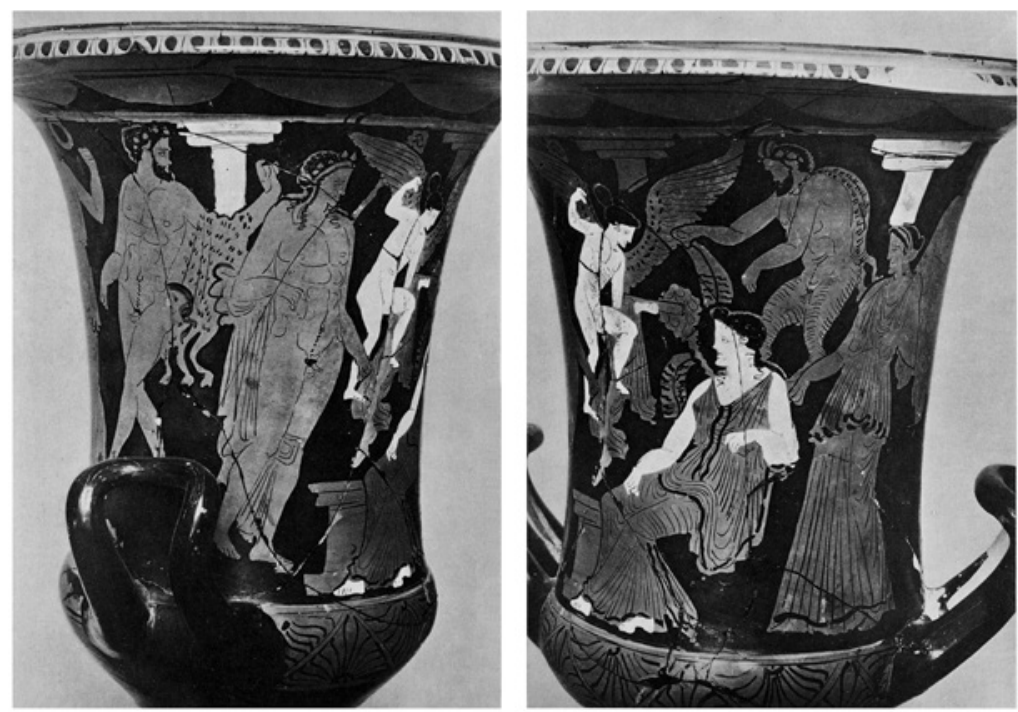

FIGURE 116

Calyx krater, Athens, National Museum 1376, two views of side A (Schefold 1934, pl. 46, no. 205).

the scene as "hiérogamie proprement dite."70 At the top of the image, partly highlighted in white, are the upper parts of three columns with capitals and architrave. Perhaps this refers to a temple front: together with the altar it would indicate that this encounter takes place in sacred space.

On the reverse the young, naked Dionysos presents himself in a way we know from countless other examples: reclining in the familiar pose of the east pediment of the Parthenon, in the company of Eros, a satyr, and a Dionysiac woman..$^{71}$

The idea of blissful peace, communicated by the Dionysos of the Parthenon's east pediment, here finds expression at a personal level in the unmistakable Bacchic atmosphere. It cannot be a coincidence that Hermes is often present in scenes of this kind - the god who is responsible for all transitions. ${ }^{72}$ His presence indicates the vessel was meant to be used as a grave gift. The meaning of the Dionysiac encounter on vases like the one just discussed, is evident: it promises erotic bliss. Or better perhaps - given the idea that vase paintings should be read in a metaphorical rather than a realistic sense: it promises a

\footnotetext{
70 Metzger 1951, 117, no. 16. Compare in addition the oinochoe LIMC III, Dionysos 731, where the erotic intent of the meeting is evident.

71 Compare for instance Schefold 1934, pls. 41 a-b, 45, and 47.

$72 \quad$ ARV 1457 f., 19.21.29.
} 
total state of felicity, like the one experienced in love. Approaching a statue of the naked ephebe Dionysos in a Greek sanctuary or a Roman garden was tantamount to having the prospect of perfect happiness.

There were other formulae with which to refer to acquired or prospective Bacchic bliss, for instance the ones we already met in the work of the Dinos Painter and the Kadmos Painter: Dionysos as a symposiast, alone, with Hephaistos or with Herakles. ${ }^{73}$ The idea is expressed in a more dynamic way when Dionysos, Ariadne close at his side, moves energetically towards the right, as he was depicted by the Pronomos Painter. Most of the time, however, it is not the god, but his companion who takes the lead. ${ }^{74} \mathrm{~A}$ similar role for women in a Bacchic context is not new and also found elsewhere. ${ }^{75}$ The numerous depictions of the seated couple could be considered a quiet version of the same formula. ${ }^{76}$ Eros bringing a bunch of grapes—whose "death" results in wine-clearly alludes to the Bacchic experience.

The examples presented here of the standing, young Dionysos turning towards Ariadne or a woman identifying with her, of the seated or reclining god, or of the euphorically advancing couple, were meant for the individual viewer and for private use. In addition, Attic vases have motifs that may have been derived from monumental, public art. Apart from the Gigantomachy already mentioned, the arrival of Dionysos riding a wild animal or enthusiastically driving a chariot drawn by animals also belongs to this category.

A fine example of the latter may be found on a calyx krater, datable to about 350 BC or shortly afterwards (Figure 117) ${ }^{77}$ It belongs to a manufacture that is known as Group $\mathrm{G}$ because of its many depictions of griffins. A relatively large number of these vases were found in the Black Sea area, but Kyrenaika (North Africa) and Spina are also well represented. Others were found in Olynthos (Macedonia) and in Athens. The usual vase type of this group is the pelike, followed at some distance by the bell krater. Only two calyx kraters made by Group $\mathrm{G}$ have so far been found. In our example, both the potter's work and the decorated parts indicate that it was an exceptionally ambitious piece for its time. In the photographs that have been published, the krater subsequently filed by Beazley, looks like a weaker piece. ${ }^{78}$ It also shows on one side two

\footnotetext{
73 Metzger 1951, 125-129; LIMC III, Dionysos 369, 559, 56o.

74 Compare Metzger 1951, 115. "Enlèvement d'Ariane" is therefore not the right expression.

75 Compare Jaccottet 2003, 88-94; Isler-Kerényi 2007, 154; Gasparri 1986, $483 \mathrm{f}$.

76 Metzger 1951, 118-120; LIMC III, Dionysos 738-740, 743, 748-750. For an example with a standing Ariadne: LIMC III, Dionysos 731-734.

77 Zurich, Archäologische Sammlung der Universität 3926: Addenda 380 (1470.164); вA 230374; Isler-Kerényi 1982 and 1983.

78 Whereabouts unknown: ARV 1470.165; BA 230375.
} 


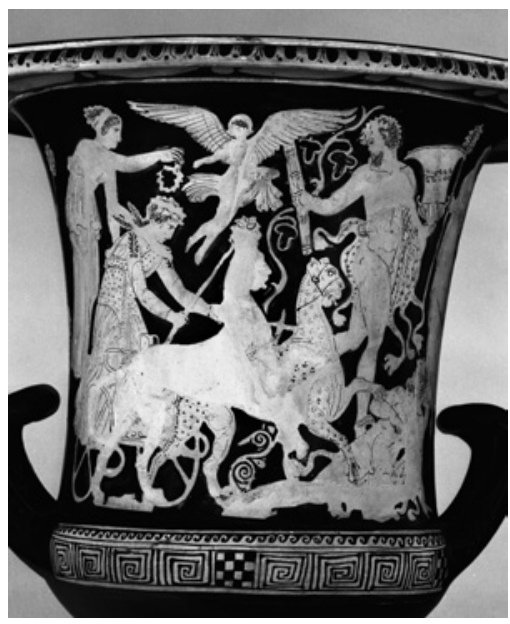

$a$

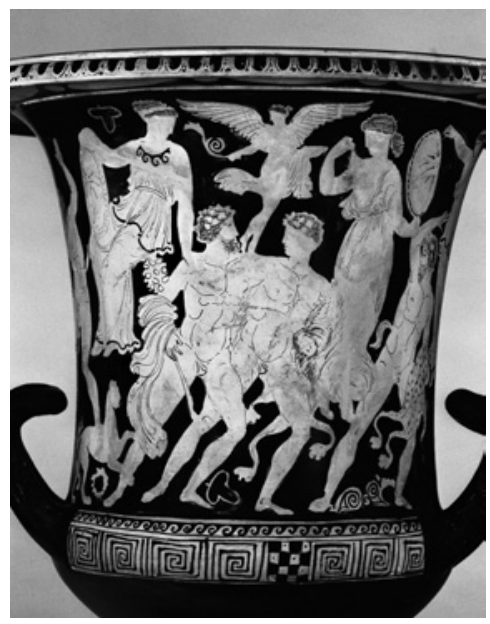

$b$

FI U URE 117 Calyx krater, Zürich, Archäologische Sammlung der Universität 3926 (photographs Archäologisches Institut der Universität Zürich, Silvia Hertig). a. side A: arrival of Dionysos.

b. side B: pair of Dionysiac men.

vigorously striding men, while the other has Dionysos reclining on the symposium couch.

As far as style and quality are concerned our calyx kraters most resemble bell kraters of the so-called Falaieff type, whose four fields of images, apart from griffins fighting amazons, all show the youthful Dionysos. ${ }^{79}$ In two instances he is reclining in a manner recalling the east pediment of the Parthenon as he watches a dancing maenad with a tympanon in her hand. The head of Dionysos (the delineation of his locks, his ivy wreath, his profile) on the krater in the Louvre so much resembles that on our krater, that it must have been created by the same hand. The clusters of grapes filling the space above the figures are, at any rate, almost identical. But because not much is known about this vase either, we can only conclude that the Bacchic Dionysos and his world apparently belonged to the more up-market segment of this manufacture.

The main side of our krater shows the young god wearing an animal skin over a long, flying chiton. He stands in a chariot drawn by two large panthers. In front of him a satyr has fallen to the ground in fear. In the upper part of the image another satyr precedes the god, half dancing, a torch in his right hand and a large wreathed calyx krater in his left. Eros spreads his wings as he hovers

79 Louvre G 530: Addenda 380 (1469.161); вA 230371; Louvre G 529: Addenda 380 (1469.162); BA 230372; Stockholm D 19310: Addenda 380 (1470.163); вA 230373 (no image). 
above the team of panthers. A woman with a vine leaf or a bunch of grapes is leaning over from the back. On the right edge of the image, a second maenad with thyrsos and tympanon is ecstatically turning around her own axis. Making a gesture of surprise, a third satyr looks on above the handle. Between the panthers, a vine that may have just sprouted from the earth fills up the space with its grapes. The panthers are shown in three quarter view and seem to detach themselves from the vase on order to move towards the viewer. It is clear that the latter should be duly impressed by the wondrous arrival of the god.

On the reverse two men wearing ivy wreaths are striding towards the right. The younger of the pair has thrown a lion skin over his left arm; the elder is carrying a thyrsos. It is probable that they are Herakles and Hephaistos. A cluster of grapes is on the ground between them. A satyr making an inviting gesture goes in front of them, a small panther makes up the rear. We also see two dancing women and a seated one who looks on from the left. A winged creature of indefinable sex hovers above the heads of the two men with a plant in its hand. In both scenes all satyrs are decked out in panther skins. The question is whether both sides of the vase can be read as one continuous scene. Unfortunately, the side views of the krater do not provide a decisive answer either. ${ }^{80}$ In any case, the level of execution is equally high on both sides: the sudden appearance of Dionyos and the arrival of the two men must have been of equal importance to the painter.

Concerning the two men we could ask ourselves who is leading who. Beazley has designated the elder Dionyos, most likely because of his thyrsos. However, by this time, Dionysos is rarely depicted bearded. Moreover, how can we explain that it is he who is looking intently at the inviting gesture of the satyr and at the beckoning maenad? The famous series of images of Herakles bringing a bearded man resembling Dionysos up from the underworld, does not show the theme we have here, but the ephedrismos motif. ${ }^{81}$ Our motif of two individuals striding forward, arms around each other's shoulders, has, as we have seen, a long history in Dionysiac imagery. It occurs for the first time

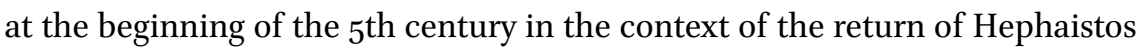
and subsequently remains in use..$^{82}$ On the basis of the tradition of the motif we can identify the elder of the two men on our vase (the one who is led) as Hephaistos, even when only a pair of tongs or a hammer could dispel all

\footnotetext{
8o Isler-Kerényi 1982, 145, figs 3-4.

81 Metzger 1951, 196 f., pl. 26, 1-3; Paul-Zinserling 1994, 24-31.

82 See above Chapter 3, note 38; London F 68 (1865.0103.14): Addenda 378 (1446.1: Pourtalès Painter); BA 218148. On the right side of the image a satyr leads Hephaistos towards Dionysos and Herakles, depicted as a pair of symposiasts.
} 
doubts. Still, if this image depicts the return of Hephaistos, it is rather surprising that it is Herakles who takes the initiative. Our discussion of, for instance, the handing over of the child Dionysos has, however, already shown the importance of taking into account unknown versions of a certain myth in view of the fluidity of the mythological tradition.

Whoever the figures in the vase may be, the meaning of the scheme is clear: euphoric reconciliation, restoration of harmony in a Dionysiac atmospherewithout the comic anecdotal element of the return of the cripple on his mule. Where are the two men going? Could it, after all, be the event on the other side of the vase? In that case the scene would unite Dionysos, Herakles and Hephaistos and, as we have just seen, this is not a unique phenomenon at this time. Despite their divine origins, all three of them were only admitted to the sphere of the gods after their vicissitudes in the world of men. ${ }^{83}$ In this way, they may have served as examples of the possible destiny of the Bacchic initiates.

\section{The Derveni Krater}

At the end of our exploration of the Dionysiac imagery of the Classical period, we must have a look at one of the most exquisite examples of Greek art: the bronze krater from Derveni (Figure 118). ${ }^{84}$ This elaborate vessel is superbly decorated both in relief and with sculpted figures. It not only served as a funerary urn for the ashes of a man and a woman, but, as the traces of wax found on the inside indicate, was especially made for this purpose ${ }^{85}$ On the basis of other objects found in the grave, the krater may be dated between 320 and 290 BC. ${ }^{86}$ The decoration consists of a frieze of large figures in relief around the belly of the vessel, an animal frieze above the foot and another below the mouth. The neck and the upper part of the belly are decorated with branches of ivy and

83 All three not only have a divine, but also an irregular origin: Dionysos and Herakles are children of Zeus by daughters of heroes; Hephaistos was either born from the secret union of Zeus and Hera, or brought forth by Hera herself: Kerényi 1997a, 77, 115 and 117.

84 Thessaloniki B 1: LIMC III, Dionysos 755; Grassigli 1999 (including the relevant literature); Holtzmann 2010, $260 \mathrm{f}$., no. 73. The impression of gilding is caused by an exceptionally high amount of tin in the alloy, see Grassigli 1999, 109 with note 31.

85 Grassigli 1999, 109; Jaccottet 2008, 42. Tiverios 2008a seems unaware of Grassigli's thorough investigation of the preceding literature and his overall interpretation. On the other hand, Grassigli's work forms the basis of Jaccottet's argumentation.

86 Grassigli 1999, 140. Compare Holtzmann (see above note 84) according to whom the vessel could have been created at a somewhat earlier date. 


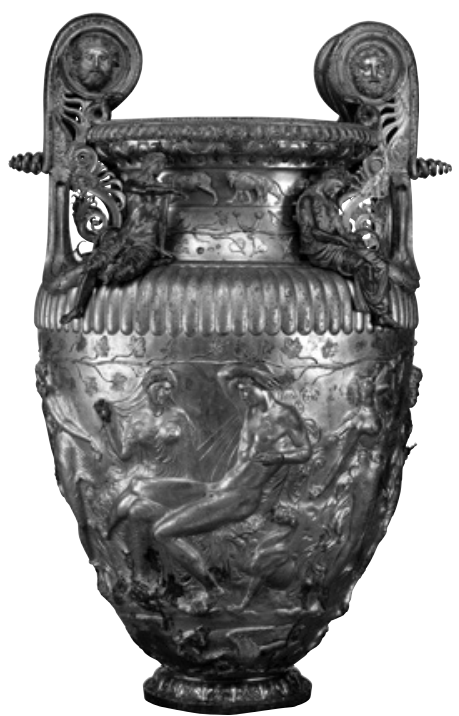

$a$

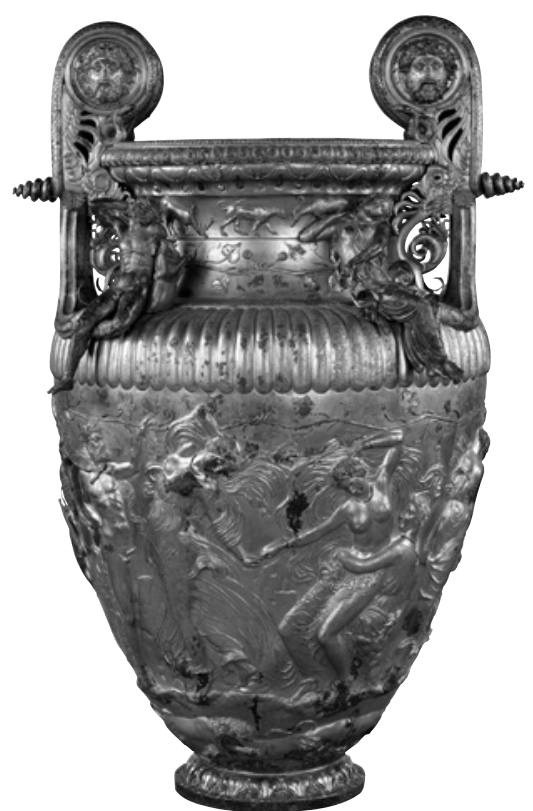

$c$

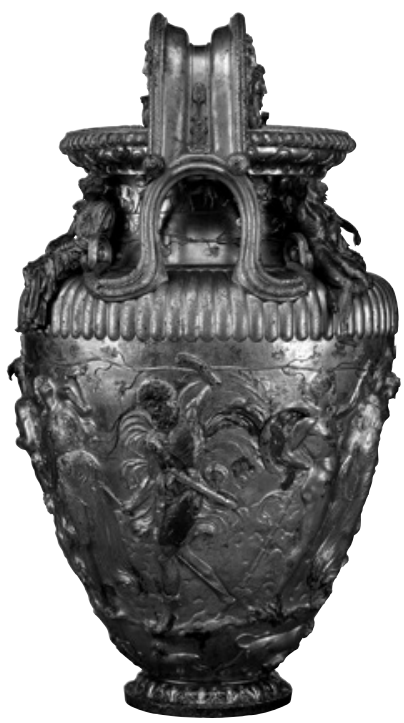

$b$

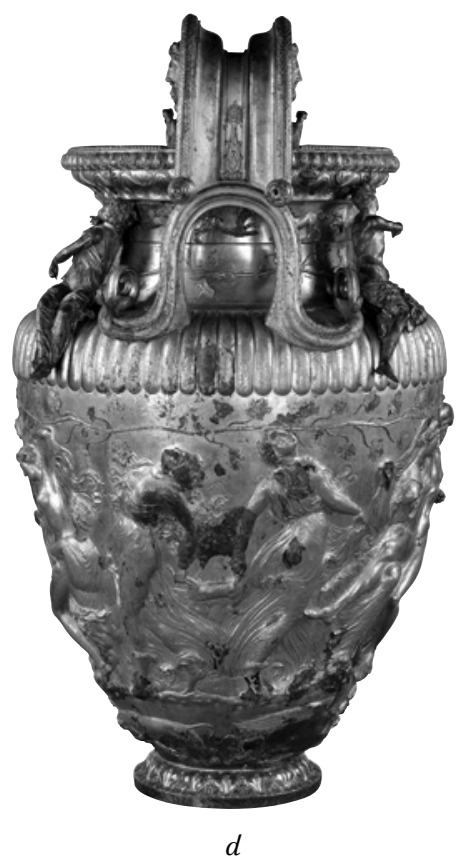

FIGURE 118 Bronze krater from Derveni, Thessaloniki, Archaeological Museum B 1 (photographs Archaeological Museum of Thessaloniki).

a. side A: Dionysos and Ariadne.

b. side view (right): Astion(?).

c. side B: bacchantes.

d. side view (left): bacchantes. 
vine. Snakes wind themselves around the medallions of the handle volutes. On both sides the medallions have bearded heads, shown full face. Four sculpted figures are sitting on the shoulders of the vase. Even after Grassigli's extensive iconographical analysis of the decoration program, questions remain. In any case, we must also consider the wreath of myrtle leaves that was put on the mouth of the vase at the time of the burial. ${ }^{87}$

The figure of the youthful Dionysos, conspicuous for its height, dominates the aspect of the main side. He is comfortably reclining on a projection in the landscape which has been covered by a cloth. His right arm is around his inclined head, and his right leg rests on the left thigh of Ariadne who sits beside him, her right hand raised in the typical gesture of the bride. We can conclude from Grassigli's argument that Dionysos is just waking up, which reminds us of the analogy between sleep and death. ${ }^{88}$ To the right of Dionysos we see a crouching panther looking up at the god. Further to the right, a maenad with a small child flung over her left shoulder is dancing furiously towards the right. ${ }^{89}$ Below the right handle, a bearded man, a sheath hanging at his side, strides animatedly towards the left. He carries a spear and wears only one boot. Among the many suggestions for the interpretation of this figure, Grassigli's well-founded contention that he should be identified as Astionthe owner of the grave, who is mentioned in an inscription incised at the mouth of the vase-makes most sense from an iconographical point of view. ${ }^{90}$ An ithyphallic satyr dancing towards the right leads us to the reverse of the krater. He looks at an ecstatically dancing maenad, whose left hand touches the right of a half-naked woman who, exhausted, seems to be falling into the lap of a companion. Below the left handle two maenads are dancing in opposite directions. Together they hold the legs of a fawn, which seems to be on the verge of undergoing his diasparagmos. ${ }^{91}$

With one exception, the lower animal frieze shows the aggressive behavior of griffins and predators attacking a fawn and a calf, whereas the upper frieze presents predators and tame animals peacefully moving along. According to

87 Compare the image of the wreath in Grassigli 1999, 111, fig. 14, with the botanical drawing in Kunze-Götte 2006, 11, fig. 1a.

88 Grassigli 1999, $128 \mathrm{f}$.

89 For other examples of the motif, see Grassigli 1999, $112 \mathrm{f}$.

9o Grassigli, 123-126; similarly Jaccottet 2008, 53. Tiverios 2008a, 204 on the other hand adheres to the identification as Lykourgos.

91 This motif can also be found on a fragmentary bronze krater in Berlin which may be dated around 400 BC: Schöne-Denkinger 2008, 49 and 52, fig. 10. 
Grassigli's view this alludes to the reconciliatory effect of Bacchic initiation. ${ }^{92}$ In his view, the bearded figure with one boot he identifies as Astion is likewise on his way towards Bacchic bliss, because he finds himself between two possible Dionysiac encounters: a peaceful one, and one characterized by the bloodthirsty acts of the dancing maenads. ${ }^{93}$ As in Euripides' Bakchai, the two approaches represent the initiates and the non-initiates. ${ }^{94}$

Of the four bearded faces in the volute medallions, only the one on the right of the main side of the vase can be identified with certainty: because of the lion skin he must be Herakles, the heros who experienced Hades. His counterpart on the left has small bull horns, like Acheloos or Dionysos Tauros. One of the two faces on the other side of the vase could perhaps be identified as Hades. However, analogous to contemporaneous Apulian ornate kraters, the position of the faces also justifies identifications such as Helios or one of the wind gods-deities who belong to the higher spheres. ${ }^{95}$ We may presume a reference to guardian deities or protective beings is intended.

The common denominator of the four seated figures attached to the shoulders of the vase is, again, the moment of awakening. On the main side, to the left, a young man, possibly Dionysos himself, turns towards a still soundly sleeping bacchante as he wakes up. On the reverse a satyr is fast asleep on a full wine sack; the bacchante to his right is just waking up. ${ }^{96}$ Because of these figures and the awakening Dionysos, sleep becomes the leading motif of the main side of the vase, which stands in sharp contrast to the violent movement of the figures of the Bacchic thiasos on the other. Like sleep, but in a different way, this movement expresses the state of ecstasy, of being outside oneself. In what way one imagined a possible life after death remains open. Reference is only made to a dissolution of boundaries, which is analogous to the one experienced in sleep and in ecstasy, and for which sleep and ecstasy are the visual metaphors. ${ }^{97}$ The message of comfort that patron and artist communicated to the beholder may be summarized as follows: just like the god himself who, overcome by sleep, will at his blissful awakening find Ariadne at his side, the Bacchic initiate may envisage a blissful awakening after death. A remarkably original element in all of this is the fact that Ariadne, the most famous sleeper

\footnotetext{
92 Grassigli 1999, $136 \mathrm{f}$.

93 Compare the pyxis from the end of the $5^{\text {th }}$ century introduced above, Chapter 8, note 70.

94 Grassigli 1999, 139. For a different interpretation see Jaccottet 2008, 56, note 40.

95 Isler-Kerényi 2008b, 240-242.

96 McNally 1985, $166 \mathrm{f}$.

97 Similar to Dionysiac sarcophagi of the Roman Imperial period: Isler-Kerényi 2012b, 75.
} 
in the history of Greek art, is awake here, whereas Dionysos, who had been the awakener since at least $400 \mathrm{BC}$, was overcome by sleep. ${ }^{98}$

The prospect of felicity in the first place concerns Astion, depicted as a bacchant. Jaccottet stresses that this depiction would have been unthinkable in the Classical polis. ${ }^{99}$ The vase imagery of the Classical period presented men in a state of Bacchic suspension in the guise of satyrs. This brings us to the following question: if the Derveni krater represents the bacchant as a dancer instead of a satyr, what then is the meaning of the satyr who, to his right, is dancing with an ecstatic maenad? The observation, made several times in the previous chapter, that after 430 BC the Dionysiac world had increasingly removed itself from the beholder of the images, may provide an explanation here: satyrs and citizens were no longer interchangeable. We can assume that the scene in the main image of the Derveni krater takes place in a paradisiacal world, which can only be imagined by the living; Astion, the monosandalos in the transitional space below the right handle, is moving towards it. ${ }^{100}$ This places the Derveni krater and its Dionysos at the end of the Classical period-at the beginning of a new era.

98 McNally 1985, 152; Apulian calyx krater, Taranto 52230: LIMC III, Ariadne 96. About this motif in monumental painting and in later times: LIMC III, Dionysos 777 and 778 .

99 Jaccottet 2008, 60.

100 After an exhaustive discussion of the motif, Grassigli 1999, 123 comes to the following conclusion: “... l'indossare un solo calzare costituisce uno degli espedienti per dichiarare alla divinità la propria adesione ai misteri.” 


\section{Summing Up}

\section{Anonymous Prototypes}

Before we focus on the Dionysiac imagery-Dionysos, satyrs, dancing or otherwise ritually engaged women, the komos and the symposium - which clearly dominates the mythological repertoire of the vase painters of the classical era, it seems expedient to have a quick look at the possible meaning of the much more common 'youths', 'boys' 'men' and 'women', as Beazley described them. ${ }^{1}$ As far as one can see, these are typical representatives of distinctive social groups: indeed boys, young men, adult men, and women. They are frequently encountered on the B side of large vases: single individuals on amphorae and pelikai, twos, threes and fours on kraters. As far as their poses, dress and attributes are concerned, they are unremarkable, uniform and rather passive. They usually just stand around, waiting while leaning on a stick, watching, quietly talking to each other. ${ }^{2}$ Apparently, they are supposed to be 'commentators', evaluating the event shown on the A side of the vase: mythological chases, departures of warriors, encounters with the goddess of victory. Like the chorus in ancient drama, they represent the large, anonymous group of those for whom the vase painters intended their work. For such individuals holds good what Beat Kaeser has said about the anonymous audience of mythological scenes on black-figure vases: “...the figures in the audience are 'witnesses', whose presence demonstrates the reality and significance of the acts they witness, and at the same time indicates the significance of the society for which such acts are important."3

1 These are also the terms used in the separate files of the Beazley Archive. The following extensively illustrated volumes from the Kerameus series have provided the basis for the present discussion: the volumes about Douris and Makron for the cups (Buitron-Oliver 1995 and Kunisch 1997), the volume about the Eretria Painter for the cups and small-size closed vases (Lezzi-Hafter 1988), and the volume about the Phiale Painter for the closed vases (Oakley 1990). In addition to the latter, there is the monograph about the Achilleus Painter of a similar format, which was published elsewhere (Oakley 1997).

2 For examples see Oakley 1990, pls. $31-36$ and 58 b, 6ob, $61 \mathrm{~b}$.

3 Kaeser 1990,156: “... die Zuschauerfiguren [sind] 'Zeugen', welche die Realität und Wichtigkeit der Tat anzeigen — und zugleich die Bedeutung der Gesellschaft, für die solche Taten wichtig sind." Compare what Ferrari 1990, 186 states about youths wrapped in mantles on the B sides of kraters: "This is not to say ... that the image is meaningless. On the contrary: by definition, what 
Men and youths who are not individualized are grouped on the outsides of countless cups by Douris and Makron in characteristic but impassive scenes, apparently familiar to the original viewers of the imagery. There is not much to distinguish these images from komos scenes or scenes with men and athletes, which we, too, can recognize. In the eyes of the vase painters they seem to have been interchangeable. On some cups by Makron, and a few by the Eretria Painter, we find groups of women, who cannot always be identified as hetaerae. ${ }^{4}$

Incidentally, such images of anonymous individuals are more characteristic of second-rate painters reluctant to attempt complicated mythological scenes, than for the leading artists discussed in this monograph. ${ }^{5}$ Athenians of

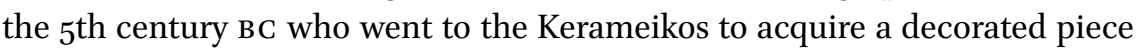
of pottery for a happy or a sad occasion would mainly have seen images they interpreted as images of themselves. The mental universe of the vase painters and their customers was not primarily peopled with gods and heroes, but with mortals in familiar circumstances, handling familiar objects. Nevertheless, they were not ordinary, but somehow characteristic - not referring to the individual case, but beyond that to the values and norms of society at large. However, when the customers were drawn to the more expensive, up-market merchandise, Dionysos and his world came into view and, in the most exclusive range, also the exemplary images of the divine and heroic mythology. In such instances, gods and heroes were the object of the gaze and interest of people like you and me.

Despite the fact that the mental world of the original customers was largely inhabited by humans, the transition from the here and now to the divine or heroic sphere was gradual and practicable. It is this characteristic that distinguishes vase painting from other forms of art, especially wall painting, and gives it a personal touch and a particular communicative quality. ${ }^{6}$ After all, the image is part of an object the customer can take in his hand, look at from all sides, and relate to his own situation or to the specific occasion for which the object is acquired. Here we should not only think of the Athenian clientele, but

is commonplace is packed with meaning, so consistent and obvious to the viewer toward whom the image is directed as to be subliminal." Compare in addition Langner 2012.

4 Kunisch 1997, pl. 43, no. 123; Lezzi-Hafter 1988, pls. 1, 24, 67.

5 See for instance the cups by the Euergides Painter, a contemporary of Oltos (ARV 88-96), by the Splanchnopt Painter who belonged to the Penthesilea workshop (ARV 891-898), and by the so-called Sub-Meidian Cup-Group (ARV 1391-1397).

6 Similarly Schmidt 2005, 281 about the "engen Verknüpfung der Bildthemen mit der Gefässform beziehungsweise mit einem potentiellen Betrachterkreis": "Mit diesen bewusst gewählten Bezügen wurde deutlicher als vorher begründet, dass es sich bei den Bildern um Mitteilungen handelt." 
also of Greeks and non-Greeks in Italy or elsewhere, whose cultural presuppositions may have modified the reception of the imagery. This permeability of different spheres is especially characteristic of the Dionysiac imagery, because, as we have frequently seen, the identity of Dionysos' companions is intentionally left indeterminate. In this way the original recipients of the imagery could identify with the komasts, who in the presence of the god would turn into satyrs or would feel like satyrs, or with the dancing women, who in the ritual encounter with the god behaved and felt like the Lydian women in the chorus of Euripides' Bakchai.

\section{The Changing Image of Dionysos}

In the decades around 500 BC no new motifs are introduced into Dionysiac imagery as compared to that of the 6th century. The iconography continues as usual with the familiar elements: the lively, erotically charged dance of the god's male and female companions in the implicit or explicit presence of the god; his epiphany; the solemn meeting with a woman; his blissful existence as a symposiast. In addition there is the mounting of the chariot as a sign of heroic elevation, or the riding of a donkey, a mule, or some other animal that is not a horse, and therefore not the mount of a citizen. This probably indicates the proximity of the rider-whether Dionysiac women, satyrs, or the god himself- to nature untouched by human activity. It should be noted that these motifs not only decorate large, prestigious vases in the new red-figure style, but also late black-figure vases, including the lekythoi largely intended as grave goods. The latter, in contrast to the white-ground lekythoi of around $45^{\circ}$ and after, do not show bereavement and mourning, but the felicity associated with Dionysos, as an antidote to the tragedy of death. In this context dance and symposium should not be taken as concrete representations of life after death. Rather they are metaphors for a timeless and boundless existence, for the yearning for and hope of a happy vista that would open up in dying, and could not be represented otherwise.

Very often the Dionysiac world—thiasos, komos, symposium—provides a counterpart to the great and strenuous labors of Herakles or the heroic death on the battlefield. This is not just the case with the most sumptuous vases of the period: Euphronios' calyx kraters. That this counter world was not supposed to be situated in a separate sphere, a mythical past or a hoped-for future after death, but was rather related to the here and now of the original beholders of the imagery is borne out by some satyrs who look away from the thiasos and seek the eye of the viewer. 
What distinguishes the Dionysiac repertoire of the first generations of redfigure vases from contemporary black-figure ones, are the many idiosyncratic and often quite prominent satyrs. As we have seen, their typology is extremely rich and varied, ranging from the beautiful satyr who plays the noble barbitos, to the one who pushes over herms and desecrates grave monuments. ${ }^{7}$ As has been pointed out in the Introduction, satyrs are, in fact, citizens in a Dionysiac state of suspension, who 'hide' behind the satiric mask. This state of suspension occurred, for instance, at the symposium and the komos, which is why satyrs are so often depicted on vessels used at the symposium, such as cups and kraters. The cup in the symposiast's hand was both the counterpart and the complement to the song that came from his mouth; the poetry recited at the symposium expressed the positive values of the group. ${ }^{8}$ The satyr on the cup was implicitly present as a counter image that was attractive and repulsive at the same time and provided a challenge to reflect on one's own position in society.

However, in the decades around 500 вС noble satyrs are also found on representative amphorae, a type of vase that evokes status and wealth, and the comic and paradoxical satyrs frequently occur on pelikai, which were also used by women in the home. This implies that the citizen was not only confronted with his opposite in komos and symposium, but, in fact, all the time. The counter image reminded him again and again of the positive and negative opportunities that belonged to his manhood, but which, under normal circumstances could or should remain unrealized. In this perspective, the satyr may be seen as the manifestation of unshackled masculinity, for better or for worse - on the one side opened up to a divine, on the other to an animal existence. This unfettered world, that was the antithesis of, but also included the humanly ordered life of the polis, was the domain of Dionysos. This is why the satyr, as the manifestation of unshackled masculinity, is predestined to mediate between Dionysos and humans.

If one sees the satyr as both the counterpart and the complement of the citizen (which is confirmed by the slightly later images of satyrs dressed in himatia) one is better able to understand two things. First of all it becomes clear why no counter image was needed for women, who were not citizens, but at the most wives, mothers, sisters and daughters of citizens. As noncitizens women inherently belonged to Dionysos and his alternative universe.

7 The satyr is, therefore, not merely a negative counterpart of men or a parody, as seems to be the viewpoint of Steinhart 2004, 101-127 and Osborne 2009, 9-12.

8 For instance the poetry of Anakreon who was particularly devoted to Dionysos: Privitera $1970,11-115$. As a significant analogy to this contention it should be noted that satyrs are not a subject for temple sculpture: Osborne 2009 . 
Secondly, one can perceive why the satyr motif was so topical in the years immediately following the Kleisthenic reforms, when it was endlessly varied upon by the vase painters.

The decades between 480 and $430 \mathrm{BC}$, the time of Kimon and Perikles, were the heyday of the motifs of komos and symposium-evocations of moments of relaxation and merriment that must have been as much part of a citizen's life as athletic, political and military activities. They are the main Dionysiac subject on the better, but above all on the mediocre cups and the numerous column kraters. At the same time, Dionysiac imagery is enriched with a plethora of new motifs. The return of Hephaistos, already popular in the 6th century, is presented in a new manner: now that Hephaistos is no longer always riding a mule, but often moves along in step with his brother, the scene loses its comic connotations and instead highlights the solidarity of these two gods, who are not much respected on the Olympus but of crucial importance for human life. At the time of the Persian Wars and shortly after, Dionysos participating in the battle against the giants and thus contributing to the safeguard of the rule of Zeus, becomes an important theme. And as ever the god is shown to be present at the birth of Athena, an event that ushers in a new era. Dionysos' important role at the marriage of Peleus, another significant breaking point in mythological history, is already there with Sophilos and continues afterwards.

A striking feature of these decades is the fact that vase painters become ever more interested in the mythology of Dionysos himself: his birth, the handing over of the infant Dionysos to the nymphs, the dramatic union with Ariadne. It is truly remarkable how much this 'biography' deviates from the ideals of the Classical polis. The divine child has a mortal and dying (or dead?) mother, is brought into the world by his father, and is subsequently left in strange hands in order to be educated not in a home, but in unspoiled nature, by young women or an aged satyr. He loves a woman and pursues her out of love, a woman who belonged to another-a hero of a lesser stature than the god-and eventually marries her. The children from this marriage appear, if they appear at all, only in a single image, even though the vase painters knew about them, just as mythology knows about them. ${ }^{9}$ For the vase painters and their customers, the love story of Dionysos and Ariadne seems to represent not so much the continuity of the oikos and the family, as the emotional and erotic aspects of the relationship. This almost human, but nevertheless unusual biography made it possible for men and women whose life histories ran counter to the norms of society to relate to Dionysos and Ariadne.

9 For a skyphos by the Lewis Painter, Vienna 1773: Addenda 309 (972.2); BA 213234. For Ariadne's children: Isler-Kerényi 2007, 122. 
Most characteristic of the decades from around 480 to after 450 is that the vase painters and their clientele turned towards a new theme, not yet present in the 6th century: the ritual around Dionysos. The euphoric, erotically charged dance of the god's retinue, found especially on cups and kraters, increasingly becomes a solemn procession on other types of vases, such as stamnoi and bell kraters. ${ }^{10}$ There is a shift from the timeless bliss induced by the god to the ceremonial preparation and attunement that should bring this about-a motif the viewer knows from his own experience. The satyr-citizens that now appear quite frequently remind him of the fact, that the transition from citizen to satyr is just as fluid for him as the transition from 'normalcy' to bacchante for his wife and daughter.

The procession of women, satyrs, and often the god himself, by torch light and to musical accompaniment, is joined by a multitude of representations of ritual activities in honor of Dionysos. These activities apparently took place in the home, in the family circle, and in addition to the festivals organized by the polis. We discussed the procession of ephebes with their fathers or educators at the occasion of the Apatouria, the wine rituals performed by women in front of a temporary idol with the god's mask, and the preparation of a chair for the god who is about to arrive. These are subjects that befit their carrier: a vase used by ordinary people in their day-to-day existence. They also befit the god who, next to Athena, was of prime importance in the mental universe and the actual life of every Athenian man and woman of the Classical age-something that is also borne out by the Athenian festival calendar. ${ }^{11}$ Dionysos, however, may have been even closer to the individual than the city's patron deity.

Dionysos could, therefore, not be absent from the two divine gatherings that decorate the Parthenon on the east pediment and the east cella frieze, conceived around 450 and presented to the Athenian public in 432 at the latest. The decoration program involved the representation of a here-and-now governed by Zeus as the outcome of subsequent generations of gods and of revolutions and struggle. ${ }^{12}$ Dionysos' new youthful appearance as the son of Zeus-an appearance that pointed to the future-better fitted this concept than his venerable traditional form. It was all the more convincing because, as argued above, Dionysos stood in a very intimate relationship to human beings. This relationship, involving the Bacchic experience, probably already

\footnotetext{
10 This subject merits further investigation. For similar ideas about the close relationship between myth and art in Dionysiac imagery, see Schöne-Denkinger 2008, $5_{1} \mathrm{f}$.

11 Compare Seaford 2006, $46 \mathrm{f}$.

12 Compare above 163 n. 5 .
} 
existed in archaic times and was continuously alluded to in the ever recurrent motifs of early red-figure vase painting: thiasos, encounter with the god, state of bliss. ${ }^{13}$ His position and pose on the east pediment show even better than before that Dionysos, like Aphrodite, was already there when Athena was born from her father's head and, in this way, inaugurated a new era-the era of Athens. As Lysios, he embodies the felicitous peace that in the vision of those who commissioned the temple would put an end to a period of warfare for the polis, analogous to what he effectuated in the life of the individual citizen. It is no coincidence that in the frieze, of all the sons of Zeus, Dionysos is closest to Hermes, the psychopompos who leads the human soul across critical barriers, especially in death. Dionysos turns towards the humans, but as Bakchos he also belongs to Demeter, the mistress of Eleusis and its mysteries.

Instead of the wished-for peace, another war was followed by a time of crisis and sadness for the Athenians, and the vase painters above all looked upon Dionysos, the Bakchos and the Lysios, as the embodiment of a now distant utopia and the prospect of a godlike existence after death. His world moved away from the present of the polis. Consequently, his life story and the rituals performed for him by women and families shifted to the background. They were replaced by symbolic elements - giant clusters of grapes, budding plants, the playful tame panther, the figure of Eros - that reminded those in the know of their Bacchic hopes and experiences.

Signs that refer to things that cannot be expressed in words are metaphors and should be understood metaphorically. We have already cast doubt on the interpretation of the symposium motif as the promise of a heavenly banquet; this reading is inadequate and may merely be characteristic of our own materialistic culture. In the same vein, we should not interpret the representations of Dionysos as lover and betrothed, as he is shown by the vase painters after $420 \mathrm{BC}$ and finally on the Derveni krater, as a promise of concrete erotic experiences. It is much more probable that the Dionysos of these images 'speaks' to the beholder of the hope of boundless felicity after death.

In contrast to vase painting, however, other forms of art, especially sculpture, had no intention of replacing the old Dionysos by the youthful, erotically attractive one. Rather we see the emergence of various other appearances, which would fit different contexts and genres. In late Classical and Hellenistic art, Dionysos, who is responsible for all metamorphoses, himself becomes a polymorphous, omnipresent god who holds sway in the world of images. 


\section{Dionysos in Classical Athens}

As mentioned at the beginning, vase imagery is only an indirect representation of historical reality. First of all, because these images do not aim for verisimilitude, but are constructions that refer to mental realities. Secondly, because they can only relate to the specific context in which they were used, to the reality that was relevant to the individuals for whom the image was intended at the moment of use. What the images seek to express, is not valid for the polis as a whole and only holds true for their own very specific time. They are just one of the windows through which we are allowed a glimpse of ancient life and thought. However, a survey of several generations of vase painters, as has been presented here, should yield some illuminating results.

It is more than obvious that the repertoire of the vase painters on the whole remains within the existing tradition, but simultaneously takes into account the carrier and its function. The cups mostly show the Dionysos of the symposium, of drinking wine and of ecstasy, and here we also find the unfettered satyrs and the euphoric maenads. On many stamnoi and bell kraters, however, the god and his retinue are in a solemn, even pious mood. Amphorae show satyrs of noble appearance; pelikai rather the comical ones. Dionsyiac mythology is more popular in one period than in another, while references to characters and plots of dramas (whose audiences and occasions not necessarily belonged to the circumstances of the vase painters) are rare altogether. Dionysos has a different guise for every context, as can be expected in a polytheistic world view. ${ }^{14}$

The Classical period confirms what has been said about the iconography of the 6th century ${ }^{15}$ It is reductionist to see Dionysos as the god of wine, theater and ecstasy. Human beings - men, women, and children-experienced the presence and the actions of the god at many occasions and in different situations: happy and sad, solemn and festive, intimate and public. Dionysos' domain embraces both the wilderness and the well-ordered world of polis and oikos. The wide, boundless and timeless universe of the god encompassed the narrow world of human order and structured time in a relationship that was now dialectic, now harmonic. No other god as effectively embraced the realities of human living and dying. From the days of classical Athens down to the end of the ancient world, no god was more worshipped, more feared and more loved.

\footnotetext{
14 Compare Versnel 2011b, 37: "One god—as identified by one name—always participates in a variety of systems. In accordance with each system the god will show a different face."

15 Isler-Kerényi 2007, 233.
} 
Cornelia Isler-Kerényi - 978-90-04-27012-1 Downloaded from Brill.com04/05/2019 09:07:34AM via free access 


\section{Works Cited}

Aélion, R. (1983) Euripide héritier d'Eschyle. Paris.

Albizzati, C. (1924-1938) Vasi antichi dipinti del Vaticano. Roma.

Angeli Bernardini, P. (ed.) (2013) Corinto. Luogo di azione e luogo di racconto. Atti del convegno internazionale, Urbino settembre 20og. Pisa/Roma.

Arafat, K.W. (1990) Classical Zeus. A Study in Art and Literature. Oxford.

Aurigemma, S. (1960) La necropoli di Spina in Valle Trebba I. Roma.

Avramidou, A. (2009) "Dionysos in Context: Two Attic Red-figure Kraters of the Early

Fourth Century BC.” In: Oakley/Palagia 2009, 1-10.

- (2011) The Codrus Painter. Iconography and Reception of Athenian Vases in the Age of Pericles. Oxford.

Bakola, E. (2010) Cratinus and the Art of Comedy. Oxford.

Barringer, J.M./J.M. Hurwit (eds) (2005) Periklean Athens and its Legacy. Problems and Perspectives. Austin.

Baumann, H. (1982) Die griechische Pflanzenwelt. München.

Beaumont, L.A. (1993) Studies on the Iconography of Divine and Heroic Children in Attic Red-figure Vase-Painting of the Fifth Century BC. Thesis University College London 1993.

Beazley, J.D. (1922) “Citharoedus.” In: JHS 42, 70-98.

- (1930) Der Berliner Maler. Berlin.

(1933) Der Kleophrades-Maler. Berlin.

Bellia, A. (2012) Strumenti musicali e oggetti sonori nell'Italia meridionale e in Sicilia (VI-III sec. a. C.). Funzioni, rituali e contesti. Lucca.

Beltrametti, A. (ed.) (2007) Studi e materiali per le Baccanti di Euripide. Storia Memorie Spettacoli. Como/Pavia.

(ed.) (2011) La storia sulla scena. Quello che gli storici antichi non hanno raccontato. Roma.

Bérard, C. (1966) “Une nouvelle péliké du Peintre de Geras.” In: AntK 9, 93-100.

(1992) "Phantasmatique érotique dans l'orgiasme dionysiaque." In: Kernos 5, $13-26$.

Bérard, C./C. Bron (1984) “Le jeu du satyre.” In: Bérard et al., La cité des images. Religion et société en Grèce antique. Lausanne, 127-145.

- (1986) "Bacchos au coeur de la cité. Le thiase dionysiaque dans l'espace politique." In: L'association dionysiaque dans les sociétés anciennes. Actes de la table ronde, Rome, mai 1984. Collection de l'Ecole Française de Rome 89. Rome, 13-28.

Bérard, C./C. Bron/A. Pomari (eds) (1987) Images et société en Grèce ancienne. L'iconographie comme méthode d'analyse. Actes du Colloque International, Lausanne 1984. Cahiers d'archéologie romande no. 36. Lausanne. 
Berger, E. (ed.) (1984) Parthenon-Kongress. Basel.

Berger, E. (1986) Der Parthenon in Basel. Dokumentation zu den Metopen. Mainz.

Berger, E./M. Gisler-Huwiler (1996) Der Parthenon in Basel. Dokumentation zum Fries. Basel/Mainz.

Berger, E./R. Lullies (eds) (1979) Antike Kunstwerke der Sammlung Ludwig I. Basel.

Bernabé, A. (2013) “Bacchide, Dioniso e un frammento dell'Europia di Eumelo." In: Angeli Bernardini 2013, 51-61.

Bertholet, F. et al. (eds) (2008) Egypte-Grèce-Rome. Les différents visages desfemmes antiques. Bern/Berlin.

Berti, F. (ed.) (1991) Dionysos. Mito e mistero. Attidel convegno internazionale, Comacchio, novembre 1989. Comacchio.

Berti, F./D. Restani (eds) (1988) Lo specchio della musica. Bologna.

Boardman, J. (1974) Athenian Black Figure Vases. London.

- (1975) Athenian Red Figure Vases. The Archaic Period. London. (1989) Athenian Red Figure Vases. The Classical Period. London.

Bonansea, N. (2008) "Menade, Baccante o Ninfa? Uno studio sull'identità femminile dionisiaca nelle fonti letterarie e iconografiche tra viII e v secolo a. C." In: Mythos 2, 107-129.

Bonaudo, R. et al. (eds) (2009) Tra Etruria, Lazio e Magna Grecia: indagini sulle necropoli. Atti del Convegno, Fisciano, marzo 2009. Paestum.

Bonfante, L. (1993) "Fufluns Pacha: The Etruscan Dionysus." In: Carpenter/Faraone 1993, 221-235.

Borbein, A.H. (1995) “Die bildende Kunst Athens im 5. und 4. Jahrhundert v. Chr." In: Eder 1995, 429-467.

Borg, B.E. (2002) Der Logos des Mythos. Allegorien und Personifikationen in der frühen griechischen Kunst. München.

Brelich, A. (1958) Gli eroi greci, un problema storico-religioso. Roma (second edition Milano 2010).

- (1985) I Greci e gli dei. Napoli.

Brinkmann, V. (ed.) (2013) Zurück zur Klassik. Ein neuer Blick auf das alte Griechenland. Exhibition catalogue Frankfurt. München, Frankfurt a. M.

Brommer, F. (1963) Die Skulpturen der Parthenon-Giebel. Mainz. (1977) Der Parthenonfries. Mainz.

- 1978) Hephaistos. Der Schmiedegott in der antiken Kunst. Mainz.

Brunori, S. (2006) “Vulci e le idrie attiche a figure nere." In: Ostraka 15.2, 249-278.

Buitron-Oliver, D. (1995) Douris. A Master-Painter of Athenian Red-figure Vases. Mainz.

Burkert, W. (1977) Griechische Religion der archaischen und Klassischen Epoche. Stuttgart/Berlin/Köln/Mainz.

Burn, L. (1987) The Meidias Painter. Oxford.

(2010) "The Contexts of the Production and Distribution of Athenian Painted

Pottery around 400 B C." In: Taplin/Wyles 2010, 15-31. 
Buschor, E. (1904-1932) “Polychromer Kelchkrater im Vatikan. Das Dionysoskind.” In: $F R$, text volume $3,302-306$.

Cain, H.-U. (1997) “Die Locken lang, ein halbes Weib?”. Exhibition catalogue Munich. München.

Calame, C. (1990) Thésée et l'imaginaire athénien. Légende et culte en Grèce ancienne. Lausanne.

- (2008) "Identités lumineuses, espaces rituels, objets textuels: itinéraires initiatiques dans les lamelles funéraires d'or." In: Estienne 2008, 153-164.

- (2010) "Aetiological Performance and Consecration in the Sanctuary of Dionysos." In: Taplin/Wyles 2010, 65-78.

Capecchi, G. et al. (eds.) (1998) In memoriam di Enrico Paribeni II. Roma.

Carpenter, T.H. (1986) Dionysian Imagery in Archaic Greek Art. Oxford.

_ (1993) “On the Beardless Dionysus." In: Carpenter/Faraone 1993, 185-206.

_ (1995) “A Symposion of Gods?” In: Murray/Tecuşan 1995, 145-163. (1997) Dionysian Imagery in Fifth-Century Athens. Oxford.

Carpenter, T.H./A. Faraone (eds) (1993) Masks of Dionysus. Ithaca/London 1993

Cartledge, P.A./F.D. Harvey (1985) (eds) Crux. Essays in Greek History presented to G.E.M. de Ste. Croix. London.

Casolari, F. (2003) Die Mythentravestie in der griechischen Komödie. Münster.

Castriota, D. (1992) Myth, Ethos, and Actuality. Official Art in Fifth-Century BC Athens. Madison Wisc. 1992.

Catoni, M.L. (1998) “Quando il regazzo si fa satiro." In: Prospettiva 89-9o, genn.- aprile 1998, 74-84.

- (2010) Bere vino puro. Immagini del simposio. Milano.

Christopoulos, M. et al. (eds) (2010) Light and Darkness in Ancient Greek Myth and Religion. Lanham/Boulder.

Clinton, K. (1992) Myth and Cult. The iconography of the Eleusinian Mysteries. Stockholm.

Cohen, B. (ed.) (2000) Not the Classical Ideal. Athens and the Construction of the Other in Greek Art. Leiden/Boston/Köln.

- (2006) The Colors of Clay. Special Techniques in Athenian Vases. Los Angeles.

Cohen, A./J.B. Rutter (eds) (2007) Constructions of Childhood in Greek and Roman Antiquity. Hesperia Supplement 41. Princeton (N.J.).

Collinge, A. (1989) “The Case of Satyrs." In: Mackenzie/Roueché 1989, 82-103.

Colpo, I./I. Favaretto/F. Ghedini (eds) (2006) Iconografia 2005. Immagini e immaginari dall'antichità classica al mondo moderno. Roma.

Coulson, W.D.E. et al. (eds) (1994) The Archaeology of Athens and Attica under the Democracy. Oxford.

Croissant, F. (2003) Les frontons du temple du IV e siècle. Fouilles de Delphes IV.7. Athènes.

Crowther, N.B. (1985) “Male 'Beauty' Contests in Greece: The Euandria and Euexia." In: Antiquité Classique 54, 287, 285-291. 
Daux, G. (ed.) (1968) Guide de Thasos. Paris.

De Cesare, M. (2007) “Crateri-cinerari in Sicilia: immagini, riti e credenze religiose." In: Sicilia Antiqua 4, 9-31.

De Miro, E. (1994) La Valle dei Templi. Palermo.

Dentzer, J.-M. (1982) Le motif du banquet couché dans le Proche-Orient et le monde grec $d u$ VII ${ }^{e}$ au IV siècle avant J.-C. Rome.

Despinis, G. (1982) Parthenoneia. Athens.

Detienne, M. (2007) Dioniso e la pantera profumata. Roma/Bari.

Diez del Corral Correidora, P. (2007) Y Dioniso desposó a la rubia Ariadna. Estudio iconográfico de la cerámica ática $(575-300$ a. C.). BAR International Series 1719. Oxford.

- (2011) "Anfítrite y Ariadna. Ambigüedades iconográficas en una Hidria del pintor de Dicaios." In: NAC 40, 129-140.

Docter, R.F./E.M. Moormann (eds) (1999) Proceedings of the Xvth International Congress of Classical Archaeology, Amsterdam, July 12-17, 1998, Allard Pierson Series. Amsterdam.

Drougou, S. (2000) "Krieg und Frieden im Athen des späten 5. Jahrhunderts v. Chr. Die rotfigurige Hydria aus Pella." In: AM 115, 147-216.

Eder, W. (ed.) (1995) Die athenische Demokratie im 4. Jahrhundert v. Chr. Vollendung oder Verfall einer Verfassungsform? Akten eines Symposiums August 1992, Bellagio. Stuttgart.

Eder, W./K.-J. Hölkeskamp (eds) (1994) Volk und Verfassung im vorhellenistischen Griechenland. Stuttgart.

Ehrhardt, W. (1993) “Der Fries des Lysikratesmonumentes." In: Antike Plastik 22, 7-67.

Ellinghaus, C. (2011) Die Parthenonskulpturen. Hamburg.

Estienne, S. et al. (eds) (2008) Image et religion dans l'antiquité grécoromaine. Actes du colloque, Rome, décembre 2003. Naples.

Etienne, R./J.-P. Braun (2007) “Autels de Délos et autels ioniens.” In: AA, 1-28.

Fahlbusch, G. (2004) Die Frauen im Gefolge des Dionysos auf den attischen Vasenbildern des 6. und 5.Jhs. v. Chr. als Spiegel weiblichen Idealbildes. Oxford.

Faulkner, A. (ed.) (2011) The Homeric Hymns. Oxford.

Fehr, B. (1979) "Zur religionspolitischen Funktion der Athena Parthenos im Rahmen des delisch-attischen Seebundes. Teil I." In: Hephaistos 1, 71-80.

Ferrari, G. (1990) "Figures of Speech: The Picture of Aidos." In: Metis 5, 185-206.

Fischer-Lichte, E./M. Warstat (eds) (2010) Staging Festivity. Theater und Fest in Europa. Tübingen/Basel.

Foxhall, L./H.-J. Gehrke/N. Luraghi (eds.) (2010) Intentional History. Spinning Time in Ancient Greece. Stuttgart.

Franke, P.R./M. Hirmer (1972) Die griechische Münze. München.

Frickenhaus, A. (1912) Lenäenvasen. 72. Winckelmannsprogramm. Berlin.

Froning, H. (1996) “Un Eracle attico in Sicilia." In: Rizza/Giudice 1996, 107-119. 
Frontisi-Ducroux, F. (1991) Le dieu-masque. Une figure du Dionysos d'Athènes. Paris/ Rome.

Furtwängler, A. (1883-87) La collection Sabouroff. Berlin.

Gasparri, C. (1986) “Dionysos.” In: LIMC III.1, 420-514.

Gehrke, H.-J. (2013) “Ägineten und Athener. Eine exemplarische Geschichte." In: Brinkmann 2013, 144-151.

Gemelli Marciano, L. (2013) Parmenide: suoni, immagini, esperienza. Eleatica vol. 3. Sankt Augustin.

Gentili, B./F. Perusino (eds) (2002) Le orse di Brauron. Un rituale di iniziazione femminile nel santuario di Artemide. Pisa.

Gerhard, E. (1840-58) Auserlesene griechische Vasenbilder. Berlin.

Giudice, G. (2007) Il tornio, la nave, le terre lontane. Ceramografi attici in Magna Grecia nella seconda metà del V. sec. a. C. Rotte e vie di distribuzione. Roma.

Giudice, G. e E. (eds) (2011) Veder greco a Camarina dal principe di Biscari ai nostri giorni. Catania.

Giudice, F./R. Panvini (eds) (2006) Il greco, il barbaro e la ceramica attica. Immaginario del diverso, processi di scambio e autorappresentazione degli indigeni III. Atti del Convegno internazionale, maggio 2001. Roma.

- (2007) Il greco, il barbaro e la ceramica attica. Immaginario del diverso, processi di scambio e autorappresentazione degli indigeni IV. Atti del Convegno internazionale, maggio 2001. Roma.

Giuliani, L. (1991) "Euphronios: Ein Maler im Wandel." In: Heilmeyer 1991, 14-24.

Goldhill, S. (1994) "Representing Democracy: Women at the Great Dionysia." In: Osborne/Hornblower 1994, 347-369.

Goldhill, S./R. Osborne (eds) (1999) Performance culture and Athenian democracy. Cambridge.

Gould, J. (2001) "Dionysus and the Hippy Convoy: Ritual, Myth, and Metaphor in the Cult of Dionysus." In: Idem, Myth, Ritual Memory, and Exchange. Essays in Greek Literature and Culture. Oxford, 269-282.

Graen, D./M. Rind/H. Wabersich (eds) (2014) Otium cum dignitate. Festschrift für Angelika Geyer zum 65. Geburtstag. Studien zur Archäologie und Rezeptionsgeschichte der Antike. BAR International Series 2605. Oxford.

Grassigli, G.L. (1999) “La fede di Astion. Per un'interpretazione del cratere di Derveni." In: Ostraka 8.1, 99-143.

Greifenhagen, A. (1957) Griechische Eroten. Berlin.

- (1972) "Neue Fragmente des Kleophradesmalers." In: Sitzungsberichte der Heidelberger Akademie der Wissenschaften, Philosophisch-historische Klasse. Heidelberg, 13-21.

Grütter, H.T. (1997) "Die athenische Demokratie als Denkmal und Monument. Überlegungen zur politischen Ikonographie im 5. Jahrhundert v. Chr." In: Eder/ Hölkeskamp 1997, 113-132. 
Halm-Tisserant, M. (1984) “Le peintre de Curti." In: $R E A$ 86, 135-170.

(1986) “La représentation du retour d'Héphaïstos dans l'Olympe. Iconographie traditionnelle et innovations formelles dans l'atelier de Polygnotos (440-430)." In: AntK 29, 8-22.

_ (1988) “Le Peintre du Dinos." In: Histoire de l'Art 4, 3-16. (1991) "Autour du mannequin dionysiaque." In: Hephaistos 10, 63-88.

Hamilton, R. (1992) Choes \& Anthesteria. Athenian Iconography and Ritual. Ann Arbor. Haspels, C.H.E. (1936) Attic Black-figured Lekythoi. Paris.

Hatzidimitriou, A. (2012) "Erythromorphos chous mé dionysiaki skini apo tin Argyroupoli." In: Kephalidou/Tsiaphaki 2012, 117-125.

Hedreen, G.M. (1992) Silens in Attic Black-figure Vase-painting. Myth and Performance. Ann Arbor.

Heilmeyer, W.-D. (ed.) (1991) Euphronios der Maler. Exhibition catalogue Berlin. Berlin. (ed.) (2002) Die griechische Klassik. Idee oder Wirklichkeit. Mainz.

Heinemann, A.A.J. (2000) "Bilderspiele beim Gelage. Symposiast und Satyr im Athen des 5. Jahrhunderts v. Chr." In: Hölscher 2000, 321-349.

Henrichs, A. (2008) “Dionysische Imaginationswelten:Wein, Tanz, Erotik.” In: Schlesier/ Schwarzmaier 2008, 19-27.

Himmelmann, N. (1990) “Frühgriechische Jünglingstatuen." In: Idem, Minima archeologica. Utopie und Wirklichkeit der Antike. Mainz, 24-40.

Hoffmann, H. (2007) Divergent Archaeology. Ruhpolding/Mainz, 24-40.

Hölscher, T. (ed.) (200o) Gegenwelten zu den Kulturen Griechenlands und Roms in der Antike. München/Leipzig.

Holtzmann, B. (2010) La sculpture grecque. Paris.

Huber, K. (1992) "Werkstattgesellen. Zur Produktion früher Kelchkratere." In: Wehgartner 1992, $57-72$.

Humphreys, S.C. (2004) The Strangeness of Gods. Historical perspectives on the interpretation of Athenian religion. Oxford.

Hurwit, J.M. (2004) The Acropolis in the Age of Pericles. Cambridge.

- (2005) "The Parthenon and the Temple of Zeus at Olympia." In: Barringer/ Hurwit 2005, 135-145.

Imperio, O. (2011) "Satira politica e leggi ad personam nell'archaía: Pericle e il Dionisalessandro di Cratino." In: Beltrametti 2011, 291-314.

Isler, H.P., (2002) “Das Dionysos-Theater in Athen." In: Heilmeyer 2002, 533-541.

Isler, H.P./G. Seiterle (eds) (1973) Zur griechischen Kunst. Festschrift H. Bloesch. 9. Beiheft AntK. Bern.

Isler-Kerényi, C. (1969) Nike. Der Typus der laufenden Flügelfrau in archaischer Zeit. Erlenbach (Zürich).

_ (1971) “Ein Spätwerk des Berlinermalers." In: AntK 14, 25-31. 
_ (1973) "Chronologie und 'Synchronologie' attischer Vasenmaler der Parthenonzeit." In: Isler/Seiterle 1973, 23-33.

— (1976) "Stamnoi e stamnoidi, genesi e funzione." In: NAC 5, 33-52.

- (1977a) Stamnoi. Lugano.

_ (1977b) Lieblinge der Meermädchen, Zürcher Archäologische Hefte 3. Zürich.

(1979) “Un nuovo stamnos del Pittore di Achille in collezione ticinese." In: NAC

$8,11-35$.

- (1982) "Il trionfo di Dioniso." In: NAC 11, 137-160.

(1983) "Dionysos auf einer attischen Vase des vierten Jahrhunderts: Mythologie oder Utopie?” In: Metzler/Otto/Müller-Wirth 1983, 95-100.

(1984a) "Boreade oder Eros?" In: $A A$ 383-386.

- (1984b) "Hermonax in Zürich III: Der Schalenmaler." In: AntK 27, 154-165.

_ (1987a) "Hermonax e i suoi temi dionisiaci." In: Bérard/Bron/Pomari 1987, $169-175$.

- $(1987 \mathrm{~b})$ "Dal ginnasio al simposio: tappe di vita giovanile su di uno psykter attico a figure rosse." In: NAC 16, 47-85.

_ (1990) "Dionysos con una sposa." In: Metis 5, 31-48.

(1993a) "Dionysos und Solon. Dionysische Ikonographie v." In: AntK 36, 3-10.

(1993b) “Anonimi ammantati." In: Nenci 1993, 93-100.

(1994) Review of F. Frontisi-Ducroux 1991, in Gnomon 66, 44-51.

(1996) “Un cratere selinuntino e il problema dei giovani ammantati." In: Rizza/

Giudice 1996, 49-53.

_ (1999a) "Il cliente etrusco del vaso greco: uno straniero?" In: Villanueva Puig 1999, $445^{-448 .}$

_ - (1999b) “Dionysos, la Thrace, la Mer Noire." In: Pontica 32, 39-49.

- (2002a) "Un cratere polignoteo fra Atene e Spina." In: NAC 31, 69-88.

- (2002b) "Nuovi contributi su Brauron." In: ASAtene 8o (Serie III.2, tomo I), $480-482$.

- (2003) “Images grecques au banquet funéraire étrusque." In: Pallas 61, 39-53.

- (2004a) Civilizing Violence. Satyrs on 6th-Century Greek Vases. Fribourg/ Göttingen.

_ (2004b) "Dioniso ed Eros nella ceramica apula." In: Sena Chiesa/Arslan 2004, $244-248$.

— (2007) Dionysos in Archaic Greece. An Understanding through Images. Leiden/ Boston.

- (2008a) “Dionysos und die anderen Götter." In: Schlesier/Schwarzmaier 2008, 70-79.

(2008b) "Eracle e Dioniso, fiori e cigni." In: Sena Chiesa 2008, 229-247.

(2009a) “The Study of Figured Pottery Today." In: Noerskov 2009, 13-21. 
(2009b) “Retour au stamnos attique: Quelques réflexions sur l'usage et le répertoire." In: Metis 7, 75-90.

_ (2010a) “Dionysos am Parthenon.” In: Fischer-Lichte/Warstat 2010, 112-126.

- (2010b) "Dionysos am Pergamonaltar." In: AntK $53,62-73$.

_ (2011a) "Immagini di Dioniso nel IV secolo." In: La vigna di Dioniso. Vite vino e culti in Magna Grecia. Atti del XLIX Convegno di Studi sulla Magna Grecia, Taranto 20og. Taranto, 73-93.

_ (2011b) "Dionysos im klassischen Athen: auf der Bühne und in der Kunst." In: Acta Antiqua Academiae Scientiarum Hungaricae 51, 207-222.

- (2012a) “Dioniso protagonista." In: Dionysus ex Machina 3, 302-317.

(2012b) "Immagini e incognite. Riflessioni sui sarcofagi romani con scene dionisiache." In: Sena Chiesa 2012, 71-75.

Jaccottet, A.-F. (1990) “Le lierre de la liberté.” In: ZPE 80, 150-156.

- (1998) "L'impossible bacchant." In: Pallas 48, 9-18.

- (2003) Choisir Dionysos. Les associations dionysiaques ou la face cachée du dionysisme. Kilchberg (Zürich).

- (2008) "Le cratère de Derveni recontextualisé ou comment héroïser une femme." In: Bertholet 2003, 41-62.

Jaillard, D. (2011) “The Seventh Homeric Hymn to Dionysus. An Epiphanic Sketch." In: Faulkner 2011, 133-159.

Jenkins, I. (2006) Greek Architecture and its Sculpture. London.

- (2007) The Parthenon Sculpture in the British Museum. London.

Johannowsky, W. (1983) Materiale di età arcaica dalla Campania. Napoli.

Kaempf-Dimitriadou, S. (1979) Die Liebe der Götter in der attischen Kunst des 5. Jahrhunderts v. Chr. 11. Beiheft AntK. Bern.

Kaeser, B. (1990) "Zuschauerfiguren" and "Rebe und Efeu." In: Vierneisel/Kaeser 1990, 151-156 and $325^{-335}$.

Karusu, S. (1975) "Eine Bronzestatuette des Dionysos aus Aetolien." In: Wandlungen. Studien zur antiken und neueren Kunst. Festschrift E. Homann-Wedeking. WaldsassenBayern, 205-216.

Kästner, U. (2008a) "Attische Vasen mit Dionysosdarstellungen. Gefässform und Dekoration." In: Schlesier/Schwarzmaier 2008, 54-69.

(2008b) "Attische Bauchlekythos: Dionysos im Gigantenkampf." In: Schlesier/ Schwarzmaier 2008, $188 \mathrm{f}$.

Kathariou, K. (2002) To ergastirio tou zographou tou Meleagrou ke i epochi tou. Thessaloniki.

Kavoulaki, A. (1999) “Processional performance and the democratic polis." In: Goldhill/ Osborne 1999, 293-320.

Kephalidou, E./D. Tsiaphaki (eds) (2012) Kerameos paides. Festschrift für Michalis Tiverios. Thessaloniki. 
Kerényi, K. (1995) Antike Religion. Stuttgart.

_- (1997a) Die Mythologie der Griechen I. Die Götter- und Menschheitsgeschichten. Stuttgart.

- (1997b) Die Mythologie der Griechen II. Die Heroengeschichten. Stuttgart.

Klein, R. (1979) "Die innenpolitische Gegnerschaft gegen Perikles." In: Wirth 1979, 494-517.

Knauer, E. (1996) "Two Cups by the Triptolemos Painter. New Light on two Athenian Festivals?" In: $A A$ 1996.2, 221-246.

Knell, H. (1990) Mythos und Polis. Bildprogramme griechischer Bauskulptur. Darmstadt. Koch, G./H. Sichtermann (1982) Römische Sarkophage. München.

Kolb, F. (1981) Agora und Theater, Volks- und Festversammlung. Berlin.

Kratzmüller, B. (2003) 'Die Inschrift IG II 2311 und die 'Nicht-Möglichkeit' einer Hochrechnung der antiken Vasenproduktion anhand der erhaltenen Panathenäischen Preisamphoren." In: Schmaltz/Söldner 2003, 277-279.

Krauskopf, I. (2001) "Thystla, Thyrsoi und Narthekophoroi. Anmerkungen zur Geschichte des dionysischen Kultstabes." In: Thetis 8, 47-52.

Krumeich, R. (1999) “Archäologische Einleitung." In:Krumeich/Pechstein/Seidensticker 1999, 41-73.

Krumeich, R./N. Pechstein/B. Seidensticker (eds) (1999) Das griechische Satyrspiel. Darmstadt.

Kunisch, N. (1997) Makron. Kerameus 110). Mainz.

Kunze-Götte, E. (2006) Myrte als Attribut und Ornament auf attischen Vasen. Kilchberg. Kurtz, D. (ed.) (2008) Essays in Classical Archaeology for Eleni Hatzivassiliou 1977-2007. Oxford.

Lada-Richards, I. (1999) Initiating Dionysus. Ritual and Theatre in Aristophanes' Frogs. Oxford.

La Genière, J. de (2013) “'Vases des Lénéennes' cent ans après.” In: REG 126, janvier-juin 2013.

Langlotz, E. (1922) Griechische Vasenbilder. Heidelberg.

Langner, M. (2012) "Mantle-figures and the Athenization of Late Classical Imagery." In: Schierup/Bundgaard-Rasmussen 2012, 10-20.

- (2013) "Grundlagen der Chronologie spätrotfiguriger Vasen aus Athen." In: BABesch 88, 127-170.

Lezzi-Hafter, A. (1976) Der Schuwalow-Maler. Eine Kannenwerkstatt der Parthenonzeit. Kerameus 2. Mainz.

— (1985) "Die Würzburger Schale des Kodrosmalers trägt Inschriften.” In: $A A$, 249-251.

(1988) Der Eretria-Maler.Werke und Weggefährten. Kerameus 6. Mainz.

Lindblom, A. (2011) Take a Walk on the Wild Side. The Behaviour, Attitude and Identity of Women Approached by Satyrs on Attic Red-Figure Vases from 53 o to 400 Bc. Stockholm. 
Lissarrague, F. (1987) “De la sexualité des satyres.” In: Metis 2.1, 63-88.

(1990a) "Why Satyrs Are Good to Represent." In: Winkler/Zeitlin 1990, 228-236.

(1990b) "Around the Krater: An Aspect of Banquet Imagery." In: Murray 1990, 196-209.

(1998) “Satyres chez les femmes." In: Veyne/Lissarrague/Frontisi-Ducroux 1998, 179-197.

- (2010) "From Flat to the Volume of the Pot." In: Taplin/Wyles 2010, 33-46.

(2013) La cité des satyres. Une anthropologie ludique (Athènes, $V^{e}{ }^{-} V^{e}$ siècle avant J.-C.). Paris.

Lubsen Admiraal, S.M. (1999) “The Getty Krater by Syriskos." In: Docter/Moormann 1999, 239-241.

Lullies, R. (1971) “Der Dinos des Berliner Malers." In: AntK 14, 44-55.

(1979) "Nr. 39 Dinos." In: Berger/Lullies 1979, 108-111.

Lynch, K.M. (2011) The Symposium in Context. Pottery from a Late Archaic House near the Athenian Agora. Hesperia Suppl. 49. Athens.

Mackenzie, M.M./C. Roueché (eds) (1989) Images of Authority. Papers presented to $J$. Reynolds on the occasion of the seventieth birthday. Cambridge.

Maggiani, A. (1996) "Appunti sulle magistrature etrusche." In: Studi etruschi 62, 95-138.

Mann, C./M. Haake/R. von den Hoff (eds) (2009) Rollenbilder in der athenischen Demokratie. Medien, Gruppen, Räume impolitischen und sozialen System. Wiesbaden.

Mannack, T. (2002) Griechische Vasenmalerei. Eine Einführung. Darmstadt.

Marcadé, P. (ed.) (1996) Sculptures déliennes. Paris.

March, J.R. (1989) 'Euripides' Bakchai: A Reconsideration in the Light of VasePaintings." In: BICs $36,33-65$.

Marconi, C. (ed.) (2004) Greekvases: images, contexts and controversies. Proceedings of the Conference, March 2002, Columbia University. Leiden/Boston.

Martelli, M. (1991) "Rivista di epigrafia etrusca." In: Studi etruschi 57, 282-283.

Massa, F. (2006-2007) "Dioniso e Apollo dal teatro attico alla cultura imperiale: i tratti salienti di un complesso quadro documentario." In: Mythos 1, 77-92.

Massa-Pairault, F.-H. (2007) "La domanda di ceramica attica e l'autorappresentazione dei principes. Alcune riflessioni." In: Giudice/Panvini 2007, 45-55.

Matheson, S.B. (1995) Polygnotos and Vase Painting in Classical Athens. Madison (Wis). McNally, S. (1985) "Ariadne and others: Images of Sleep in Greek and Roman Art." In: Classical Antiquity 4.2, 152-192.

McPhee, I.D. (1973) Attic Vase-Painters of the Late 5th Century BC. PhD University of Cincinnati.

Metzger, H. (1951) Les représentations dans la céramique attique du IVe siècle. Paris.

Metzler, D./B. Otto/C. Müller-Wirth (eds) (1983) Antidoron, Festschrift für J. Thimme zum 65. Geburtstag am 26.9.82. Karlsruhe. 
Miller, M./U. Kästner (2005) Verlustdokumentation der Staatlichen Museen zu Berlin. Antikensammlung. Bd. v.1. Berlin.

Mingazzini, P. (1971) Catalogo dei vasi della collezione A. Castellani II. Roma.

Mommsen, H. (2002/2003) "Dionysos und sein Kreis im Werk des Exekias." In: 19./20. Trierer Winckelmannsprogramm, 20-44.

Montepaone, C. (2002) “Ifigenia a Brauron.” In: Gentili/Perusino 2002, 65-77.

Moore, M.B. (2006) "Satyrs by the Berlin Painter and a new Interpretation of his Namepiece." In: AntK 49, 17-28.

Moormann, E.M./V. Stissi (eds) (2009) Shapes and Images. Studies on Attic Black Figure and Related Topics in Honour of Herman A.G. Brijder. Leuven/Paris/Walpole, MA.

Moraw, S. (1998) Die Mänade in der attischen Vasenmalerei des 6. und 5. Jahrhunderts $v$. Chr. Mainz.

- (2011) "Visual Differences: Dionysos in Ancient Art." In: Schlesier 2011, 233-252.

Moret, J.-M. (1982) “L“Apollinisation' de l'imagerie légendaire à Athènes dans la seconde moitié du V viècle." In: $R A$ 1982, 109-136.

Murray, O. (ed.) (1990) Sympotica. A Symposium on the Symposion. Oxford.

Murray, O./M. Tecuşan (eds) (1995) In vino veritas. Roma.

Musti, D. (2008) Storia greca. Linee di sviluppo dall'età micenea all'età romana ${ }^{2}$. Bari.

Natale, A. (2008) Il riso di Hephaistos. All'origine del comico nella poesia e nell'arte dei Greci. Roma.

Neils, J. (200o) "Others Within the Other: An Intimate Look at Hetairai and Maenads." In: Cohen 2000, 203-226.

- (2001) The Parthenon Frieze. Cambridge. (ed.) (2005) The Parthenon. From Antiquity to Present. Cambridge.

(2013) "Salpinx, Snake, and Salamis. The Political Geography of the Pella Hydria." In: Hesperia 82, 595-613.

Nenci, G. (ed.) (1993) Studi sulla Sicilia Occidentale in onore di Vincenzo Tusa. Padova.

Noerskov, V. et al. (eds) (2009) The World of Greek Vases. Analecta Romana Instituti Danici, Suppl. 41. Rome.

Oakley, J.H. (1990) The Phiale Painter. Kerameus 8. Mainz.

- (1997) The Achilles Painter. Mainz.

Oakley, J.H./W.D.E. Coulson/O. Palagia (eds) (1997) Athenian Potters and Painters. Oxford.

Oakley, J.H./O. Palagia (eds) (2009) Athenian Potters and Painters II. Oxford.

Oakley, J.H./R.H. Sinos (1993) The Wedding in Ancient Athens. Madison (Wis).

Osborne, R. (1994) "Democracy and Imperialism in the Panathenaic Procession: The Parthenon Frieze in its Context." In: Coulson 1994, 143-150.

(1997) "The Ecstasy and the Tragedy: Varieties of Religious Experience in Art, Drama, and Society." In: Pelling 1997, 187-212. 
_ (1998) "Men without Clothes: Heroic Nakedness and Greek Art." In: Wyke 1998, 80-104.

(2009) "The Narratology and Theology of Architectural Sculpture or What you can do with a Chariot but can't do with a Satyr on a Greek Temple." In: Schultz/van der Hoff 2009, 2-12.

Osborne, R./S. Hornblower (eds) (1994) Ritual, Finance, Politics. Athenian Democratic Accounts presented to David Lewis. Oxford.

Pala, E. (2012) Acropoli di Atene. Un microcosmo della produzione e distribuzione della ceramica attica. Archeologia Classica Suppl. 8 (n. s. 5). Roma.

Palagia, O. (1993) The Pediments of the Parthenon. Leiden.

- (2005) "Fire from Heaven: Pediments and Akroteria of the Parthenon." In: Neils $2005,225^{-259}$.

Paleothodoros, D. (2010) "Light and Darkness in Dionysiac Rituals as Illustrated on Attic Vase Paintings of the 5th Century BCE." In: Christopoulos 2010, 237-26o.

- (2011) "Dionysos a Camarina." In: Giudice 2011, 133-143.

Parker, R.C.T. (1985) “Greek States and Greek Oracles." In: Cartledge/Harvey 1985, 298-326.

Parker, R. (2011) On Greek Religion. Ithaka.

Paul-Zinserling, V. (1994) Der Jena-Maler und sein Kreis. Zur Ikonologie einer attischen Schalenwerkstatt um 400 v. Chr. Mainz.

Pellegrini, G. (1912) Catalogo dei vasi greci dipinti delle necropolifelsinee. Bologna.

Pellegrini, E. (2009) Eros nella Grecia arcaica e classica. Roma.

Pelling, C. (ed.) (1997) Greek Tragedy and the Historian. Oxford.

Pellizer, E. (1990) “Outlines of a Morphology of Sympotic Entertainment." In: Murray 1990, 177-184.

Peredolskaja, A.K. (1967) Kraznofigurnje Attischeskje Vasei. Leningrad.

Pfeiff, K.A. (1943) Apollon. Die Wandlung seines Bildes in der griechischen Kunst. Frankfurt a. M.

Pfuhl, E. (1923) Malerei und Zeichnung der Griechen. München.

Philippaki, B. (1967) The Attic Stamnos. Oxford.

Pironti, G. (2007) Entre ciel et guerre. Figures d'Aphrodite en Grèce ancienne. Kernos Suppl. 18. Liège.

Pizzirani, C. (2009) "Iconografia dionisiaca e contesti tombali tra Felsina e Spina." In: Bonaudo 2009, 37-49.

Pochmarski, E. (1984) “Zur Deutung der Figur D im Parthenon-Ostgiebel." In: Berger 1984, 278-280.

- (1990) Dionysische Gruppen. Eine typologische Untersuchung zur Geschichte des Stützmotivs. Wien.

Pontrandolfo, A. (1995) "Simposio e élites sociali nel mondo etrusco e italico." In: Murray/Tecuşan 1995, 176-195. 
Prange, M. (1989) Der Niobidenmaler und seine Werkstatt. Untersuchungen zu einer Vasenwerkstatt frühklassischer Zeit. Frankfurt a. M./Bern.

Praschniker, C. (1928) Parthenonstudien. Augsburg/Wien.

Privitera, A. (1970) Dioniso in Omero e nella poesia greca arcaica. Roma.

Queyrel, A. (1984) “Scènes apolliniennes et dionysiaques du Peintre de Pothos.” In: $B C H$ 108, 123-159.

Queyrel, F. (2006) “Le fronton est du Parthénon. Système visuel et paysage." In: Colpo/ Favaretto/Ghedini 2006, 217-234.

Raubitschek, A.E. (1979) “The Peace Policy of Pericles.” In: Wirth 1979, 350-358.

Raubitschek, I.K./A.E. Raubitschek (1982) “The Mission of Triptolemos." In: Studies in Athenian Architecture Sculpture and Topography, presented to Homer A. Thompson. Hesperia Suppl. 20, 109-117.

Rausa, F. (1991) “Dionysos nella Gigantomachia: raffigurazioni del mito su alcuni vasi di Spina." In: Berti 1991, 55-69.

Richter, G.M.A. (1936) Red-figured Athenian Vases in the Metropolitan Museum of Art. New Haven.

(1966) The Furniture of the Greeks, Etruscans and Romans. London.

Rizza, G./F. Giudice (eds) (1996) I vasi attici e altre ceramiche coeve in Sicilia. Atti del convegno internazionale, marzo-aprile 1990, vol. I. Cronache di archeologia 29. Palermo.

Robertson, M. (1986) “Two Pelikai by the Pan Painter." In: Greek Vases in the J. Paul Getty Museum 3 (Occasional Papers in Antiquities 2), 71-89.

(1992) The art of vase-painting in classical Athens. Cambridge.

Rolley, C. (1994) La sculpture grecque I. Paris.

- (1999) La sculpture grecque II. Paris.

Rotroff, S.I. (2009) "Early Red-figure in Context." In: Oakley/Palagia 2009, 250-26o.

Rudhardt, J. (1978) "A propos de l'hymne homérique à Déméter. La répartition des timaí, articulation centrale des systèmes mythiques grecs. Le rapt de Perséphone considéré comme un épisode de cette répartition." In: $M H 35,1-17$.

(1981) "Du mythe, de la religion grecque et de la compréhension d'autrui." In: Revue européenne des sciences sociales XIX, no. 58. Genève.

- (2008) Opera inedita. Essai sur la religion grecque. Recherches sur les Hymnes orphiques. Liège.

Sabetai, V. (2011) "Eros reigns Supreme: Dionysos' Wedding on a New Krater by the Dinos Painter." In: Schlesier 2011, 137-160.

Salviat, F. (1960) "Le bâtiment de scène du théâtre de Thasos." In: $B C H$ 84, 300-316.

Samara-Kauffmann, A. (ed.) (2008) I thalassa/La mer. Athens.

Sapirstein, P. (2013) “Painters, Potters, and the Scale of the Attic Vase-Painting Industry." In: AJA 117.4, 493-510, with appendix: www.ajaonline.org.

Schefold, K. (1934) Untersuchungen zu den Kertscher Vasen. Berlin 1934. 
Scheibler, I. (1983) Griechische Töpferkunst. Herstellung, Handel und Gebrauch der antiken Tongefässe. München.

- (1987) "Bild und Gefäss. Zur ikonographischen und funktionalen Bedeutung der attischen Bildfeldamphoren." In: JdI 102, 57-118.

- (1992) "Euphronios zwischen Tradition und Fortschritt: Die dionysischen Bilder." In: Wehgartner 1992, 104-112.

Schierup, S./B. Bundgaard-Rasmussen (eds) (2012) Red-figure Pottery in its Ancient Setting. Aarhus.

Schlesier, R. (1997) “Dionysos." In: DNP 3, 651-662.

- (2010) “Tragic Memories of Dionysos." In: Foxhall/Gehrke/Luraghi 2010, 211-224.

Schlesier, R. (ed.) (2011) A different God? Dionysos and Ancient Polytheism. Berlin.

Schlesier, R./A. Schwarzmaier (eds) (2008) Dionysos. Verwandlung und Ekstase. Exhibition catalogue Berlin. Berlin.

Schmaltz, B./M. Söldner (eds) (2003) Griechische Keramik im kulturellen Kontext. Akten des Internationalen Vasen-Symposions, Kiel, September 2001. Münster.

Schmidhuber, G. (2007) "Dionysische Frauen in der griechischen Vasenmalerei: Nymphen oder Mänaden?" In: öJh 76, 353-370.

Schmidt, S. (2005) Rhetorische Bilder auf attischen Vasen. Visuelle Kommunikation im 5. Jahrhundert v. Chr. Berlin.

- (2009) "Between Toy Box and Wedding Gift: Functions and Images of Athenian Pyxides." In: Metis 7, 11-130.

Schmitt Pantel, P. (2011) "Dionysos, the Banquet and Gender." In: Schlesier 2011, 119-136.

Schneider, L./C. Höcker (2001)Die Akropolisvon Athen. Eine Kunst-und Kulturgeschichte. Darmstadt.

Schöne, A. (1987) Der Thiasos. Eine ikonographische Untersuchung über das Gefolge des Dionysos in der attischen Vasenmalerei des 6. und 5. Jhs. v. Chr. Göteborg.

_ (1990) "Die Hydria des Meidias-Malers im Kerameikos. Zur Ikonographie der Bildfriese." In: AM 105, 163-178.

Schöne-Denkinger, A. (2008) “Dionysos und sein Gefolge in der attischen Vasenmalerei.” In: Schlesier/Schwarzmaier 2008, 43-53.

— (2009) CVA Berlin, Antikensammlung 11. Attisch-rotfigurige Mischgefässe. Böotisch rotfigurige Kratere. München.

- (2014) CVA Berlin, Antikensammlung 15. Attisch-rotfigurige und schwarzgefirnisste Peliken, Loutrophoren und Lebetes gamikoi. München.

Schultz, P./R. van den Hoff (eds) (2009) Structure, Image, Ornament: Sculpture in the Greek World. Proceedings of the International Conference, Athens 2004. Oxford. 
Schwab, K.A. (2005) “Celebrations of Victory: The Metopes of the Parthenon.” In: Neils 2005, 159-197.

Schwarzmaier, A. (2008) "Dionysos, der Maskengott: Kultszenen und Theaterbilder." In: Schlesier/Schwarzmaier 2008, 80-93.

Seaford, R. (ed.) (1996) Euripides. Bacchae. Warminster. (2006) Dionysos. Abingdon (Oxon)/New York.

Sena Chiesa, G. (ed.) (2008) Vasi immagini collezionismo. Giornate distudio, Milano, 7-8 novembre 2007. Milano.

(ed.) (2012) Costantino 313. L'editto di Milano e il tempo della tolleranza. Exhibition catalogue, Milano 2012.

Sena Chiesa, G./E.A. Arslan (eds) (2004) Miti greci. Archeologia e pittura dalla Magna Grecia al collezionismo. Exhibition catalogue, Milano.

Shapiro, H.A. (1989) Art and Cult under the Tyrants in Athens. Mainz.

- (1993) Personifications in Greek Art. Kilchberg (Zürich).

- (1995) Art and Cult under the Tyrants in Athens. Supplement: Hephaistos. Mainz.

- (1997) “Correlating shape and subject. The case of the archaic pelike." In: Oakley/Coulson/Palagia 1997, 63-70.

- (2004) "Leagros the Satyr." In: Marconi 2004, 1-11.

Sichtermann, H. (1966) Griechische Vasen in Unteritalien aus der Sammlung Jatta in Ruvo. Tübingen.

Simon, E. (1963) "Ein Anthesterienskyphos des Polygnotos." In: AntK 6.1, 6-22. (1976) Griechische Vasen. München.

Simon, E. et al. (eds) (1997) Mythen und Menschen.Griechische Vasenkunst aus einer deutschen Privatsammlung. Mainz.

Simon, E. (1998a) “Apollon und Dionysos." In: Capecchi 1988, 451-46o.

— (1998b) "Neue Deutung zweier eleusinischer Denkmäler des vierten Jahrhunderts v. Chr." In: Idem, Ausgewählte Schriften I. Mainz., 173-195.

Sisto, M.A. (2006) "Forma e decorazione figurata dello stamnos dalla Grecia alla Magna Grecia." In: Giudice/Panvini 2006, 151-163.

Smith, A.C. (2007) "Komos Growing up among Satyrs and Children." In: Cohen/Rutter 2007, 153-171.

(2011) Polis and Personification in Classical Athenian Art. Leiden/Boston.

Sparkes, B.A. (1976) “Treading the Grapes." In: BABesch 51, 47-56.

(1996) The Red and the Black. Studies in Greek Pottery. London.

Spineto, N. (2005) Dionysos a teatro. Il contesto festivo del dramma greco. Roma.

Stark, M. (2012) Göttliche Kinder. Ikonographische Untersuchung zu den Darstellungskonzeptionen von Gott und Kind bzw. Gott und Mensch in der griechischen Kunst. Stuttgart 2012. 
Steinhart, M. (2004) Die Kunst der Nachahmung. Darstellungen mimetischer Vorführungen in der griechischen Bildkunst archaischer und klassischer Zeit. Mainz.

Strocka, V.M. (ed.) (2005) Meisterwerke. Internationales Symposion anlässlich des 150. Geburtstages von Adolf Furtwängler, Freiburg i. Br.,Juni-Juli 2003. München.

Suàrez de la Torre, E. (2002) “La 'rationalité' des mythes de Delphes: les dieux, les héros, les médiateurs." In: Kernos 15, 155-178.

Taplin O./R. Wyles (eds) (2010) The Pronomos Vase and its Context. Oxford.

Tasinato, M. (2003) "Sulle tracce d'un antico duello: le Baccanti di Euripide a tenzone con le Rane di Aristofane." In: Simplegadi viII/21, 3-26.

Tausend, K. (1992) Amphiktyonie und Symmachie. Formen zwischenstaatlicher Beziehungen im archaischen Griechenland. Stuttgart.

Thomsen, A. (2011) Die Wirkung der Götter. Bilder mit Flügelfiguren auf griechischen Vasen des 6. und 5. Jahrhunderts v. Chr. Berlin/Boston.

Tiverios, M.A. (1991) "Ikonographie und Geschichte (Überlegungen anlässlich einer Abbildung des Strymon im Garten der Hesperiden)." In: AM 106, 129-136.

(2005) "Der Streit um das attische Land. Götter, Heroen und die historische Wirklichkeit." In: Strocka 2005, 299-319.

- (2008a) “The Derveni Krater." In: Kurtz 2008, 203-212.

(2008b) "Athéna et Poséidon se disputent les faveurs d'Athènes." In: SamaraKauffmann 2008, 125-135.

(ed.) (2011) “The Cadmus Painter and his Time.” In: Giudice 2011, 161-176.

Torelli, M. (2002) "Divagazioni sul tema della palma. La palma di Apollo e la palma di Artemide." In: Gentili/Perusino 2002, 139-151.

_ (2012) Semainein. Significare. Scritti vari di ermeneutica archeologica II. Pisa/ Roma.

Traficante, V. (2007) "Quale Dioniso nelle Baccanti di Euripide? Nota iconografica sull'evoluzione dell'immagine di Dioniso nel V sec. a. C." In: Beltrametti 2007, $65^{-93}$.

Tsingarida, A. (ed.) (2009) Shapes and Uses of Greek Vases (7th-4th centuries BC). Proceedings of the Symposium, Bruxelles April 2006. Bruxelles.

Tullio, A. (1996) "I crateri attici del Museo Mandralisca e le maniere del Pittore di Firenze." In: Cronache di archeologia 30, 1991 (published 1996), 141-154.

Tzachou-Alexandrí, O. (1997) "Apeikoniseis ton Anthesterion ké o chous tis Odos Peiraios tou zographou tis Eretrias." In: Oakley/Coulson/Palagia 1997, 473-49o.

Ulf, C. (1997) "Überlegungen zur Funktion überregionaler Feste im archaischen Griechenland." In: Eder/Hölkeskamp 1997, 37-61.

van de Put, W. (2009) "Dionysos on lekythoi: a surprising presence?" In: Moormann/

Stissi 2009, 37-43. 
van Keuren, F. (1998) "The Upbringing of Dionysos on an Unpublished Neck-Amphora by the Eucharides Painter." In: Idem (ed.), Myth, Sexuality and Power. Images of Jupiter in Western Art. Providence (USA)/Louvain-La-Neuve, 9-27.

Vernant, J.-P. (1986) “Conclusion.” In: L'association dionysiaque dans les sociétés anciennes. Rome, 291-303.

— (1988) "Prométhée et la fonction technique." In: Idem, Mythe et pensée chez les Grecs. Paris.

Versnel, H.S. (1990) Ter Unus. Isis. Dionysos, Hermes. Three Studies in Henotheism. Leiden. (2011a) Coping with the Gods. Wayward Readings in Greek Theology. Leiden/ Boston.

(2011b) "Heis Dionysos!-One Dionysos? A Polytheistic Perspective." In: Schlesier 2011, 23-46.

Veyne, P./F. Lissarrague/F. Frontisi-Ducroux (eds) (1998) Les mystères du gynécée. Paris. Vierneisel, K./B. Kaeser (eds) (1990) Kunst der Schale, Kultur des Trinkens. München.

Villanueva Puig, M.-C., et al. (eds) (1999) Céramique et peintures grecques. Modes d'emploi. Actes du colloque international, Ecole du Louvre, avril 1995. Paris.

Villanueva-Puig, M.-C. (2009a) "Un Dionysos pour les morts à Athènes à la fin de l'archaïsme: à propos des lécythes à figures noires trouvés à Athènes en contexte funéraire." In: Tsingarida 2009, 215-224.

$-(2009 \mathrm{~b})$ Ménades. Recherches sur la génèse iconographique du thiase féminin de Dionysos des origines à la fin de la période archaïque. Paris.

Voelke, P. (2001) Un théâtre de la marge. Aspects figuratifs et configurationnels du drame satyrique dans l'Athènes classique. Bari.

Vollkommer, R. (1994) "Peleus." In: LIMC VII.1, 251-269.

Walter, H. (1959) Vom Sinnwandel griechischer Mythen. Waldsassen-Bayern.

Weaver, B. (2009) “Euripides' Bacchae and Classical Typologies of Pentheus' Sparagmos, 510-406 вс." In: BICs 52, 15-43.

Wehgartner, I. (1992) Euphronios und seine Zeit. Kolloquium Berlin, April 1991. Berlin.

— (1997) "Dionysos im Kreise von Frauen." In: Simon 1997, 116-119.

Weiss, C. (1997) "Spitzamphora des Syriskos." In: Simon 1997, 104-110.

Welwei, K.-W. (1999) Das klassische Athen. Demokratie und Machtpolitik im 5. und 4. Jahrhundert. Darmstadt 1999.

Wesenberg, B. (1983) "Parthenongebälk und Südmetopenproblem.” In:JdI 98, 57-86.

- (2014) "Parthenonische Peploshäresie (Ostfries 34-35)." In: Graen/Rind/ Wabersich 2014, 65-81.

Wiesner, J. (1965) “Panther." In: Lexikon der alten Welt. Zürich, 2213.

Will, W. (1995) Perikles. Hamburg.

(2000) "Perikles." In: DNP 9, 567-572.

Winkler, J.J./F. Zeitlin (eds) (1990) Nothing to do with Dionysos? Athenian Drama and its

Social Context. Princeton. 
Wirth, G. (ed.) (1979) Perikles und seine Zeit. Darmstadt.

Wolf, S.R. (1993) Herakles beim Gelage: eine motiv- und bedeutungsgeschichtliche Untersuchung des Bildes in der archaisch-frühklassischen Vasenmalerei. Köln.

Wyke, M. (ed.) (1998) Gender and Body in the Ancient Mediterranean. Oxford.

Zanker, P. (1965) Wandel der Hermesgestalt in der attischen Vasenmalerei. Mainz.

Zanker, P./B.C. Ewald (2004) Mit Mythen leben. Die Bilderwelt der römischen Sarkophage. München.

Zervoudaki, E.A. (1968) "Attische polychrome Keramik des späten 5. und des 4. Jahrhunderts v. Chr." In: $A M$ 83, 1-88. 


\section{Museums}

Adolphseck $42 \quad 83$ n. 62

Adria B $1412 \quad 48$ n. 38

Adria B $482 \quad 118$ n. 111

Adria B $515 \quad 48$ n. 38

Adria B $604 \quad 131 \mathrm{n} .40$

$\begin{array}{ll}\text { Adria B } 626 & 131 \text { n. } 40\end{array}$

Agrigento $34 \quad 83$ n. 62

Agrigento AG $22797 \quad 95$ n. 25, 96

Agrigento C $1538 \quad 41$ n. 8, 72 n. 9, 73

Ancona $4862 \quad 88 \mathrm{n} .5$

Arezzo $1465 \quad 29$ n. 44

Athens $1376 \quad 223$ n. 65, 225

Athens BS $318 \quad 143$ n. 79,198 n. 51

Athens Bs $319 \quad 143$ nn. 79-80

Athens NM 1227320

Athens NM $15002 \quad 39$ n. 95

Athens NM $541 \quad 21$

Athens, 1st ephory $3500 \quad 198$ n. $5^{2}$

Athens, 3rd ephory $143 \mathrm{n} .79$

Athens, Acr. $18063 \quad 94$ n. 24

Athens, Acr. 2.307 61 n. 94

Athens, Acr. $2.325 \quad 64$ n. 112, 100 n. 51, 101

Athens, Acr. $2.742 \quad 49$ n. 42

Athens, Acr. 2.780 $\quad 81$ n. 53

Athens, Acropolis Museum 1956 NAK 232

215 n. 22

Athens, Agora P $5729 \quad 92$ n. 16

Athens, Kerameikos $2712 \quad 201$ n. 64

Baltimore $48.74 \quad 154$ n. 128 , 200 n. 59

Baltimore B $10 \quad 61 \mathrm{nn} .98,102$

Baltimore, without number 55 n. 74

Basel $2405 \quad 76$ n. 29

Basel BS $407 \quad 197$ n. 47

Basel Kä $410 \quad 61$ nn. 97,100

Basel Kä $420 \quad 73$ n. 18

Basel Lu 39 49 n. 44, 50

Basel Lu $45 \quad 66$ n. 124

Bedford, Woburn Abbey 153 n. 126

Berkeley 8.3316 101 n. 56

Berkeley $8.4583 \quad 5^{2}$ n. $5^{8}$

Berlin $1964.4 \quad 59$ n. 88

Berlin $1966.19 \quad 33$ n. 63

Berlin 1970.5 77 n. 34

Berlin F $1704 \quad 175$ n. 59
Berlin F 216o 45 n. 25

Berlin F $2165 \quad 78$ n. 37

Berlin F $2173 \quad 52$ n. 59, 83 n. 62

Berlin F $2179 \quad 51$ n. 48, 113 n. 98, 114

Berlin F 2180 28 n. 41

Berlin F $2278 \quad 36$ n. 81, 99 n. 49

Berlin F $2290 \quad 61$ n. 95, 65 n. 114, 125 n. 10, 126

Berlin F $2315 \quad 38$ n. 91

Berlin F $2321 \quad 164$ n. 17

Berlin F $2334 \quad 38$ n. 85

Berlin F $2402 \quad 151$ n. 114, 168 n. 33, 186 n. 8

Berlin F $2471 \quad 200$ n. 60

Berne $12227 \quad 83$ n. 62

Bochum, Univ. S $1062 \quad 63$ n. 107, 64

Bologna $151 \quad 23$ n. 23, 24

Bologna $17100 \quad 100 \mathrm{n} .5^{2}$

Bologna $283 \quad 188 \mathrm{n} .14$

Bologna 338 9o n. 8

Bonn 1216.19 101 n. 55

Bonn $70 \quad 34$ n. 70

Boston 00.334 39 n. 96

Boston $01.8072 \quad 55$ n. 74

Boston $03.790 \quad 26 \mathrm{n} .30$

Boston $10.179 \quad 53$ n. 67,54

Boston 10.221 29 n. 49

Boston $13.193 \quad 38 \mathrm{n} .91$

Boston $13.67 \quad 61$ n. 95

Boston 64.2032 $5^{2} \mathrm{n} .55$

Boston 91.226b $126 \mathrm{n} .14$

Boston 91.227a $126 \mathrm{n} .14$

Boston 95.39 72 n. 13, 101 n. 54

Boston $98.882 \quad 5^{2} \mathrm{n} .53$

Boston $98.932 \quad 43$ n. 20

Brussels A $3091 \quad 95$ n. 27

Brussels A $717 \quad 32$ n. 6o, 33

Brussels R 239 148, 149 n. 98

Brussels R $247 \quad 61 \mathrm{n} .95$

Brussels R $249 \quad 146$ n. 92

Brussels R $250 \quad 67$ n. 129

Brussels R $303 \quad 77$ n. 36

Budapest 50.568 168 n. 137, 223 n. 64

Cab. Méd. $357 \quad 78$ n. 46, 93 n. 20, 94, 200 n. 59

Cab. Méd. $440 \quad$ 51 n. 49, 103 n. 6o, 104

Cab. Méd. $444 \quad 84$ n. 71 
Cab. Méd. 460 9o n. 6, 118 n. 110

Cab. Méd. 50938 n. 91

Cab. Méd. 54257 n. 81, 58

Cab. Méd. $573 \quad 42$ n. 19, 164 n. 17

Cab. Méd. $576 \quad 54$ n. 69

Caltanissetta $69 \quad 70 \mathrm{n} .5$

Caltanissetta S $46 \quad 113$ n. 94

Cambridge (Ma) 1925.30.40 200 n. 59

$\begin{array}{ll}\text { Cambridge (Ma) } 1960.347 \quad 205 & \text { n. } 76\end{array}$

Cape Town $15 \quad 38$ n. 85

Castle Ashby (formerly) $\quad 48 \mathrm{n} .36$

Cefalù $1 \quad 125$ n. 9

Compiègne 102599 n. 43, 149 n. 99

Copenhagen $13817 \quad 97$ n. 33

Copenhagen $4833 \quad 168$ n. 34, 170

Copenhagen $731 \quad 212$ n. 4

Copenhagen ABC $1021 \quad 147$ n. 96

Copenhagen, New Carlsberg Glyptotek $293 \quad 95$ n. 27

Copenhagen, Thorvaldsen Museum $99 \quad 5^{2}$ n. 53

Delphi $2380 \quad 220$

Dresden ZV $2635 \quad 72$ n. 14

Eleusis $636 \quad 127$ n. 17

Ferrara $1685 \quad 72$ n. 8

Ferrara $2683 \quad 88$ n. 5,89

Ferrara $2737 \quad 105$ n. 67,106

Ferrara 2738 103 n. 64, 105, 15 o n. 105

Ferrara $2818 \quad 72$ n. 15

Ferrara $2891 \quad 88$ n. 2, 89, 138 n. 59

Ferrara $2897 \quad 159$ n. 143, 189 n. 16

Ferrara $42684 \quad 73$ n. 17

Ferrara 44834 95 n. 28, 96

Ferrara $5388 \quad 207$ n. 83

Ferrara $9355 \quad 88$ n. 2

Ferrara $9379 \quad 95$ n. 27

Florence 1 B $16 \quad 35$ n. 76

Florence 12 B $105 \quad 43$ n. 29

Florence 394361 n. 96

Florence 3950 123 n. 6, 124

Florence $3988 \quad 92$ n. 17

Florence $4227 \quad 94$ n. 24

Florence v $5 \quad 5^{2} \mathrm{n} .63$

Fort Worth AP2000.02 $\quad 58$ n. 83, 59

Frankfurt, without number 34 n. 72
Hamburg 1908.253 21

Hamburg $1980.174 \quad 84$ n. 68

Harrow 55 43 n. 24, 44

Harvard 1925.30.34 52 n. 57

Harvard 1960.236 40 n. 5, 41

Harvard 1972.41 61 n. 96

Karlsruhe 206 (B 10) 83 n. 62

Karlsruhe $208 \quad 153$ n. 122, 154

Karlsruhe 259 (B 36) 202 n. 68, 203

Karlsruhe 296 (B 1873) 204 n. 73

Kurashiki, Ninagawa $40 \quad 84$ n. 67

Lausanne $3250 \quad 5^{2}$ n. 63,53

Lecce $603 \quad 74$ n. 23,75

Leiden PC $80 \quad 43$ n. 22, 44

Leipzig T $3376 \quad 131 \mathrm{n} .40$

Leipzig T $643 \quad 5^{2} \mathrm{n} .5^{6}$

London 1843.11-3.4 (E 54) 57 n. 82

London 1843.11-3.54 57 n. 78

London 1956.2-17.1 195 n. 33

London E $102 \quad 38$ n. 85, 196 n. 44

London E $140 \quad 63 \mathrm{n} .104$

London E $16 \quad 36$ n. 79

London E $184 \quad 118$ n. 113, 119

London E $257 \quad 88$ n. 5

London E $279 \quad 67$ n. 132

London E $350 \quad 67$ n. 129, 78 n. 44, 79

London E $377 \quad 43$ n. 24, 72 n. 16

London E $384 \quad 132$ n. 42

London E $410 \quad 83 \mathrm{n} .60$

London E $437 \quad 126 \mathrm{n} .14$

London E $439 \quad 57$ n. 78

London E $444 \quad 479$ n. 41

London E $454 \quad 94$ n. 24

London E $465 \quad 138 \mathrm{n}$. 60

London E $492 \quad 106$ n. 68

London E $503 \quad 150 \mathrm{n} .106$

London E $65 \quad 56 \mathrm{n} .75$

London E $703 \quad 205$ n. 79

London E $767 \quad 35$ n. 74

London E 76859 n. 86, 60

London E 775 (1893.11-3.2) 204 n. 70

London E $8 \quad 36$ n. 83, 98 n. 42

London E 82 (1847.9-9.6) 98 n. 42, 167 n. 27, 187 n. 11,195 n. 37

London F 68 (1865.0103.14) 228 n. 82

Louvre $406 \quad 94$ n. 24 


\begin{tabular}{|c|c|}
\hline Louvre C 10748 & $42 \mathrm{n} .16$ \\
\hline Louvre C 10774 & 74 n. 20 \\
\hline Louvre C 11072 & 33 n. 66 \\
\hline Louvre CA 1947 & $5^{2}$ n. 63 \\
\hline Louvre CA 944 & 38 n. 86,46 n. 35 \\
\hline Louvre CP 11070 & $0 \quad 29$ n. 45 \\
\hline Louvre CP 11115 & 584 n. 70 \\
\hline Louvre ELE $15^{2}$ & 20 \\
\hline Louvre F 204 & 24 n. 24 \\
\hline Louvre G 110 & 28 n. 39 \\
\hline Louvre G 121 & 123 n. 4 \\
\hline Louvre G 135 & 125 n. 9 \\
\hline Louvre G 138 & $122 \mathrm{n} .2$ \\
\hline Louvre G 144 & 61 n. 96,62 \\
\hline Louvre G 145 & 61 nn. 98,100 \\
\hline Louvre G 160 & 61 n. 97 \\
\hline Louvre G 162 & 42 n. 9 \\
\hline Louvre G 174 & 46 n. 29 \\
\hline Louvre G 187 & 76 n. 26 \\
\hline Louvre G 202 & $5^{2}$ n. 64 \\
\hline Louvre G 206 & 55 n. 74 \\
\hline Louvre G 227 & $5^{2}$ n. 54 \\
\hline Louvre G $25^{\circ}$ & 60 n. 90 \\
\hline Louvre G $30 \quad 2$ & 29 n. 48,30 \\
\hline Louvre G 33 & 29 n. 42 \\
\hline Louvre G 34 & $3^{1}$ n. $5^{2}, 39$ n. 93 \\
\hline Louvre G 406 & 146 n. 95 \\
\hline Louvre G 41 & 35 n. 75 \\
\hline Louvre G 422 & 132 n. 42,140 n. 68 \\
\hline Louvre G $43 \quad 3$ & 33 n. 62 \\
\hline Louvre G 445 & 171 n. 42,202 n. 66 \\
\hline Louvre G 478 & 110 n. 78 \\
\hline Louvre G 486 & 200 n. 59 \\
\hline Louvre $G_{529}$ & 227 n. 79 \\
\hline Louvre G 530 & 227 n. 79 \\
\hline Louvre G $57 \quad 4$ & $42 \mathrm{n} .12$ \\
\hline Louvre G $6 \quad 38$ & 8 n. 90 \\
\hline Louvre G $88 \quad 3$ & 38 n. 91 \\
\hline Louvre MNB $16 \mathrm{~g}$ & $95\left(G_{188}\right) \quad 103$ n. 63,104 \\
\hline Louvre MNE 96 & $61 \quad 61$ n. 99 \\
\hline Louvre S 1328 & 55 n. 74 \\
\hline Louvre S 1339 & 55 n. 74 \\
\hline Madrid 11008 & 26 n. 28 \\
\hline Madrid 11011 & 207 n. 85,208 \\
\hline Madrid 11040 & $72 \mathrm{n} .11$ \\
\hline Madrid $1105^{2}$ & 146 n. 91, 151 nn. $112-113$ \\
\hline Madrid 11074 & $151 \mathrm{n} .111$ \\
\hline Madrid L 188 & 153 n. 125 \\
\hline
\end{tabular}

Malibu 81.AE.62 63 n. 105

Malibu 92.AE.6 81 n. 54

Matera, without number 218 n. 36

Metaponto $202446 \quad 92 \mathrm{n} .18$

Minneapolis (Mn) $09.6 \quad 95$ n. 27

Montpellier $140 \quad 92 \mathrm{n} .14$

Moscow II Ів $600 \quad 137$ n. 57

Moscow II IB $732 \quad 106$ n. 68

Munich $2300 \quad 27$ n. 31

Munich $2301 \quad 24$ n. 25, 25

Munich 2302 25 n. 26, 26

Munich $2311 \quad 46$ n. 27, 47

Munich $234366 \mathrm{n} .126$

Munich $2345 \quad 78$ n. 37

Munich 2361 95 n. 32, 97, 167 n. 27

Munich $2381 \quad 5^{1}$ n. $5^{1}$

Munich $2403 \quad 93$ n. 19

Munich $2414 \quad 95$ n. 27

Munich $2416 \quad 56$ n. 76

Munich $2418 \quad 27$ n. 32

Munich $2419 \quad 27$ n. 33

Munich $2581 \quad 36$ n. 78

Munich $2606 \quad 38$ n. 87

Munich $2645 \quad 54$ n. 70, 55

Munich 2654 61 n. 96

Munich $2657 \quad 61$ n. 99

Munich $67 \quad 209$ n. 88

Munich 8731 (2307) 33 n. 65, 34

Munich 8732 (2344) 40 n. 1, 77 n. 33

Munich $8766 \quad 72$ n. 11

Munich $8935 \quad 28$ n. 40

Munich S $68 \quad 208$ n. 87

Naples $164332 \quad 132$ n. 44

Naples $2410 \quad 67$ n. 131

Naples $2419 \quad 184$ n. 4, 185

Naples $81483 \quad 117$ n. 106

Naples $82922 \quad 218$ n. 36

Naples H $3240 \quad 205$ n. 8o, 206

Naples Stg $199 \quad 88$ n. 5

Naples Stg $240 \quad 132$ n. 42

Naples Stg $283 \quad 108$ n. 77

Naples Stg $701 \quad 90$ n. 7

Naples, Capodimonte $960 \quad 74$ n. 20

Naples, without number $66 \mathrm{n} .124$

New Haven (Ct), Yale University 1913.132 148 n. 97

New York 06.1152 61 n. 96

New York 07.286.69 46 n. 30, 47 
New York 07.286.85 154 n. 128, 171 n. 39

New York 08.258.22 157 n. 134, 197 n. 48

New York 12.229.13 51 n. 51

New York $16.72 \quad 136$ n. 56

New York 1983.524.3a 29 n. 46

New York $20.246 \quad 61 \mathrm{n} .96$

New York 25.19o 145 n. 86

New York 31.11.11 40 n. 6

New York 56.171.59 118 n. 112

New York 75.2.11 143 n. 79, 144 n. 82

New York 99.13.2 $88 \mathrm{n} .5$

New York L. $1982.27 .8 \quad 102$ n. 58

New York SL 1990.1.21 80 n. 47

New York X.313.1 107 n. 70

Orvieto, Faina $64 \quad 23$ n. 22

Orvieto, Faina 68 35 n. 73

Orvieto, Museo civico $1040 \quad 67$ n. 129

Orvieto, Museo Civico 1049 38 n. 86, 46 n. 34

Oxford (Ms) 1977.3.87A-B 114 n. 101, 115

Oxford (Ms) 1977.3.89 $\quad 90 \mathrm{n} .7$

Oxford (Ms) 1977.3.96 94 n. 24

Oxford 1911.631 62 n. 103

Oxford $1922.67 \quad 5^{2}$ n. 61

Oxford 1925.621 97 n. 34

Oxford $283 \quad 52 \mathrm{n} .60$

Oxford $307 \quad 52$ n. 64

Palermo 1109 108 n. 73, 109

Palermo 2183 133 n. 45

Pella $80514 \quad 180$ n. 88

Princeton University L. $1984.5^{6} \quad 30$ n. $5^{1}$

Princeton University L. $1984.57 \quad 30 \mathrm{n} .5^{1}$

Reading, Univ. 85.3.1 38 n. 85

Reggio Calabria $4379 \quad 84$ n. 71

Rome, villa Giulia $1296 \quad 108$ n. 72

Rome, villa Giulia $20846 \quad 84$ n. 65

Rome, villa Giulia $20847 \quad 84$ n. 65

Rome, villa Giulia $27250 \quad 31 \mathrm{n} .54$

Rome, villa Giulia $3584 \quad 95$ n. 25

Rome, villa Giulia $49002 \quad 108$ n. 75

Rome, villa Giulia $50459 \quad 70$ n. 3, 71

Rome, villa Giulia $50388 \quad 36$ n. 83, 37

Rome, villa Giulia $50396 \quad 61$ n. 94

Rome, villa Giulia $50471 \quad 114$ n. 101

Rome, villa Giulia 50511 141 n. 74, 142

Rome, villa Giulia $846 \quad 74$ n. 22, 75, 137 n. 59,

154 n. 127,171 n. 39
Rome, villa Giulia $909 \quad 123$ n. 7

Rouen $583.3 \quad 55$ n. 73,56

Ruvo 1093151 n. 114,171 n. 42, 191 n. 21

Ruvo $1442 \quad 196$ n. 46

Ruvo 1529A 57 n. 79

Samothrake $57.5^{65} \quad 5^{1 \mathrm{n} .} 5^{2}$

Sarajevo $34 \quad 204$ n. 71

St. Petersburg П1872.130 (КАв 6 а) 182 n. 84,195 n. 32

St. Petersburg 0.28 (St. 1807) 192 n. 25, 193

St. Petersburg 1549 (B 642) 126 n. 14

St. Petersburg 1867.68.953 205 n. 77

St. Petersburg $2007 \quad 110 \mathrm{n} .80$

St. Petersburg 2353 (810) 95 n. 27

St. Petersburg $4121 \quad 69$ n. 2

St. Petersburg $727 \quad 72$ n. 7

St. Petersburg $734 \quad 72$ n. 15

St. Petersburg B 1550 (6og) 43 n. 23

St. Petersburg B $165^{\circ} \quad 29$ n. 49, 31

St. Petersburg B $201 \quad 72$ n. 12

St. Petersburg St. $1624 \quad 35$ n. 73

St. Petersburg St. $2077 \quad 97$ n. 35

St. Petersburg St. $1792 \quad 110$ n. 81

St. Petersburg St. $1793 \quad 223$ n. 64, 224

Stanford University 70.2 $88 \mathrm{n} .3$

Stockholm D $19310 \quad 227$ n. 79

Syracuse $15205 \quad 46 \mathrm{n} .28$

Syracuse $17427 \quad 119$ n. 116, 192 n. 24

Syracuse $23794 \quad 29$ n. 48

Tapley Park (Devon) 151 n. 112

Taranto $4545 \quad 115$ n. 102, 116 n. 103, 117

Taranto $52.230 \quad 222 \mathrm{n} .55$

Taranto, without number 38 n. 85

Tarquinia $683 \quad 48$ n. 38

Tarquinia RC $1118 \quad 61$ n. 102

Tarquinia RC $2066 \quad 39$ n. 94

Tarquinia RC $4197 \quad 155$ n. 129, 171 n. 39, 195 n. 37

Tarquinia RC $5291 \quad 115$ n. 102, 116

Tarquinia RC $6843 \quad 32$ n. 58

Tarquinia RC $6848 \quad 32$ n. 55,36 n. 8 o

Thessaloniki B $1 \quad 229$ n. 84, 230

Tübingen $5439 \quad 156$ n. 131, 195 n. 37

Vatican 1650574 n. 20

Vatican $16541 \quad 59$ n. 87

Vatican 16586 (559) 108 n. 76, 109, 131 n. 38

Vatican $17886 \quad 117$ n. 107 
Vatican $498 \quad 36$ n. 78, 37

Vatican AST $703 \quad 48$ n. 37

Vatican G $71 \quad 34$ n. 71

Vatican, Sala della Biga $2363 \quad 219$

Vienna 1024168 n. 33, 189 n. 18

Vienna $1065 \quad 151 \mathrm{n} .112$

Vienna $1773 \quad 238$ n. 9

Vienna $341 \quad 74$ n. 22

Vienna $350 \quad 92 \mathrm{n} .15$

Vienna $782 \quad 154$ n. 128

Vienna $895 \quad 83$ n. 62

Vienna 98549 n. 39, 90 n. 7, 91
Warsaw $142332 \quad 33$ n. 67

Warsaw $142465 \quad 134$ n. 48

Warsaw, ex Goluchow 11955 n. 72

Würzburg H 4616 (491) 157 n. 135, 195 n. 37

Würzburg $515 \quad 81$ n. 51, 126 n. 14

Zurich L $5 \quad 78$ n. 39

Zurich $3926 \quad 226$ n. 77, 227 


\section{Vases Following Beazley}

\begin{tabular}{|c|c|}
\hline Addenda 149 (3.5) & Addenda 186 (183.7) \\
\hline Addenda $149(4.9) \quad 24$ n. 25 & Addenda 187 (183.11) \\
\hline Addenda 149 f. $(4 \cdot 7,9,11) \quad 22$ n. 13 & Addenda $187(185 \cdot 31)$ \\
\hline Addenda $150(4.10) \quad 23$ n. 23 & Addenda 187 (186.47) \\
\hline Addenda 150 (4.11) & Addenda 188 (187.55) \\
\hline Addenda $150(6.1)$ & Addenda 188 (188.65) \\
\hline Addenda $150(7.2)$ & Addenda 188 (188.68) \\
\hline Addenda 151 (11.1) & Addenda $190(196.1) \quad 45$ n. 25 \\
\hline Addenda 151 (11.2) & Addenda $190(197.9) \quad 46 \mathrm{n} .27$ \\
\hline Addenda $151(12.7)$ & Addenda 191 (198.21bis) $72 \mathrm{n} .11$ \\
\hline Addenda $152(13.1)$ & Addenda $192(201.70) \quad 46$ n. 30 \\
\hline Addenda $15^{2}(14.3)$ & Addenda $193(205.117) \quad 49$ n. 42 \\
\hline Addenda $15^{2}$ (14.3bis) 28 n. 40 & Addenda 194 (1634.132bis) $\quad 48$ n. 37 \\
\hline Addenda $152(15.6) \quad 29 \mathrm{n} .44$ & Addenda $194(207.142) \quad 38$ n. 86 \\
\hline Addenda $15^{2}(15.9)$ & Addenda $194(208.145)$ \\
\hline Addenda $153(16.14) \quad 29$ n. 49 & Addenda $195(208.151) \quad 126$ n. 14 \\
\hline Addenda $153(16.15) \quad 29$ n. 49 & Addenda $198(221.14) \quad 5^{1}$ n. $5^{1}$ \\
\hline Addenda $154(20.1) \quad 32$ n. 60 & Addenda $199(226.1) \quad 67$ n. 132 \\
\hline Addenda $154(20.2) \quad 33$ n. 62 & Addenda $199(228.30) \quad 126 \mathrm{n} .14$ \\
\hline Addenda 154 (20.3bis) 33 n. 63 & Addenda $201(239.18)$ \\
\hline Addenda $154(21) \quad 38$ n. 91 & Addenda $201(240.44) \quad 5^{2}$ n. 63 \\
\hline Addenda $154(21.1) \quad 36 \mathrm{n} .81$ & Addenda 202 ( 246 below) $\quad 48$ n. 38 \\
\hline Addenda $155(23.2)$ & Addenda $203(249.6) \quad 77$ n. 36 \\
\hline Addenda $155(26.1)$ & Addenda $203(251.27)$ \\
\hline Addenda $156(27.8) \quad 33 \mathrm{n} .67$ & Addenda $203\left(25^{2.51}\right)$ \\
\hline Addenda $156(28.12) \quad 34$ n. 70 & Addenda $203\left(25^{2.5^{2}}\right) \quad 5^{1}$ n. 48,113 n. 98 \\
\hline Addenda 156 (28.14) & Addenda $204(256.2) \quad 67$ n. 129,78 n. 44 \\
\hline Addenda $156(28.15)$ & Addenda $204(256.5)$ \\
\hline Addenda $157(31.6) \quad 35$ n. 74 & Addenda $206(272.1)$ \\
\hline Addenda $157(33.8)$ & Addenda $206(272.2)$ \\
\hline Addenda $163(54.5)$ & Addenda $208(279.7) \quad 5^{2} \mathrm{n} .53$ \\
\hline Addenda $163(55.11) \quad 36$ n. 78 & Addenda $208(281.34) \quad 5^{2}$ n. 63 \\
\hline Addenda $163(55.15) \quad 36 \mathrm{n} .78$ & Addenda $208(283.2)$ \\
\hline Addenda $165(60.66) \quad 32$ n. 55 & Addenda $209(285.2) \quad 5^{2}$ n. 55 \\
\hline Addenda $165(61.75) \quad 36 \mathrm{n} .79$ & Addenda $209(286.10) \quad 5^{2}$ n. $5^{8}$ \\
\hline Addenda $165(63.88) \quad 36$ n. 83 & Addenda $209(286.18) \quad 5^{2}$ n. 59,83 n. 62 \\
\hline Addenda $166(64.102) \quad 38$ n. 87 & Addenda $209(286.9) \quad 5^{2}$ n. 56 \\
\hline Addenda $166(65.114) \quad 36$ n. 83 & Addenda $209(287.24) \quad 5^{2} \mathrm{n} .53$ \\
\hline Addenda $169(77.91) \quad 38$ n. 91 & Addenda $210(290.7) \quad 48$ n. 38 \\
\hline Addenda $172(98.2) \quad 39$ n. 95 & Addenda 211 ( 298 center $) \quad 57$ n. 78 \\
\hline Addenda $176(124.8) \quad 31 \mathrm{n} .54$ & Addenda $215(320.10) \quad 55 \mathrm{n} .74$ \\
\hline Addenda $176(126.23) \quad 39$ n. 94 & Addenda $221(355.45) \quad 125$ n. 9 \\
\hline Addenda $176(126.27) \quad 39$ n. 96 & Addenda $222(361.2) \quad 76$ n. 26 \\
\hline Addenda 177 (Para 334) 59 n. 88 & Addenda $223(365.58) \quad 60$ n. 90 \\
\hline Addenda $186(182.6) \quad 40$ n. 1,77 n. 33 & Addenda $223(365.61)$ \\
\hline
\end{tabular}




\begin{tabular}{|c|c|}
\hline Addenda $224(370.13) \quad 56$ n. 75 & Addenda $264(589 \cdot 3)$ \\
\hline Addenda 225 (371.14) & Addenda 264 (591.20) \\
\hline Addenda $225(371.15) \quad 54$ n. 70 & Addenda 264 (591.21) \\
\hline Addenda $228(382.185) \quad 55$ n. 72 & Addenda $264(593.41)$ \\
\hline Addenda $228(385.228) \quad 56$ n. 76 & Addenda $265(595.65)$ \\
\hline Addenda $231(405.1) \quad 115$ n. 102 & Addenda $265(596.1) \quad 83$ n. 62 \\
\hline Addenda $232(406.2) \quad 57$ n. 78 & Addenda $266(600.14) \quad 88$ n. 2 \\
\hline Addenda $232(408.33) \quad 57$ n. 79 & Addenda 266 (6o2.24) \\
\hline Addenda $234(417.1) \quad 42$ n. 19,164 n. 17 & Addenda 267 (604.50) \\
\hline Addenda $238(434.78) \quad 123$ n. 4 & Addenda 267 (6o6.77) \\
\hline Addenda $238(436.96) \quad 57$ n. 82 & Addenda 267 (6o6.83) \\
\hline Addenda 239 (438.133) & Addenda $270(618.1) \quad 123$ n. 7 \\
\hline Addenda $241(446.262) \quad 59$ n. 86 & Addenda 270 (618.3) \\
\hline Addenda $242(451.1) \quad 59$ n. 87 & Addenda 270 (618.4) \\
\hline Addenda $242(451.3)$ & Addenda $270(619.16)$ \\
\hline Addenda $243\left(45^{6}\right) \quad 31 \mathrm{n} .5^{2}$ & Addenda $271(623.69) \quad 107$ n. 70 \\
\hline Addenda $243(459 \cdot 3) \quad 63$ n. 104 & Addenda $272(632.3) \quad 154$ n. 128 \\
\hline Addenda $244(460.20) \quad 64$ n. 112 & Addenda $272(633.8)$ \\
\hline Addenda $244(461.36)$ & Addenda $29(108.5) \quad 40$ n. 6 \\
\hline Addenda 244 (462.43) & Addenda $309(972.2) \quad 238$ n. 9 \\
\hline Addenda $244(462.48) \quad 61$ n. 95,65 n. 114, & Addenda $310(975 \cdot 38)$ \\
\hline 125 n. 10 & Addenda $311(987.2) \quad 78$ n. 46,93 n. 20 \\
\hline Addenda 244 (Para 378.46bis) $61 \mathrm{n} .102$ & Addenda $312(992.67) \quad 93$ n. 19 \\
\hline Addenda $245(463.51) \quad 61$ nn. 98,102 & Addenda $312(992.74)$ \\
\hline Addenda $245\left(463.5^{2}\right)$ & Addenda 315 (1017.54) \\
\hline Addenda $245(463.53) \quad 61 \mathrm{nn} .97,100$ & Addenda 315 (1019.77) \\
\hline Addenda $245(465.82) \quad 61 \mathrm{n} .94$ & Addenda 315 (1019.82) \\
\hline Addenda $246(475.267) \quad 61 \mathrm{n} .99$ & Addenda 317 (1028.12) \\
\hline Addenda $247(478.312) \quad 61$ n. 97 & Addenda 317 (1028.13) \\
\hline Addenda $248(485.27) \quad 70 \mathrm{n} .3$ & Addenda $318(1035.2)$ \\
\hline Addenda $25^{\circ}(494.1) \quad 83$ n. 60 & Addenda $318(1035 \cdot 4)$ \\
\hline Addenda 250 (494.2) & Addenda 318 (1037.1) \\
\hline Addenda 250 (494.3) & Addenda $320(1042.1)$ \\
\hline Addenda $250(495.5)$ & Addenda $320(1047.10) \quad 154$ n. 128 \\
\hline Addenda $25^{\circ}(495.5$ bis $) \quad 84$ n. 67 & Addenda 321 (1052.23) \\
\hline Addenda $25^{\circ}(496.2) \quad 78$ n. 37 & Addenda $322\left(105^{2.25}\right)$ \\
\hline Addenda $25^{2}(508.1)$ & Addenda $322(1055 \cdot 76)$ \\
\hline Addenda $25^{2}\left(5^{11.5}\right)$ & Addenda $322(1057.96)$ \\
\hline Addenda $25^{2}\left(5^{12.8}\right)$ & Addenda $322(1057 \cdot 97)$ \\
\hline Addenda $253(518.4) \quad 74$ n. 20 & Addenda $325(1067.8)$ \\
\hline Addenda $254\left(5^{24.23}\right) \quad 72$ n. 15 & Addenda 329 (1104.7) \\
\hline Addenda $254\left(5^{24.26}\right)$ & Addenda 330 (1112.1) \\
\hline Addenda 254 (529.13) & Addenda 330 (1112.3) \\
\hline Addenda 254 (531.29) & Addenda 330 (1113.4) \\
\hline Addenda $255\left(533.5^{8}\right)$ & Addenda 334 (1143.1) \\
\hline Addenda $257(551.6) \quad 136$ n. 56 & Addenda 334 (1143.6) \\
\hline Addenda $25^{8}(555.95) \quad 72$ n. 12 & Addenda 334 (1144.10) \\
\hline Addenda $259\left(5^{60.5}\right) \quad 116 \mathrm{n} .103$ & Addenda 334 (1144.11) \\
\hline Addenda $260(563.4)$ & Addenda 334 (1144.7) \\
\hline
\end{tabular}




\begin{tabular}{|c|c|}
\hline Addenda 334 (1144.8) & ARV $1024.15^{2}$ \\
\hline Addenda 334 (1144.9) & ARV 1024.153 $131 \mathrm{n} .40$ \\
\hline Addenda $335(1145 \cdot 30)$ & ARV 1028.11 94 n. 24 \\
\hline Addenda 335 (1145.35) & ARV 1028.14 \\
\hline Addenda $335(1145 \cdot 36)$ & ARV $1028.15 \quad 95$ n. 25 \\
\hline Addenda $335(1147.68) \quad 97$ n. 34 & ARV 1028.15bis 94 n. 24 \\
\hline Addenda 336 (1151.1) 188 n. 14 & ARV $1036.9 \quad 149$ n. 98 \\
\hline Addenda 336 (1151.2) & 154 n. 128,200 n. 59 \\
\hline Addenda 336 (1152.3) & ARV $1047.12 \quad 154$ n. 128 \\
\hline Addenda $336\left(115^{2.8}\right)$ & ARV $1047.13 \quad 154$ n. 128 \\
\hline Addenda 337 (1156.17) $\quad 110 \mathrm{n} .78$ & ARV $1080.3 \quad 108 \mathrm{n} .77$ \\
\hline Addenda 337 (1159) 150 n. 106 & ARV $1130.144-149 \quad 184$ n. 1 \\
\hline Addenda 340 (1184.1) 171 n. 42,191 n. 21 & ARV $1151 \quad 184$ n. 2 \\
\hline Addenda 341 (1184.4) & ARV $1152.3-6 \quad 186$ n. 7 \\
\hline Addenda 341 (1185.7) & ARV $115^{2.8} \quad 168 \mathrm{n} .33$ \\
\hline Addenda 341 (1188.4) & ARV 1163.34 200 n. 59 \\
\hline Addenda $353(1247.1) \quad 200$ n. 60 & ARV $1170.7 \quad 74$ n. 20 \\
\hline Addenda 354 (1249.12 bis) 197 n. 47 & ARV $1185.17 \quad 151$ n. 111 \\
\hline Addenda 354 (1249.12) 157 n. 134 & ARV $1186.31 \quad 195$ n. 33 \\
\hline Addenda 354 (1249.13) & ARV $1188.2 \quad 151 \mathrm{n} .112$ \\
\hline Addenda 356 (1269.3) $\quad 98$ n. 42,167 n. 27 & ARV 1188.3 \\
\hline Addenda 356 (1270.17) 157 n. 135 & ARV $12.9 \quad 27$ n. 33 \\
\hline Addenda $362(1313.11) \quad 144$ n. 82 & ARV $1253.70 \quad 38$ n. 85,196 n. 44 \\
\hline Addenda $362(1313.6)$ & ARV 1261.54 \\
\hline Addenda $362(1315.1) \quad 202$ n. 68 & ARV $1329.117 \quad 205$ n. 77 \\
\hline Addenda $364(1328.92) \quad 204$ n. 70 & ARV 1391-1397 235 n. 5 \\
\hline Addenda $364(1328.95) \quad 204$ n. 73 & ARV $14.4 \quad 29$ n. 42 \\
\hline Addenda 365 (1330.9) 205 n. 79 & ARV $1439.1 \quad 168$ n. 37,223 n. 64 \\
\hline Addenda $365(1336.1) \quad 205$ n. 80 & ARV 1457 f., 19. $21.29 \quad 225$ n. 72 \\
\hline Addenda 366 (1336.1 below) $\quad 207$ n. 85 & ARV $1458.34 \quad 223$ n. 65 \\
\hline Addenda $367(1341.2) \quad 205$ n. 76 & ARV 146-153 \\
\hline Addenda 367 (1343.1) & ARV $1470.165 \quad 226$ n. 78 \\
\hline Addenda $368(1347.2) \quad 209$ n. 88 & ARV $15.7 \quad 29$ n. 45 \\
\hline Addenda $378(1446.1) \quad 228$ n. 82 & ARV 185 f., 31-49 40 n. 4 \\
\hline Addenda 380 (1469.161) 227 n. 79 & ARV $185.30 \quad 83$ n. 62 \\
\hline Addenda $380(1469.162) \quad 227$ n. 79 & ARV 205.121 46 n. 28 \\
\hline Addenda $380(1470.163) \quad 227$ n. 79 & ARV 205.123 \\
\hline Addenda $380(1470.164) \quad 226$ n. 77 & ARV 207.142 \\
\hline Addenda 381 (1471.1) $110 \mathrm{n} .81$ & ARV 208.149 \\
\hline Addenda $43(151) \quad 73$ n. 18 & ARV $226.4 \quad 5^{2}$ n. 64 \\
\hline ARV 320.11 & ARV $232.1 \quad 5^{1} \mathrm{n} .5^{2}$ \\
\hline ARV $543.45 \quad 38$ n. 85 & ARV $242.81 \quad 48$ n. 38 \\
\hline ARV $1015.18 \quad 153$ n. 125 & ARV 258.28 \\
\hline ARV 1015.19 & ARV 261.20 \\
\hline ARV 1015.22 & ARV $27.7 \quad 33$ n. 66 \\
\hline ARV 1017.48 & ARV $272.2 \quad 114$ n. 101 \\
\hline ARV 1019.83 & ARV $276.80 \quad 5^{1}$ n. $5^{1}$ \\
\hline ARV 1019.84 133 n. 45 & ARV $28.13 \quad 34$ n. 72 \\
\hline ARV $1023.149 \quad 131 \mathrm{n} .40$ & ARV 28.16 \\
\hline
\end{tabular}




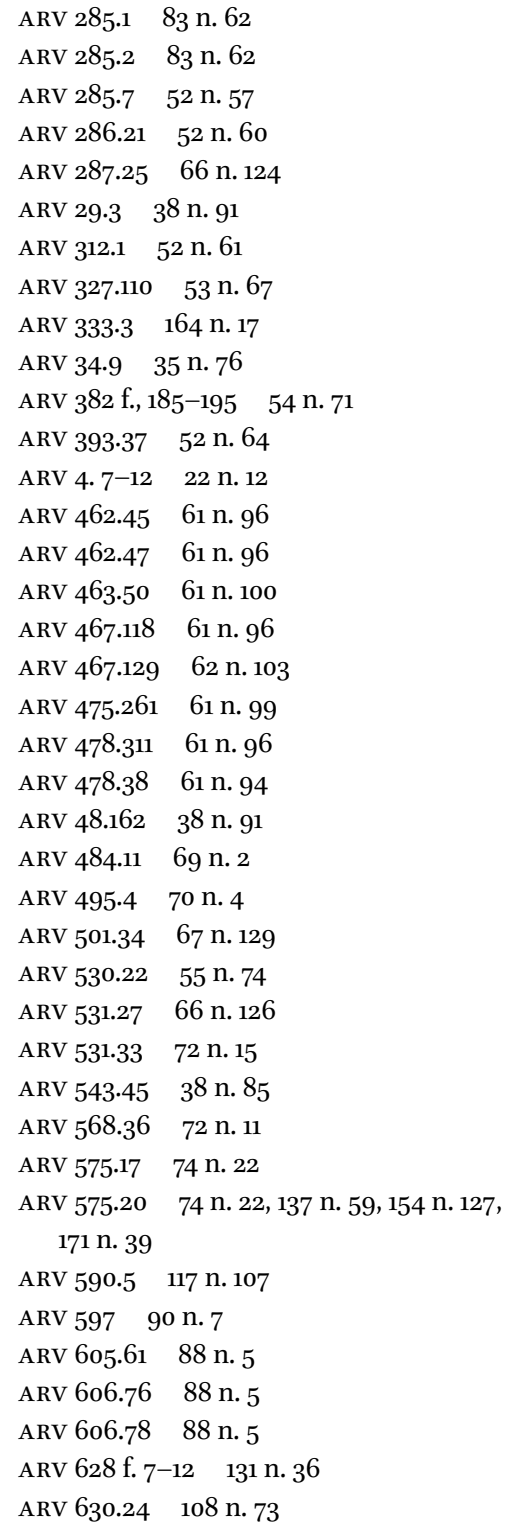

ARV $632.3 \quad 171$ n. 39

ARV $633.9 \quad 131$ n. 36

ARV $64.103 \quad 38$ n. 86,46 n. 34

ARV $646.5 \quad 38$ n. 85

ARV $668.38 \quad 146$ n. 92

ARV $67.3 \quad 36 \mathrm{n} .78$

ARV $67.5 \quad 36 \mathrm{n} .78$

ARV 70-81 38 n. 88

ARV $72.21 \quad 38$ n. 90

ARV 735.111 83 n. 62

ARV $78.98 \quad 39$ n. 92

ARV 789-797, nos 1-135 98 n. 36

ARV 830-832, nos 1-24 98 n. 37

ARV $859-876 \quad 98$ n. 38

ARV 883 f., nos $47-75 \quad 98$ n. 39

ARV 88-96 235 n. 5

ARV 891-898 235 n. 5

ARV 914.142 123 n. 6

ARV 917.197 118 n. 111

ARV 992.75 92 n. 15

ARV $993.78 \quad 92$ n. 16

Para 174.23 bis $51 \mathrm{n} .5^{2}$

Para $35^{2}$ above 66 n. 124

Para 355 center 52 n. 63

Para $377(462.41) \quad 61$ n. 95

Para $377(462.44) \quad 61$ nn. 95, 102

Para 377 (462.49) 61 n. 101

Para 378 (478.309) 61 n. 95

Para $380(496.1) \quad 78$ n. 37

Para $380(497.7) \quad 41$ n. 8

Para $381(501.35) \quad 43$ n. 24,72 n. 16

Para $385 \quad 70$ n. 5

Para 435 (973.13) 118 n. 112

Para 437 (992.66) 92 n. 17

Para 445 (1057.102) 138 n. 60

Para 457 (1144.18) 29 n. 48

Para $482(1347) \quad 208$ n. 87

Para 482 (1347.1) 208 n. 87

Para $510(184.19) \quad 43$ n. 23

Para $512(486.45) \quad 72$ n. 7 


\section{Vases Following Beazley Archive Database (BA)}

$\begin{array}{ll}308 & 49 \text { n. } 44 \\ 503 & 145 \\ 526 & 141 \\ 5.74 \\ 5647 & 84 \text { n. } 68 \\ 5703 & 103 \text { n. } 61 \\ 5766 & 77 \text { n. } 34 \\ 6306 & 105 \text { n. } 66 \\ 6988 & 182 \text { n. } 94 \\ 7928 & 212 \text { n. } 4 \\ 8110 & 88 \text { n. } 3 \\ 8904 & 204 \text { n. } 71 \\ 9495 & 204 \text { n. } 71 \\ 11686 & 58 \text { n. } 83 \\ 12464 & 101 \text { n. } 55 \\ 13378 & 63 \text { n. } 107 \\ 17333 & 180 \text { n. } 88 \\ 19154 & 207 \text { n. } 83 \\ 19347 & 137 \text { n. } 57 \\ 19768 & 92 \text { n. } 18 \\ 28005 & 113 \text { n. } 94 \\ 28083 & 81 \text { n. } 54 \\ 28128 & 198 \text { n. } 52 \\ 30676 & 78 \text { n. } 41 \\ 31374 & 133 \text { n. } 46 \\ 31415 & 95 \text { n. } 25 \\ 43937 & 80 \text { n. } 47 \\ 45070 & 171 \text { n. } 42 \\ 50396 & 61 \text { n. } 94 \\ 200000 & 27 \text { n. } 31 \\ 200005 & 23 \text { n. } 22 \\ 200009 & 24 \text { n. } 25 \\ 200010 & 23 \text { n. } 23 \\ 200011 & 24 \text { n. } 24 \\ 200019 & 26 \text { n. } 30 \\ 200021 & 25 \text { n. } 26 \\ 200022 & 26 \text { n. } 28 \\ 200054 & 27 \text { n. } 32 \\ 200057 & 27 \text { n. } 33 \\ 200063 & 28 \text { n. } 41 \\ 200065 & 28 \text { n. } 39 \\ 200066 & 29 \text { n. } 42 \\ 200068 & 29 \text { n. } 44 \\ 200069 & 29 \text { n. } 45 \\ 200071 & 29 \text { n. } 48 \\ 200077 & 29 \text { n. } 49\end{array}$

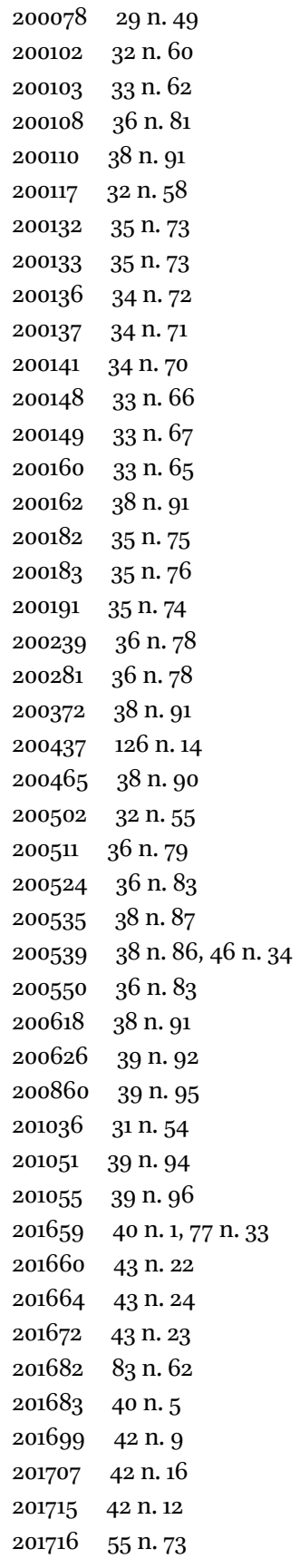




\begin{tabular}{|c|c|}
\hline 201809 & 45 n. 25 \\
\hline 201817 & 46 n. 27 \\
\hline 201878 & 46 n. 30 \\
\hline 201926 & 49 n. 42 \\
\hline 201930 & 46 n. 28 \\
\hline 201932 & 46 n. 29 \\
\hline 201961 & 38 n. 86,46 n. 35 \\
\hline 201964 & 48 n. 36 \\
\hline 201968 & 49 n. 41 \\
\hline 201970 & 126 n. 14 \\
\hline 202054 & 67 n. 132 \\
\hline 202099 & $5^{1} \mathrm{n} .5^{1}$ \\
\hline 202223 & $5^{2}$ n. 64 \\
\hline 202231 & 126 n. 14 \\
\hline 202274 & $5^{1}$ n. $5^{2}$ \\
\hline 202367 & 67 n. 131 \\
\hline 202393 & $5^{2}$ n. 63 \\
\hline 202432 & 48 n. 38 \\
\hline 202463 & 48 n. 38 \\
\hline 202485 & 77 n. $3^{6}$ \\
\hline 202504 & 84 n. 71 \\
\hline 202540 & $5^{2}$ n. 63 \\
\hline 202563 & $5^{2}$ n. 54 \\
\hline 202574 & 83 n. 62 \\
\hline 202575 & 83 n. 62 \\
\hline 202577 & 52 n. 55 \\
\hline 202582 & $5^{2}$ n. 57 \\
\hline $2025^{84}$ & $5^{2}$ n. $5^{6}$ \\
\hline $2025^{8} 5$ & $5^{2}$ n. $5^{8}$ \\
\hline $2025^{89}$ & $5^{2}$ n. 59,83 n. 62 \\
\hline 202592 & 52 n. 60 \\
\hline 202595 & $5^{2}$ n. 53 \\
\hline 202596 & 66 n. 124 \\
\hline 202639 & 48 n. $3^{8}$ \\
\hline 202679 & $5^{1}$ n. $5^{1}$ \\
\hline 202711 & $5^{2}$ n. 53 \\
\hline 202837 & 114 n. 101 \\
\hline 202838 & 114 n. 101 \\
\hline 202896 & $5^{1}$ n. 49,103 n. 60 \\
\hline 202898 & $5^{1}$ n. 48,113 n. 98 \\
\hline 202921 & 67 n. 129,78 n. 44 \\
\hline 202924 & 81 n. 51,126 n. 14 \\
\hline 202929 & 81 n. $5^{2}$ \\
\hline 202946 & 81 n. 53 \\
\hline 202974 & 67 n. 129 \\
\hline 203092 & 57 n. 78 \\
\hline 203213 & $5^{2}$ n. 61 \\
\hline 203260 & 55 n. 74 \\
\hline 203261 & 55 n. 74 \\
\hline
\end{tabular}

\begin{tabular}{|c|c|}
\hline 203364 & 53 n. 67 \\
\hline 203728 & 125 n. 9 \\
\hline 203793 & 76 n. 26 \\
\hline 203850 & 60 n. 90 \\
\hline 203853 & 122 n. 2 \\
\hline 203912 & $5^{6}$ n. 75 \\
\hline 203913 & 54 n. 69 \\
\hline 203914 & 54 n. 70 \\
\hline 204084 & 55 n. 72 \\
\hline 204129 & $5^{6}$ n. 76 \\
\hline 204235 & 52 n. 64 \\
\hline 204395 & 115 n. 102 \\
\hline 204401 & 57 n. 78 \\
\hline 204431 & 57 n. 79 \\
\hline 204546 & 42 n. 19,164 n. 17 \\
\hline 204701 & 63 n. 104,64 n. 112 \\
\hline 204718 & 55 n. 74 \\
\hline 204723 & 61 n. 95 \\
\hline 204725 & 61 n. 96 \\
\hline 204726 & 61 nn. 95,102 \\
\hline 204727 & 61 n. 96 \\
\hline 204729 & 61 n. 96 \\
\hline 204730 & 61 n. 95,65 n. 114,125 n. 10 \\
\hline 204731 & $61 \mathrm{n} .101$ \\
\hline $20473^{2}$ & 61 n. 98 \\
\hline 204733 & 61 nn. 98,102 \\
\hline 204734 & 61 n. 96 \\
\hline 204735 & $61 \mathrm{nn} \cdot 97,100$ \\
\hline 204800 & 61 n. 96 \\
\hline 204811 & 62 n. 103 \\
\hline 204940 & 61 n. 99 \\
\hline 204946 & 61 n. 99 \\
\hline 204990 & 61 n. 94 \\
\hline 204991 & 61 n. 95 \\
\hline 204993 & 61 n. 96 \\
\hline 204994 & 61 n. 97 \\
\hline $205^{0} 3^{8}$ & 43 ก. 20 \\
\hline 205123 & 123 n. 4 \\
\hline 205142 & 57 n. 82 \\
\hline 205179 & 57 n. 81 \\
\hline 205309 & 59 n. 86 \\
\hline 205372 & 59 n. 87 \\
\hline 205374 & 83 n. 62 \\
\hline 205394 & 69 n. 2 \\
\hline 205410 & $70 \mathrm{n} .3$ \\
\hline 205428 & 72 n. 7 \\
\hline 205560 & 83 n. 60 \\
\hline $2055^{61}$ & 84 n. 65 \\
\hline 205562 & 84 n. 65 \\
\hline
\end{tabular}




\begin{tabular}{|c|c|c|c|}
\hline 205563 & 70 n. 4 & 207338 & 154 n. 128,171 n. 39 \\
\hline $2055^{64}$ & 84 n. 70 & 207343 & 131 n. 36 \\
\hline 205621 & 67 n. 129 & 207344 & 131 n. 36 \\
\hline 205622 & 43 n. 24,72 n. 16 & 207517 & 38 n. 85 \\
\hline 205715 & 103 n. 63 & 207833 & 146 n. 92 \\
\hline 205738 & 72 n. 8 & 209103 & 83 n. 62 \\
\hline 205744 & $3^{8}$ n. 85 & 211080 & 123 n. 6 \\
\hline $205^{809}$ & 74 n. 20 & 211134 & 118 n. 111 \\
\hline 205905 & 72 n. 15 & 212467 & $3^{1}$ n. $5^{2}$ \\
\hline 205908 & 73 n. 17 & 213234 & 238 n. 9 \\
\hline 205985 & 72 n. 10,117 n. 106 & 213247 & 118 n. 112 \\
\hline 205992 & 41 n. 8 & 213392 & 94 n. 24 \\
\hline 205998 & 55 n. 74 & 213393 & 94 n. 24,146 n. 95 \\
\hline 206003 & 66 n. 126 & 213394 & 94 n. 24 \\
\hline 206005 & 72 n. 14 & 213395 & 94 n. 24 \\
\hline 206009 & 72 n. 15 & 213396 & 95 n. 25 \\
\hline 206036 & 72 n. 13,101 n. 54 & 213397 & 94 n. 24 \\
\hline 206176 & 38 n. 85 & 213467 & 147 n. 96 \\
\hline 206281 & 136 n. $5^{6}$ & 213471 & 148 n. 97 \\
\hline 206338 & $72 \mathrm{n} .12$ & 213480 & 149 n. 98 \\
\hline 206410 & 116 n. 103 & 213538 & 200 n. 59 \\
\hline 206421 & 78 n. 37 & 213579 & 154 n. 128 \\
\hline 206422 & 78 n. 37 & $2135^{80}$ & 154 n. 128,200 n. 59 \\
\hline 206429 & 74 ก. 20 & 213653 & 127 n. 17 \\
\hline 206525 & 72 n. 11 & 213655 & 159 n. 143 \\
\hline 206617 & 74 ก. 22 & 213708 & 149 n. 99 \\
\hline 206620 & 74 n. 22,137 n. 59,154 n. 127,171 n. 39 & 213726 & 155 n. 129 \\
\hline 206838 & 49 n. 39,90 n. 7 & 213727 & 156 n. 131 \\
\hline 206839 & 90 n. 7 & 213732 & 138 n. 60 \\
\hline 206865 & 103 n. 64 & 213788 & 5 n. 18 \\
\hline 206890 & 90 n. 8 & 213822 & 78 n. 46,93 n. 20 \\
\hline 206905 & 83 n. 62 & 213887 & 92 n. 17 \\
\hline 206922 & $90 \mathrm{n} .7$ & 213888 & 93 n. 19 \\
\hline 206942 & 88 n. 2 & 213895 & 92 n. 14 \\
\hline 206956 & 88 n. 2,138 n. 59 & 213896 & 92 n. 15 \\
\hline 206989 & 88 n. 5 & 213899 & 92 n. 16 \\
\hline 207000 & 88 n. 5 & 214195 & 153 n. 125 \\
\hline 207017 & 88 n. 5 & 214196 & 153 ก. 126 \\
\hline 207018 & 88 n. 5 & 214199 & 132 n. 42 \\
\hline 207019 & 88 n. 5 & 214226 & 132 n. 42 \\
\hline 207024 & 90 n. 6,118 n. 110 & 214232 & 108 n. 76 \\
\hline 207139 & 105 n. 67 & 214255 & 132 n. 42,140 n. 68 \\
\hline 207147 & 117 n. 107 & 214262 & 134 n. 48 \\
\hline 207149 & 123 n. 7 & 214263 & 132 n. 44 \\
\hline 207151 & 153 n. 122 & 214264 & 133 n. 45 \\
\hline $20715^{2}$ & 106 n. 68 & 214332 & 131 n. 40 \\
\hline 207166 & 106 n. 68 & 214335 & $131 \mathrm{n} .40$ \\
\hline 207223 & 107 n. 70 & 214336 & $131 \mathrm{n} .40$ \\
\hline 207307 & 108 n. 73 & 214379 & 108 n. 75 \\
\hline
\end{tabular}




\begin{tabular}{|c|c|}
\hline $2145^{10}$ & 108 n. 77 \\
\hline 214704 & 84 n. 71 \\
\hline 214706 & $3^{8}$ n. 85 \\
\hline 214724 & 118 n. 113 \\
\hline 215141 & 95 n. 28 \\
\hline 215146 & 95 n. 27 \\
\hline 215147 & 95 n. 27 \\
\hline 215148 & 95 n. 27 \\
\hline 215149 & 95 n. 27 \\
\hline 215150 & 95 n. 27 \\
\hline 215151 & 95 n. 27 \\
\hline $21515^{8}$ & 29 n. 48 \\
\hline 215170 & 97 n. 35 \\
\hline 215175 & 97 n. 33 \\
\hline 215176 & 95 n. 32,167 n. 27 \\
\hline $215^{208}$ & 97 n. 34 \\
\hline 215253 & 188 n. 14 \\
\hline $215^{254}$ & 184 n. 4 \\
\hline 215255 & 168 n. 33,186 n. 8 \\
\hline $215^{261}$ & 168 n. 33,189 n. 18 \\
\hline 215317 & $110 \mathrm{n} .78$ \\
\hline 215344 & 150 n. 106 \\
\hline 215383 & 200 n. 59 \\
\hline 215533 & 74 n. 20 \\
\hline 215689 & 171 n. 42,191 n. 21 \\
\hline 215692 & 119 n. 116 \\
\hline 215695 & 192 n. 25 \\
\hline 215705 & 151 n. 111 \\
\hline 215720 & 195 n. 33 \\
\hline 215736 & $15^{1}$ n. 112 \\
\hline 215737 & $15^{1 \mathrm{n} .} 112$ \\
\hline 215738 & 146 n. $91,15^{1}$ n. 113 \\
\hline 216174 & 74 n. 23 \\
\hline 216937 & 200 n. 60 \\
\hline 216948 & 157 n. 134 \\
\hline 216949 & 198 n. $5^{1}$ \\
\hline $21695^{\circ}$ & 143 n. 80 \\
\hline 217008 & 38 n. 85,196 n. 44 \\
\hline 217123 & 196 n. 46 \\
\hline 217212 & 98 n. 42,167 n. 27 \\
\hline 217226 & 157 n. 135 \\
\hline 217500 & 205 n. 80 \\
\hline
\end{tabular}

\begin{tabular}{|c|c|}
\hline 217505 & 207 n. 85 \\
\hline 217539 & 205 n. 76 \\
\hline 217563 & 101 n. 56 \\
\hline 217593 & 208 n. 87 \\
\hline 217594 & 209 n. 88 \\
\hline 217595 & 208 n. 87 \\
\hline 218088 & 168 n. 37,223 n. 64 \\
\hline 218148 & 228 n. 82 \\
\hline 218307 & 223 n. 65 \\
\hline 220498 & 201 n. 64 \\
\hline 220503 & 144 n. 82 \\
\hline 220515 & 202 n. 68 \\
\hline 220648 & 204 n. 70 \\
\hline 220651 & 204 n. 73 \\
\hline 220672 & 205 n. 77 \\
\hline 220684 & 205 n. 79 \\
\hline 230371 & 227 n. 79 \\
\hline 230372 & 227 n. 79 \\
\hline 230373 & 227 n. 79 \\
\hline 230374 & 226 n. 77 \\
\hline 230375 & 226 n. 78 \\
\hline 230431 & 110 n. 81 \\
\hline 275007 & 28 n. 40 \\
\hline 275092 & 48 n. 37 \\
\hline $275^{252}$ & 78 n. 39 \\
\hline $2755^{12}$ & 197 n. 47 \\
\hline $275^{6} 3^{8}$ & 59 n. 88 \\
\hline 275643 & 72 n. 11 \\
\hline 275978 & 61 n. 102 \\
\hline 275985 & 84 n. 67 \\
\hline 275997 & $70 \mathrm{n} .5$ \\
\hline 276060 & 142 n. 76 \\
\hline $31015^{1}$ & $40 \mathrm{n} .6$ \\
\hline 350468 & 73 n. 18 \\
\hline $35^{2401}$ & 33 n. 63 \\
\hline 352509 & 66 n. 124 \\
\hline $35^{2} 5^{24}$ & $5^{2}$ n. 63 \\
\hline 1012120 & 188 n. 15 \\
\hline 1012159 & 205 n. 76 \\
\hline 9017837 & 30 n. $5^{1}$ \\
\hline 9021718 & 204 n. 71 \\
\hline 9025040 & 102 n. $5^{8}$ \\
\hline
\end{tabular}




\section{Vases and Other Works Following LIMC}

\begin{tabular}{|c|c|}
\hline I.1, 291, Aglauros $38 \quad 183$ n. 99 & III, Dionysos 720 \\
\hline II, Apollo $295 \quad 173$ n. 55 & 223 n. 64,225 n. 70,226 \\
\hline II.1, 201 Apollo $101 \quad 219$ n. 47 & n. 76 \\
\hline II.1, 234 Apollo $390 \quad 173$ n. 55 & III, Dionysos 731-734 \\
\hline II.1, $315 \quad 173$ n. 54 & III, Dionysos 738-40 \\
\hline III, Ariadne $96 \quad 233$ n. 98 & III, Dionysos $743 \quad 226$ n. 76 \\
\hline III, Dionysos 119-125 168 n. 35 & III, Dionysos $748-75^{0} \quad 226$ n. 76 \\
\hline III, Dionysos $120 \quad 220$ n. $5^{0}$ & III, Dionysos $755 \quad 229$ n. 84 \\
\hline III, Dionysos 121-124 220 n. $5^{1}$ & III, Dionysos 777 \\
\hline III, Dionysos $126 \quad 221$ n. $5^{2}$ & III, Dionysos 77-79 218 n. 39 \\
\hline III, Dionysos 127 & III, Dionysos $778 \quad 233$ n. 98 \\
\hline III, Dionysos 128 168 n. 35, 214 n. 19, 215 n. 22 & III, Dionysos $79^{2} \quad 174$ n. $5^{8}$ \\
\hline III, Dionysos 130-133 218 n. 41 & III, Dionysos 84-86 218 n. 39 \\
\hline III, Dionysos $137 \quad$ 168 n. 34 & III, Dionysos $853 \quad 216$ n. 24 \\
\hline III, Dionysos $138-140 \quad 218$ n. 42 & III, Dionysos 869159 n. 143 \\
\hline III, Dionysos $142 \quad 168$ n. 34 & III, Dionysos $88 \quad 219$ n. 45 \\
\hline III, Dionysos 194 & III, Dionysos 89 \\
\hline III, Dionysos 195 & III, Dionysos $97 \quad 218$ n. 40 \\
\hline III, Dionysos 205 & III, Dionysos/Bacchus $181 \quad 221$ n. $5^{2}$ \\
\hline II I, Dionysos $206 \quad 219$ n. 47 & III, Dionysos/Bacchus 186 \\
\hline III, Dionysos $215^{-217} \quad 220$ n. $5^{0}$ & III, Dionysos/Bacchus 28 \\
\hline III, Dionysos $315 \quad 223$ n. 62 & III, Dionysos/Bacchus 40 \\
\hline III, Dionysos $316 \quad 223$ n. 62 & III, Erigone I $1 \quad 216$ n. 26 \\
\hline III, Dionysos 362-381 167 n. 25 & III, Eris $7 \quad 192$ n. 25 \\
\hline III, Dionysos 369 226 n. 73 & III.1, 19 f., Attike $2 \quad 183$ n. 97 \\
\hline III, Dionysos $489 \quad 219$ n. 47 & III.1, 446 Dionysos $214 \quad 176$ n. 68,217 n. 32 \\
\hline III, Dionysos 490-492 175 n. 59 & III.1, 8o, Bakche $2 \quad 150$ n. 106 \\
\hline III, Dionysos $559 \quad 226$ n. 73 & IV, Gigantes $171 \quad 42$ n. 17 \\
\hline III, Dionysos 560 & IV, Gigantes 175 \\
\hline III, Dionysos 598 & IV, Gigantes 289 \\
\hline III, Dionysos 6o9-65o 164 n. 14 & IV, Gigantes 389 \\
\hline III, Dionysos $630 \quad 223$ n. 61 & IV, Herakles 1477 \\
\hline III, Dionysos 631 & IV, Herakles 1562 \\
\hline III, Dionysos 633 & IV.1, 629 f. $\quad 173$ n. $5^{6}$ \\
\hline III, Dionysos 641 & V.1, $373 \quad 178$ n. 81 \\
\hline III, Dionysos 648 & v.2, Hermes $101 \quad 140$ n. 66 \\
\hline III, Dionysos 651 & V.2, Hermes 147 \\
\hline III, Dionysos 655 & v.2, Hermes $820 \quad 140$ n. 67 \\
\hline III, Dionysos 656 & V.2, Hippothoon $10 \quad 140$ n. 66 \\
\hline III, Dionysos 66o 223 n. 61 & VI.1, 96 f., Komos 6-20 149 n. 102 \\
\hline III, Dionysos 669-671 218 n. 43 & VII, Paridis Iudicium $40 \quad 212$ n. 4 \\
\hline III, Dionysos $692 \quad 113$ n. 94 & VII, Paridis Iudicium 48 \\
\hline III, Dionysos 699 & VII, Peleus $210 \quad 80$ n. 47 \\
\hline III, Dionysos 705 & VII, Pentheus $16 \quad 202$ n. 65,215 n. 23 \\
\hline
\end{tabular}


VII.1, 186-188 212 n. 3

VII.1, 315-317 214 n. 15

VII.1, $64 \quad 78 \mathrm{n} .38$

VIII.1, 49, Tragoidia 7-10 149 n. 104
VIII.1, 540 Belos II $1 \quad 82$ n. 57 VIII.1, 574 Epaphos $1 \quad 82$ n. 57

VIII.2, Silenoi 43a 140 n. 66 


\section{General}

abduction $74,78,107$ n. 69,118 n. 114, 126

Acheloos 126, 232

Achilles 27, 51, 78, 80, 112

Achilles Painter $\quad 76,78,90-93,131,200$ n. 59 acrobat, acrobatic 59

Acropolis $8,60,76,81,100,163,166,168$,

$174-175,180,183,215$ n. 22

actor 143, 206, 209, 214

adjudicator, see referee

adolescent, see youth

Adria 87

Adriatic Sea 161

adult, adulthood 23,140 n. $66,147,15^{2-158}$, $160,167,178,221,234$

Aegean Sea $\quad 84-85,120$

Aegeus 84

Aegina $\quad 84,126$

Agamemnon 115

age, aging $1-4,23,68,84-85,145,149,151$,

$153,158,163,179$

Agrigento 95

Agrigento Painter 74 n. 22, 137 n. 59, 154

n. $127,170,171$ n. 39

aidos 138,140

Aigisthos $\quad 126$

Aione 185

Aischylos, Aischylos' Eumenides $\quad$ 76, 81, 172, 179, 213-214

Aithra 126

Ajax 27

Akamas 84

alabastron 39

Alexandros, see Paris

Alkaios 56, 173 n. $5^{1}$

Alkamenes 176, 217-218, 223

Alkimachos Painter 55 n. 74, 66 n. 126, 72, 101, 117

ally, alliance $\quad 85,179-180$

Altamura Painter 49 n. 39, 83 n. 62,87 , 90-91, 100, 103, 105-106, 111-112, 117, 150 altar $7,18,39,55,65,70,74,76,78,88$, 100, $116,123,135,140,176$ n. $67,183,187,192,197$, 217, 224-225

Amasis Painter $\quad 22,27,32,73,93,122$ amazon, Amazonomachy $\quad 13,39,88,162-163$,
Amphitrite $\quad 35-36,49,63,98,180,182$

Amphitrite Painter 43 n. 20

amphora, amphorae, see also Panathenaic prize-amphora, Panathenaic-type amphora $12-13,16-17,22-24,26,29-30$, $3^{2-34}, 40,43,45-46,51,53,55$ n. 74, 66-67, $69,72-73,76-78,80-81,83,85,88,91,93$, 99-100, 102, 114, 117, 121, 125, 131, 132 n. 42, 146 n. $92,153-154,175$ n. $59,180,186-187$, 191, 200 n. 59, 234, 237, 241

Amymone 84, 126

Amymone Painter 98

anakalypsis 80

Anakreon 237 n. 8

Anavyssos 198 n. 51

Andokides Painter 19, 22-24, 26

androgynous 221

animal 166, 189, 221, 226, 236-237

animal frieze 229,231

anonymous $1,4,12-17,19,23,38,49,51-52$, $54,57,60,69,76,85^{-86}, 90,98,101,108$, 118-119, 123, 125, 138, 141, 185, 192, 201, 204 n. 71, 209, 234-235

Anthesteria (festival) 92, 123 n. 8, 142 n. 77, 144, 146, 152, 155, 194, 198-199, 206

Apatouria (festival) 123, 239

Apennines $87,161 \mathrm{n} .15^{2}$

Aphrodite $6,14,36,63,98-99,101,118,120$, 158, 175-176, 192, 204-205, 240

Apollo, Apollo Parnopios $\quad 42,49,63,76$, 8o, 95, 113, 168, 171-173, 180, 191-195, 202, 214, 219

apotheosis 2 n. 5, 63, 207

appearance, see epiphany

architrave 80,225

Ares 26, 36, 42, 43 n. 19, 63, 98-99, 173

Argos 82

Ariadne $8 \mathrm{n} .33,14,16-17,35-36,51,63$, 66-67, 77, 90, 98-99, 108, 113-114, 115 n. 102, 116-121, 138 n. 63, 147, 149, 157-158, 181, 187-188, 190, 192, 195-196, 204-207, 222-226, 225-226, 231-233, 238

Ariagne 108

aristocracy, aristocrat, aristocratic $180 \mathrm{n} .91$, 181

Aristophanes, Aristophanes' Frogs 211-212 
armor, see also helmet, leg guard, shield $\quad 85$, 90, 173-175, 181

armrest 103

arrival, see also epiphany $\quad 32,38,69,116,144$, $146,152,199,226,228$

Arrhephoria (festival) $178 \mathrm{n} .79$

Artemis 49, 63, 8o, 85, 180, 191-192, 193 n. 27, 214,216

artisan, see craftsman

aryballos 150

ashes 129, 229

Asia Minor 160, 218

Asia, Asiatic $\quad 63,82,164,177,181-183,189$,

193-194, 212-214, 217

assassination $\quad 126$

assembly of gods $36,42,63,173,177^{-178}$

Astion 231-233

Athena $\quad 2,8,13,16,23-24,32,35,49,51,53$, $63,77-78,83-84,100,110,113-114,116$, 118 n. 114, 119-121, 162-163, 166, 168, 170-172, 173 n. $54,174-175,178$ n. $79,180-183$,

191-192, 194, 238-240

Athena Promachos 77

Athens, Athenians $\quad 1,8,11-12,19,30,40,61$, 69, 74, 77-78, 81-82, 84, 87, 114, 116, 119 n. $116,120,125,128,130-131,145,152$, 154 n. 128, 160-161, 163-164, 171-173, 175, 176 n. $66,181,183,186-187,190-191,194-198$, 201, 211-212, 215 n. 22, 216, 218-219, 223, $226,240-241$

athlete, athletic $13,15,28,38,43,51,53-54$, $77,98,103,106,111,167,177,196,201,221$, 235, 238

Attica, Attic 8 n. 33, 11, 22, 66, 78, 83-85, 97, $110,127,135$ n. 53,149 n. 104, 152, 159, $161-163,180,183,197,201,211$ n. 2, 215 n. 22, $216,223,226$

audience $158,174,211-213,216-217,234,241$ aulos, flute $\quad 23,30,34-35,55,69-70,97,106$, $110,118,123,128,130,133,135,147,150-151$,

153-154, 157, 160, 191, 194, 203, 207 axe 85

baby 135, 199

bacchant 149, 233

bacchante, bakche, Dionysiac woman, see also maenad, nymph $\quad 6,58,106,141,150$, 176, 187, 189, 191-192, 203, 225, 232, 239

Bakchos, see Dionysos
Balos 82

banausos, banausoi 83

barbaric regions 183

barbitos $29,35,43,45-46,54,57,92$, 132 n. $44,133-134,141,147-148,154$ n. 127 , 237

Barclay Painter 108, 112

Basilinna 119, 145, 155

basket $56,73,88,100,129,145,187,192,198$, 204

battle, battle field $28,42,81,88,90,160$, $162-164,236$

beard, bearded $9,12,23,24$ n. $25,35,41$ n. 8 , 42 n. 19, 43, 46 n. 26, 48-49, 57, 85, 97, 99, 103, 107, 114, 117-119, 123, 133, 136-138, 148, $150,151,154,164,166-167,171,184-185,194$, 196-198, 208-209, 212, 214, 217-218, 223, 228, 231-232

beauty $167,177,179-180,212$

Beazley $6,11-12,22-23,35,40,52,69,87,108$, $128,184,201,224,226-228,234$

bed, see also couch $\quad 80,116,119,156,186,206$ bellows 57

Bérard, C. 141

Berger, E. 175

Berlin Painter 23, 33, 38 n. 86, 40, 43, 46, $48-49,57,67,69,72$ n. $11,85,90-91,126$

birth $72,80,85,101,113,121,163,238$

birth of Athena 2, 8, 166, 168, 180, 173 n. 54, 175,238

birth of Dionysos 101

Birth of Athena, Painter of the $70,83-85$, 121,180

Black Sea 15, 97, 182, 192, 194, 226

bliss, state of, see happiness

blossom, see flower

body $29,33,54,58,68,138,141,155,167-168$, 177-178, 187, 201, 206, 219 n. 47, 221, 224

Boeotia, Boeotian 223

Bologna 87, 100 n. 52, 188

Bologna 228, Painter of 38 n. 85,72 n. 8

Bologna 322, Painter of 74 n. 20

Bologna 417, Painter of 118 n. 111

boots, see also sandals, shoes $\quad 35,168,181$, $183,194,196,205,214,216$

Boreas 78, 84, 115, 126

Borg, B. 209

boundaries, see frontier

bow 24, 205 


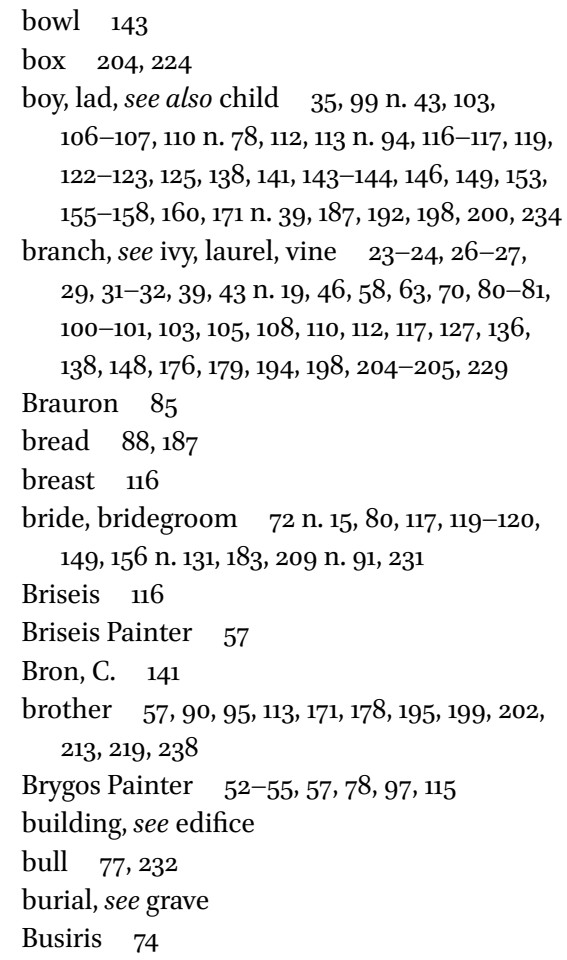

cake, see also sweetmeats, pastries $\quad 127,143$

Calame, C. 120, 206

calendar 2, 239

calf 231

Calliope Painter 196

cap, see also coif $\quad$ 30, 93, 197

Cape Artemision $\quad 78$

capital $\quad 180-181$

Capua 127

caricature 74,118

Carpenter, T. H. 25

Carrey, J. 175

casket 92

cast 167,178 n. 80

Castor 84

cat 105

centaur, Centauromachy $\quad 13,77-78,80-81$, 112

Cerberus 24

Cerveteri 84

chair, stool, footstool, see also diphros,

klismos $58,74,103,105,135-138,140-146$, 152, 194, 199, 239 chariot, charioteer $\quad 8,17,19,23,26,31^{1-32}, 36$, $63,67,80,193,204,226-227,236$

Charon 212

chastity, see virginity

Chicago Painter 108

chignon 203, 224

child, children, childhood, infant $\quad 9,51,64$, $68,73,80,81$ n. 55, 90, 100-103, 105-108, 110-113, 120, 134-135, 143, 149, 152-153, 158, 16o, 163, 170-171, 189, 196, 199, 204, 214, 229, $231,238,241$

Chiron 80,112

chiton 40, 41 n. 8, 48, 70, 72, 93, 95, 114, 117-118, 133-134, 145, 147-148, 164, 181, 183-184, 194, 196, 203, 213-214, 216-218, 227

chlamys $35,43,123,154$

Choes (festival) 90, 141-142

Choreia 185

chorus 42, 65, 97, 212, 217 n. 29, 234, 236

chous, choes $\quad 91,141-146,15^{-152,156,187}$, 197-198

Christ, Christian, Christianity $\quad 5,164$

Christie Painter 134, 154, 200 n. 59

church 164

citizen $3,5,22-23,43,46,49,52,65,66,72$, 74, 93, 131-132, 141, 148-149, 155, 159, 161, 163, 174, 183, 193, 196, 199, 201, 209, 222, 233, 236-240

City Dionysia, see Dionysia megala (festival)

Clio Painter 108

cloak 108

cloth $103,107-108,143-144,152,160,177,198$, 231

Codrus Painter, see Kodros Painter

coif, see also cap $\quad 107,135,145,148$

coin, coinage $\quad 171,217-218$

Colmar Painter 125 n. 9

column, colonnade $\quad 80,225$

combat, combatant $\quad 28,36,38,41$ n. $8,77-78$, $176,183,217$

comedy, see also theater $\quad 211-213$

comic, comical $46,5^{2}, 68,93,140,212,229$, 237-238, 241

community $3,23,179,210,217$

Copenhagen Painter 66 n. 128,76 n. 30

Corinth 205

costume 49 n. 39, 52, 61 n. 99, 72, 90 n. 7,

194, 212-213 
couch, see also bed $\quad 17,25,29,58,98,101,136$, $141,187,192,195$ n. 33, 227

counter world $2,38,210,236$

counterpose $\quad 43,87$

countryside 66

couple $17,29,32,36,69-70,80-81,98-99$,

$155,158-160,189,207,211,226$

craftsman, artisan $\quad 83,143,198$

cremation 127

Crete, Cretan $\quad 120,218$

Crimea 188 n. 15

crown 106, 119, 136, 147, 149, 156, 189

cult, cultic 6 n. 20, 18-19, 22, 78, 97, 120-121,

127,129 n. $24,131,160,161$ n. 152, 171-173,

$175^{-176,217-218,220}$

culture, cultural, enculturation $\quad 1,4,5,19,63$,

$88,130-131,135,161,183,223,236,240$

cup 11-17, 28-32, 34-36, 38-39, 42, 52-55,

$57-60,62-65,69-70,73,76,81$ n. 55 ,

83 n. $62,87,92,97-102,115,118,122$ n. 2, 123, 125, 131, 141 n. 71, 146 n. 94, 157-159, 161,

164 n. 17,167 n. $27,168,187,195-196,201$,

203, 205, 214, 222, 234 n. 1, 235 n. 5 ,

237-239, 241

Curti Painter 159, 161, 189, 200 n. 59

Cyclades, Cycladic 146 n. 93

cymbal $93,127,160,207$

Cyprus 163

Danae 126

dance, dancer, dancing $\quad 2,4,6-7,13-14$, 16-19, 25-27, 29, 32-33, 38-39, 42, 46, 51, $57,60-61,65-67,70,72,74,77,90,93-94$, $110,112,123,126,128-129,135,144,147$, 153-158, 16o, 184, 186-189, 191, 196, 200, 203-204, 207, 227-228, 231-234, 236, 239

daughter $85,170,209$ n. 91, 229 n. 83, 237, 239

Day (personification) 193

dead, death $8 \mathrm{n} .33,13,17,19,26,28,29$ n. 49, $81,84,99,101,117,126,129,144,161,182$, 192, 202, 207, 209, 214, 224, 226, 231-232, 236, 238,240

Deepdene Painter 43 n. 24, 67 n. 129

Delian Triad 26

Delos, Delian $\quad$ 163-164, 172, 193, 214

Delphi 95, 164, 172-173, 193, 195, 214, 219, 223

Demeter 110, 179, 240

democracy, democrat 99 n. 45,181
Demophon 84

departure 17, 19, 36, 69, 115 n. 102, 234

Derveni krater 204, 229, 233, 240

desire 158

diadem 30, 54, 103, 117-118, 132, 138, 147, 157, $160-161,178,182,192$

diasparagmos 231

Dikaios Painter 35

dinos 36, 49, 51, 85, 95, 99, 151 n. 114, 168 n. 33, 186-187, 189, 192, 203

Dinos Painter 101, 110, 145, 168, 184, 186-188, 190, 192, 200-201, 203, 207, 222-223, 226

Dione $\quad 189$

Dionysiac woman, see bacchante, bakche, maenad, nymph

Dionysia, Dionysia Megala, City Dionysia (festival) 66 n. 123

Dionysos Bakcheios, Dionysos Bakchos 131

Dionysos Eleuthereus 119 n. 116, 206

Dionysos Gigantomachos 164 n. 17, 217, 223

Dionysos Kitharodos 219

Dionysos Lysios 175

Dionysos Meilichios 81 n. 55

Dionysos Sardanapalos 218, 223

Dionysos Sykeatis $81 \mathrm{n} .55$

Dionysos Tauros 232

Dionysos Thriambos 215

diphros, see also chair 136, 141

discus 28

disguise 5,213

dish 38 n. 91, 127, 198

dithyrambos 97

dolphin 182

domestic, see house, home

donkey, see also mule 38 n. 84, 196, 212, 236

door $57,155,187$

Douris 52, 57-59, 97-98, 123 n. 4, 214, 234 n. 1,235

drama, dramatic, dramatic contest, see also theater, play $3,93,116,166,174,195,206$, 207 n. $82,234,238,241$

dress, garment 192,234

Duris, see Douris

ear 158

ecstasy, ecstatic, rapture $\quad 2,6,19,32-33,42$, $54,66,77,112,141,160-161,188,196$, 203-204, 228, 231-233, 241 
edifice, building $\quad 1,8,103,160,162-163,172$ education, educator $\quad 81,102,135,238-239$

Egypt, Egyptian $\quad 82,163$

Eileithyia 85

Eirene 176 n. 67, 189, 209

Eleusis, Eleusinian, Eleusinion $\quad 63,110,127$, 175,240

elite $\quad 32,77,181$

embrace 32, 39, 93, 207

encounter, see meeting

Epaphos 82

Epeleios Painter 38

ependytes 95,160

ephedrismos 228

epidemic 195

Epiktetos $\quad 38-39$

Epimetheus 198

epiphany, sudden appearance see also

arrival 35, 76, 146, 189, 211, 213, 224, 228, 236

era $8,46,170,175,194,196,233-234,238,240$

Erechtheus 180

Eretria Painter 38 n. 85, 98, 143, 156, 196-197, 198 n. 49, 199-201, 203-204, 210, 234 n. 1, 235

Eretria, Eretrian 204

Ergotimos, see Kleitias

Erigone 144

Erinyes 160

Eris 193, 202-203

Eros, erotes $\quad 13-15,63,115$ n. 102, 116, 118-119, 145, 156, 187, 189, 192, 196, 201, 204-205, 207, 208 n. $86,221,223-227,240$

erotic, erotical $\quad 5^{-6,18,29,31,70,106,123}$ n. 4, 149 n. 104, 110, 112, 161, 179, 196, 208, 219-220, 224-225, 236, 238-240

Etruria 15, 19, 22, 30 n. 50, 6o, 76, 130-131 Etruscan $1,28,30,68,77,78$ n. 42, 84, 86-87, 99 n. $46,125,131,159-161,188-189$

Euaion Painter $\quad 97-98$

Euandria (festival) $\quad 179$

Eucharides Painter 51 n. $52,5^{2}$ n. $64,67,100$, 102,126

Eudaimonia 192 n. 23, 209

Eudia 192

Euergides Painter 235 n. 5

Eumolpos 180

Euphronios $28-29,32-34,36,39,43,53$, 58 n. 83,236
Eupolis Painter 185

Euripides, Eiripides' Bakchai $\quad$ 1, 6, 9, 58, 88, 194, 199, 210-215, 217, 232, 236

Europe 164

Euthymides $23,28,33-35,38$ n. 91, 40, 43

Exekias $22,28,36,63,122$

export $17,22,87,125,130,199$

face, see also frontal view $\quad 26,31-32,58,77$, $87,94,97,116,123,147,155,178,198-199$, 204, 214, 231-232, 241 n. 14

Falaieff type 227

family $42,49,63,80,111 \mathrm{n} .89,135,152,185$, 199, 220, 238-239

farewell 126

father 8,46 n. 26, 72, 84-85, 100-101, 105, 111-112, 119, 123, 135, 143, 149-150, 158, 163, 167-168, 170-171, 173-174, 194, 199-200, $238-240$

fawn, fawn skin, nebris $6,27,36,45,70,93$, $95,105,107,148,192,204,231$

felicity, see happiness

feline 151

fertility $4-5,5^{2}$ n. 63,80

ferula communis $\quad 176$

festival, see also Anthesteria, Apatouria, Arrhephoria, Choes, Dionysia, Euandria, Koureotis, Oschophoria Plynteria, Panathenaea $2,68,77,83,122-123,128$, 141-142, 149 n. 104, 155, 163, 166, 178 n. 79, 179, 199-200, 239

fig $81 \mathrm{n} .55$

fillet, see also headband $\quad 145,150,204$

fire 40,176

fish 49

Florence Centauromachy, Painter of 125 n. 9

Florence Painter 38 n. 85,70 n. 5

Florence Stamnoi, Painter of the 100, 102-103

flower, see also blossom $\quad 23,103,105,117$, 205

flute, see aulos $\quad 29,31-33,51,58,64,77,93$, 125 n. 9,188

Flying-Angel Painter $\quad 51,5^{2}$ nn. 53, 63

foot (of a vase) 22, 28, 229

foot, feet $31,85,95,98-99,110,116,141,151$, $187,192,194,203,221$

footstool, see chair 
fortune, good fortune 209

François krater $\quad 42,80,99$

frieze $41 \mathrm{n} .8,88,162-163,168,173,175$,

177-180, 183, 201, 203-204, 212, 217, 229, 231, 240

frog 212

frontal view, full face, en face $26,32,58,77$,

$97,123,129,141,147-148,155,198,203,231$

frontier, boundaries $\quad 2,131,158,194,232$

Frontisi-Ducroux, F. 128

Fufluns Pachies $\quad$ 131, 160-161

funerary, see grave

Ganymede $\quad 36,63,99$

garden $78,222,226$

garment, see dress $127,129,134,138,151,160$, 214

Ge Panteleia 81

gender 3,158

genitalia, genital 221-222

Geras Painter $\quad 5^{1-52}, 66$ n. 124, 83 n. 62, 131, 141

giant, Gigantomachy $\quad 2,13,36,41-42,69,77$,

$83,88,90,160,162-164,166,176-177,183$,

202, 217 n. 29, 222-223, 226, 238

gift $13-14,17,22,78,84,100,143-146$,

149 n. 104, 151-152, 189, 207, 209, 218, 223, 225

girl $70,93,115,118,123,125,152,160,198,203$

glory 78

goat 38 n. $86,46,51,57$

goblet 28,214

gold, gilded $143,182,187,207,217$

graffiti $77,131,160 \mathrm{n} .149$

grain 88

grape, see also treading grapes, vine 3,30 ,

$5^{2}, 73,88,100,116,129,146,151,160,187,189$, $192,198,207,214,226-228,240$

Grassigli, G. L. 231-232

grave, burial, funerary $13-14,17,19,22,84,91$,

$95,115,125,127,145,159,161,182,198$ n. 52,

$218,225,229,231,236-237$

gravestone $5^{2}$

Greece, Greek 15, 42, 88, 130, 146, 160-162,

164, 168, 183, 193-194, 211-212, 218, 222-223,

236

greave, see leg guard

Greifenhagen, A. 196

grief, see mourning

griffin $\quad 226-227,231$
Group G 226

gymnasium, see also palaestra, sport $\quad 150$

gynè 189

Hades 76 n. 26, 98-99, 113, 160-161, 212-213, 232

hair, hairstyle 24 n. 25, 30, 70, 72, 78, 93, 118, 123, 134-135, 145, 147-148, 150, 166-168, 171 n. $43,173,174$ n. $58,178,194,200,203$, 214, 218, 224

hammer 57,228

handle (of a vase) 22, 29, 33, 43, 67, $92 \mathrm{n} .18$, 93, 114, 127, 134, 157, 191, 231

handshake 194

happiness, felicity, bliss $\quad 7,13 \mathrm{n} .11,19,25$, 38-39, 65, 99, 181, 189-190, 207-210, 217, $225-226,232-233,236,240$

hare $43,72,149,207$

harmony 163, 229

Harrow Painter 51, 114, 195

harvest 73

hat 106

headband, see also fillet $\quad$ 147, 150, 160, 203

healer 195

heaven, heavenly $\quad 213,240$

Hebe 192, 209 n. 91

Hector Painter 148

Hedyoinos 189

heel, see also foot $\quad 3^{2}$

Helena 116, 126, 211

Helike 148

Helios 8-9, 166, 232

helmet, see also armor $\quad 43,72$

Hephaistieion Painter 57 n. 78

Hephaistos 2, 4, 5 n. 18, 18, 38, 40, 42, 48-49, $57,63,65,69-70,74,85,90,95,156,173$, 175-176, 188-190, 196-197, 199, 202, 208, 212-213, 222, 226, 228-229, 238

Hera $36,42,55,57,98,101,103,110,179$ 188-189, 191-192, 209 n. 91, 229 n. 83

Herakles $2,13,16,23-24,26,28,32,35^{-3} 6$, $46,53,58,63,69,78,126,166$ n. 20 , 167 n. 25, 168, 195 n. 33, 204, 209 n. 91, 212-213, 223, 226, 228-229, 232, 236

herms $\quad 52,237$

Hermes $26,35,42,45-46,49,51,59,72$, 100-101, 103, 106-108, 110-112, 116, 140, 178-180, 191-192, 204-205, 225, 240

Hermes Psychopompos 240 
Hermonax $\quad 69-70,72,83,87-88,90$, 100 n. 53, 102-103, 111

hero, heroes, heroic $\quad 9,13,16,19,25,32,46$, $51,63,77-78,81,84,110,120,162-164,170$, 176 n. $69,180,194,204,216,229$ n. 83,232 , 235-236, 238

Herodotus 1, 176, 193

Hesperides 78

hetaera, hetaerae $6,30,38,235$

hill, see landscape

Himeros 192

Hippothoon 140 n. 66

home, see house

Homer, homeric $\quad 6,9$

homoerotic, homosexual 59

hope $13,210,213,236,240$

Hopla 80

horn, drinking horn $\quad 27,46,54,133,187,205$

horse $4,9,23,31-32,38,53,166,182$, 236

house, home, domestic $\quad 17,57,80,128-129$, $135,152,155,160,184,216,237-239$

household 152, 201

hunt, hunter $\quad$ 166-167

hydria, hydriae $12-14,16-17,19,27,34-35$, $69,87-88,101,107,118,120,163$ n. 6 , 180-183, 194, 201, 214

Hypnos 115 n. 102, 116

hypothesis 173, 211

Ida, mount $\quad 211$

idol $5,17,125,127,129-131,133-134,159,184$, 199, 239

Ikarios 216

Iktinos 8

Ilioupersis 74

infant, see child

initiation 221, 232

inscription, inscribe 6 n. 26,68 n. 136, 78 n. 40, 123, 145-148, 150, 156, 158, 175, 189, 192, 198, 201, 209, 231

intoxication, intoxicated $\quad 3,31-32,42,74,95$

inventor 19, 129

Iolaos 26

Ionian 172

Iris 49, 55, 84, 101, 192

island, isle $\quad 84,121$

Italy, Italian $1,12,14,130,87,159,168,191,223$, 236 ivory 217

ivy, see also branch $\quad 23,26-27,43$ n. 19, 46, 55, 58, 63, 70, 81, 93, 97, 99, 100 n. 52, 101, $103,105,108,110,112,117-118,134,136,138$, $147-148,150,156,160,176,180,192,194$, 197-198, 205, 227-229

Jaccottet, A.-F. $\quad 175,233$

Jena Painter 222

jewelry, see also necklace 224

judgment 192-193, 202-204, 211-212

jug 100, 143

justice 195

Kadmos Painter 95, 119, 151-152, 156 n. 131, 171 n. 42, 173 n. 51, 190-192, 191 n. 20, 195, 200-202, 209 n. 91, 210, 223, 226

Kaeser, B. $\quad 234$

kalathos 56,78

Kallias $\quad 164$

kalpis, kalpides $\quad 34,55,100,103,112-113,119$, 201-203, 205

Karlsruhe Painter 83 n. 62

Kekrops $\quad 180-181,183$

Kephalos 126

Kerameikos 1, 19, 30, 40, 87, 90, 93, 125, 130, 161, 201, 235

Kerch, Pantikapaion, Kerch style $\quad 110,182$, 192, 194, 205, 222

kerykeion $\quad 45-46,59,106$

kid 35,100

kithara $23-24,36,49,80,90,106,191$

Kleisthenes 66

Kleitias, see also François krater 6, 8o

Kleophon Painter 29 n. 48, 88 n. 3, 95, 97, $138,167,184,190$

Kleophrades Painter $\quad 23,33,40,42-43,55$, $57,67,69,76-78,81,83$ n. 62

klismos, see also chair $\quad 137-138,141-152,198$

Knauer, E. 123

knoll, see landscape

Kodros Painter 86 n. 73, 98-99, 141 n. 71, 157, 167 n. 27,168 n. $37,187,195^{-196}$

Komos 99, 149, 156-157, 189

komos, komast $\quad 13-14,16,29,35,53-54,57$, 90, 92, 94-95, 97, 125 n. 9, 126, 155, 201, $234-238$

kottabos $\quad 29-30$

Koureotis (festival) $\quad 123$ 
krater, bell krater, calyx krater, column krater, volute krater $5 \mathrm{n} .18,6,11-17,28-30,32$, 38 n. $85,40-42,46,48-49,57,60-61$ n. 99, 69-70, 72-74, 80-81, 83, 84 n. 71, 88, 90, 92-93, 95, 97, 99-101, 103, 105-108, 110 n. 79, 111-112, 113 n. 94, 117, 119, 123 n. 7, 125 n. 9, $127,131,132$ n. 42,134 n. $48,136,137$ n. 59 , 138, 140, 146-147, 149-156, 158-161, 168 n. 33, 170-171, 173 n. 51, 187-189, 191-192, 195, 198, 200 n. 59, 201-202, 204-205, 207-209 n. 91, 210, 215, 218 n. 36, 222-223, 226-229, 231-234, 236-241

Kratinos, Kratinos' Dionysalexandros 211-212

\section{Kronos 170}

krotala 24-26, 29

Kybele 160

kymbalon, kymbala see cymbal

Kyrenaika $\quad 226$

laborer 83, 199

landscape, hill, knoll $\quad 87,100,152,200,207$, 209, 224, 231

laughter 212

laurel, see also branch $\quad$ 143, 194, 198, 202, 204 law, lawful 111, 121, 193

LC Group 223

Leagros 29

lebes, lebetes 184,201

leg 29, 137, 167-168, 204, 231

leg guard, see also armor $\quad 72$

leggings, trousers 192, 212

legitimacy, legitimate, legitimization $\quad 51$, $111-112,120,180$

lekanis, lekanides $\quad 110,171 \mathrm{n} .42,180$, 202-203, 207, 214-215 n. 22

lekythos, lekythoi $\quad 16-17,19,69,72,74$ n. 24, 91, 101, 115-116, 125, 131, 200-201, 203, 205, 210,236

Leningrad Painter 72

leopard, leopard skin $\quad 58,72$

Leto 49,80

Lewis Painter $118,137,138$ n. 63, 142 n. 76, 195, 238 n. 9

libation $23,45,66,122-123,127,146,15^{1}$

lid $110,127,180,204,212,214-215$ n. 22 lightning 180,183

liknon 160,198

lion, lioness, lion skin $\quad 23,28,31,72$ n. 11, 16o, $177,188-189,213,228,232$

Lissarrague, F. $\quad 158$

locks, see hair $\quad 119,174,205,213-214,227$

Lokri 161 n. 151

Louvre G 238, Painter of $\quad 5^{2}$ n. 54

love, lover $43,57,113,115$ n. 102, 116, 120, 135 n. 53,149 n. 104, 150, 158, 168, 175, 205, $212,223,226,238,240$

louterion 18

loutrophoros 69, 184, 201

Lydos 22, 31, 40

lyra 29 n. 48, 35 n. 74, 92, 102, 151, 154, 173, 186, 189, 204, 207

Lysikrates 174

Lysippides Painter $\quad$ 22-24

Macedonia, Macedonian $\quad$ 180-181, 226 mad, madness 66

maenad, see also bacchante, bakche,

Dionysiac woman $6,14-18,25^{-27}, 29$,

31-32, 36, 38-39, 42, 48, 54-55, 57, 6o-61,

64, 66-67, 69-70, 72, 74, 77-78, 90, 93, 95, 97-98, 108, 112 n. 90, 131, 141, 148, 151, 153, 18 o n. 89, 184, 189, 200-202, 204 n. 71, $215^{-217}, 227-228,231-233,241$

Magna Graecia 15

Maia 201 n. 62

Mainas 153,185

Makaria 201 n. 62, 209-210

Makron 52, 55 n. 74, 6o, 62-64, 70, 81 n. 55, $88,97-98,100-103,111,125,203,234$ n. 1, 235 man, men, manhood $\quad 3-5,9,12,16,23,35,38$, 43, 49, 51, 57, 6o, 68, 73, 85, 90, 97, 99, 103, $106,115,118,123,125,129,143-144,149-150$, $15^{2-153}, 158,160,166-168,179,182,184-185$, 192, 196-197, 198-199, 206, 214, 227-229,

231-235, 237-239, 241

Mannerists, early $87,90,118,120$ mantle 12, 95 n. 25, 97, 111 n. 88, 138, 234 n. 3 manuscript 1 Marathonian bull 77 market 12, 28, 30, 87, 125, 199, 227, 235 Maroneia $\quad 171 \mathrm{n} .43$ 
marriage, wedding $\quad 2,36,51,80-81,99-100$, 113, 116, 118-120, 141, 155, 184, 187, 196, 202, 205, 238

Marsyas 148, 153, 171, 191-192, 202

Marsyas Painter 145

mask 18, 65, 127, 129, 198-200, 237, 239

matrimony 99,120

mattress 156

meal $5^{2}$

medallion, tondo $\quad 29,38,53-54,57-58$, $60-61,64,73,83$ n. $62,97-99,115,122-123$, $157,231-232$

meeting, encounter $5,19,23-24,56-57,60$, $65,67,69-70,88,113,120,122,141,173,192$, 197, 224-225 n. 70, 232, 234, 236, 240

Meidias Painter $143-144,195,198,201-204$, 207, 214

Meilichios, see Dionysos Meilichios

Meleager Painter 152, 222

Menelaos 116

messenger $84,111,178-179$

metamorphosis 129,141

metaphor, metaphorical $17,84,126,137,225$, 232, 236, 240

Methyse Painter 131 n. 36, 134, 154, 170-171 n. 39

metope $87,162,164,166,177-179,183$, $216-217$

military $77,163,238$

Minotaur $16,77,81$

mirror 168, 204, 217

mold 182, 214

monosandalos 233

monument, monumental $\quad 9,87,174,183,195$, 212, 217-220, 226, 233 n. 98, 237

mortal $7-8$ n. 33, 36, 49, 51, 8o, 100, 151, 170, $205,224,235,238$

mother $16,80,85,112,135,189,213,237-238$

mountain 45

mourning, mourner, grief $\quad 78,140$ n. 66,188 , 236

mouth 30,237

mouth (of a vase) 22, 83, 229, 231

mug 161

mule, see also donkey $\quad 18-19,38,46,48,74$, 90 n. $7,95,118,156,188,192,196-197,199$, $212,229,236,238$

multiformity, see polymorphism 218, 220

Munich 2676, Painter of $\quad 52$ n. 64
Munich Amphora, Painter of the 48 n. 38 , $77-78$

Muse 49, 102, 108, 135, 203

music, musical, musician $7,23-24,29,31,34$, $36,40,43,46,51,54,57,70,74,77,83,103$, $108,125,133,135,153,160,173$ n. 54, 188-189, 191, 194, 200, 202-203, 209, 223, 239

myrtle 231

Myson 48 n. 38, 51, 52 n. 63, 67 n. 131

mystery, mysteries $110,160,179,240$

myth, mythic, mythology, mythological $\quad 2$, $4-7,12-15,19,23,28,35,42,46,51-53,55$, $57-58,65,69,72,77,82-84,86,88,90,93$, 95, 98, 101-103, 110-113, 115, 119-122, 126, 149, $152,158,163,168,171-173,176,181,183,185$, 189, 194, 196, 198 200, 205, 207-209, 216, 218, 222-223, 229, 234-236, 238-239 n. 10, 241

Nachleben 213

naked, see also nude $\quad 8-9,30,35,38,43,74$, 103,110 n. $78,114,116,123,148,151,155,164$ n. 17, 167, 170, 174, 188, 198, 204-205, 207, 214, 217, 220, 223, 225-226, 231

nature $35,46,88,93,100,102,105^{-106,135}$, $186,236,238$

Nausikaa Painter $100,105,111$ n. 88

Naxos 121, 171

nebris see fawn skin

necklace, see also jewelry 224

necropolis $\quad 90,95,117,159,180,182$

Neils, J. $\quad 168$

Nemean lion $\quad 23,28$

newborn, see baby $\quad 135,153$

Nietzsche, F. $\quad 171,173$

Night (personification) 193

Nike $13,15,49,63,76,85,106,151,180$, $182-183,192,215$

Nikosthenes Painter $\quad 31,39,59$

Nikoxenos Painter $\quad 51$ n. 51

Niobid Painter $63,76,87-88,90,93,118,120$, 138 n. 59, 195

Nola 117

nothos, nothoi 49

nude, nudity, see also naked $\quad$ 167-168, 177, 201, 218

nurse 77

nymph see also Dionysiac woman $\quad 6,51,57$, 6o-61, 64, 78, 100-103, 105-106, 111-112, 135, 149 n. 104, 160, 180, 200, 205, 238 
Nymphaia $\quad 66,78$

Nymphaion 97

Nymphe $201 \mathrm{n} .62$

Nysa, mount $\quad 100,102-103,110$

Nyx $\quad 116$

Oedipus Painter 59 n. 87,83 n. 62

offering 91,187

oikos $80,98,103,238,241$

oil $\quad 22,83$

Oinanthe 189

oinochoe, oinochoai 5 n. 18, 12, 24, 45-46, 6o, 69-70, 90-92, 107, 118, 120, 133, 135, 140, 146-148, 150-151, 155-156, 187, 201, 225 n. 70

Oinopion 122, 125, 192

ointment 205

Okeanos $\quad 81-82$

oligarch, oligarchy $\quad 181$

olive $179,181-182$

Oltos $32,36,38,42,46,126,235$ n. 5

Olympia 87,168 n. 34, 171, 217

Olympus, Olympian, Olympic $\quad 2,4,35^{-36}$, $38,40,42,49,63,69,99-100,163,175$ n. 6o, 177, 196, 202, 209 n. 91, 212-213, 220, 238

Olynthos 226

omphalos 193-194

Onesimos $\quad 5^{2-53}, 55$ n. 74

Opora 189,192

Orania 150

Orchard Painter 73 n. 17

Oreias 192 n. 23

Oreimachos 45

Oreithyia $72,78,84,126$

Oreithyia Painter $\quad 41$ n. 8, 72, 76-77

Orestes 126

Oriental, oriental $\quad 202,208,212$

oriental dress 192,212

Orochares 45

Orpheus Painter 74 n. 23

Osborne, R. 177

Oschophoria (festival) $122 \mathrm{n.} 2$

painting, monumental painting, wall painting 87,119 n. 116,212 n. 6, 218, 233 n. 98,235

pais amphithales $\quad 116$

palaestra see also gymnasium, sport $\quad$ 106-107 palm 192-193

palmette 102
Pan 14, 224

Pan Painter $\quad 63,72$ n. 12, 116-117, 136

Panathenaea (festival) $\quad 83,179$

Panathenaic prize-amphora, Panathenaictype amphora $40,43,46,76-77,83,163$, 175,179

pantheon $\quad 162$

panther, panther skin $\quad 40,48,54,63,81-82$, 90, 93, 164, 167, 177, 180-181, 183, 189, 205, 207, 214, 224, 227-228, 231, 240

Pantikapaion, see Kerch

papyri 1

Paradise, paradisiacal $\quad$ 207, 233

parasol 128

Paris Gigantomachy, Painter of the $\quad 42$ n. 19 Paris, Paris-Alexandros, Dionysos-

Alexandros 192-194, 202-204, 211-212 parody $213,237 \mathrm{n} .7$

Paros 110 n. 79

Partheneia $\quad 116$

Parthenon $8-9,88,95,110,113,150,157$, 161-164, 166-168, 170-177, 179-184, 187, 189, 195-196, 199, 201, 205, 212, 217, 221, 223-225, 227, 239

pastries, see also cake, sweetmeats 127,143 , 146

Patroklos 78

patron, patroness $\quad 8,23,80,119,163,170,232$, 239

Paul-Zinserling, V. 222

Pausanias 9, 119 n. 116, 218

pax atheniensis 164, 166

peace, peaceful $\quad 63,69,164,174-177,179,181$, 189, 192, 194, 203-204, 209, 217, 225, 231-232, 240

pedestal 18,192

pediment $8,87,95,110,150,162-164$, 166-168, 170-171, 173-184, 189, 195-196

n. $40,205,212,214,217,219,225,227$, 239-240

Peisistratos 36

Peitho $\quad 157-15^{8}$

Peleus 2, 36, 51, 80, 100, 115, 117 n. 108, 126, 202, 238

pelike, pelikai $\quad 43$ n. $24,51-52,60,63,67-70$, $72,83-85,87,95,100,105,107-108,110-112$, 121,132 n. 42, 136-137, 167 n. 27, 180, 184, 195 n. $33,201,208$ n. 87,223 n. $64,226,234,237$, 241 
Pella 163 n. 6, 180-183, 205

Peloponnesos, Peloponnesian $\quad 12,84,87,194$, 213, 217

Penthesilea Painter $87,98,123$

Penthesilea Workshop 118, 235 n. 5

Pentheus 29 n. 49, 58, 171, 201-202, 204, 213-214, 215, 217

peplos $70,147,149,157,178$ n. 79

perfume $17,83,144$

Pergamon 183, 217

Perikles 9, 111, 166, 171-173, 176-177, 212, 238

Periklymene 201 n. 62

Persephone $\quad 98-99,110,160$

Perseus $\quad 126$

Persia, Persian $\quad 12,42,63,78,81,87,163^{-164}$, $171,177,238$

personification 116,180 n. 89, 183, 209

persuasion 158

Pethon $\quad 157-158$

Phaidrosbema 216

phallus, ithyphallic $\quad 29-31,49$ n. 39, 52-53,

61 n. 99,90 n. $7,136,159,161,231$

Phanagoria $188 \mathrm{n} .15$

Pherekydes 120

phiale $99,103,156,160,176,190$

Phiale Painter 108, 131, 134, 140-141, 150, 153, 190, 234 n. 1

Phidias 8-9, 95, 150, 163, 168, 171, 173 n. 55, $176,217,221$

Philyra 80

Phintias 32

Pig Painter 74 n. 20

piggyback 23

pillar $65,98,102-103,127,134,160,184$

pillow $30,116,118,156$

Pistoxenos Painter 98

pitcher 51,66, 90

pithos, pithoi 73

plague 195

plait 168

plant $81,153,228,240$

plate 146

Plato $\quad 176$

play, playful, satyr play see also theater 4

n. $13,5,23,27,30,42,46,49,51^{-52}, 56$,

65-66, 111-112, 135, 149, 153, 158, 161, 174,

177, 189, 205, 207, 209, 211-214, 240 playing of an instrument $23,29-35,45,54$, 57-58, 64, 69, 70, 77, 90, 92-93, 97, 106, 110-118, 123, 125 n. 9, 133, 147-148, 150-151, 153-154, 157, 16o, 186, 189, 191, 203, 207, 237 plemochoe 205

Plutarch 164 n. 11, 195 n. 34

Plynteria (festival) 178 n. 79

Pochmarski, E. $\quad$ 167-168

podium 187, 189, 207

poetry 68,237

polis $1,3,8,22-23,38,40,66,68,77,80,85$, $88,93,99,112,120-121,135,152,158,162,177$, 180-181, 183, 196, 199, 210, 212-213, 217, 222, 233, 237-241

Pollux 84

Polygnotos 93, 95, 119, 138, 146, 148, 150, 154-156, 159, 195

polymorphism, multiformity $195,218,220$

polytheistic 110, 162, 241

Pompe 145

Pophs 157

Poseidon $\quad 35^{-36}, 42$ n. 19, 49, 63, 77, 84-85, $98,100,113,119-120,126,163,173,180-183$, 195

Poseidon Hippios 181

Posthon 153, 158

Pothos 158, 192

Pothos Painter 146, 151-152, 171 n. 42, 195 potter 19, 28, 53, 66, 99

Pourtalès Painter 228 n. 82

Praschniker, C. 164

Pratinas 65

Praxiteles 218-220, 223

precentor 97

pregnancy 111, 218

prince, princess $\quad 78,120,211-212$

procession, see also thiasos $\quad 27-28,31,35,46$, $57,61,72,74,90,95,99,123,125,127,133$, $137-138,145,153,157,160,163,170,175$, 177-179, 181, 184, 187, 190, 209, 218, 239

Prometheus $\quad 176,198-199$

Pronomos Painter 180, 201, 205, 207-208, 222, 226

prototype, prototypical $12-13,65,86,15^{8}$, 210 ก. 92, 220

Psiax 24, 26

psykter 29,30 n. 50, 35, 42, $5^{8}$ n. 83,59 
punishment $58,201-202,213,217$ pursuit 18, 84, 90, 113, 115, 117, 120, 126, 192 pyramid 205

pyxis, pyxides $\quad 201,204,212$ n. 4, 232 ก. 93

quadriga $\quad 49,69$

quiver 24

ram 46

rapture, see ecstasy $\quad 19,32$

reception, ritual of $146,151,173$ n. 51, 187

reconciliation $42,181,213,229$

referee, adjudicator $\quad 106,213$

reigns $3^{1}$

rejuvenation 150

relief (bas relief) 1, 30, 182, 214-217, 229

religion 5 n. 14, 8 ก. 33, 128

retinue $2,3,7,14,17-18,28,38,69,76,90,95$, 152, 176 n. 67, 201, 208-209, 217, 222-223, 239,241

revival 184

revolution $\quad 239$

rhyton, rhyta 54

ribbon 87,224

rider $\quad 236$

ritual $3,5-7,17-18,39,42,52,60,64,67-68$, 70, 72, 74, 84, 88, 90-93, 95, 97, 111, 113, 116, 118-119, 122-123, 125-135, 137, 140-146, 149, $151-153,155,158-159,161,170,176,178-179$, 184-187, 189-190, 196, 198-200, 206-207, 209, 218, 234, 236, 239-240

rock 106-108, 116, 186, 197

Rome, Roman $1,13-14,94,220,222,224,226$, 232 n. 97

Ruvo 57, 191, 205, 209 n. 91, 210

Sabazios $\quad 160$

sacrifice, sacrificial $\quad 88,95,100,129,145,209$

sacrilege $\quad 52,67$

safety valve 3,174

saffron 213

salute, gesture of $29,32,42,60,92,197$

sanctuary, temenos $17,85,103,127,166,172$,

$175,187,192-195,215,217-219$ n. 47, 222, 226

sandals, see also shoes, boots $\quad 38,116,145,192$

Sappho, Sapphic $\quad 56,93$

sarcophagus, sarcophagi 13 n. 11, 187 n. 12,

224, 232 n. 97 satyr $\quad 4-7,13-19,23-36,38-43,45-46,49$

n. $39,5^{1-61}, 64-70,72-74,77-78,90,92-93$,

95, 97-99, 101, 107-108, 110, 112, 117-119, 122, 126, 131-132, 134-138, 140-141, 146-158, 161, 171, 184, 186-189, 191-192, 194, 196-197, 200, 203-205, 207-209, 211, 223-225, 227-228, 231-234, 236-239, 241

satyr play, see also theater 4 n. 13, 42, 46, 49, 56, 65-66, 70, 77, 111-112, 135, 153-158, 174, 207, 209

scene house, see also theater (building) $\quad 216$ scepter 49, 81, 102-103, 105, 160, 183

Scheibler, I. $\quad 22-23,83$

sculpture, sculptor, sculptural $\quad 1,8-9,13,88$, $95,162-163,167-168,177,195,214,217-218$, 221-223, 237 n. 8, 240

Second World War 200

seed 22

Seilenos, Silenos see also Silenus $\quad$ 192, 201 n. 62,208

Selene $8,166,193$

Semele 8 n. 33, 16-17, 36, 80, 101, 192, 210

Semele Painter 101

servant $28,32,137,140,212$

severe style $\quad 87$

sex, sexual, sexuality $\quad 4-6,65-66,77,114,135$

n. $53,141,161,228$

Shapiro, H.A. $\quad 83-84$

shawl 118

sheath 231

shepherd 211-212

shield, see also armor $\quad 43$ n. 19, 182

shin guard, see leg guard 43

shoes, see also boots, sandals 134

shoulder 18, 29, 31, 35, 43, 57, 70, 72, 105, 117, $123,127,138,140,149,189,191,204,224,228$, 231

shoulder (of a vase) $\quad 34,77-78,81,93,161$, 231-232

Shuvalov Painter 141, 152, 195

Sicily 14

sidesaddle 42

sieve 161

Sikinnos 192

Sikyon 218

Silenus $\quad 107-108,111-112,158$

Simos 192

Siphnos, Siphnian $\quad 41 \mathrm{n} .8$ 
Siphnian Treasury 164

sister 85,237

skin, animal skin $\quad 6,31,40,48,57,70,72,93$,

$95,105,110,118,134,145,148,167,177$,

183-184, 203, 213-214, 216-217, 224,

227-228, 232

skopeuma $\quad 137,189$

skyphos $30,35,63,88,118,123,129,135^{-138}$

n. 63,142 n. $76,198,238$ n. 9

slave 3,213

sleep, sleeper, sleeping $\quad 18,55,115 \mathrm{n} .102,116$, 119 n. 116, 231-233

Smikros $\quad 32-33,43$

smith $\quad 40,42,74,197$

snake $25,31,36,39,42,54,93,160-161,164$,

$182,189,231$

Solon 171

son $49,80,84,110-112,122,126,135,158,168$, 170-171, 173, 189, 202, 239-240

song 80,237

Sophilos $36,51,80-81,99,238$

Sophokles, Sophokles' Dionysiskos $\quad 76,111$

n. 89,173 n. 52, 206 n. 81

Sosias 36,38 n. 91, 63, 99

Soteles 153

soul, see also Hermes 46, 111, 179, 240

Southern Italy, see Italy $\quad$ 14, 168, 191, 223

Sparta 164, 172, 181, 211

spear, see also armor $\quad 43,115,182,231$

sphyrelaton, sphyrelata 218

Spina $15,87,90,159,161,189,207,226$

spit 192

Splanchnopt Painter 235 n. 5

sport, sporting, see also gymnasium, palaestra $43,57,77$

spouse $8,99,113,167-168,195$

spring $52,146,155$

staff 168

stage, see also theater $\quad 3,72,106,158,190$, 210-211, 213-214, 216

stamnos, stamnoi $\quad 29,32,40,42,46,49,57$

n. $78,60,69,81,83,90,92-95,100,103,112$, $125^{-135}, 146,148,153,159,184-185$, 190, 199-200 n. 59, 239, 241

stand, ring stand 38 n. 91, 76, 80

statue, statuette $\quad 52,168$ n. 34, 171-173 n. 55, $176,215,217-218,220,226$

status $3,22,36,49,68,99,123,149,189,203$ 237 stick $35,43,48,92,103,110,123,138,141,155$, 187,234

stool, see chair $\quad 143$

street 35

strife $\quad 193-194$

strigil 150

struggle, see also combat $\quad 163,239$

Sub-Meidian Cup-Group 235 n. 5 sweetmeats, see also cake, pastries 146 swing 123, 143-144, 146, 198-199, 207

sword, see also armor $\quad 24$

Sykeatis see Dionysos Sykeatis

Syleus Painter $\quad 51,76-77,84$ n. 71, 100, 102, 113-114, 116, 119, 195

symposium, symposiast $\quad 3,6,12-14,16-17$, 19, 24-26, 28-30, 32, 34, 38-40, 42-43, 46, 51, 53-54, 57-59, 61-62, 65, 68-69, 76 n. 29, 90-91, 94-95, 97-99, 125-127, 131, 136, 141, 149, 157, 159-161, 167, 174, 186, 195 n. 33, 201, 226-228, 234, 236-238, 240-241

Syracuse Painter 74 n. 20

Syriskos $51,66-67$ n. 129, 76, 78, 8o-82, 85, 99, 117 n. $108,126,131$ n. 36

table $103,127,129,134,143-144,146,198$

tablet, gold tablet $\quad 207$

taboret 103

tail $4,58,15^{8}$

Tarquinia 171

Tarquinia 707, Painter of 38 n. 85,84 n. 71

Telephos 217

temenos, see also sanctuary $\quad 166,176$

temple $8,13,76,87,103,110,119$ n. 116, 162, 171, 176-177, 183, 195, 212 n. 6, 214, 217, 219, 225, 237 n. 8, 240

thalamos 187

Thaleia 185

thallophoros 179

Thasos 216

théai 179

theater (building) 166, 174, 176, 216, 217-218 theater, drama, see also play $68,72,110,166$, 176, 179, 213, 216, 241

Thebes 176 n. 66, 194, 213

Themis 81, 193, 202

Theseus $16,51,77-78,81,84,113,116,118-121$, $126,162,171$

Thespis 214

Thessaly 218 
Thetis $2,36,51,80,99-100,117$ n. 108, 126, 202

thiasos, see also procession 6 n. 20, 7, 14, 18, 28-29, 31-32, 35-36, 38-39, 42-43, 48, 53-54, 57, 6o-62, 65-66, 69-70, 74, 77-78, $84,88,90,93,95,97-98,112,131,134,146$, 150-151, 158, 160, 176, 188-189, 196-197, 200, 208-209, 219, 232, 236, 240

thigh $72,101,103,221,231$

Thrace 218

threshold 155

throne, enthroned, dethroned $42,57,63,84$, $103,141,159-161,170,217$

Thyone 192

thyrsos $6,29,31-32,36,43$ n. $24,48,58,66$

n. $126,69-70,72,80,91-93,95,97,100$

n. 52, 103, 107-108, 110, 117-119, 133-134, 137-138, 140-141, 145, 147-148, 150-151, $153-154,156-157,160,164,168,176,178,187$, 190-192, 196-197, 202-205, 207, 224, 228

Tithonos 126

tondo, see also medallion $\quad 29,38,54,57-58$, $60-61,83$ n. 62, 115, 122-123, 157

tongs 197,228

torch 5 n. $18,7,38$ n. $85,49,52$ n. 64,67 , $69-70,74,80,88,90-93,97,123,133,135$, 137-138, 147-148, 153-155, 157, 181, 184, 190-191, 196, 200, 207, 227, 239

tortoise-shell 173

Trachones $145,15^{-152,187}$

tragedy, tragic, see also theater 9,144 , 149 n. 104, 192, 216, 236

Tragoidia 149 n. 104

trainer 106

transition, transitional $\quad 23,80,145,149,163$, 176 n. $69,187,225,233,235,239$

transport $22,53,73,176$

traveler $213-214$

treading grapes 73

treasury $163-164,172$

tree $81,100,181-182,192-193,203$

trident $49,85,182$

tripod 192

Triptolemos 63, 88

Triptolemos Painter 59, 76 n. 26, 122-123, 125
Triton 180

trousers, see also leggings 192

Troy, Trojan, Trojan War $\quad$ 51, 116, 162-163,

$$
\text { 193-194, 211-212 }
$$

truce 164

twig, see also branch $\quad 144$

tympanon $93,95,150,160,184,187-188,194$, 203-204, 227-228

tyrannicides 81

tyrant $\quad 126$

Tyrrhenian Sea $\quad 9,87$

Uranos 170

urn $84,95,125,127,129,182,229$

utopia 189,240

vegetation $\quad 4,161 \mathrm{n} .15^{2}$

veil 117

Versnel, H.S. $\quad 194$

victory, victorious $\quad 2,63,78,81,87,103,111$, 180, 183, 206-207 n. 82, 217, 223, 234

Vienna 3717, Class of $52 \mathrm{n} .61$

Vienna 895, Group of 83 n. 62

Villa Giulia Painter $87,90,106,108,111-112$, 123 n. $7,129-131,153,158$

vine, see also branch $\quad 18,23^{-24}, 27,29,3^{-}-32$, $39,100,116,176,192,216,228,231$

virginity, chastity $\quad 80,116$

visit, visitor $142,144,152,170-171,179$

voyage 17,19

Vulci $76,84,130-131,160$

waking up, awakening $\quad$ 231-233

war, warfare, warrior $\quad 12-13,16,32,36,38$, $42-43,51,54,57,63,77,84,87,98,116,126$, 163, 171, 173, 193-194, 200, 212-213, 217, 234, 238,240

water $11,34,52,78,182$

wax 229

wedding, see marriage $\quad 80-81,99,119,141$,

$184,187,205$

wedlock (out of) 111, 135

wellbeing 209

wife, see also spouse $\quad 211,239$

wild, wilderness $\quad 19,66,81-82,105,112,135$, 149, 216, 224, 226, 241 
window 241

wine, wine sack $2-5,11,16,22,24,28,29-30$,

33, 39-40, 43, 49, 51, 66, 73-74, 76 n. 29, 81,

$88,127,129,135,137,140,146-149,151$,

153-154, 16o, 184, 223, 226, 232, 239, 241

wing, winged figures $63,115 \mathrm{n} .102,143,192$, $196,224,227-228$

witness 8,234

woman, women $3-8,12-19,23-24,27-28$,

$30,34-35,39,43$ n. $24,49,52$ n. $64,5^{6-58}$, $60,63-64,66-70,72-74,76,78,80,83,85$, $88,90-93,97,100,102-103,105-108,110$, 112-119, 122-123, 125-129, 131-135, 137-138, 140-142, 144-16o, 171, 176, 182-184, 187-189, 191-194, 196-201, 203-205, 207-209,

215-217, 224-226, 228-229, 231, 234-241

workshop 24, 118, 141, 152, 156, 180, 191, 201, 222-223

wreath $24,30,61$ n. 99, 80, 93, 99, 100 n. 52, 103, 107-108, 110 n. 79, 112, 118-119, 134, 136, 143-145, 147-148, 150, 153-154, 16o, 180, 187, $189,192,194,197-198,216,224,227-228,231$
Xanthias 212-213

Xenokles 214

xoanon, xoana 218

youth, adolescent $\quad 9,12,15^{-16}, 29,33,38,51$, $60,72,77,85,90,95$ n. $25,97,99,108,110$

n. 78,111 n. $88,123,125,138,151-153,166,168$

n. $32,198,205,221,234-235$

\section{Zagreus 110}

Zeus $\quad 2,8,36,42,49,51,57,63,84,87,98-102$, $105,110-113,115,120,126,135,160,163,168$, $170-171,173,175,180,202,214,217,220$, 229 n. $83,238-240$ 